ANA PAOLA VILLALVA BRAGA

ANÁLISE DE LIGAS DE ALUMÍNIO AERONÁUTICAS CONFORMADAS POR JATEAMENTO COM GRANALHAS CARACTERIZAÇÃO E PREVISÃO DE DEFORMAÇÃO 

ANA PAOLA VILLALVA BRAGA

\section{ANÁLISE DE LIGAS DE ALUMÍNIO AERONÁUTICAS CONFORMADAS POR JATEAMENTO COM GRANALHAS - CARACTERIZAÇÃO E PREVISÃO DE DEFORMAÇÃO}

Dissertação apresentada à Escola Politécnica da Universidade de São Paulo para obtenção do título de Mestre em Engenharia 



\section{ANÁLISE DE LIGAS DE ALUMÍNIO AERONÁUTICAS CONFORMADAS POR JATEAMENTO COM GRANALHAS - CARACTERIZAÇÃO E PREVISÃO DE DEFORMAÇÃO}

Dissertação apresentada à Escola Politécnica da Universidade de São Paulo para obtenção do título de Mestre em Engenharia

Área de Concentração: Engenharia Metalúrgica e de Materiais

Orientador: Prof. Dr. Fernando José Gomes Landgraf 

Este texto foi escrito em $\mathrm{HT}_{\mathrm{E}} \mathrm{X}$. Conheça e divulgue!
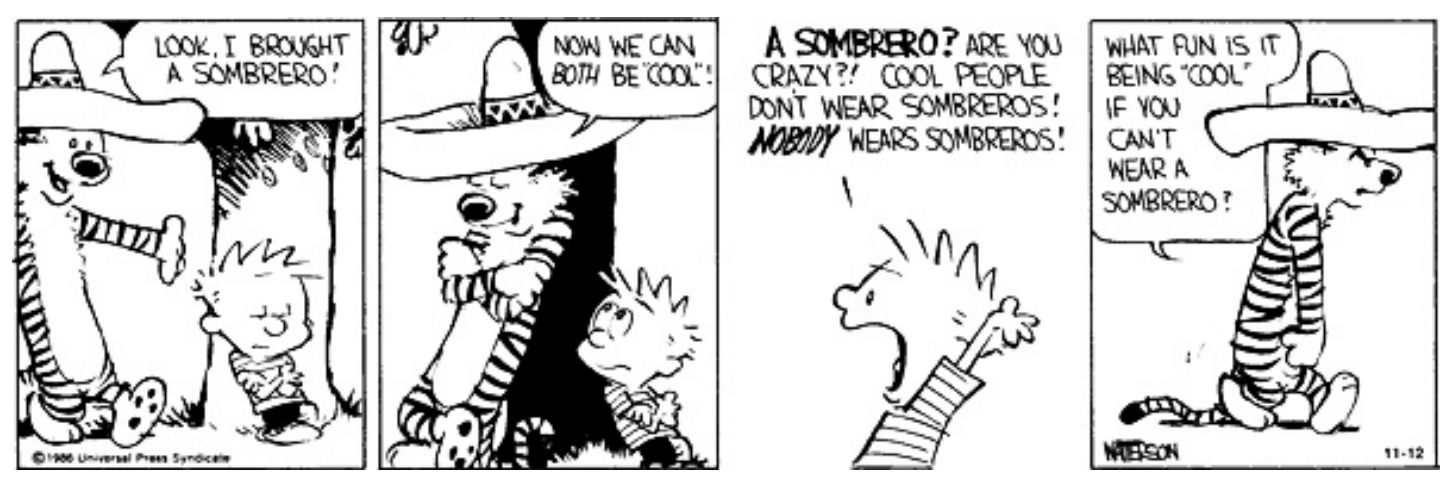

A pesquisa só sobreviverá enquanto os sonhadores julgarem-se ignorantes. 



\section{Agradecimentos}

Agradeço às pessoas responsáveis pelo meu trabalho: ao meu orientador Prof. Dr. Fernando José Gomes Landgraf, por ter-me atendido sempre com atenção, carinho e respeito, desde a Graduação, e por ser um exemplo a ser seguido; ao Marcelo Gonçalves, PhD, pelas inúmeras oportunidades de desenvolvimento profissional e pessoal que me ofereceu, por ter sido um chefe ao mesmo tempo exigente e companheiro no IPT.

Ao Instituto de Pesquisas Tecnológicas (IPT) pela estrutura de apoio técnica e administrativa para a condução deste trabalho e aos órgãos de financiamento do projeto de pesquisa (Finep e Embraer), que tornaram a sua execução possível. À Embraer, pela concessão do direito de divulgar os resultados obtidos neste trabalho, e por se mostrar parceira do IPT e da Universidade de São Paulo nos projetos de pesquisa, desenvolvimento e inovação na indústria aeronáutica.

À Companhia Brasileira do Alumínio (CBA), por compartilhar experiências e auxiliar na preparação de amostras metalográficas.

Aos pesquisadores que participaram do projeto 'Peen Forming': Agenor de T. Fleury, Dr. (FEl/EPUSP); Walter A. P. Ferreira, Dr. (IPT); Flavius P. R. Martins, Dr. (EPUSP); Gisele Szilágyi, MSc. (Mackenzie); Rynaldo Z. H. de Almeida, MSc. (EPUSP).

A Rene R. de Oliveira e Nelson B. de Lima, Dr., do Departamento de Caracterização de Materiais do IPEN, pelas medições de perfis de tensões residuais por difração de raios- $X$.

À Sandra da S. Munarim, pelo apoio técnico e, principalmente, pela companhia e amizade. Ao Damien A. Chaves, ex-estagiário, pela amizade e ajuda no trabalho experimental. Aos demais colegas do IPT e da Poli, que me servem de sustentação.

Impossível agradecer suficientemente aos meus pais, Malu e Edson, à minha irmã Marcela e ao restante da minha família, e ao meu marido Rafael, por fazerem a vida valer a pena. 
${ }^{m 5}$ Mas, se aquele servo disser em seu coração: 'O meu senhor tarda em vir'; e começar a espancar os criados e criadas, e a comer, e a beber, e a embriagar-se, ${ }^{46}$ Virá o senhor daquele servo no dia em que o não espera, e numa hora que ele não sabe, $e$ separá-lo-á, e lhe dará a sua parte com os infiéis. ${ }^{47} \mathrm{E}$ o servo que soube a vontade do seu senhor, e não se aprontou, nem fez conforme a sua vontade, será castigado com muitos açoites; ${ }^{48}$ Mas o que a não soube, $e$ fez coisas dignas de açoites, com poucos açoites será castigado. E, a qualquer que muito for dado, muito se Ihe pedirá, e ao que muito se lhe confiou, muito mais se Ihe pedirá."

(Lucas, 12)

Orgulhosos! Que éreis antes de serdes nobres e poderosos? Talvez estivésseis abaixo do último dos vossos criados. Curvai, portanto, as vossas frontes altaneiras, que Deus pode fazer se abaixem, justo no momento em que mais as elevardes. $\mathrm{Na}$ balança divina, são iguais todos os homens; só as virtudes os distinguem aos olhos de Deus. São da mesma essência todos os Espíritos e formados de igual massa todos os corpos. Em nada os modificam os vossos títulos e os vossos nomes. Eles permanecerão no túmulo e de modo nenhum contribuirão para que gozeis da ventura dos eleitos. Estes, na caridade e na humildade é que têm seus títulos de nobreza. (O Evangelho Segundo o Espiritismo, cap. VII, item 11) 


\section{Resumo}

O processo de conformação por jateamento com granalhas (peen forming) trata da conformação de chapas ou painéis através da ação de um jato de esferas de aço que, atingindo uma de suas superfícies, torna-a convexa na face de recepção do jato e gera tensões residuais superficiais de compressão. Tornar o processo de jateamento com granalhas reprodutível e controlável é um grande objetivo a ser alcançado para que o mesmo possa ser aplicado de forma segura na indústria aeronáutica. Buscando-se estudar a viabilidade e o desenvolvimento de conhecimento da técnica de jateamento de esferas, definiu-se uma metodologia para o projeto de experimentos focalizados nos dois tópicos principais: variáveis de processo e características do material jateado. As varíaveis de processo observadas foram diâmetro de granalha, velocidade de impacto, porcentagem de cobertura e pré-tensão. No material jateado, variaram-se a liga de alumínio (7050-T7451 e 7475-T7351) e espessura. As chapas de alumínio foram caracterizadas em: raio de curvatura, microestrutura, dureza, profundidade e morfologia da camada deformada e perfis de tensões residuais. Avaliou-se o efeito do processo nas características do material. Analisando-se os dados, foi possível obter equações semi-empíricas de relação entre processo e raio de curvatura através de um novo parâmetro chamado densidade de energia cinética, que engloba os parâmetros diâmetro de granalha, velocidade de impacto e espessura da chapa. Encontrou-se ainda forte relação entre energia cinética e espessura da camada deformada e profundidade da máxima tensão residual. Os dados experimentais foram utilizados para o treinamento de uma rede neural artificial, que gerou boa previsibilidade do raio de curvatura.

Palavras chave: Jateamento. Alumínio. Ligas aeronáuticas. 



\section{Abstract}

The peen forming process is the forming of metal sheet or panels through the action of a jet of hard spheres, hitting one of the surfaces, making it convex and causing residual compressive stresses on surface. Making the peen forming process reproducible and controllable is a major goal to its safe application in the aircraft industry. Aiming the study of the feasibility of peen forming and the development of its technical knowledge, a methodology for the design of experiments was created focusing on two main topics: process variables and the properties of the formed material. The process variables observed were shot diameter, impact velocity, percentage of coverage and pre-tension. With respect to the formed material, two aluminum alloys (7050-T7451 and 7475T7351) and four different thicknesses were used. The aluminum plates were characterized by: radius of curvature, microstructure, hardness, depth and morphology of the deformed layer and profiles of residual stresses. The effect of the process on material was evaluated. Analyzing the data, semi-empirical equations were obtained for the relationship between process and radius of curvature through a new parameter called the density of kinetic energy, which includes the parameters shot diameter, impact velocity and plate thickness. It was also found a strong relationship between kinetic energy and thickness of the deformed layer and depth of maximum residual stress. Experimental data were used to train an artificial neural network, which generated a good predictability of the radius of curvature.

Keywords: Peen forming. Aluminum. Aerospace alloys. 



\section{Sumário}

\section{Lista de Figuras}

\section{Lista de Tabelas}

1 Introdução 31

1.1 Visão geral . . . . . . . . . . . . . . . . . . 32

1.2 Alumínio e Ligas de Alumínio . . . . . . . . . . . . . . . . 34

1.2 .1 Introdução Geral . . . . . . . . . . . . . . . . . . 34

1.2.2 Ligas AA 7050-T7451 e AA 7475-T7351 . . . . . . . 39

1.3 Conformação por jateamento com granalhas . . . . . . . . . 42

1.3.1 O Processo de jateamento . . . . . . . . . . . 42

1.3.2 Tecnologia do processo . . . . . . . . . . . . . . 45

1.3.3 Camada deformada plasticamente . . . . . . . . . . . 51

1.4 Difração de Elétrons Retroespalhados - EBSD . . . . . . . . 58

1.4.1 Noções básicas de EBSD . . . . . . . . . . . . . . . 58

1.4 .2 Experimentos de EBSD . . . . . . . . . . . . 61

1.4.3 Preparação da amostra . . . . . . . . . . . . . 63

1.5 Medição de Tensões Residuais por Difração de Raios-X . . . . . 66

1.5 .1 Introdução . . . . . . . . . . . . . 66

1.5.2 Perfis de Tensões Residuais . . . . . . . . . . . . 66

1.6 Previsão de deformação . . . . . . . . . . . . . . . . . . . . 71

1.6.1 Redes neurais artificiais . . . . . . . . . . . . . 72

2 Resultados Esperados $\quad 77$

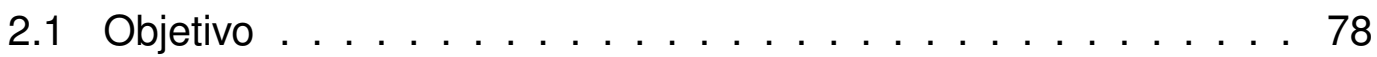


3.1 Confecção dos corpos de prova . . . . . . . . . . . . . . . 82

3.2 Conformação por Jateamento com Granalhas . . . . . . . . . . 83

3.2.1 Matriz de experimentos em JCG . . . . . . . . . . 85

3.3 Medição de curvatura . . . . . . . . . . . . . . . . . 89

3.4 Análise microestrutural . . . . . . . . . . . . . . . . . . 92

3.5 Recristalização . . . . . . . . . . . . . . . . . . . . 93

3.5.1 Tratamentos térmicos $\ldots \ldots \ldots \ldots$

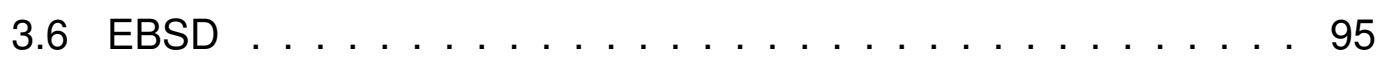

3.7 Perfil de tensões residuais . . . . . . . . . . . . . . . 96

3.8 Redes Neurais Artificiais . . . . . . . . . . . . . . . . . . . . 98

4 Resultados e Discussões 101

4.1 Microscopia óptica . . . . . . . . . . . . . . . . . . . 102

4.1.1 Perfil de microdureza . . . . . . . . . . . . . 108

4.2 Recristalização . . . . . . . . . . . . . . . . . . . . 112

4.2.1 Amostras com baixa intensidade de jateamento . . . . 112

4.2.2 Amostras com média intensidade de jateamento . . . . 117

4.2.3 Amostras com alta intensidade de jateamento . . . . . 121

4.2 .4 Discussão . . . . . . . . . . . . . . . . . . . . 125

4.2 .5 Experimentos de laminação . . . . . . . . . . . . . 126

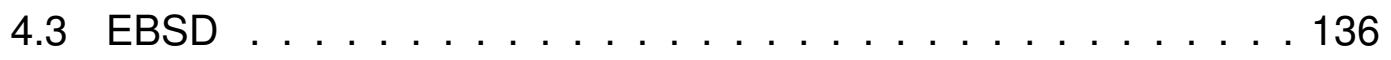

4.4 Deformações . . . . . . . . . . . . . . . . . . . . . . . 139

4.5 Medição de curvatura . . . . . . . . . . . . . . . . . . . 142

4.5.1 Efeitos dos parâmetros . . . . . . . . . . . . . . 142

4.5 .2 Discussão. . . . . . . . . . . . . . . . . . . . . . . 172

4.6 Perfil de tensões residuais . . . . . . . . . . . . . . . . 193

4.6 .1 Discussão . . . . . . . . . . . . . . . . . . . . . . 195 
4.7 Redes Neurais Artificiais . . . . . . . . . . . . . . . . . . . . 203

5 Conclusões

Referências

Apêndice A - Método de determinação de tensões residuais por difração de raios- $X$

Apêndice B - Parâmetros de jateamento dos corpos de prova

225

Apêndice C - Medidas do raio de curvatura dos corpos de prova

237

Apêndice D - Perfis de Tensão Residual 



\section{Lista de Figuras}

1.1 Microestrutura típica da liga 7050-T7451 . . . . . . . . . . 40

1.2 Microestrutura típica da liga 7475-T7351 . . . . . . . . . 40

1.3 Efeito do impacto da granalha na distribuição de tensões: a) no momento do impacto; b) imediatamente após o impacto. . . . . . 43

1.4 Diagramas de tensões indicando carregamento e tensões em chapas sem e com shot peening. Embaixo, o efeito do jateamento durante carregamento em flexão. . . . . . . . . . . . . 44

1.5 Distribuição de tensões residuais em um painel conformado por jateamento de granalhas. . . . . . . . . . . . . . . . 44

1.6 Métodos de conformação por JCG. . . . . . . . . . . . . . . . 46

1.7 O princípio do método de conformação por jateamento com granalhas.

1.8 Esquema do teste da tira Almen. À esquerda, a tira Almen sendo jateada. À direita, a altura do arco sendo medida. Acima, as espessuras $\mathrm{A}, \mathrm{N}$ e $\mathrm{C}$ utilizadas nos ensaios. . . . . . . . 48

1.9 Relações entre $K_{d}^{2}, K_{h}$ e a dureza Vickers da amostra. . . . . 52

1.10 Microestrutura da seção transversal de uma chapa de alumínio 7050 jateada por esferas $\mathrm{S} 230 \ldots \ldots$

1.11 Amostra laminada de alumínio EN AW-1200 mostrando grãos maiores próximos à superfície.

1.12 Resultado prévio de medição de camada deformada plasticamente através de EBSD. (a) Figura de pólo inversa (IPF); (b) Qualidade de imagem (IQ). Espessura da camada $=130 \mu \mathrm{m} . ~ . ~ .56$

1.13 Resultado prévio de medição de camada deformada plasticamente através de EBSD. (a) Figura de pólo inversa (IPF); (b) Qualidade de imagem (IQ). Espessura da camada $=90 \mu \mathrm{m} . ~ . ~ . ~ 57$ 
1.15 Formação do padrão de difração de elétrons retroespalhados. 59

1.16 Padrão de difração de níquel coletado a uma voltagem de aceleração de $20 \mathrm{kV}$. . . . . . . . . . . . . . . . . . 60

1.17 Relações entre os padrões de difração e o cristal. . . . . . . . . 60

1.18 Coloração de mapas de orientação cristalina. . . . . . . . . . . 62

1.19 Mapa de qualidade de imagem mostrando contornos de grão e o contraste de IQ entre grãos de orientações cristalinas diferentes. 63

1.20 Representação esquemática dos perfis de tensões residuais que podem ser esperados após o shot peening. . . . . . . . 67

1.21 Perfis de tensões residuais determinados por difração de raios$X$ para diferentes pressões de jateamento em aço AISI 4140 temperado. . . . . . . . . . . . . . . . 68

1.22 Comparação dos perfis de tensões residuais observados por nêutrons e raios- $X$ após remoção eletrolítica de camadas em um aço AISI 4140 jateado com granalhas, na condição temperada e revenida. . . . . . . . . . . . . . . 69

1.23 Perfil de tensões residuais calculado pelo MEF para diferentes diâmetros de granalha. . . . . . . . . . . . . . . . 70

1.24 Perfil de tensões residuais calculado pelo MEF para diferentes velocidades de impacto das granalhas. . . . . . . . . . 70

1.25 Exemplo de rede neural do tipo feedforward. . . . . . . . . . 74

3.1 Modelos dos corpos de prova jateados. . . . . . . . . . . . 82

3.2 Máquina utilizada para o JCG. . . . . . . . . . . . . . 83

3.3 Esquema da trajetória do bocal para obtenção de cobertura homogênea. . . . . . . . . . . . . . . . . . . 84

3.4 Esquema geométrico de imposição de carga estática aos corpos de prova. . . . . . . . . . . . . . 85

3.5 Localização dos pontos do corpo de prova para medição de coordenadas. . . . . . . . . . . . . . . . . . . . . . 89

3.6 Saída do software QM Data 200 para medição de coordenadas. 90

3.7 Divisões do corpo de prova para obtenção de amostras. . . . . . 94 
3.8 Esquema das seções longitudinal e transversal, em relação às direções de laminação e jateamento de esferas. . . . . . . . . . 95

4.1 Microestrutura da amostra 006_24 (Liga 7050, sem jateamento, sem tratamento térmico). Centro da espessura (seção longitudinal). . . . . . . . . . . . . . . . . . . . . . 103

4.2 Microestrutura da amostra 074_24 (Liga 7475, sem jateamento, sem tratamento térmico). Centro da espessura (seção longitudinal). . . . . . . . . . . . . . . . . . . . . . . 103

4.3 Microestrutura de toda a espessura da amostra $206(7475,5$ mm, pré-tensionada, $\mathrm{S} 230,200 \%) \ldots \ldots . .104$

4.4 Microestrutura da amostra $206(7475,5 \mathrm{~mm}$, pré-tensionada, S230, 200\%), após o jateamento. . . . . . . . . . . . 105

4.5 Microestrutura da amostra 206 (liga 7475, $5 \mathrm{~mm}$, pré-tensionada, S230, 200\%), após o jateamento. . . . . . . . . . . . 105

4.6 Microestrutura da amostra 206 (liga 7475, $5 \mathrm{~mm}$, pré-tensionada, S230, 200\%), após o jateamento. . . . . . . . . . . 106

4.7 Superfície não jateada, observada após ataque Keller (seção longitudinal). Amostra 074_21 (7475, sem TT). . . . . . . . . . 106

4.8 Superfície jateada, observada após ataque Keller (seção longitudinal). Amostra 074_15 (7475, $2 \mathrm{~mm}$, pré-tensionada, S230, 20 psi, 66\%; sem TT). . . . . . . . . . . . . . . . . 107

4.9 Superfície jateada, observada após ataque Keller (seção longitudinal). Amostra 083_14 (7475, 2 mm, pré-tensionada, S230, 60 psi, 92\%; sem TT). . . . . . . . . . . . . . . . . 107

4.10 Micrografia óptica mostrando a microestrutura da liga de alumínio 7475-T7351 nas superfícies longitudinal, transversal e de topo $($ montagem 3D). . . . . . . . . . . . . . . . 108

4.11 Perfil de durezas da amostra 439 (7475, espessura $15 \mathrm{~mm}$, esfera 1/8", alta pressão, alta cobertura, pré-tensionada), da superfície até a metade da espessura. . . . . . . . . . . . . 109

4.12 Perfil de microdurezas em amostras como-recebidas e após o jateamento. . . . . . . . . . . . . . . . . . . 109 
4.13 Perfil de durezas na superfície ao longo de uma direção perpendicular à junta soldada de aços dual phase. . . . . . . . . . . 110

4.14 Perfil de durezas de chapa de alumínio da liga 7050, com $5 \mathrm{~mm}$ de espessura, após JCG. . . . . . . . . . . . . . . . . . . 111

4.15 Microestrutura da amostra 006_01 após o tratamento térmico (liga 7050, 2 mm, livre, S230, 20 psi, 66\%; TT 300 $\mathrm{C}-30 \mathrm{~min}$ ). . . 112

4.16 Microestrutura da amostra 006_05 após o tratamento térmico (liga 7050, 2 mm, livre, S230, 20 psi, 66\%; TT 300 C-60 min). . . 113

4.17 Microestrutura da amostra 006_02 após o tratamento térmico (liga 7050, 2 mm, livre, S230, 20 psi, 66\%; TT 400 $\mathrm{C}-30 \mathrm{~min}$ ). . . 113

4.18 Microestrutura da amostra 006_06 após o tratamento térmico (liga 7050, 2 mm, livre, S230, 20 psi, 66\%; TT 400 $\mathrm{C}-60 \mathrm{~min}$ ). . . 113

4.19 Microestrutura da amostra 006_10 após o tratamento térmico (liga 7050, 2 mm, livre, S230, 20 psi, 66\%; TT 400 ${ }^{\circ} \mathrm{C}-120 \mathrm{~min}$ ). . 114

4.20 Microestrutura da amostra 006_03 após o tratamento térmico (liga 7050, 2 mm, livre, S230, 20 psi, 66\%; TT 500 C-15 min). . . 114

4.21 Microestrutura da amostra 006_07 após o tratamento térmico (liga 7050, 2 mm, livre, S230, 20 psi, 66\%; TT 500 ${ }^{\circ} \mathrm{C}-30 \mathrm{~min}$ ). . . 114

4.22 Microestrutura da amostra 006_11 após o tratamento térmico (liga 7050, 2 mm, livre, S230, 20 psi, 66\%; TT 500 ${ }^{\circ} \mathrm{C}-60 \mathrm{~min}$ ). . . 115

4.23 Microestrutura da amostra 006_16 sem tratamento térmico (liga 7050, 2 mm, livre, S230, 20 psi, 66\%). . . . . . . . . . . 115

4.24 Microestrutura da amostra 006_20 após o tratamento térmico (liga 7050, $2 \mathrm{~mm}$, sem jateamento; TT 400 ${ }^{\circ} \mathrm{C}-60 \mathrm{~min}$ ). . . . . . 115

4.25 Microestrutura da amostra 006_22 após o tratamento térmico (liga 7050, 2 mm, sem jateamento; TT 500 ${ }^{\circ} \mathrm{C}-60 \mathrm{~min}$ ). . . . . . . 116

4.26 Microestrutura da amostra 006_24 sem tratamento térmico (liga 7050, 2 mm, sem jateamento). . . . . . . . . . . . 116

4.27 Microestrutura da amostra 074_01 após o tratamento térmico (liga 7475, $2 \mathrm{~mm}$, pré-tensionada, S230, $20 \mathrm{psi}, 66 \%$; TT $300^{\circ} \mathrm{C}$ 30 min) . . . . . . . . . . . . . . . . . . . . . . 117 
4.28 Microestrutura da amostra 074_02 após o tratamento térmico (liga 7475, $2 \mathrm{~mm}$, pré-tensionada, S230, $20 \mathrm{psi}, 66 \%$; TT $400^{\circ} \mathrm{C}$ $30 \min ) \ldots \ldots \ldots \ldots$. . . . . . . . . . . . . 117

4.29 Microestrutura da amostra 074_06 após o tratamento térmico (liga 7475, $2 \mathrm{~mm}$, pré-tensionada, S230, 20 psi, 66\%; TT $400^{\circ} \mathrm{C}$ 60 min). . . . . . . . . . . . . . . . . . . . 118

4.30 Microestrutura da amostra 074_10 após o tratamento térmico (liga 7475, $2 \mathrm{~mm}$, pré-tensionada, S230, 20 psi, 66\%; TT $400^{\circ} \mathrm{C}$ $120 \mathrm{~min})$.

4.31 Microestrutura da amostra 074_07 após o tratamento térmico (liga 7475, $2 \mathrm{~mm}$, pré-tensionada, S230, $20 \mathrm{psi}, 66 \%$; TT $500^{\circ} \mathrm{C}$ $30 \mathrm{~min})$

4.32 Microestrutura da amostra 074_11 após o tratamento térmico (liga 7475, $2 \mathrm{~mm}$, pré-tensionada, S230, 20 psi, 66\%; TT 500 $\mathrm{C}$ $60 \mathrm{~min})$

4.33 Microestrutura da amostra 074_16 sem tratamento térmico (liga 7475, 2 mm, pré-tensionada, S230, 20 psi, 66\%) . . . . . . . . 119

4.34 Microestrutura da amostra 074_20 após o tratamento térmico (liga 7475, 2 mm, sem jateamento; TT 400 C-60 min). . . . . . 119

4.35 Microestrutura da amostra 074_22 após o tratamento térmico (liga 7475, 2 mm, sem jateamento; TT 500 ${ }^{\circ} \mathrm{C}-60 \mathrm{~min}$ ). . . . . . 120

4.36 Microestrutura da amostra 074_24 sem tratamento térmico (liga 7475,2 mm, sem jateamento). . . . . . . . . . . . . . 120

4.37 Microestrutura da amostra 083_01 após o tratamento térmico (liga 7475, $2 \mathrm{~mm}$, pré-tensionada, S230, $60 \mathrm{psi}, 92 \%$; TT $300^{\circ} \mathrm{C}$ $30 \mathrm{~min})$

4.38 Microestrutura da amostra 083_02 após o tratamento térmico (liga 7475, $2 \mathrm{~mm}$, pré-tensionada, S230, $60 \mathrm{psi}, 92 \%$; TT $400^{\circ} \mathrm{C}$ $30 \mathrm{~min})$

4.39 Microestrutura da amostra 083_06 após o tratamento térmico (liga 7475, $2 \mathrm{~mm}$, pré-tensionada, S230, $60 \mathrm{psi}, 92 \%$; TT $400^{\circ} \mathrm{C}$ $60 \mathrm{~min})$ 
4.40 Microestrutura da amostra 083_10 após o tratamento térmico (liga 7475, $2 \mathrm{~mm}$, pré-tensionada, S230, $60 \mathrm{psi}, 92 \%$; TT $400^{\circ} \mathrm{C}$ $120 \mathrm{~min}$ ). . . . . . . . . . . . . . . . . . . . . 122

4.41 Microestrutura da amostra 083_03 após o tratamento térmico (liga 7475, $2 \mathrm{~mm}$, pré-tensionada, S230, $60 \mathrm{psi}, 92 \%$; TT 500 $\mathrm{C}$ -

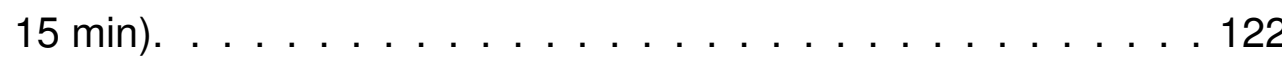

4.42 Microestrutura da amostra 083_07 após o tratamento térmico (liga 7475, $2 \mathrm{~mm}$, pré-tensionada, $\mathrm{S} 230,60 \mathrm{psi}, 92 \%$; TT $500^{\circ} \mathrm{C}$ $30 \mathrm{~min}$ ). . . . . . . . . . . . . . . . . . . . 123

4.43 Microestrutura da amostra 083_11 após o tratamento térmico (liga 7475, $2 \mathrm{~mm}$, pré-tensionada, S230, $60 \mathrm{psi}, 92 \%$; TT 500 $\mathrm{C}$ -

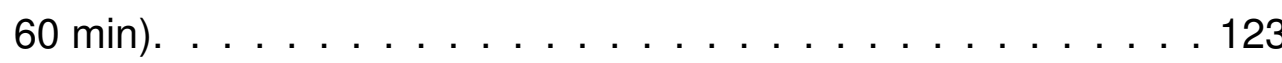

4.44 Microestrutura da amostra 083_16 sem tratamento térmico (liga 7475, 2 mm, pré-tensionada, S230, 60 psi, 92\%). . . . . . . . 123

4.45 Microestrutura da amostra 083_20 após o tratamento térmico (liga 7475, 2 mm, sem jateamento; TT 400 ${ }^{\circ} \mathrm{C}-60 \mathrm{~min}$ ). . . . . . . 124

4.46 Microestrutura da amostra 083_22 após o tratamento térmico (liga 7475, $2 \mathrm{~mm}$, sem jateamento; TT 500 ${ }^{\circ} \mathrm{C}-60 \mathrm{~min}$ ). . . . . . 124

4.47 Microestrutura da amostra 083_24 sem tratamento térmico (liga 7475,2 mm, sem jateamento. . . . . . . . . . . . . . . . . 124

4.48 Indicação da espessura da camada recristalizada após tratamento térmico na amostra 083_07 (liga 7475, $2 \mathrm{~mm}$, pré-tensionada,

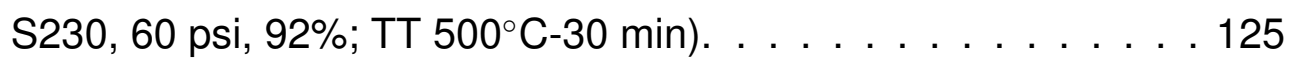

4.49 Microestrutura da amostra 357A . . . . . . . . . . . . . 127

4.50 Microestrutura da amostra 369A . . . . . . . . . . . . . . 127

4.51 Microestrutura da amostra 357B . . . . . . . . . . . . . 128

4.52 Microestrutura da amostra 369B . . . . . . . . . . . . . 128

4.53 Microestrutura da amostra 357C . . . . . . . . . . . . . 129

4.54 Microestrutura da amostra 369C . . . . . . . . . . . . . 129

4.55 Microestrutura da amostra 357D. . . . . . . . . . . 130

4.56 Microestrutura da amostra 369D . . . . . . . . . . . . . 130

4.57 Microestrutura da amostra 357E. . . . . . . . . . . . . . . 131 
4.58 Microestrutura da amostra 369E. . . . . . . . . . . . . . . . . 131

4.59 Microestrutura da amostra 357F. . . . . . . . . . . . . . 132

4.60 Microestrutura da amostra 369F. . . . . . . . . . . . . . 132

4.61 Microestrutura da amostra 357G. . . . . . . . . . . . . . 133

4.62 Microestrutura da amostra 369G. . . . . . . . . . . . . . . . 133

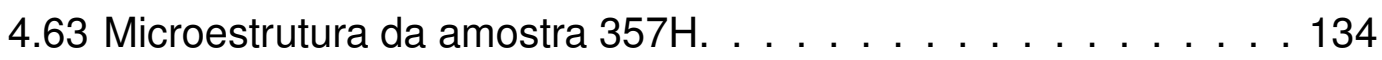

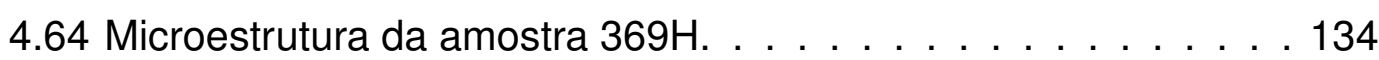

4.65 Mapa de EBSD obtido da amostra $090 . \quad \ldots \ldots$. . . . . . . . 136

4.66 Mapa de EBSD obtido da amostra 206 . . . . . . . . . . 137

4.67 Mapa de EBSD obtido da amostra 252 . . . . . . . . . . . 137

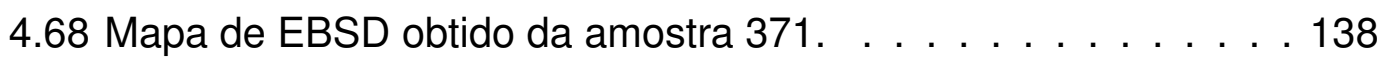

4.69 Efeitos das variáveis de jateamento no empenamento de corpos de prova da liga 7050, de espessura $2 \mathrm{~mm}$. . . . . . . . . 139

4.70 Esquema do dispositivo de medição de velocidade de impactos utilizado pelo IPT. . . . . . . . . . . . . . . . . . . . . 140

4.71 Efeito da cobertura sobre o raio de curvatura. Chapas da liga 7050, espessura 2 mm, jateadas com esfera S230 . . . . . . . 144

4.72 Efeito da cobertura sobre o raio de curvatura. Chapas da liga 7475, espessura 2 mm, jateadas com esfera S230 . . . . . . . 145

4.73 Efeito da cobertura sobre o raio de curvatura. Chapas da liga 7050, espessura 5 mm, jateadas com esfera S230 . . . . . . 145

4.74 Efeito da cobertura sobre o raio de curvatura. Chapas da liga 7475, espessura $5 \mathrm{~mm}$, jateadas com esfera S230 . . . . . . 146

4.75 Efeito da cobertura sobre o raio de curvatura. Chapas da liga 7050, espessura $5 \mathrm{~mm}$, jateadas com esfera S550 . . . . . . 146

4.76 Efeito da cobertura sobre o raio de curvatura. Chapas da liga 7475, espessura $5 \mathrm{~mm}$, jateadas com esfera S550. . . . . . . 147

4.77 Efeito da cobertura sobre o raio de curvatura. Chapas da liga 7050, espessura $10 \mathrm{~mm}$, jateadas com esfera S550 . . . . . . 147 
4.78 Efeito da cobertura sobre o raio de curvatura. Chapas da liga 7475 , espessura $10 \mathrm{~mm}$, jateadas com esfera S550. . . . . . 148

4.79 Efeito da cobertura sobre o raio de curvatura. Chapas da liga 7050, espessura $10 \mathrm{~mm}$, jateadas com esfera $1 / 8$ ". . . . . . . . 148

4.80 Efeito da cobertura sobre o raio de curvatura. Chapas da liga 7475, espessura $10 \mathrm{~mm}$, jateadas com esfera $1 / 8$ ". . . . . . . . 149

4.81 Efeito da cobertura sobre o raio de curvatura. Chapas da liga 7050, espessura 15 mm, jateadas com esfera 1/8". . . . . . . . 149

4.82 Efeito da cobertura sobre o raio de curvatura. Chapas da liga 7475 , espessura $15 \mathrm{~mm}$, jateadas com esfera $1 / 8$ ". . . . . . . 150

4.83 Efeito do diâmetro da esfera sobre o raio de curvatura. Chapas da liga 7050 , espessura $5 \mathrm{~mm}$, baixa cobertura. . . . . . . 150

4.84 Efeito do diâmetro da esfera sobre o raio de curvatura. Chapas da liga 7050 , espessura $10 \mathrm{~mm}$, baixa cobertura. . . . . . . . 151

4.85 Efeito do diâmetro da esfera sobre o raio de curvatura. Chapas da liga 7475 , espessura $5 \mathrm{~mm}$, baixa cobertura. . . . . . . . 151

4.86 Efeito do diâmetro da esfera sobre o raio de curvatura. Chapas da liga 7475 , espessura $10 \mathrm{~mm}$, baixa cobertura. . . . . . . . 152

4.87 Efeito do diâmetro da esfera sobre o raio de curvatura. Chapas da liga 7050, espessura $5 \mathrm{~mm}$, alta cobertura. . . . . . . . 152

4.88 Efeito do diâmetro da esfera sobre o raio de curvatura. Chapas da liga 7050 , espessura $10 \mathrm{~mm}$, alta cobertura. . . . . . . . 153

4.89 Efeito do diâmetro da esfera sobre o raio de curvatura. Chapas da liga 7475 , espessura $5 \mathrm{~mm}$, alta cobertura. . . . . . . . 153

4.90 Efeito do diâmetro da esfera sobre o raio de curvatura. Chapas da liga 7475 , espessura $10 \mathrm{~mm}$, alta cobertura. . . . . . . . . 154

4.91 Efeito do diâmetro da esfera sobre o raio de curvatura. Chapas da liga 7050 , espessura $5 \mathrm{~mm}$, baixa pressão do jato. . . . . . 154

4.92 Efeito do diâmetro da esfera sobre o raio de curvatura. Chapas da liga 7050, espessura 5 mm, média pressão do jato. . . . . . . 155

4.93 Efeito do diâmetro da esfera sobre o raio de curvatura. Chapas da liga 7050 , espessura $5 \mathrm{~mm}$, alta pressão do jato. . . . . . . 155 
4.94 Efeito do diâmetro da esfera sobre o raio de curvatura. Chapas da liga 7475 , espessura $5 \mathrm{~mm}$, baixa pressão do jato. . . . . . . 156

4.95 Efeito do diâmetro da esfera sobre o raio de curvatura. Chapas da liga 7475 , espessura $5 \mathrm{~mm}$, média pressão do jato. . . . . . . 156

4.96 Efeito do diâmetro da esfera sobre o raio de curvatura. Chapas da liga 7475 , espessura $5 \mathrm{~mm}$, alta pressão do jato. . . . . . . 157

4.97 Efeito do diâmetro da esfera sobre o raio de curvatura. Chapas da liga 7050, espessura $10 \mathrm{~mm}$, baixa pressão do jato. . . . . . 157

4.98 Efeito do diâmetro da esfera sobre o raio de curvatura. Chapas da liga 7050, espessura $10 \mathrm{~mm}$, média pressão do jato. . . . . . 158

4.99 Efeito do diâmetro da esfera sobre o raio de curvatura. Chapas da liga 7050 , espessura $10 \mathrm{~mm}$, alta pressão do jato. . . . . . 158

4.100Efeito do diâmetro da esfera sobre o raio de curvatura. Chapas da liga 7475 , espessura $10 \mathrm{~mm}$, baixa pressão do jato. . . . . . 159

4.101Efeito do diâmetro da esfera sobre o raio de curvatura. Chapas da liga 7475, espessura $10 \mathrm{~mm}$, média pressão do jato. . . . . . 159

4.102Efeito do diâmetro da esfera sobre o raio de curvatura. Chapas da liga 7475 , espessura $10 \mathrm{~mm}$, alta pressão do jato. . . . . . 160

4.103Efeito da velocidade de impacto sobre o raio de curvatura. Chapas da liga 7050, espessura $2 \mathrm{~mm}$, jateadas com esfera S230. . 160

4.104Efeito da velocidade de impacto sobre o raio de curvatura. Chapas da liga 7050, espessura $5 \mathrm{~mm}$, jateadas com esfera S230. . 161

4.105Efeito da velocidade de impacto sobre o raio de curvatura. Chapas da liga 7050, espessura $5 \mathrm{~mm}$, jateadas com esfera S550. . 161

4.106Efeito da velocidade de impacto sobre o raio de curvatura. Chapas da liga 7050, espessura $10 \mathrm{~mm}$, jateadas com esfera S550. 162 4.107Efeito da velocidade de impacto sobre o raio de curvatura. Chapas da liga 7050, espessura $10 \mathrm{~mm}$, jateadas com esfera 1/8". . 162 4.108Efeito da velocidade de impacto sobre o raio de curvatura. Chapas da liga 7050, espessura $15 \mathrm{~mm}$, jateadas com esfera 1/8". . 163 4.109Efeito da velocidade de impacto sobre o raio de curvatura. Chapas da liga 7475, espessura $2 \mathrm{~mm}$, jateadas com esfera S230. . 163 
4.110Efeito da velocidade de impacto sobre o raio de curvatura. Chapas da liga 7475, espessura $5 \mathrm{~mm}$, jateadas com esfera S230. . 164

4.111 Efeito da velocidade de impacto sobre o raio de curvatura. Chapas da liga 7475, espessura $5 \mathrm{~mm}$, jateadas com esfera S550 . 164

4.112Efeito da velocidade de impacto sobre o raio de curvatura. Chapas da liga 7475, espessura $10 \mathrm{~mm}$, jateadas com esfera S550. 165

4.113Efeito da velocidade de impacto sobre o raio de curvatura. Chapas da liga 7475, espessura $10 \mathrm{~mm}$, jateadas com esfera 1/8". . 165

4.114Efeito da velocidade de impacto sobre o raio de curvatura. Chapas da liga 7475, espessura $15 \mathrm{~mm}$, jateadas com esfera 1/8". . 166

4.115Efeito da espessura da chapa sobre o raio de curvatura. Chapas da liga 7050, jateadas com esfera S230, baixa cobertura. . . 166

4.116 Efeito da espessura da chapa sobre o raio de curvatura. Chapas da liga 7050, jateadas com esfera S550, baixa cobertura. . . 167

4.117 Efeito da espessura da chapa sobre o raio de curvatura. Chapas da liga 7050, jateadas com esfera 1/8", baixa cobertura. . . 167

4.118Efeito da espessura da chapa sobre o raio de curvatura. Chapas da liga 7050, jateadas com esfera S230, alta cobertura. . . 168

4.119Efeito da espessura da chapa sobre o raio de curvatura. Chapas da liga 7050, jateadas com esfera S550, alta cobertura. . . 168

4.120 Efeito da espessura da chapa sobre o raio de curvatura. Chapas da liga 7050, jateadas com esfera 1/8", alta cobertura. . . . 169

4.121 Efeito da espessura da chapa sobre o raio de curvatura. Chapas da liga 7475, jateadas com esfera S230, baixa cobertura. . . 169

4.122 Efeito da espessura da chapa sobre o raio de curvatura. Chapas da liga 7475, jateadas com esfera S550, baixa cobertura. . . 170

4.123 Efeito da espessura da chapa sobre o raio de curvatura. Chapas da liga 7475 , jateadas com esfera 1/8", baixa cobertura. . . 170

4.124 Efeito da espessura da chapa sobre o raio de curvatura. Chapas da liga 7475 , jateadas com esfera $\mathrm{S} 230$, alta cobertura. . . . 171

4.125Efeito da espessura da chapa sobre o raio de curvatura. Chapas da liga 7475 , jateadas com esfera $\$ 550$, alta cobertura. . . . 171 
4.126 Efeito da espessura da chapa sobre o raio de curvatura. Chapas da liga 7475 , jateadas com esfera 1/8", alta cobertura. . . . 172

4.127 Efeito da espessura da chapa sobre $r / H^{2}$. Chapas da liga 7050, jateadas com esfera S230, baixa cobertura. . . . . . . . 174

4.128 Efeito da espessura da chapa sobre $r / H^{2}$. Chapas da liga 7475 , jateadas com esfera S230, baixa cobertura. . . . . . . 174

4.129 Efeito da espessura da chapa sobre $r / H^{2}$. Chapas da liga 7050, jateadas com esfera S550, baixa cobertura. . . . . . . 175

4.130 Efeito da espessura da chapa sobre $r / H^{2}$. Chapas da liga 7475 , jateadas com esfera S550, baixa cobertura. . . . . . . 175

4.131 Efeito da espessura da chapa sobre $r / H^{2}$. Chapas da liga 7050, jateadas com esfera 1/8", baixa cobertura. . . . . . . . 176

4.132 Efeito da espessura da chapa sobre $r / H^{2}$. Chapas da liga 7475 , jateadas com esfera $1 / 8$ ", baixa cobertura. . . . . . . . 176

4.133 Efeito da espessura da chapa sobre $r / H^{2}$. Chapas da liga 7050, jateadas com esfera S230, alta cobertura. . . . . . . . . 177

4.134 Efeito da espessura da chapa sobre $r / H^{2}$. Chapas da liga 7475, jateadas com esfera S230, alta cobertura. . . . . . . . . 177

4.135 Efeito da espessura da chapa sobre $r / H^{2}$. Chapas da liga 7050, jateadas com esfera S550, alta cobertura. . . . . . . . 178

4.136 Efeito da espessura da chapa sobre $r / H^{2}$. Chapas da liga 7475 , jateadas com esfera $\$ 550$, alta cobertura. . . . . . . 178

4.137 Efeito da espessura da chapa sobre $r / H^{2}$. Chapas da liga 7050, jateadas com esfera $1 / 8$ ", alta cobertura. . . . . . . . 179

4.138 Efeito da espessura da chapa sobre $r / H^{2}$. Chapas da liga 7475, jateadas com esfera 1/8", alta cobertura. . . . . . . . . 179

4.139 Efeito da liga sobre $r / H^{2}$. Chapas jateadas com esfera S230, baixa cobertura. . . . . . . . . . . . . . . . . 180

4.140 Efeito da liga sobre $r / H^{2}$. Chapas jateadas com esfera S550, baixa cobertura. . . . . . . . . . . . . . . . . 180

4.141 Efeito da liga sobre $r / H^{2}$. Chapas jateadas com esfera 1/8", baixa cobertura. . . . . . . . . . . . . . . . . . 181 
4.142 Efeito da liga sobre $r / H^{2}$. Chapas jateadas com esfera S230, alta cobertura. . . . . . . . . . . . . . . . . 181

4.143 Efeito da liga sobre $r / H^{2}$. Chapas jateadas com esfera S550, alta cobertura. . . . . . . . . . . . . . . . . . 182

4.144 Efeito da liga sobre $r / H^{2}$. Chapas jateadas com esfera 1/8", alta cobertura. . . . . . . . . . . . . . . . . . 182

4.145Efeito da cobertura sobre $r / H^{2}$. Chapas das ligas 7050 e 7475 jateadas com esfera $\mathrm{S} 230 . \ldots \ldots$. . . . . . . . . 183

4.146Efeito da cobertura sobre $r / H^{2}$. Chapas das ligas 7050 e 7475 jateadas com esfera $\$ 550 . \ldots \ldots$. . . . . . . . 183

4.147Efeito da cobertura sobre $r / H^{2}$. Chapas das ligas 7050 e 7475

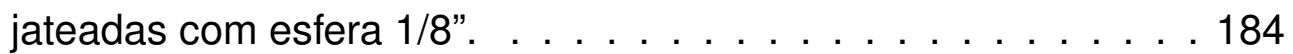

4.148 Efeito do diâmetro da esfera sobre $r / H^{2}$. Chapas das ligas 7050 e 7475 jateadas com baixa cobertura. . . . . . . . . . . 184

4.149 Efeito do diâmetro da esfera sobre $r / H^{2}$. Chapas das ligas 7050 e 7475 jateadas com alta cobertura. . . . . . . . . . . 185

4.150 Efeito do diâmetro da esfera sobre $r / H^{2}$. Chapas das ligas 7050 e 7475 jateadas com baixa pressão. . . . . . . . . . . 185

4.151 Efeito do diâmetro da esfera sobre $r / H^{2}$. Chapas das ligas 7050 e 7475 jateadas com média pressão. . . . . . . . . . 186

4.152 Efeito do diâmetro da esfera sobre $r / H^{2}$. Chapas das ligas 7050 e 7475 jateadas com alta pressão. . . . . . . . . . . . 186

4.153Efeito da velocidade de impacto sobre $r / H^{2}$. Chapas das ligas 7050 e 7475 jateadas com baixa cobertura. . . . . . . . . . . 187

4.154Efeito da velocidade de impacto sobre $r / H^{2}$. Chapas das ligas 7050 e 7475 jateadas com alta cobertura. . . . . . . . . . . 187

4.155 Relação entre energia cinética e raio de curvatura dos corpos de prova conformados por jateamento de esferas. . . . . . . . 189

4.156Relação entre energia cinética e raio de curvatura normalizado dos corpos de prova conformados por jateamento de esferas. . . 190

4.157 Relação entre densidade de energia cinética e raio de curvatura dos corpos de prova conformados por jateamento de esferas.192 
4.158 Perfil de tensões residuais após JCG em chapa da liga 7050, $2 \mathrm{~mm}$ de espessura, esfera S230, velocidade baixa, sem prétensão.

4.159 Perfil de tensões residuais, com valores de máxima tensão de compressão e espessura da camada deformada, mostrando inflexão a $150 \mu \mathrm{m}$ da superfície.

4.160 Relação entre profundidade de máxima compressão $\left(x_{\min }\right)$ e energia cinética $\left(E_{C}\right) . \ldots \ldots \ldots$

4.161 Relação entre máxima tensão residual de compressão $\left(\mathrm{y}_{\min }\right)$ e energia cinética $\left(\mathrm{E}_{C}\right) . \ldots \ldots \ldots$

4.162 Relação entre espessura da camada deformada (h) e energia cinética $\left(\mathrm{E}_{C}\right) . \ldots \ldots$. . . . . . . . . . . . . . 198

4.163 Relação entre profundidade de máxima compressão $\left(\mathrm{x}_{\min }\right) \mathrm{e}$ densidade de energia cinética $(K)$. . . . . . . . . . 198

4.164Relação entre máxima tensão residual de compressão $\left(\mathrm{y}_{\min }\right) \mathrm{e}$ densidade de energia cinética $(K)$. . . . . . . . . . . . . 199

4.165 Relação entre espessura da camada deformada (h) e densidade de energia cinética $(K)$. . . . . . . . . . . . . . 199

4.166 Relação entre profundidade de máxima compressão $\left(\mathrm{x}_{\min }\right) \mathrm{e}$ raio de curvatura $(r) \ldots \ldots \ldots$. . . . . . . . . . 200

4.167Relação entre máxima tensão residual de compressão $\left(\mathrm{y}_{\min }\right) \mathrm{e}$ raio de curvatura $(r) \ldots \ldots \ldots$. . . . . . . . . . 200

4.168 Relação entre espessura da camada deformada (h) e raio de curvatura $(r) \ldots \ldots \ldots$. . . . . . . . . . . . . . 201

4.169 Relação entre profundidade de máxima compressão $\left(\mathrm{x}_{\min }\right)$ e raio de curvatura normalizado $\left(r / H^{2}\right) \ldots \ldots \ldots$. . . . . 201

4.170Relação entre máxima tensão residual de compressão $\left(\mathbf{y}_{\min }\right)$ e raio de curvatura normalizado $\left(r / H^{2}\right)$. . . . . . . . . 202

4.171 Relação entre espessura da camada deformada (h) e raio de curvatura normalizado $\left(r / H^{2}\right) . \quad \ldots \ldots$. . . . . . . . 202

4.172Aderência da rede neural artificial aos 62 testes (exemplares). . 203

4.173Correlação entre a previsão de curvatura e os dados reais. . . . 204 
4.174 Efeito da velocidade de impacto sobre $\mathrm{r} / \mathrm{H}^{2}$. Chapas com cobertura baixa. . . . . . . . . . . . . . . . . 206

4.175 Efeito da velocidade de impacto sobre $\mathrm{r} / \mathrm{H}^{2}$. Chapas com cobertura alta. . . . . . . . . . . . . . . . 206

4.176 Efeito da cobertura sobre $r / \mathrm{H}^{2}$. Granalha S230. . . . . . . . 207

4.177Efeito da cobertura sobre $\mathrm{r} / \mathrm{H}^{2}$. Granalha S550. . . . . . . 208

4.178Efeito da cobertura sobre $r / \mathrm{H}^{2}$. Granalha $1 / 8$ ". . . . . . . . . 208

A.1 Relações angulares entre a tensão a ser medida $\left(\sigma_{\phi}\right)$, tensões principais $\left(\sigma_{1}, \sigma_{2}\right.$ e $\left.\sigma_{3}\right)$, e eixos arbitrários $(x, y$ e $z) \ldots \ldots \ldots 222$

D.1 Perfil de tensões residuais, com valores de máxima tensão de compressão e espessura da camada deformada. Chapa da liga 7050, espessura $2 \mathrm{~mm}$, esfera S230, velocidade baixa, sem prétensão. . . . . . . . . . . . . . . . . . . . . . 251

D.2 Perfil de tensões residuais, com valores de máxima tensão de compressão e espessura da camada deformada. Chapa da liga 7050, espessura $2 \mathrm{~mm}$, esfera S230, velocidade média, sem pré-tensão. . . . . . . . . . . . . . . . . . . . . . 252

D.3 Perfil de tensões residuais, com valores de máxima tensão de compressão e espessura da camada deformada. Chapa da liga 7050 , espessura $2 \mathrm{~mm}$, esfera S230, velocidade alta, sem prétensão.

D.4 Perfil de tensões residuais, com valores de máxima tensão de compressão e espessura da camada deformada. Chapa da liga 7050 , espessura $2 \mathrm{~mm}$, esfera S230, velocidade baixa, com prétensão.

D.5 Perfil de tensões residuais, com valores de máxima tensão de compressão e espessura da camada deformada. Chapa da liga 7050, espessura $2 \mathrm{~mm}$, esfera S230, velocidade média, com pré-tensão.

D.6 Perfil de tensões residuais, com valores de máxima tensão de compressão e espessura da camada deformada. Chapa da liga 7050, espessura 2 mm, esfera S230, velocidade alta, com prétensão. 
D.7 Perfil de tensões residuais, com valores de máxima tensão de compressão e espessura da camada deformada. Chapa da liga 7050 , espessura $5 \mathrm{~mm}$, esfera S230, velocidade baixa, sem prétensão.

D.8 Perfil de tensões residuais, com valores de máxima tensão de compressão e espessura da camada deformada. Chapa da liga 7050, espessura $5 \mathrm{~mm}$, esfera S230, velocidade média, sem pré-tensão.

D.9 Perfil de tensões residuais, com valores de máxima tensão de compressão e espessura da camada deformada. Chapa da liga 7050, espessura $5 \mathrm{~mm}$, esfera S230, velocidade alta, sem prétensão.

D.10 Perfil de tensões residuais, com valores de máxima tensão de compressão e espessura da camada deformada. Chapa da liga 7050 , espessura $5 \mathrm{~mm}$, esfera S230, velocidade baixa, com prétensão.

D.11 Perfil de tensões residuais, com valores de máxima tensão de compressão e espessura da camada deformada. Chapa da liga 7050 , espessura $5 \mathrm{~mm}$, esfera S230, velocidade média, com pré-tensão.

D.12 Perfil de tensões residuais, com valores de máxima tensão de compressão e espessura da camada deformada. Chapa da liga 7050 , espessura $5 \mathrm{~mm}$, esfera S230, velocidade alta, com prétensão.

D.13 Perfil de tensões residuais, com valores de máxima tensão de compressão e espessura da camada deformada. Chapa da liga 7050 , espessura $5 \mathrm{~mm}$, esfera S550, velocidade baixa, sem prétensão.

D.14 Perfil de tensões residuais, com valores de máxima tensão de compressão e espessura da camada deformada. Chapa da liga 7050, espessura $5 \mathrm{~mm}$, esfera S550, velocidade média, sem pré-tensão. 
D.15 Perfil de tensões residuais, com valores de máxima tensão de compressão e espessura da camada deformada. Chapa da liga 7050 , espessura $5 \mathrm{~mm}$, esfera S550, velocidade alta, sem prétensão.

D.16 Perfil de tensões residuais, com valores de máxima tensão de compressão e espessura da camada deformada. Chapa da liga 7050 , espessura $5 \mathrm{~mm}$, esfera S550, velocidade baixa, com prétensão.

D.17 Perfil de tensões residuais, com valores de máxima tensão de compressão e espessura da camada deformada. Chapa da liga 7050, espessura $5 \mathrm{~mm}$, esfera S550, velocidade média, com pré-tensão.

D.18 Perfil de tensões residuais, com valores de máxima tensão de compressão e espessura da camada deformada. Chapa da liga 7050 , espessura $5 \mathrm{~mm}$, esfera $\mathrm{S} 550$, velocidade alta, com prétensão.

D.19 Perfil de tensões residuais, com valores de máxima tensão de compressão e espessura da camada deformada. Chapa da liga 7050, espessura $10 \mathrm{~mm}$, esfera S550, velocidade baixa, sem pré-tensão.

D.20 Perfil de tensões residuais, com valores de máxima tensão de compressão e espessura da camada deformada. Chapa da liga 7050, espessura $10 \mathrm{~mm}$, esfera S550, velocidade média, sem pré-tensão.

D.21 Perfil de tensões residuais, com valores de máxima tensão de compressão e espessura da camada deformada. Chapa da liga 7050, espessura $10 \mathrm{~mm}$, esfera S550, velocidade alta, sem prétensão.

D.22 Perfil de tensões residuais, com valores de máxima tensão de compressão e espessura da camada deformada. Chapa da liga 7050 , espessura $10 \mathrm{~mm}$, esfera S550, velocidade baixa, com pré-tensão. 
D.23 Perfil de tensões residuais, com valores de máxima tensão de compressão e espessura da camada deformada. Chapa da liga 7050, espessura $10 \mathrm{~mm}$, esfera S550, velocidade média, com pré-tensão. . . . . . . . . . . . . . . . . . . . . . 262

D.24 Perfil de tensões residuais, com valores de máxima tensão de compressão e espessura da camada deformada. Chapa da liga 7050 , espessura $10 \mathrm{~mm}$, esfera S550, velocidade alta, com prétensão.

D.25 Perfil de tensões residuais, com valores de máxima tensão de compressão e espessura da camada deformada. Chapa da liga 7050 , espessura $10 \mathrm{~mm}$, esfera 1/8", velocidade baixa, sem prétensão.

D.26 Perfil de tensões residuais, com valores de máxima tensão de compressão e espessura da camada deformada. Chapa da liga 7050 , espessura $10 \mathrm{~mm}$, esfera 1/8", velocidade média, sem pré-tensão.

D.27 Perfil de tensões residuais, com valores de máxima tensão de compressão e espessura da camada deformada. Chapa da liga 7050 , espessura $10 \mathrm{~mm}$, esfera 1/8", velocidade alta, sem prétensão.

D.28 Perfil de tensões residuais, com valores de máxima tensão de compressão e espessura da camada deformada. Chapa da liga 7050, espessura $10 \mathrm{~mm}$, esfera 1/8", velocidade baixa, com prétensão.

D.29 Perfil de tensões residuais, com valores de máxima tensão de compressão e espessura da camada deformada. Chapa da liga 7050 , espessura $10 \mathrm{~mm}$, esfera 1/8", velocidade média, com pré-tensão.

D.30 Perfil de tensões residuais, com valores de máxima tensão de compressão e espessura da camada deformada. Chapa da liga 7050 , espessura $10 \mathrm{~mm}$, esfera 1/8", velocidade alta, com prétensão. 
D.31 Perfil de tensões residuais, com valores de máxima tensão de compressão e espessura da camada deformada. Chapa da liga 7050 , espessura $15 \mathrm{~mm}$, esfera $1 / 8$ ", velocidade baixa, sem prétensão.

D.32 Perfil de tensões residuais, com valores de máxima tensão de compressão e espessura da camada deformada. Chapa da liga 7050, espessura $15 \mathrm{~mm}$, esfera 1/8", velocidade média, sem pré-tensão. . . . . . . . . . . . . . . . . . . . . 267

D.33 Perfil de tensões residuais, com valores de máxima tensão de compressão e espessura da camada deformada. Chapa da liga 7050 , espessura $15 \mathrm{~mm}$, esfera 1/8", velocidade alta, sem prétensão.

D.34 Perfil de tensões residuais, com valores de máxima tensão de compressão e espessura da camada deformada. Chapa da liga 7050 , espessura $15 \mathrm{~mm}$, esfera 1/8", velocidade baixa, com prétensão.

D.35 Perfil de tensões residuais, com valores de máxima tensão de compressão e espessura da camada deformada. Chapa da liga 7050 , espessura $15 \mathrm{~mm}$, esfera 1/8", velocidade média, com pré-tensão. . . . . . . . . . . . . . . . . . . . . . . . . . 268

D.36 Perfil de tensões residuais, com valores de máxima tensão de compressão e espessura da camada deformada. Chapa da liga 7050, espessura $15 \mathrm{~mm}$, esfera 1/8", velocidade alta, com prétensão. 


\section{Lista de Tabelas}

1.1 Dados de propriedades dos materiais disponíveis para as ligas de alumínio 7050 e 7475 . . . . . . . . . . . . . . . . . 41

3.1 Matriz de experimentos. . . . . . . . . . . . . . . 8 87

3.2 Valores de interesse para o cálculo da curvatura da chapa medida. 90

3.3 Condições de jateamento dos CPs selecionados. . . . . . . . . . 93

3.4 Temperatura e tempo de tratamento para as amostras, conforme posição no CP. . . . . . . . . . . . . . . . . . . . . 94

3.5 Corpos de prova e condições de análise por EBSD. . . . . . . 95

3.6 Corpos de prova selecionados para obtenções de perfis de tensões residuais por difração de raios-X. . . . . . . . . . . . . 97

4.1 Medidas de dureza das amostras dos corpos de prova 357 e 369 submetidas ao ensaio de laminação e tratamento térmico. . 135

4.2 Correspondência entre valores de pressão do jato de esferas dos três tamanhos e a velocidade das esferas. Medidas experimentais. . . . . . . . . . . . . . . . . . . . . . 140

4.3 Valores calculados da energia cinética de 1 esfera. . . . . . . . 141

4.4 Números das figuras com resultados de efeitos dos parâmetros sobre o raio de curvatura. . . . . . . . . . . . . . . . . 142

4.5 Números das figuras com resultados de efeitos dos parâmetros sobre o raio de curvatura normalizado $\left(r / H^{2}\right) \ldots \ldots \ldots \ldots$

4.6 Equações de ajuste da relação entre densidade de energia cinética e raio de curvatura dos corpos de prova conformados por jateamento com granalhas. . . . . . . . . . . . . . . 191

4.7 Pontos $\left(\mathrm{x}_{\min }, \mathrm{y}_{\min }\right)$ de máxima compressão e espessura das

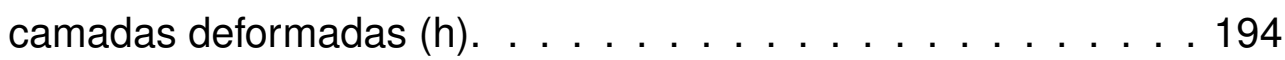


4.8 Efeito qualitativo dos parâmetros de jateamento nos pontos de máxima tensão residual de compressão e na espessura da camada deformada. . . . . . . . . . . . . . . . . . . . 196

4.9 Relatório de valores estatísticos após treinamento da RNA. . . . 203

4.10 Resultados de previsão de raio de curvatura para as chapas fictícias de 4, 7 e 12 mm de espessura. . . . . . . . . . . . 205

B.1 Parâmetros de jateamento dos corpos de prova ensaiados. . . . 225

C.1 Curvatura dos corpos de prova de $2 \mathrm{~mm}$ da liga AA 7050 . . . 238

C.2 Curvatura dos corpos de prova de $2 \mathrm{~mm}$ da liga AA 7475 . . . 239

C.3 Curvaturas dos corpos de prova de $5 \mathrm{~mm}$, granalhas S230, liga AA 7050 . . . . . . . . . . . . . . . . . . 240

C.4 Curvaturas dos corpos de prova de $5 \mathrm{~mm}$, granalhas S230, liga AA $7475 . \ldots \ldots$. . . . . . . . . . . . . . . 241

C.5 Curvaturas dos corpos de prova de $5 \mathrm{~mm}$, granalhas S550, liga AA $7050 \ldots \ldots \ldots$. . . . . . . . . . . . . . . . . . . .

C.6 Curvaturas dos corpos de prova de $5 \mathrm{~mm}$, granalhas S550, liga AA $7475 . \ldots \ldots \ldots \ldots$. . . . . . . . . . . . . . . . . . . . . .

C.7 Curvaturas dos corpos de prova de $10 \mathrm{~mm}$, granalhas S550, liga AL7050.

C.8 Curvaturas dos corpos de prova de $10 \mathrm{~mm}$, granalhas S550, liga AA $7475 \ldots \ldots \ldots$. . . . . . . . . . . . . . . . . . . . .

C.9 Curvaturas dos corpos de prova de $10 \mathrm{~mm}$, granalhas 1/8", liga AA 7050 . . . . . . . . . . . . . . . . . . 247

C.10 Curvaturas dos corpos de prova de $10 \mathrm{~mm}$, granalhas 1/8", liga AA $7475 . \ldots \ldots$. . . . . . . . . . . . . . . . . . . . . . . .

C.11 Curvaturas dos corpos de prova de $15 \mathrm{~mm}$, granalhas 1/8", liga

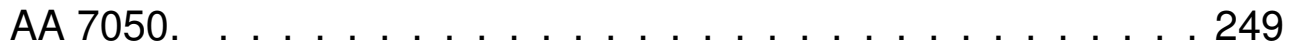

C.12 Curvaturas dos corpos de prova de $15 \mathrm{~mm}$, granalhas 1/8", liga

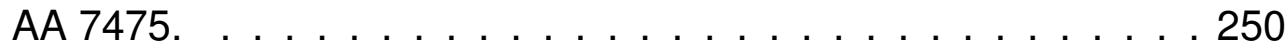


1 Introdução 


\subsection{Visão geral}

O alumínio é um dos metais mais abundantes na crosta terrestre e sua obtenção comercialmente viável foi desenvolvida independentemente por Heroult, na França, e por Hall, nos EUA, em 1886. Desde então, o alumínio despertou grande interesse e seu uso tem crescido sempre, devido à sua baixa densidade e ampla faixa de propriedades físicas, mecânicas, elétricas e térmicas.

$\mathrm{Na}$ indústria aeronáutica, o uso do alumínio começou com o surgimento na Alemanha do DURALUMIN, da série 2xxx, envelhecível naturalmente, e a busca por ligas mais resistentes e de menor densidade, que possibilitem 0 projeto de estruturas mais leves e com maior tolerância ao dano, tem sido o foco das atenções.

Atualmente, as ligas de alumínio mais utilizadas em aviões comerciais são as ligas Al-Cu, Al-Li e Al-Zn, das séries 2xxx,7xxx e 8xxx. Entre elas, destacam-se as ligas 7050 e 7475, usadas no revestimento da fuselagem, painéis e armações da fuselagem, revestimento inferior da asa e empenagem

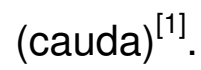

Estruturas de aviões, como são submetidas a cargas variáveis e cíclicas por tempos prolongados, sofrem com problemas de fadiga. Como se sabe, a fratura por fadiga inicia-se na superfície do material sob tensões de tração ${ }^{[2]}$, portanto, esforços no sentido de minimizar as tensões de tração na superfície são essenciais. ${ }^{[3]}$

Os métodos convencionais de conformação de materiais - estampagem, forjamento etc. - têm a desvantagem de deixar a peça conformada com tensões superficiais de tração, que diminuem a vida em fadiga do material. $O$ método tradicional de fabricação de asas de aviões é a usinagem do perfil a partir de uma chapa grossa. Este método, além de demandar tempo, equipamento e mão de obra em grande quantidade, gera uma enorme quantidade de sucata (menos de 10\% da chapa é aproveitada).

Nos anos 1940, trabalhando na Lockheed Aircraft Corporation, na Califórnia, o engenheiro Jim Boerger percebeu que, se uma faixa Almen - corpo de prova de aço SAE 1070 utilizado para medir a intensidade de um processo de jateamento com granalhas (shot peening) - curva-se após o jateamento, $O$ mesmo princípio poderia ser utilizado para conformar um painel de asa ${ }^{[4]}$. A esse processo de conformação por jateamento com granalhas deu-se o nome de peen forming. 
Tornar o processo de conformação por jateamento reprodutível e controlável é um objetivo importante a ser alcançado para que o mesmo possa ser aplicado de forma segura na indústria aeronáutica. Buscando-se estudar a viabilidade e o desenvolvimento de conhecimento da técnica de conformação por jateamento, definiu-se em um projeto realizado no Instituto de Pesquisas Tecnológicas uma metodologia para o projeto de experimentos focalizados nos dois tópicos principais: variáveis de processo e características do material jateado.

Neste trabalho, tais chapas de alumínio foram caracterizadas em: deformação ou encurvamento, microestrutura das amostras jateadas, dureza, profundidade e morfologia da camada deformada e perfis de tensões residuais. Os dados experimentais foram utilizados para o treinamento de uma rede neural artificial, visando um método eficiente para previsão de deformação.

A seguir, é apresentada uma revisão bibliográfica sobre os principais pontos abordados neste trabalho. 


\subsection{Alumínio e Ligas de Alumínio}

\subsubsection{Introdução Geral}

Alumínio é o segundo elemento metálico mais abundante na terra e tornou-se um competidor econômico em aplicações de engenharia no final do século 19. O crescimento da produção e uso do novo metal foi impulsionado pelas demandas de características e propriedades de materiais utilizados na indústria.

As primeiras aplicações comerciais do alumínio foram ítens nobres, como molduras de espelhos, números de casas e bandejas. Utensílios de culinária, como panelas e assadeiras também foram um grande mercado inicial. Em tempo, o alumínio cresceu em diversidade de aplicações ao ponto que virtualmente qualquer aspecto da vida moderna possa ser direta ou indiretamente afetado pelo seu uso.

$\mathrm{Na}$ indústria automobilística, os componentes de alumínio representam, em média, 8,6\% do peso total dos veículos ${ }^{[5]}$. Na indústria aeronáutica, cerca de $70 \%$ da estrutura dos aviões é composta de alumínio ${ }^{[6]}$.

Hoje, os Estados Unidos e o Canadá são os maiores produtores mundiais de alumínio. Entretanto, nenhum deles possui jazidas de bauxita em seu território, dependendo exclusivamente da importação. O Brasil tem a terceira maior reserva do minério no mundo, localizada na região amazônica, perdendo apenas para Austrália e Guiné ${ }^{[7]}$.

\subsubsection{Ligas de Alumínio}

É conveniente dividir as composições das ligas de alumínio em duas categorias principais, segundo sua utilização: composições para fundição e composições para ligas trabalháveis. Uma diferenciação posterior para cada categoria é baseada no mecanismo primário de desenvolvimento de propriedades.

O sistema da Aluminum Association é largamente reconhecido no Brasil e Estados Unidos, como também no restante do mundo. Esse sistema de identificação de ligas emprega nomenclaturas diferentes para ligas trabalháveis e fundidas, mas também divide as ligas em famílias, para simplificação. Para ligas trabalháveis, é usado um sistema de quatro dígitos para produzir uma lista de famílias de composições como segue ${ }^{[8]}$ : 
trica e química.

$\mathbf{2} \boldsymbol{x} \boldsymbol{x} \boldsymbol{x}$ Ligas nas quais o cobre é o principal elemento ligante, além de outros elementos, como o magnésio, principalmente. As ligas da série $2 x x x$ são bastante usadas na aeronáutica.

$3 \boldsymbol{x} \boldsymbol{x} \boldsymbol{x}$ Ligas nas quais o manganês é o principal elemento ligante. Usada como ligas de uso geral para aplicações arquitetônicas e vários produtos.

4xxx Ligas nas quais o silício é o principal elemento ligante. Usado em varetas de solda e folha de brasagem.

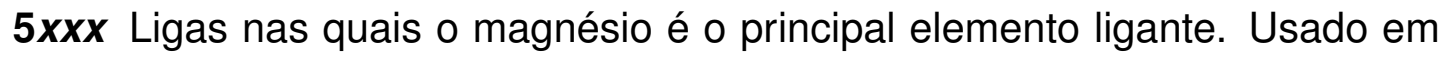
cascos de barcos, pranchas e outros produtos expostos a ambientes marítimos.

6xxx Ligas nas quais o magnésio e o silício são os principais elementos ligantes. Geralmente usadas para extrusão.

$\mathbf{7} \boldsymbol{x} \boldsymbol{x} \boldsymbol{x}$ Ligas nas quais o zinco é o principal elemento ligante, mas outros elementos como cobre, magnésio, cromo e zircônio podem ser especificados. Usado em estruturas aeronáuticas e outras aplicações de alta resistência.

$\mathbf{8} \boldsymbol{x} \boldsymbol{x} \boldsymbol{x}$ Ligas que incluem algumas composições com estanho e lítio, caracterizando composições diversas.

9xxx Reservado para uso futuro.

Muitas ligas respondem a tratamentos térmicos baseados em solubilidades de fases. Esses tratamentos incluem solubilização, têmpera (resfriamento rápido) e precipitação ou envelhecimento. Essas ligas são denominadas ligas de alumínio tratáveis termicamente. Algumas ligas, usualmente nas séries $2 x x x, 6 x x x$ e $7 x x x$, são tratáveis por solubilização - aquecimento e têmpera. Elas podem ser fortalecidas futuramente por trabalho a frio - deformação controlada a temperatura ambiente.

Ligas de alumínio não-tratáveis termicamente são endurecidas por trabaIho a frio, mas não por tratamento térmico. A resistência inicial dessas ligas, geralmente nas séries $1 x x x, 3 x x x, 4 x x x$ e $5 x x x$, é gerada pelo efeito endurecedor dos seus elementos de liga. Fortalecimento adicional pode ser criado por trabalho a frio, induzindo endurecimento por deformação, conhecido por têmpera $\mathrm{H}$. 
O sistema de designação de têmperas utilizado para alumínio e ligas de alumínio é usado para todas as formas de produto (tanto trabalháveis como fundidas), com a exceção de lingotes. O sistema é baseado nas sequências de tratamentos térmicos e mecânicos, ou ambos, usados para produzir as várias têmperas. A designação de têmpera segue a designação da liga e é separada dela por um hífen. Designações básicas de têmpera consistem em simples letras maiúsculas. Maiores subdivisões de têmperas básicas, quando requeridas, são indicadas por um ou mais dígitos seguindo a letra.

T, tratada termicamente, aplica-se a ligas cuja resistência seja estável dentro de alguns meses, se forem solubilizadas. O "T" é sempre seguido por um numeral de 1 a 10, cada um indicando uma sequência específica de tratamentos básicos: ${ }^{[8,9]}$

- $\mathrm{T} 1$ = Conformado em alta temperatura e envelhecido naturalmente.

- T2 = Conformado em alta temperatura, resfriado, deformado a frio e envelhecido naturalmente.

- T3 = solubilizado, trabalhado a frio e envelhecido naturalmente.

- T4 = solubilizado e envelhecido naturalmente .

- T5 = Conformado em alta temperatura e envelhecido artificialmente.

- $\mathrm{T} 6$ = Solubilizado e envelhecido artificialmente.

- $\mathrm{T} 7$ = Solubilizado e estabilizado

- T8 = Solubilizado, deformado a frio e envelhecido artificialmente .

- $\mathrm{T} 9$ = Solubilizado, envelhecido artificialmente e trabalhado a frio.

- $\mathrm{T} 10$ = Conformado em alta temperatura, resfriado, trabalhado a frio e envelhecido artificialmente.

Outros algarismos diferentes de zero podem ser adicionados para indicar uma variação de tratamento que altere significativamente as propriedades do produto. $^{[9]}$

Nos aviões, as ligas tradicionais utilizadas para fabricação do revestimento das partes inferior e superior da asa, respectivamente, são 7050-T7451 e 7475-T7351. Essas têmperas significam que o material foi solubilizado, submetido a alívio de tensão por estiramento e super envelhecido. 
As principais preocupações na metalurgia física das ligas de alumínio incluem os efeitos da composição, trabalho mecânico e/ou tratamento térmico nas propriedades mecânicas e físicas. Em termos de propriedades, o aumento da resistência é um objetivo principal no desenvolvimento de ligas de alumínio porque a baixa resistência do alumínio puro (cerca de $10 \mathrm{MPa}$ de limite de escoamento na condição recozida) limita a sua utilidade comercial. ${ }^{\left[{ }^{8]}\right.}$

\subsubsection{Fases nas Ligas de Alumínio}

Os elementos que são mais comumente presentes nas ligas de alumínio comerciais para promover aumento de resistência - particularmente quando acoplados a encruamento por trabalho a frio ou tratamento térmico, ou ambos são o cobre, magnésio, manganês, silício e zinco.

Para esses elementos, em concentrações abaixo dos limites de solubilidade, os elementos de liga estão essencialmente em solução sólida e constituem uma única fase. No entanto, não se conhece nenhum elemento que tenha completa miscibilidade com o alumínio no estado sólido.

Quando a quantidade de um elemento ligante excede o limite de solubilidade no sólido, o elemento ligante produz constituintes microestruturais de "segunda fase", que podem ser o elemento ligante puro ou uma fase de composto intermetálico. ${ }^{[8]}$

As partículas de segunda fase são divididas em quatro classes baseadas no modo de formação e nas suas habilidades de serem dissolvidas: partículas primárias, constituintes, dispersóides e precipitados.

As partículas primárias são chamadas assim pois são as primeiras a se solidificarem, antes do alumínio. Aparecem em ligas hipereutéticas, durante a solidificação, e em ligas trabalháveis, por reações peritéticas $\left(\mathrm{Al}_{7} \mathrm{Cr}, \mathrm{Al}_{3} \mathrm{Ti}\right.$ ou $\mathrm{Al}_{3} \mathrm{Zr}$ ).

Partículas constituintes são compostos intermetálicos formados em reações eutéticas durante a solidificação e têm uma interface não coerente com a matriz. Elas podem servir como sítios de nucleação de grãos recristalizados. Não causam aumento de resistência, por não interagirem com as discordâncias, porém são geralmente prejudiciais para a resistência à fadiga e tenacidade à fratura de ligas de alta resistência. Nas ligas $7 \times 50$, as partículas constituintes mais comuns são $\mathrm{Al}_{7} \mathrm{Cu}_{2} \mathrm{Fe}, \mathrm{Mg}_{2} \mathrm{Si}$ e $\mathrm{Al}_{2} \mathrm{CuMg}$ e, nas ligas $7 x 75$, são $\mathrm{Al}_{7} \mathrm{Cu}_{2} \mathrm{Fe}, \mathrm{Al}_{12}(\mathrm{Fe}, \mathrm{Mn})_{3} \mathrm{Si}, \mathrm{Al}_{6}(\mathrm{Fe}, \mathrm{Mn}), \mathrm{Mg}_{2} \mathrm{Si}, \mathrm{SiO}_{2}$ e $\mathrm{Al}_{23} \mathrm{CuFe}_{4}$. Elas são 
insolúveis ou parcialmente solúveis.

Dispersóides são finas distribuições de precipitados muito pequenos, submicrométricas (de menos de $1 \mu \mathrm{m}$ de tamanho), formados tanto durante a solidificação quanto durante o pré-aquecimento do lingote. Eles podem impedir ou atrasar a recristalização estática durante o processamento, por atuarem como bloqueio mecânico à movimentação dos contornos de grão. As ligas $7 \times 50$ possuem como dispersóide o $\mathrm{Al}_{3} \mathrm{Zr}$, que é coerente com a matriz e mais efetivo que os dispersóides incoerentes, como $\circ \mathrm{Al}_{12} \mathrm{Mg}_{2} \mathrm{Cr}$, encontrado nas ligas $7 \times 75^{[10-12]}$

Além das partículas de segunda fase, interferem nas propriedades físicas e mecânicas das ligas de alumínio as inclusões, porosidades, estrutura de grãos e de discordâncias e textura cristalográfica. ${ }^{[10]}$

Consequentemente, o projeto de ligas de alumínio resistentes a danos, como são 7475 e 7050, tem sido baseado primariamente no controle da microestrutura pela composição e processo de fabricação.

\subsubsection{Microestrutura das Ligas de Alumínio Trabalháveis}

As ligas de alumínio trabalháveis são produzidas convencionalmente a partir de lingotes fundidos, e todos os processos mecânicos e térmicos subsequentes representam graus variados de mudança na estrutura bruta de fundição. As modificações são relativamente menores para formas grandes trabalhadas, como forjados, chapas grossas e extrudados pesados que são trabalhados a quente. Elas tornam-se maiores ao passo em que a redução total da área transversal aumente por trabalho a quente ou frio e enquanto é aumentada a frequência de tratamentos térmicos, como recozimento e solubilização.

Cada classe de ligas de alumínio representa um tipo diferente de microestrutura por causa das diferenças dos elementos de liga. Nas ligas $7 x x x$ (alumínio-zinco), o zinco, sozinho, é altamente solúvel no alumínio e não exerce influência apreciável na microestrutura de uma liga simples. No entanto, a classe de ligas encontrada mais frequentemente contém magnésio e cobre, assim como aditivos como o cromo, manganês ou zircônio, e os sempre presentes ferro e silício. Na forma de lingotes, a liga 7075 forma um ou mais variantes do $(\mathrm{Fe}, \mathrm{Cr})_{3} \mathrm{SiAl}_{12}, \mathrm{Mg}_{2} \mathrm{Si}$, e um eutético pseudobinário constituído de alumínio e $\mathrm{MgZn}_{2}$. Esta última fase contém alumínio + cobre como um substituto para o zinco e pode ser escrita como $\mathrm{Mg}(\mathrm{Zn}, \mathrm{Cu}, \mathrm{Al})_{2}$. Aque- 
cimento subsequente causa a transformação das fases ricas em ferro em $\mathrm{Al}_{7} \mathrm{Cu}_{2} \mathrm{Fe}$. O Mg 2 Si é relativamente insolúvel e tende um pouco a esferoidizar; o $\mathrm{Mg}(\mathrm{Zn}, \mathrm{Cu}, \mathrm{Al})_{2}$ rapidamente começa a dissolver-se, e ao mesmo tempo há precipitação de $\mathrm{Al}_{2} \mathrm{CuMg}$, o que requer altas temperaturas e encharque lento para dissolver-se completamente. $\mathrm{O}$ cromo é precipitado da solução supersaturada como um dispersóide $\mathrm{Cr}_{2} \mathrm{Mg}_{3} \mathrm{Al}_{18}$, bastante concentrado nas regiões dendríticas primárias. Uma liga trabalhada bem solubilizada contém apenas $\mathrm{Al}_{7} \mathrm{Cu}_{2} \mathrm{Fe},(\mathrm{Fe}, \mathrm{Cr})_{3} \mathrm{SiAl}_{12}$ e $\mathrm{Mg}_{2} \mathrm{Si} \mathrm{junto} \mathrm{com} \mathrm{o} \mathrm{dispersóide.}$

Grãos recristalizados são extremamente alongados ou achatados devido ao bandeamento dos dispersóides, e não raro são encontradas regiões não recristalizadas, mesmo em chapas finas. As regiões não recristalizadas são constituídas de subgrãos muito finos, nos quais os contornos são decorados por precipitados endurecedores. Isto é mais óbvio em estruturas trabalhadas a quente, especialmente nas regiões mais trabalhadas próximas à superfície, onde a deformação acima da deformação crítica pode ter causado formação de grãos recristalizados grosseiros. Os dispersóides inibem a recristalização e a formação rápida de estruturas finas de subgrãos. $\mathrm{O} \mathrm{ZrAl}_{3}$ é coerente com a matriz, e tem efeitos similares.

O recozimento em ligas tratáveis termicamente tem um propósito duplo: 1. A remoção do trabalho a frio residual equivalente; e 2. A precipitação de soluto da solução sólida. Este último é conseguido por um esfriamento lento controlado e resulta em uma distribuição aleatória de precipitados. A presença dessa precipitação densa torna a estrutura de grãos de ligas com têmpera $O$ difícil de revelar. Outras ligas $7 x x x$ de alta e moderada resistência representam variantes da $7075 .{ }^{[8]}$

\subsubsection{Ligas AA 7050-T7451 e AA 7475-T7351}

A composição das ligas AA 7050 (ISO Al Zn6CuMgZr) e AA 7475 (ISO Al

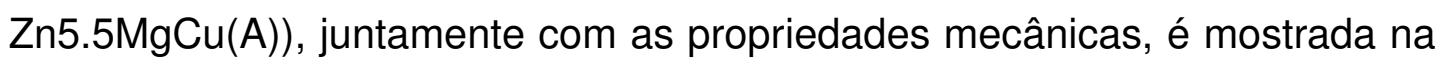
Tabela 1.1.

A liga 7050, com teor mais alto de cobre e zinco em relação à liga 7475 , tem mais $\mathrm{Al}_{2} \mathrm{CuMg}$ a ser dissolvido na temperatura de solubilização ${ }^{[8]}$. A microestrutura típica após têmpera de ambas consiste de grãos alongados e achatados, alinhados na direção de laminação ${ }^{[6,13]}$. Ligas mais diluídas podem facilmente dissolver todas as fases ricas em zinco. Sinais de supera- 
quecimento em ligas $7 x x x$ são geralmente relacionadas a regiões segregadas com concentrações não usuais de $\mathrm{Al}_{2} \mathrm{CuMg}$. No diagrama de equilíbrio de fases, a linha solidus - entre as fases líquida e sólida - é inferior à faixa de temperaturas de solubilização, ou seja, os precipitados são insolúveis na fase sólida. ${ }^{[8,14]}$.

As Figuras $1.1^{[15]}$ e $1.2^{[6]}$ mostram, respectivamente, a microestrutura típica das ligas de alumínio 7050-T7451 e 7475-T7351 utilizadas neste trabalho.

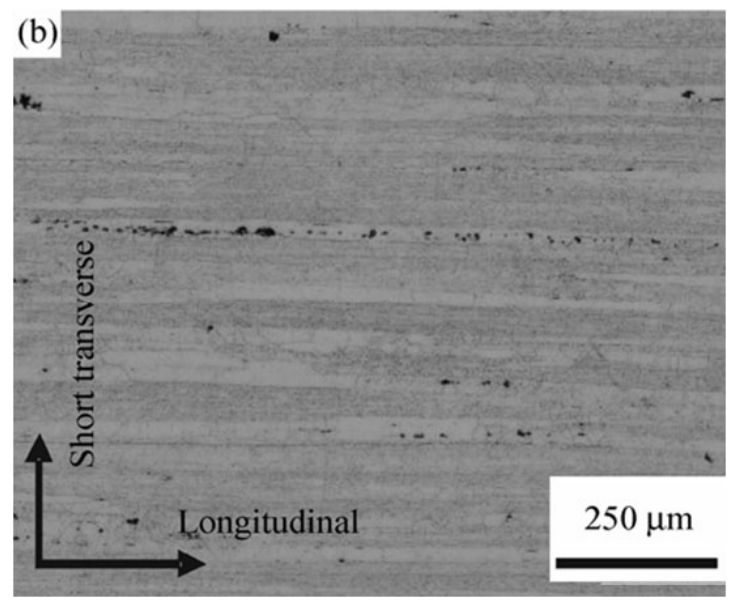

Figura 1.1: Microestrutura típica da liga 7050-T7451. ${ }^{[15]}$

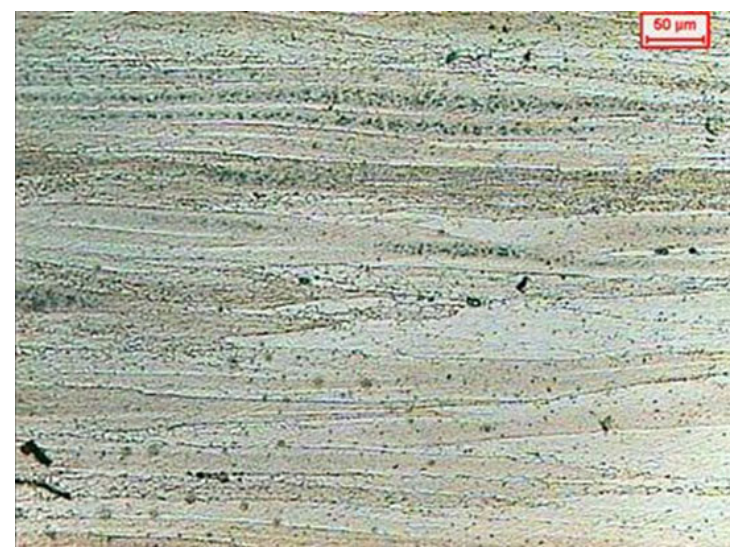

Figura 1.2: Microestrutura típica da liga 7475-T7351. ${ }^{[6]}$

O envelhecimento das ligas de alumínio 7050, 7075, 7175 e 7475 de qualquer têmpera para as séries de têmperas T73 e T76 requer controles mais apertados que o normal das variáveis como tempo, temperatura, taxa de aquecimento e assim por diante, para cada item dado. Além disso, quando o material em uma têmpera T6 é re-envelhecido para outra têmpera T73 ou T76, as condições específicas do material T6 são extremamente importantes e afetarão a capacidade do material re-envelhecido ser conformado às requisições especificadas para as têmperas T73 ou T76 ${ }^{[14]}$. 
A designação de têmpera $T x 51$ serve para alívio de tensões por estiramento e aplica-se especificamente para chapas grossas, bastões e barras laminadas e acabadas a frio, para forjados (em matriz fechada ou anel) e para anéis laminados. Esses produtos não recebem endireitamento posterior após o estiramento. ${ }^{[16]}$

Tabela 1.1: Dados de propriedades dos materiais disponíveis para as ligas de alumínio 7050 e $7475 .^{[6,17-20]}$

\begin{tabular}{|c|c|c|c|c|}
\hline Propriedade & \multicolumn{2}{|c|}{$\begin{array}{l}\text { Liga AA7050-T7451 } \\
\text { (ISO Zn6CuMgZr } \\
\text { UNS A7050) }\end{array}$} & \multicolumn{2}{|c|}{$\begin{array}{l}\text { Liga AA7475-T7351 } \\
\text { (ISO Zn5.5MgCu(A) } \\
\text { UNS A97475) }\end{array}$} \\
\hline Especificações & $\begin{array}{l}\text { AMS } 4050 \\
\text { MEP 02-014 }\end{array}$ & & $\begin{array}{l}\text { AMS } 4202 \\
\text { MEP 02-013 }\end{array}$ & \\
\hline Composição & $\begin{array}{ll}\text { Alumínio } & \text { B } \\
\text { Cobre } & 2 \\
\text { Cromo } & 0 \\
\text { Ferro } & 0 \\
\text { Magnésio } & 1 \\
\text { Manganês } & 0 \\
\text { Silício } & 0 \\
\text { Titânio } & 0 \\
\text { Zinco } & 5 \\
\text { Zircônio } & 0\end{array}$ & $\begin{array}{l}\text { Balanço } \\
2-2,6 \\
0,04 \max \\
0,15 \max \\
1,9-2,6 \\
0,1 \max \\
0,12 \max \\
0,06 \max \\
5,7-6,7 \\
0,08-0,15\end{array}$ & $\begin{array}{ll}\text { Alumínio } & \\
\text { Cobre } & 1 \\
\text { Cromo } & 0 \\
\text { Ferro } & 0 \\
\text { Magnésio } & 1 \\
\text { Manganês } & 0 \\
\text { Silício } & 0 \\
\text { Titânio } & 0 \\
\text { Zinco } & 5 \\
\text { Zircônio } & -\end{array}$ & $\begin{array}{l}\text { Balanço } \\
1,2-1,9 \\
0,18-0,25 \\
0,12 \max \\
1,9-2,6 \\
0,06 \max \\
0,1 \max \\
0,06 \max \\
5,2-6,2 \\
-\end{array}$ \\
\hline Vantagens & \multicolumn{2}{|c|}{ Alta tolerância ao dano. } & \multicolumn{2}{|c|}{$\begin{array}{l}\text { Alta resistência à compressão } \\
\text { (flambagem). }\end{array}$} \\
\hline Aplicação & \multicolumn{2}{|c|}{$\begin{array}{l}\text { Comumente usada em aerona- } \\
\text { ves em painéis integrais superi- } \\
\text { ores. }\end{array}$} & \multicolumn{2}{|c|}{$\begin{array}{l}\text { Comumente usada em aerona- } \\
\text { ves em painéis integrais inferio- } \\
\text { res. }\end{array}$} \\
\hline Dados Físicos & $\begin{array}{l}\rho\left(\mathrm{g} / \mathrm{cm}^{3}\right) \\
\sigma_{e}(\mathrm{MPa}) \\
\sigma_{R}(\mathrm{MPa}) \\
\epsilon(\%) \\
\mathrm{E}(\mathrm{GPa}) \\
\mathrm{T} \text { Fusão }\left({ }^{\circ} \mathrm{C}\right) \\
\mathrm{T}_{\text {Recoz. }}\left({ }^{\circ} \mathrm{C}\right) \\
\mathrm{T}_{\text {Solub. }}\left({ }^{\circ} \mathrm{C}\right) \\
\mathrm{T}_{\text {Envelh. }}\left({ }^{\circ} \mathrm{C}\right) \\
\text { Dureza }\end{array}$ & $\begin{array}{l}2,83 \\
469 \\
524 \\
11,0 \\
71,7 \\
488-629 \\
413 \\
477 \\
121-177 \\
162 \mathrm{HV}\end{array}$ & $\begin{array}{l}\rho\left(\mathrm{g} / \mathrm{cm}^{3}\right) \\
\sigma_{e}(\mathrm{MPa}) \\
\sigma_{R}(\mathrm{MPa}) \\
\epsilon(\%) \\
\mathrm{E}(\mathrm{GPa}) \\
\mathrm{T} \text { Fusão }\left({ }^{\circ} \mathrm{C}\right) \\
\mathrm{T}_{\text {Recoz. }}\left({ }^{\circ} \mathrm{C}\right) \\
\mathrm{T}_{\text {Solub. }}\left({ }^{\circ} \mathrm{C}\right) \\
\mathrm{T}_{\text {Thvelh. }}\left({ }^{\circ} \mathrm{C}\right) \\
\text { Dureza }\end{array}$ & $\begin{array}{l}2,81 \\
421 \\
496 \\
13,0 \\
71,7 \\
477-635 \\
413 \\
516 \\
121-177 \\
155 \mathrm{HV}\end{array}$ \\
\hline
\end{tabular}

$\rho=$ Densidade; $\sigma_{e}=$ Limite de escoamento; $\sigma_{R}=$ Limite de resistência; $\epsilon=$ alongamento; $\mathrm{E}=$ módulo de elasticidade. 


\subsection{Conformação por jateamento com granalhas}

Em poucas palavras, a conformação por jateamento com granalhas (JCG ou peen forming) consiste no método de conformação de chapas e painéis através de um jato de granalhas de alta energia que deforma a superfície do material, fazendo-o curvar. É um método de conformação derivado do tratamento de superfície utilizado para aumentar a vida em fadiga de materiais conhecido como shot peening.

\subsubsection{O Processo de jateamento}

Shot peening pode ser definido como um tratamento superficial a frio promovido por impactos controlados de granalhas. Essas esferas são projetadas em altas velocidades a fim de trabalhar (deformar) a frio a superfície do material, com o objetivo de gerar uma camada superficial com tensões compressivas que aumente a resistência à fadiga do material. Esse tratamento pode aumentar em até $300 \%$ a vida em fadiga de um componente. ${ }^{[3]}$

A resposta do material a múltiplos impactos por projéteis é uma função complexa das propriedades físicas do alvo e do projétil. Quando projéteis esféricos duros atingem um alvo de um material elástico/plástico (Figura 1.3a) e a velocidade de impacto é suficientemente alta, o material do alvo sofre deformação plástica local e, como repercussão (Figura 1.3b), o resto do material elástico tende a empurrar a zona plasticamente deformada, resultando em tensões de compressão paralelas à superfície. A principal preocupação no processo de jateamento é controlar a magnitude e distribuição dessas tensões residuais $^{[21,22]}$.

O impacto das granalhas causa deformação plástica com alongamento lateral e distorção de grão e, sob a recuperação elástica, o alvo adquire uma camada rasa de tensões residuais superficiais de compressão, abaixo da qual ele desenvolve tensões menores de tração de equilíbrio (Figura 1.4) ${ }^{[21]}$. 


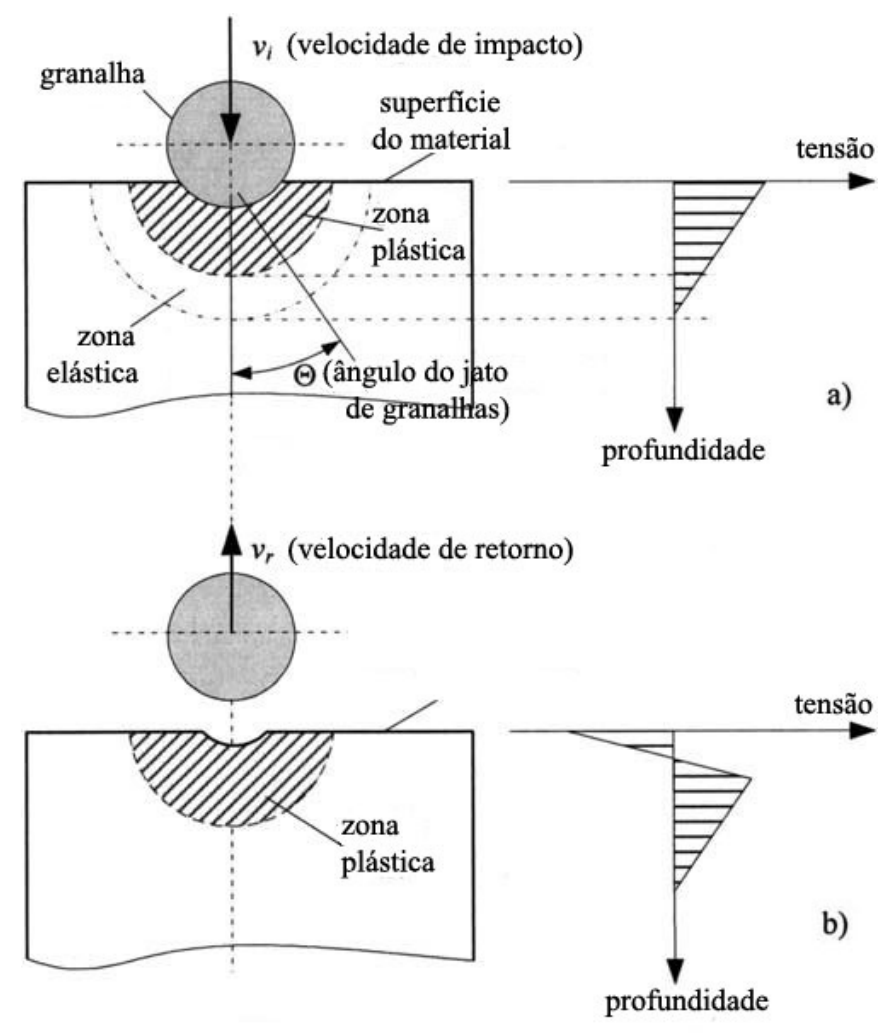

Figura 1.3: Efeito do impacto da granalha na distribuição de tensões: a) no momento do impacto; b) imediatamente após o impacto. ${ }^{[22]}$

Chapas finas (até $20 \mathrm{~mm}$ ) normalmente curvam para cima (face jateada convexa), mas blocos espessos são muito resilientes para mostrar qualquer curvatura detectável. Materiais duros produzem um pico de tensão residual abaixo da superfície (Figura 1.5) ${ }^{[22]}$, enquanto materiais mais moles têm a máxima tensão compressiva na superfície. No processo de shot peening, a magnitude das tensões residuais de compressão na camada superficial, até a profundidade em que a deformação plástica se estende, tem um papel crucial na fadiga e na corrosão sob tensão, de modo que o ajuste dos parâmetros físicos do processo deve focar-se em predizer ou controlar corretamente a distribuição de tensões residuais desejada ${ }^{[21]}$.

Brown $^{[23]}$ investigou as vantagens em redução de peso, em resistência mecânica e à corrosão e em custos para determinar a possibilidade de substituir o aço estrutural convencional por ligas de alumínio mais leves na indústria naval. Markovina ${ }^{[22,24]}$ mostrou que a tecnologia da conformação por jateamento com granalhas pode ser adaptada com sucesso à produção de partes estruturais de navios, particularmente dos navios de alta e super alta velocidades, que utilizam materiais leves, similar àqueles de aeronaves. 


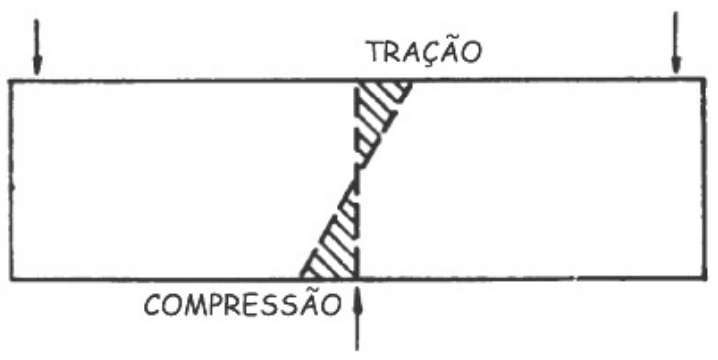

TENSÃO EM UM COMPONENTE JATEADO
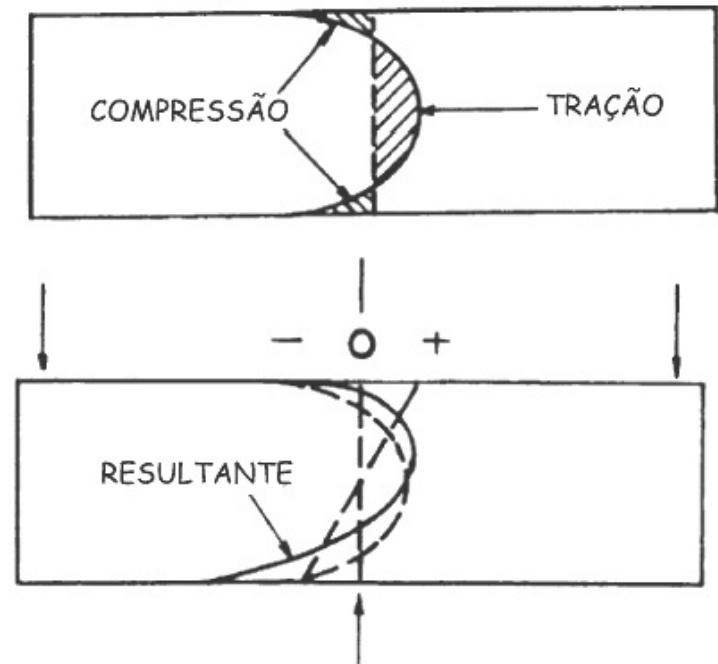

Figura 1.4: Diagramas de tensões indicando carregamento e tensões em chapas sem (topo) e com (meio) shot peening. Embaixo, o efeito do jateamento durante carregamento em flexão ${ }^{[3]}$.

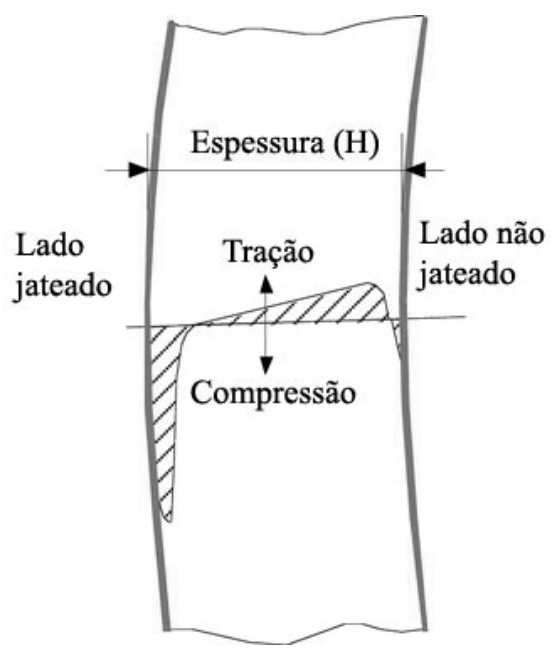

Figura 1.5: Distribuição de tensões residuais em um painel conformado por jateamento de granalhas. ${ }^{[22]}$

\subsubsection{Histórico}

O processo de conformação por jateamento com granalhas foi patenteado pela Lockheed Aircraft Corporation, em Burbank, Califórnia no final da década de 1940. O engenheiro Jim Boerger e sua equipe, trabalhando com uma tira 
Almen, supuseram que, se uma curvatura podia ser induzida em uma tira Almen, então ela poderia ser induzida em um painel de asa. Várias amostras de painel foram processadas e foi provado que, por jateamento em um dos lados, pode-se certamente induzir uma curvatura razoável.

Os primeiros painéis de asa em tamanho real foram selecionados, mas foram consideravelmente distorcidos devido à falta de conhecimento da manufatura em painéis reforçados integralmente. Felizmente, foi possível trazê-los de volta a uma forma razoavelmente plana; trabalhos subsequentes provaram que a curvatura aerodinâmica requerida poderia ser produzida.

A Lockheed Corporation garantiu uma licença livre de royalties para o processo e ultimamente, desde que a patente expirou, as empresas Boeing, McDonnell Douglas, British Aerospace e subsequentemente Airbus, assim como a Embraer, empregaram esse processo como a técnica de manufatura mais rentável para induzir curvaturas em painéis aerodinâmicos complexos totalmente usinados ${ }^{[4]}$.

\subsubsection{Tecnologia do processo}

Desde 1968, o uso da técnica de jateamento com granalhas (JCG ${ }^{[25]}$ ) para curvar asas de aeronaves tem aumentado, de modo que a maioria das aeronaves médias a grandes produzidas no mundo hoje utilizam esse processo. A conformação por JCG classifica-se como um dos maiores avanços na tecnologia de manufatura de aeronaves. Ela não apenas substitui métodos de conformação mais caros e que geram mais resíduos (p.e. usinagem, estampagem, forjamento), como também conforma mais facilmente asas cônicas e esculpidas, permitindo que o projeto de asas maximize a razão resistência por peso.

A conformação por JCG não pode formar todas as formas concebíveis; o projeto da asa da aeronave deve ser compatível com o JCG. O processo é capaz de produzir apenas curvaturas suaves com controle acurado. Ele é vantajoso quando aplicado entre os reforços principais, porque intensidades de jateamento controladas e facilmente produzidas podem formar essa combinação de partes relativamente espessas, porém levemente curvadas. ${ }^{[26]}$

Embora o jato de granalhas possa variar em uma larga escala de intensidades (p.e. escala Almen N, A e C), a máxima espessura de alumínio que pode ser conformada com segurança é limitada pelas intensidades de jatea- 
mento que não causem dano superficial ${ }^{[26]}$, o que favoreceria a nucleação de trincas superficiais durante o trabalho. Há alguns padrões que especificam essas máximas intensidades que não prejudicam a vida em fadiga do componente ${ }^{[3]}$.

No processo de conformação por jateamento com granalhas, há três métodos usados para criar curvaturas em painéis (Figura 1.6). Primeiramente, 0 curvamento pode ser atingido com o jateamento em apenas uma superfície (1.6a). Neste caso, a compressão da superfície pela esfera alonga o metal, causando a mudança no formato do painel. A limitação desse método de conformação é que ele está apenas no alcance elástico que o movimento pode realizar-se, e portanto apenas pequenas curvaturas são alcançadas. Para obter maiores graus de curvatura, é usado o jateamento sob tensão, no qual o componente é mantido em uma condição pré-tensionada unidirecional e então é jateado na superfície tracionada (1.6b). Isso significa que quando o componente é liberado dessa condição tracionada após o jateamento, a tensão compressiva é maior em uma direção que na outra, e é maior na direção da curvatura formada pelo processo de pré-tensão. O terceiro método de conformação é por jateamento na periferia de ambos os lados de uma região de metal ao mesmo tempo (1.6c). Isso fornece alongamento do componente causado pelo material esticado nas duas faces, superando a resistência à deformação elástica exercida pelo núcleo. ${ }^{[4]}$

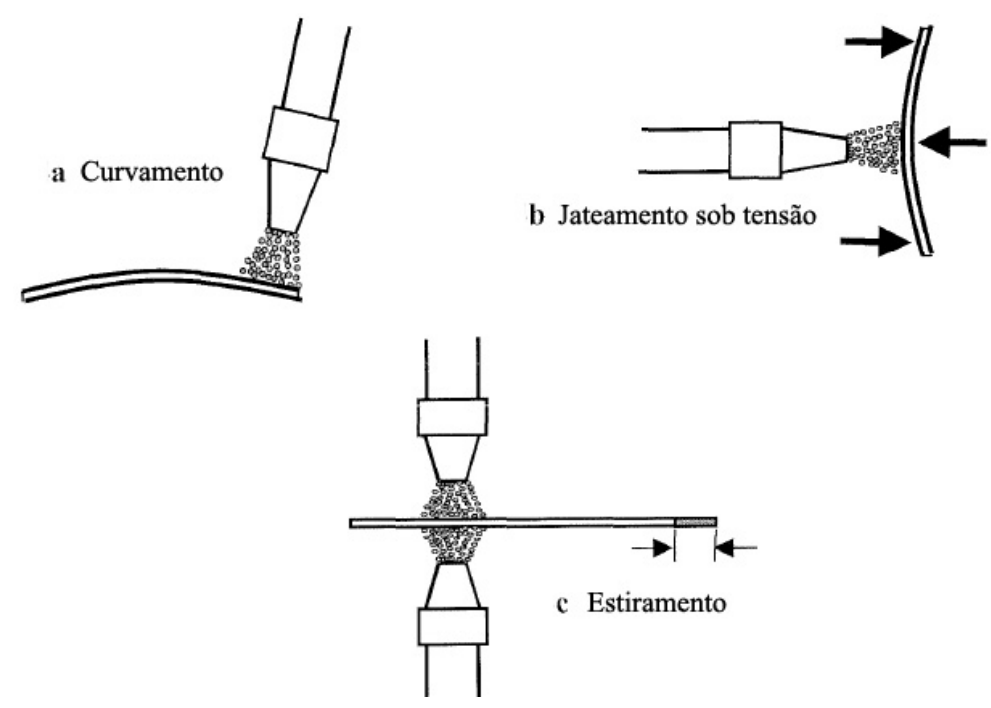

Figura 1.6: Métodos de conformação por JCG ${ }^{[4]}$.

JCG pode ser utilizado não apenas para formar painéis com um dado formato a partir de uma peça original do material que esteja plano, mas também 
pode ser usado para criar materiais planos a partir de um componente que tenha sido distorcido durante a manufatura ou tratamento térmico, esticando-se o material no lado côncavo do componente distorcido.

O processo é normalmente realizado dentro de um recinto fechado, por máquinas automáticas. Quando são requeridas tolerâncias pequenas, alguma conformação pode ser realizada manualmente por técnicos habilidosos.

São usados dois tipos básicos de máquinas, diferindo apenas em como o meio conformador é transmitido para a parte sendo formada: em máquinas do tipo bocal, usa-se ar comprimido ou a gravidade para impulsionar as granalhas sobre a peça trabalhada. Jateamento com roda centrífuga é outro método pelo qual as esferas podem ser arremessadas: essas máquinas usam controles eletrônicos para regular as velocidades de rotação de uma roda de palhetas, que acelera as esferas em direção à peça ${ }^{[4]}$.

A Figura 1.7 resume os princípios do método de conformação por jateamento com granalhas. ${ }^{[22]}$

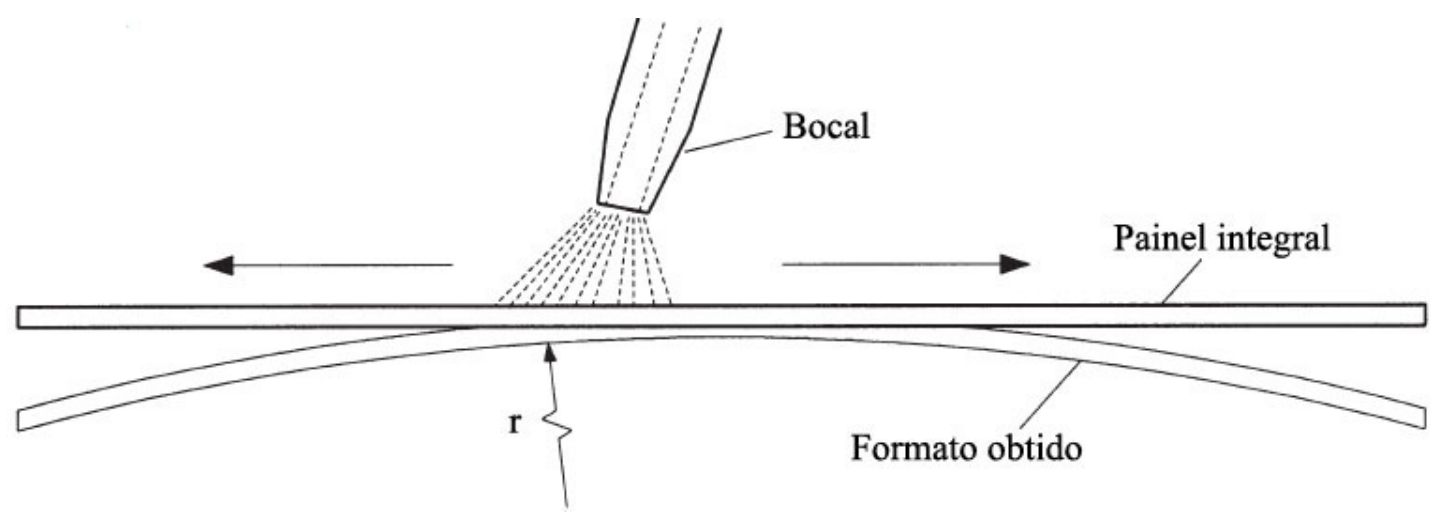

Figura 1.7: O princípio do método de conformação por jateamento com granalhas $^{[22]}$.

\subsubsection{Medidas de intensidade}

No tratamento de shot peening visa-se tanto reproduzir uma intensidade de jateamento previamente estabelecida como induzir um nível de intensidade de tensões residuais específico. É necessário considerar-se qual o real parâmetro que está envolvido no monitoramento das intensidades de jateamento.

O método da tira Almen foi patenteado ${ }^{[27]}$ por John O. Almen em 1944 e consiste em uma tira de aço SAE 1070 fixada sobre um aparato (Figura 1.8) que é submetido ao JCG. É um método semi-quantitativo largamente usado para especificar a intensidade do jateamento. Uma tira Almen desenvolve uma 
camada comprimida na superfície jateada. Quando o material é esticado, a tira curva-se relativamente à direção do jateamento em um grau que varia com a intensidade do jato, tamanho de granalha utilizada e porcentagem da área superficial indentada pelas granalhas (cobertura). Consequentemente, com a conformação por JCG, o mesmo método se aplica e, com o uso de diferentes parâmetros, várias formas podem ser alcançadas. Geralmente, para fins de conformação de chapas, utilizam-se esferas de aço fundido para alcançar a alta deformação requerida, porém outros meios, como arames cortados, vidro, cerâmica etc podem ser usados para uma conformação com menor demanda [4].

As intensidades de jateamentos são classificadas em três tipos e, para cada tipo é utilizada uma espessura diferente de tira de aço para o teste Almen. O tipo "A" é predominantemente usado para jateamentos com granalhas fundidas ou arame cortado. As tiras do tipo "N" são usadas usualmente para granalhas de vidro e cerâmica e medem intensidades menores que o tipo "A". As do tipo "C" são usadas para os jateamentos mais severos. As espessuras das tiras (em polegadas) são indicadas na Figura 1.8.

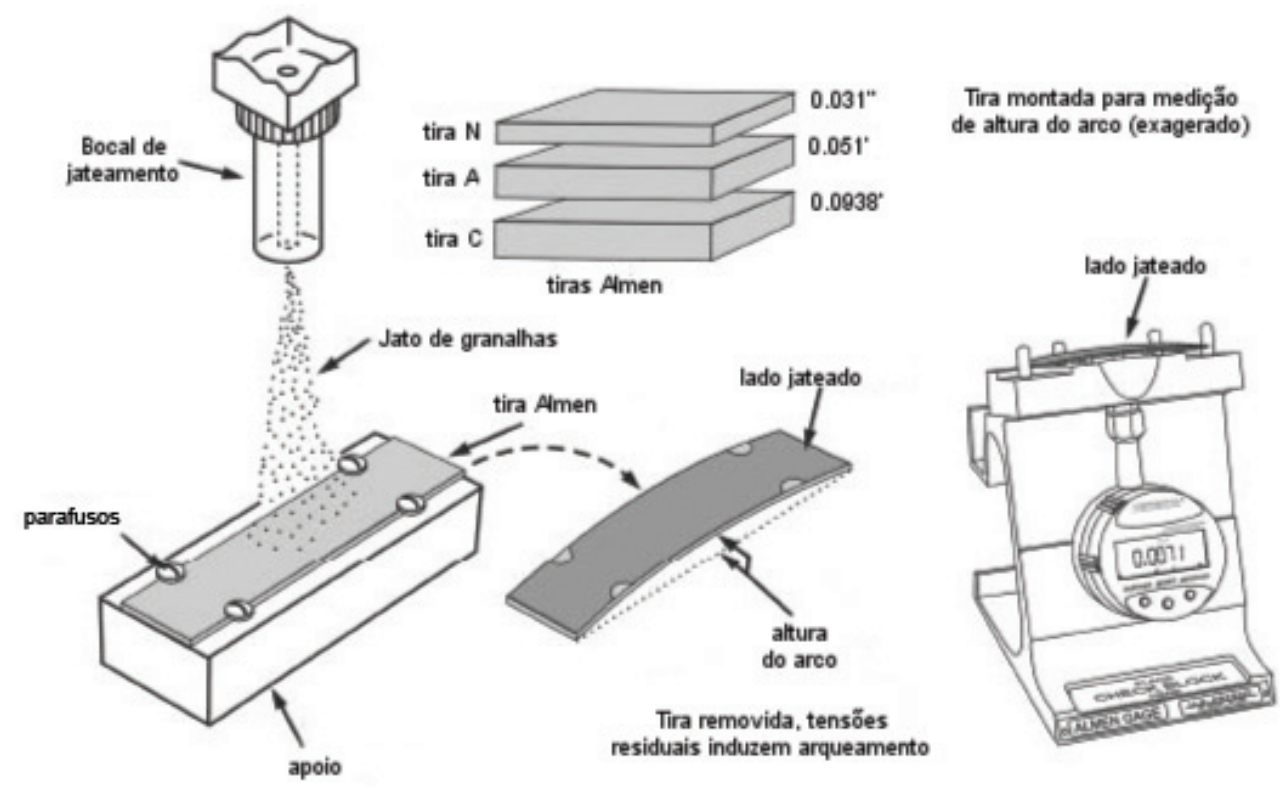

Figura 1.8: Esquema do teste da tira Almen. À esquerda, a tira Almen sendo jateada. À direita, a altura do arco sendo medida. Acima, as espessuras A, N e $\mathrm{C}$ utilizadas nos ensaios.

Uma camada de material comprimido é induzida pelo JCG com um momento fletor correspondente que é resistido enquanto a tira jateada é mantida plana. Na liberação da tira, esse momento fletor não é mais resistido e a tira dobra em um arco para acomodar um balanceamento de momentos fletores, configurando um novo padrão de tensões residuais. Ambos os componentes 
curvam a faixa na mesma direção de curvatura, então o que se tem é uma curvatura total composta de dois elementos. Essencialmente, quando a "intensidade" do jateamento aumenta, a curvatura de uma tira Almen aumenta.

A causa essencial da curvatura é o trabalho sendo realizado na faixa pelas partículas do jato que tiveram que ser aceleradas a uma velocidade alta o suficiente para causar deformação plástica na superfície da peça.

O trabalho total sobre a faixa, $\tau$, pode ser expresso pela seguinte equação:

$$
\tau=\sum_{0}^{t} p_{j} \cdot \frac{1}{2} \cdot m_{j} \cdot v_{j}^{2} \cdot n \cdot d t
$$

onde $p_{j}=$ proporção de energia cinética, $\frac{1}{2} \cdot m_{j} \cdot v_{j}{ }^{2}$, absorvida pela faixa quando é atingida por uma esfera individual, $j$, das $n$ partículas que atingem a faixa em um intervalo de tempo, $d t$, dentro do tempo total de jateamento, $t$, e $m_{j}$ é a massa da esfera $j$, viajando à velocidade $v_{j}$.

A Equação 1.1 resume os problemas que são associados a um controle efetivo do jateamento. A proporção da energia absorvida de 1 partícula variará de acordo com fatores como ângulo de impacto na superfície da peça e as características do material da superfície. A massa de cada partícula variará dentro de uma faixa de diâmetros permitidos para uma determinada categoria de granalhas. A norma SAE J444 ${ }^{[28]}$ especifica diâmetros de granalhas em frações de polegadas (p.e. $\mathrm{S} 780=\oslash=0,0780 \mathrm{in}=1,9812 \mathrm{~mm}$ ). A velocidade das esferas variará de acordo com as características físicas e mecânicas do equipamento de jateamento. Finalmente, a taxa de distribuição de partículas, (vazão de granalhas), não permanecerá constante.

A medida de intensidade Almen tem vantagens e desvantagens. A grande vantagem da medida Almen é que ela integra os fatores relevantes sobre 0 tempo total de jateamento. Além disso, o método de medição e o equipamento usado são claramente definidos e facilmente acessíveis. O amplo uso dos valores de intensidade Almen é outra vantagem. A maior desvantagem da medida Almen é que ela é retrospectiva, no sentido que ela olha para trás para o trabalho total que foi realizado. De um ponto de vista de pesquisa, pode ser desejável conhecer todas as variáveis separadamente. A medida de deflexões não dá indicações sobre as variações durante o jateamento e não diferencia se foram utilizadas granalhas pequenas com alta velocidade ou granalhas grandes com baixa velocidade. ${ }^{[29,30]}$ Por esta razão, não será utilizada a medida de intensidade Almen neste trabalho, que tem a intenção 
de analisar os parâmetros de jateamento e seus efeitos separadamente.

O desenvolvimento de uma intensidade total de jateamento pode apenas ser avaliado usando uma série de medidores expostos por diferentes períodos de tempo à mesma taxa de intensidade nominal. Um método interativo poderia avaliar o trabalho sendo realizado durante o processo de jateamento, o que permitiria então que os procedimentos de controle disponíveis fossem ativados durante o processo para garantir que uma intensidade de jateamento desejada seja obtida ${ }^{[30]}$.

\subsubsection{Controle dos parâmetros}

A maior desvantagem do JCG é que esse processo é muito difícil de ser controlado $^{[31,32]}$. A razão é que muitas variáveis podem afetar a curvatura gerada pelo jateamento, como o diâmetro da granalha, a velocidade de impacto, a porcentagem de cobertura das impressões, o ângulo de impacto, o material das granalhas e das chapas. Segundo Zeng ${ }^{[31]}$, é um processo feito a esmo, devido ao impacto de um grande número de pequenas granalhas contra a superfície de um componente metálico. Em geral, a definição dos parâmetros ótimos de processo para a obtenção da forma desejada tem se baseado no método de tentativa e erro ${ }^{[32]}$. A experiência dos operadores exerce um papel de grande importância.

Alguns esforços foram feitos no sentido de observar o efeito da intensidade (I) do jato de granalhas. Entretanto, geralmente observam-se como resultados as tensões residuais e sua distribuição em amostras submetidas a jateamento como tratamento superficial (shot peening) e como método de conformação

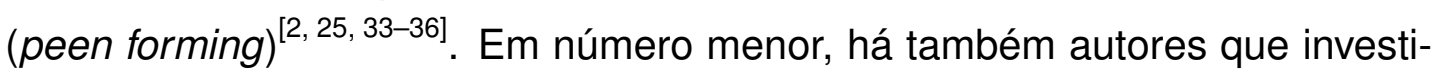
garam o efeito de $I$ na forma final dos componentes jateados ${ }^{[34,37-39]}$.

Há poucas informações sobre trabalhos que investiguem especificamente um dos parâmetros de processo e seu efeito na deformação e nas tensões residuais de amostras que receberam jateamento com granalhas. Gonzales et al. ${ }^{[25]}$ fizeram uma modelagem computacional do processo de JCG empregando o método dos elementos finitos (MEF) e chegaram à conclusão, entre outras, que, com relação à variação de espessura das chapas, não houve uma diferença significativa no que se refere aos valores de tensões residuais obtidos.

Wang, Platts e Levers ${ }^{[40]}$ calcularam a forma final da curvatura através de 
MEF variando a velocidade de impacto das granalhas e obtiveram boa comprovação experimental. Zeng ${ }^{[31]}$ calculou tensões residuais para diferentes diâmetros de granalha, velocidades de impacto e coberturas.

É usual envolver-se todos os elementos do jateamento, representados pela intensidade do jato, e aproximar-se o efeito do impacto de granalhas na superfície à deformação e tensão residual gerados por gradientes de temperatura, baseando-se em elementos de casca. Essa aproximação dá uma boa noção do resultado final, mas não gera bom conhecimento sobre detalhes do processo.

Não há trabalhos que observem, numérica e empiricamente, cada parâmetro de processo e seus efeitos na deformação de chapas conformadas por jateamento de granalhas.

\subsubsection{Camada deformada plasticamente}

O processo de JCG corresponde essencialmente a um mecanismo de endurecimento superficial por deformação plástica localizada, no qual cada esfera de material duro, arremessada sobre a superfície de uma chapa dútil, atua de forma semelhante ao impacto de um minúsculo martelo, provocando uma pequena ondulação de contorno aproximadamente circular (indentação ou endentação). Para que esta ondulação se forme, é necessário que ocorra uma deformação plástica por escoamento da superfície da chapa. Abaixo da superfície submetida a um estiramento, os grãos comprimidos tendem a restabelecer a forma original, criando uma região hemisférica de alta tensão compressiva (Figura 1.3), que é submetida a um encruamento em condições ambientais, ou seja, "a frio". Uma sequência de impactos adjacentes e sobrepostos provoca o aparecimento de um campo de tensões compressivas, atuando numa camada aproximadamente uniforme. ${ }^{[34,41]}$

lida $^{[33]}$ estudou a formação da indentação e da camada deformada produzidas pelo jateamento com granalhas de aço $(0,2 \% \mathrm{C})$. Segundo seu trabalho, quando uma esfera de diâmetro $D$ atinge uma superfície com velocidade $v$, a indentação formada tem um diâmetro $d$ que pode ser calculado por

$$
d=K_{d} \cdot D \cdot v^{1 / 2}
$$

onde $K_{d}$ é constante para a dureza do material. Similarmente, a profundidade 
$h$ da indentação deixada na superfície pode ser calculada por

$$
h=K_{h} \cdot D \cdot v
$$

onde $K_{h}$ é constante para a dureza do material.

O efeito do ângulo do impacto é a diminuição do diâmetro e profundidade da indentação, porque tanto a forma quanto a intensidade do impacto são produzidos apenas pela componente da velocidade normal à superfície jateada $(v \cdot \sin \alpha$, onde $\alpha$ é o ângulo entre a direção de jateamento e a superfície jateada).

A partir de diversos experimentos com materiais de dureza Vickers 100400, foram obtidos valores de $K_{d}$ e $K_{h}$. $K_{d}^{2}$ e $K_{h}$ são proporcionais à dureza Vickers (HV) da superfície, como mostra a Figura 1.9. Desse modo, podem-se obter equações para $d$ e $h$ de indentações produzidas por impactos de esferas duras em diversos materiais de dureza conhecida.

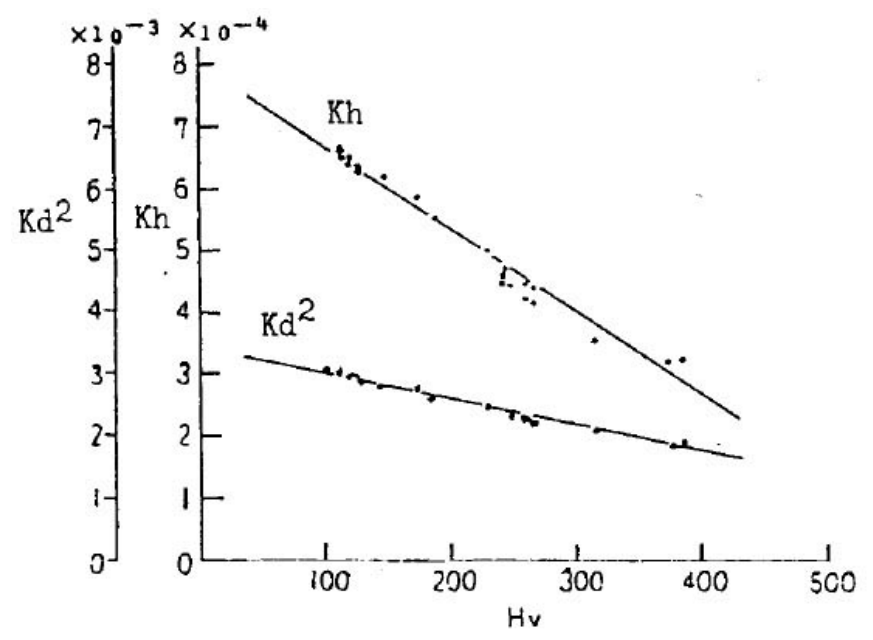

Figura 1.9: Relações entre $K_{d}^{2}, K_{h}$ e a dureza Vickers da amostra ${ }^{[33]}$.

A partir das equações de diâmetro e altura da indentação, pode-se calcular o seu volume ${ }^{[33]}$ :

$$
\begin{aligned}
V & =K_{v} \cdot D^{3} \cdot v^{2} \\
& =K_{v}^{\prime} \cdot m \cdot v^{2} \\
& =K_{v}^{\prime \prime} \cdot E_{C}
\end{aligned}
$$

onde $K_{v}, K_{v}^{\prime}$ e $K_{v}^{\prime \prime}$ são constantes para a dureza do material, $m$ é a massa e $E_{C}$ é a energia cinética das esferas.

lida fez as seguintes afirmações sobre a formação da indentação e da camada deformada plasticamente: 
1. Produzindo-se uma indentação por impacto de uma esfera rígida no aço, a zona abaixo dela pode ser afetada pelo fluxo plástico.

2. A camada afetada pelo impacto pode ser visualizada no aço com o reagente de Fry e tem cerca de oitenta vezes o volume da calota esférica da indentação.

3. A repetição de impactos em um mesmo local aumenta apenas ligeiramente o volume da camada deformada.

4. A camada deformada é simétrica e diminui com o aumento do ângulo de impacto, assim como a indentação.

Experimentalmente, foi possível determinar fórmulas para a espessura $h^{\prime}$ e volume $V^{\prime}$ da camada deformada:

$$
\begin{aligned}
h^{\prime} & =K_{1} \cdot D \cdot(v \sin \alpha)^{2 / 3} \cdot N^{1 / 40} \\
V^{\prime} & =K_{2} \cdot D^{3} \cdot(v \sin \alpha)^{2} \cdot N^{3 / 40}
\end{aligned}
$$

onde $\mathrm{N}$ é o número de repetições de impactos no mesmo local, $v \sin \alpha$ é a componente normal da velocidade, $D$ é o diâmetro da esfera e $K_{1}$ e $K_{2}$ são constantes para o material ${ }^{[33]}$.

Analogamente, pode-se relacionar o volume da camada deformada com a energia cinética das esferas, para um dado valor de cobertura (\% de área indentada):

$$
V^{\prime}=K_{3} \cdot E_{C}
$$

\subsubsection{Medição da camada deformada}

A medição da espessura da camada deformada plasticamente pelo jateamento de esferas na superfície de uma chapa curvada tem o objetivo de verificar qual é a fração da estrutura responsável pela forma assumida e que recebe a maior parte da solicitação durante o trabalho, uma vez que o momento fletor $(\bar{M})$ gerado pelas forças $(F)$ de compressão é diretamente proporcional à espessura da camada $(\bar{M}=F \cdot h)$.

Alguns métodos para a realização dessa medição são apresentados a seguir:

(a) Metalografia 
No alumínio laminado, como os grãos são bastante alongados, a deformação superficial pode ser visualizada de certo modo por metalografia, porém é muito imprecisa a posição da região limite entre material deformado e não-deformado pelo impacto das esferas. A Figura 1.10 mostra a microestrutura da seção transversal de uma chapa de alumínio 7050 jateada por esferas S230 ( $\oslash=0,0230 \mathrm{in}=0,584 \mathrm{~mm})$, sem pré-tensionamento. Notase a deformação dos grãos na superfície, acompanhando as marcas de indentação, porém não é possível saber até onde o material foi realmente afetado pelo jateamento.

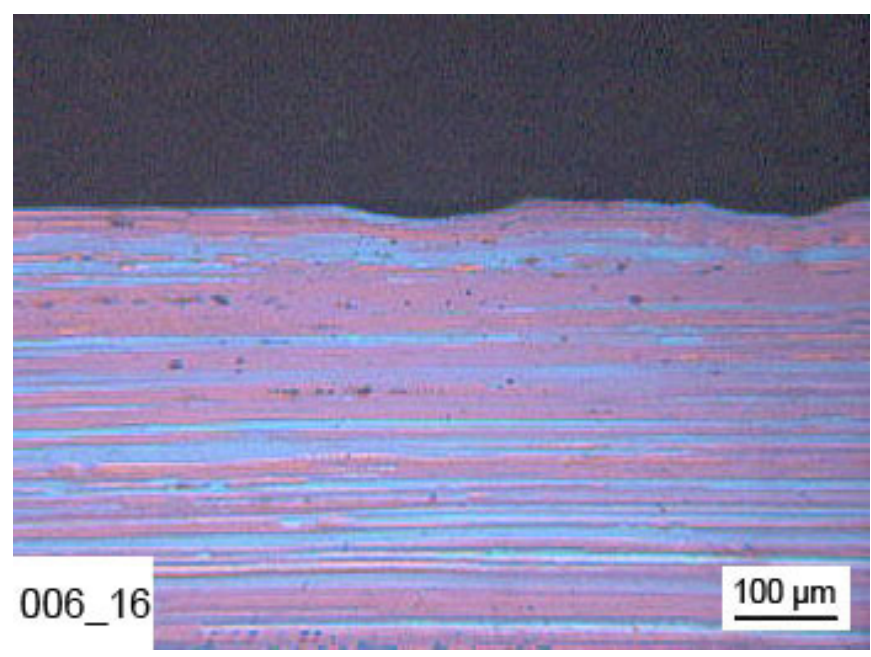

Figura 1.10: Microestrutura da seção transversal de uma chapa de alumínio 7050 jateada por esferas S230 $(\oslash=0,0230 \mathrm{in}=0,584 \mathrm{~mm})$.

(b) Recristalização

Outro método possível é um tratamento térmico visando a recristalização da região deformada na superfície jateada. Como a recristalização acontece apenas em regiões com alta densidade de discordâncias, ou seja, na região encruada pela deformação plástica superficial, é possível visualizar, em algumas situações, a presença de grãos equiaxiais superficiais, diferentes do material no centro da peça, que tem grãos alongados, como é o caso da Figura $1.11^{[42]}$.

Essa região de grãos diferenciados pode então ser entendida como a camada deformada plasticamente. Pode ocorrer, entretanto, crescimento de grão nas demais regiões, o que pode atrapalhar as análises. Além disso, em ligas de alumínio com fina dispersão de precipitados (como é o caso das ligas estudadas neste trabalho), a mobilidade dos contornos de grão é prejudicada e a recristalização pode ser inibida.

(c) Perfil de tensões residuais 


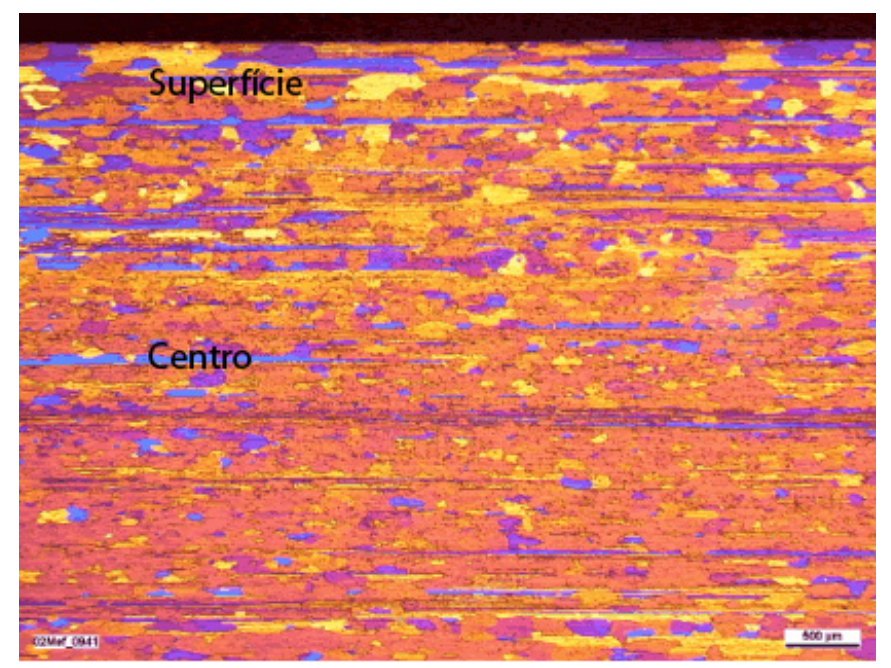

Figura 1.11: Amostra laminada de alumínio EN AW-1200 mostrando grãos maiores próximos à superfície (espessura total da amostra $=4,5 \mathrm{~mm})^{[42]}$.

Sabe-se, como já foi mencionado, que o material submetido ao JCG adquire uma camada superficial deformada plasticamente, a qual, após a recuperação elástica, fica permanentemente submetida a uma tensão residual de compressão.

Al-Hassani ${ }^{[21]}$ apresentou uma fórmula útil para o cálculo da espessura da zona plástica $\left(h_{p}\right)$ :

$$
\frac{h_{p}}{R}=2,57 \cdot\left(\frac{2}{3}\right)^{1 / 4} \cdot\left(\frac{\rho V^{2}}{\bar{p}}\right)^{1 / 4}
$$

onde $R$ é o raio da indentação, $\rho$ é a densidade do material do componente conformado, $V$ é a velocidade e $\bar{p} \cong 3 \sigma_{E}$.

A partir de evidências experimentais, o formato da distribuição de tensões residuais pode ser representado por uma função cosseno. Considerando que a tensão é "elástica" - ou seja, $\sigma=-E \epsilon(Z)$, onde $\mathrm{E}$ é o módulo de Young - e a deformação em função da profundidade $(Z), \epsilon(Z)$, é

$$
\begin{array}{r}
\epsilon(Z)=\epsilon_{m} \cos \pi\left[\frac{Z-\alpha h_{p}}{2(1-\alpha) h_{p}}\right] \\
0 \leq \alpha \leq 1
\end{array}
$$

A equação mostra que, quando $Z=h_{p}, \epsilon(Z)=\cos \pi / 2=0$ e $\sigma=0$, ou seja, a espessura da camada deformada é igual à espessura da camada submetida a tensões residuais de compressão.

Baseando-se nisso, ao se obter um perfil das tensões residuais superficiais em uma chapa submetida ao JCG, a espessura da camada deformada pode ser considerada igual à profundidade em que a tensão residual é 
nula.

(d) Image Quality (IQ) em EBSD

A nitidez das linhas de Kikuchi de um ponto de análise por difração de elétrons retroespalhados (EBSD) depende, entre outros fatores, da deformação do reticulado cristalino. Mapas de EBSD podem mostrar e diferenciar regiões com baixo índice de qualidade de imagem (IQ) dentro de uma amostra com regiões deformadas e não-deformadas, como é o caso dos componentes em estudo (ver Seção 1.4.2.1).

Em estudos preliminares ${ }^{[34]}$, foi possível observar a camada deformada na superfície de duas chapas de alumínio de $3 \mathrm{~mm}$ submetidas ao processo de conformação por JCG através da técnica de EBSD (Figuras 1.12 e 1.13).

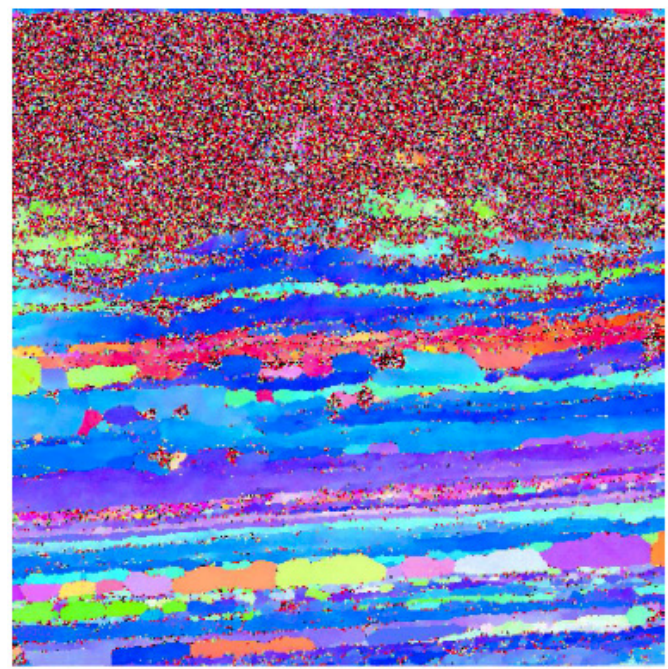

$80.00 \mu \mathrm{m}=80$ passos

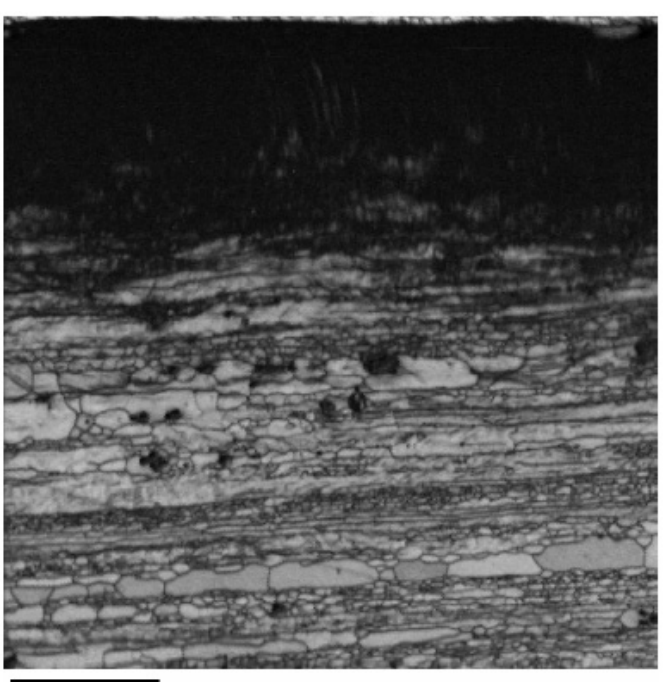

$80.00 \mu \mathrm{m}=80$ passos

(b)

(a)

Figura 1.12: Resultado prévio de medição de camada deformada plasticamente através de EBSD. (a) Figura de pólo inversa (IPF); (b) Qualidade de imagem (IQ). Espessura da camada $=130 \mu \mathrm{m}^{[34]}$. 


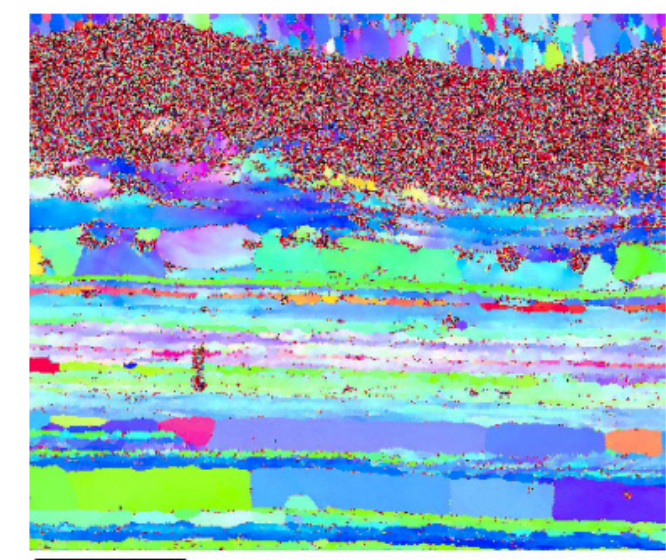

(a) $\overline{90.00 \mu \mathrm{m}}=90$ passos IPF [001]

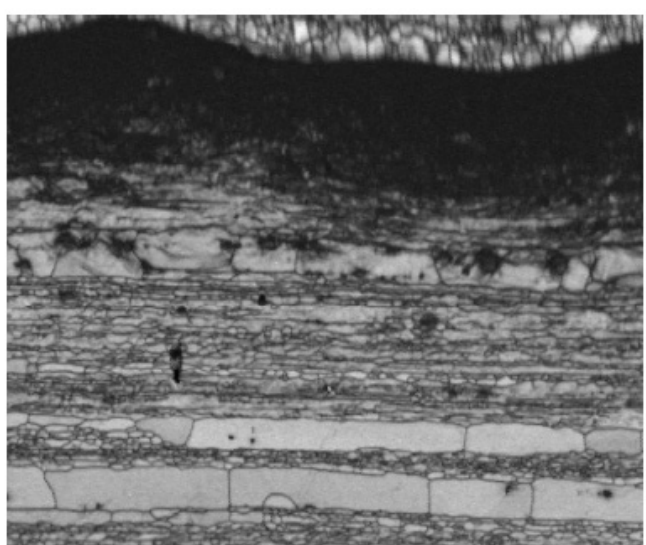

(b) $\overline{90.00 \mu \mathrm{m}}=90$ passos

IQ

Figura 1.13: Resultado prévio de medição de camada deformada plasticamente através de EBSD. (a) Figura de pólo inversa (IPF); (b) Qualidade de imagem (IQ). Espessura da camada $=90 \mu \mathrm{m}^{[34]}$. 


\subsection{Difração de Elétrons Retroespalhados - EBSD}

O website da Oxford Instruments ${ }^{[43]}$ oferece um tutorial resumido mas bastante abrangente sobre a técnica de análise por difração de elétrons retroespalhados (EBSD - Electron Backscatter Diffraction).

\subsubsection{Noções básicas de EBSD}

Os principais componentes de um sistema de EBSD são (Figura 1.14):
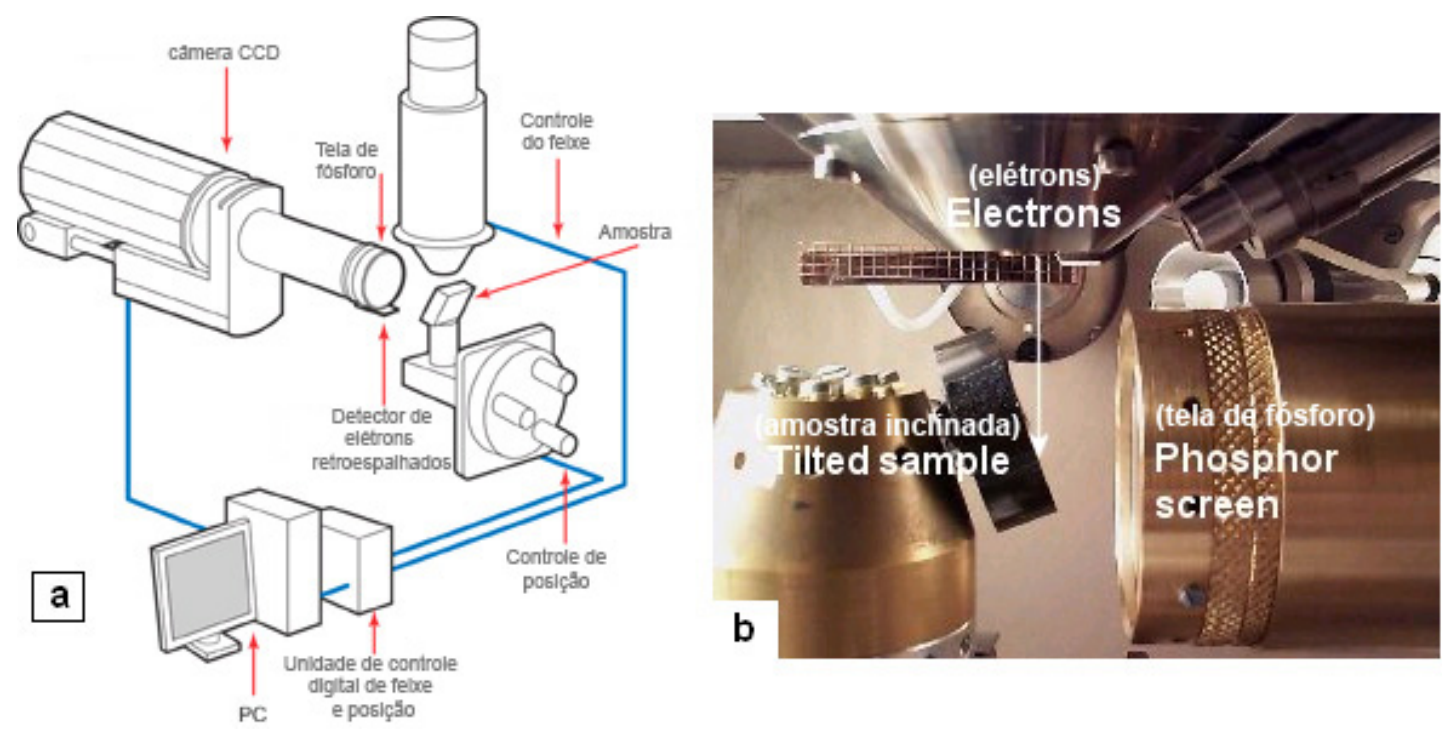

Figura 1.14: A montagem experimental para o EBSD. a. Diagrama dos componentes principais de um sistema de EBSD; b. Uma fotografia tirada de dentro de uma câmera de MEV, mostrando o arranjo experimental típico para EBSD.

- Uma amostra inclinada de $70^{\circ}$ em relação à horizontal.

- Uma tela de fósforo que é fluorescida por elétrons da amostra para formar padrões de difração.

- Uma câmera de vídeo CCD (charged-couple device) para visualização dos padrões de difração na tela de fósforo.

- Uma interface em vácuo para a montagem do fósforo e da câmera em uma câmara de microscópio eletrônico de varredura (MEV). A câmera monitora o fósforo por uma tela de vidro de chumbo na interface e o fósforo pode ser retraído para a borda do MEV quando não está em uso.

- Controles eletrônicos para o MEV, incluindo a posição do feixe, distância de trabalho, foco e aumento. 
- Um computador para controlar os experimentos de EBSD, analisar os padrões de difração e processar e mostrar os resultados.

- Um detector de elétrons (opcional) montado abaixo da tela de fósforo para os elétrons espalhados pela amostra.

Para o EBSD, um feixe de elétrons é direcionado a um ponto de interesse em uma amostra cristalina inclinada no microscópio eletrônico de varredura (Figura 1.15).

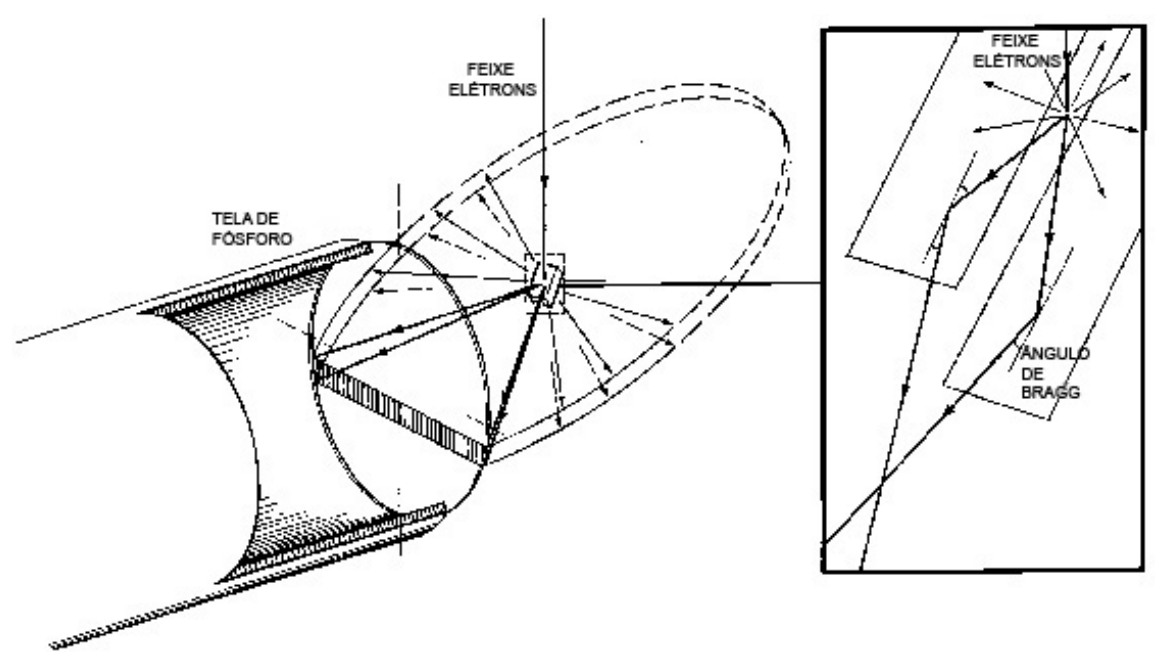

Figura 1.15: Formação do padrão de difração de elétrons retroespalhados. Elétrons de uma fonte divergente incidentes em planos cristalinos no ângulo de Bragg são difratados em um par de cones para formar as bandas de Kikuchi no padrão de difração.

O mecanismo pelo qual os padrões de difração são formados é complexo, mas o modelo seguinte descreve os aspectos principais. Os átomos no material espalham inelasticamente uma fração dos elétrons com uma pequena perda de energia para formar uma fonte divergente de elétrons próxima à superfície da amostra. Alguns desses elétrons incidem em planos atômicos em ângulos que satisfazem a equação de Bragg:

$$
n \lambda=2 d \sin \theta
$$

onde $n$ é um inteiro, $\lambda$ é o comprimento de onda dos elétrons, $d$ é o espaçamento interplanar e $\theta$ é o ângulo de incidência dos elétrons no plano de difração. Esses elétrons são difratados e formam uma configuração de cones de alto ângulo pareados, correspondendo a cada plano de difração. Quando usados para formar uma imagem na tela fluorescente, as regiões de intensidade eletrônica reforçada entre os cones produzem as bandas de Kikuchi características do padrão de difração de elétrons retroespalhados (Figura 1.16). 


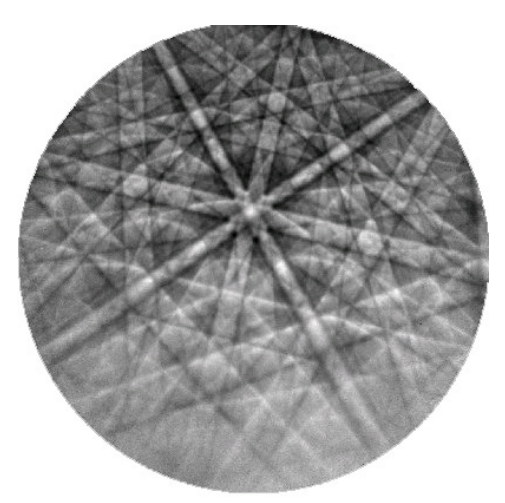

Figura 1.16: Padrão de difração de níquel coletado a uma voltagem de aceleração de 20 kV.

As linhas centrais das bandas de Kikuchi correspondem à projeção dos planos de difração na tela de fósforo. Consequentemente, cada banda de Kikuchi pode ser indexada pelos índices de Miller do plano cristalino difratado que a formou. Cada ponto na tela de fósforo corresponde à intersecção de uma direção cristalina com a tela. Em particular, as intersecções das bandas de Kikuchi correspondem à interseção de polos cristalinos (ou eixos de zona) com a tela de fósforo. Esses pontos podem ser rotulados pela direção cristalina do polo (Figura 1.17).

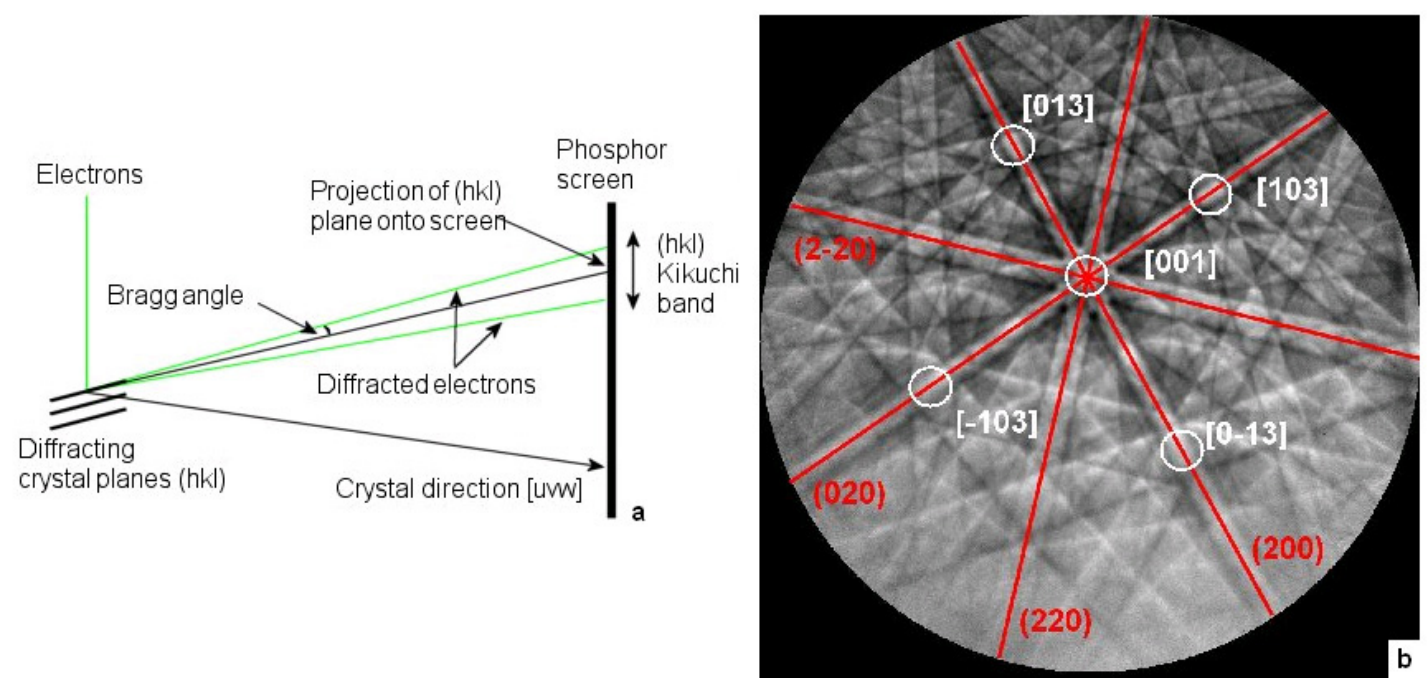

Figura 1.17: Relações entre os padrões de difração e o cristal. a. Mostra esquematicamente como as características do padrão de difração estão relacionadas à estrutura cristalina; b. A indexação dos planos cristalinos mostrados na Figura 1.16. As bandas de Kikuchi estão rotuladas com os índices de Miller dos planos cristalinos que as geraram (vermelho). Os planos projetam-se na tela no centro das bandas. Intersecções de bandas de Kikuchi estão rotuladas com a direção cristalina que encontra a tela nesses pontos (branco). Essas direções são os polos cristalinos dos planos correspondentes às bandas de Kikuchi que se interceptam. 
O padrão é uma projeção gnomônica ${ }^{1}$ dos cones de elétrons difratados na tela de fósforo. Como o padrão de difração está ligado à estrutura cristalina da amostra, quando a orientação do cristal muda, o padrão de difração resultante também muda. As posições das bandas de Kikuchi podem, portanto, ser utilizadas para calcular a orientação do cristal difratante.

\subsubsection{Experimentos de EBSD}

$\mathrm{Na}$ análise pontual por EBSD, o feixe é posicionado em um ponto de interesse na amostra, um padrão de difração é coletado e a orientação cristalina é calculada. No mapeamento de orientações cristalinas, de acordo com a identificação do padrão de difração, o sistema indexa uma orientação cristalina para o ponto analisado. Através de uma varredura ponto a ponto, com um passo determinado pelo usuário, obtém-se uma matriz com a posição e a orientação cristalina, que posteriormente será analisada pelo software para fornecer uma larga variedade de informações sobre a microestrutura da amostra. ${ }^{[43,44]}$

Os mapas mostrados podem ser baseados nas direções normal (ND), de laminação (RD) e transversal (TD) da amostra. Em cada ponto do mapa, a direção cristalográfica correspondente à direção da amostra em particular é calculada e uma cor é alocada de acordo com a sua posição na figura de polo inversa (Figura 1.18).

Nos mapas de orientação cristalina, um grão é definido pela coleção de pixels vizinhos no mapa que tenham uma desorientação menor do que um certo ângulo limite. A distribuição de tamanhos de grãos pode ser medida pelos dados coletados para o mapa. Ainda, pode-se mostrar a distribuição de ângulos de desorientação de contornos de grãos e a distribuição e posição de contornos de grãos especiais.

\subsubsection{Mapas de qualidade de imagem - IQ}

A qualidade de imagem (IQ - Image Quality) é uma medida que descreve a qualidade (nitidez) das linhas de um padrão de difração. Um mapa de IQ é construído através do mapeamento do valor de IQ para cada padrão de difração obtido durante uma análise de uma área. ${ }^{[45]}$

O IQ pode ser utilizado qualitativamente para avaliar o grau de deformação

\footnotetext{
${ }^{1}$ Projeção gnomônica ou central é a projeção de uma esfera sobre um plano tangente a partir do seu centro.
} 


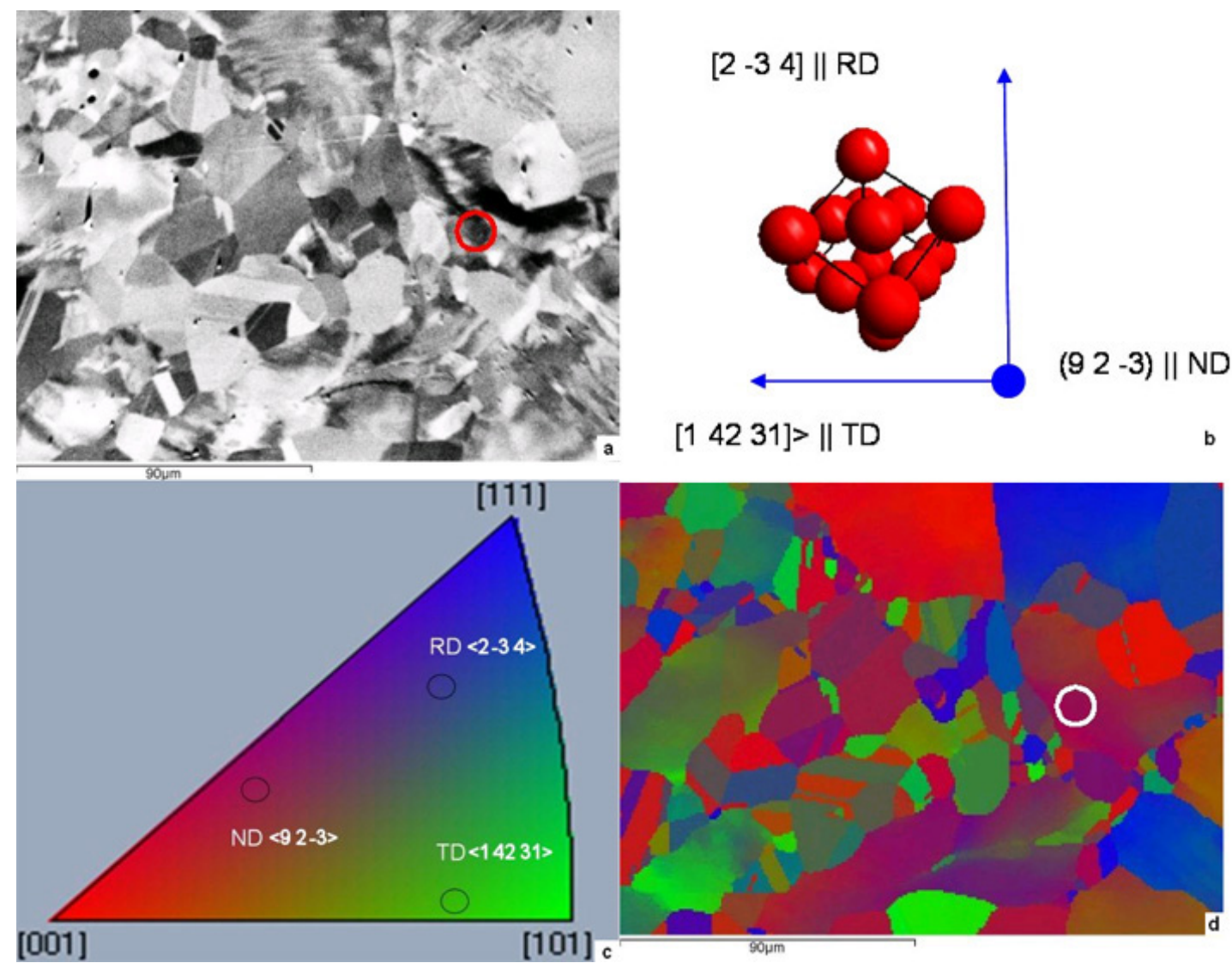

Figura 1.18: Coloração de mapas de orientação cristalina. a. Um ponto de referência na imagem eletrônica é circulado em vermelho; b. A orientação

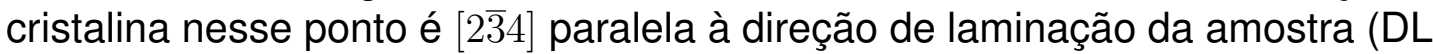
ou RD) e o plano normal (923) à direção normal (DN ou ND); c. As direções cristalinas paralelas a DN, DL e DT plotadas em uma figura de polo inversa. A figura de polo inversa é colorida com uma mistura de vermelhos, verdes e azuis, dependendo da posição do triângulo estereográfico; d. O ponto correspondente no mapa de orientação DN colorido de acordo com a chave de cores da figura de polo inversa.

do material. ${ }^{[4]} \mathrm{O}$ cálculo da qualidade de imagem IQ é:

$$
I Q=\sum_{i=1}^{3} h_{i} /\left(3 \sigma_{h}\right)
$$

onde $h_{i}$ é a altura do pico na transformada de Hough $^{2}$ da $i$-ésima banda de Kikuchi mais intensa e $\sigma_{h}$ é o desvio padrão da transformada de Hough.

Mapas de IQ podem ser coloridos ou em tons de cinza e geralmente revelam alguns detalhes invisíveis à imagem eletrônica, como grãos, contornos de grãos e danos superficiais, como riscos (Figura 1.19).

\footnotetext{
${ }^{2} \mathrm{~A}$ transformada de Hough é uma transformação necessária para que as linhas de difração sejam representadas como pontos, facilitando o armazenamento de dados e os cálculos necessários para construção de mapas de orientação. ${ }^{[44]}$
} 


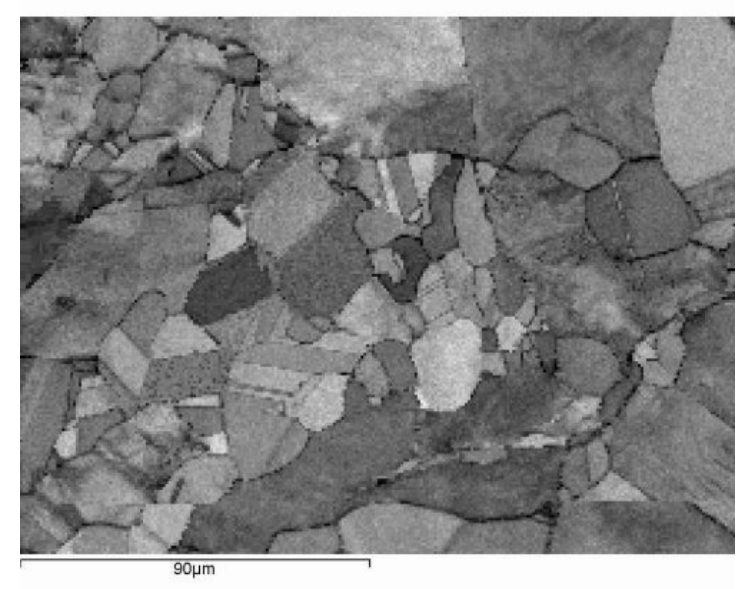

Figura 1.19: Mapa de qualidade de imagem mostrando contornos de grão e o contraste de IQ entre grãos de orientações cristalinas diferentes.

A difusividade ou qualidade do padrão de difração é influenciado por um número de fatores, incluindo condições do feixe de elétrons, deformação, perfeição cristalina local, preparação da amostra, contaminação da superfície e a fase e orientação sendo analisadas. Por causa desses fatores e outros, o contraste observado em mapas construídos usando o parâmetro IQ podem surgir da deformação, contornos de grão, fase, topologia superficial e/ou outras características da microestrutura ${ }^{[45]}$.

Em um mapa de IQ realizado em amostra cuja superfície tenha sido trabalhada a frio, como no caso do JCG, as regiões de grãos deformados terão menor qualidade de imagem do que regiões com grãos recristalizados, tornando possível a visualização e medição da espessura da camada deformada plasticamente.

\subsubsection{Preparação da amostra}

O ponto crítico de uma análise EBSD é o polimento da amostra. Os padrões de EBSD são formados em uma profundidade de 10-50 nm, e qualquer deformação superficial residual introduzida durante a preparação deve ser minimizada nessa região, para maximizar a qualidade do padrão. ${ }^{[46]}$ Além disso, a superfície deve estar livre de filmes óxidos, manchas e outras contaminações superficiais. Embora a uma análise por microscopia óptica ou microscopia eletrônica com elétrons secundários a superfície pareça estar perfeitamente polida, o EBSD detecta riscos, deformações, principalmente em materiais de preparação difícil, como alumínio, magnésio e algumas substâncias cerâmicas. 
Há diversas referências que citam inúmeras maneiras de preparar uma amostra de alumínio para observação em EBSD:

1. Polimento mecânico

A descrição do preparo inclui, quando necessário: método de corte, material de embutimento, lixamento e polimento.

(a) Embutimento em baquelite

- Corte com disco diamantado

- Polimento com pasta de diamante até $1 \mu \mathrm{m}$

- Sílica coloidal ${ }^{[47]}$

(b) - Embutimento em baquelite

- Lixamento com SiC \#100, \#220, \#320, \#400 e \#600

- Polimento com pasta de diamante $6 \mu \mathrm{m}, 3 \mu \mathrm{m}$ e $1 \mu \mathrm{m}$

- Sílica coloidal $1 \mu \mathrm{m}$ por 2 horas.

(c) Corte com disco diamantado

- Embutimento em resina de cura a frio Struers EPOFIX ${ }^{\circledR}$

- Lixamento com SiC \#180, \#220, \#400 e \#600

- Polimento com líquido para polimento de não ferrosos, de marca comercial Brasso ${ }^{\circledR 3}$ em pano para polimento típico para abrasivos de $3 \mu \mathrm{m}$

- Polimento com diamante em suspensão de $1 \mu \mathrm{m}$

- Sílica coloidal ${ }^{[48]}$

(d) Corte com disco abrasivo

- Embutimento em baquelite

- Lixamento com SiC \#220, \#400 e \#800 (Struers) ${ }^{\circledR}$

- Polimento com Pasta de Polir n², sem lubrificação, em pano DPmol, da Struers ${ }^{\circledR}$.

- Polimento com sílica coloidal azul, da Struers ${ }^{\circledR}$, em Minimet, por 10 minutos.

2. Polimento Eletroquímico

A descrição do preparo inclui, quando necessário: composição da solução, temperatura da solução, voltagem aplicada e tempo de exposição.

\footnotetext{
${ }^{3} \mathrm{O}$ mesmo produto pode ser encontrado sob as marcas Brasso ${ }^{\circledR}$, Silvo ${ }^{\circledR}, \mathrm{Kao}^{\circledR}$ e Polibril ${ }^{\circledR}$. Composição: querosene, álcool, oleína, bentonita, sílica e amônia
} 
(a) $\quad 1 / 3 \mathrm{HNO}_{3}$

- $2 / 3$ metanol

- $25 \mathrm{~V}$

- $-30{ }^{\circ} \mathrm{C}^{[49]}$

(b) $\quad 5 \% \mathrm{HClO}_{4}$

- $95 \%$ metanol

- $10 \mathrm{~V}$

- $-20{ }^{\circ} \mathrm{C}^{[50]}$

(c) $\quad 80 \%$ etanol

- $14 \%$ água destilada

- $6 \% \mathrm{HClO}_{4}$

- $16-20 \mathrm{~V}$

- $20-30 \mathrm{~s}^{[51]}$

(d) $700 \mathrm{~mL}$ etanol

- $120 \mathrm{~mL}$ água destilada

- $100 \mathrm{~mL}$ butil glicol

- $68 \mathrm{~mL} \mathrm{HClO}_{4}$

- $40 \mathrm{~V}$

- $10 \mathrm{~s}^{[52]}$

(e) $6 \mathrm{~mL} \mathrm{HClO}_{4}$

- 35 mL 2-butoxietanol (Butil Celossolve) ou etilenoglicol monobutil éter $\left(\mathrm{C}_{6} \mathrm{H}_{14} \mathrm{O}_{2}\right)$

- $59 \mathrm{~mL}$ metanol

- $1,2 \mathrm{~A} / \mathrm{cm}^{2}$

- $40 \mathrm{~s}^{[53]}$ 


\subsection{Medição de Tensões Residuais por Difração de Raios-X}

\subsubsection{Introdução}

O conhecimento da distribuição de tensões residuais na região próxima à superfície de um componente submetido a carregamentos cíclicos, como asas de aviões, é crítico para uma estimativa correta da sua vida em serviço. $\bigcirc$ dano por fadiga origina-se tipicamente na superfície, onde normalmente são alcançadas as maiores tensões de tração ${ }^{[2]}$. Em componentes submetidos a tratamentos superficiais, as tensões residuais na superfície interferem na vida em fadiga, suavizando ou acentuando as tensões durante o carregamento (Seção 1.3.2).

O processo de jateamento com granalhas - e a conformação por jateamento com granalhas - foi desenvolvido com a função de induzir na superfície tensões residuais de compressão, devido ao esforço exercido pelo material abaixo da superfície deformada plasticamente pelos impactos das esferas em recuperar a posição inicial antes da conformação ${ }^{[21]}$. Tais tensões causam uma alteração no espaçamento interplanar dos grãos do material constituinte, do seu valor livre de tensões para um novo valor correspondente à magnitude da tensão aplicada, assumindo-se uma distorção linear elástica do reticulado cristalino ${ }^{[54,55]}$.

A análise de tensões residuais por difração de raios-X é uma técnica nãodestrutiva baseada na avaliação das distâncias interplanares em amostras deformadas ao longo de diferentes orientações ${ }^{\left[{ }^{2]}\right.}$. O tipo de análise tratada aqui é a macroscópica, ou medição de macrotensões, a qual é realizada sobre regiões grandes, relativamente ao tamanho dos grãos do material. No caso de microtensões, as alterações observadas são alargamento dos picos de difração, devido a defeitos cristalinos gerados pela deformação ${ }^{[55]}$.

O Apêndice A descreve o método de cálculo das tensões residuais através da análise por difração de raios-X.

\subsubsection{Perfis de Tensões Residuais}

Devido à penetração limitada dos raios- $X$ em materiais metálicos, a técnica é bem-sucedida para avaliações de tensões residuais na região superficial, 
tipicamente de 10-40 $\mu \mathrm{m}$ (dependendo da absorção do material e do comprimento de onda do raio-X). A avaliação de tensões em profundidade não é simples, mas pode ser obtida pelo desbaste progressivo da amostra (a técnica torna-se destrutiva) e coleta de padrões de difração após cada passo de remoção de material. Os dados coletados devem ser corrigidos, por algoritmos numéricos, para contabilizar o relaxamento de tensões devido à remoção de camadas $^{[2]}$.

As tensões residuais de compressão na região próxima à superfície devem ser balanceadas por tensões residuais de tração no volume do componente. No entanto, há ainda um debate sobre se as tensões residuais são constantes na região do núcleo (linha cheia na figura 1.20) ou estão concentradas em uma camada relativamente fina adjacente à camada diretamente influenciada pelo procedimento de shot peening (linha tracejada na figura 1.20) ${ }^{[36]}$.

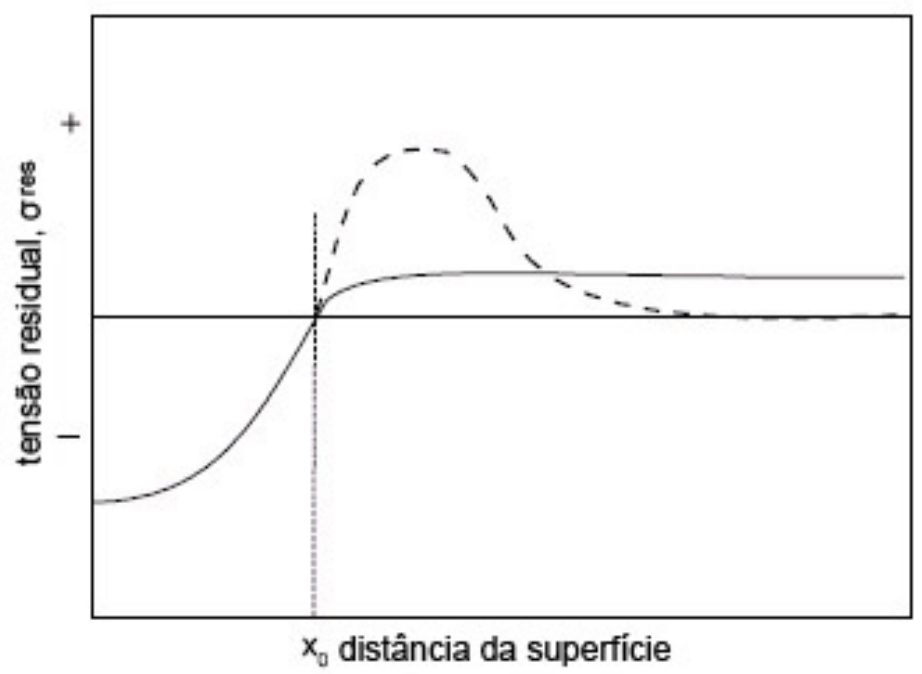

Figura 1.20: Representação esquemática dos perfis de tensões residuais que podem ser esperados após o shot peening; $x_{0}$ denota a profundidade da camada que está diretamente afetada pelo procedimento de shot peening ${ }^{[36]}$.

Segundo $\mathrm{H}$. Wohlfahrt ${ }^{[35]}$, em materiais de baixa dureza, a máxima magnitude de tensão residual fica localizada na superfície, enquanto em materiais de média dureza o maior valor de tensão localiza-se abaixo da superfície jateada.

Em 1958, Moore e Evans ${ }^{[56]}$ propuseram uma equação para a correção matemática de tensões em remoção de camadas em análise por difração de raios-X que é utilizada até hoje ${ }^{[57]}$ :

$$
\sigma\left(z_{i}\right)=\sigma_{m}\left(z_{i}\right)+2 \int_{z_{i}}^{H} \frac{\sigma_{m}(z) d z}{z}-6 z_{i} \int_{z_{i}}^{H} \frac{\sigma_{m}(z) d z}{z^{2}}
$$


onde:

- $\sigma\left(z_{i}\right)$ é a tensão corrigida na profundidade $z_{i}$;

- $\sigma_{m}\left(z_{i}\right)$ é a tensão medida na profundidade $z_{i}$;

- $\sigma_{m}(z)$ é a função de ajuste dos pontos medidos;

- $H$ é a espessura inicial da chapa.

\subsubsection{Perfis de Tensões Residuais após JCG}

Wick et al. ${ }^{[58]}$ estudaram o efeito dos parâmetros de jateamento (pressão do jato, fluxo de massa, dureza e tamanho das esferas) nas características superficiais em amostras de $2 \mathrm{~mm}$ de espessura do aço AISI 4140 com diferentes tratamentos térmicos, com dureza entre HV 230 e HV 660. As camadas superficiais foram caracterizadas em termos da distribuição de tensões residuais determinadas por difração de raios-X. A Figura 1.21 mostra três perfis de tensões residuais no aço na condição temperada, para diferentes pressões de jato.

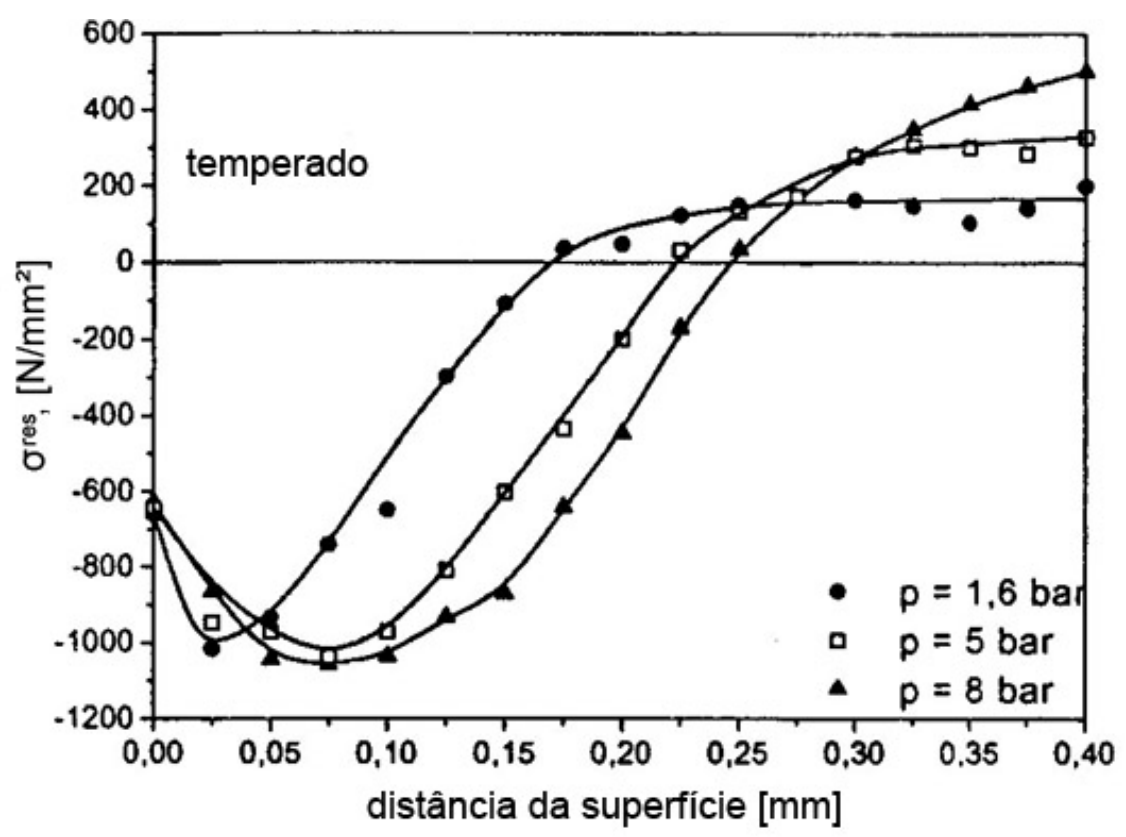

Figura 1.21: Perfis de tensões residuais determinados por difração de raios-X para diferentes pressões de jateamento em aço AISI 4140 temperado. (Extraído de Wick et al., 1999 ${ }^{[58]}$ )

Menig et al. ${ }^{[36]}$ utilizaram as mesmas amostras que Wick et al. para determinar os perfis de tensões residuais por difração de nêutrons. A Figura 1.22 mostra uma comparação entre os perfis obtidos por difração de raios-X e por 
difração de nêutrons, nas direções $\sigma_{11}$ e $\sigma_{33}$, em uma amostra temperada e revenida.

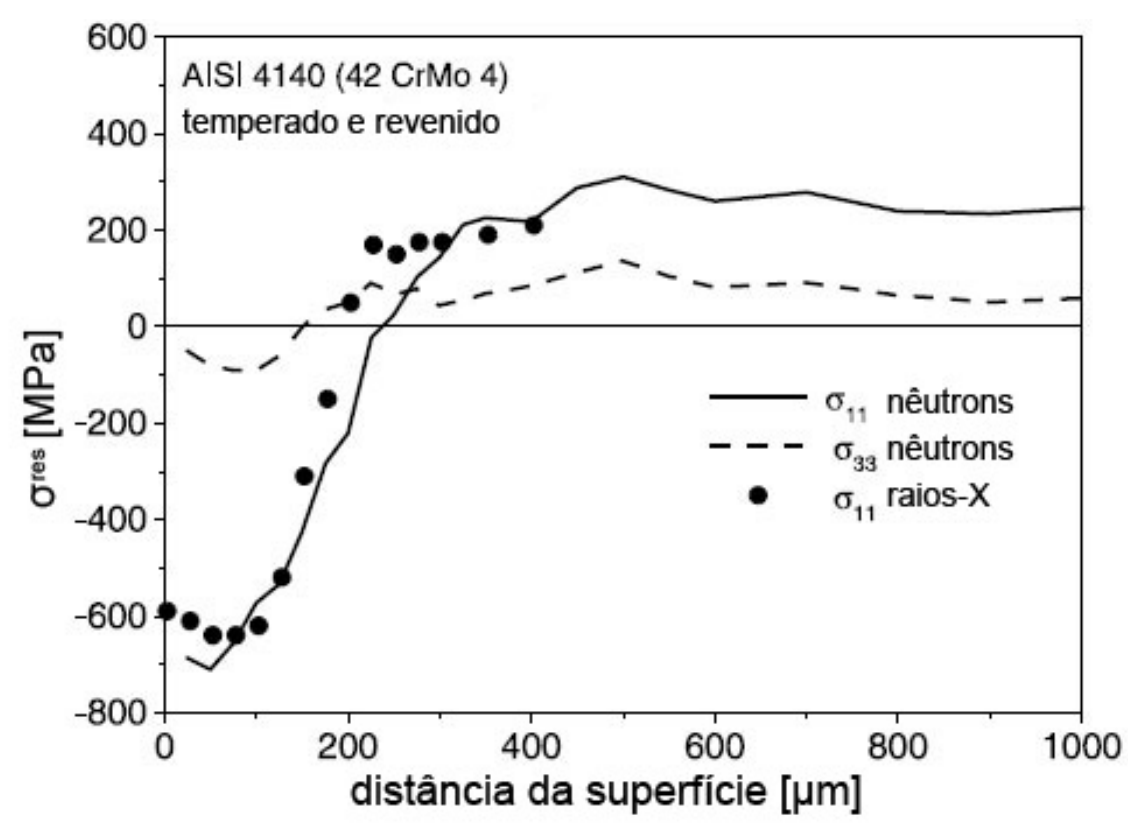

Figura 1.22: Comparação dos perfis de tensões residuais observados por nêutrons e raios- $X$ após remoção eletrolítica de camadas em um aço AISI 4140 jateado com granalhas, na condição temperada e revenida. (Extraído de Menig et al., 2001 ${ }^{[36]}$ )

Wohlfahrt ${ }^{[35]}$ revisou diversos trabalhos sobre perfis de tensões residuais em diferentes materiais e comparou o efeito das condições de jateamento e das características do material na distribuição e magnitude das tensões. Chegou à conclusão que, comparando-se materiais de maior dureza com materiais menos duros, a profundidade e diâmetro das indentações tornam-se menores e, portanto, como a força de impacto é a mesma, a pressão (força/área) devida ao impacto das granalhas, bem como a tensão de cisalhamento máxima, tornam-se maiores. Em outras palavras, com uma dureza maior, menos energia é consumida para a deformação plástica das camadas superficiais do material jateado, e mais energia está disponível para deformação plástica nas camadas mais profundas. Portanto, maior deformação plástica pode ocorrer em camadas mais profundas e um máximo de tensões residuais compressivas de magnitude superior pode ser produzido - mesmo com uma pressão de jato menor.

Zeng $^{[31]}$ utilizou a simulação pelo método de elementos finitos (MEF) para calcular a deformação, o perfil de tensões residuais e a camada deformada plasticamente, variando-se a velocidade de impacto (Figura 1.23) e o diâmetro das granalhas (Figura 1.24). 


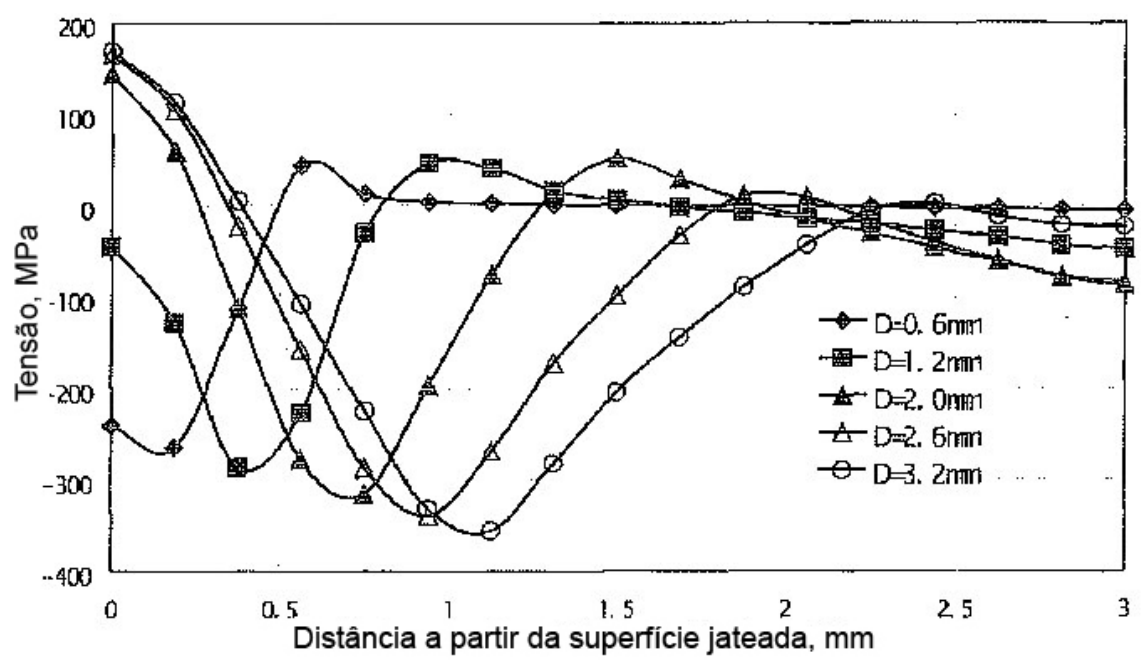

Figura 1.23: Perfil de tensões residuais calculado pelo MEF para diferentes diâmetros de granalha (velocidade=60 m/s). (Extraído de Zeng, 2002 $2^{[31]}$ )

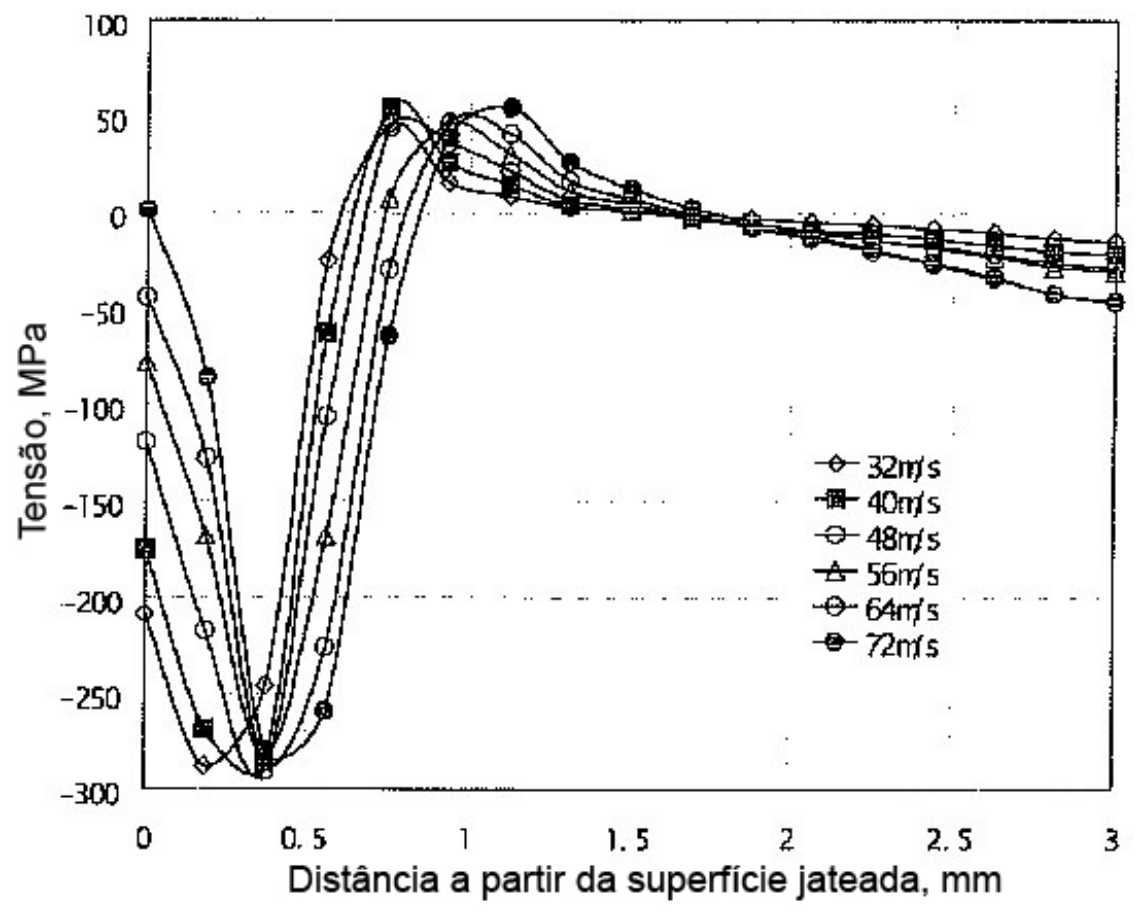

Figura 1.24: Perfil de tensões residuais calculado pelo MEF para diferentes velocidades de impacto das granalhas (diâmetro=1,2 mm). (Extraído de Zeng, 2002 $\left.{ }^{[31]}\right)$ 


\subsection{Previsão de deformação}

A conformação por jateamento com granalhas (JCG) é um processo comercial viável, apesar do fato de ser pouco entendido e ser comumente citado como "black art", pois a geração de uma rotina de jateamentos envolve a mistura (às vezes considerável) de experiências com componentes similares e então um pouco de tentativa e erro.

Grasty e Andrew ${ }^{[37]}$ buscaram, através de simulações com elementos finitos, fornecer entendimento e, consequentemente, previsibilidade para o processo, para melhorar a prática nas aplicações atuais e estender a variedade de aplicações potenciais. Algumas afirmações foram admitidas:

- Na prática, os parâmetros tamanho, densidade, velocidade e cobertura não são definidos separadamente com absoluta pecisão;

- A velocidade é difícil de ser definida ab initio em uma máquina de jato de ar, porque depende do design do bocal e varia com o fluxo de massa;

- A ordem e o padrão de formação da cobertura também têm um efeito significante na forma final.

Após os cálculos, foram feitos experimentos em condições similares às simulações, para comparação dos resultados. A correspondência da previsão com os experimentos trouxe confiança de que o modelo utilizado e a análise por EF associada são representações razoáveis da prática.

Han, Owen e Peric ${ }^{[38]}$, por causa da demanda irrealista de recursos em termos de memória e tempos de processamento para as simulações numéricas diretas de processos práticos de JCG, propuseram uma estratégia de dois estágios combinados de elementos finitos/discretos e solução explícita/implícita. Um perfil de tensões residuais/deformação é inicialmente identificado simulando o jateamento de uma pequena região da peça com análise dinâmica explícita. A deformação final e a distribuição de tensões da peça inteira são então obtidos introduzindo os perfis de tensões residuais como condições iniciais na subsequente solução implícita estática.

A aplicabilidade da metodologia foi ilustrada através do ensaio de JCG de uma tira de teste e os resultados numéricos tiveram boa acordância com os resultados experimentais. Os benefícios diretos da estratégia proposta são que ela resulta em modelos de elementos finitos/discretos de tamanho aceitável, 
o que permite que problemas práticos de JCG sejam simulados com custos computacionais razoáveis. Além disso, o procedimento de solução não recai em nenhum empiricismo, com todos os dados fornecidos sendo baseados em quantidades fisicamente relacionadas.

Kittel et al. ${ }^{[39]}$ apresentaram uma ferramenta de jateamento e medição em tempo real e seu sistema de controle que calcula os parâmetros reais, juntamente com resultados das primeiras aplicações. Eles descreveram como é possível obter componentes com curvaturas convexas exatas com medidas em tempo real do contorno e adaptação assistida por computador das operações de jateamento subsequentes. No entanto, para estimar quais parâmetros de jateamento teriam um efeito ótimo na conformação, algumas pequenas amostras de teste foram jateadas antes da série de testes reais com diferentes combinações de fluxo de massa, velocidade de impacto e massa por unidade de área. Os resultados - curvatura em função dos parâmetros de jateamento - desses pré-testes foram alimentados no banco de dados dos experimentos seguintes. Após os experimentos com o novo equipamento, foram obtidas tolerâncias dimensionais de 0,2 mm.

\subsubsection{Redes neurais artificiais}

Uma Rede Neural Artificial (RNA) - Artificial Neural Network (ANN) - é um modelo de processamento de informações inspirado na maneira com que os sistemas nervosos biológicos, como o cérebro, processam informações. O elemento chave desse modelo é a curiosa estrutura do sistema de processamento de informações, que é composta de um grande número de elementos de processamento (neurônios) altamente interconectados e trabalhando em uníssono para resolver problemas específicos ${ }^{[59]}$.

Esse campo amplo e multidisciplinar tem três bases de interesse de trabaIho:

Biologia A tarefa de entender como o cérebro funciona é um dos grandes problemas não-solucionados pela ciência. Alguns modelos de redes neurais têm a motivação de iluminar o modo com que cálculos e a memória são realizados pelo cérebro.

Engenharia Muitos pesquisadores gostariam de criar máquinas que pudessem 'aprender', realizar 'reconhecimento de padrões' ou 'descobrir padrões em dados'. 
Sistemas complexos Uma terceira motivação para se estudar redes neurais é que elas são sistemas adaptativos complexos cujas propriedades são interessantes por si mesmas. ${ }^{[60]}$

RNAs, como as pessoas, aprendem por exemplos. Uma RNA é configurada para uma aplicação específica, como um reconhecimento de padrões ou classificação de dados, através de um processo de aprendizagem. A aprendizagem, tanto nos sistemas biológicos como nas redes neurais artificiais, envolve ajustes nas conexões sinápticas que existem entre os neurônios ${ }^{[59]}$.

Os algoritmos de redes neurais podem ser grosseiramente divididos em duas classes: supervisionadas e não-supervisionadas. Neste trabalho, utilizou-se uma rede neural supervisionada, onde os dados são dados na forma de inputs e targets ou alvos, que são como uma especificação de um professor sobre qual a resposta que a rede neural deve dar aos inputs.

A ideia central das redes neurais supervisionadas é a seguinte: Dados exemplos de uma relação entre um vetor de entrada (input) $\mathbf{x}$, e um alvo (target) $t$, espera-se fazer com que a rede neural 'aprenda' um modelo de relação entre $\mathbf{x}$ e $t$. Uma rede neural com treinamento bem-sucedido dará, para qualquer dado $\mathbf{x}$, um valor de saída (output) y que é próximo ao alvo $t$. Treinamento de uma rede envolve buscar no espaço de pesos sinápticos de uma rede um valor de peso $\mathbf{w}$ que produza uma função tal que ajuste bem os dados do treino. ${ }^{[60]}$

Um exemplo simples de rede neural é a rede do tipo feedforward representada na Figura 1.25. Nesse tipo de rede, cada unidade de processamento recebe certos inputs, os agrega e retorna um output do tipo:

$$
y=\phi\left(\sum_{i} w_{i} x_{i}\right) .
$$

Os números $w_{i}$, denominados pesos sinápticos, são adaptados no processo de aprendizado. A função $\phi(x)$, denominada função de ativação, determina o tipo de unidade de processamento ou "neurônio". A função de ativação pode ser de vários tipos, a depender do objetivo da rede neural. Alguns tipo são: função sigmoidal, função linear, etc. O output de cada neurônio é direcionado como input aos que estão diretamente ligados a ele como nós filhos na rede. $O$ aprendizado se dá através de exemplos de inputs com seus respectivos outputs corretos, adaptando-se os pesos sinápticos para que os exemplos sejam reproduzidos com o menor erro possível. 


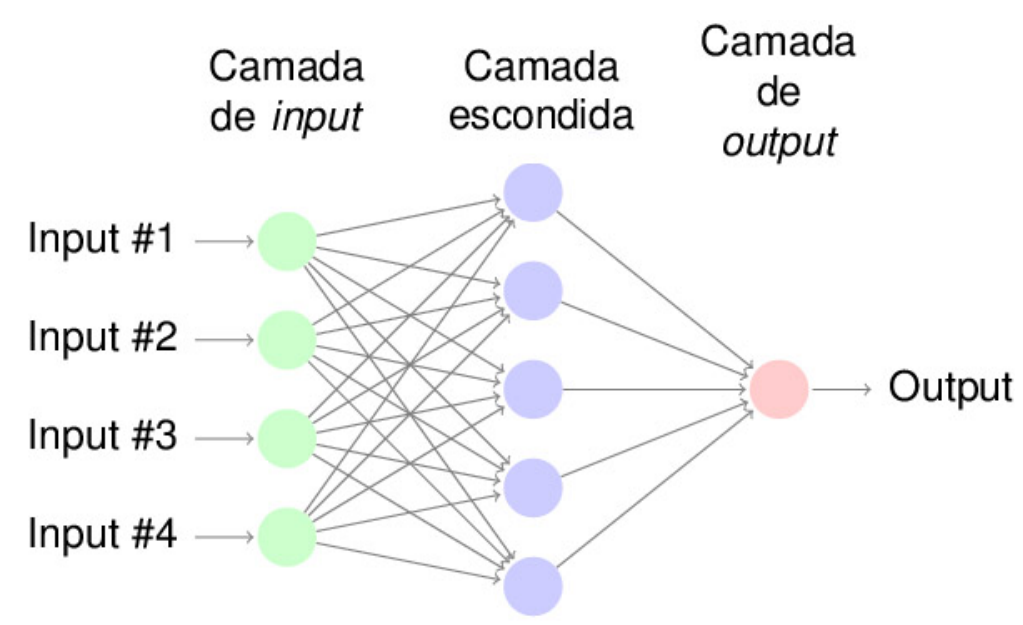

Figura 1.25: Exemplo de rede neural do tipo feedforward. Cada seta representa uma conexão sináptica com um certo peso e cada nó da rede representa um elemento de processamento que agrega os valores que recebe e produz um valor de saída, que é enviando para o próximo nó. O aprendizado se dá pelo ajuste dos pesos sinápticos para que um certo conjunto de exemplos de pares (input, output) seja reproduzido com o mínimo erro possível.

A RNA da Figura 1.25 pode ser descrita como uma rede de três camadas totalmente conectadas, perfazendo $(4 * 5)+(5 * 1)=25$ conexões e contendo: uma camada de entrada com quatro elementos de processamento; uma camada oculta, com cinco elementos de processamento; e uma camada de saída, com 1 elemento de processamento.

Resumindo, as RNA podem ser categorizadas por sua topologia, isto é, pelo número de camadas, de elementos de processamento e de conexões; pelas características de seus elementos de processamento; e pelas leis de aprendizagem a que foram submetidas. ${ }^{[61]}$

\subsubsection{Aplicações na indústria}

Redes neurais artificiais são das mais atrativas técnicas de inteligência artificial, principalmente por se tratar de uma técnica de fácil manuseio para modelamento, estimativa, previsão, diagnóstico e controle adaptativo em sistemas complexos não lineares.

Campana e Plaut empregaram o conceito das RNAs ao processo de extrusão de alumínio para prever a temperatura emergente do perfil extrudado a partir dos parâmetros de processo. A conclusão foi que a RNA possibilita prever resultados com erro menor que $1 \%$, viabilizando assim a sua utilização em ambiente industrial ${ }^{[62,63]}$. 
A vantagem de se utilizar redes neurais adaptativas na indústria é a possibilidade de utilizar um processo auto-ajustável, capaz de obter os exemplos para treinamento durante o próprio processo industrial.

Através de sensores que meçam os resultados obtidos durante a realização do processo com certos parâmetros, similar à simulação feita por Kittel et al. ${ }^{[39]}$, porém em maior escala, usa-se os próprios resultados como exemplos e, com o passar do tempo, a rede aprende a determinar, com grande precisão, os parâmetros necessários para obter um certo resultado desejado, eliminando o fator humano, o tempo de ajuste de máquinas e cálculos de processo. Esse aprendizado pode ser feito de forma online e automatizada, com poucos exemplos de calibração, uma vez que durante o próprio processo a rede aprenderá a obter o resultado desejado. 
2 Resultados Esperados 
Tornar o processo de conformação por jateamento com granalhas (JCG) reprodutível e controlável é, sem dúvida, o grande objetivo a ser alcançado para que o mesmo possa ser aplicado de forma segura na indústria aeronáutica. Para tanto, é essencial: 1) desenvolver planos de fabricação baseados em modelos matemáticos capazes de prever deflexões permanentes e tensões residuais elásticas; 2) dispor de instrumentação adequada para monitorar em tempo real as variáveis do processo; 3) dispor de equipamento de jateamento com granalhas que seja capaz de aplicar o plano de fabricação desenvolvido previamente.

Embora tal objetivo venha sendo buscado por diversas instituições usuárias de processos de JCG, observa-se que, a despeito de utilizarem equipamentos CNC, muitas vezes bastante avançados, em geral, os planos de fabricação são desenvolvidos a partir de conhecimentos puramente empíricos, o que os faz assemelharem-se a processos artesanais.

Em setembro de 2008, o Instituto de Pesquisas Tecnológicas (IPT) emitiu um relatório ${ }^{[34]}$ tratando de progressos alcançados em projeto apoiado pelo CTAero/FINEP e desenvolvido por equipes de diversas especialidades do IPT, da Unicamp e da EMBRAER, com apoio também de pesquisadores do Centro Universitário da FEI e da Escola Politécnica da USP. No relatório expõem-se os resultados obtidos pela equipe do IPT durante a realização de bateladas de ensaios de conformação de corpos de prova de ligas de alumínio, bem como modelos de elementos finitos desenvolvidos pela Unicamp para a descrição fenomenológica do referido processo. O conjunto de resultados experimentais obtidos, relacionando as principais variáveis do processo - velocidade de impacto, diâmetro das granalhas, cobertura, pré-tensionamento, curvatura e perfil de tensões residuais - desenvolvidos nos corpos de provas, compõe uma base de informações que permitirão verificar se uma determinada chapa de liga de Al pode ou não ser conformada por meio de jateamento com granaIhas, de maneira a apresentar uma dada curvatura estabelecida a priori.

\subsection{Objetivo}

O objetivo deste trabalho é caracterizar amostras de duas ligas de alumínio aeronáuticas que foram jateadas em diferentes condições de processamento, visando a busca de um método eficiente de controle do processo de conformação por jateamento com granalhas (peen forming). 
Serão observados:

1. Deformação ou encurvamento;

2. Microestrutura das amostras jateadas (microscopia óptica);

3. Perfil de durezas;

4. Recristalização da camada deformada plasticamente;

5. Camada deformada (morfologia e espessura), por EBSD;

6. Tensão residual, por difração de raios-X, em função da profundidade (perfil de tensões residuais) - espessura da camada deformada;

7. Correlação entre o encurvamento e o perfil de tensões residuais;

8. Correlação entre encurvamento, perfil de tensões ou camada deformada e condições de processo;

9. Correlação empírica ou semi-empírica entre variáveis do processo e encurvamento;

10. Previsão de curvatura através de redes neurais artificiais. 
3 Materiais e Métodos 


\subsection{Confecção dos corpos de prova}

Os corpos de prova utilizados nos experimentos consistem de placas planas sem reforçadores, usinadas a partir de blocos de ligas Al 7050-T7451 e Al 7475-T7351. As duas ligas são comumente utilizadas para a fabricação de paineis integrais de asas de aviões superiores e inferiores, respectivamente, e são, em alguns casos, empregadas em processos de conformação por jateamento com granalhas.

Com o propósito de se abranger toda a gama de espessuras típicas de painéis submetidos a esse processo, foram confeccionados corpos de prova com largura de $50 \mathrm{~mm}$, comprimento de $400 \mathrm{~mm}$ e espessuras de $2 \mathrm{~mm}$, $5 \mathrm{~mm}, 10 \mathrm{~mm}$ e $15 \mathrm{~mm}$ (Figura 3.1). Em aviões, a máxima espessura de uma chapa de alumínio que se utiliza é de $6 \mathrm{~mm}$.

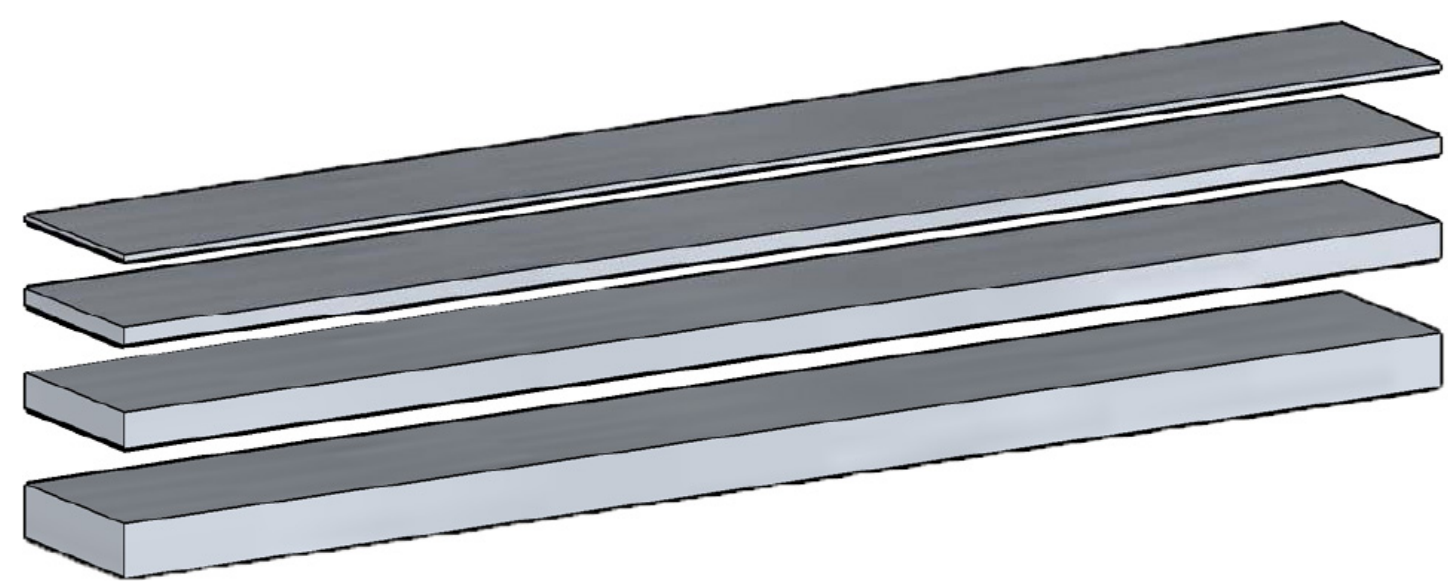

Figura 3.1: Modelos dos corpos de prova jateados. Comprimento: $400 \mathrm{~mm}$; Largura: $50 \mathrm{~mm}$; Espessuras: $2 \mathrm{~mm}, 5 \mathrm{~mm}, 10 \mathrm{~mm}$ e $15 \mathrm{~mm}$. 


\subsection{Conformação por Jateamento com Granalhas}

Os jateamentos foram feitos em uma máquina (Figura 3.2) projetada e construída pela empresa Brasibrás Tratamento de Metais Ltda., a partir de especificação técnica fornecida pela equipe do IPT, com as seguintes características:

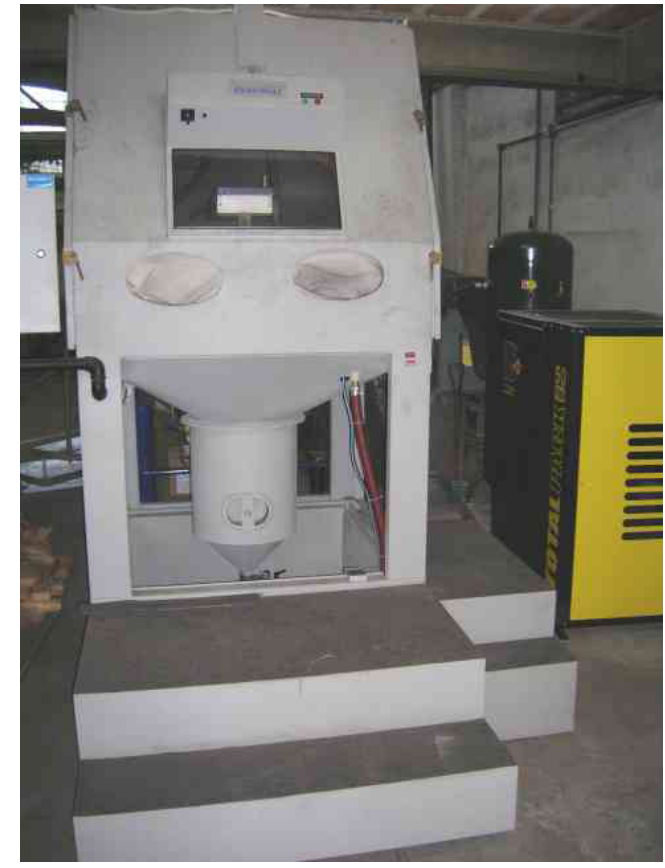

(a) Vista exterior, mostrando o gabinete com reservatório e o compressor.

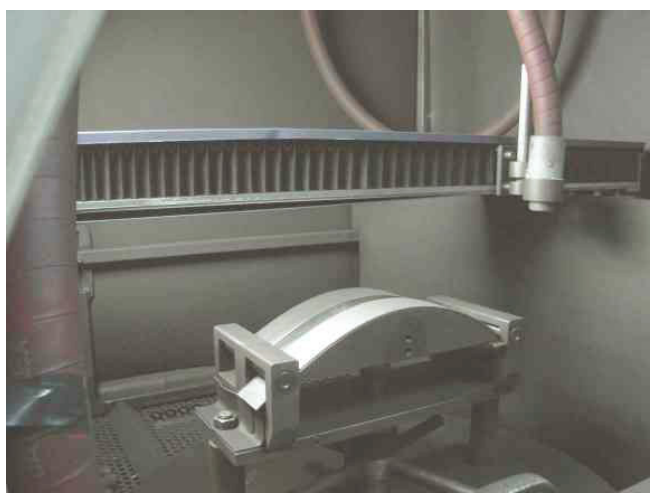

(b) Vista interior, mostrando bocal de jateamento e sistema de fixação da chapa.

Figura 3.2: Máquina utilizada para o JCG.

- Gabinete em chapa de aço carbono, dentro do qual se localiza uma base rotativa acionada manualmente e que serve de suporte a uma mesa $X Y$ (cursos $\mathrm{X}=\mathrm{Y}=700 \mathrm{~mm}$ ) acionada por dois servomotores;

- Sistema contínuo de reciclagem do abrasivo ;

- Sistema pneumático de emissão do jato de granalhas composto por filtro separador de umidade, válvula reguladora de pressão, manômetro de 0 a 200 psi, mangueira de 1/2", válvula dosadora de abrasivo, bocal modelo venturi de 3/8" fabricado em carboneto de tungstênio, válvulas de pressurização e despressurização de 1", válvulas de segurança, válvula silenciadora pneumática e filtro de granalha;

- Compressor volumétrico de parafusos (fabricado pela MPL Marlins Ltda.)

\footnotetext{
${ }^{1}$ As granalhas são coletadas após o jateamento em um reservatório e ficam disponíveis para a continuação do processo, sem peneiramento ou seleção de granalhas fraturadas. Para evitar utilização de granalhas deterioradas pelo uso, estas foram trocadas periodicamente.
} 
conectado a uma câmara reguladora de pressão para controle da velocidade do jato de granalhas;

- Vaso pressurizado com reservatório de 100 litros;

- Driver programável para controle de servomotor;

- Controlador multi-eixo, composto por hub para comunicação com até 4 drivers controladores dos servomotores e software para comando simultâneo desses drivers.

Almeida, Martins e Fleury ${ }^{[64]}$,a partir dos parâmetros das distribuições de impactos, dos diâmetros de impressão e do modelo de cálculo de cobertura baseado na equação de Avrami ${ }^{2}$, definiram as trajetórias necessárias à obtenção de coberturas aproximadamente homogêneas requeridas em cada experimento. Devido à facilidade de geração, utilizou-se sequência de trajetórias restritas a linhas retas paralelas, como mostra a Figura 3.3. ${ }^{[34]}$

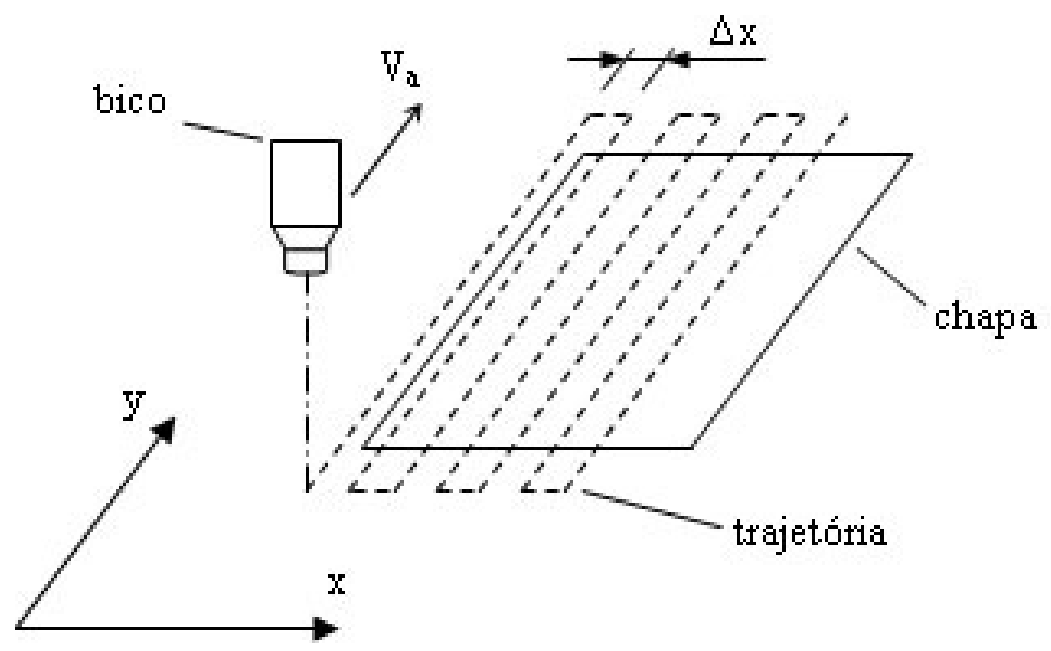

Figura 3.3: Esquema da trajetória do bocal para obtenção de cobertura homogênea. (Extraído de Almeida, Martins e Fleury, 2008 ${ }^{[64]}$ )

Um dispositivo para aplicação de carga estática distribuída uniformemente sobre a superfície dos corpos de prova submetidos aos ensaios de peen forming foi projetado e construído no IPT, de forma a atender às especificações básicas apresentadas na Figura 3.4. ${ }^{[34]}$

A partir do esquema geométrico simplificado dos ensaios, determinaramse as formas de 4 cabeçotes de aplicação de carga requeridos para a aplicação de carga aproximadamente uniforme sobre os corpos de prova de espessuras $2 \mathrm{~mm}, 5 \mathrm{~mm}, 10 \mathrm{~mm}$ e $15 \mathrm{~mm}$ fabricados nas ligas Al 7050-T7451

\footnotetext{
${ }^{2}$ Equação de Avrami: $y=1-\exp \left(k \cdot t^{n}\right), k$ e $n$ constantes.
} 


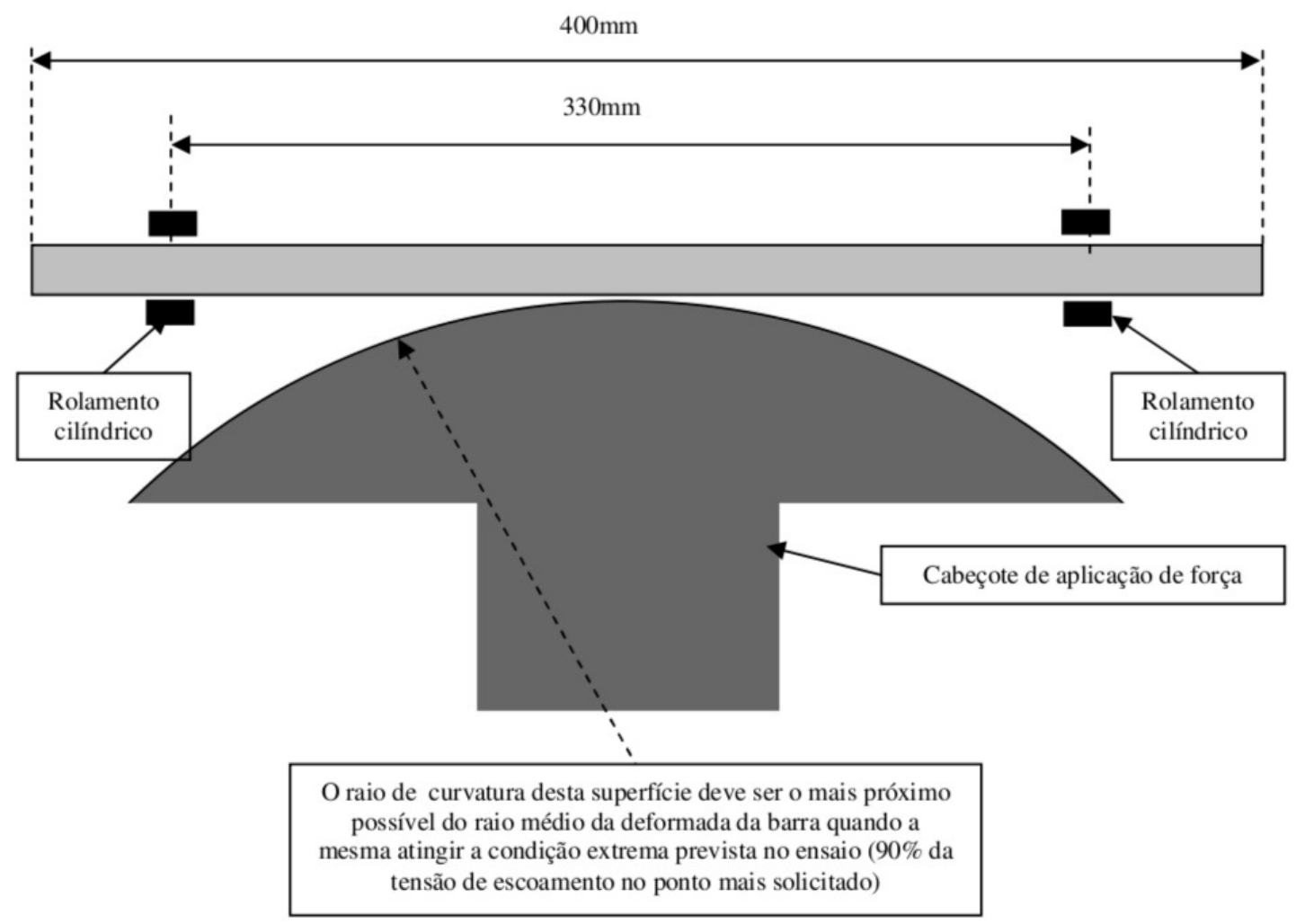

Figura 3.4: Esquema geométrico de imposição de carga estática aos corpos de prova. (Extraído do relatório do projeto IPT/Unicamp/Embraer/FINEP ${ }^{[34]}$ )

e Al 7475-T7351. Para tanto, adotou-se um modelo de viga bi-apoiado sujeita a carregamento distribuído segundo forma trapezoidal, tal que no centro da placa a tensão fosse da ordem de $90 \%$ da tensão de escoamento do material.

Feitas as considerações anteriores, calcularam-se os esforços solicitantes sobre a "viga" e, em decorrência, determinaram-se as curvas elásticas para cada um dos 4 casos. Uma vez que os cabeçotes impõem o pré-carregamento aos corpos de prova por meio de força de contacto, utilizaram-se as coordenadas definidoras das linhas elásticas calculadas como referência para a fabricação dos perfis dos 4 cabeçotes utilizados nos ensaios de peen forming, associando-os, cada qual, a seu respectivo tipo de corpo de prova. A Figura 3.2b mostra um corpo de prova de $2 \mathrm{~mm}$ carregado no dispositivo de prétensão dentro da máquina de ensaios. ${ }^{[34]}$

\subsubsection{Matriz de experimentos em JCG}

Para que o processo de conformação de chapas de alumínio por JCG seja controlável e reprodutível, promovendo a deformação requerida em um dado ponto da estrutura, é necessário haver uma base de dados experimentais que englobe todas as variáveis significativas de projeto $^{[34]}$. 
A metodologia para o projeto dos experimentos focalizou os dois agentes principais do experimento: processo e corpo de prova. O primeiro deles é influenciado pelas variáveis associadas às características físicas do jato de granalhas e à estratégia de aplicação espaço-temporal do jato à superfície do corpo de prova. O segundo, para que possam ser avaliadas as alterações sofridas, é necessário que se façam medições das variáveis observáveis associadas às deformações permanentes e às tensões residuais, ao mesmo tempo que se controlem as variáveis de controle associadas às características geométricas e de rigidez, às condições de contorno e à distribuição do pré-carregamento estático.

Deste modo, as variáveis observadas foram:

- Variáveis associadas ao corpo de prova:

Liga de alumínio: Duas ligas de alumínio aeronáuticas: 7050-T7451 e 7475-T7351.

Espessura: Quatro espessuras: $2 \mathrm{~mm}, 5 \mathrm{~mm}, 10 \mathrm{~mm}$ e $15 \mathrm{~mm}$.

- Variáveis associadas ao processo:

Diâmetro de granalhas: Três tipos de granalhas de aço (não especificado) foram utilizadas, com dureza média em torno de $43 \mathrm{HR}_{C}$ : S230 $(\oslash \approx 0,0230$ in $\approx 0,584 \mathrm{~mm})$, S550 $(\oslash \approx 0,0550$ in $\approx 1,397$ $\mathrm{mm})$ e $1 / 8 "(\oslash \approx 0,125 \mathrm{in} \approx 3,175 \mathrm{~mm}) .^{3}$

Pressão do jato (velocidade de impacto): A vazão em massa de granalha fornecida pelo equipamento de JCG é função da pressão na seção de entrada do bocal. A pressão de ar é controlável por meio de uma válvula reguladora de pressão e, para cada tamanho de granalha, foram utilizadas três valores de pressão (baixa, média e alta): 20, 40 e $60 \mathrm{psi}(138,276$ e $414 \mathrm{kPa})$, para a esfera pequena; 10, 20 e 30 psi (69, 138 e $209 \mathrm{kPa})$, para a esfera média; 10, 20 e $25 \mathrm{psi}(69,138$ e $172 \mathrm{kPa})$, para a esfera grande.

Pré-tensão: Considerando-se que a aplicação de pré-tensão elástica ao corpo de prova exerce expressiva influência sobre o perfil de tensões residuais resultante da aplicação do jateamento, foram estabelecidas duas condições de pré-carregamento estático do corpo

\footnotetext{
${ }^{3}$ Os diâmetros de granalha são especificações de uma média de diâmetros permitidos, selecionados por peneiramentos em malhas de aberturas decrescentes, até uma tolerância especificada pela norma SAE J444 ${ }^{[28,65]}$.
} 
de prova: livre (carga estática externa nula) e pré-tensionado (conforme descrito anteriormente).

Cobertura: Foram testadas as condições de saturação (200\% de cobertura) e não-saturação ( $60 \%$ de cobertura). Por limitações da regulagem do fluxo de granalhas na máquina de jateamento para as esferas pequenas nas pressões escolhidas (uma vez que os testes iniciais foram feitos na condição de saturação), a mínima cobertura possível era maior que $60 \%$. Portanto, foram utilizadas coberturas de $66 \%$, 85\% e 92\% para as pressões 20 psi, 40 psi e 60 psi, respectivamente.

Para que se obtivesse máxima eficiência no processo de conformação, estabeleceu-se em 90 mm a menor distância entre o bocal e o corpo de prova, para minimizar a variação de ângulos de impacto por volta de $90^{\circ}$.

Para a elaboração da matriz de experimentos, foram considerados todos os fatores citados anteriormente, com a limitação de que a espessura das chapas limita inferior ou superiormente o diâmetro das granalhas. A Tabela 3.1 apresenta as combinações de variáveis requeridas:

Tabela 3.1: Matriz de experimentos.

\begin{tabular}{|c|c|c|c|c|c|c|}
\hline $\begin{array}{l}\text { Espessura } \\
\text { CDP }\end{array}$ & Liga de Al & Diâmetro & $\begin{array}{c}\text { Pressão } \\
\text { (psi) }\end{array}$ & Cobertura & Pré-tensão & $\begin{array}{c}\mathrm{N}^{\circ} \text { de } \\
\text { condições }\end{array}$ \\
\hline $2 \mathrm{~mm}$ & $\begin{array}{l}7050-T 7451 \\
7475-T 7351\end{array}$ & S230 & $\begin{array}{l}20 \\
40 \\
60\end{array}$ & $\begin{array}{c}66-85-92 \% \\
200 \%\end{array}$ & $\begin{array}{c}0 \\
90 \% \text { LE }\end{array}$ & 24 \\
\hline $5 \mathrm{~mm}$ & $\begin{array}{l}\text { 7050-T7451 } \\
\text { 7475-T7351 }\end{array}$ & $\begin{array}{l}\text { S230 / } \\
\text { S550 }\end{array}$ & $\begin{array}{l}20 / 10 \\
40 / 20 \\
60 / 30\end{array}$ & $\begin{array}{c}66-85-92 \% / \\
60 \% \\
200 \%\end{array}$ & $\begin{array}{c}0 \\
90 \% \text { LE }\end{array}$ & 48 \\
\hline $10 \mathrm{~mm}$ & $\begin{array}{l}7050-T 7451 \\
7475-T 7351\end{array}$ & $\begin{array}{c}\mathrm{S} 550 / \\
1 / 8^{\prime \prime}\end{array}$ & $\begin{array}{c}10 \\
20 \\
30 / 25\end{array}$ & $\begin{array}{c}60 \% \\
200 \%\end{array}$ & $\begin{array}{c}0 \\
90 \% \text { LE }\end{array}$ & 48 \\
\hline $15 \mathrm{~mm}$ & $\begin{array}{l}7050-T 7451 \\
7475-T 7351\end{array}$ & $1 / 8 "$ & $\begin{array}{l}10 \\
20 \\
25\end{array}$ & $\begin{array}{c}60 \% \\
200 \%\end{array}$ & $\begin{array}{c}0 \\
90 \% \text { LE }\end{array}$ & 24 \\
\hline \multicolumn{6}{|c|}{ Total de combinações } & 144 \\
\hline
\end{tabular}

Para que se possa aferir as incertezas das medições, é necessário que, para cada condição de jateamento, se realize ao menos 3 experimentos, o que gera um número mínimo de 432 ensaios de JCG. Durante a execução 
dos ensaios, alguns corpos de prova foram rejeitados e outros foram repetidos mais de 3 vezes, por motivos diversos. O número final de corpos de prova foi 429.

O Apêndice B contém os parâmetros de jateamento de todos os 429 corpos de prova ensaiados. 


\subsection{Medição de curvatura}

Para realizar o levantamento das deflexões das placas conformadas adotouse o equipamento QM353 acompanhado do software QM Data 200, ambos fornecidos pela Mitutoyo Sul Americana Ltda. Trata-se de uma máquina de medição com movimentação manual que, em virtude de utilizar uma ponta de toque de alta sensibilidade, permite determinar as coordenadas tridimensionais de um ponto com elevada precisão e repetitividade ${ }^{[34]}$.

O software QM Data 200 permite a programação de rotinas de medições para diversas geometrias de corpos de prova. A rotina que foi utilizada para a medição da curvatura interna ${ }^{4}$ (face não-jateada) dos corpos de prova, após a indicação do plano de referência e as extremidades do CP, calcula a linha central $(Y=0 \mathrm{~mm})$ e armazena 9 medições ao longo desta linha, na região central $(-100 \mathrm{~mm}<X<100 \mathrm{~mm})$ (Figura 3.5).

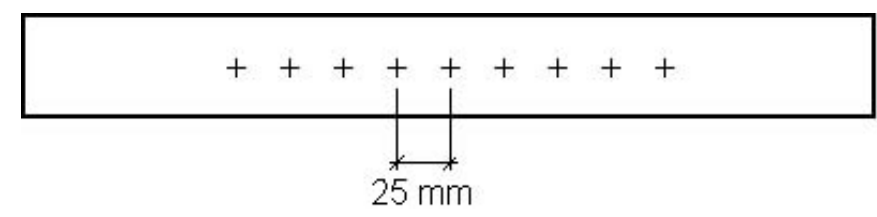

Figura 3.5: Localização dos pontos do corpo de prova para medição de coordenadas.

A saída no computador é semelhante à Figura 3.6 e estes dados foram utilizados para o cálculo do raio de curvatura, $r$, da seguinte forma:

Os pontos de interesse para o cálculo de curvatura são os que contêm os valores de $\mathrm{X}$ e Z, onde X é a distância do ponto ao centro da chapa e Z é a cota. A Tabela 3.2 mostra os valores de interesse para o cálculo.

\footnotetext{
${ }^{4} \mathrm{O}$ fato de a medição ter sido feita na parte interna da chapa não altera os resultados de maneira significativa, pois as espessura da chapa é algumas ordens de grandeza menor do que os raios de curvatura medidos. De fato, a medição da curvatura interna é apenas vantajosa, porque diminui as imprecisões que seriam causadas pela rugosidade da face jateada.
} 


\begin{tabular}{|c|c|c|c|}
\hline \multicolumn{4}{|c|}{ AMOSTRA 338 18-04-08 17:09 } \\
\hline 0125 & Difer, : & YD & $-49,9875$ \\
\hline 0126 & Difer, : & $\times D$ & 401,6493 \\
\hline 0127 & Coord: & $\times$ & $-99,9996$ \\
\hline 0127 & Coord: & $Y$ & 0,0019 \\
\hline 0127 & Coord: & Z & 12,6944 \\
\hline 0128 & Coord: & $\times$ & $-75,0000$ \\
\hline 0128 & Coord: & $Y$ & $-0,0142$ \\
\hline 0128 & Coord: & Z & 11,6487 \\
\hline 0129 & Coord: & $\times$ & $-49,9965$ \\
\hline 0129 & Coord: & Y & $-0,0072$ \\
\hline 0129 & Coord: & Z & 10,8516 \\
\hline 0130 & Coord: & $\times$ & $-24,9865$ \\
\hline 0130 & Coord: & $Y$ & $-0,0196$ \\
\hline 0130 & Coord: & Z & 10,3129 \\
\hline 0131 & Coord: & $\times$ & 0,0111 \\
\hline 0131 & Coord: & $Y$ & 0,0044 \\
\hline 0131 & Coord: & Z & 10,0467 \\
\hline 0132 & Coord: & $\times$ & 25,0106 \\
\hline 0132 & Coord: & $Y$ & $-0,0135$ \\
\hline 0132 & Coord: & Z & 10,0516 \\
\hline 013 & Coord: & $\times$ & 50,0136 \\
\hline 013 & Coord: & $Y$ & $-0,0104$ \\
\hline 0133 & Coord: & Z & 10,3324 \\
\hline 013 & Coord: & $\times$ & 75,0020 \\
\hline 0134 & Coord: & $Y$ & $-0,0023$ \\
\hline 01 & Coord: & Z & 10,8838 \\
\hline & Coord: & $\times$ & 100,0115 \\
\hline 013 & Coord: & $Y$ & $-0,0122$ \\
\hline 013 & Coord: & $Z$ & 11,6686 \\
\hline
\end{tabular}

Figura 3.6: Saída do software QM Data 200 para medição de coordenadas.

Tabela 3.2: Valores de interesse para o cálculo da curvatura da chapa medida.

\begin{tabular}{cc}
\hline$X$ & $Z$ \\
\hline$-99,9996$ & 12,6944 \\
$-75,0000$ & 11,6487 \\
$-49,9965$ & 10,8516 \\
$-24,9865$ & 10,3129 \\
0,0111 & 10,0467 \\
25,0106 & 10,0516 \\
50,0136 & 10,3324 \\
75,0020 & 10,8838 \\
100,0115 & 11,6686 \\
\hline
\end{tabular}

A parábola $X=a+b Z+c Z^{2}$ de melhor ajuste dos pontos é obtida através do método dos mínimos quadrados, em que se resolve um sistema do tipo

$$
\left[\begin{array}{ccc}
N & S Z & S Z^{2} \\
S Z & S Z^{2} & S Z^{3} \\
S Z^{2} & S Z^{3} & S Z^{4}
\end{array}\right] \cdot\left[\begin{array}{l}
a \\
b \\
c
\end{array}\right]=\left[\begin{array}{c}
S X \\
S Z X \\
S Z^{2} X
\end{array}\right]
$$

onde $N=$ número de termos da matriz dos coeficientes (9 pontos); $S Z^{i}=$ Soma dos valores $Z$ elevados à potência $i ; S Z^{j} X=$ Soma dos produtos dos valores $X$ e dos valores $Z$ elevados à potência $j$.

O raio de curvatura $r$ de uma parábola é definido como o raio da circunferência que melhor se ajusta à parábola no seu vértice e é calculado por: 


$$
r=\frac{\left(1+b^{2}\right)^{3 / 2}}{2 c}
$$

Assim, ajustando-se a parábolas todas as coordenadas medidas na máquina, pode-se calcular o raio de curvatura dos corpos de prova. 


\subsection{Análise microestrutural}

As análises microestruturais foram feitas nas amostras embutidas em baquelite, de maneira a se observar a seção longitudinal das chapas. A preparação metalográfica foi feita através de lixamento em lixas d'água de granulometrias 180\#, 240\#, 360\#, 400\# e 600\#, nesta ordem. O polimento subsequente foi realizado com pastas diamantadas de granulometria $6 \mu \mathrm{m}, 3 \mu \mathrm{m}$ e $1 \mu \mathrm{m}$, nesta ordem, usando-se álcool etílico como lubrificante, e sílica coloidal $1 \mu \mathrm{m}$, quando necessário.

Para visualização de precipitados, após o polimento foi utilizado ataque com reagente Keller ${ }^{5}$. Para visualização de estrutura de grãos, após o polimento foi utilizado ataque eletroquímico com reagente de Barker ${ }^{6}$. A diferença de potencial aplicada ao circuito amostra (ânodo) / placa de aço inoxidável (cátodo) manteve-se constante em $20 \mathrm{~V}$. O tempo de permanência no eletrólito foi de 2 minutos.

As microestruturas foram observadas em microscópios ópticos Neophot 30, da Carl Zeiss Jena, um deles equipado com luz polarizada para visualização da estrutura de grãos.

Uma amostra do corpo de prova $206^{7}$ foi preparada e fotografada no laboratório de metalografia da CBA - Companhia Brasileira do Alumínio, em ocasião em que se trocavam informações a respeito da preparação utilizada por eles para análise por EBSD.

As medidas de microdureza Vickers foram feitas no durômetro de marca Buehler, modelo Micromet 5104, com carga de $200 \mathrm{gf}$.

A preparação de amostras para EBSD é detalhada na Seção 1.4.3.

\footnotetext{
$52 \mathrm{~mL} \mathrm{HF} \mathrm{(48 \% ),} 3 \mathrm{~mL} \mathrm{HCl}$ (conc), $5 \mathrm{~mL} \mathrm{HNO}_{3}$ (conc), $190 \mathrm{~mL} \mathrm{H} \mathrm{H}_{2} \mathrm{O}$.

${ }^{6} 4$ to $5 \mathrm{~mL} \mathrm{HBF}_{4}(48 \%), 200 \mathrm{~mL} \mathrm{H}_{2} \mathrm{O}$.

${ }^{7}$ Condições de jateamento descritas na Tabela B.1.
} 


\subsection{Recristalização}

Como é dito na Seção 1.3.3.1, é possível em alguns casos visualizar a camada deformada através do tratamento térmico de recristalização.

O primeiro passo desta etapa foi determinar experimentalmente a condição de tratamento térmico (temperatura e tempo de tratamento) ideal para se observar a camada recristalizada superficial.

\subsubsection{Tratamentos térmicos}

Após as medições de curvatura e deflexão vertical (flecha) dos corpos de prova jateados, confirmou-se que as maiores deformações ocorreram em chapas de $2 \mathrm{~mm}$ de espessura, que foram todas jateadas com esferas S230. Dentre esses, foram selecionados 3 CPs com baixa, média e alta deformação, cujas condições são mostradas na Tabela 3.3.

Tabela 3.3: Condições de jateamento dos CPs selecionados.

\begin{tabular}{cccccc}
\hline No.CP & Liga & Pressão & Pré-tensão & Cobertura & $R_{\text {curv }}$ \\
\hline 006 & 7050 & $20 \mathrm{psi}$ & Não & $66 \%$ & $927,7 \mathrm{~mm}$ \\
074 & 7475 & $20 \mathrm{psi}$ & Sim & $66 \%$ & $450,2 \mathrm{~mm}$ \\
083 & 7475 & $60 \mathrm{psi}$ & Sim & $92 \%$ & $261,5 \mathrm{~mm}$ \\
\hline
\end{tabular}

O tempo de tratamento deve envolver a nucleação e o crescimento dos grãos recristalizados. Três possíveis temperaturas foram estimadas para os tratamentos térmicos: 300,400 e $500^{\circ} \mathrm{C}$. Para tentar determinar essas etapas da transformação, para cada temperatura foram definidos tempos diferentes de tratamento, porém de modo que houvesse sempre uma amostra de cada temperatura que permanecesse aquecida por 1 hora, para comparação.

Como controle, foram retiradas amostras das extremidades não jateadas do corpo de prova para que fossem submetidas aos mesmos tratamentos térmicos das amostras retiradas da região jateada, pelo tempo mais longo. Essa precaução é necessária para se verificar se não há possibilidade de haver uma superfície previamente encruada, antes do jateamento, devido à laminação das chapas, o que é muito comum. Extraiu-se também, de cada região, uma amostra que não foi submetida a nenhum tratamento térmico.

A Tabela 3.4 mostra as condições de tratamento térmico e a nomenclatura 
utilizada para as amostras, em correspondência com a numeração utilizada para a retirada de amostras do corpo de prova, como mostra a Figura 3.7.

Tabela 3.4: Temperatura e tempo de tratamento para as amostras, conforme posição no CP.

\begin{tabular}{lccc}
\hline Amostra* & Posição no CP & Temperatura & Tempo (min) \\
\hline XXX_01 & 01 & $300^{\circ} \mathrm{C}$ & 30 \\
XXX_05 & 05 & $300^{\circ} \mathrm{C}$ & 60 \\
XXX_09 & 09 & $300^{\circ} \mathrm{C}$ & 120 \\
XXX_13 & 13 & $300^{\circ} \mathrm{C}$ & 180 \\
XXX_02 & 02 & $400^{\circ} \mathrm{C}$ & 30 \\
XXX_06 & 06 & $400^{\circ} \mathrm{C}$ & 60 \\
XXX_10 & 10 & $400^{\circ} \mathrm{C}$ & 120 \\
XXX_03 & 03 & $500^{\circ} \mathrm{C}$ & 15 \\
XXX_07 & 07 & $500^{\circ} \mathrm{C}$ & 30 \\
XXX_11 & 11 & $500^{\circ} \mathrm{C}$ & 60 \\
XXX_16 & 16 & - & - \\
XXX_18 & 18 & $300^{\circ} \mathrm{C}$ & 60 \\
XXX_20 & 20 & $400^{\circ} \mathrm{C}$ & 60 \\
XXX_22 & 22 & $500^{\circ} \mathrm{C}$ & 60 \\
XXX_24 & 24 & - & - \\
\hline
\end{tabular}

* Nomenclatura das amostras: $\mathrm{XXX}=$ número do corpo de prova $(006,074$ ou 083).

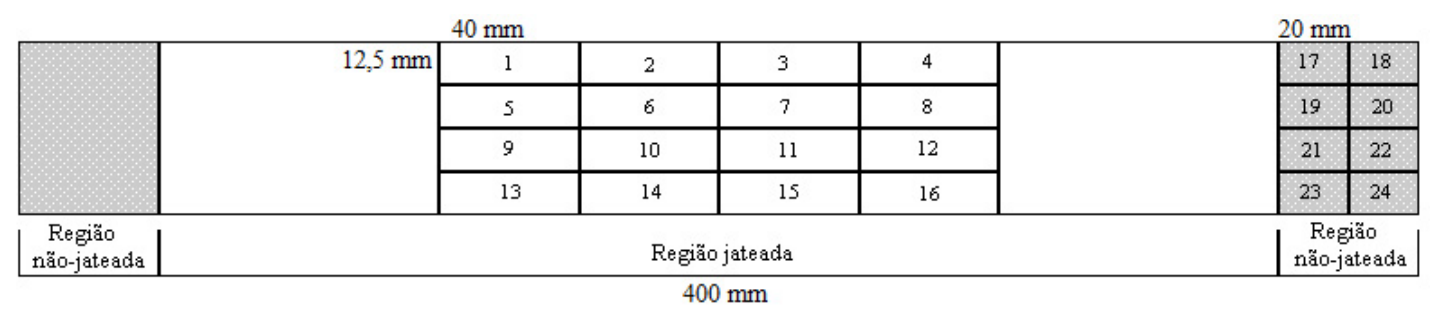

Figura 3.7: Divisões do corpo de prova para obtenção de amostras.

Os tratamentos foram feitos em um forno mufla ${ }^{8}$ e o resfriamento foi feito em água. 


\subsection{EBSD}

Como foi dito anteriormente (Seção 1.4.3), o ponto crítico de uma análise EBSD é a preparação da superfície da amostra. Das opções de polimento apresentadas, foram feitas tentativas de obtenção de padrão com as opções 1.a, 1.b, 1.d, 2.a e 2.b. As seções observadas foram as seções longitudinais, conforme o esquema da Figura 3.8.

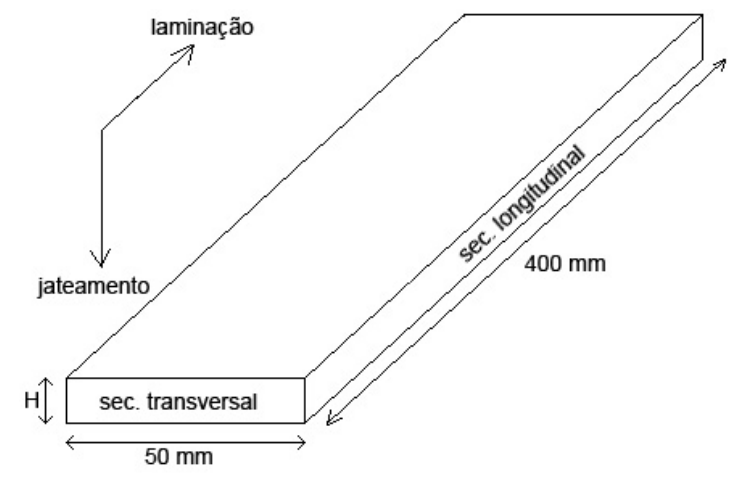

Figura 3.8: Esquema das seções longitudinal e transversal, em relação às direções de laminação e jateamento de esferas.

As análises foram feitas em um microscópio eletrônico de varredura (MEV) Jeol JSM6300 equipado com o detector HKL NordlysS, que utiliza o software HKL CHANNEL5, ambos da Oxford Instruments ${ }^{\circledR}$.

Os corpos de prova que foram analisados (todos com cobertura 200\%) e as condições de análise são mostradas na Tabela 3.5:

Tabela 3.5: Corpos de prova e condições de análise por EBSD.

\begin{tabular}{c|c|c|c|c|c|c|c}
\hline CP & liga & espessura & granalha & velocidade & pré-tensão & posição & passo \\
\hline 090 & 7050 & $5 \mathrm{~mm}$ & S230 & média & não & vertical & $1 \mu \mathrm{m}$ \\
206 & 7475 & $5 \mathrm{~mm}$ & S550 & alta & sim & horiozntal & $1 \mu \mathrm{m}$ \\
252 & 7050 & $10 \mathrm{~mm}$ & S550 & alta & sim & vertical & $4 \mu \mathrm{m}$ \\
371 & 7050 & $10 \mathrm{~mm}$ & $1 / 8 ”$ & média & não & vertical & $4 \mu \mathrm{m}$ \\
\hline
\end{tabular}




\subsection{Perfil de tensões residuais}

Para a obtenção dos perfis de tensões residuais por difração de raios- $X$, pelo método do $\sin ^{2} \psi$, foram selecionados corpos de prova da liga 7050, jateados até a saturação - alta cobertura -, nas diversas condições de jateamento, para observação dos efeitos de todas as demais variáveis de processo - espessura da chapa, diâmetro da esfera, pressão ou velocidade de impacto e pré-tensionamento.

A Tabela 3.6 mostra os corpos de prova selecionados e as condições de jateamento a que foram submetidos.

Para as medições de tensões residuais, foi utilizado um difratômetro de raios-X RIGAKU Rint 2000 disponível no Departamento de Caracterização de Materiais do IPEN, com radiação $\operatorname{Cr} K_{\alpha}(\lambda=2,291 \AA$ ). O plano cristalográfico do alumínio observado foi $(311)\left(2 \theta=139,49^{\circ}\right)$. Nesse plano, o módulo de Young é $\mathrm{E}=70,3 \mathrm{GPa}$ e o coeficiente de Poisson é $\nu=0,345$.

A remoção de camadas foi feita com ácido clorídrico concentrado, que proporciona uma taxa de remoção de $10 \mu \mathrm{m}$ a cada 20 segundos.

Os perfis foram obtidos até valores de compressão próximos de zero e a equação 1.12 foi usada para corrigir os valores medidos devido ao relaxamento de tensões por remoção de camadas. ${ }^{[66]}$ 
Tabela 3.6: Corpos de prova selecionados para obtenções de perfis de tensões residuais por difração de raios-X.

\begin{tabular}{|c|c|c|c|c|c|}
\hline$C P n^{\circ}$ & $\mathrm{H}(\mathrm{mm})$ & Esfera & Velocidade & Pré-tensão & $r(m)$ \\
\hline 009 & 2 & $\mathrm{~S} 230$ & baixa & não & 0,732 \\
\hline 008 & 2 & $\mathrm{~S} 230$ & média & não & 0,556 \\
\hline 100 & 2 & $\mathrm{~S} 230$ & alta & não & 0,597 \\
\hline 092 & 5 & $\mathrm{~S} 230$ & baixa & não & 4,610 \\
\hline 090 & 5 & S230 & média & não & 3,193 \\
\hline 038 & 5 & $\mathrm{~S} 230$ & alta & não & 2,832 \\
\hline 187 & 5 & S550 & baixa & não & 3,158 \\
\hline 179 & 5 & S550 & média & não & 2,317 \\
\hline 193 & 5 & S550 & alta & não & 2,075 \\
\hline 314 & 10 & S550 & baixa & não & 16,463 \\
\hline 286 & 10 & S550 & média & não & 12,351 \\
\hline 255 & 10 & S550 & alta & não & 13,070 \\
\hline 376 & 10 & 1/8" & baixa & não & 8,298 \\
\hline 371 & 10 & $1 / 8 "$ & média & não & 5,103 \\
\hline 365 & 10 & $1 / 8 "$ & alta & não & 4,137 \\
\hline 432 & 15 & $1 / 8 "$ & baixa & não & 24,136 \\
\hline 423 & 15 & $1 / 8 "$ & média & não & 13,785 \\
\hline 418 & 15 & $1 / 8 "$ & alta & não & 14,871 \\
\hline 062 & 2 & $\mathrm{~S} 230$ & baixa & $\operatorname{sim}$ & 0,312 \\
\hline 024 & 2 & $\mathrm{~S} 230$ & média & $\operatorname{sim}$ & 0,257 \\
\hline 015 & 2 & S230 & alta & sim & 0,238 \\
\hline 144 & 5 & S230 & baixa & $\operatorname{sim}$ & 2,005 \\
\hline 137 & 5 & $\mathrm{~S} 230$ & média & sim & 1,526 \\
\hline 133 & 5 & S230 & alta & sim & 1,528 \\
\hline 185 & 5 & S550 & baixa & $\operatorname{sim}$ & 1,440 \\
\hline 182 & 5 & S550 & média & $\operatorname{sim}$ & 1,092 \\
\hline 171 & 5 & S550 & alta & sim & 0,844 \\
\hline 292 & 10 & S550 & baixa & sim & 5,434 \\
\hline 263 & 10 & S550 & média & $\operatorname{sim}$ & 4,822 \\
\hline 252 & 10 & S550 & alta & sim & 5,343 \\
\hline 378 & 10 & 1/8" & baixa & sim & 3,297 \\
\hline 370 & 10 & 1/8" & média & sim & 2,218 \\
\hline 364 & 10 & 1/8" & alta & sim & 1,935 \\
\hline 431 & 15 & $1 / 8 "$ & baixa & $\operatorname{sim}$ & 7,421 \\
\hline 420 & 15 & 1/8" & média & $\operatorname{sim}$ & 4,963 \\
\hline 413 & 15 & 1/8" & alta & $\operatorname{sim}$ & 5,574 \\
\hline
\end{tabular}




\subsection{Redes Neurais Artificiais}

Os parâmetros de processo e os valores de curvatura medidos foram utilizados para treinar uma rede neural utilizando o software NeuroSolutions for Excel (Evaluation Mode). Os parâmetros Liga, Espessura, Diâmetro de esfera, Velocidade de impacto, Pré-tensão e Cobertura foram utilizados como entrada (input) e o raio de curvatura foi a saída desejada (output).

O software NeuroSolutions possui dois assistentes que ajudam a criar redes neurais baseadas nos dados e especificações fornecidos. Um desses assistentes, o NeuralBuilder (builder = construtor), centraliza as especificações de design da rede acerca das arquiteturas de redes neurais específicas que se deseja criar. Algumas das arquiteturas de redes neurais mais comuns incluem:

- MLP - Multilayer Perceptron (Perceptron multicamada)

- Generalized Feedforward (Pré-alimentação generalizada)

- Modular

- Jordan/Elman

- PCA - Principal Component Analysis (Análise de Componente Principal)

- RBF - Radial Basis Function (Função Radial de Base)

- GRNN - General Regression Neural Network (Rede Neural de Regressão Genérica)

- PNN - Probabilistic Neural Network (Rede Neural Probabilística)

- SOM - Self-Organizing Map (Mapa Auto-Organizado)

- TLRN - Time-Lag Recurrent Network (Rede Recorrente com Atraso)

- Recurrent Network (Rede Recorrente)

- CANFIS Network - Fuzzy Logic (Rede CANFIS - Lógica difusa)

- SVM - Support Vector Machine (Máquina a Vetor de Suporte)

O segundo assistente de construção de redes é chamado NeuralExpert. Ele centraliza a especificação do design acerca do tipo de problema que se 
deseja solucionar com a rede neural (Classificação, Previsão, Aproximação de Função ou Clustering). Dado o tipo de problema e o tamanho do conjunto de dados, o NeuralExpert seleciona inteligentemente o tamanho e arquitetura da rede neural que vai provavelmente produzir a melhor solução. ${ }^{[67]}$

Esse assistente é ideal para usuários iniciantes e/ou com pouco conhecimento a respeito de RNAs, com interesse basicamente na saída da rede, como é o caso deste trabalho, que não tem a intenção de se aprofundar sobre o assunto. É por isso que ele foi utilizado, com a opção de Aproximação de Função.

Os 429 dados de parâmetros e raio de curvatura passaram por uma seleção prévia para excluir os dados de corpos de prova que tiveram resultado muito diferente dos outros $2 \mathrm{CPs}$ de mesma condição de jateamento ${ }^{9}$. Esses dados destoantes seriam prejudiciais à RNA, pois não são verdadeiros e gerariam um aprendizado equivocado.

Durante o treinamento, notou-se que os corpos de prova com raio de curvatura superiores a $20 \mathrm{~m}$ geravam confusão na RNA, que não conseguia lidar com esses valores e acabava diminuindo a qualidade da previsão em CPs com raio de curvatura pequeno. Por esse motivo e, considerando-se também que os aviões não utilizam chapas de alumínio de espessuras de 10 e $15 \mathrm{~mm}$, os CPs com raio de curvatura maior que $20 \mathrm{~m}$ foram excluídos.

Os 402 dados restantes foram embaralhados e divididos em três conjuntos:

1. 280 linhas para treinamento da RNA;

2. 60 linhas para validação cruzada durante o treinamento;

3. 62 linhas para teste de aderência do modelo gerado.

Para testar a qualidade da previsão de raio de curvatura gerada pela rede, foram calculados valores para corpos de prova fictícios da liga 7050, de espessura $12 \mathrm{~mm}$, da liga 7475, de espessura $7 \mathrm{~mm}$, e de ambas as ligas, de espessura $4 \mathrm{~mm}$, como se fossem jateados, respectivamente, nas mesmas condições dos corpos de prova de $10 \mathrm{~mm}$, com esferas grandes (1/8"), de 5 $\mathrm{mm}$, com esferas médias (S550), e de $2 \mathrm{~mm}$, com esferas pequenas (S230).

\footnotetext{
${ }^{9}$ Cada condição de jateamento foi realizada com 3 repetições.
} 


\section{Resultados e Discussões}




\subsection{Microscopia óptica}

As Figuras 4.1 e 4.2 mostram a microestrutura de grãos das amostras 006_24 (liga 7050) e 074_24 (liga 7475) ${ }^{1}$, que não sofreram jateamento nem tratamento térmico. Os grãos estão bastante alongados devido à laminação das placas e são maiores na amostra da liga 7475.

A microestrutura das amostras possui grãos alongados em toda a espessura da chapa. Nas amostras da região jateada, próximo à superfície notamse grãos deformados acompanhando as marcas de indentação. Não é possível notar, no entanto, uma região específica que possa ser chamada de "camada deformada". A Figura 4.3 apresenta toda a espessura da amostra 206 (Liga 7475, espessura $5 \mathrm{~mm}$, esfera S550, alta pressão, cobertura 200\%, prétensionada $)^{2}$, mostrando a face jateada na parte superior e a zona de grãos recristalizados na parte inferior. A Figura 4.4 mostra a seção longitudinal da amostra 206 na borda da face oposta ao jateamento, toda composta de grãos recristalizados. As Figuras 4.5 e 4.6 mostram a mesma amostra, na borda da face jateada, apresentando alguns grãos recristalizados e outros grãos alongados, deformados pela indentação. Não é possível medir a espessura da camada deformada.

$O$ ataque Keller revela apenas os precipitados grosseiros da microestrutura e alguns contornos de grãos. Como é o ataque químico mais simples de ser feito, seria extremamente útil se a camada deformada pudesse ser visualizada e caracterizada através de microscopia óptica com ataque Keller.

A Figura 4.7 mostra a estrutura de precipitados da amostra 074_21, que não sofreu jateamento. Podem-se notar precipitados muito pequenos e alinhados e outros grandes, da ordem de $20 \mu \mathrm{m}$. As Figuras 4.8 e 4.9 mostram regiões jateadas, nas amostras 074_15 e 083_14, com deformações superficiais causadas pelas indentações das esferas. É possível verificar, através da disposição dos precipitados finos, que há uma região de 70 a $150 \mu \mathrm{m}$ abaixo da superfície que acompanha as marcas das indentações, porém não é nítida a divisão entre o que se chamaria de "camada deformada" e o restante da microestrutura.

\footnotetext{
${ }^{1}$ Nomenclatura de amostras na Seção 3.5, pág. 93.

${ }^{2}$ Parâmetros de jateamento no Apêndice $A$.
} 


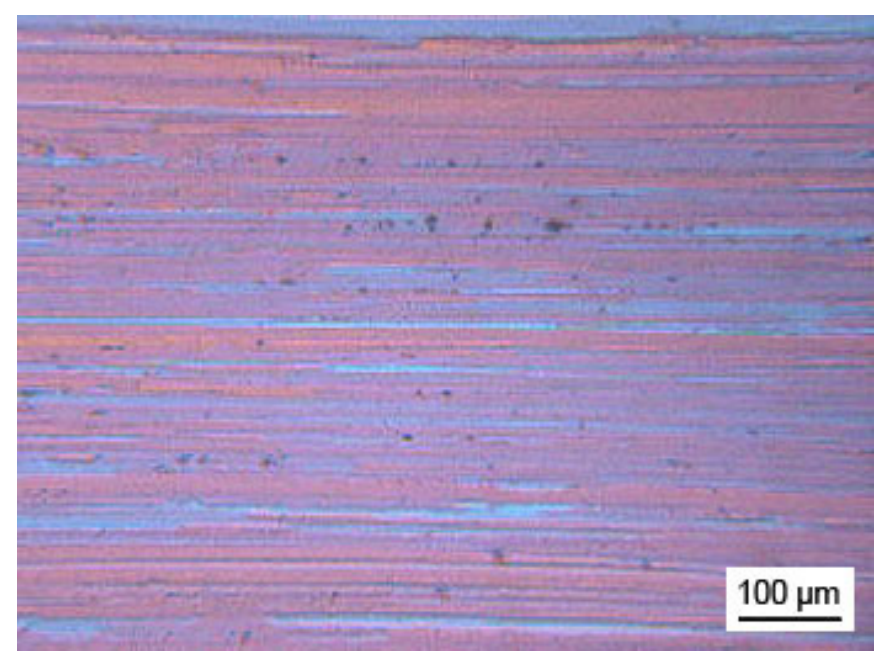

Figura 4.1: Microestrutura da amostra 006_24 (Liga 7050, sem jateamento, sem tratamento térmico). Centro da espessura (seção longitudinal).

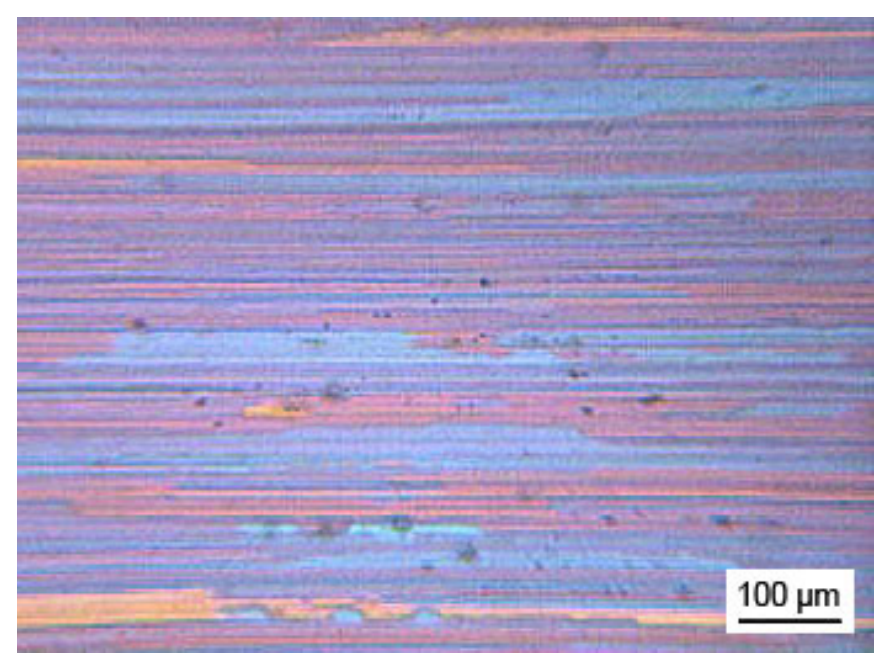

Figura 4.2: Microestrutura da amostra 074_24 (Liga 7475, sem jateamento, sem tratamento térmico). Centro da espessura (seção longitudinal). 


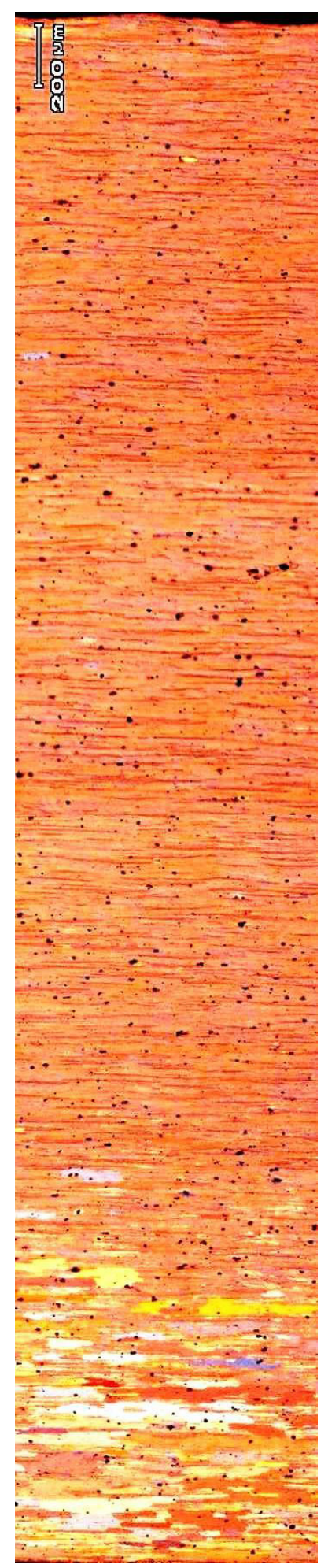

Figura 4.3: Microestrutura de toda a espessura da amostra 206 (liga 7475, 5 mm, pré-tensionada, S230, 200\%) (seção longitudinal).(Cortesia CBA) 


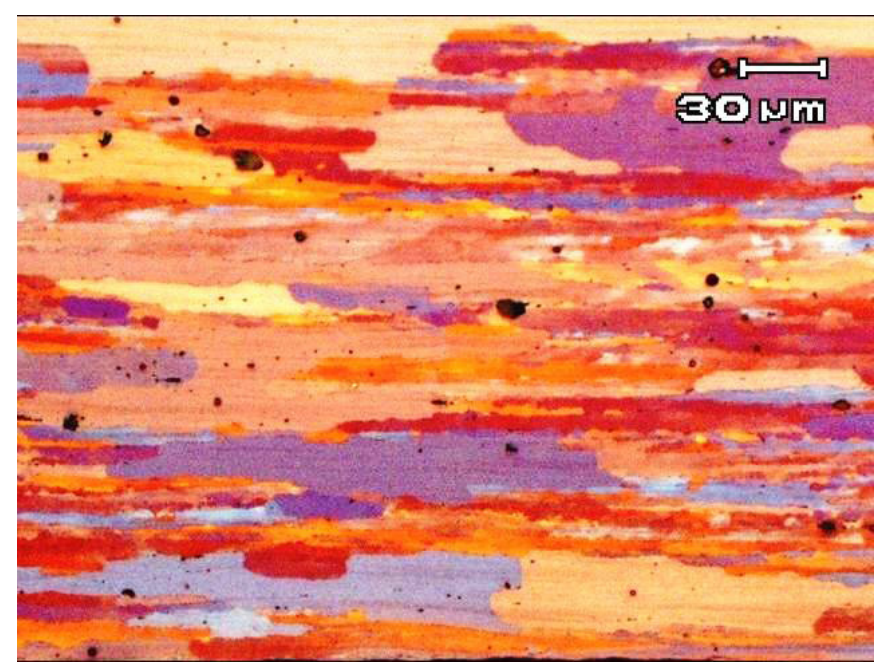

Figura 4.4: Microestrutura da amostra 206 (liga 7475, $5 \mathrm{~mm}$, pré-tensionada, S230, 200\%), após o jateamento. Superfície não jateada, recristalizada (seção longitudinal). (Cortesia CBA)

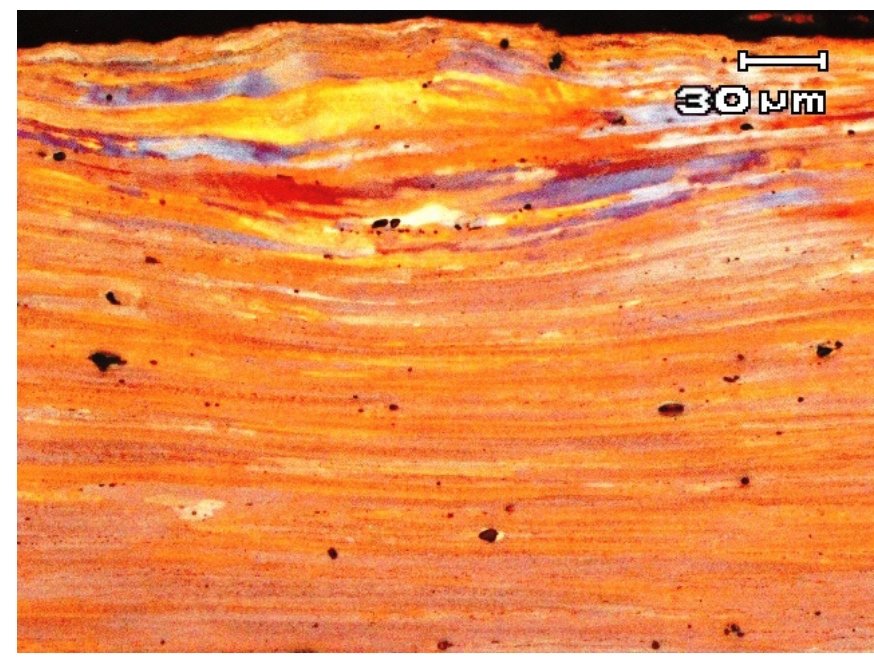

Figura 4.5: Microestrutura da amostra 206 (liga 7475, $5 \mathrm{~mm}$, pré-tensionada, S230, 200\%), após o jateamento. Superfície jateada, mostrando grãos deformados pelo jateamento (seção longitudinal). (Cortesia CBA) 


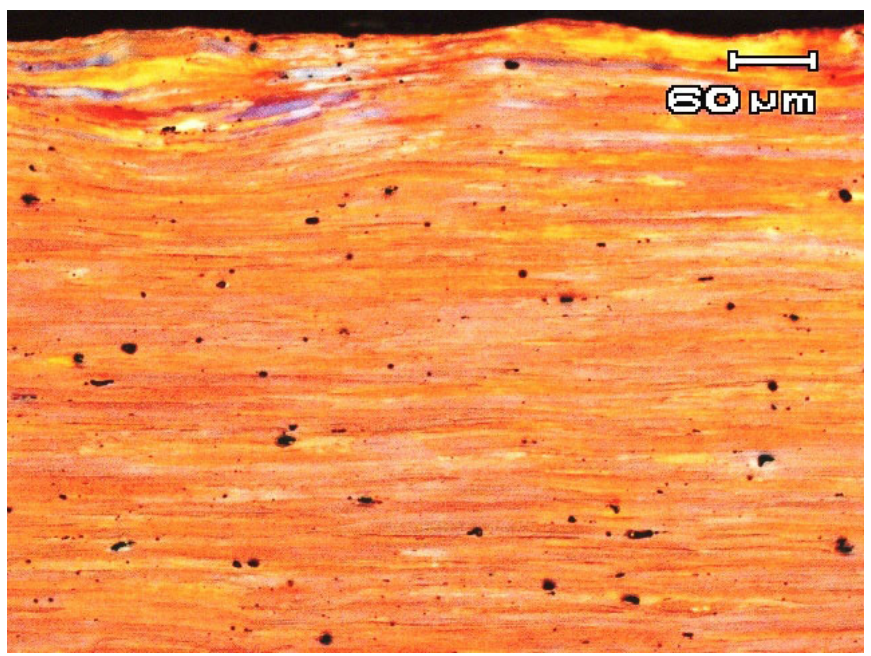

Figura 4.6: Microestrutura da amostra 206 (liga 7475, $5 \mathrm{~mm}$, pré-tensionada, S230, 200\%), após o jateamento. Superfície jateada, mostrando grãos deformados pelo jateamento (seção longitudinal). (Cortesia CBA)

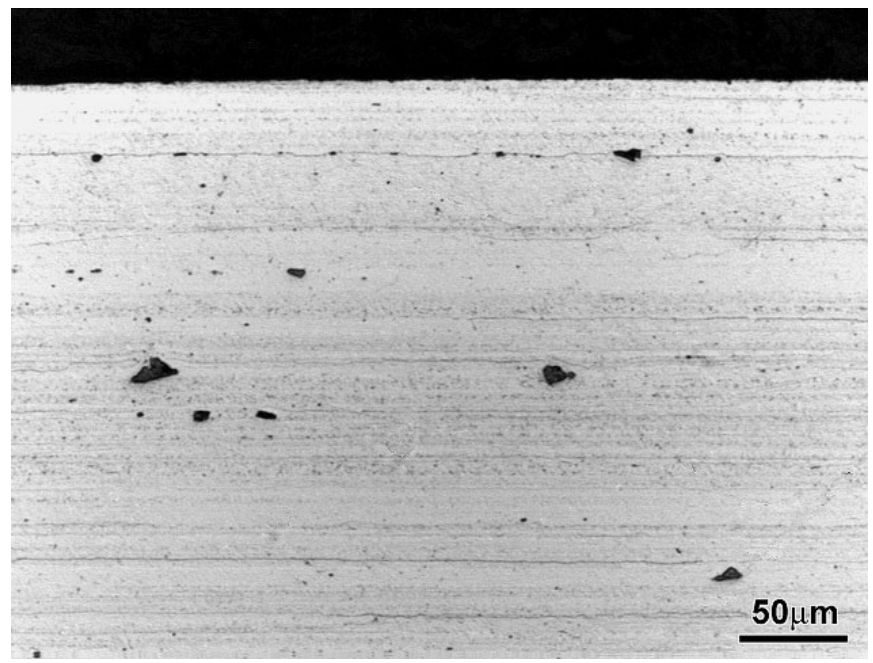

Figura 4.7: Superfície não jateada, observada após ataque Keller (seção longitudinal). Amostra 074_21 (7475, sem TT). 


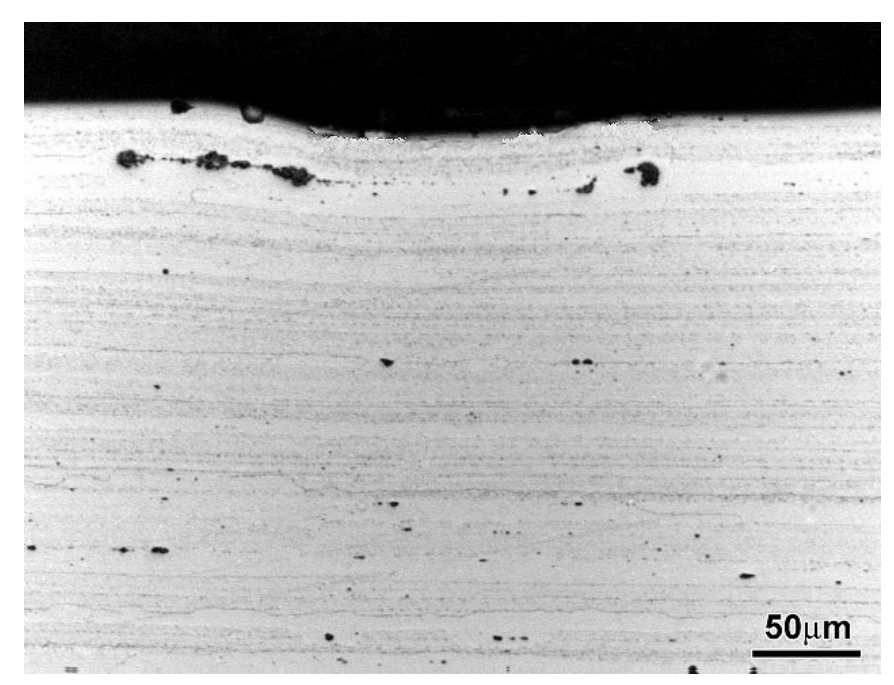

Figura 4.8: Superfície jateada, observada após ataque Keller (seção longitudinal). Amostra 074_15 (7475, 2 mm, pré-tensionada, S230, 20 psi, $66 \%$; sem TT).

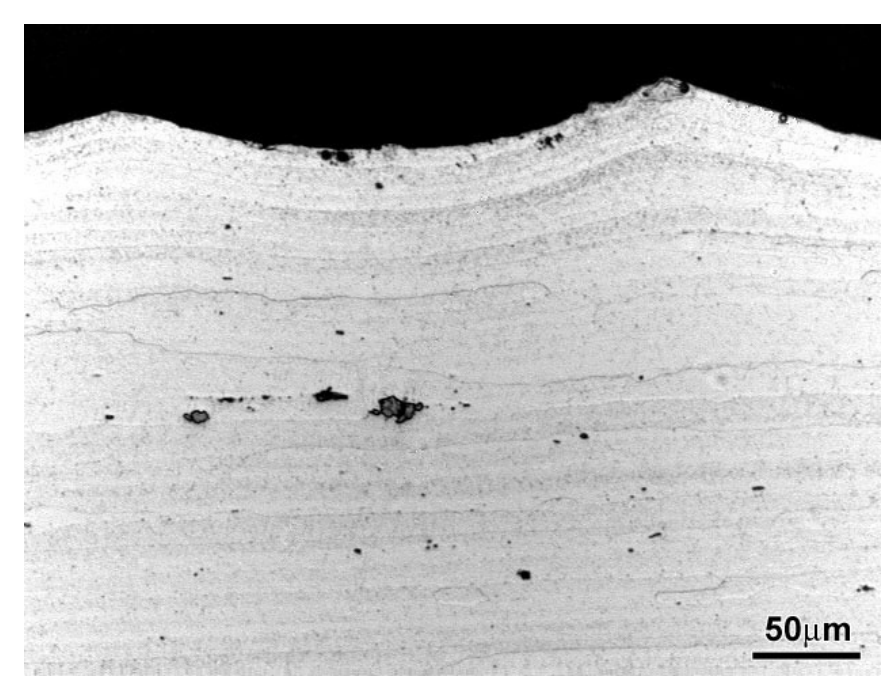

Figura 4.9: Superfície jateada, observada após ataque Keller (seção longitudinal). Amostra 083_14 (7475, 2 mm, pré-tensionada, S230, 60 psi, 92\%; sem TT).

Em comparação com a microestrutura mostrada na literatura ${ }^{[68,69]}$, para as ligas 7050 e 7475, os corpos de prova ensaiados estão dentro da normalidade, em relação ao tamanho dos grãos e à quantidade e distribuição de precipitados. Isso significa que as propriedades mecânicas (dureza, limite de escoamento, fadiga etc) determinadas pela literatura podem ser aplicadas às amostras utilizadas neste trabalho.

A estrutura de precipitados mostrada nas Figuras 4.7, 4.8 e 4.9 coincide com a estrutura apresentada por Ruckert et al. ${ }^{[69]}$ para a liga 7475 , mostrada na Figura 4.10. Os precipitados grosseiros mais comumente encontrados nesta liga são $\mathrm{Al}_{7} \mathrm{Cu}_{2} \mathrm{Fe}, \mathrm{Al}_{12}(\mathrm{Fe}, \mathrm{Mn})_{3} \mathrm{Si}, \mathrm{Al}_{6}(\mathrm{Fe}, \mathrm{Mn}), \mathrm{Mg}_{2} \mathrm{Si}, \mathrm{SiO}_{2}$ e 
$\mathrm{Al}_{23} \mathrm{CuFe}_{4} \cdot{ }^{[10]}$.

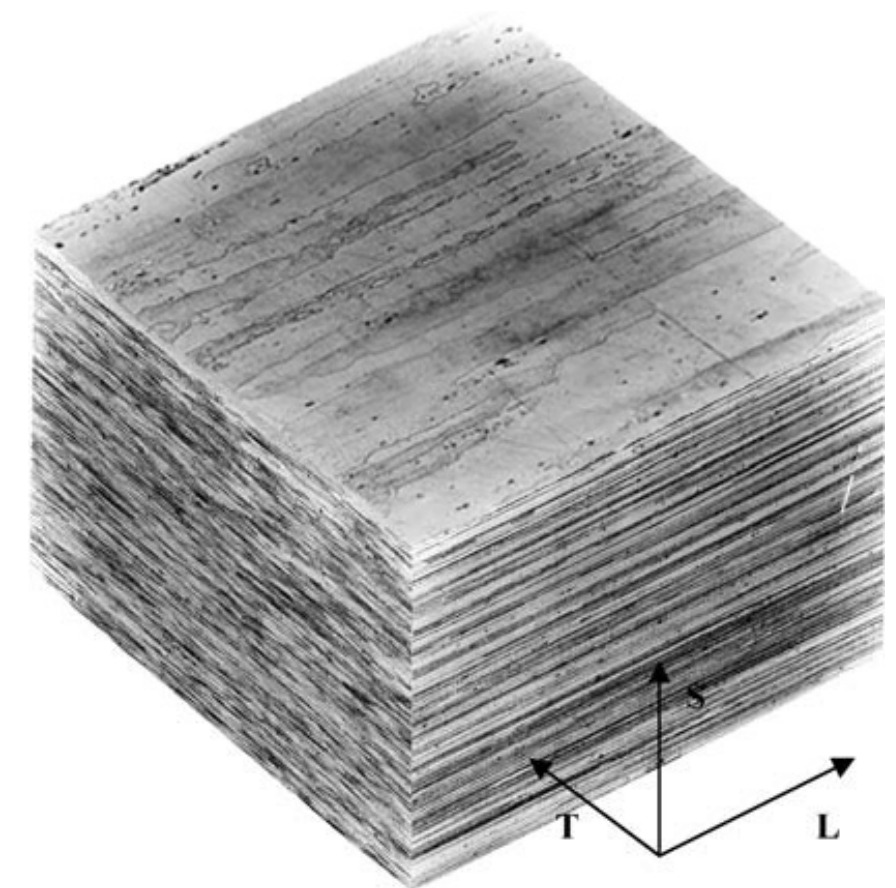

Figura 4.10: Micrografia óptica mostrando a microestrutura da liga de alumínio 7475-T7351 nas superfícies longitudinal, transversal e de topo (montagem 3D). (Adaptado de Ruckert et al. ${ }^{[69]}$ )

\subsubsection{Perfil de microdureza}

Não foi observada variação significativa de microdureza Vickers ao longo da espessura dos corpos de prova jateados, considerando-se a incerteza das medidas. O valor mais baixo de microdureza, com carga de $200 \mathrm{gf}$, foi $164 \pm$ $5 \mathrm{HV}$ e o valor mais alto foi $198 \pm 5 \mathrm{HV}$, mas não se pode inferir uma relação com a profundidade abaixo da superfície jateada.

A Figura 4.11 mostra o perfil de durezas da superfície até a metade da espessura da amostra 439 (15 mm), submetida ao jateamento de maior intensidade (maior esfera, alta pressão, alta cobertura, pré-tensionada): 


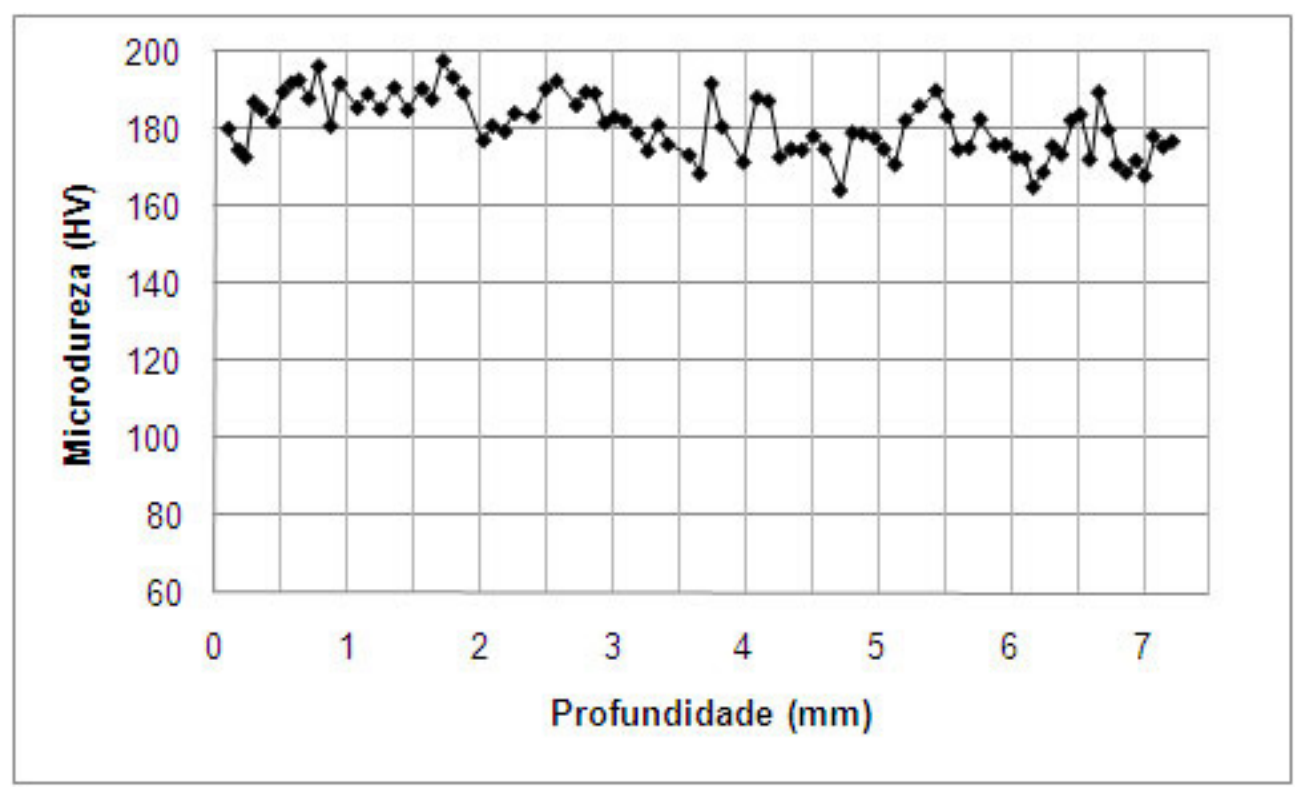

Figura 4.11: Perfil de durezas da amostra 439 (7475, espessura $15 \mathrm{~mm}$, esfera 1/8", alta pressão, alta cobertura, pré-tensionada), da superfície até a metade da espessura.

Asquith et al. ${ }^{[70]}$ realizaram o tratamento de jateamento com granalhas em amostras da liga de alumínio 2024-T7351 com granalhas de tamanho S110, $200 \%$ de cobertura e intensidade de 20 AlmenC. A Figura 4.12 mostra o perfil de microdurezas Knoop obtido em amostras como-recebidas (as-received $A R$ ) e após o jateamento (as-received, shot-peened-AR-SP).

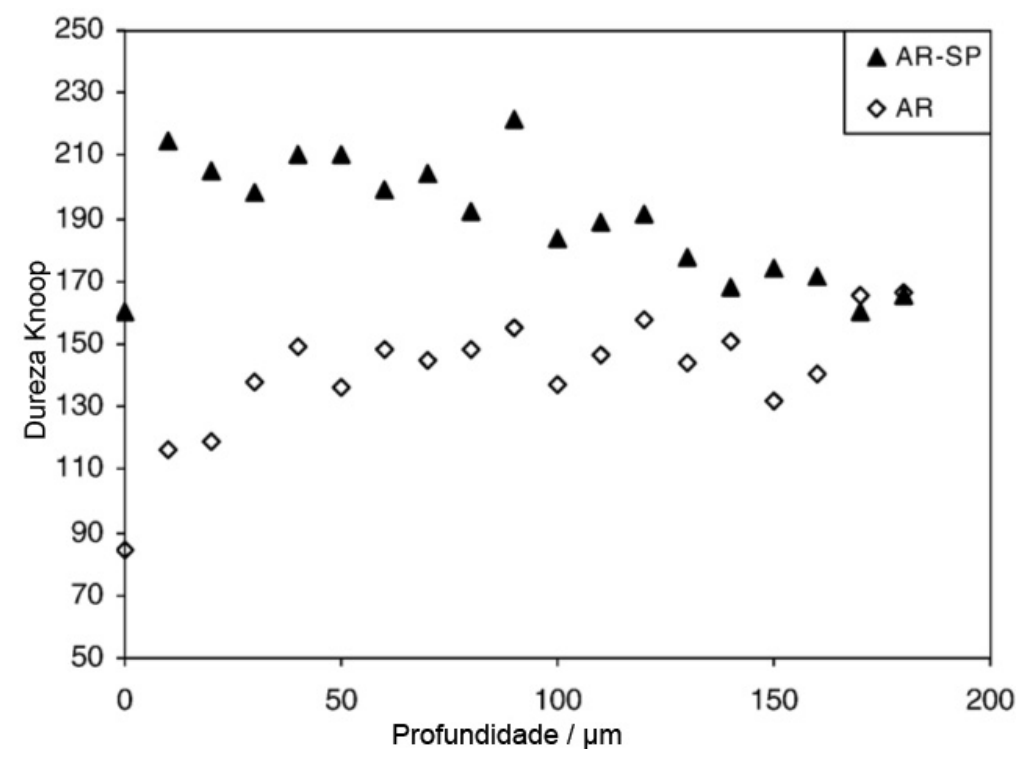

Figura 4.12: Perfil de microdurezas em amostras como-recebidas (as-received - AR) e após o jateamento (as-received, shot-peened$A R-S P) \cdot{ }^{[70]}$

O tratamento de JCG quase dobrou o valor de microdureza Knoop logo abaixo da superfície e manteve-se acima da dureza do material sem jatea- 
mento até cerca de $170 \mu \mathrm{m}$ de profundidade.

Lee et al. ${ }^{[71]}$ utilizaram o jateamento com granalhas para aumentar a dureza de zonas afetadas termicamente (ZAT) por soldagem GMAW ${ }^{3}$ em aços dual phase (martensítico-ferrítico). As ZATs são regiões em que o aquecimento gerado pelo processo de soldagem gera alterações, geralmente causando perdas de propriedades mecânicas. A Figura 4.13 mostra o perfil de durezas na superfície jateada, ao longo de uma linha que passa pelo metal de base, pela ZAT e pelo metal de adição. O tratamento de jateamento com granalhas causou uma sensível melhoria na dureza do material, e diminuiu a variação de durezas ao longo da faixa afetada pelo calor.

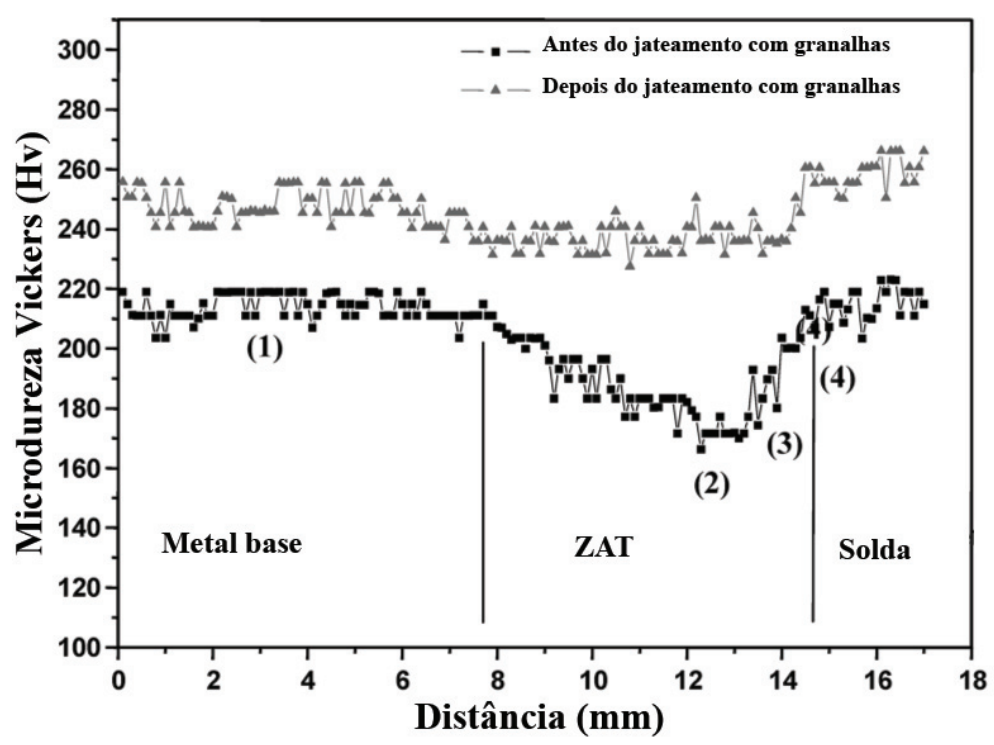

Figura 4.13: Perfil de durezas na superfície ao longo de uma direção perpendicular à junta soldada de aços dual phase. ${ }^{[71]}$

No trabalho desenvolvido no $\mathrm{IPT}^{[34]}$, no entanto, não houve sucesso na observação da camada deformada por JCG por perfis de microdureza Vickers, como mostra a Figura 4.14. A amostra analisada foi uma chapa de $5 \mathrm{~mm}$ de espessura, da liga 7050-T7451, jateada com granalhas de tamanho S230.

\footnotetext{
${ }^{3}$ GMAW = Gas Metal Arc Welding (Soldagem por arco elétrico com gás de proteção) MIG/MAG
} 


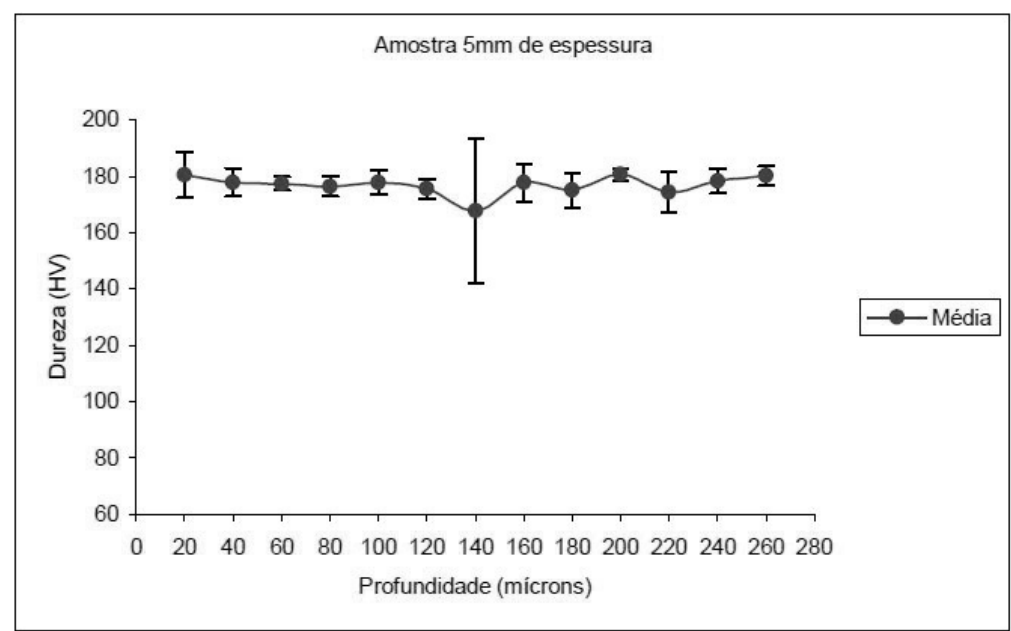

Figura 4.14: Perfil de durezas de chapa de alumínio da liga 7050, com $5 \mathrm{~mm}$ de espessura, após JCG. ${ }^{[34]}$

Esses resultados assemelham-se bastante aos resultados obtidos neste trabalho, levando à conclusão que as características da liga 7050-T7451 tornam mais difícil a obtenção de um perfil de durezas.

Novas medições de durezas e considerações a respeito da sua variação são feitas na Seção 4.2.5, pág. 126. 


\subsection{Recristalização}

Das 45 amostras, entre elas 39 submetidas a aquecimento, 12 apresentaram certa resistência ao ataque eletrolítico com reagente de Barker (estrutura muito deformada), gerando uma camada oxidada sem o contraste necessário para a análise da microestrutura.

As Figuras 4.15 a 4.47 mostram as microestruturas da superfície jateada nas amostras retiradas dos corpos de prova 006 (AA7050, baixa intensidade de jateamento), 074 (AA7475, média intensidade de jateamento) e 083 (AA7475, alta intensidade de jateamento), respectivamente.

A nomenclatura utilizada para as amostras é mostrada na Seção 3.5.

\subsubsection{Amostras com baixa intensidade de jateamento}

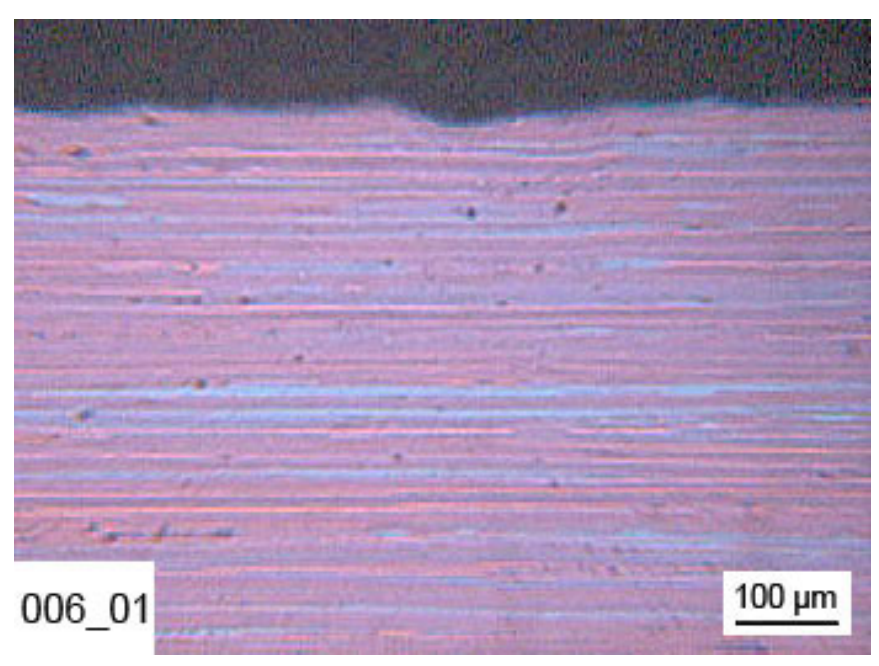

Figura 4.15: Microestrutura da amostra 006_01 após o tratamento térmico (liga 7050, $2 \mathrm{~mm}$, livre, S230, $20 \mathrm{psi}, 66 \%$; TT $300^{\circ} \mathrm{C}-30 \mathrm{~min}$ ). 


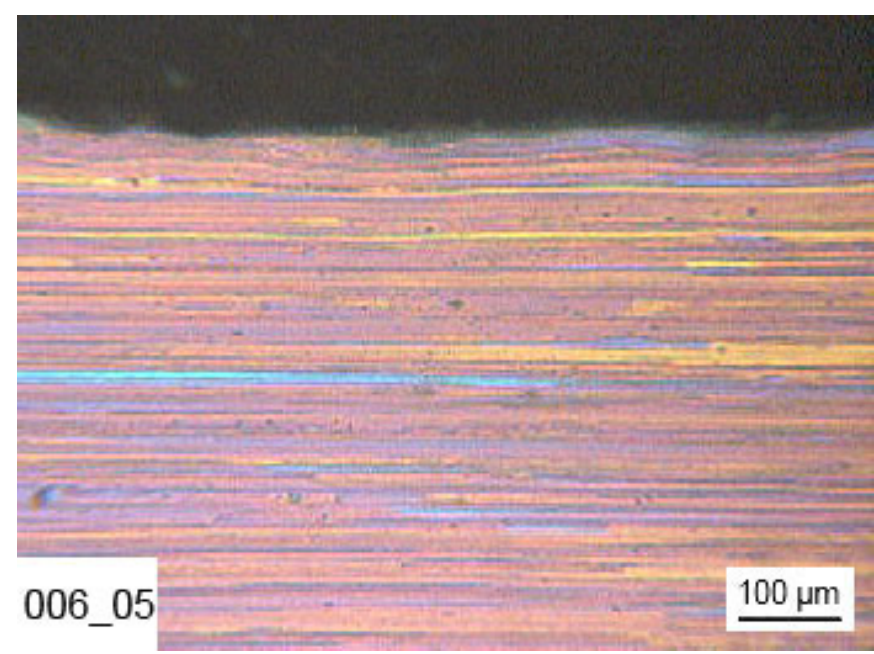

Figura 4.16: Microestrutura da amostra 006_05 após o tratamento térmico (liga 7050, $2 \mathrm{~mm}$, livre, S230, $20 \mathrm{psi}, 66 \%$; TT $300^{\circ} \mathrm{C}-60 \mathrm{~min}$ ).

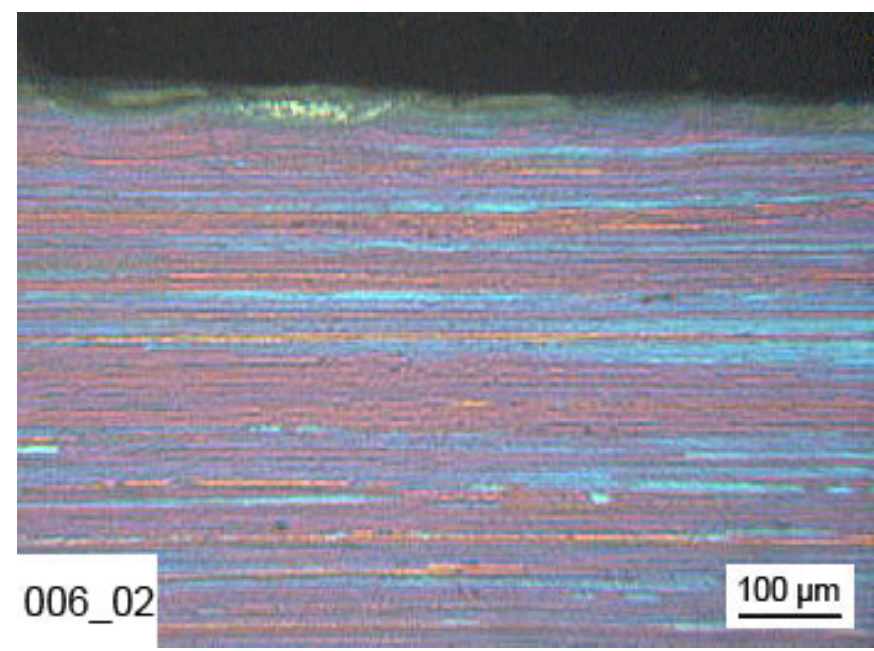

Figura 4.17: Microestrutura da amostra 006_02 após o tratamento térmico (liga 7050, 2 mm, livre, S230, 20 psi, 66\%; TT 400 C-30 min).

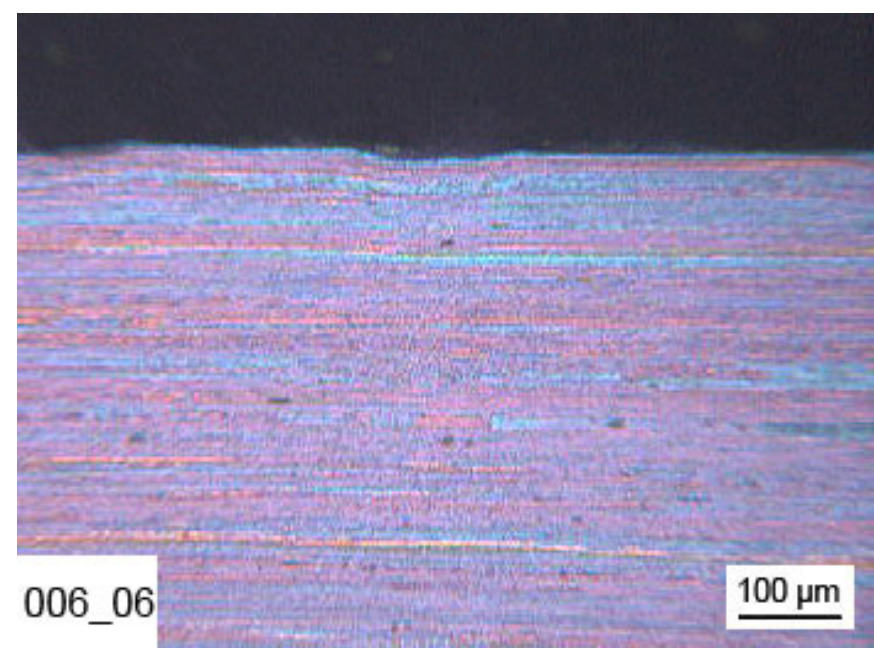

Figura 4.18: Microestrutura da amostra 006_06 após o tratamento térmico (liga 7050, $2 \mathrm{~mm}$, livre, S230, 20 psi, 66\%; TT 400 C-60 min). 


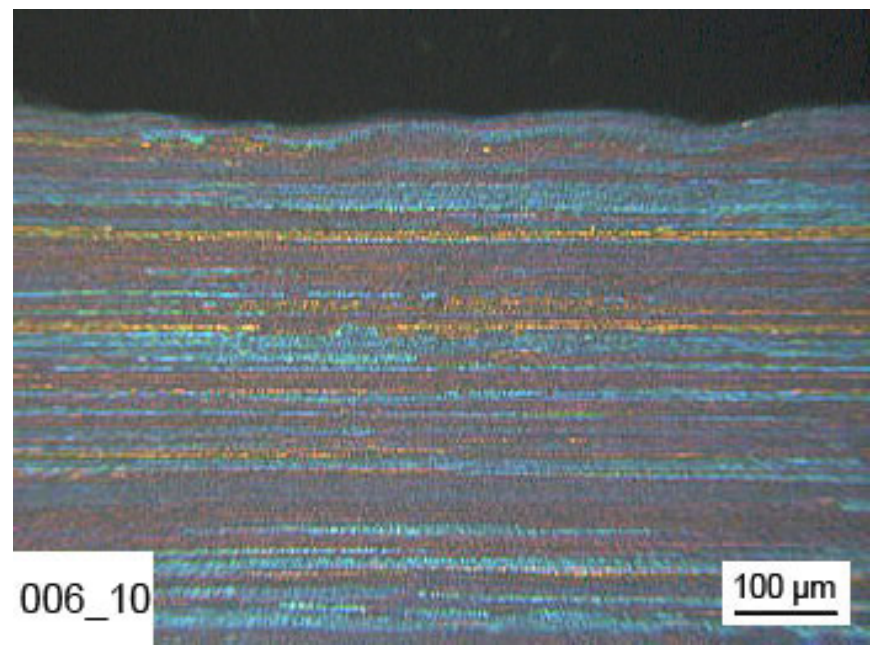

Figura 4.19: Microestrutura da amostra 006_10 após o tratamento térmico (liga 7050, $2 \mathrm{~mm}$, livre, S230, $20 \mathrm{psi}, 66 \%$; TT $400^{\circ} \mathrm{C}-120 \mathrm{~min}$ ).

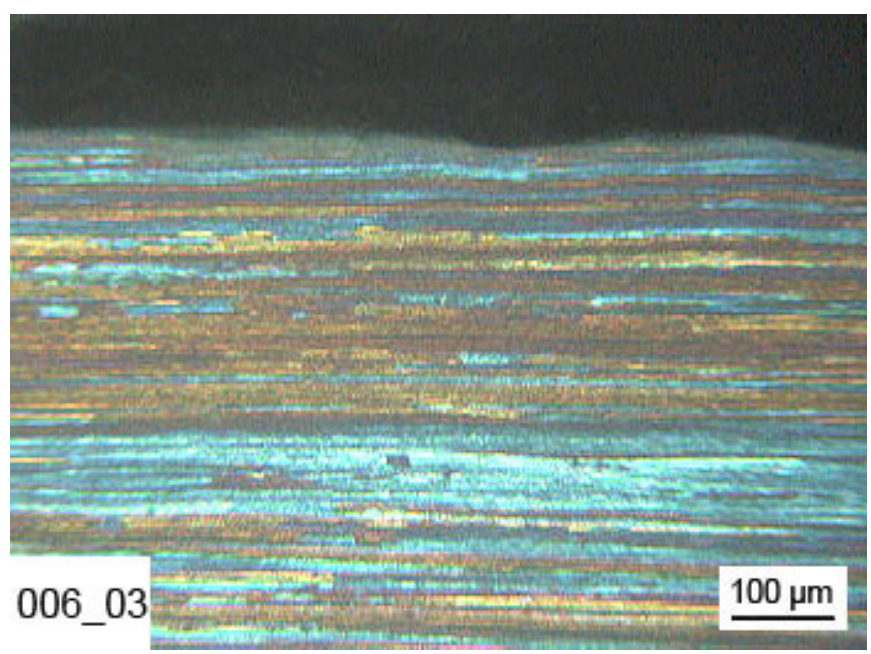

Figura 4.20: Microestrutura da amostra 006_03 após o tratamento térmico (liga 7050, 2 mm, livre, S230, 20 psi, 66\%; TT 500 $\mathrm{C}-15 \mathrm{~min}$ ).

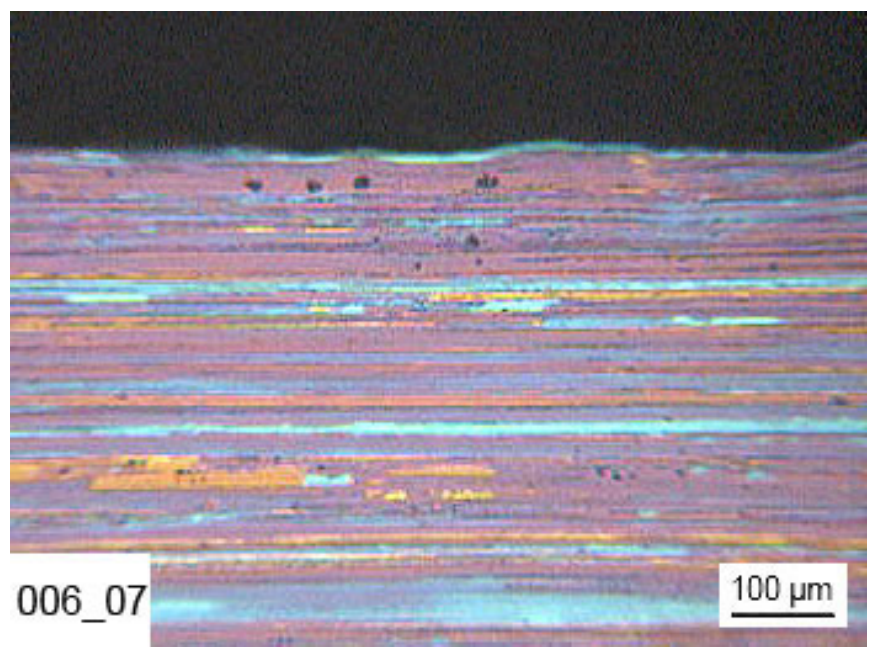

Figura 4.21: Microestrutura da amostra 006_07 após o tratamento térmico (liga 7050, 2 mm, livre, S230, 20 psi, 66\%; TT 500 C-30 min). 


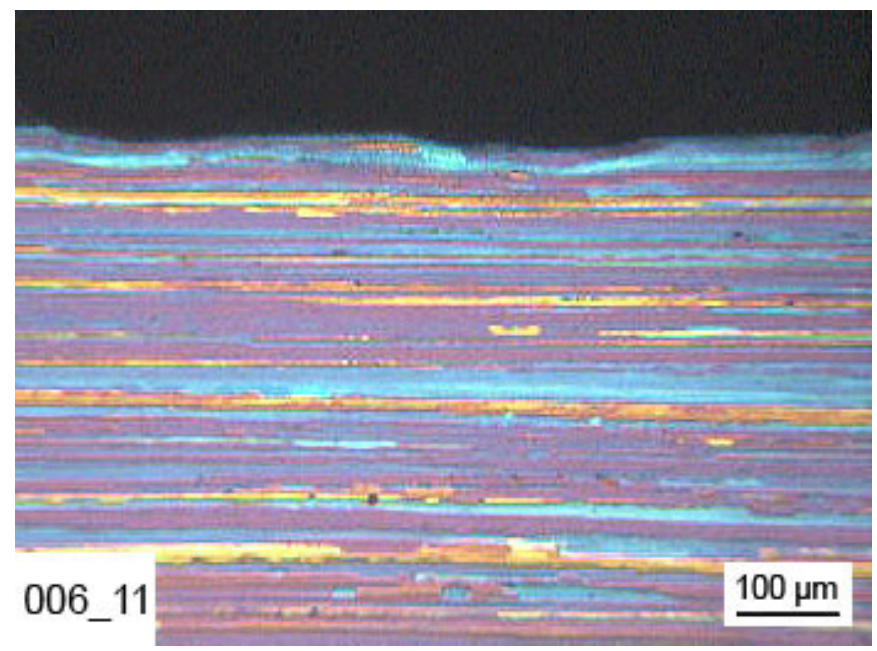

Figura 4.22: Microestrutura da amostra 006_11 após o tratamento térmico (liga 7050, $2 \mathrm{~mm}$, livre, S230, $20 \mathrm{psi}, 66 \%$; TT 500 C-60 min).

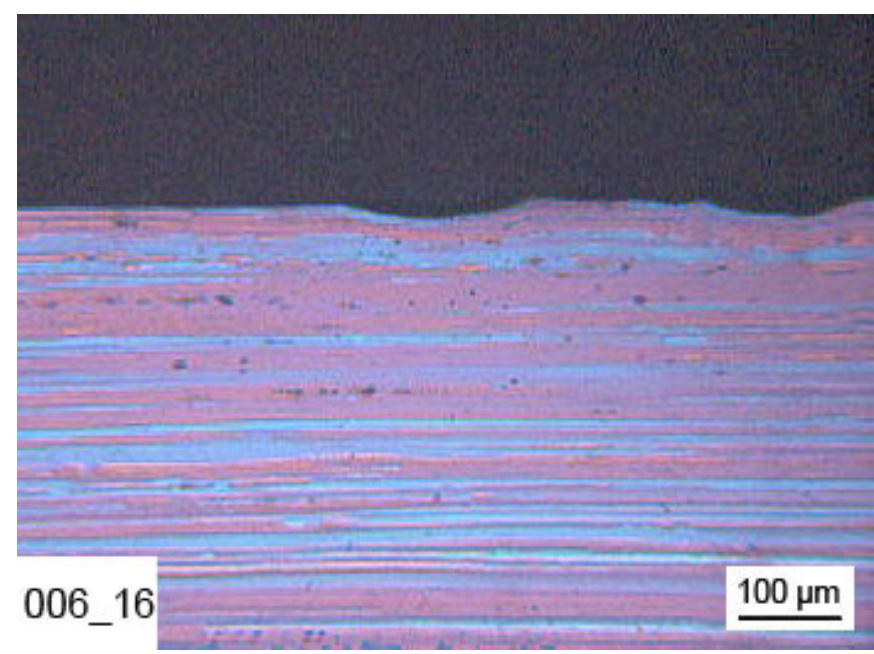

Figura 4.23: Microestrutura da amostra 006_16 sem tratamento térmico (liga 7050, 2 mm, livre, S230, 20 psi, 66\%).

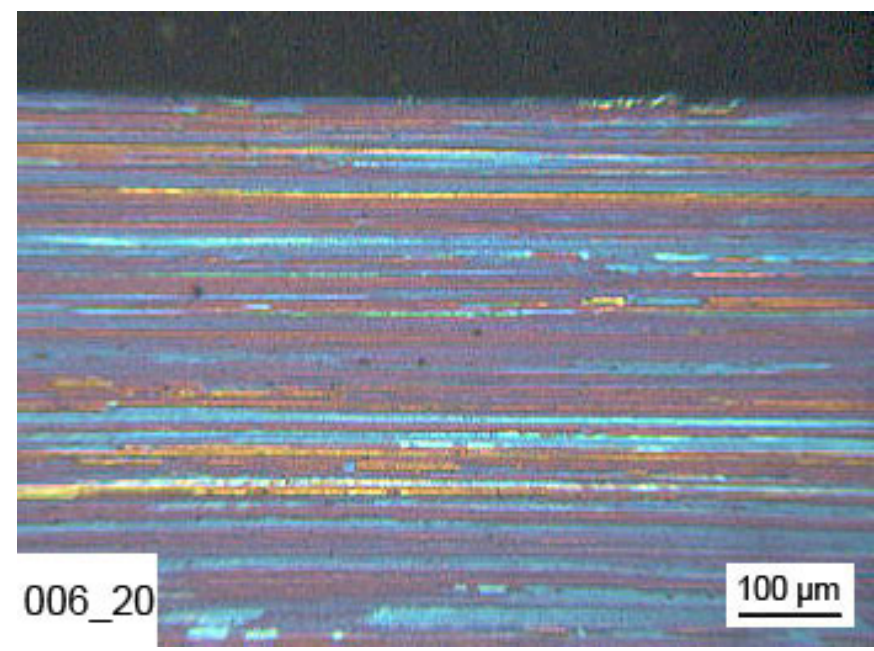

Figura 4.24: Microestrutura da amostra 006_20 após o tratamento térmico (liga $7050,2 \mathrm{~mm}$, sem jateamento; $\mathrm{TT} 400^{\circ} \mathrm{C}-60 \mathrm{~min}$ ). 


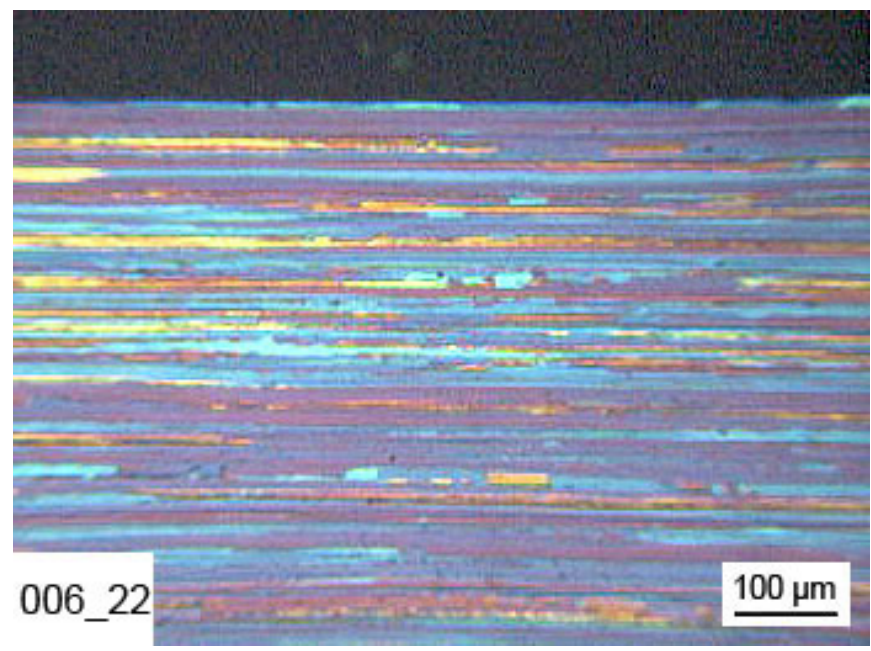

Figura 4.25: Microestrutura da amostra 006_22 após o tratamento térmico (liga 7050, $2 \mathrm{~mm}$, sem jateamento; TT $500^{\circ} \mathrm{C}-60 \mathrm{~min}$ ).

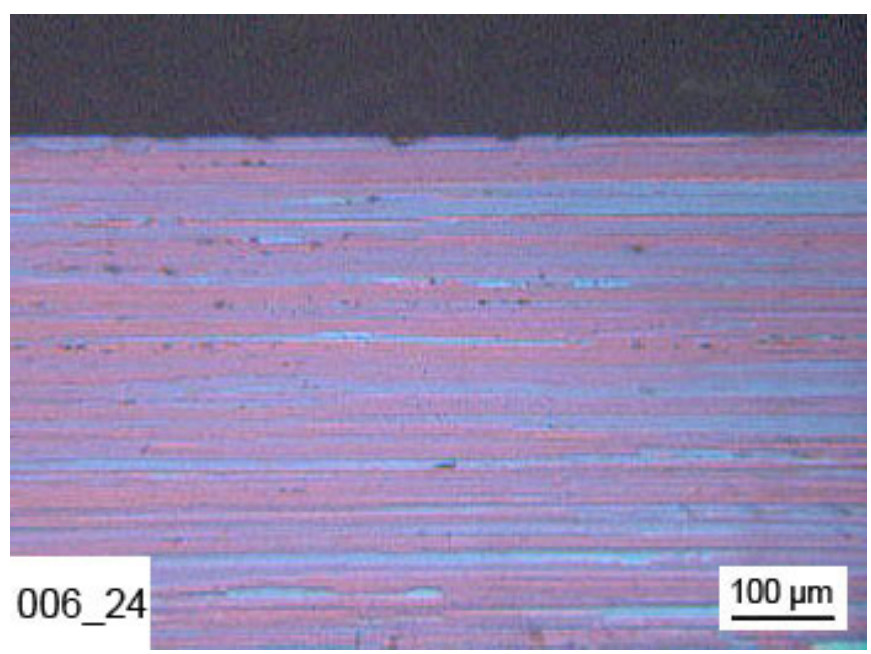

Figura 4.26: Microestrutura da amostra 006_24 sem tratamento térmico (liga 7050, $2 \mathrm{~mm}$, sem jateamento). 


\subsubsection{Amostras com média intensidade de jateamento}

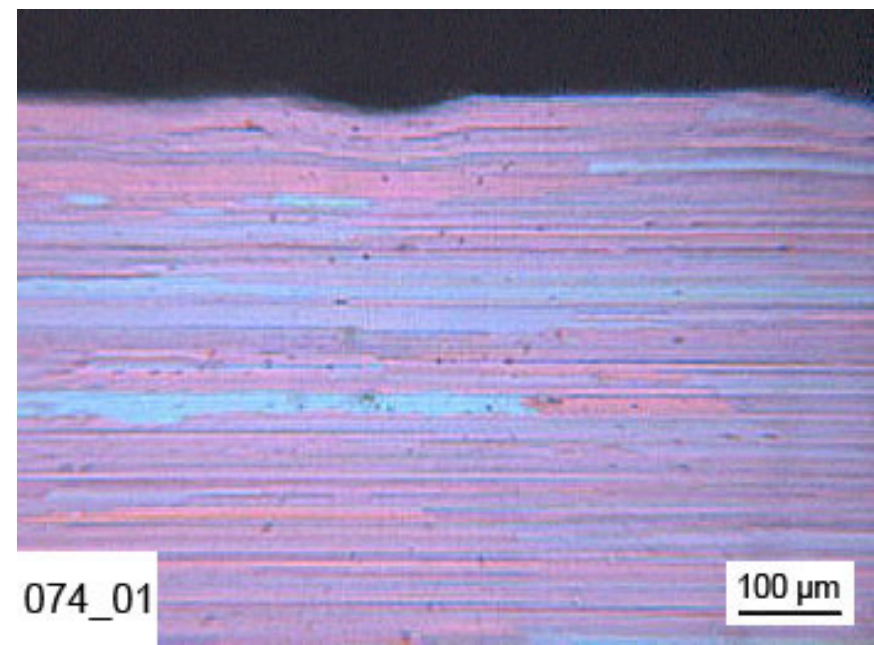

Figura 4.27: Microestrutura da amostra 074_01 após o tratamento térmico (liga 7475, $2 \mathrm{~mm}$, pré-tensionada, S230, 20 psi, 66\%; TT $300^{\circ} \mathrm{C}-30 \mathrm{~min}$ ).

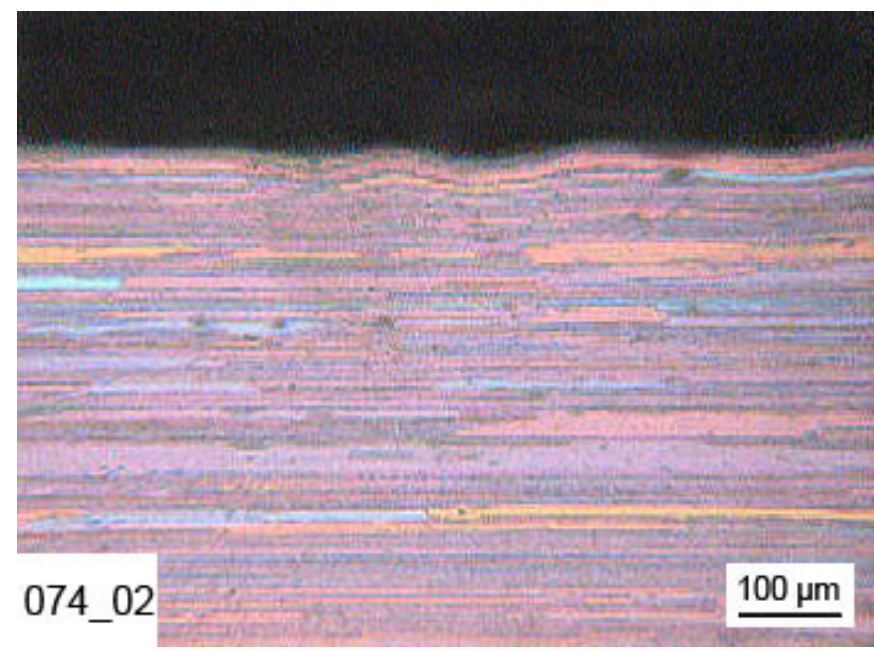

Figura 4.28: Microestrutura da amostra 074_02 após o tratamento térmico (liga 7475, 2 mm, pré-tensionada, S230, 20 psi, 66\%; TT $400^{\circ} \mathrm{C}-30 \mathrm{~min}$ ). 


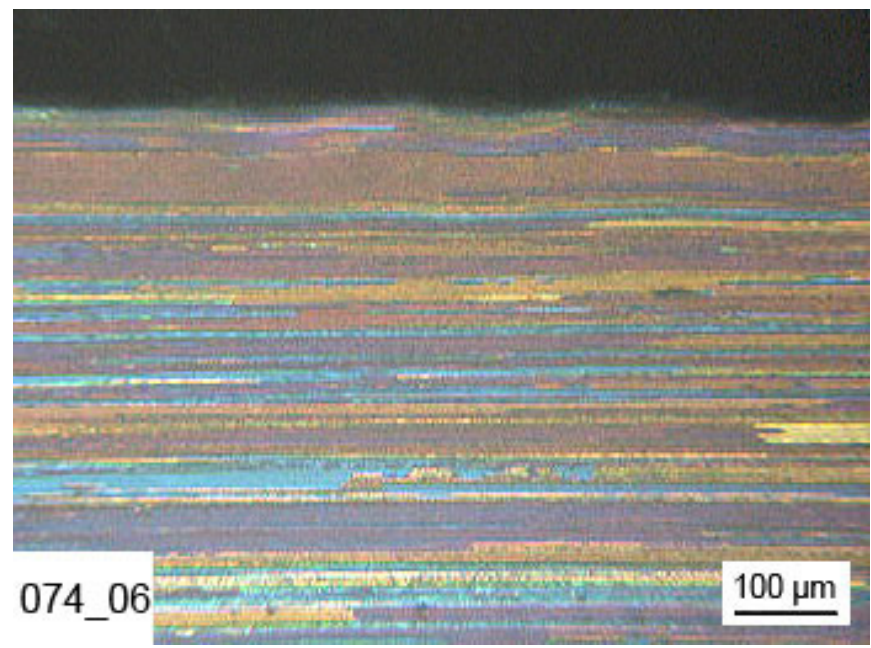

Figura 4.29: Microestrutura da amostra 074_06 após o tratamento térmico (liga 7475, $2 \mathrm{~mm}$, pré-tensionada, S230, 20 psi, 66\%; TT $400^{\circ} \mathrm{C}-60 \mathrm{~min}$ ).

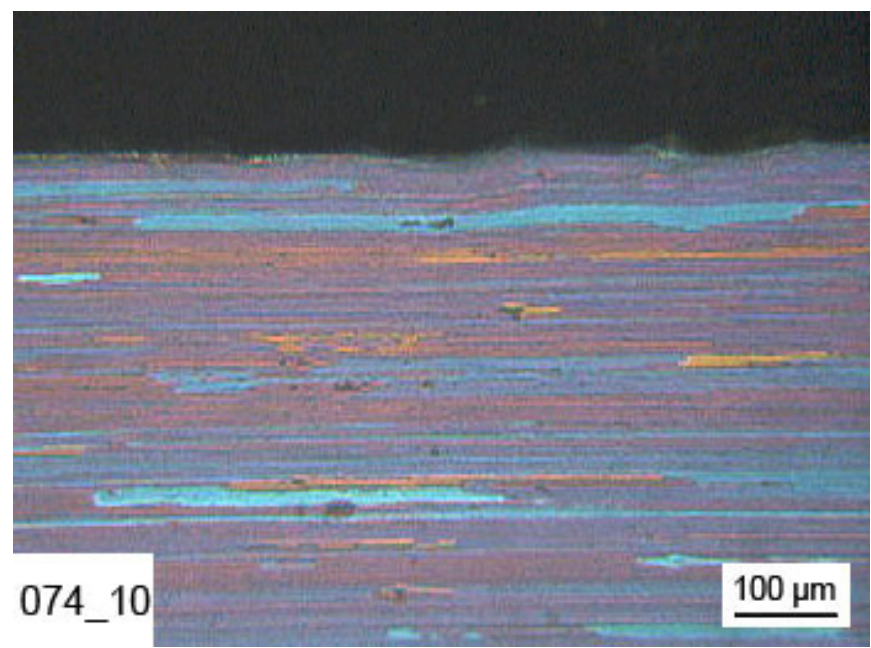

Figura 4.30: Microestrutura da amostra 074_10 após o tratamento térmico (liga 7475, $2 \mathrm{~mm}$, pré-tensionada, S230, 20 psi, 66\%; TT $400^{\circ} \mathrm{C}-120 \mathrm{~min}$ ).

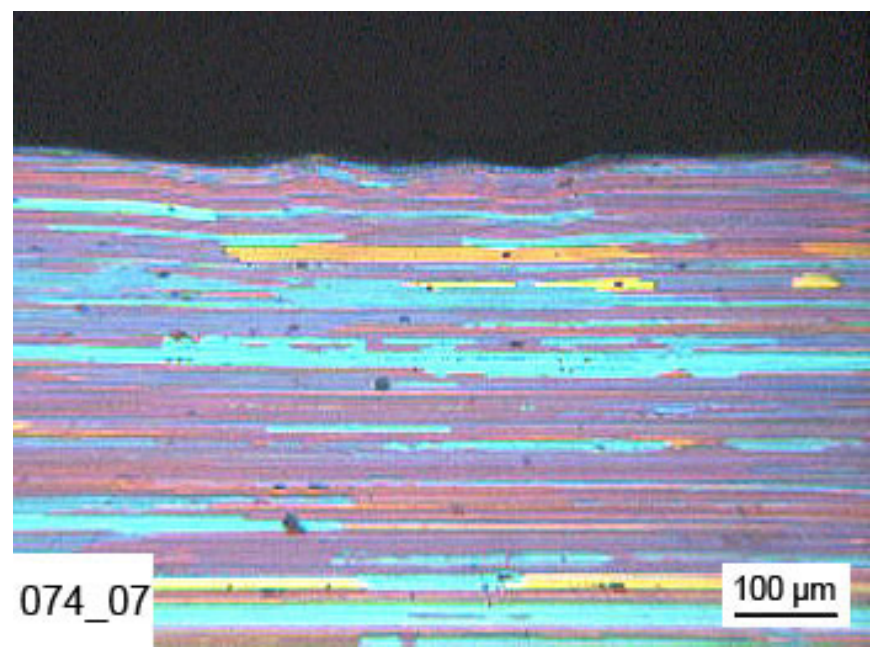

Figura 4.31: Microestrutura da amostra 074_07 após o tratamento térmico (liga 7475, 2 mm, pré-tensionada, S230, 20 psi, $66 \%$; TT $500^{\circ} \mathrm{C}-30 \mathrm{~min}$ ). 


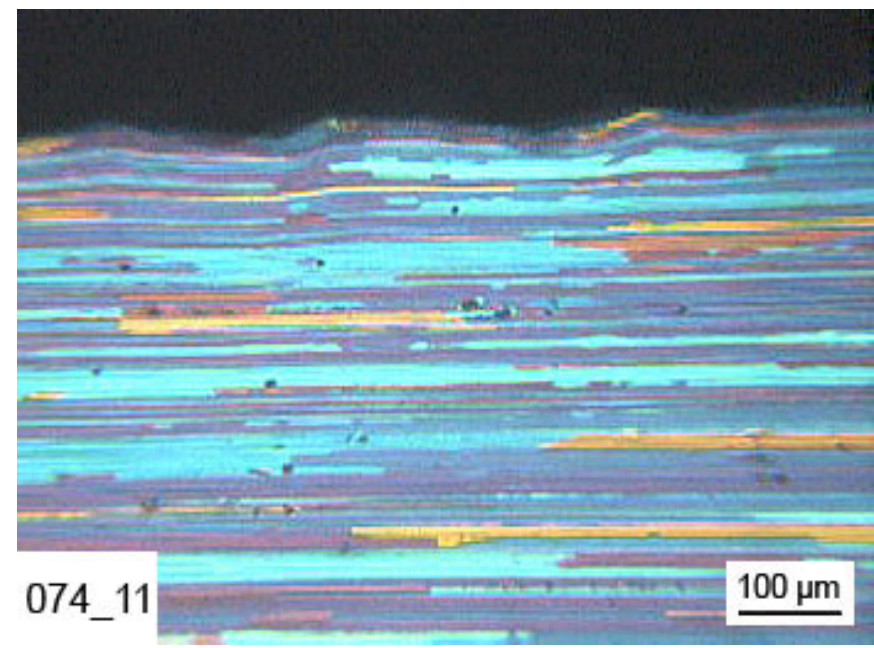

Figura 4.32: Microestrutura da amostra 074_11 após o tratamento térmico (liga 7475, $2 \mathrm{~mm}$, pré-tensionada, S230, 20 psi, 66\%; TT $500^{\circ} \mathrm{C}-60 \mathrm{~min}$ ).

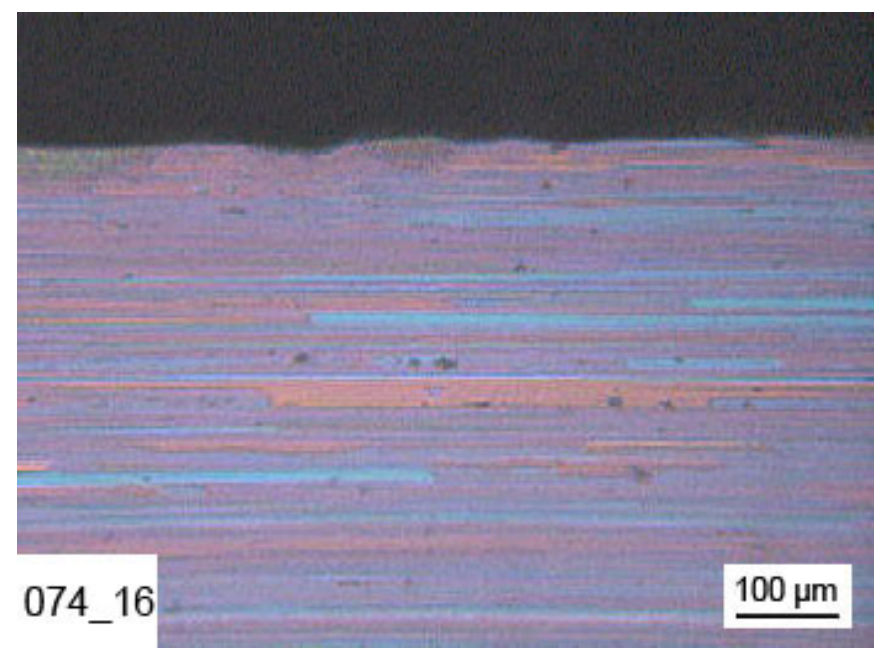

Figura 4.33: Microestrutura da amostra 074_16 sem tratamento térmico (liga 7475, 2 mm, pré-tensionada, S230, 20 psi, 66\%).

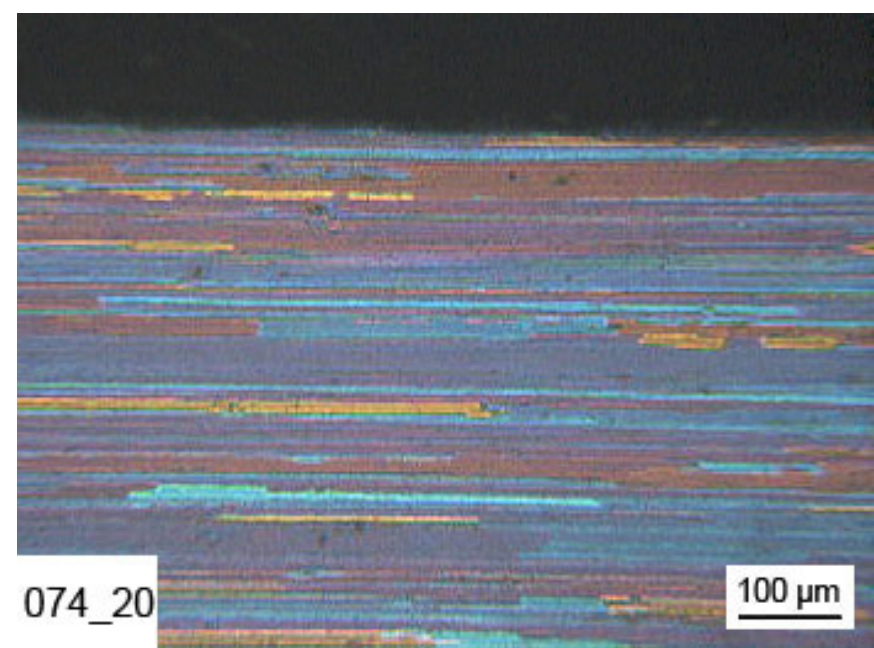

Figura 4.34: Microestrutura da amostra 074_20 após o tratamento térmico (liga 7475, $2 \mathrm{~mm}$, sem jateamento; TT $400^{\circ} \mathrm{C}-60 \mathrm{~min}$ ). 


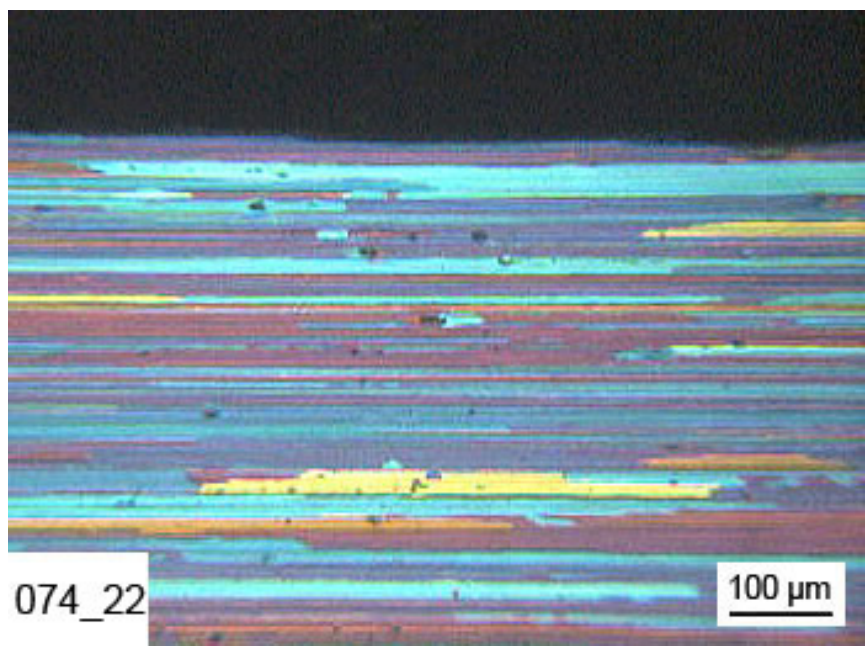

Figura 4.35: Microestrutura da amostra 074_22 após o tratamento térmico (liga 7475, $2 \mathrm{~mm}$, sem jateamento; TT $500^{\circ} \mathrm{C}-60 \mathrm{~min}$ ).

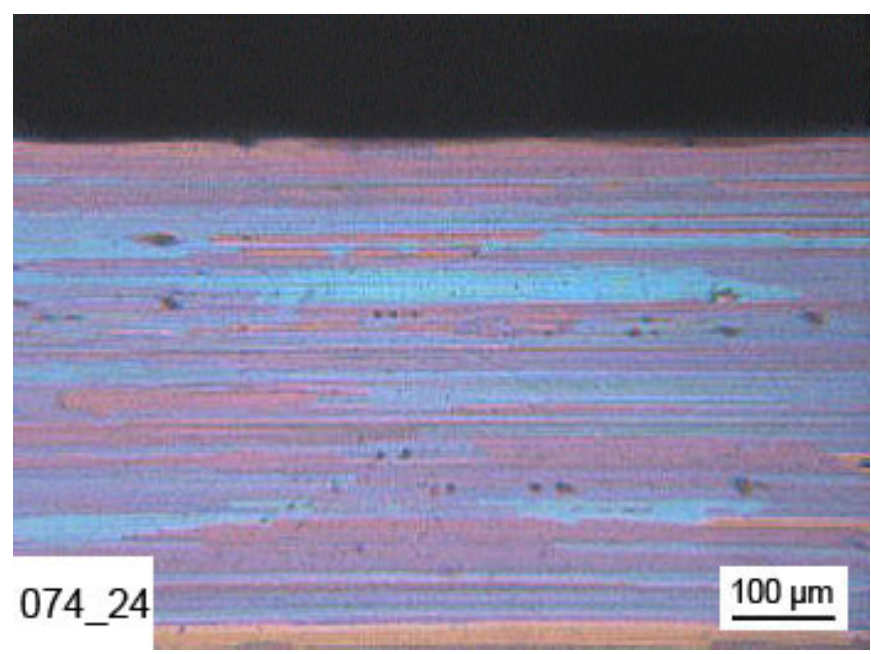

Figura 4.36: Microestrutura da amostra 074_24 sem tratamento térmico (liga 7475, $2 \mathrm{~mm}$, sem jateamento). 


\subsubsection{Amostras com alta intensidade de jateamento}

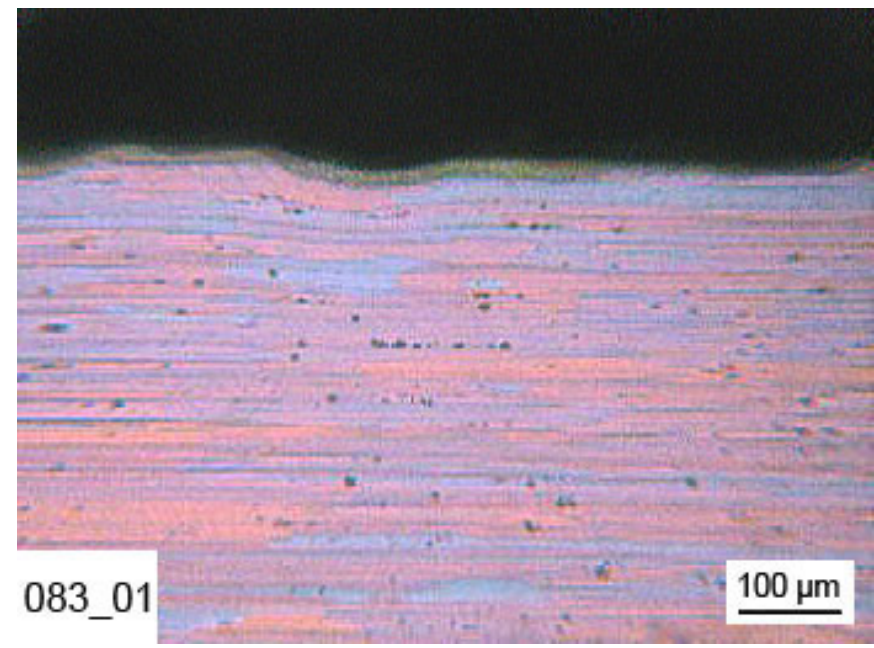

Figura 4.37: Microestrutura da amostra 083_01 após o tratamento térmico (liga 7475, 2 mm, pré-tensionada, S230, 60 psi, 92\%; TT $300^{\circ} \mathrm{C}-30 \mathrm{~min}$ ).

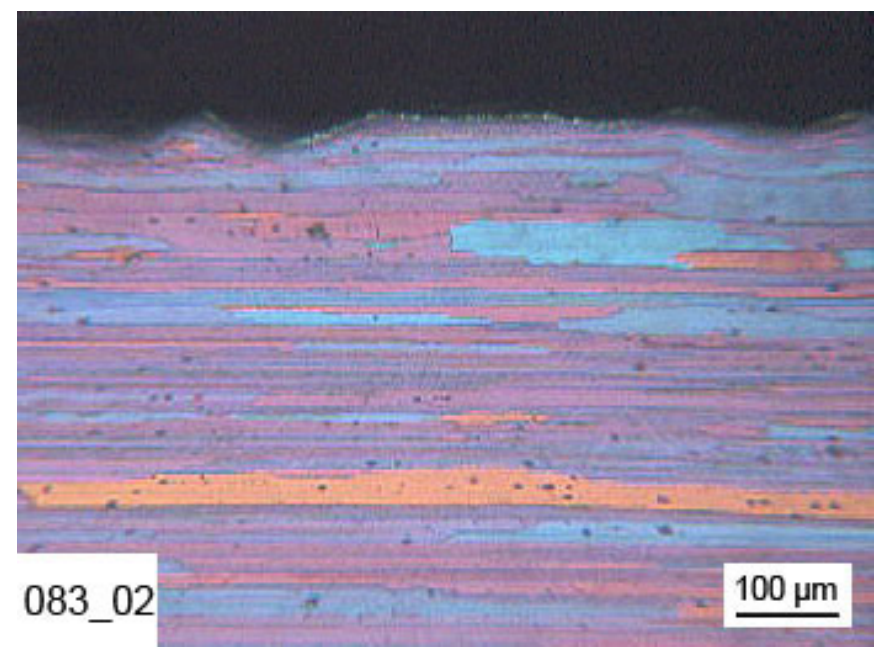

Figura 4.38: Microestrutura da amostra 083_02 após o tratamento térmico (liga 7475, 2 mm, pré-tensionada, S230, 60 psi, 92\%; TT $400^{\circ} \mathrm{C}-30 \mathrm{~min}$ ). 


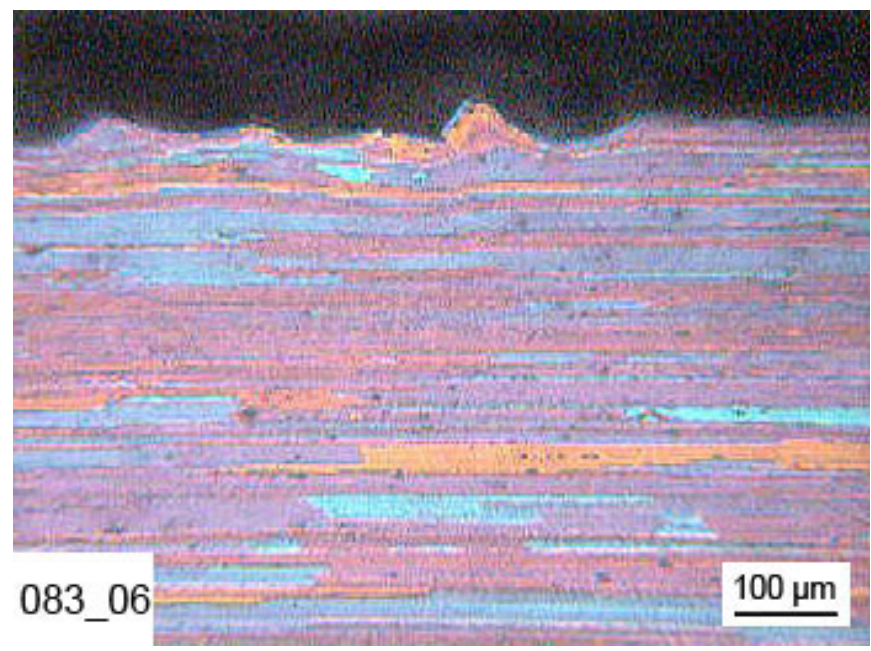

Figura 4.39: Microestrutura da amostra 083_06 após o tratamento térmico (liga 7475, $2 \mathrm{~mm}$, pré-tensionada, S230, 60 psi, 92\%; TT $400^{\circ} \mathrm{C}-60 \mathrm{~min}$ ).

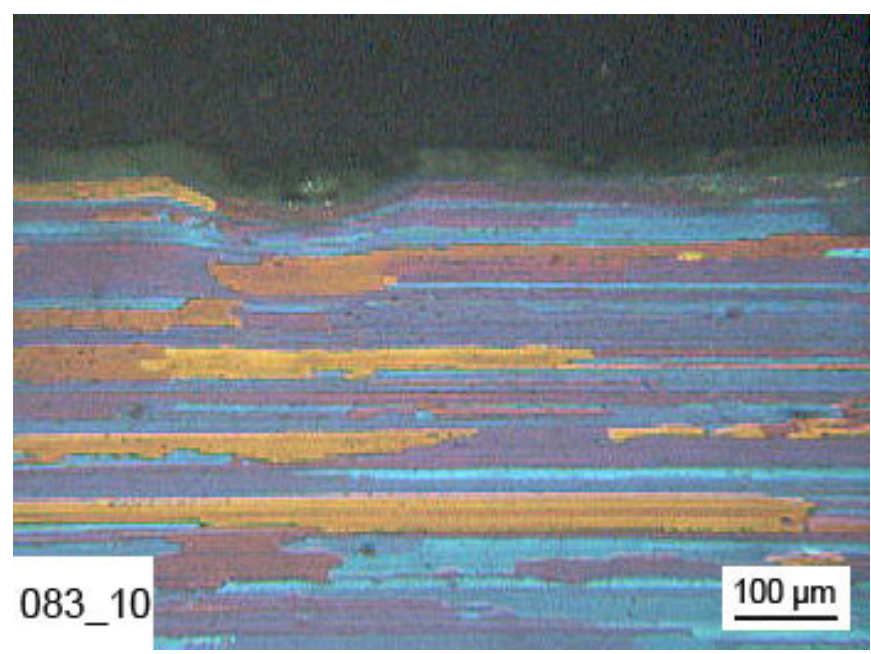

Figura 4.40: Microestrutura da amostra 083_10 após o tratamento térmico (liga 7475, 2 mm, pré-tensionada, S230, 60 psi, 92\%; TT $400^{\circ} \mathrm{C}-120 \mathrm{~min}$ ).

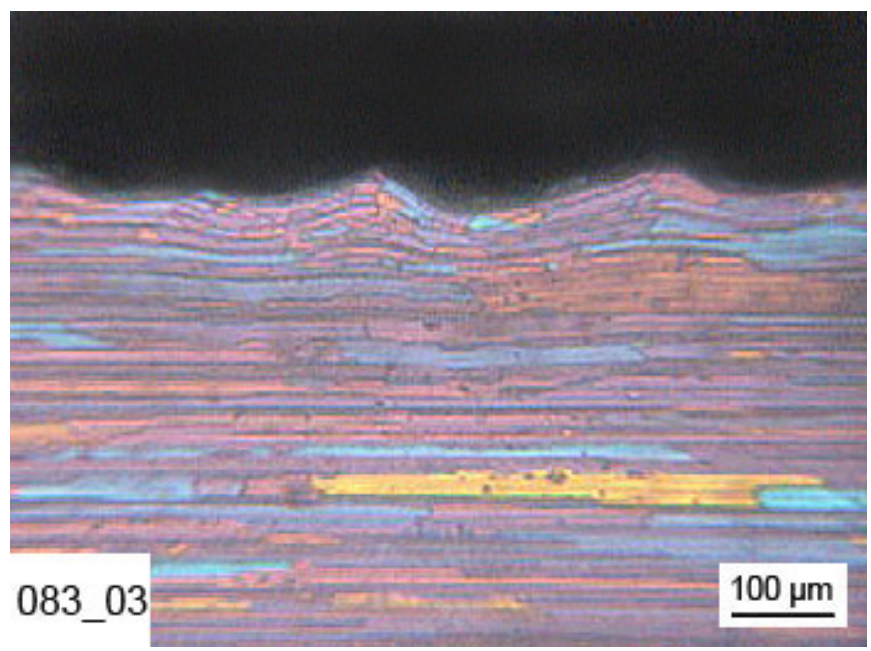

Figura 4.41: Microestrutura da amostra 083_03 após o tratamento térmico (liga 7475, 2 mm, pré-tensionada, S230, 60 psi, 92\%; TT $500^{\circ} \mathrm{C}-15 \mathrm{~min}$ ). 


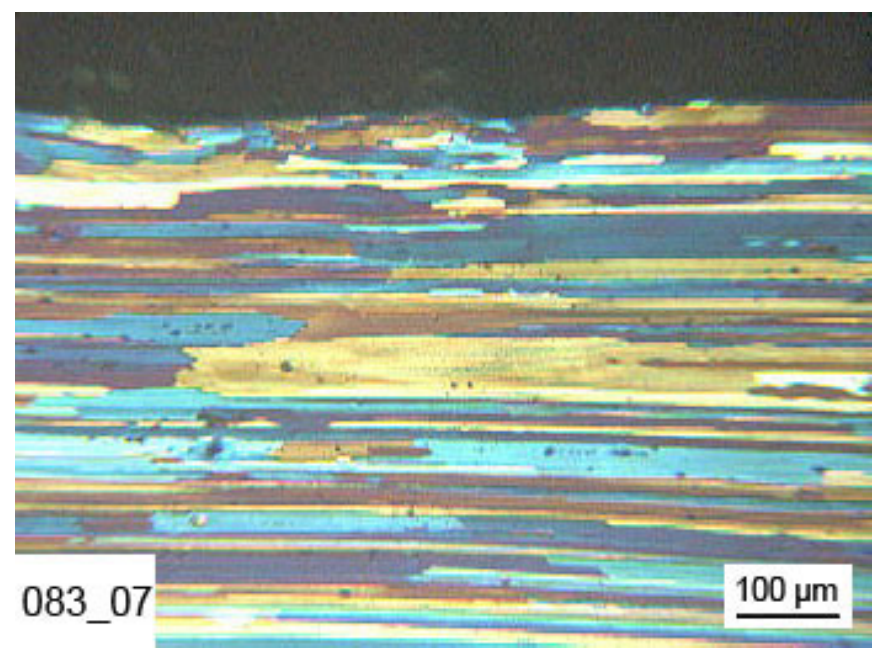

Figura 4.42: Microestrutura da amostra 083_07 após o tratamento térmico (liga 7475, $2 \mathrm{~mm}$, pré-tensionada, S230, 60 psi, $92 \%$; TT $500^{\circ} \mathrm{C}-30 \mathrm{~min}$ ).

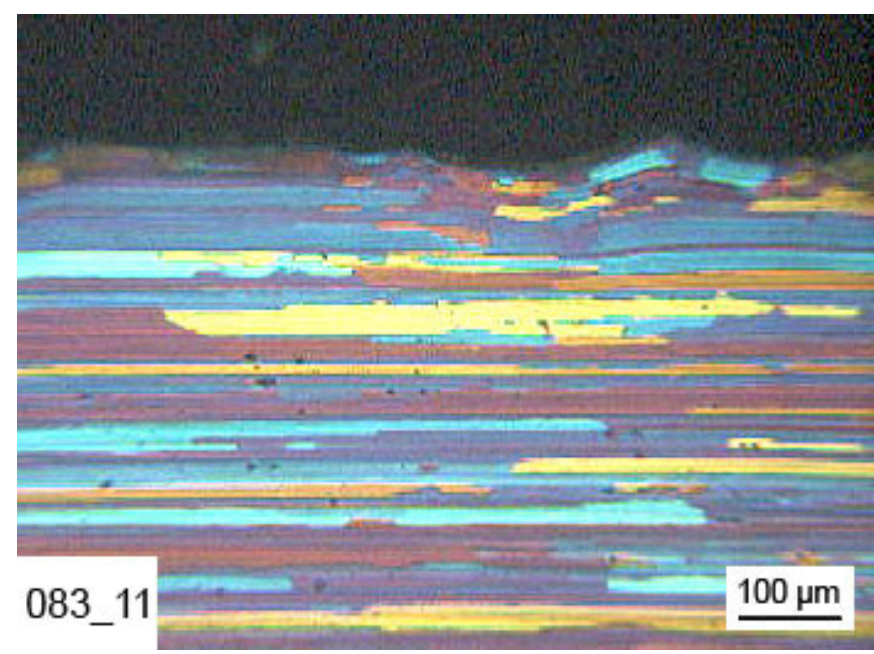

Figura 4.43: Microestrutura da amostra 083_11 após o tratamento térmico (liga 7475, 2 mm, pré-tensionada, S230, 60 psi, 92\%; TT $500^{\circ} \mathrm{C}-60 \mathrm{~min}$ ).

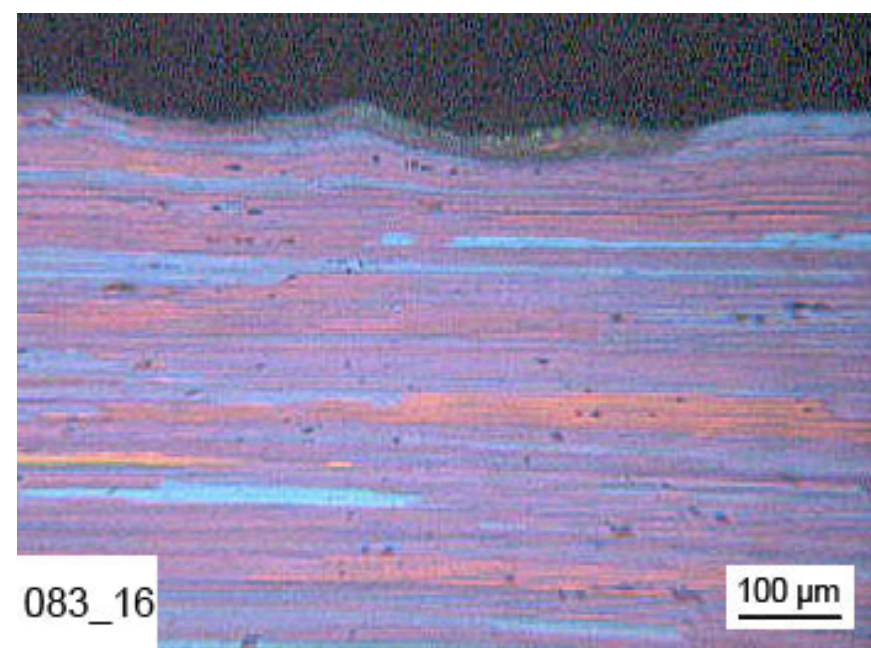

Figura 4.44: Microestrutura da amostra 083_16 sem tratamento térmico (liga 7475, 2 mm, pré-tensionada, S230, 60 psi, 92\%). 


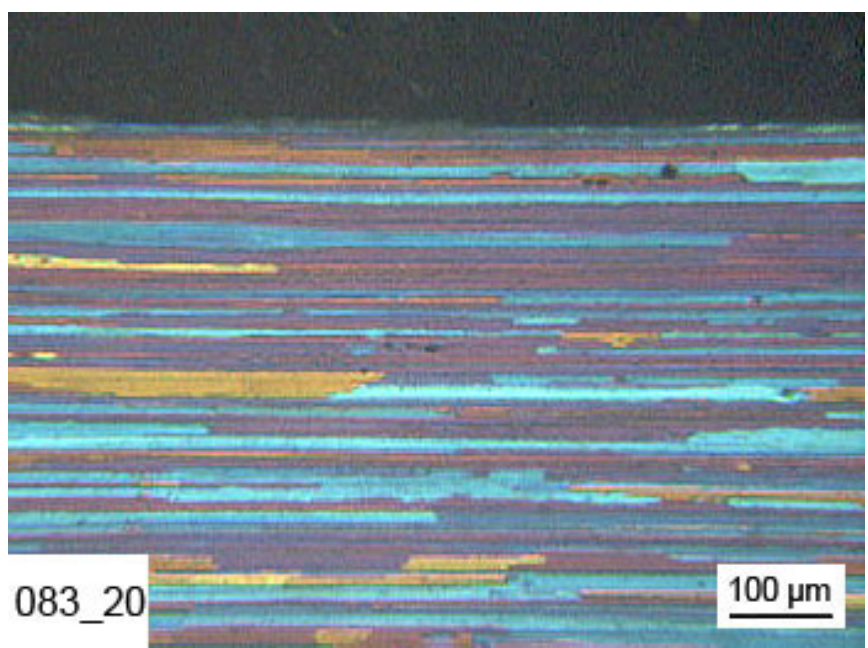

Figura 4.45: Microestrutura da amostra 083_20 após o tratamento térmico (liga 7475, $2 \mathrm{~mm}$, sem jateamento; TT $400^{\circ} \mathrm{C}-60 \mathrm{~min}$ ).

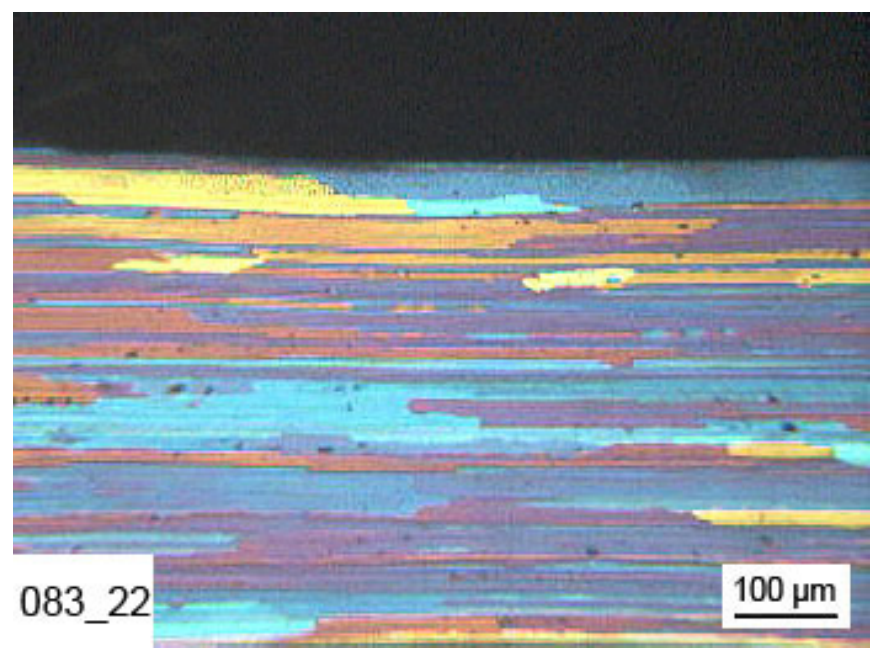

Figura 4.46: Microestrutura da amostra 083_22 após o tratamento térmico (liga 7475, $2 \mathrm{~mm}$, sem jateamento; TT $500^{\circ} \mathrm{C}-60 \mathrm{~min}$ ).

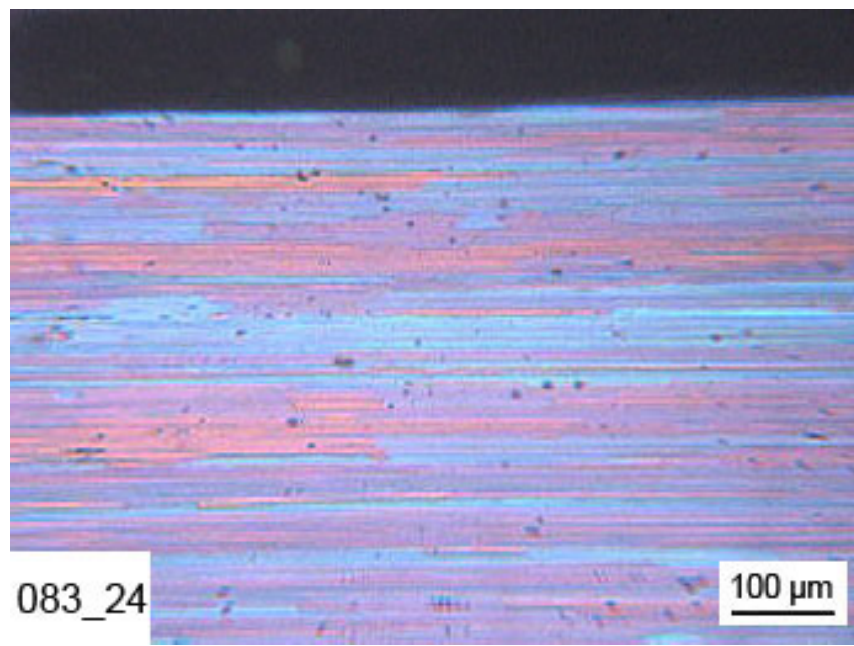

Figura 4.47: Microestrutura da amostra 083_24 sem tratamento térmico (liga 7475, $2 \mathrm{~mm}$, sem jateamento. 


\subsubsection{Discussão}

Não foram todas as amostras submetidas a tratamentos térmicos que sofreram recristalização na borda. A camada de grãos diferenciados é visível apenas nas chapas da liga 7475 jateadas com maior intensidade, recozidas à temperatura mais alta.

Nessas amostras, a camada que se apresenta com grãos menores e menos alongados não é facilmente diferenciável do restante da espessura, mas a sua espessura é de aproximadamente $65 \mu \mathrm{m}$ (Figura 4.48), cerca de 1/7 do valor medido pelo perfil de tensões residuais.

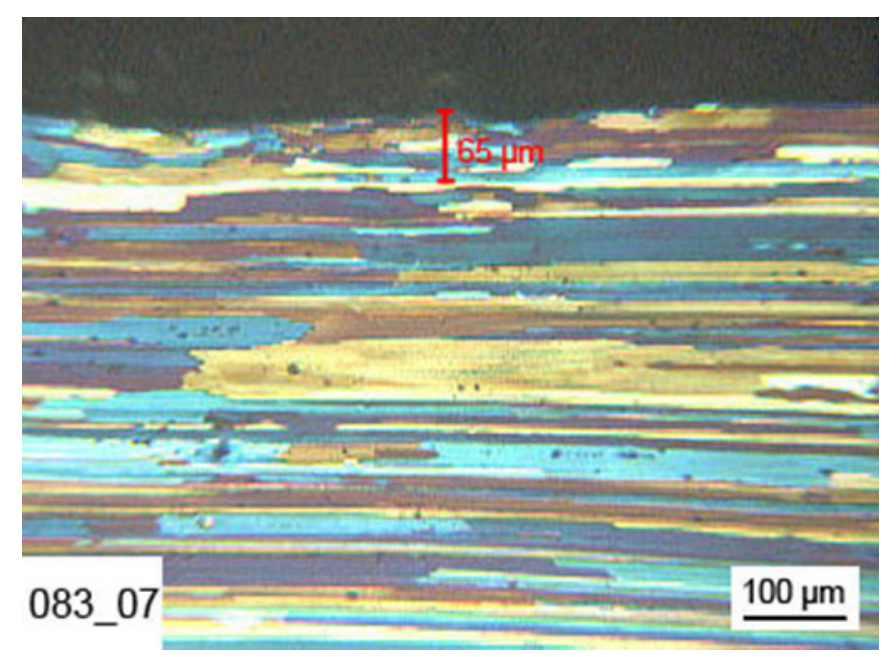

Figura 4.48: Indicação da espessura da camada recristalizada após tratamento térmico na amostra 083_07 (liga 7475, $2 \mathrm{~mm}$, pré-tensionada, S230, $60 \mathrm{psi}, 92 \%$; TT $\left.500^{\circ} \mathrm{C}-30 \mathrm{~min}\right)$.

As amostras sem jateamento não sofreram alterações microestruturais significativas, o que indica que os corpos de prova não são suscetíveis a recristalização de borda devido à laminação das chapas.

De fato, a recristalização das amostras da liga 7050 não era esperada, uma vez que a adição de $\mathrm{Zr}$ gera a precipitação de dispersóides de $\mathrm{Al}_{3} \mathrm{Zr}$, que podem não gerar grande endurecimento por precipitação (devido à baixa fração volumétrica), mas funcionam como inibidores da recuperação e da recristalização ${ }^{[10,14]}$.

O baixo número de amostras da liga 7475 em que houve recristalização pode também ser explicado pela presença de dispersóides insolúveis nas temperaturas de tratamento térmico utilizadas, e também pela baixa densidade de discordâncias na superfície das chapas gerada pelas indentações. 


\subsubsection{Experimentos de laminação}

Englobando os dois problemas apresentados nas últimas sessões - dificuldade de obtenção de perfil de durezas (pág. 108) e ausência de recristalização -, foram feitos experimentos visando submeter corpos de prova das duas ligas estudadas a situações extremas, para verificar se as ligas sofrem alterações observáveis.

Para isso, foram selecionados os seguintes corpos de prova:

369 Liga 7050, espessura $10 \mathrm{~mm}$, jateado com granalhas 1/8", com velocidade média (20 psi), sem pré-tensão, com cobertura 200\%;

357 Liga 7475, espessura $10 \mathrm{~mm}$, jateado com granalhas 1/8", com velocidade média (20 psi), sem pré-tensão, com cobertura $200 \%$.

Foram retiradas 8 amostras de cada corpo de prova. Destas, 4 amostras da região não jateada (amostras $A, B, C$ e D) e 4 da região jateada. (amostras E, F, G e H). O planejamento dos experimentos segue abaixo:

- Amostras A e E: Laminadas e tratadas termicamente;

- Amostras B e F: Laminadas;

- Amostras C e G: Tratadas termicamente;

- Amostras D e H: Controle.

A laminação foi feita a frio, na mesma direção da laminação anterior das chapas, em 5 passes de $1 \mathrm{~mm}$, totalizando uma redução de $50 \%$. O tratamento térmico foi feito em forno mufla, a $500{ }^{\circ} \mathrm{C}$, por 30 minutos, com resfriamento em água.

Todas as amostras foram embutidas de modo a se visualizar a direção longitudinal e preparadas conforme o item 1.d da Seção 1.4.3, pág. 63. O ataque eletrolítico foi feito com reagente Barker, para visualização da estrutura de grãos. As medidas de dureza Vickers foram feitas com carga de $1000 \mathrm{gf}$.

As Figuras 4.49 a 4.64 mostram a região próxima à superfície das amostras citadas anteriormente. 


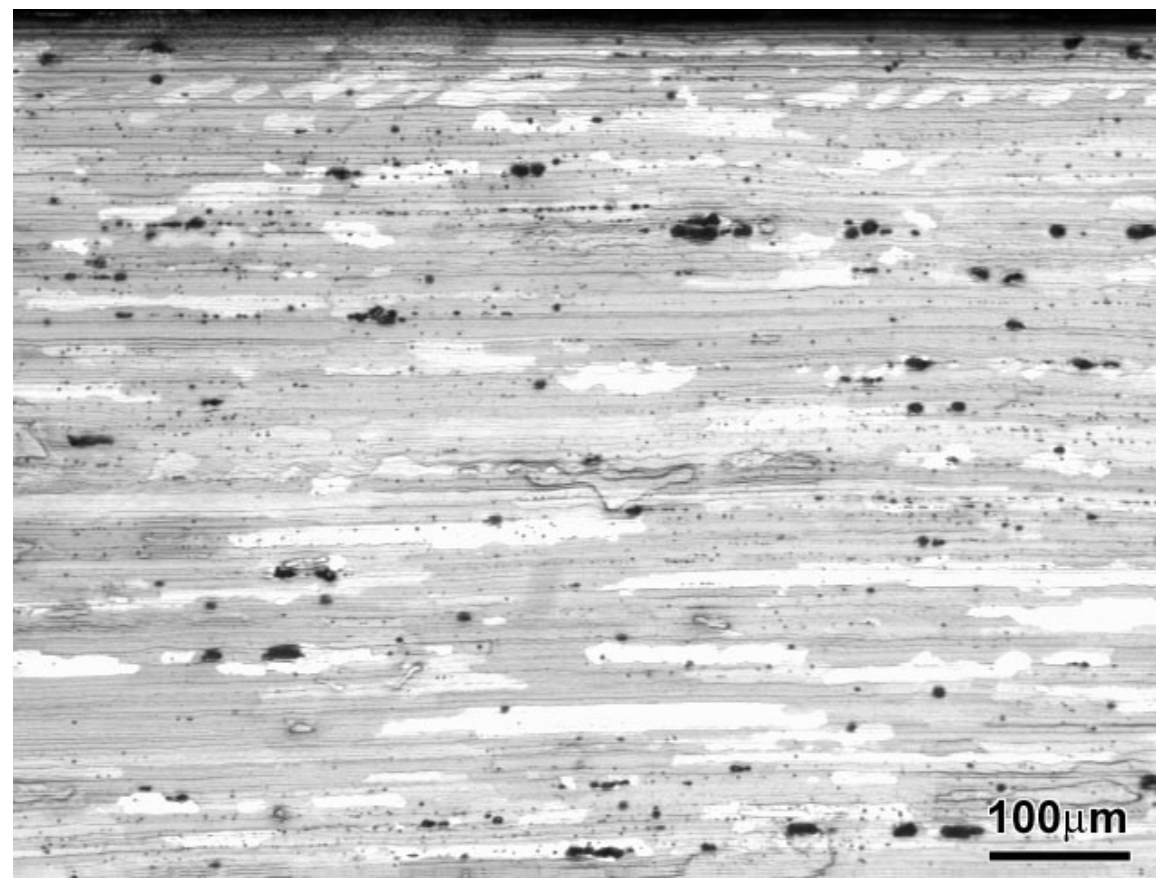

Figura 4.49: Microestrutura da amostra 357A (região não jateada, 7475, laminada e tratada termicamente).

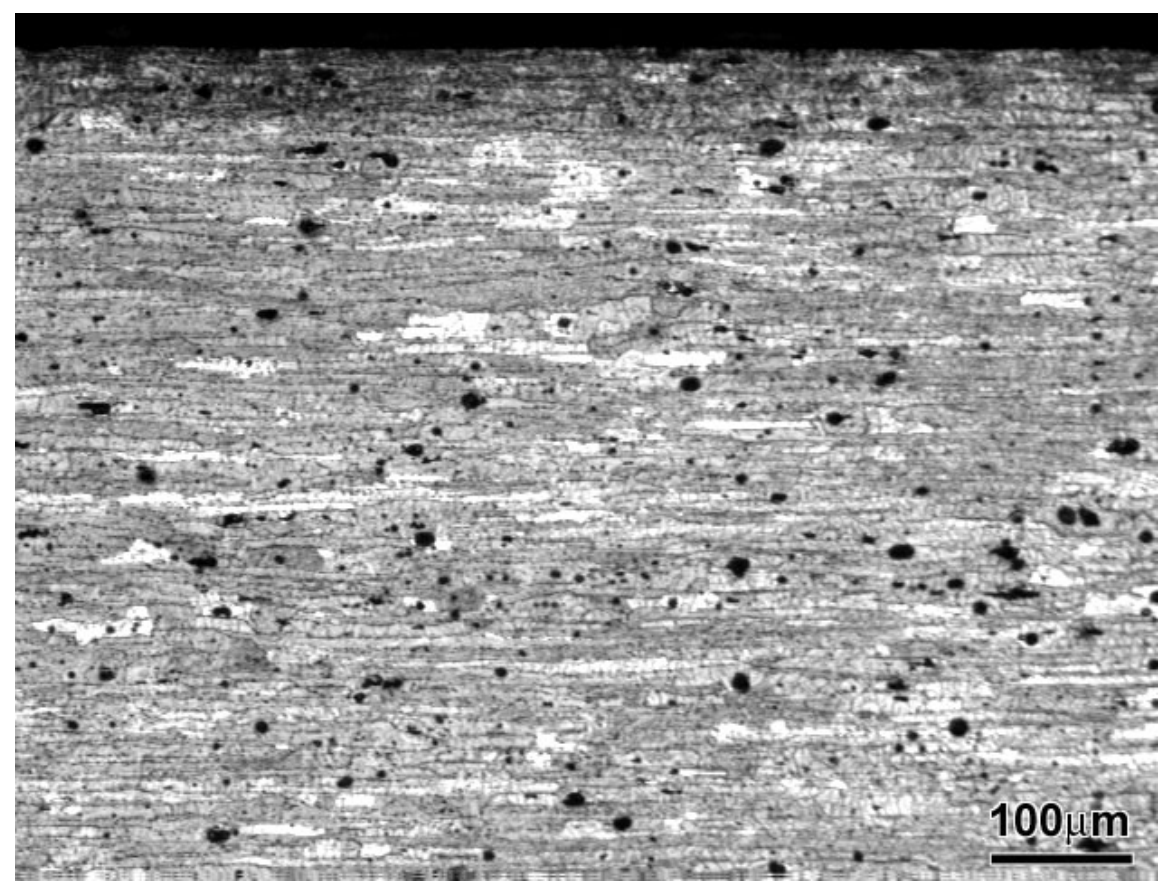

Figura 4.50: Microestrutura da amostra 369A (região não jateada, 7050, laminada e tratada termicamente). 


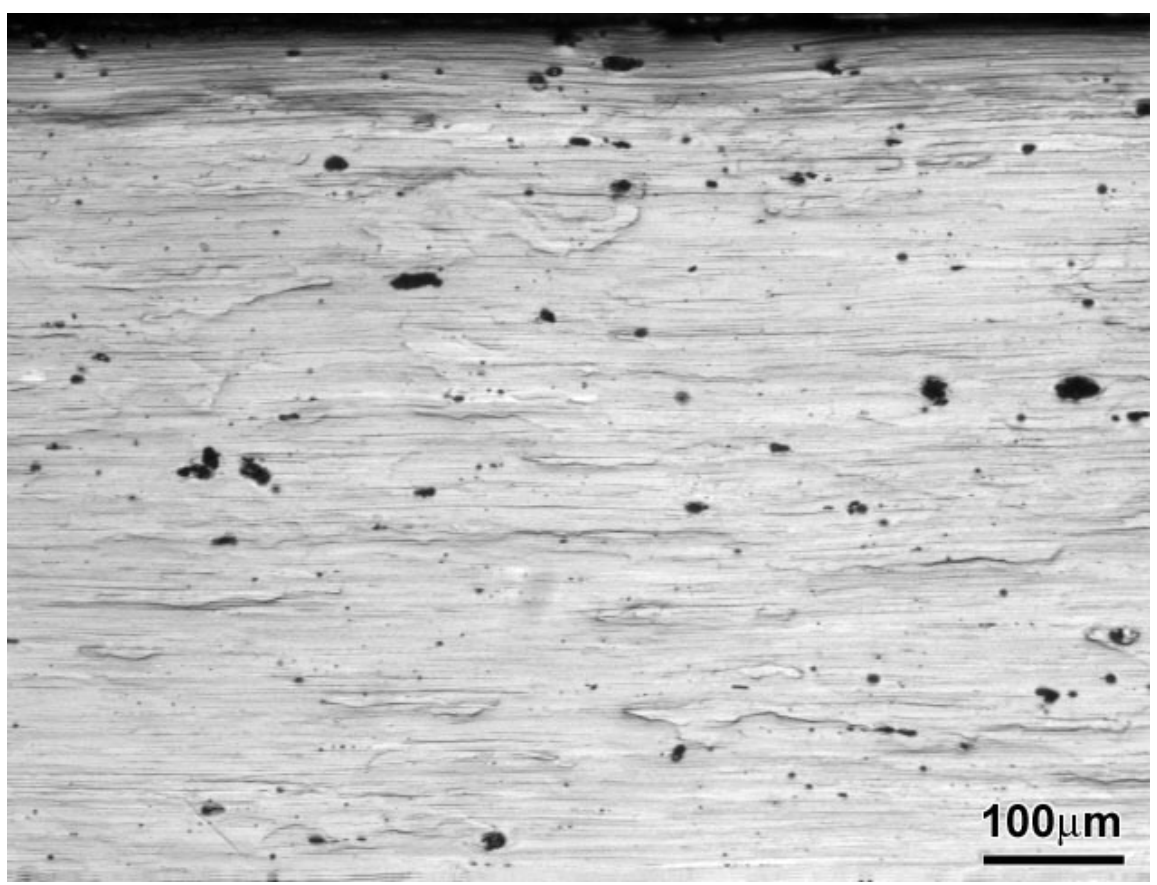

Figura 4.51: Microestrutura da amostra 357B (região não jateada, 7475, apenas laminada).

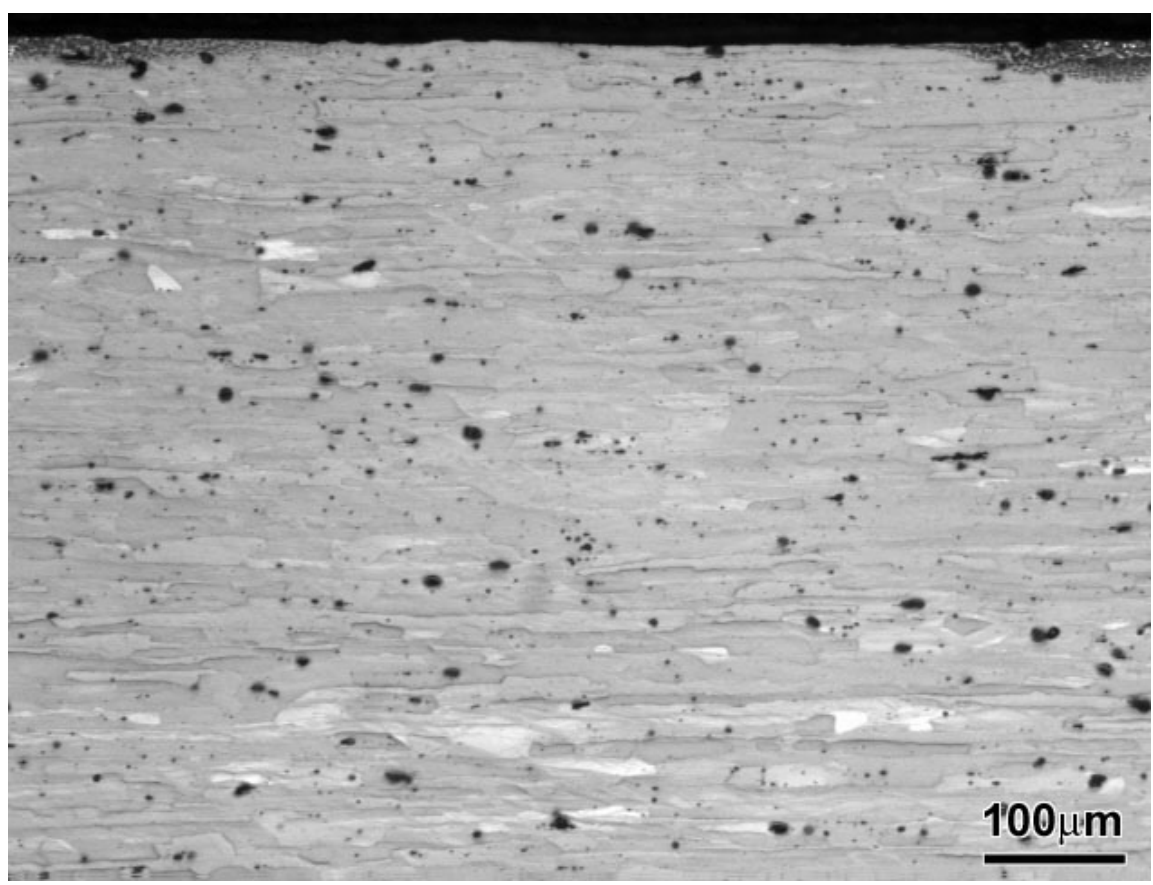

Figura 4.52: Microestrutura da amostra 369B (região não jateada, 7050, apenas laminada). 


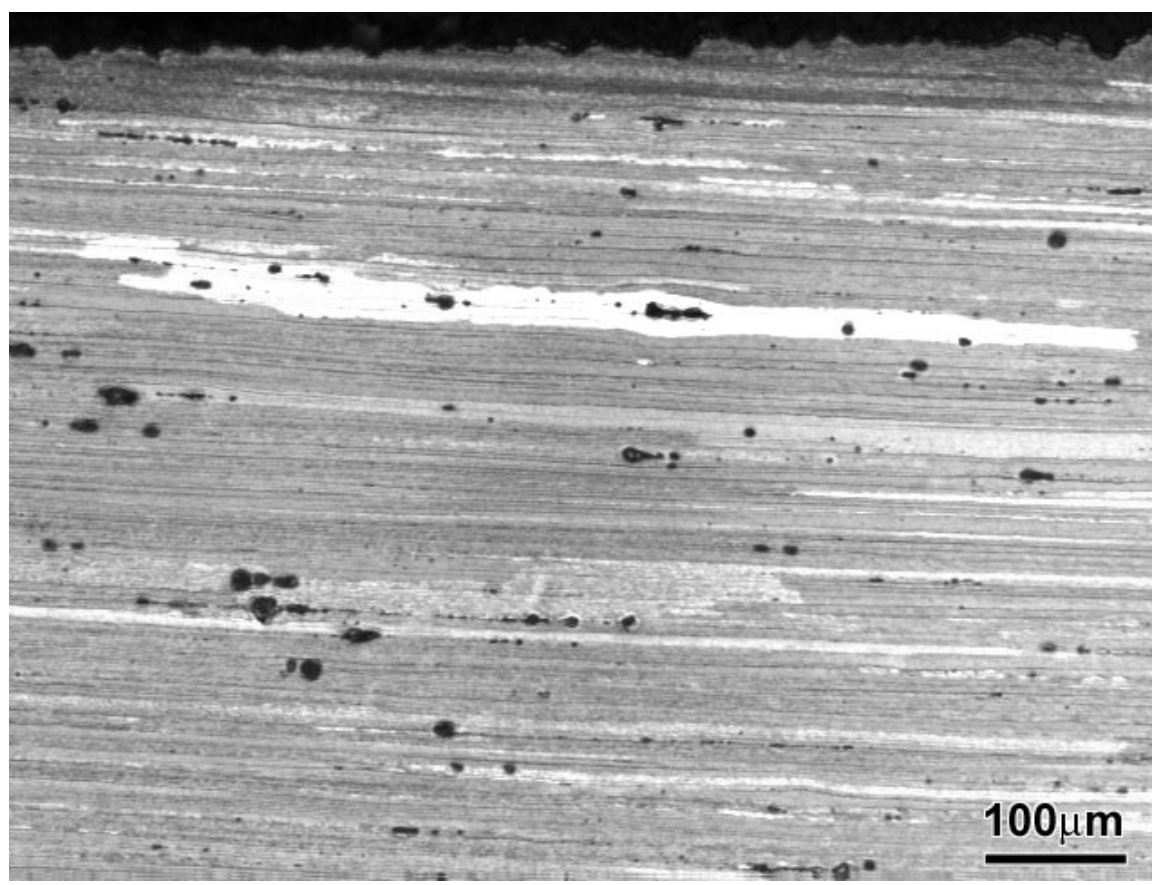

Figura 4.53: Microestrutura da amostra 357C (região não jateada, 7475, apenas tratada termicamente).

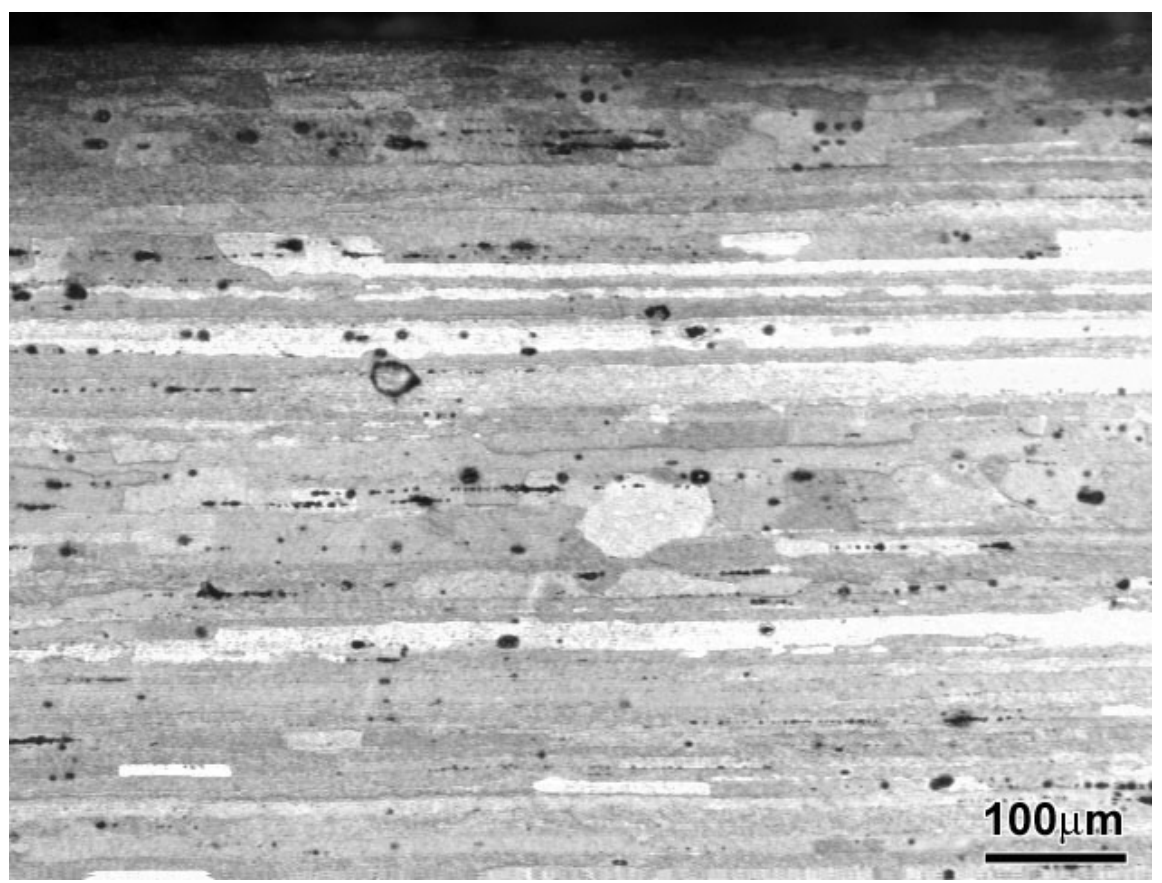

Figura 4.54: Microestrutura da amostra 369C (região não jateada, 7050, apenas tratada termicamente). 


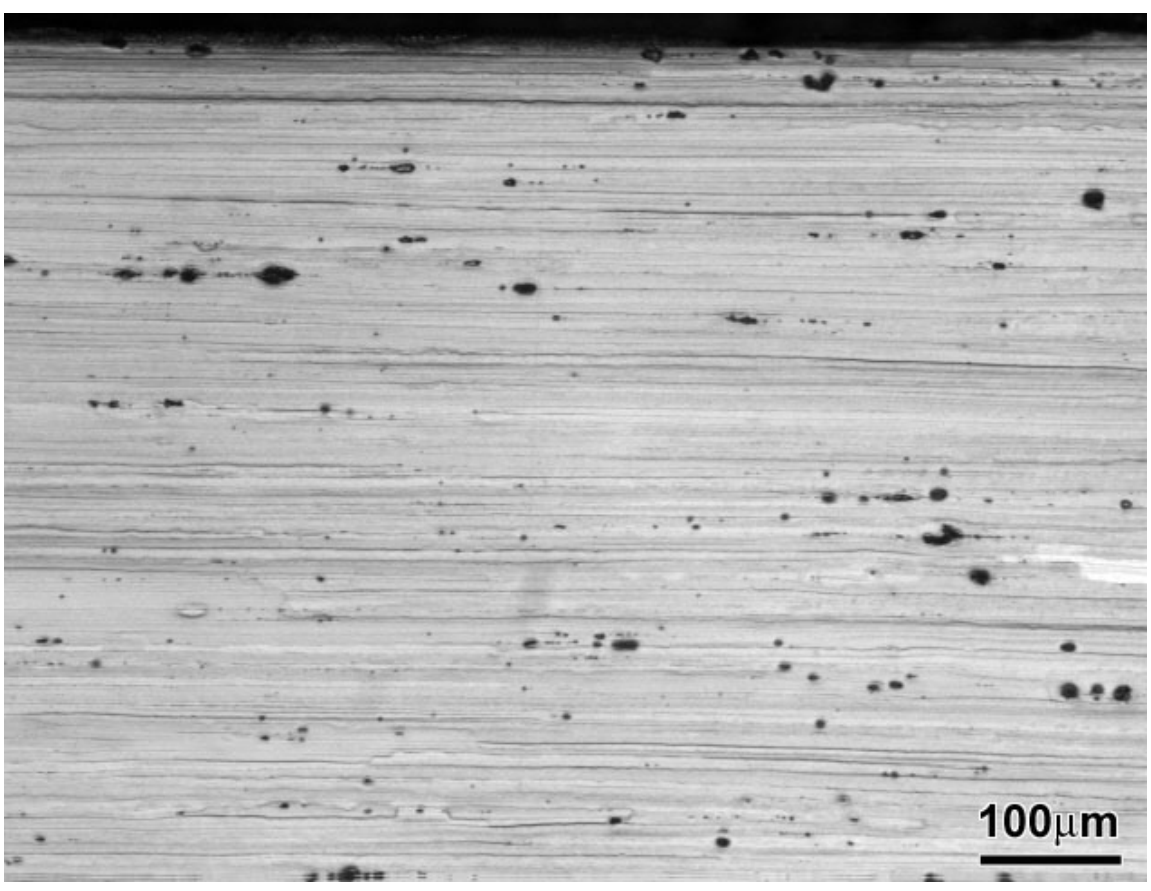

Figura 4.55: Microestrutura da amostra 357D (região não jateada, 7475, não-transformada).

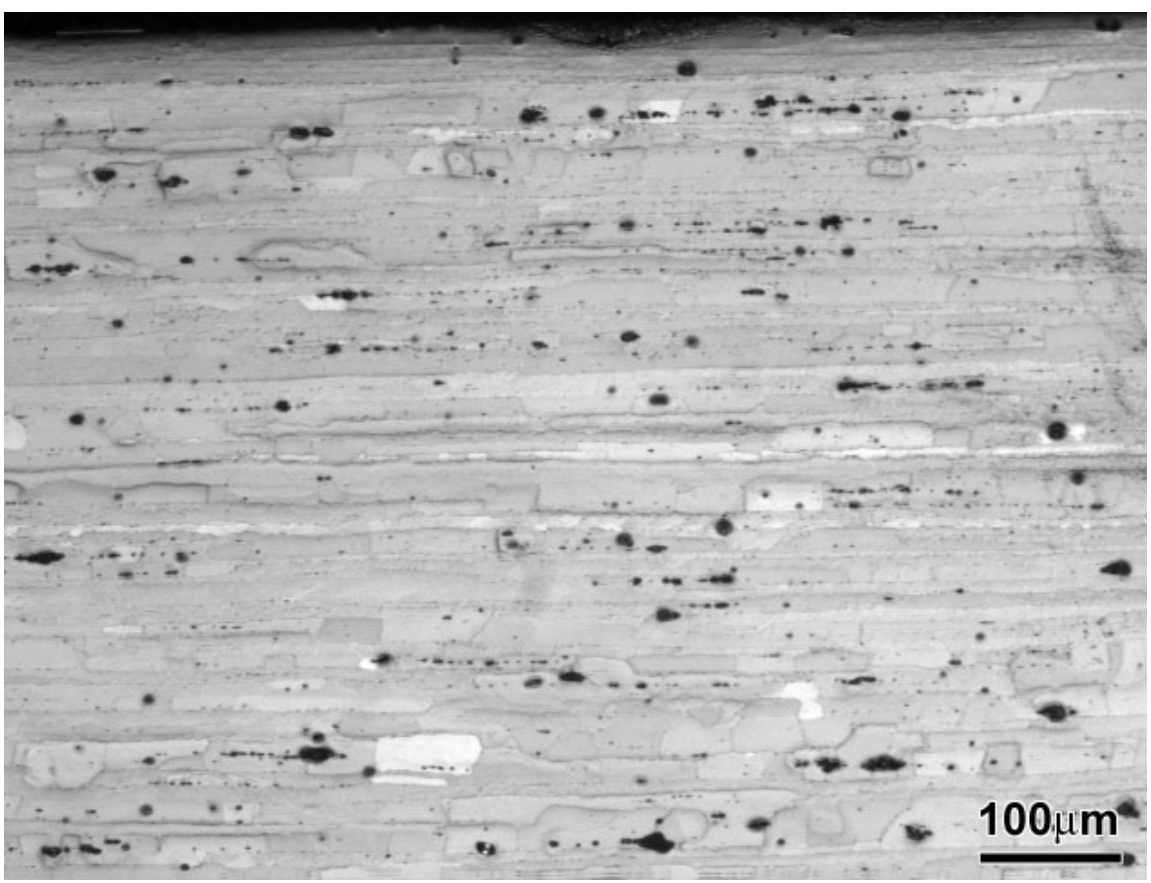

Figura 4.56: Microestrutura da amostra 369D (região não jateada, 7050, não-transformada). 


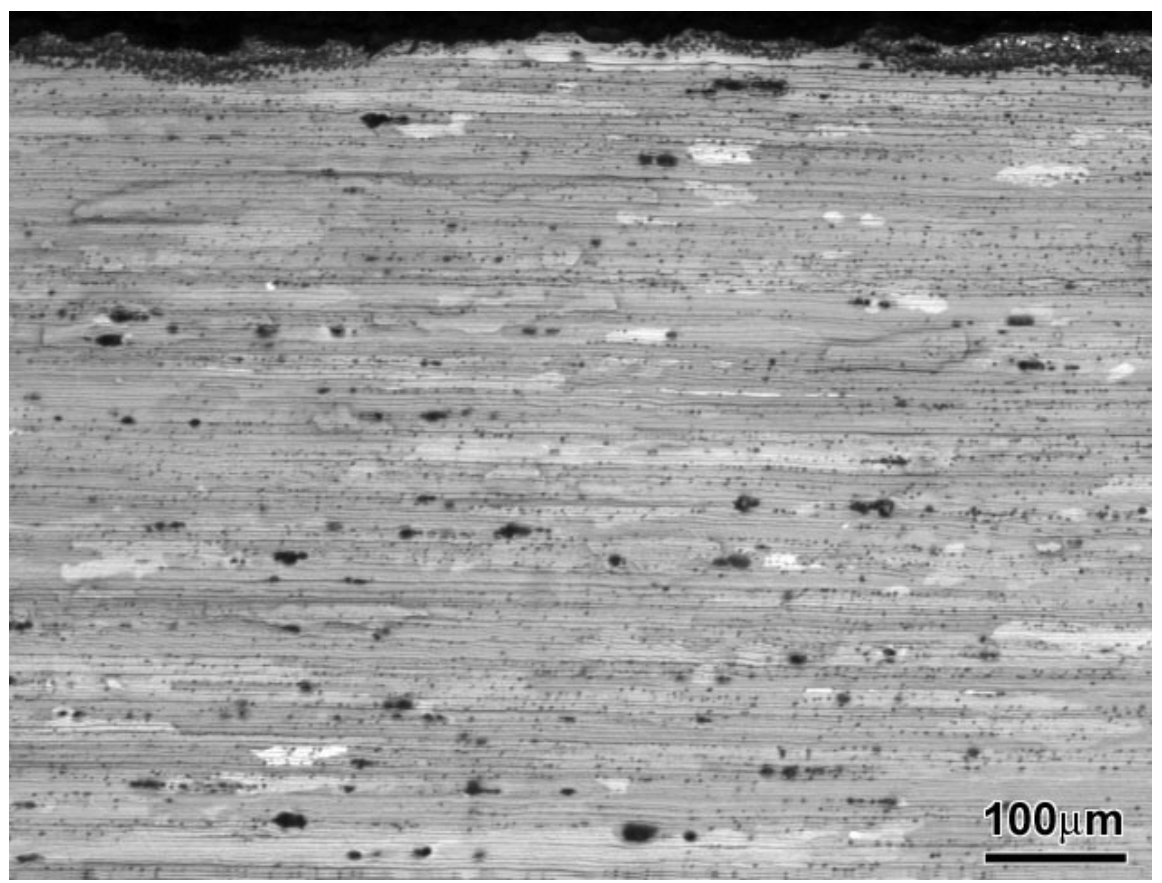

Figura 4.57: Microestrutura da amostra 357E (região jateada, 7475, laminada e tratada termicamente).

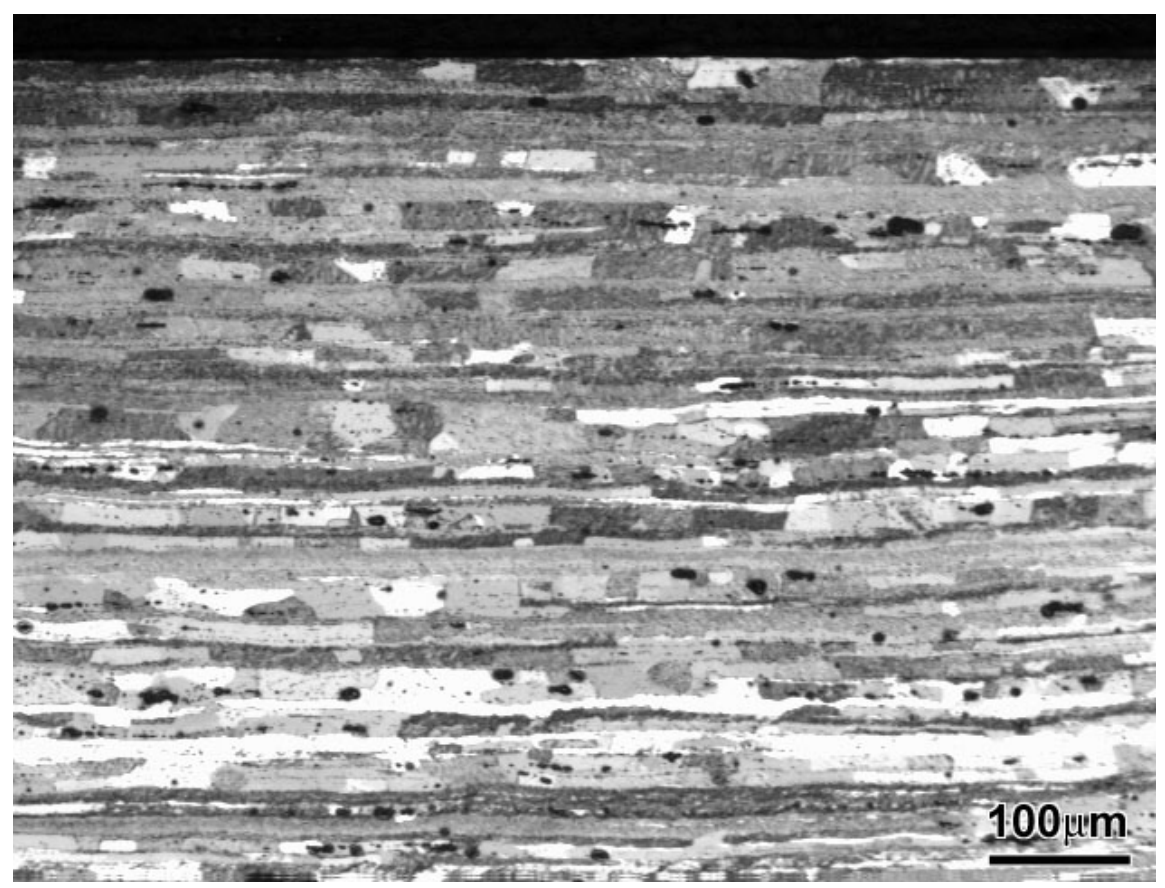

Figura 4.58: Microestrutura da amostra 369E (região jateada, 7050, laminada e tratada termicamente). 


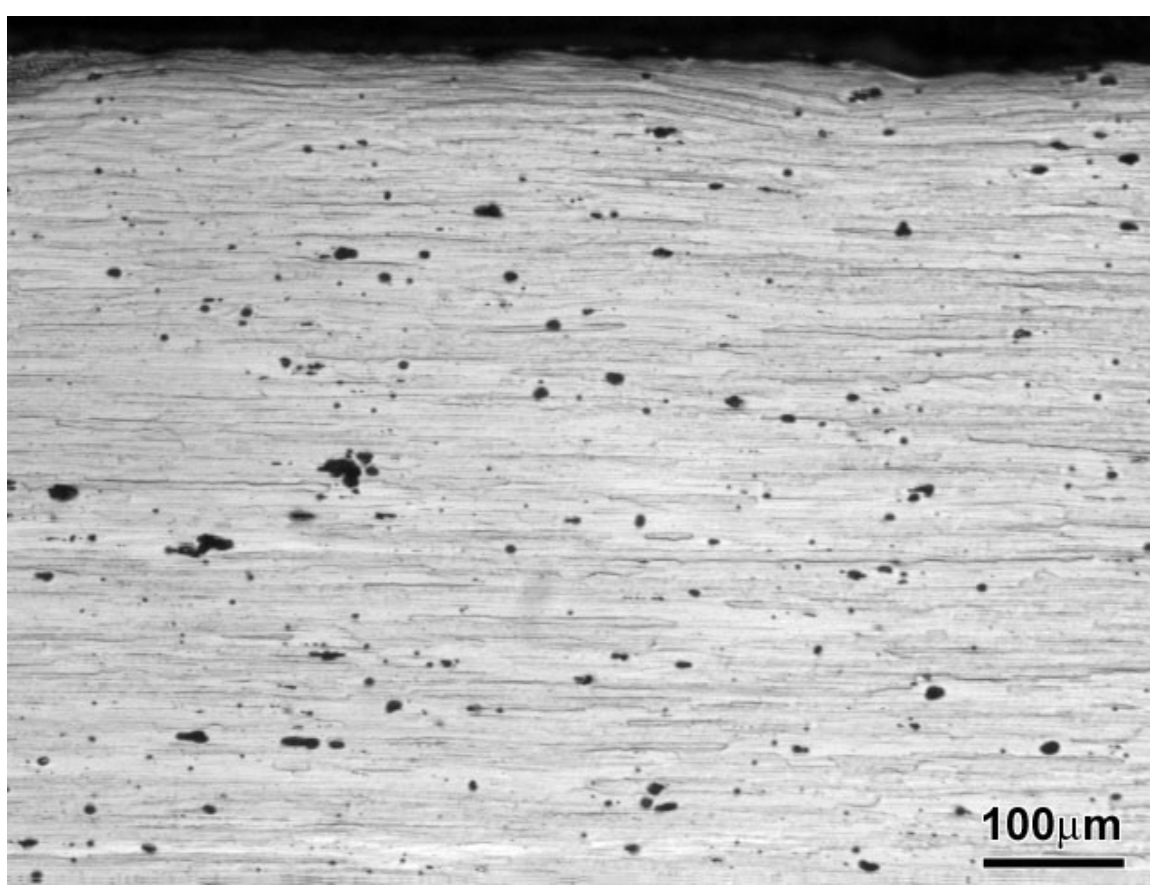

Figura 4.59: Microestrutura da amostra 357F (região jateada, 7475, apenas laminada).

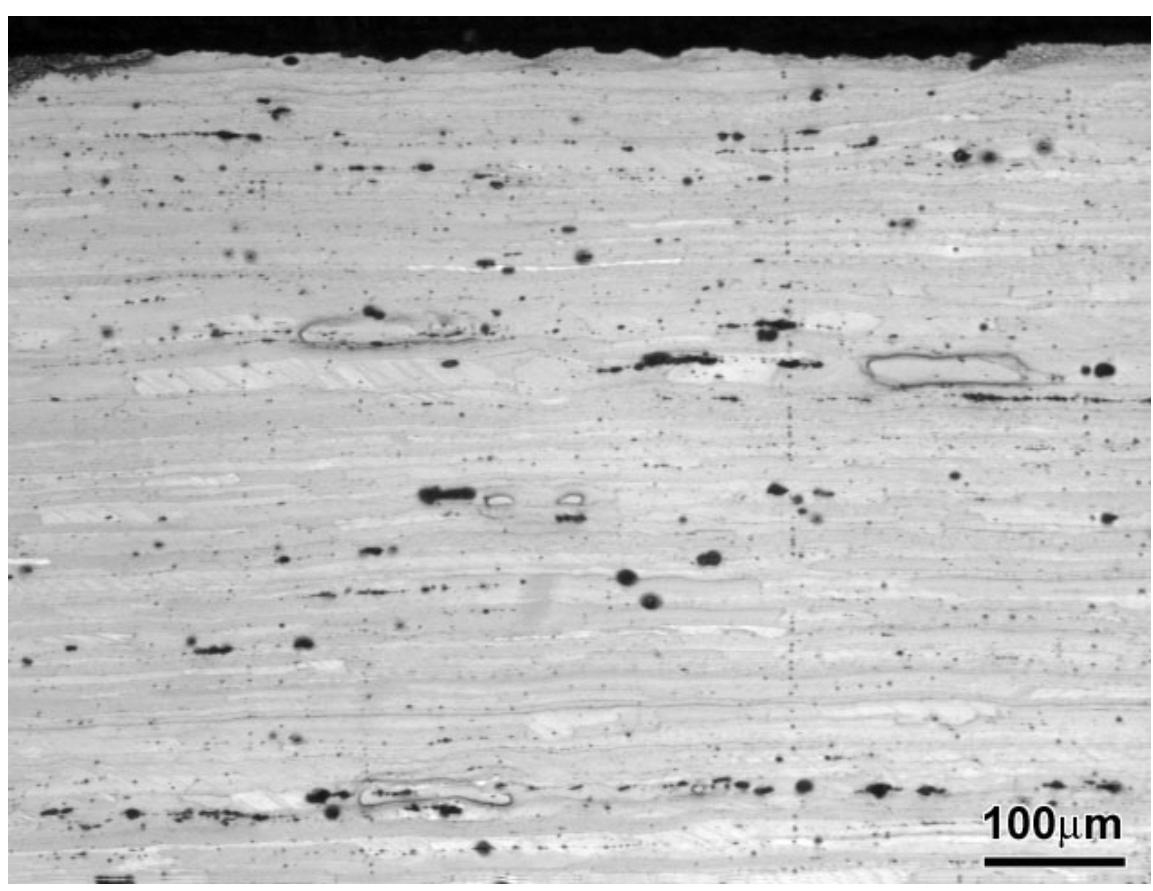

Figura 4.60: Microestrutura da amostra 369F (região jateada, 7050, apenas laminada). 


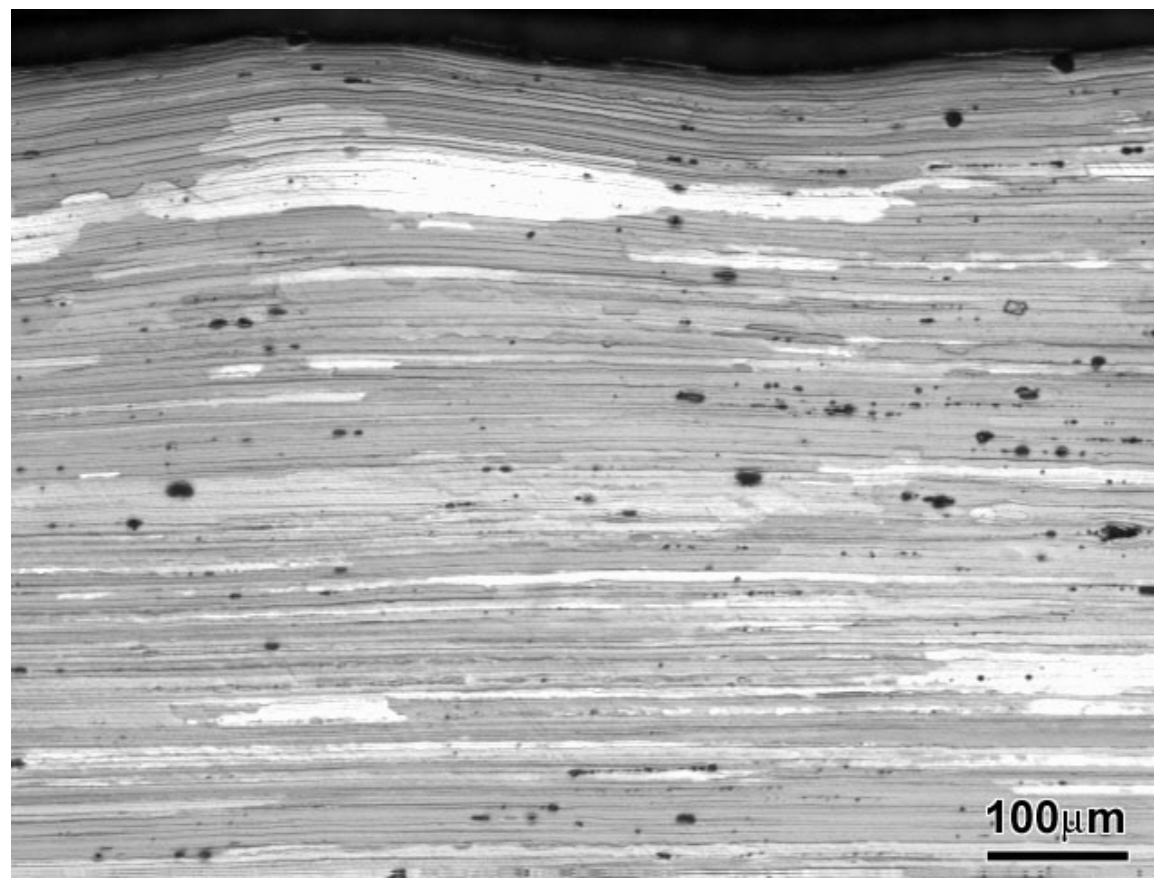

Figura 4.61: Microestrutura da amostra 357G (região jateada, 7475, apenas tratada termicamente).

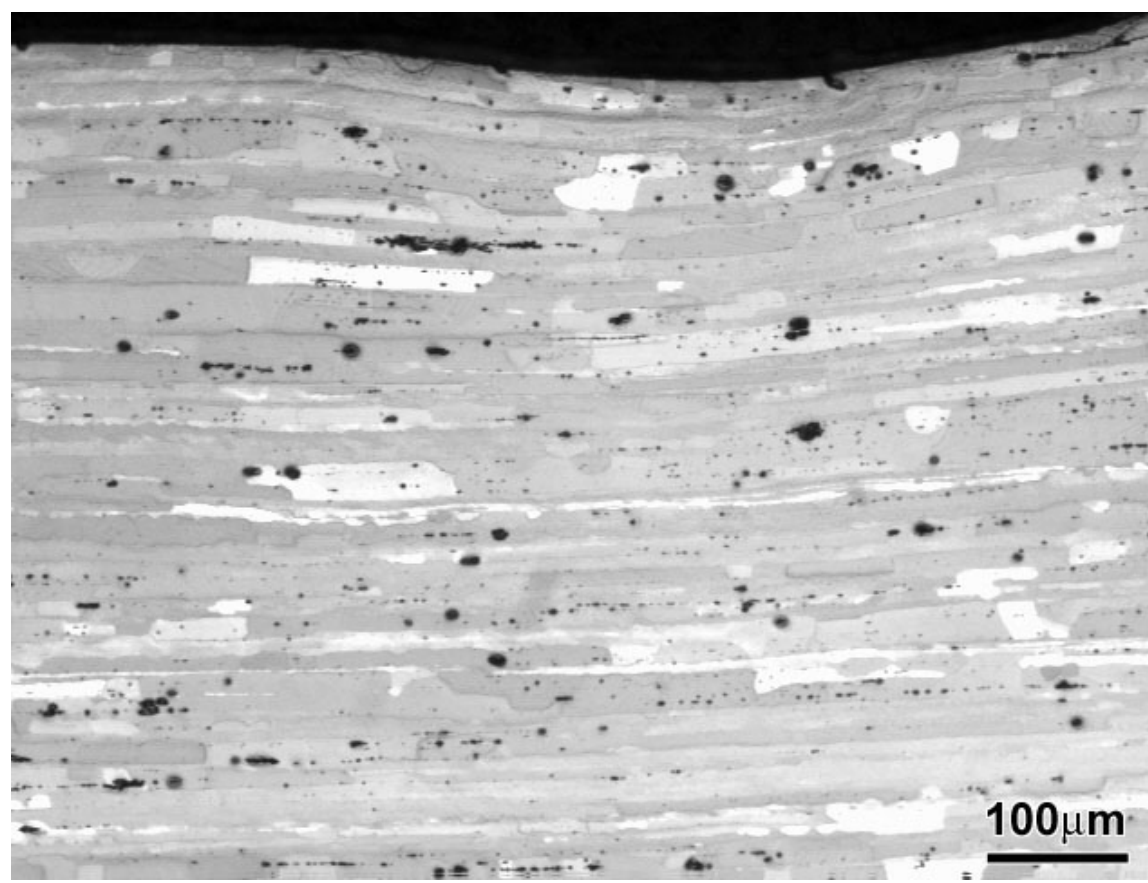

Figura 4.62: Microestrutura da amostra 369G (região jateada, 7050, apenas tratada termicamente). 


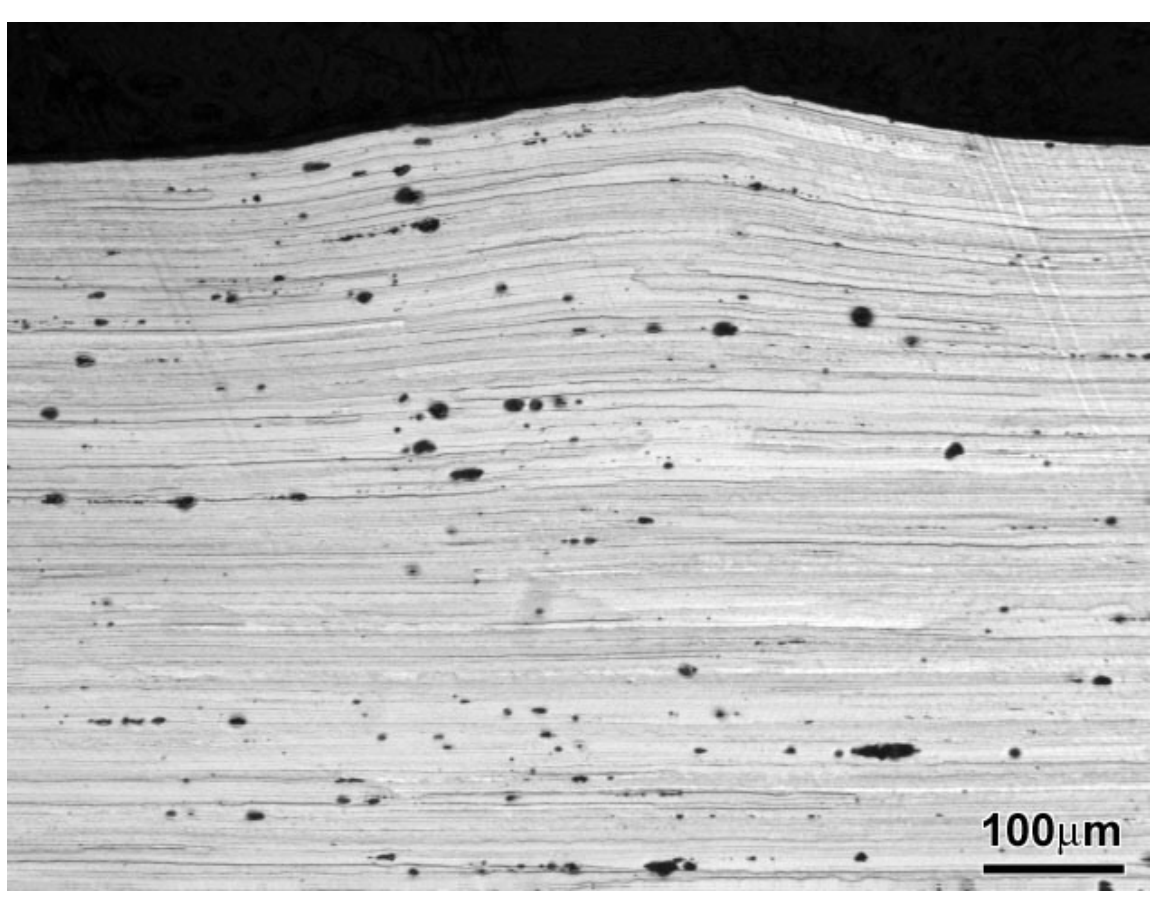

Figura 4.63: Microestrutura da amostra 357H (região jateada, 7475, não-transformada).

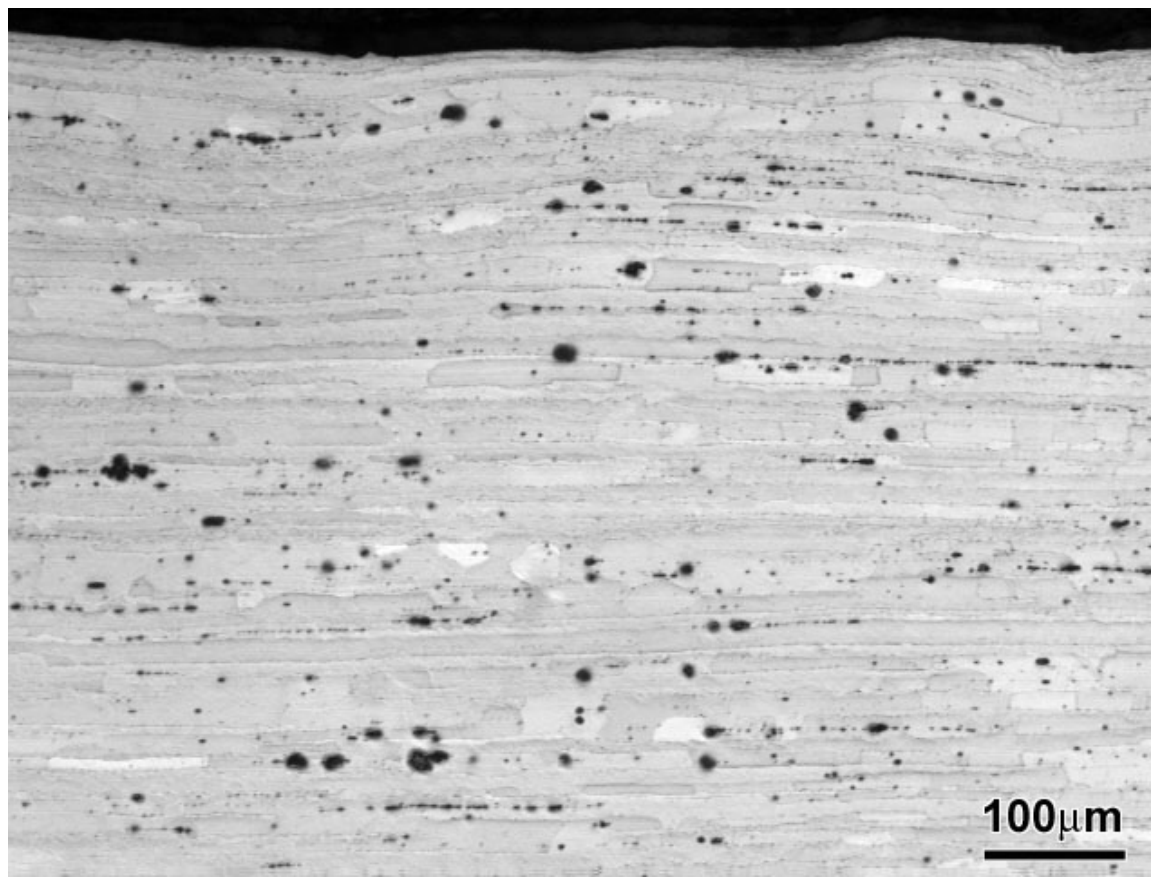

Figura 4.64: Microestrutura da amostra 369H (região jateada, 7050, não-transformada).

Pode-se observar que, em todas as amostras submetidas ao tratamento térmico a $500^{\circ} \mathrm{C}$ por 30 minutos, houve mudanças na estrutura de grãos. A liga 7475 manteve a estrutura de grãos alongados, enquanto a liga 7050 formou grãos mais arredondados. Não houve, entretanto, diferenciação na forma e tamanho dos grãos entre a superfície jateada e o centro da chapa. Nas amostras submetidas apenas ao tratamento térmico, sem laminação prévia, 
o tamanho dos grãos é maior, pois houve mais tempo para o crescimento de grão ${ }^{4}$.

As medidas de dureza são mostradas na Tabela 4.1. Novamente, não foi possível observar variação de dureza ao se comparar as amostras de controle com as amostras laminadas, recozidas e com as laminadas e recozidas, pois estão todos os valores dentro da mesma faixa (entre $149 \mathrm{HV}$ e $165 \mathrm{HV}$ para a liga 7475 e entre 152 HV e 183HV para a liga 7050).

Tabela 4.1: Medidas de dureza das amostras dos corpos de prova 357 e 369 submetidas ao ensaio de laminação e tratamento térmico.

\begin{tabular}{c|c||c|c}
\hline Amostra & Dureza (HV) & Amostra & Dureza (HV) \\
\hline 357A & $154 \pm 6$ & $369 \mathrm{~A}$ & $167 \pm 6$ \\
$357 \mathrm{~B}$ & $154 \pm 8$ & $369 \mathrm{~B}$ & $169 \pm 6$ \\
357C & $153 \pm 8$ & $369 \mathrm{C}$ & $159 \pm 4$ \\
357D & $156 \pm 7$ & 369D & $177 \pm 6$ \\
357E & $158 \pm 6$ & $369 \mathrm{E}$ & $155 \pm 3$ \\
357F & $152 \pm 3$ & $369 \mathrm{~F}$ & $170 \pm 8$ \\
$357 \mathrm{G}$ & $154 \pm 8$ & $369 \mathrm{G}$ & $161 \pm 10$ \\
$357 \mathrm{H}$ & $162 \pm 3$ & $369 \mathrm{H}$ & $169 \pm 11$ \\
\hline
\end{tabular}

Percebe-se, então, que a deformação causada pelos impactos do jato de granalhas sobre a superfície das chapas ensaiadas não causa o encruamento que antes se esperava observar. Como a fina camada de grãos deformados é responsável pelo encurvamento de toda a chapa, havia uma espectativa de encontrar grande encruamento, facilmente detectável. O que se pode dizer agora é que o encruamento da superfície é desprezível em relação à deformação prévia causada pela laminação das placas de onde as chapas foram usinadas, embora não haja diferença de durezas entre as amostras laminadas e as recozidas. Provavelmente, se o jateamento fosse realizado sobre amostras recozidas, a camada deformada seria melhor e mais facilmente caracterizada visualmente, mas as medições de dureza estão descartadas como método de caracterização dessas ligas.

\footnotetext{
${ }^{4}$ Lembrando que o recozimento dos metais pode ser dividido nas etapas: recuperação, recristalização e crescimento de grão. As duas primeiras ocorrem apenas em materiais encruados, com alta densidade de discordâncias. ${ }^{[72]}$
} 


\subsection{EBSD}

Entre os diferentes métodos de polimento mostrados na Seção 1.4.3, foram feitas diversas tentativas de obtenção de um mapa de EBSD. Apenas o polimento 1.d foi suficiente para conseguir um resultado razoável, ou seja, para gerar EBSPs nítidos e identificáveis na amostra toda. A grande deformação dos grãos laminados é um dos fatores que dificulta a identificação dos EBSPs e o mapeamento de grãos na região.

Foram obtidos mapas de EBSD das amostras 090, 206, 252 e 371 (conforme descritas na Seção 3.6). As Figuras 4.65 a 4.68 mostram (a) Mapas de orientação (IPF-Z) e (b) Mapas de qualidade de imagem (IQ).
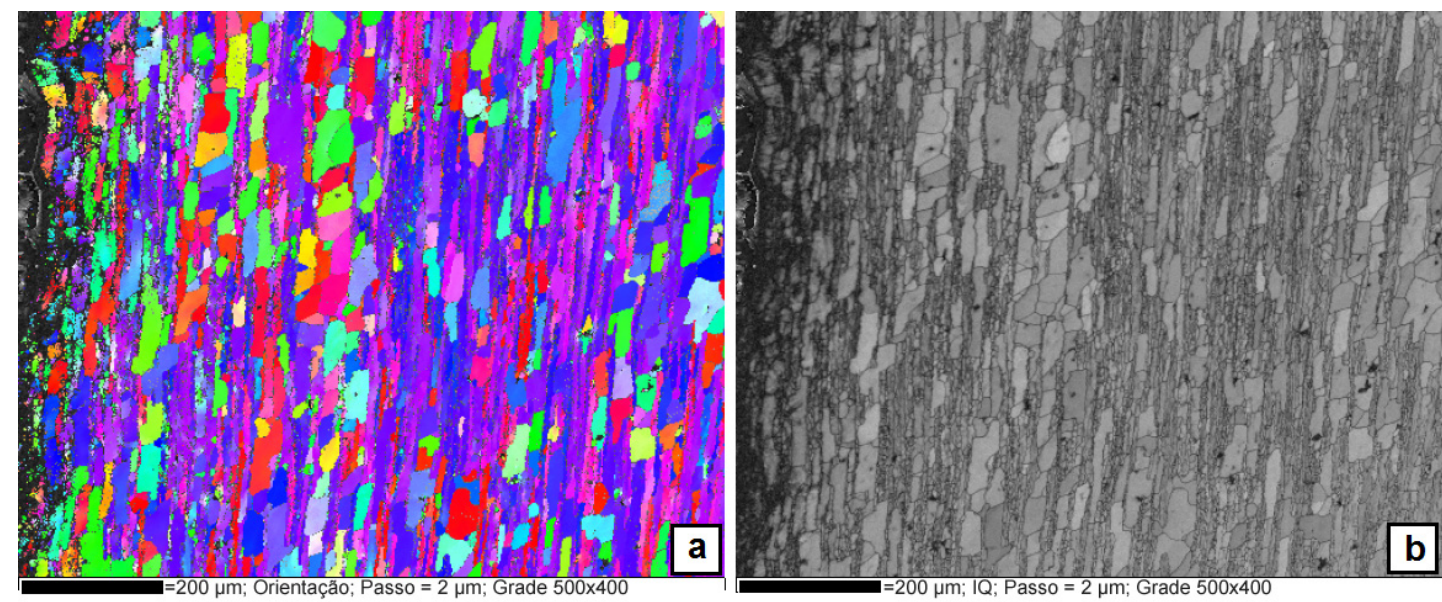

Figura 4.65: Mapa de EBSD obtido da amostra 090 (Liga 7050, espessura 5 $\mathrm{mm}$, granalha S230, velocidade média, sem pré-tensão, $200 \%$ cobertura), próximo à superfície jateada. (a) Mapa de orientação (IPF-Z); (b) Mapa de qualidade de imagem (IQ). 

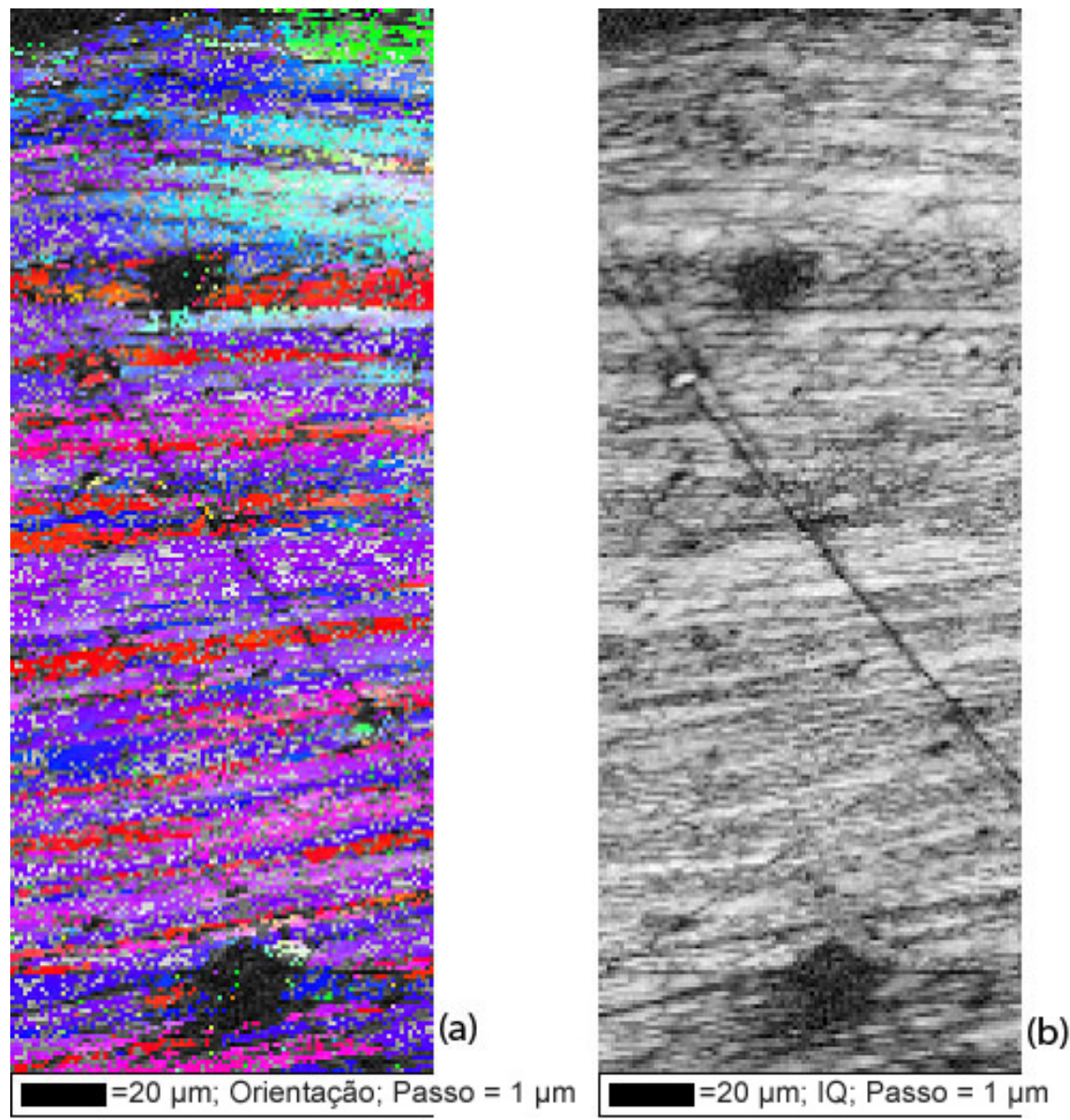

Figura 4.66: Mapa de EBSD obtido da amostra 206 (liga 7475, espessura 5 $\mathrm{mm}$, granalha $\mathrm{S550}$, velocidade alta, pré-tensionada, 200\% cobertura), próximo à superfície jateada. (a) Mapa de orientação (IPF-Z); (b) Mapa de qualidade de imagem (IQ).
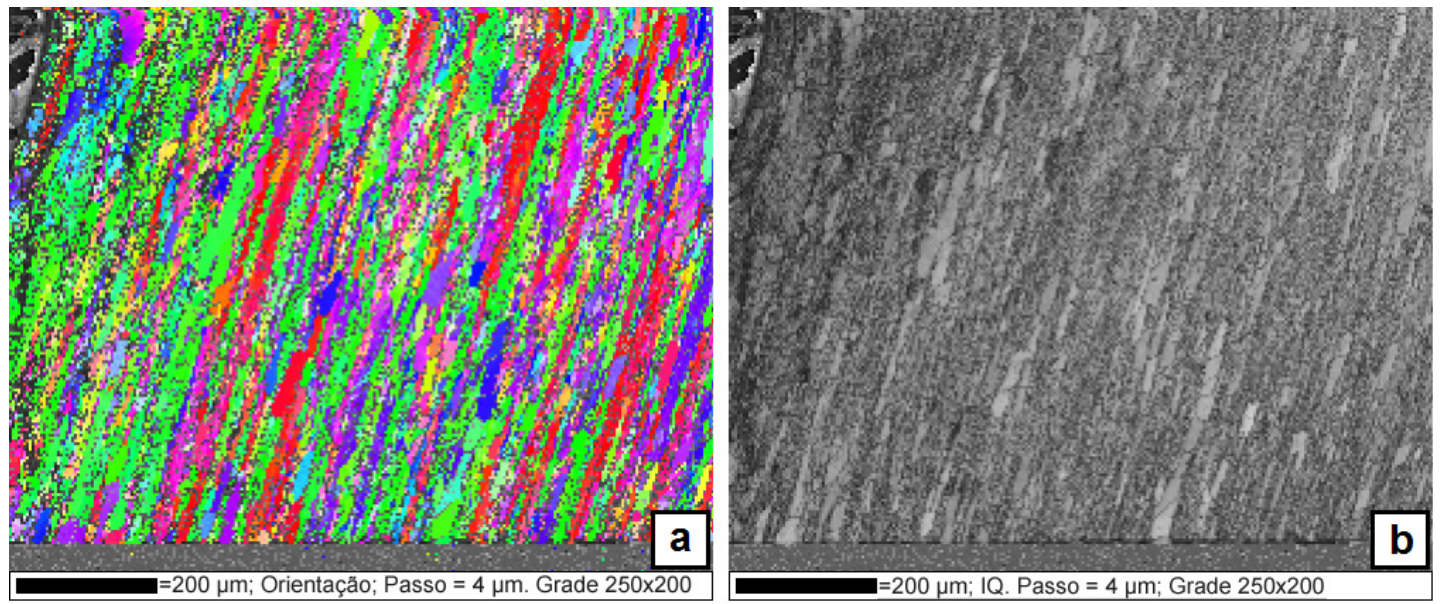

Figura 4.67: Mapa de EBSD obtido da amostra 252 (Liga 7050, espessura $10 \mathrm{~mm}$, granalha 5550 , velocidade alta, pré-tensionada, $200 \%$ cobertura), próximo à superfície jateada. (a) Mapa de orientação (IPF-Z); (b) Mapa de qualidade de imagem (IQ). 

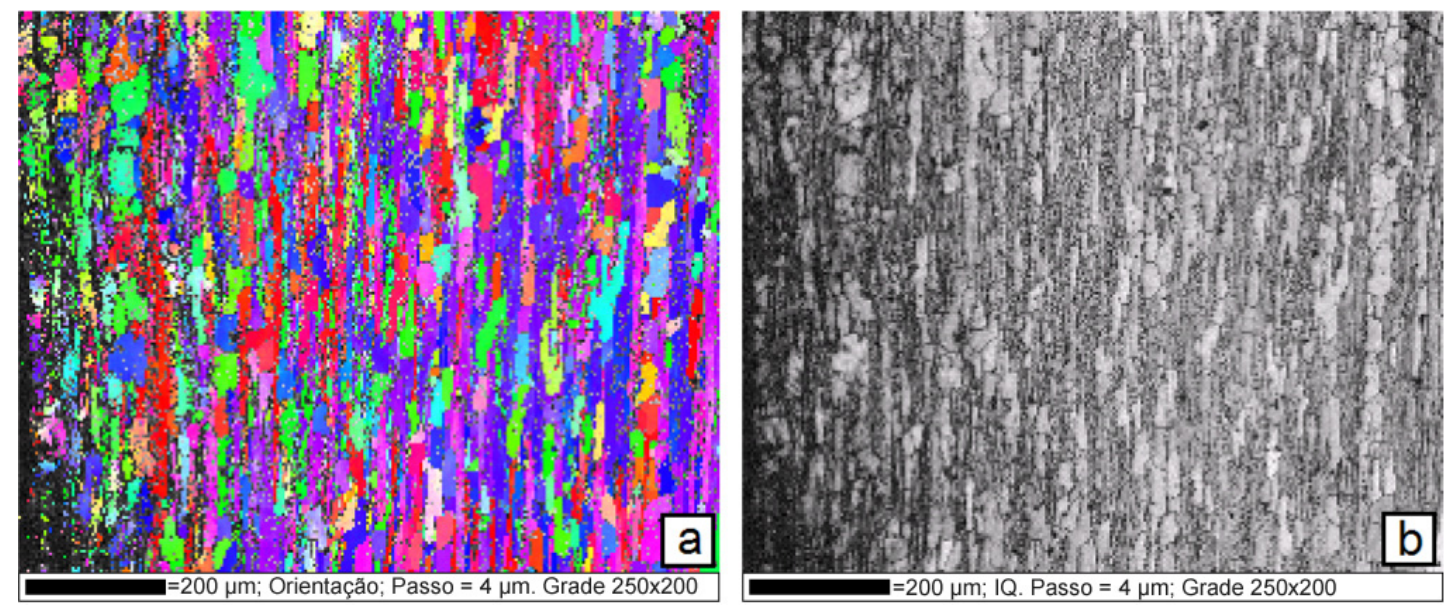

Figura 4.68: Mapa de EBSD obtido da amostra 371 (Liga 7050, espessura $10 \mathrm{~mm}$, granalha 1/8", velocidade média, sem pré-tensão, 200\% cobertura), próximo à superfície jateada. (a) Mapa de orientação (IPF-Z); (b) Mapa de qualidade de imagem (IQ).

Nas proximidades da superfície jateada, a IQ é menor e há menor número de pontos com identificação positiva do padrão do alumínio. No entanto, não é possível se distinguir uma camada em que o sinal seja nitidamente pior que no restante da amostra, como foi mostrada nas Figuras 1.12 e 1.13 (pág. 56). Logo, não foi possível utilizar a técnica de EBSD para caracterização da camada deformada plasticamente.

Esses resultados mostram apenas o quanto de know how é necessário para este tipo de análise, que não é feita com facilidade e depende tanto do corpo de prova, quanto da experiência do preparador da amostra e do operador do microscópio eletrônico. Diversos trabalhos são publicados mostrando análises de EBSD em alumínio ${ }^{[13,34]}$, provando que não é um método impossível, embora seja improdutivo devido ao grande tempo de obtenção de uma imagem.

Conclui-se que, para este material, o mapa de IQ obtido por EBSD não é o melhor método de análise a ser utilizado para a medição da camada deformada plasticamente. 


\subsection{Deformações}

As variações nos parâmetros de jateamento surtiram efeitos visíveis no encurvamento das chapas de alumínio. Todos os parâmetros (cobertura, diâmetro da granalha, pressão - velocidade de impacto -, pré-tensão, espessura e liga) foram influentes no grau de deformação.

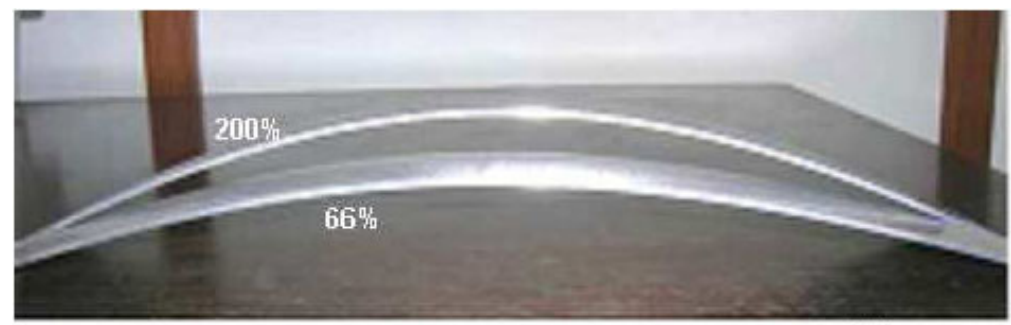

(a)

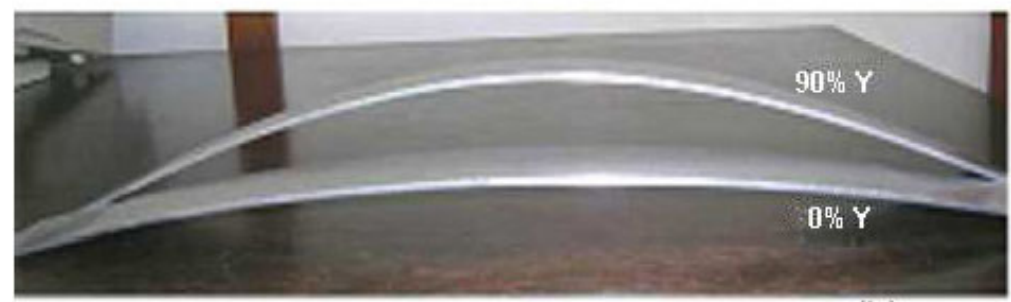

(b)

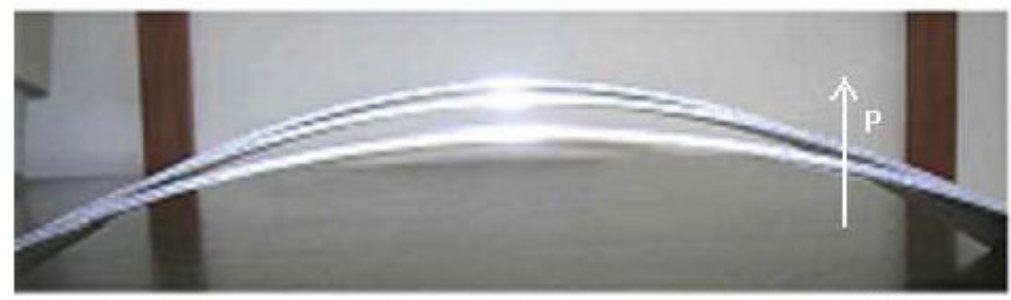

(c)

Figura 4.69: Efeitos das variáveis de jateamento no empenamento de corpos de prova da liga 7050, de espessura $2 \mathrm{~mm}$. (a) Diferentes coberturas $(66 \% \mathrm{e}$ $200 \%$ ); (b) Diferentes pré-tensionamentos (0 e $90 \%$ do limite de escoamento); (c) Diferentes pressões (20, 40 e 60 psi).

Uma análise visual pode dar noção do grau de influência de alguns parâmetros, como mostra a Figura 4.69. Os corpos de prova reunidos em cada fotografia têm todos os demais parâmetros mantidos iguais, exceto o que se deseja observar. Nota-se que a aplicação de pré-tensão gera maior encurvamento do que o aumento da pressão do jato e da cobertura.

\subsubsection{Mudanças de parâmetros}

Outra forma de apresentar as variáveis de processo é através da velocidade média das esferas e da sua energia cinética, que está diretamente ligada ao 
encurvamento final da chapa jateada, conforme foi dito anteriormente (Seção 1.3.3, página 51) e será comprovado neste trabalho.

As velocidades das esferas correspondentes às pressões do jato e aos tamanhos de esferas foram medidas experimentalmente pelo $\mathrm{IPT}^{[34]}$ através de um dispositivo eletromecânico criado por Clausen e Stangenberg ${ }^{[73]}$ para medição de velocidade média de granalhas baseado no Método dos Dois Discos (Figura 4.70) e são mostradas na Tabela 4.2.
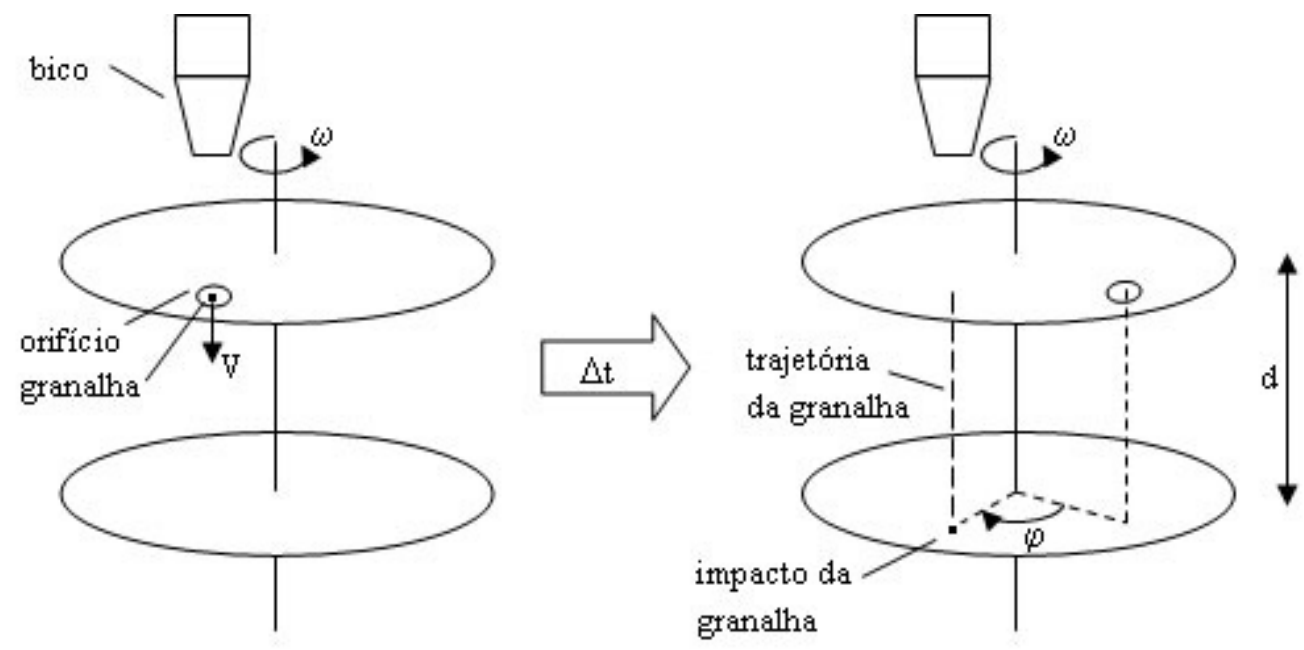

Figura 4.70: Esquema do dispositivo de medição de velocidade de impactos utilizado pelo IPT. ${ }^{[34]}$

Sendo conhecidas a distância $d$ entre os discos, sua velocidade de rotação $\omega$ e a defasagem angular $\varphi$, a velocidade média das granalhas é dada por $\vee=\frac{d \cdot \omega}{\varphi}$.

Tabela 4.2: Correspondência entre valores de pressão do jato de esferas dos três tamanhos e a velocidade das esferas. Medidas experimentais ${ }^{[34]}$.

\begin{tabular}{ccc}
\hline Esfera & Pressão (psi) & Velocidade $(\mathrm{m} / \mathrm{s})$ \\
\hline \multirow{3}{*}{ S230 } & 20 & 50,2 \\
& 40 & 61,2 \\
& 60 & 72,2 \\
\hline \multirow{3}{*}{ S550 } & 10 & 16,2 \\
& 20 & 22,4 \\
& 30 & 28,6 \\
\hline \multirow{3}{*}{ 1/8” } & 10 & 12,5 \\
& 20 & 16,9 \\
& 25 & 18,5 \\
\hline
\end{tabular}

Há na literatura trabalhos que se utilizam do valor da energia cinética das granalhas como variável importante ou principal na avaliação da deformação 
plástica superficial gerada pelo jateamento. ${ }^{[22,30,33,35]}$

A energia cinética $\left(E_{C}\right)$ é calculada pela Equação 4.1:

$$
\begin{aligned}
E_{C} & =\frac{1}{2} \cdot m \cdot v^{2} \\
& =\frac{1}{2} \cdot\left(\rho \cdot V_{e s f}\right) \cdot v^{2} \\
& =\frac{1}{2} \cdot\left[\rho \cdot \frac{4}{3} \cdot \pi\left(\frac{D_{e s f}}{2}\right)^{3}\right] \cdot v^{2} \\
& =\frac{\pi}{12} \cdot D_{e s f}{ }^{3} \cdot \rho \cdot v^{2}
\end{aligned}
$$

onde $m$ é massa da granalha $(\mathrm{g})$ de volume $V_{e s f}$, $\mathrm{D}_{e s f}$ é o diâmetro nominal da esfera $(\mathrm{mm}), \rho$ é a densidade típica dos aços-carbono $\left(7,86 \mathrm{~g} / \mathrm{cm}^{3}\right)$ e $v$ é a velocidade com que a esfera atinge a chapa $(\mathrm{m} / \mathrm{s})$.

Dessa forma, pode-se completar os dados da Tabela 4.2 com os valores calculados pela Equação 4.1 na Tabela 4.3.

Tabela 4.3: Valores calculados da energia cinética de 1 esfera.

\begin{tabular}{ccccc}
\hline Esfera & $\mathrm{D}_{\text {esf }}(\mathrm{mm})$ & $\mathrm{P}(\mathrm{psi})$ & $v(\mathrm{~m} / \mathrm{s})$ & $\mathrm{E}_{C}(\mathrm{~mJ})$ \\
\hline \multirow{3}{*}{ S230 } & \multirow{2}{*}{0,584} & 20 & 50,2 & 1,0 \\
& & 40 & 61,2 & 1,5 \\
& & 60 & 72,2 & 2,1 \\
\hline \multirow{2}{*}{ S550 } & \multirow{2}{*}{1,397} & 10 & 16,2 & 1,5 \\
& & 20 & 22,4 & 2,8 \\
& & 30 & 28,6 & 4,6 \\
\multirow{2}{*}{ 1/8” } & \multirow{2}{*}{3,175} & 20 & 12,5 & 10,3 \\
& & 25 & 16,9 & 18,8 \\
& & & 10,5 & 22,5 \\
\hline
\end{tabular}




\subsection{Medição de curvatura}

O valor que se tomou como resultado da curvatura foi o raio de curvatura da parábola de ajuste dos pontos de medições de coordenadas feitos nos 20 centímetros centrais da chapa. Esse valor foi calculado pelo método apresentado na Seção 3.3.

O Anexo $\mathrm{C}$ contém as tabelas de parâmetros de processo e valores de raio de curvatura medidos de todos os corpos de prova ensaiados.

\subsubsection{Efeitos dos parâmetros}

O efeito de cada parâmetro relativo ao processo (diâmetro da esfera, pressão, cobertura e pré-tensão) ou ao corpo de prova (liga de alumínio e espessura) deve ser analisado independentemente, com os demais parâmetros fixos.

A seguir, são mostrados os gráficos dos efeitos da cobertura (C), diâmetro da esfera $(D)^{5}$, velocidade de impacto e espessura $(H)$. As chapas com prétensão e sem pré-tensão (livres) são analisadas separadamente, em todos os gráficos.

Estes gráficos serão apresentados para fins de documentação e para futuras consultas sobre o efeito separado de cada parâmetro referente aos corpos de prova e ao processo de jateamento. Entretanto, para uma leitura mais leve do capítulo, sugere-se seguir direto para o item 4.5.2, pág. 172 e então para a pág. 187.

A Tabela 4.4 relaciona os gráficos que apresentam as comparações citadas anteriormente.

Tabela 4.4: Números das figuras com resultados de efeitos dos parâmetros sobre o raio de curvatura.

\begin{tabular}{c|c|c|c|c|c|c}
\hline Figura & Parâmetro & Liga & $H(\mathrm{~mm})$ & $\mathrm{D}_{\text {medio }}(\mathrm{mm})$ & Pressão & $\mathrm{C}$ \\
\hline 4.71 & Cobertura & 7050 & 2 & 0,58 & var & var \\
\hline 4.72 & Cobertura & 7475 & 2 & 0,58 & var & var \\
\hline 4.73 & Cobertura & 7050 & 5 & 0,58 & var & var \\
\hline 4.74 & Cobertura & 7475 & 5 & 0,58 & var & var \\
\hline \multicolumn{7}{l}{ Continua na próxima página. } \\
\hline
\end{tabular}

\footnotetext{
${ }^{5} \mathrm{O}$ efeito do diâmetro da esfera é aplicável apenas às chapas de $5 \mathrm{~mm}$ e $10 \mathrm{~mm}$, que foram jateadas com duas esferas diferentes.
} 
Tabela 4.4 - Continuação da página anterior.

\begin{tabular}{|c|c|c|c|c|c|c|}
\hline Figura & Parâmetro & Liga & $\mathrm{H}(\mathrm{mm})$ & $\mathrm{D}_{\text {medio }}(\mathrm{mm})$ & Pressão & C \\
\hline 4.75 & Cobertura & 7050 & 5 & 1,40 & var & var \\
\hline 4.76 & Cobertura & 7475 & 5 & 1,40 & var & var \\
\hline 4.77 & Cobertura & 7050 & 10 & 1,40 & var & var \\
\hline 4.78 & Cobertura & 7475 & 10 & 1,40 & var & var \\
\hline 4.79 & Cobertura & 7050 & 10 & 3,18 & var & var \\
\hline 4.80 & Cobertura & 7475 & 10 & 3,18 & var & var \\
\hline 4.81 & Cobertura & 7050 & 15 & 3,18 & var & var \\
\hline 4.82 & Cobertura & 7475 & 15 & 3,18 & var & var \\
\hline 4.83 & Esfera & 7050 & 5 & var & var & baixa \\
\hline 4.84 & Esfera & 7050 & 10 & var & var & média \\
\hline 4.85 & Esfera & 7475 & 5 & var & var & alta \\
\hline 4.86 & Esfera & 7475 & 10 & var & var & baixa \\
\hline 4.87 & Esfera & 7050 & 5 & var & var & alta \\
\hline 4.88 & Esfera & 7050 & 10 & var & var & baixa \\
\hline 4.89 & Esfera & 7475 & 5 & var & var & média \\
\hline 4.90 & Esfera & 7475 & 10 & var & var & alta \\
\hline 4.91 & Esfera & 7050 & 5 & var & baixa & var \\
\hline 4.92 & Esfera & 7050 & 5 & var & média & var \\
\hline 4.93 & Esfera & 7050 & 5 & var & alta & var \\
\hline 4.94 & Esfera & 7475 & 5 & var & baixa & var \\
\hline 4.95 & Esfera & 7475 & 5 & var & média & var \\
\hline 4.96 & Esfera & 7475 & 5 & var & alta & var \\
\hline 4.97 & Esfera & 7050 & 10 & var & baixa & var \\
\hline 4.98 & Esfera & 7050 & 10 & var & média & var \\
\hline 4.99 & Esfera & 7050 & 10 & var & alta & var \\
\hline 4.100 & Esfera & 7475 & 10 & var & baixa & var \\
\hline 4.101 & Esfera & 7475 & 10 & var & média & var \\
\hline 4.102 & Esfera & 7475 & 10 & var & alta & var \\
\hline 4.103 & Velocidade & 7050 & 2 & 0,58 & var & var \\
\hline 4.104 & Velocidade & 7050 & 5 & 0,58 & var & var \\
\hline 4.105 & Velocidade & 7050 & 5 & 1,40 & var & var \\
\hline 4.106 & Velocidade & 7050 & 10 & 1,40 & var & var \\
\hline 4.107 & Velocidade & 7050 & 10 & 3,18 & var & var \\
\hline 4.108 & Velocidade & 7050 & 15 & 3,18 & var & var \\
\hline 4.109 & Velocidade & 7475 & 2 & 0,58 & var & var \\
\hline 4.110 & Velocidade & 7475 & 5 & 0,58 & var & var \\
\hline 4.111 & Velocidade & 7475 & 5 & 1,40 & var & var \\
\hline 4.112 & Velocidade & 7475 & 10 & 1,40 & var & var \\
\hline
\end{tabular}


Tabela 4.4 - Concluído da página anterior.

\begin{tabular}{c|c|c|c|c|c|c}
\hline Figura & Parâmetro & Liga & $\mathrm{H}(\mathrm{mm})$ & $\mathrm{D}_{\text {medio }}(\mathrm{mm})$ & Pressão & $\mathrm{C}$ \\
\hline \hline 4.113 & Velocidade & 7475 & 10 & 3,18 & var & var \\
\hline 4.114 & Velocidade & 7475 & 15 & 3,18 & var & var \\
\hline 4.115 & Espessura & 7050 & var & 0,58 & var & baixa \\
\hline 4.116 & Espessura & 7050 & var & 1,40 & var & média \\
\hline 4.117 & Espessura & 7050 & var & 3,18 & var & alta \\
\hline 4.118 & Espessura & 7050 & var & 0,58 & var & alta \\
\hline 4.119 & Espessura & 7050 & var & 1,40 & var & baixa \\
\hline 4.120 & Espessura & 7050 & var & 3,18 & var & média \\
\hline 4.121 & Espessura & 7475 & var & 0,58 & var & baixa \\
\hline 4.122 & Espessura & 7475 & var & 1,40 & var & média \\
\hline 4.123 & Espessura & 7475 & var & 3,18 & var & alta \\
\hline 4.124 & Espessura & 7475 & var & 0,58 & var & alta \\
\hline 4.125 & Espessura & 7475 & var & 1,40 & var & baixa \\
\hline 4.126 & Espessura & 7475 & var & 3,18 & var & média \\
\hline
\end{tabular}

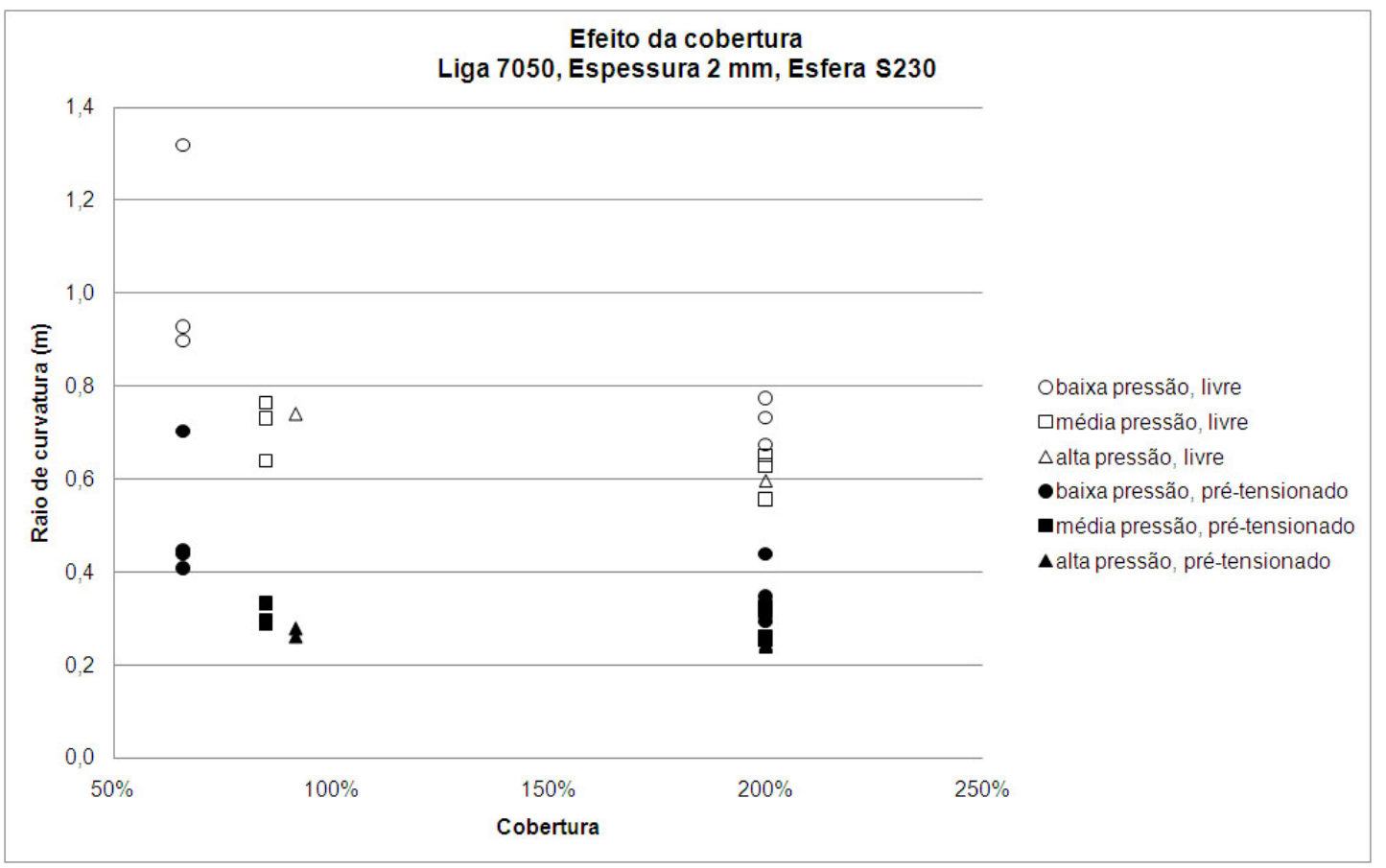

Figura 4.71: Efeito da cobertura sobre o raio de curvatura. Chapas da liga 7050, espessura $2 \mathrm{~mm}$, jateadas com esfera S230. 


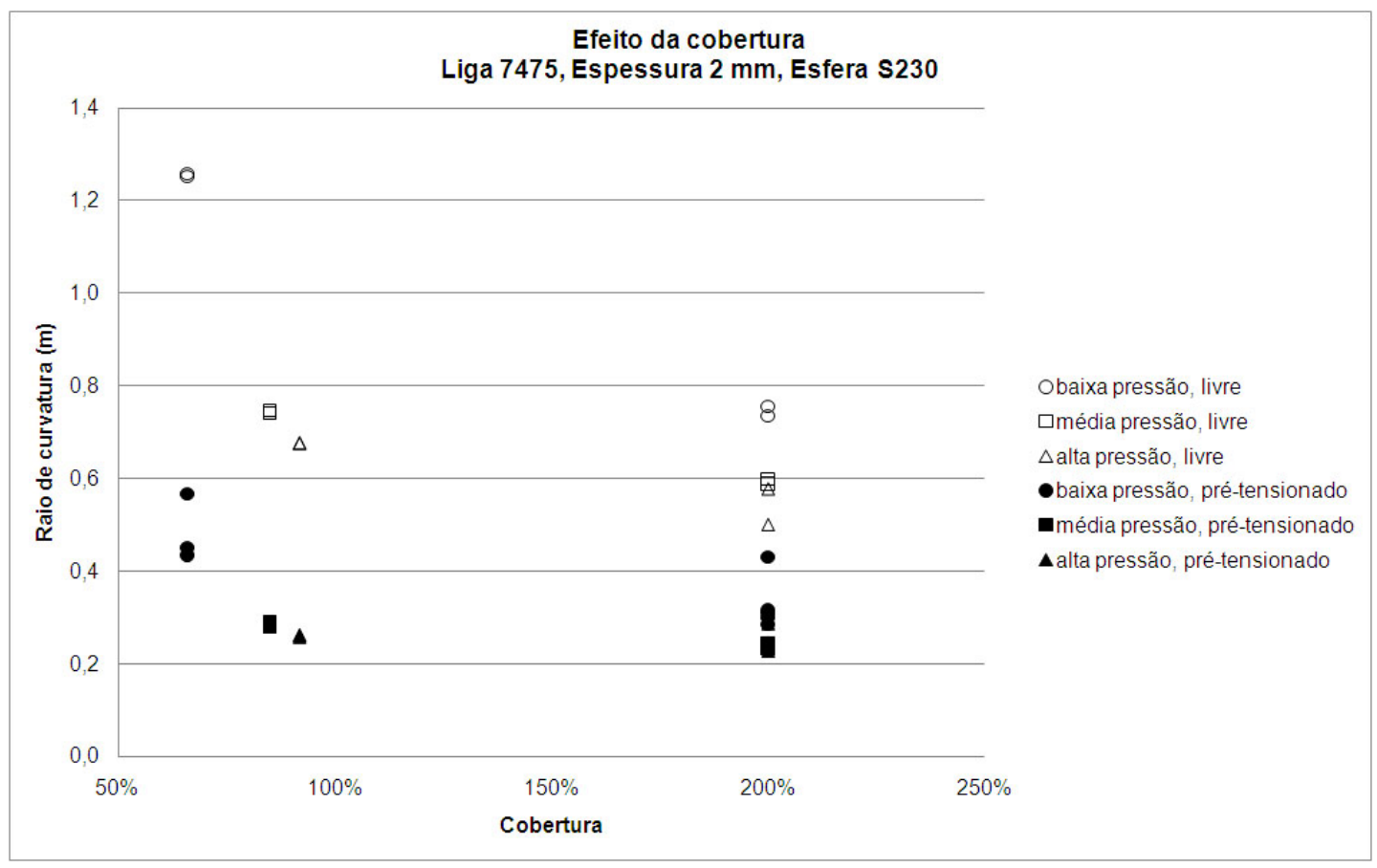

Figura 4.72: Efeito da cobertura sobre o raio de curvatura. Chapas da liga 7475 , espessura $2 \mathrm{~mm}$, jateadas com esfera S230.

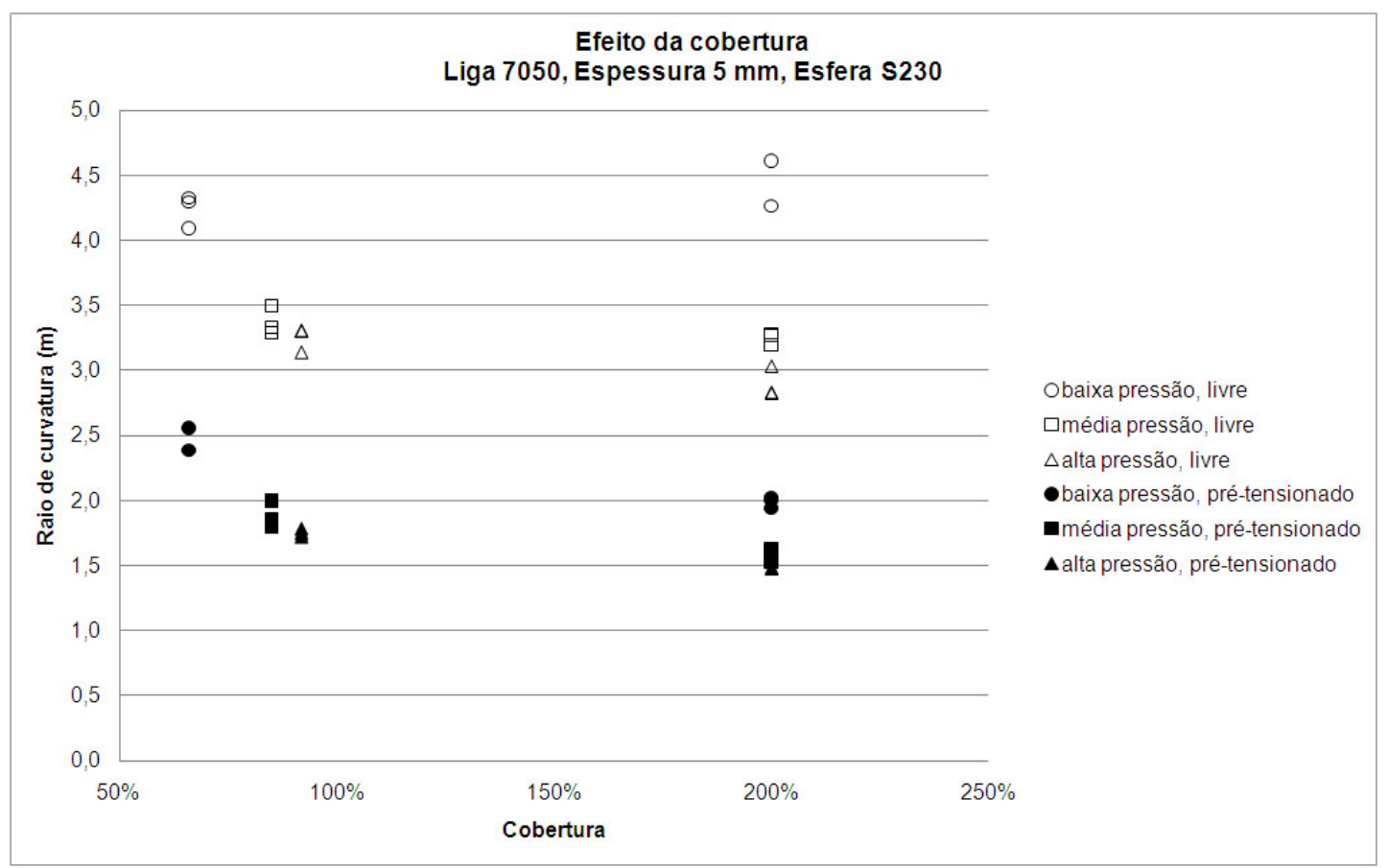

Figura 4.73: Efeito da cobertura sobre o raio de curvatura. Chapas da liga 7050 , espessura $5 \mathrm{~mm}$, jateadas com esfera S230. 


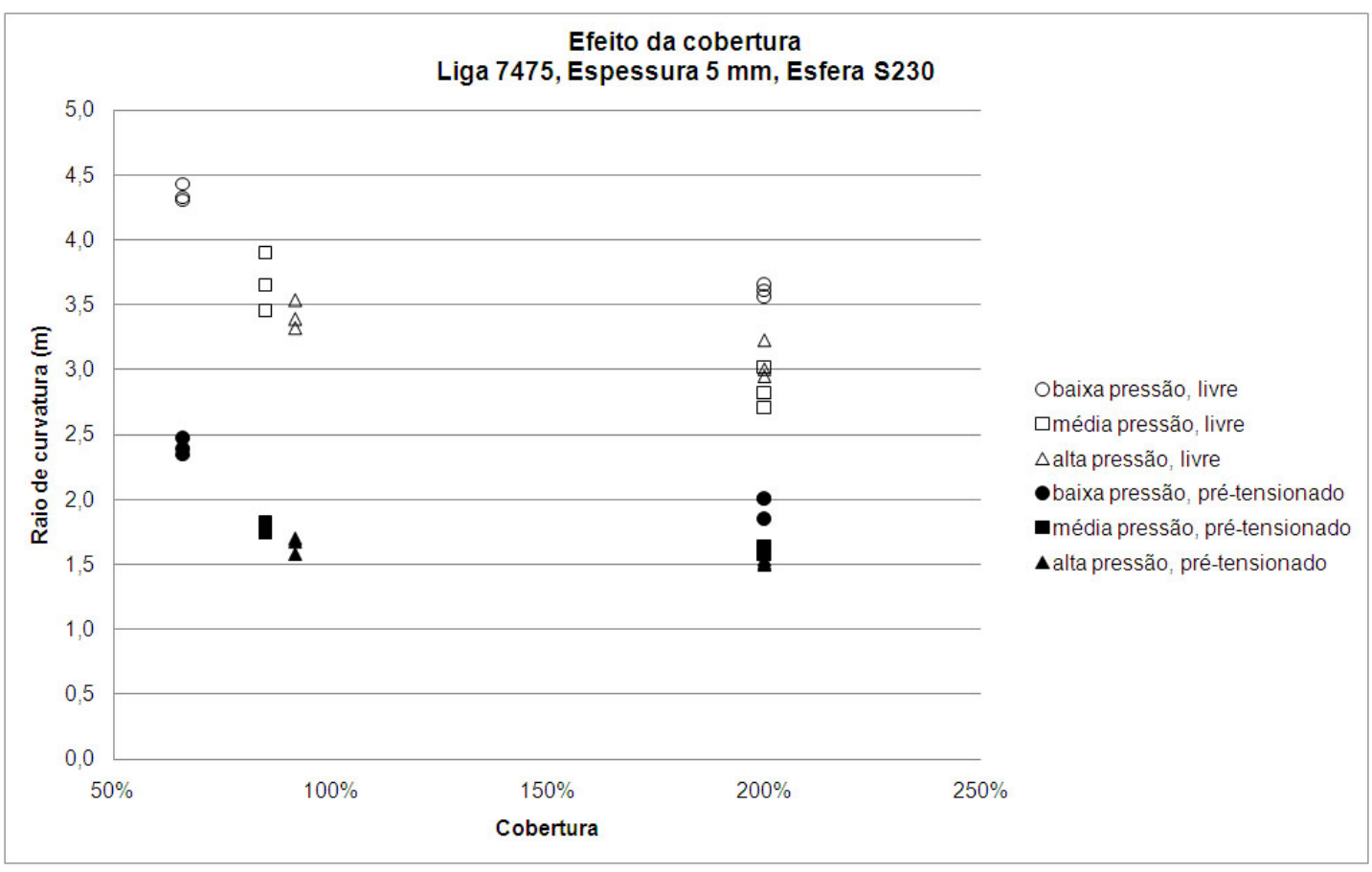

Figura 4.74: Efeito da cobertura sobre o raio de curvatura. Chapas da liga 7475 , espessura $5 \mathrm{~mm}$, jateadas com esfera $\$ 230$.

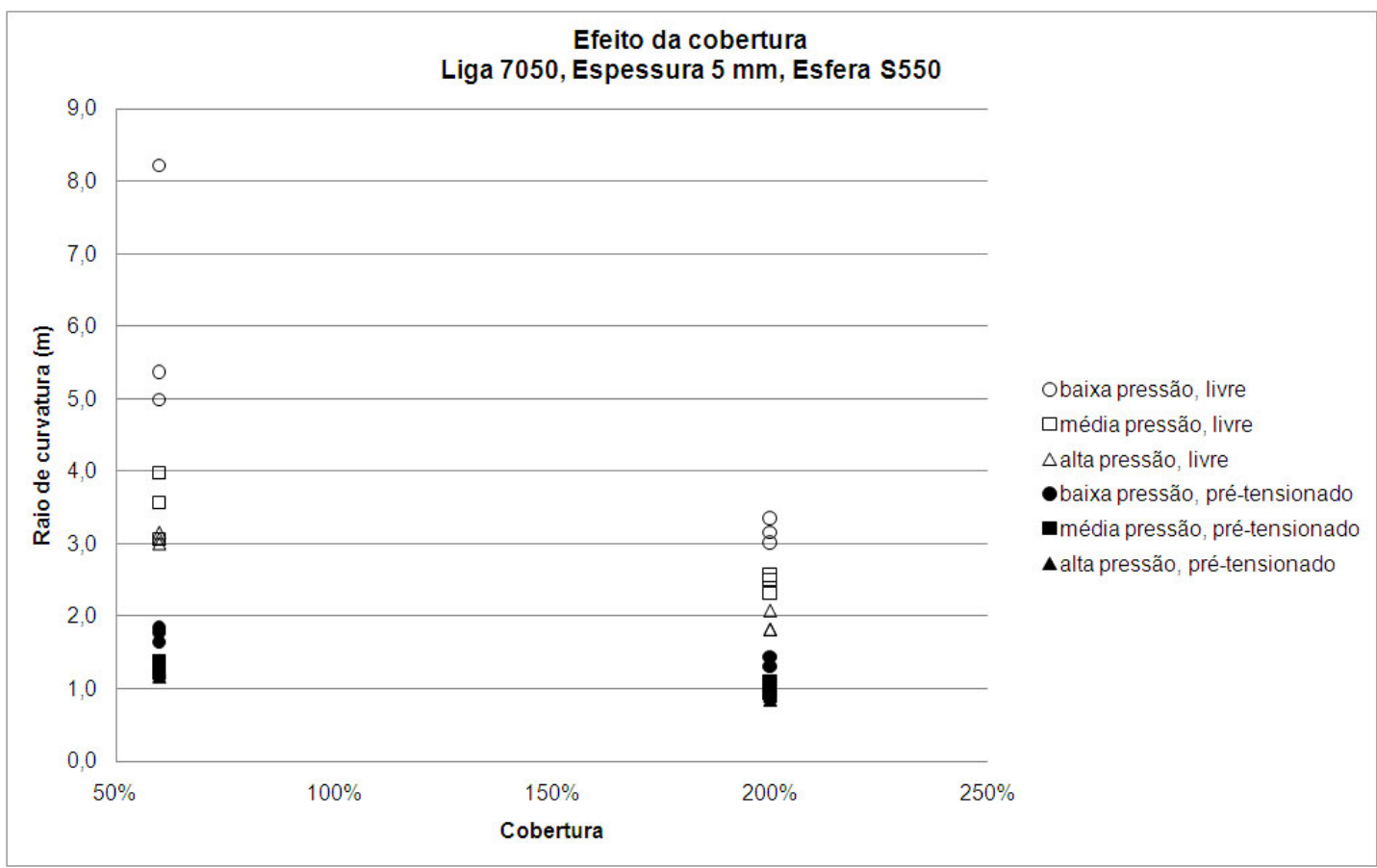

Figura 4.75: Efeito da cobertura sobre o raio de curvatura. Chapas da liga 7050 , espessura $5 \mathrm{~mm}$, jateadas com esfera S550. 


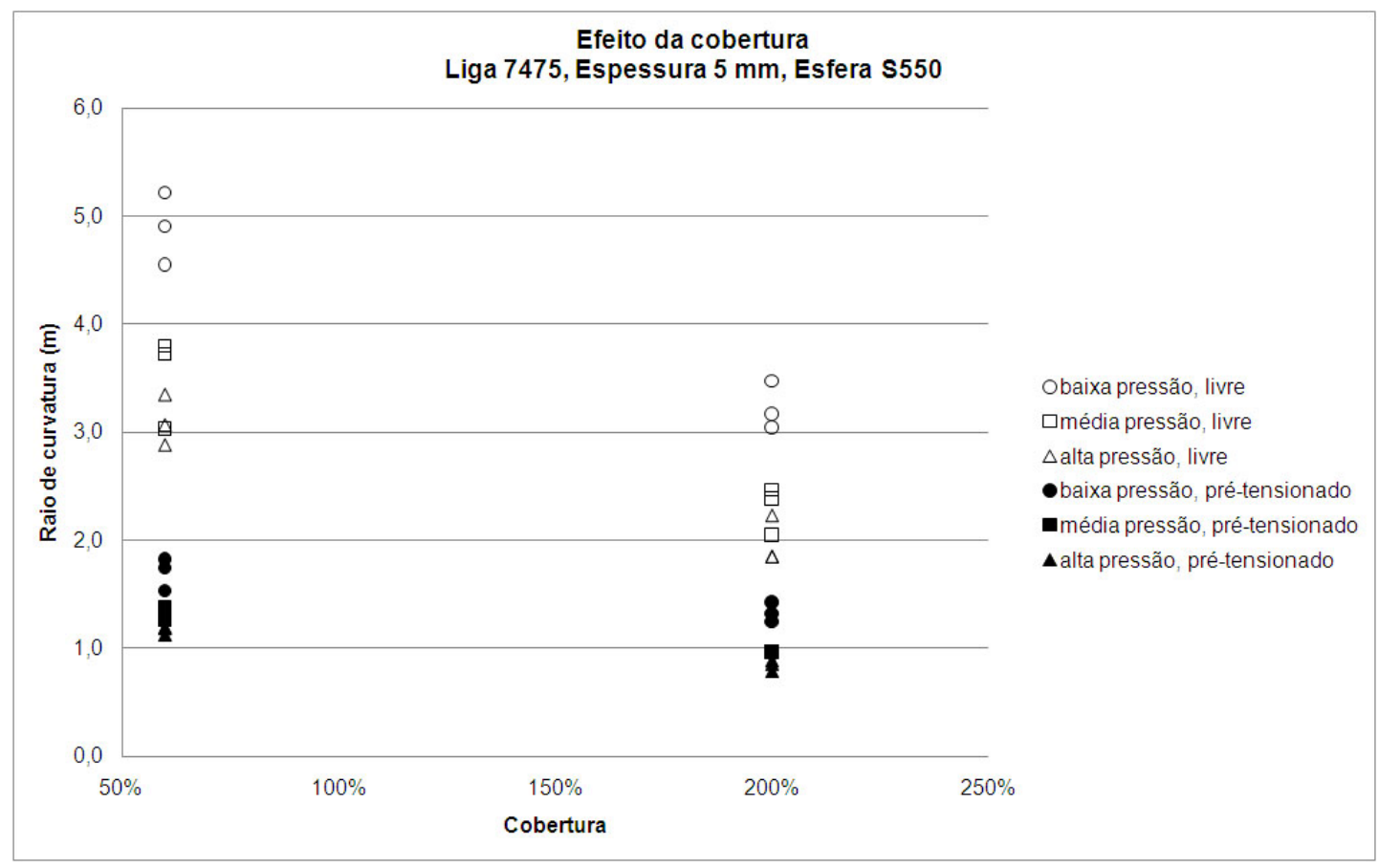

Figura 4.76: Efeito da cobertura sobre o raio de curvatura. Chapas da liga 7475 , espessura $5 \mathrm{~mm}$, jateadas com esfera S550.

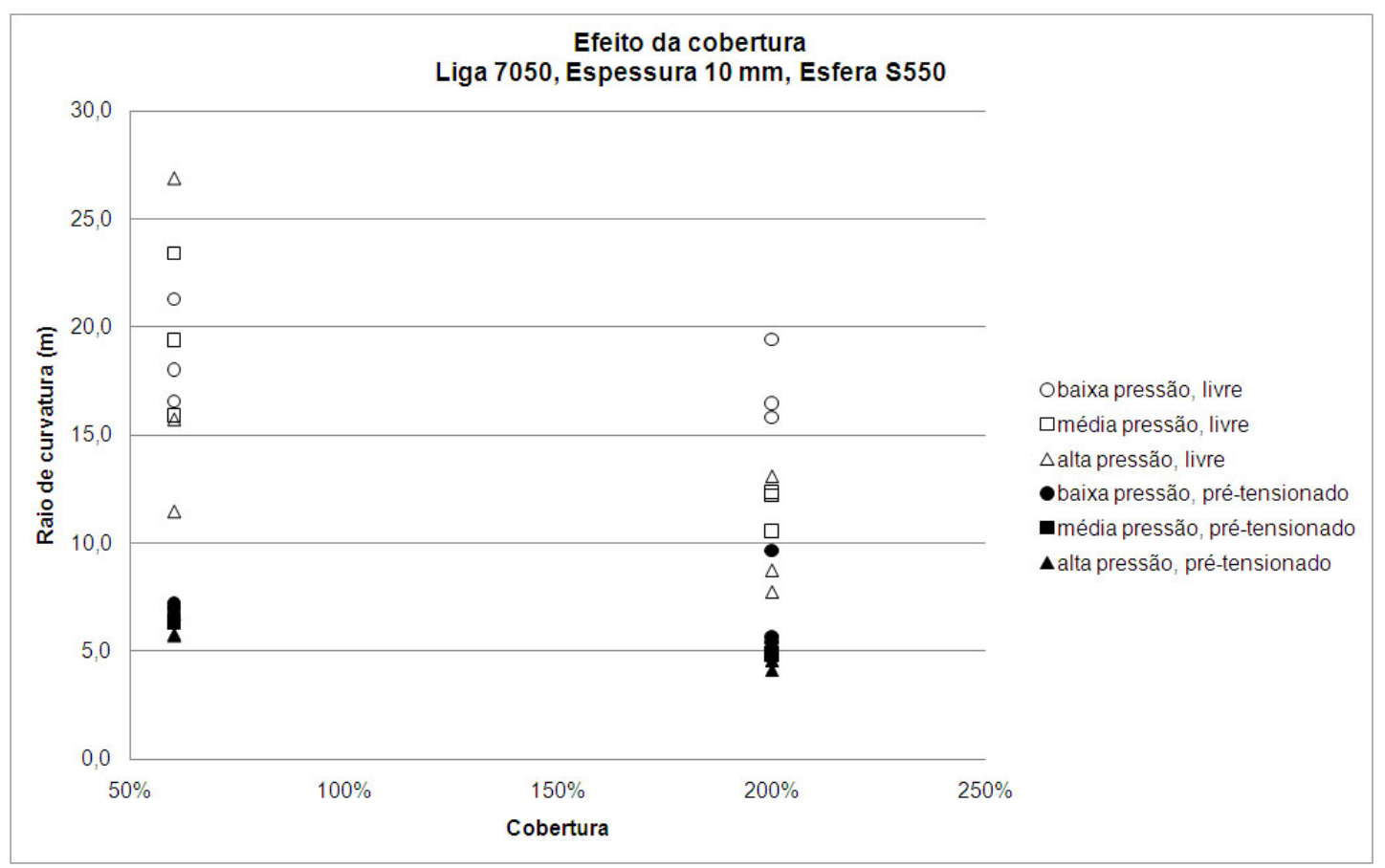

Figura 4.77: Efeito da cobertura sobre o raio de curvatura. Chapas da liga 7050 , espessura $10 \mathrm{~mm}$, jateadas com esfera S550. 


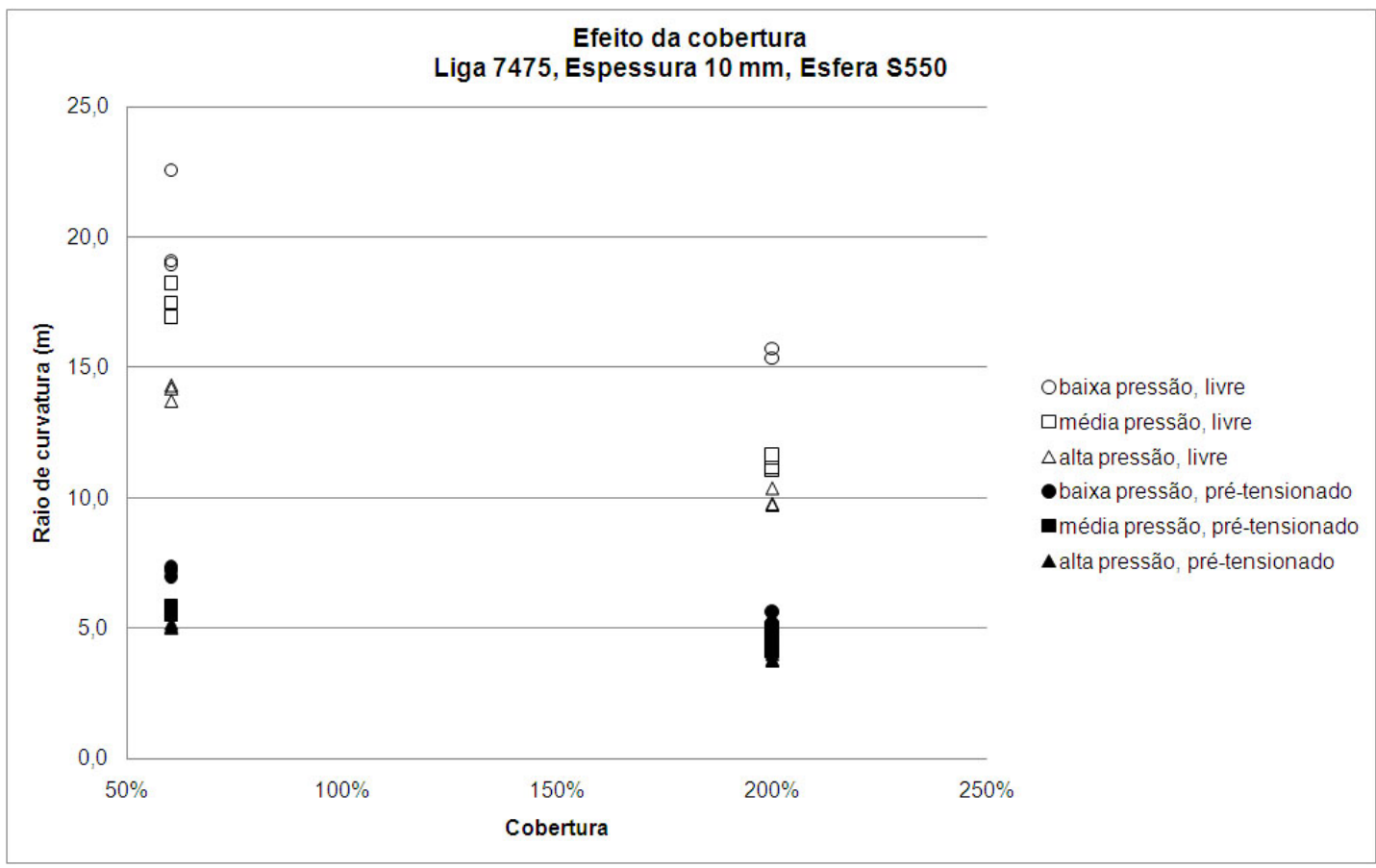

Figura 4.78: Efeito da cobertura sobre o raio de curvatura. Chapas da liga 7475 , espessura $10 \mathrm{~mm}$, jateadas com esfera S550.

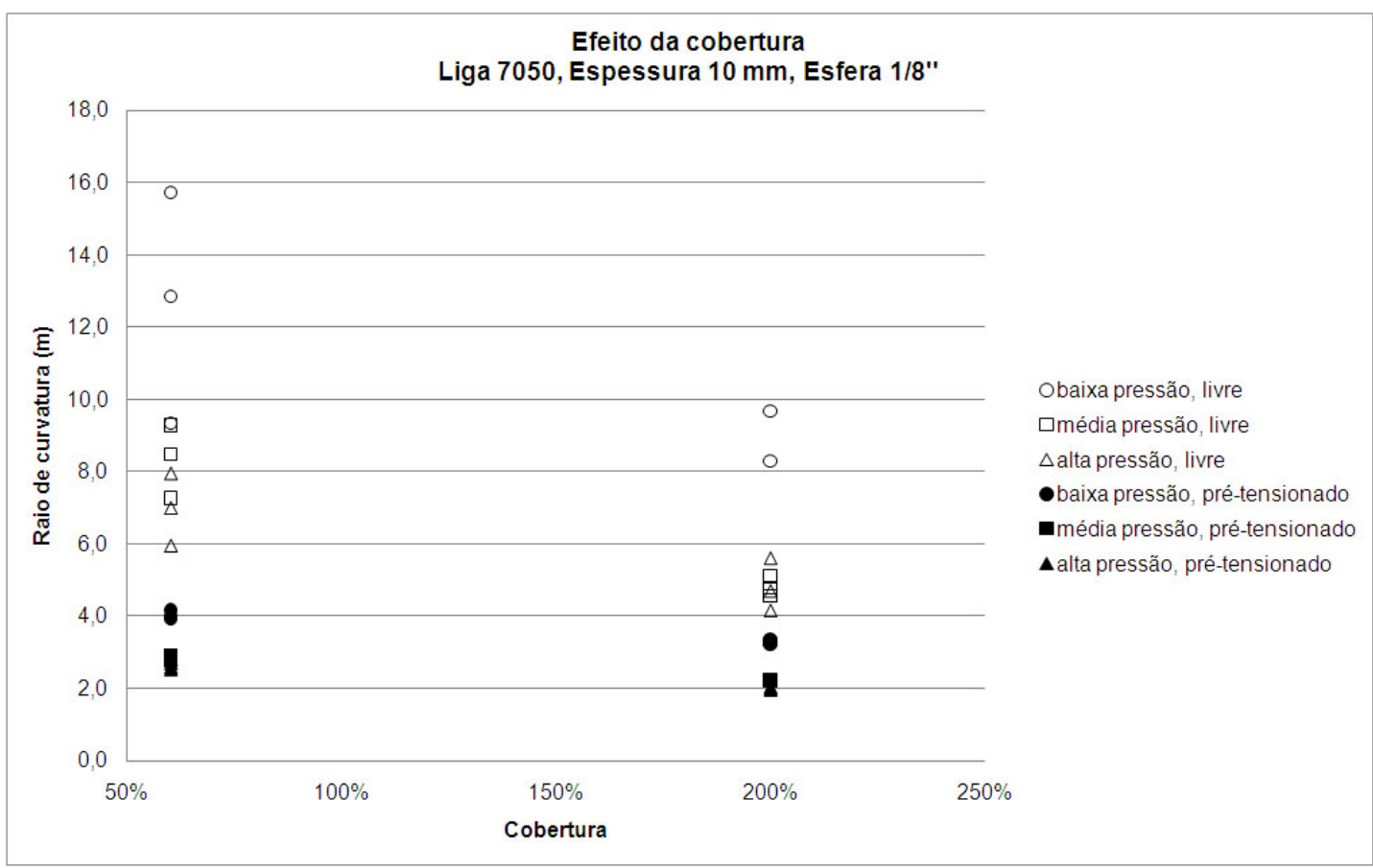

Figura 4.79: Efeito da cobertura sobre o raio de curvatura. Chapas da liga 7050 , espessura $10 \mathrm{~mm}$, jateadas com esfera $1 / 8$ ". 


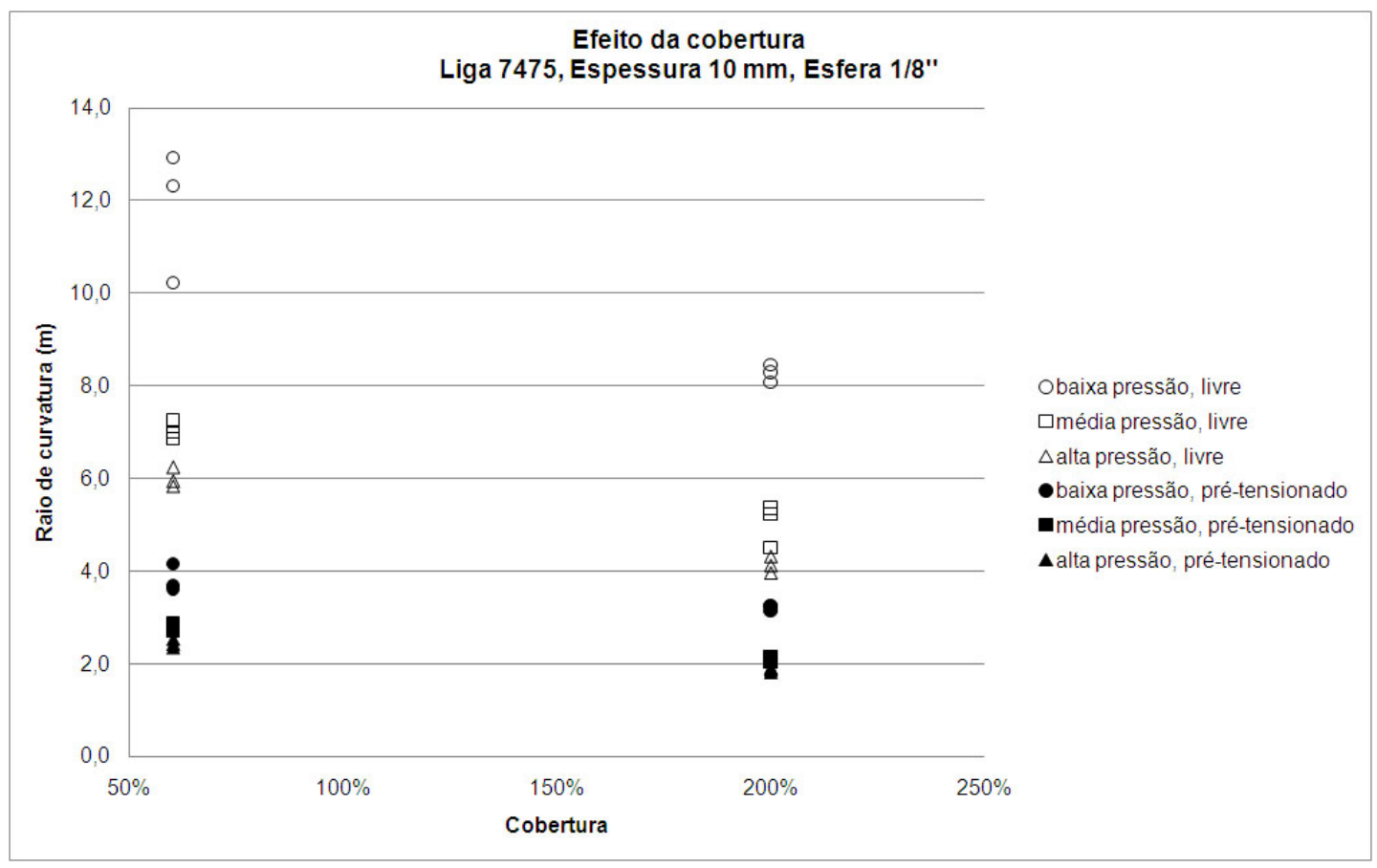

Figura 4.80: Efeito da cobertura sobre o raio de curvatura. Chapas da liga 7475 , espessura $10 \mathrm{~mm}$, jateadas com esfera $1 / 8$ ".

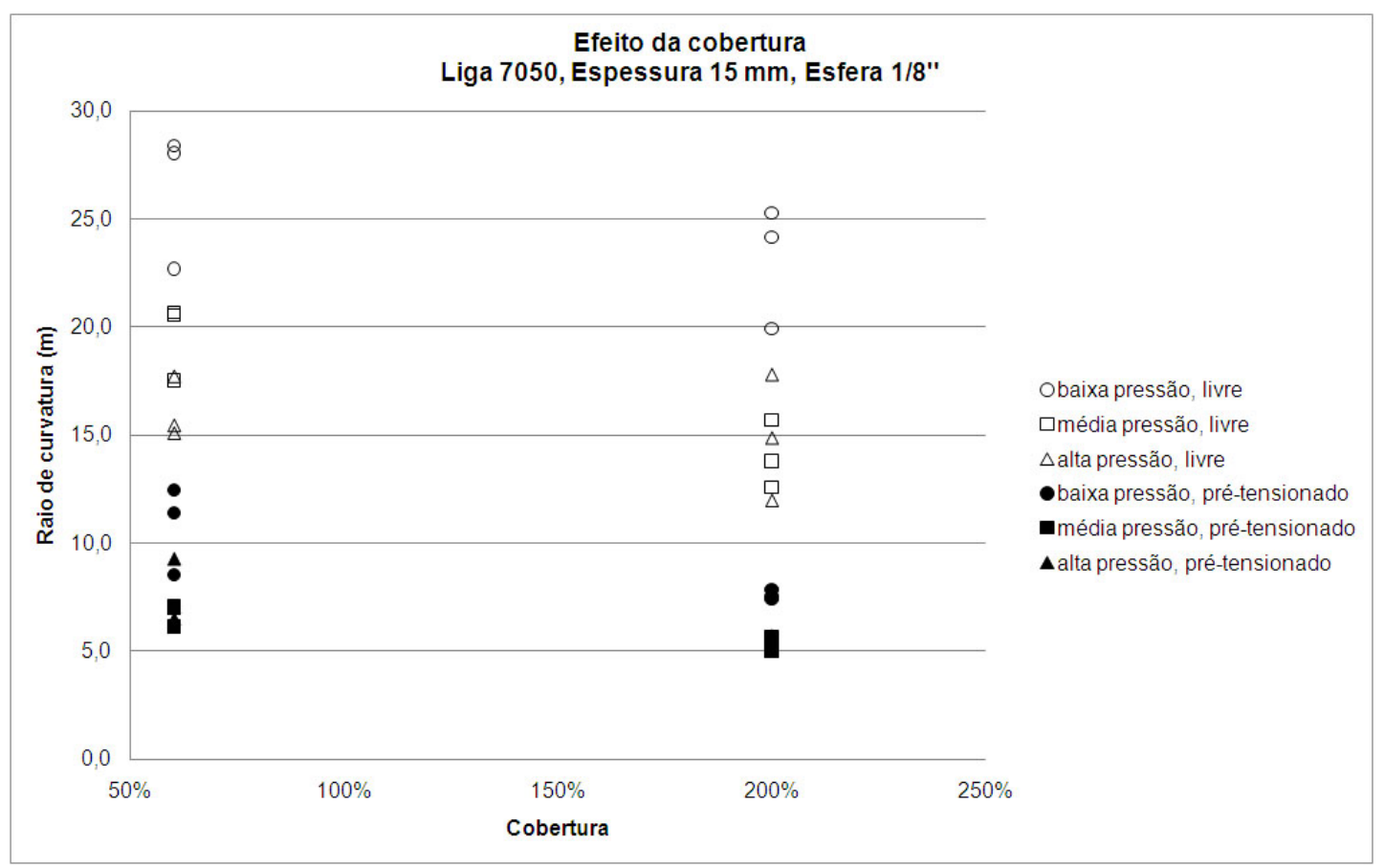

Figura 4.81: Efeito da cobertura sobre o raio de curvatura. Chapas da liga 7050 , espessura $15 \mathrm{~mm}$, jateadas com esfera $1 / 8$ ". 


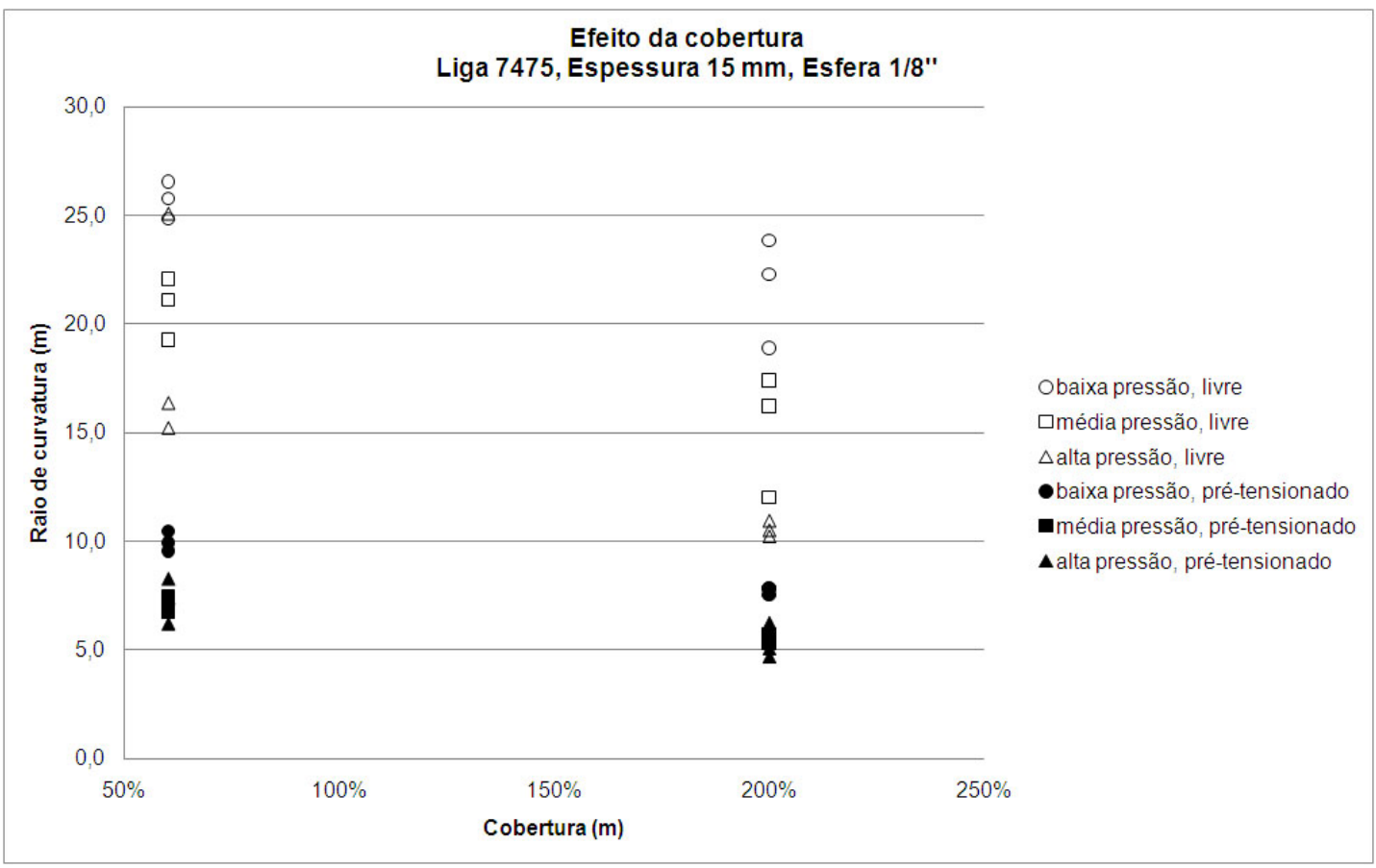

Figura 4.82: Efeito da cobertura sobre o raio de curvatura. Chapas da liga 7475 , espessura $15 \mathrm{~mm}$, jateadas com esfera $1 / 8$ ".

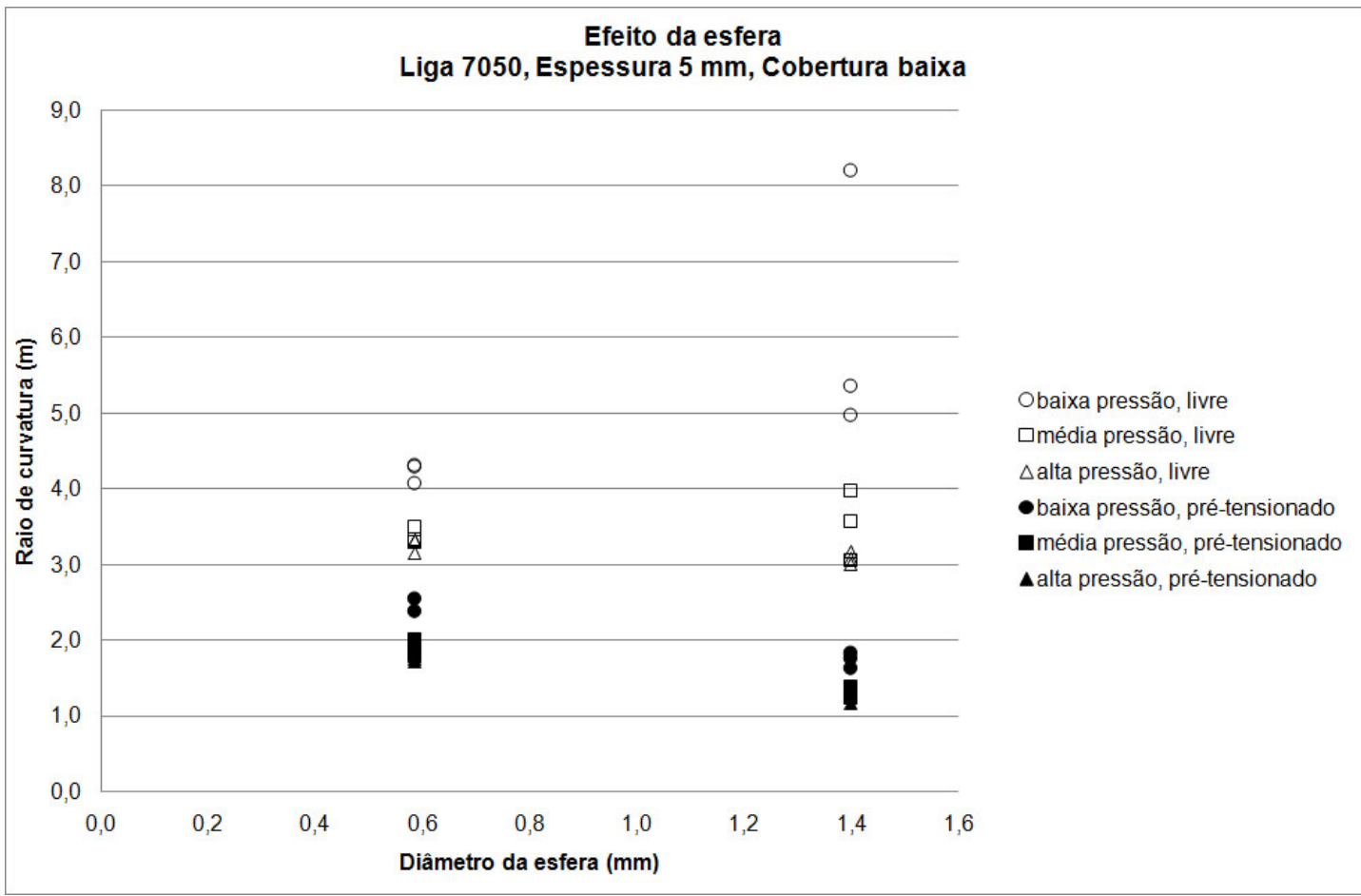

Figura 4.83: Efeito do diâmetro da esfera sobre o raio de curvatura. Chapas da liga 7050 , espessura $5 \mathrm{~mm}$, baixa cobertura. 


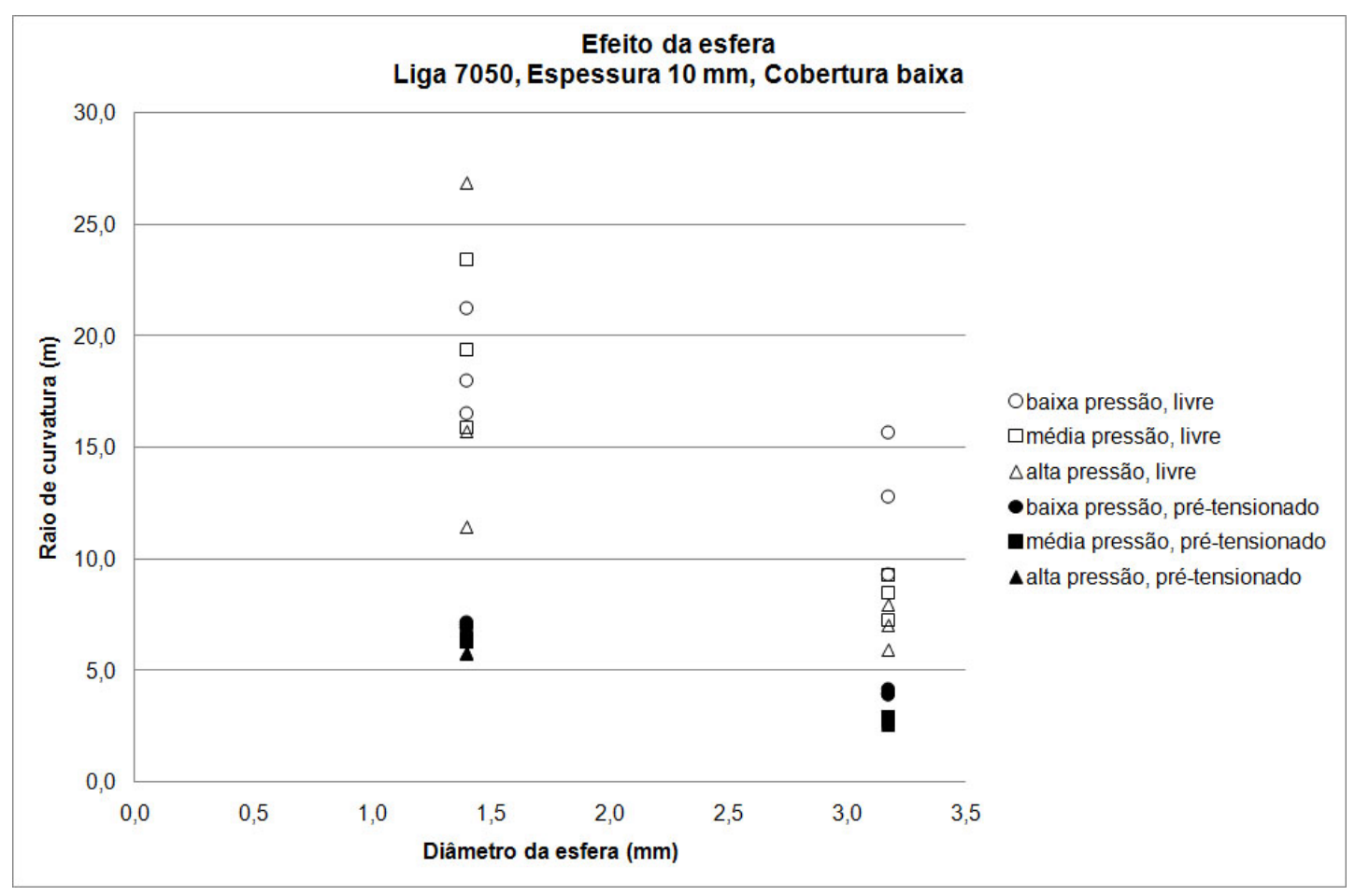

Figura 4.84: Efeito do diâmetro da esfera sobre o raio de curvatura. Chapas da liga 7050, espessura $10 \mathrm{~mm}$, baixa cobertura.

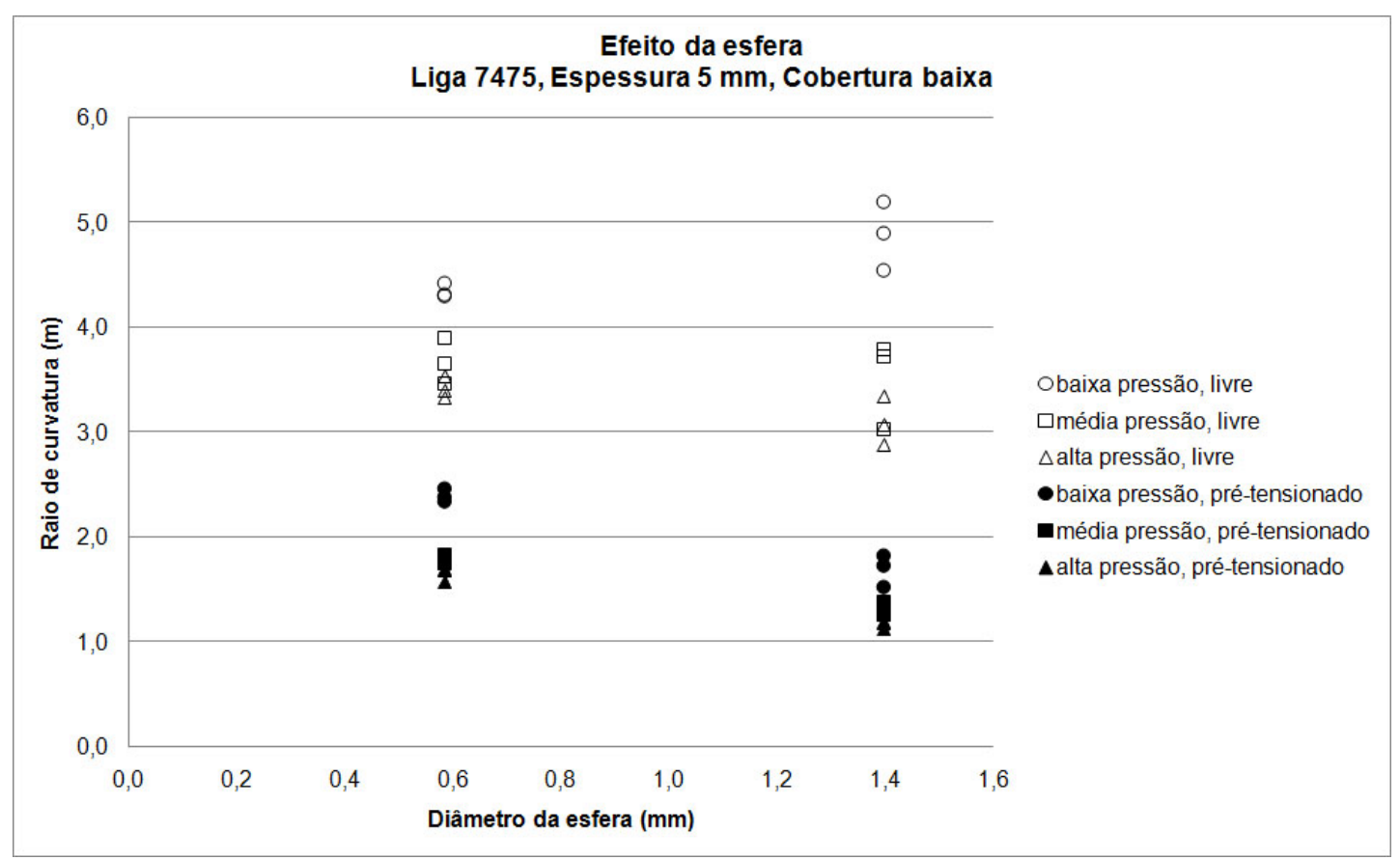

Figura 4.85: Efeito do diâmetro da esfera sobre o raio de curvatura. Chapas da liga 7475 , espessura $5 \mathrm{~mm}$, baixa cobertura. 


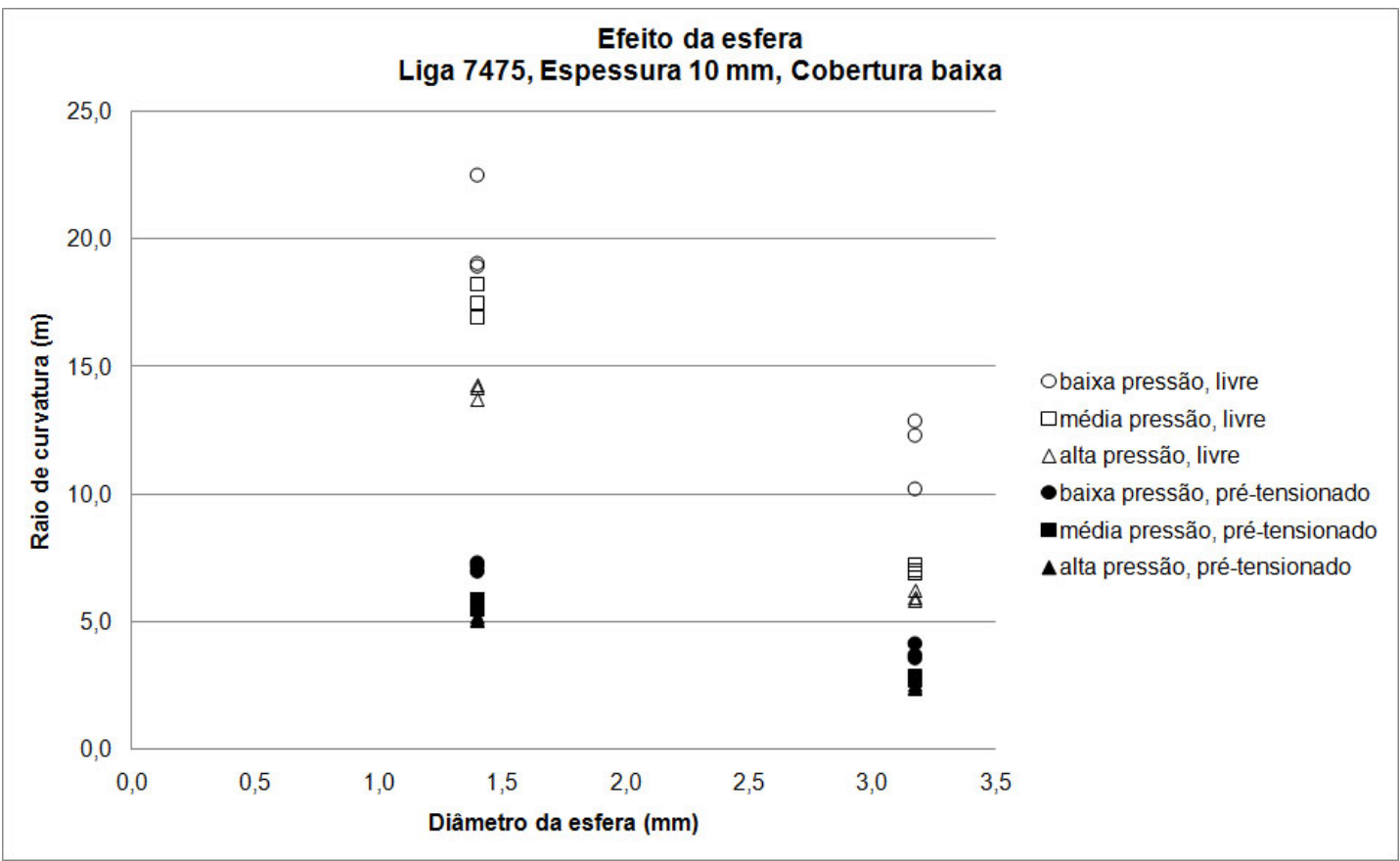

Figura 4.86: Efeito do diâmetro da esfera sobre o raio de curvatura. Chapas da liga 7475, espessura $10 \mathrm{~mm}$, baixa cobertura.

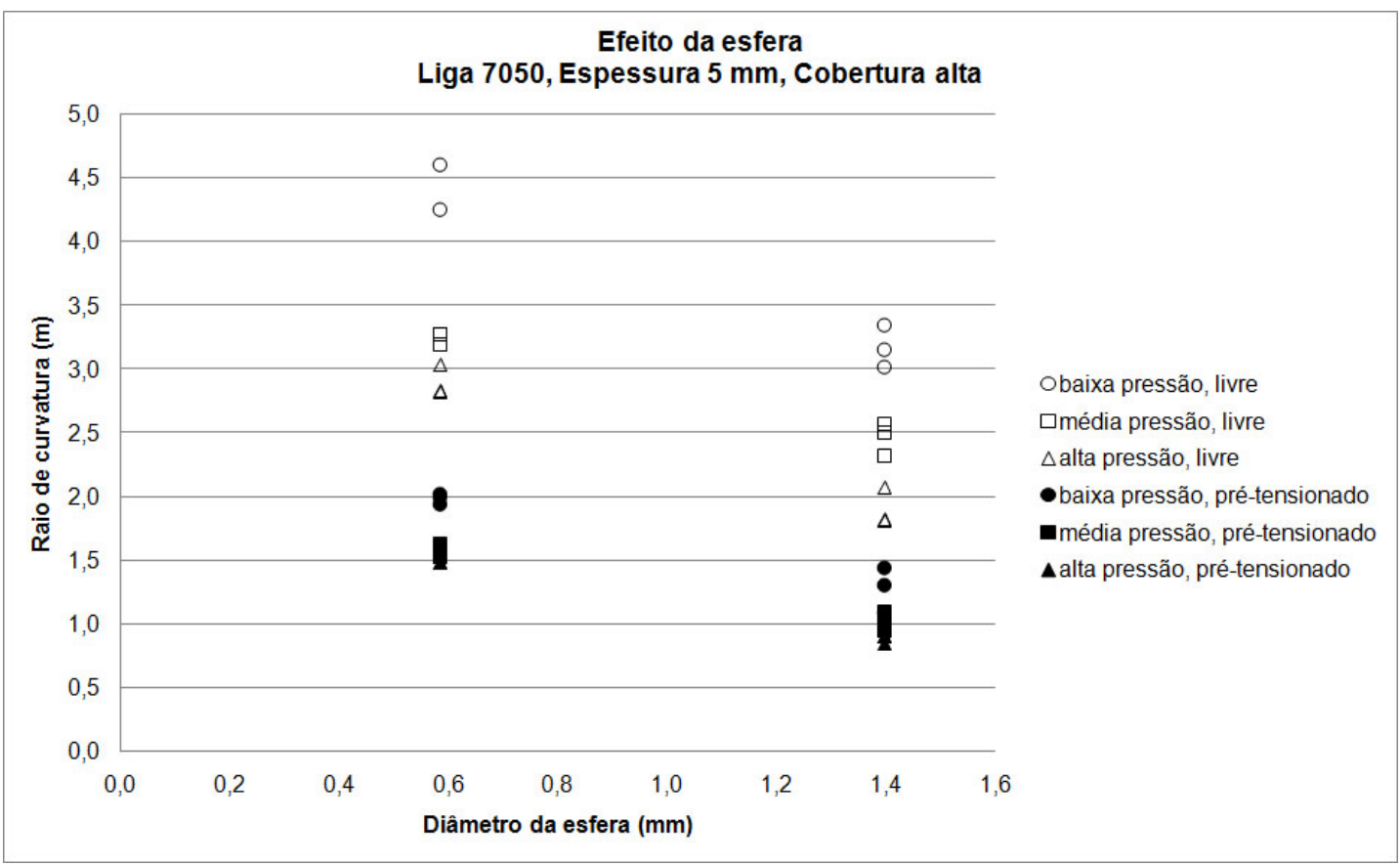

Figura 4.87: Efeito do diâmetro da esfera sobre o raio de curvatura. Chapas da liga 7050, espessura $5 \mathrm{~mm}$, alta cobertura. 


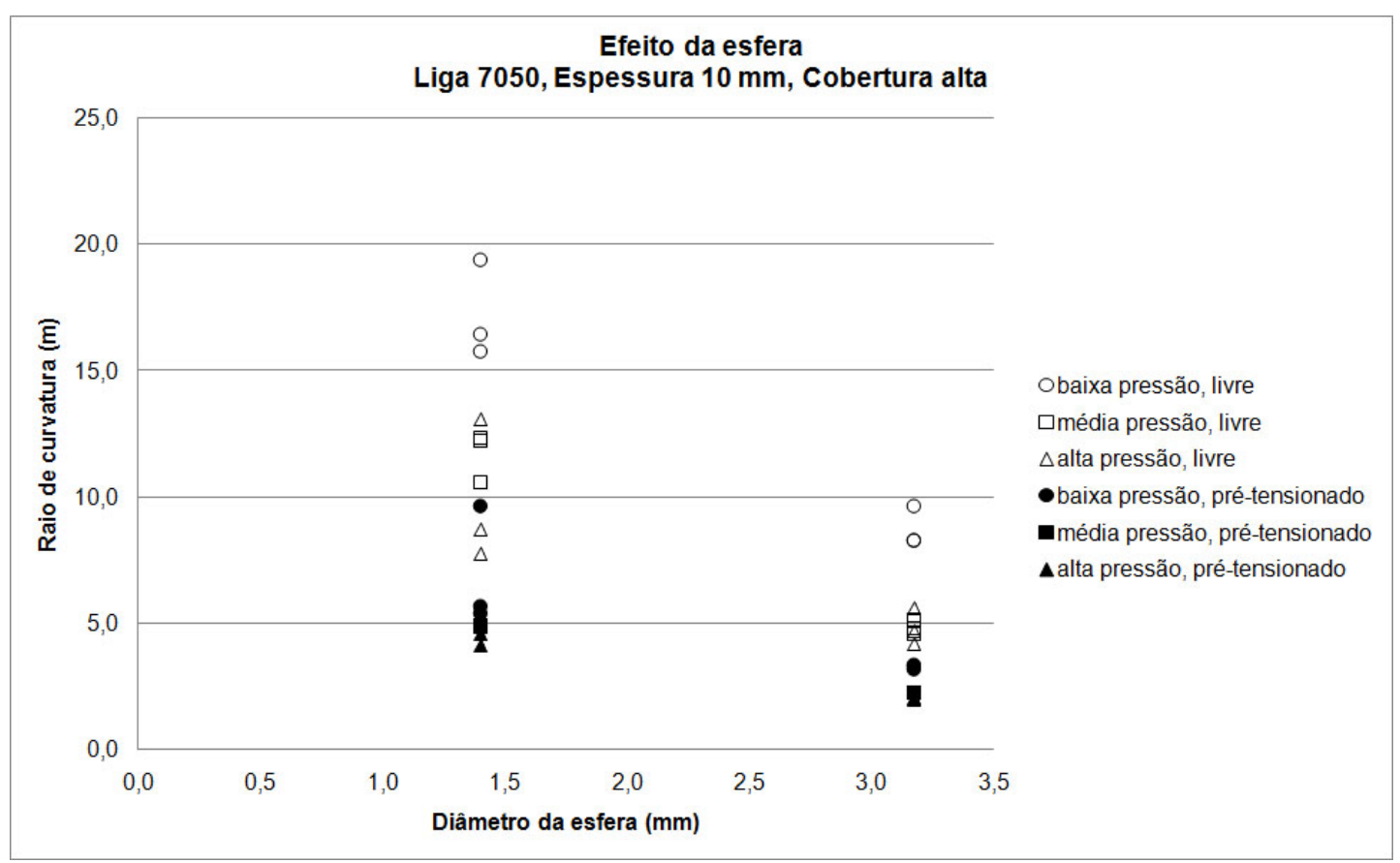

Figura 4.88: Efeito do diâmetro da esfera sobre o raio de curvatura. Chapas da liga 7050, espessura $10 \mathrm{~mm}$, alta cobertura.

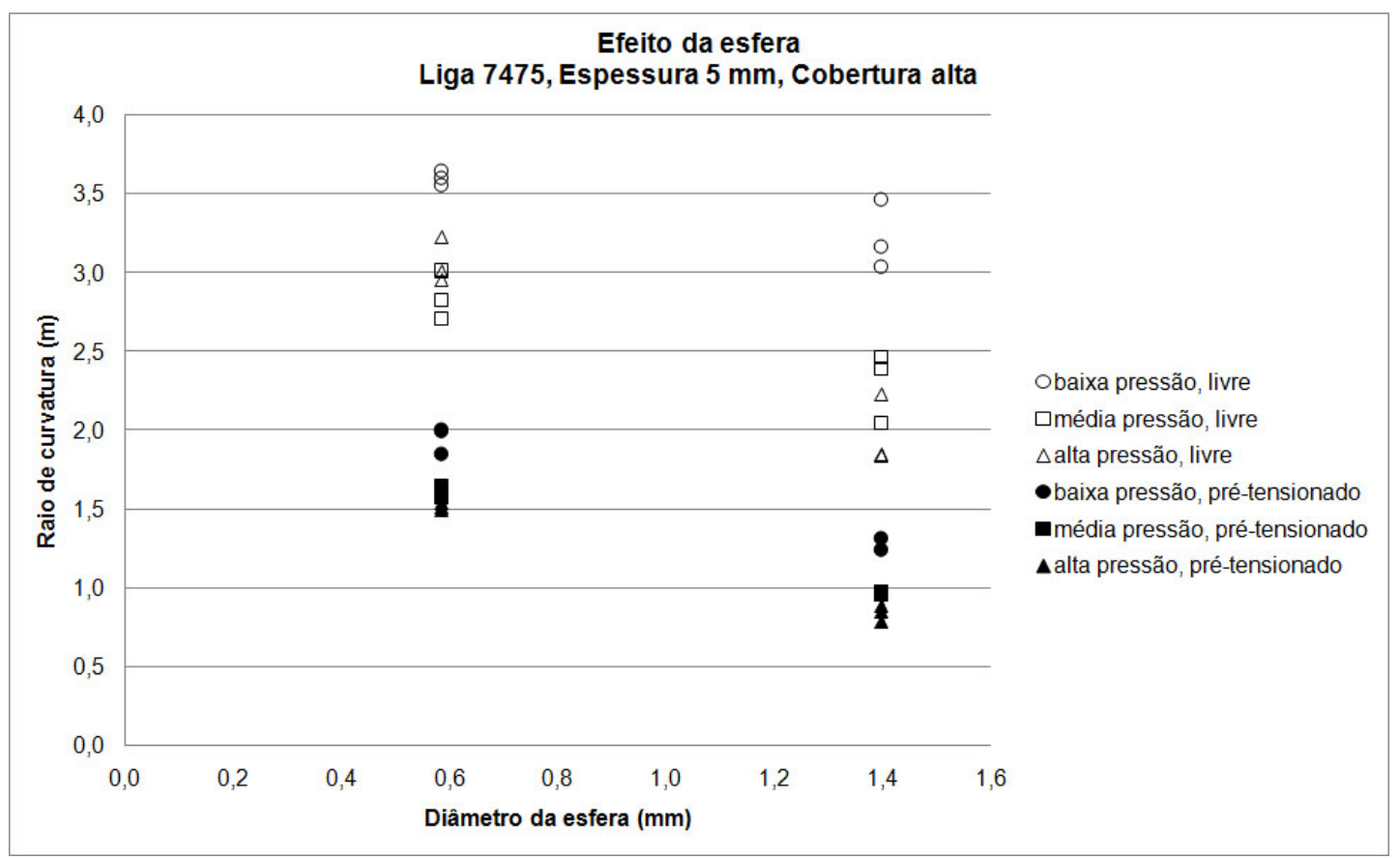

Figura 4.89: Efeito do diâmetro da esfera sobre o raio de curvatura. Chapas da liga 7475, espessura $5 \mathrm{~mm}$, alta cobertura. 


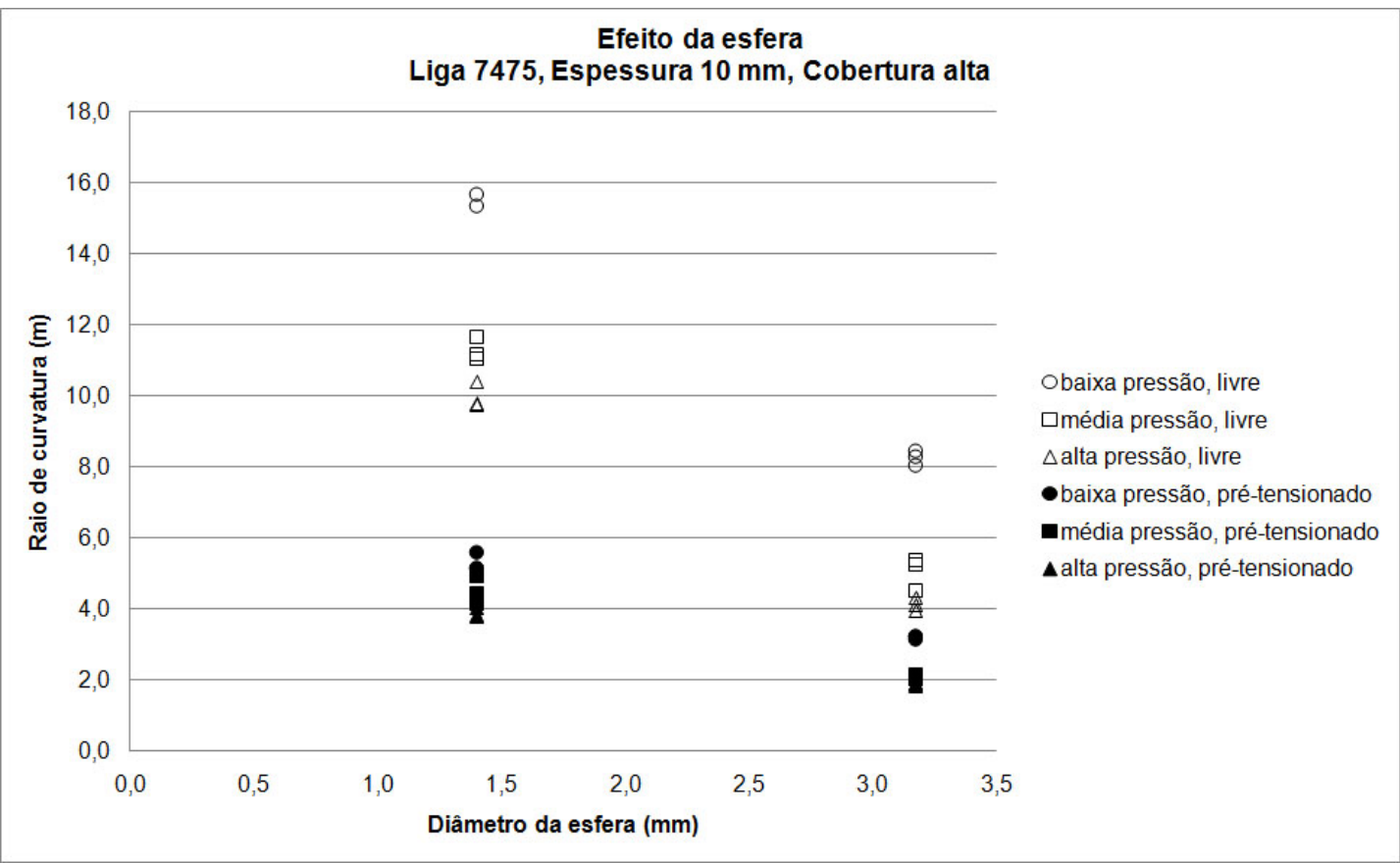

Figura 4.90: Efeito do diâmetro da esfera sobre o raio de curvatura. Chapas da liga 7475, espessura $10 \mathrm{~mm}$, alta cobertura.

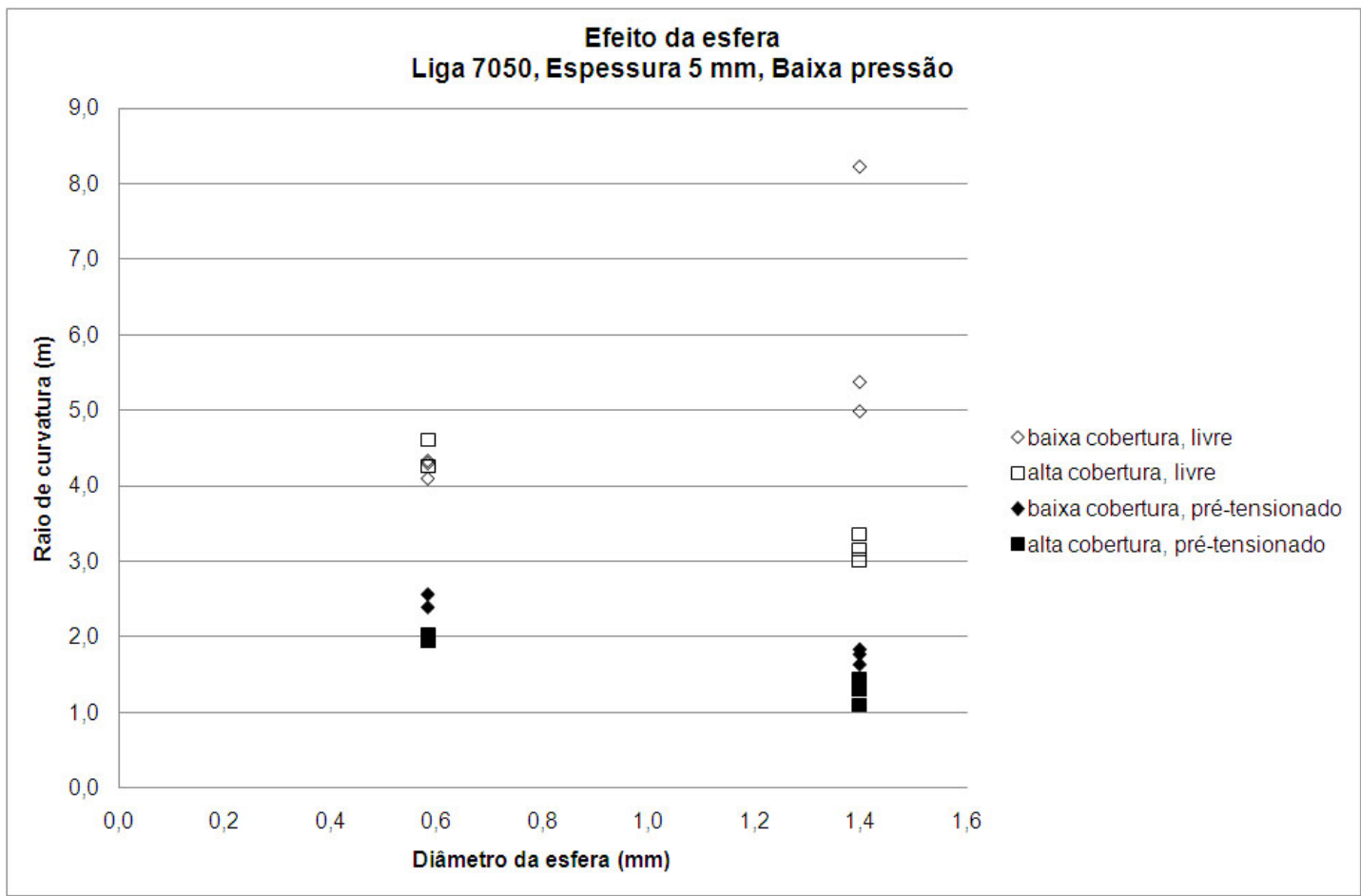

Figura 4.91: Efeito do diâmetro da esfera sobre o raio de curvatura. Chapas da liga 7050, espessura $5 \mathrm{~mm}$, baixa pressão do jato. 


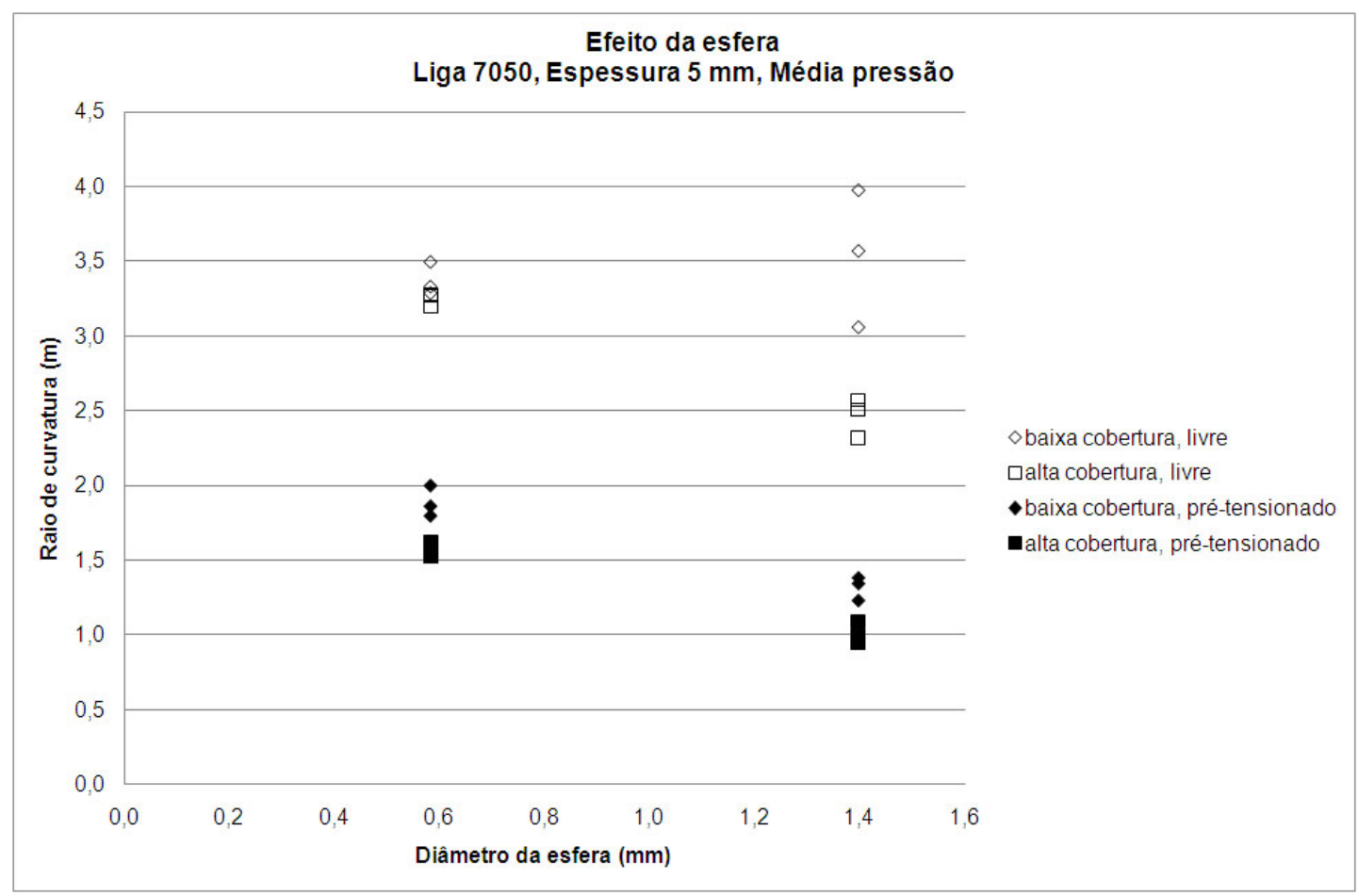

Figura 4.92: Efeito do diâmetro da esfera sobre o raio de curvatura. Chapas da liga 7050, espessura $5 \mathrm{~mm}$, média pressão do jato.

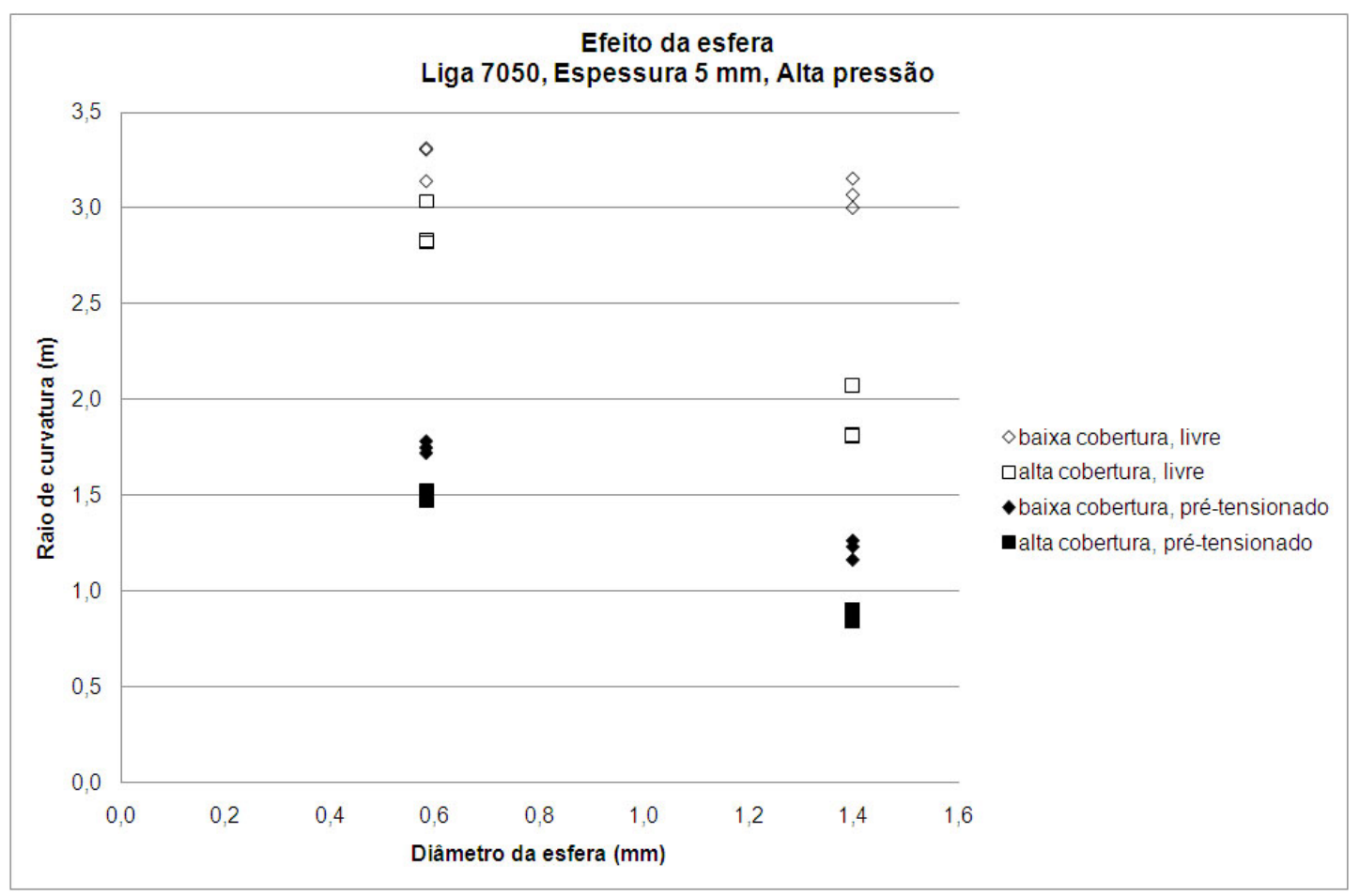

Figura 4.93: Efeito do diâmetro da esfera sobre o raio de curvatura. Chapas da liga 7050 , espessura $5 \mathrm{~mm}$, alta pressão do jato. 


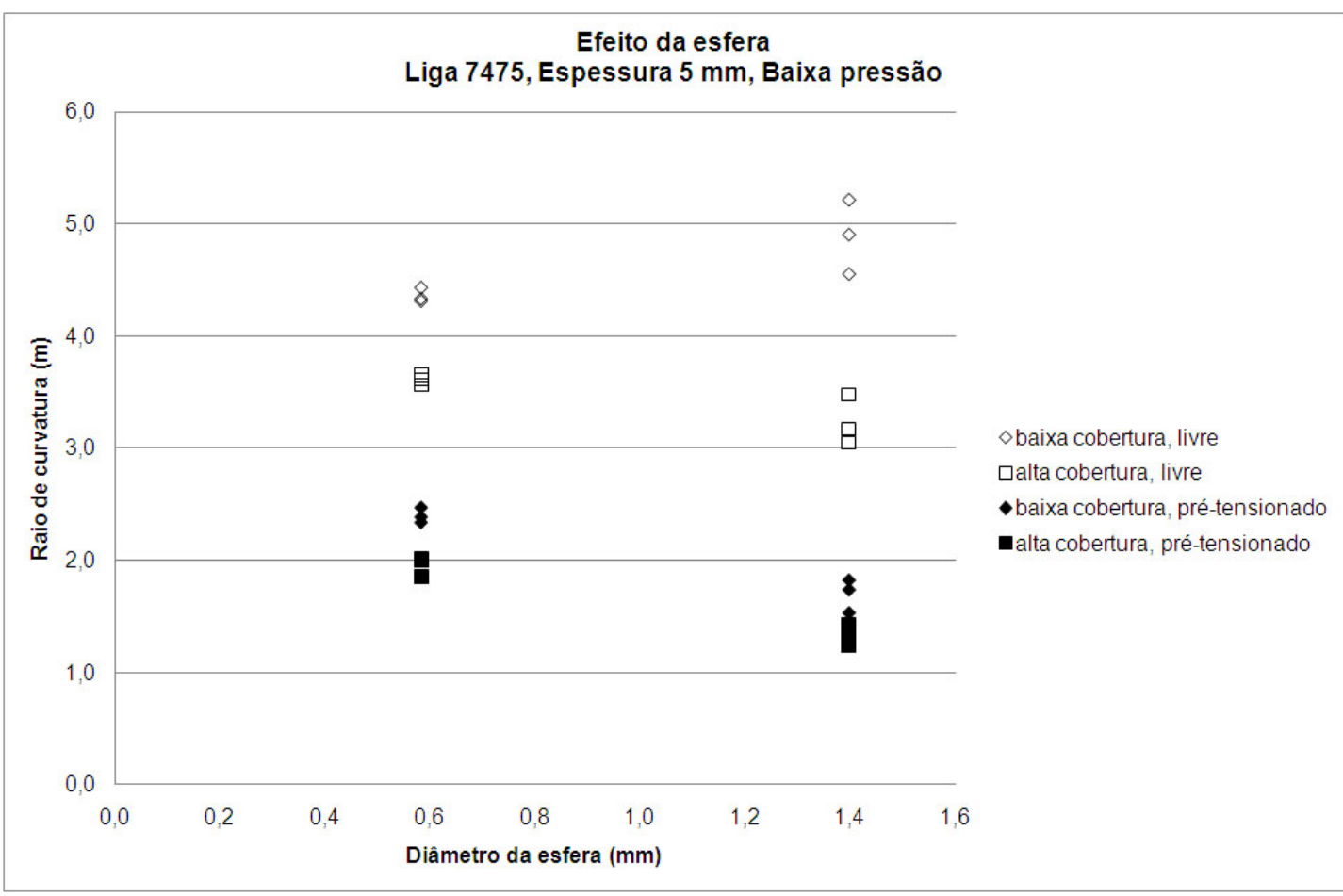

Figura 4.94: Efeito do diâmetro da esfera sobre o raio de curvatura. Chapas da liga 7475, espessura $5 \mathrm{~mm}$, baixa pressão do jato.

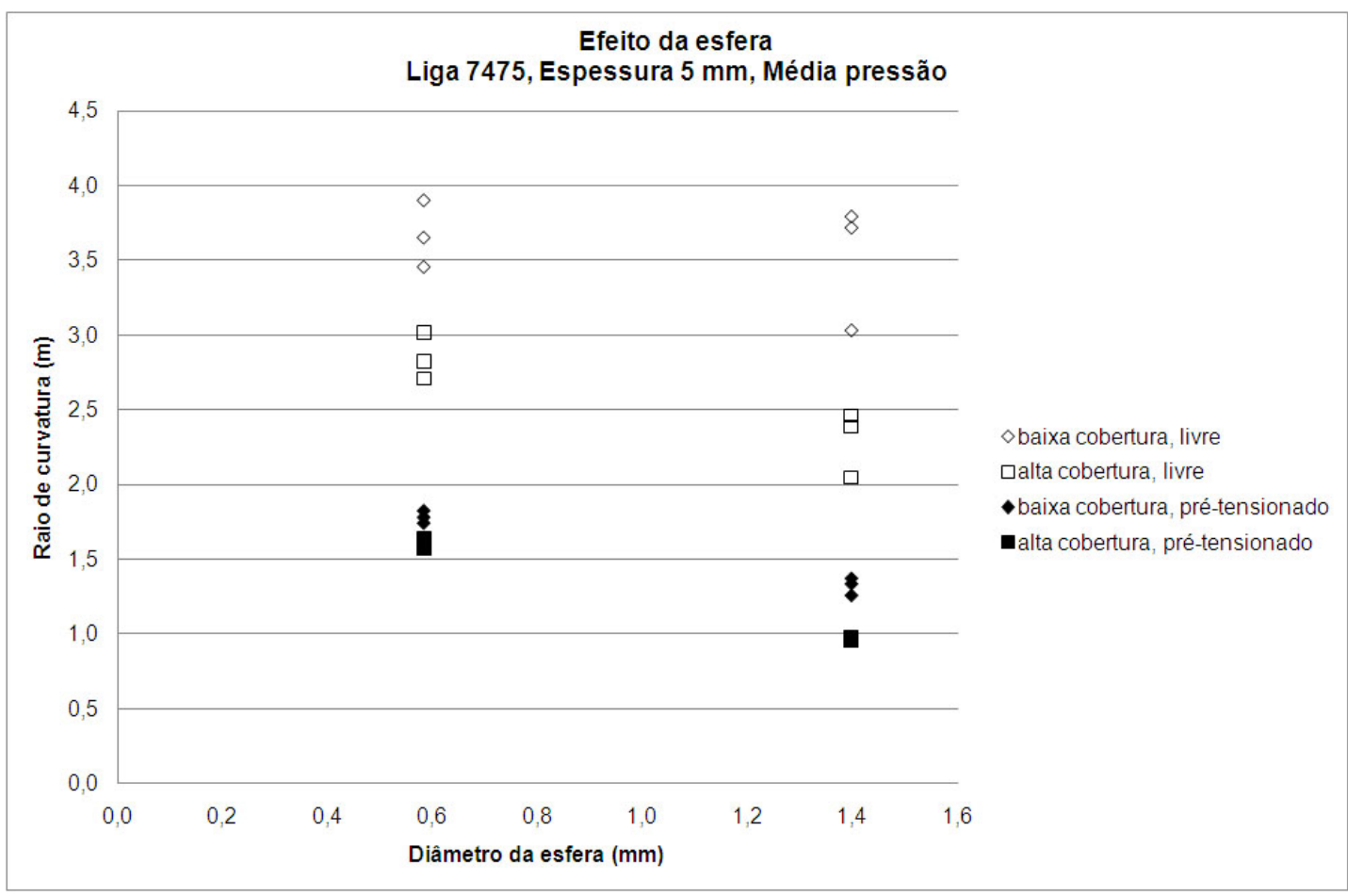

Figura 4.95: Efeito do diâmetro da esfera sobre o raio de curvatura. Chapas da liga 7475, espessura $5 \mathrm{~mm}$, média pressão do jato. 


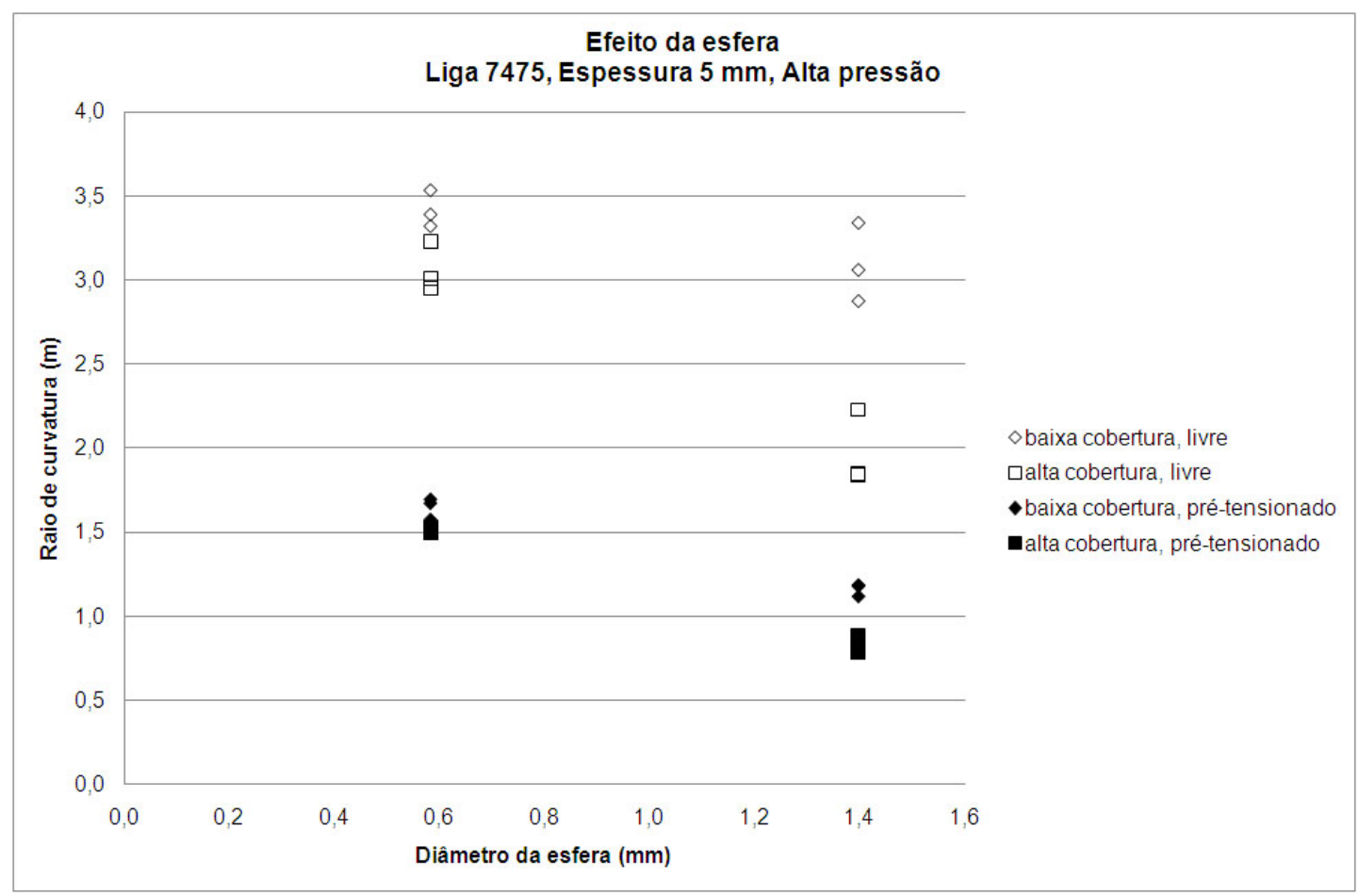

Figura 4.96: Efeito do diâmetro da esfera sobre o raio de curvatura. Chapas da liga 7475 , espessura $5 \mathrm{~mm}$, alta pressão do jato.

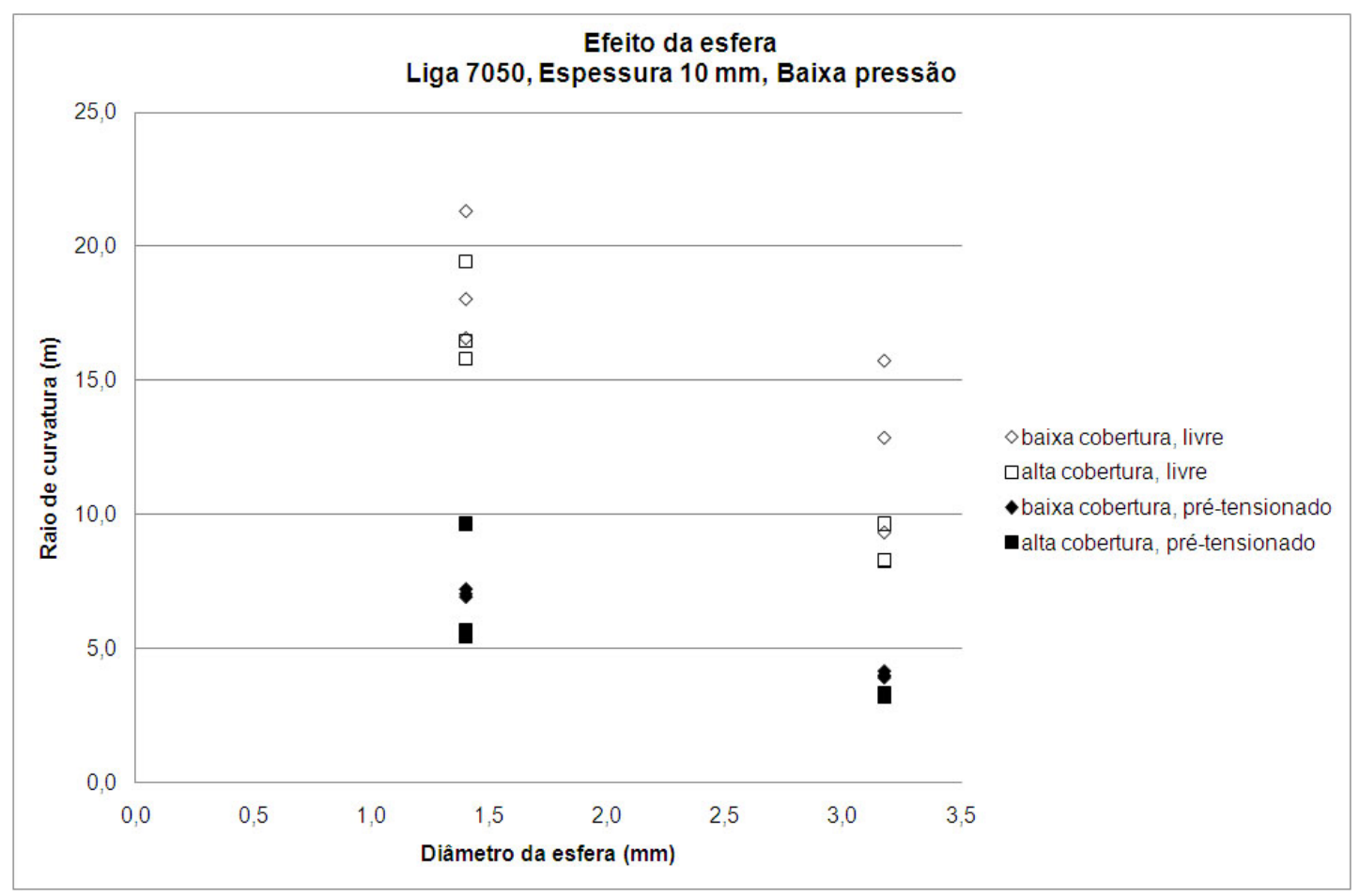

Figura 4.97: Efeito do diâmetro da esfera sobre o raio de curvatura. Chapas da liga 7050, espessura $10 \mathrm{~mm}$, baixa pressão do jato. 


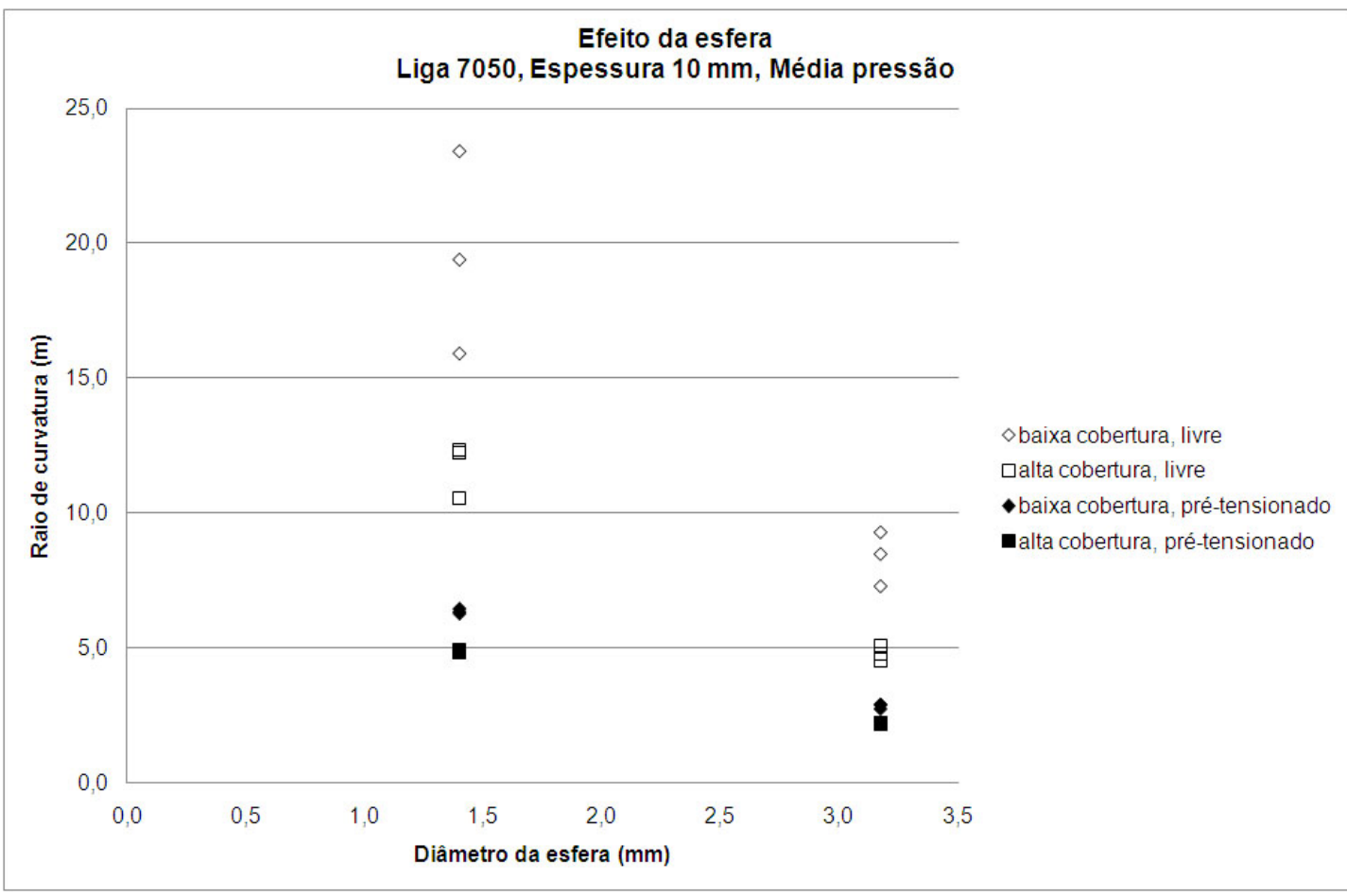

Figura 4.98: Efeito do diâmetro da esfera sobre o raio de curvatura. Chapas da liga 7050, espessura $10 \mathrm{~mm}$, média pressão do jato.

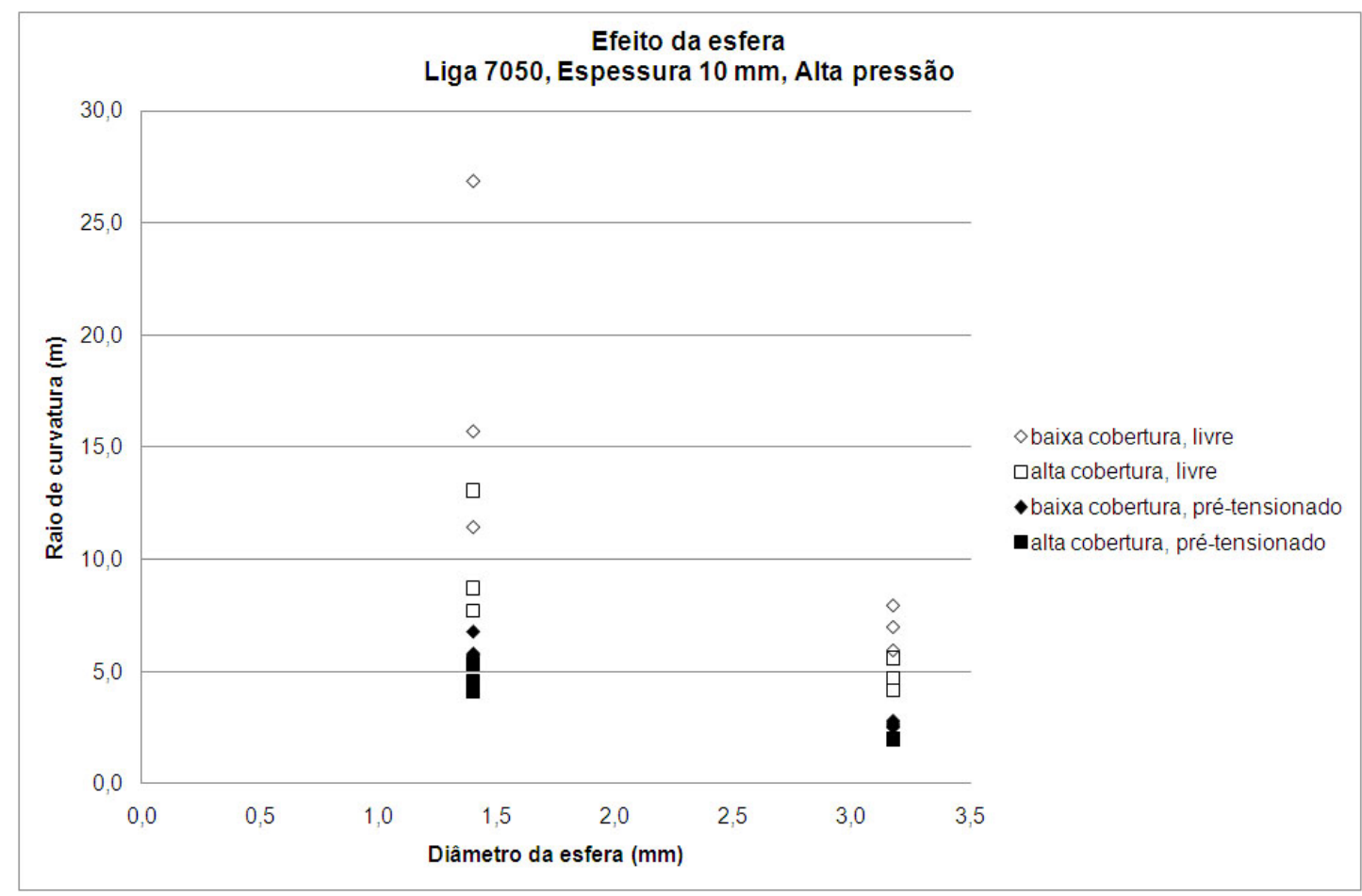

Figura 4.99: Efeito do diâmetro da esfera sobre o raio de curvatura. Chapas da liga 7050, espessura $10 \mathrm{~mm}$, alta pressão do jato. 


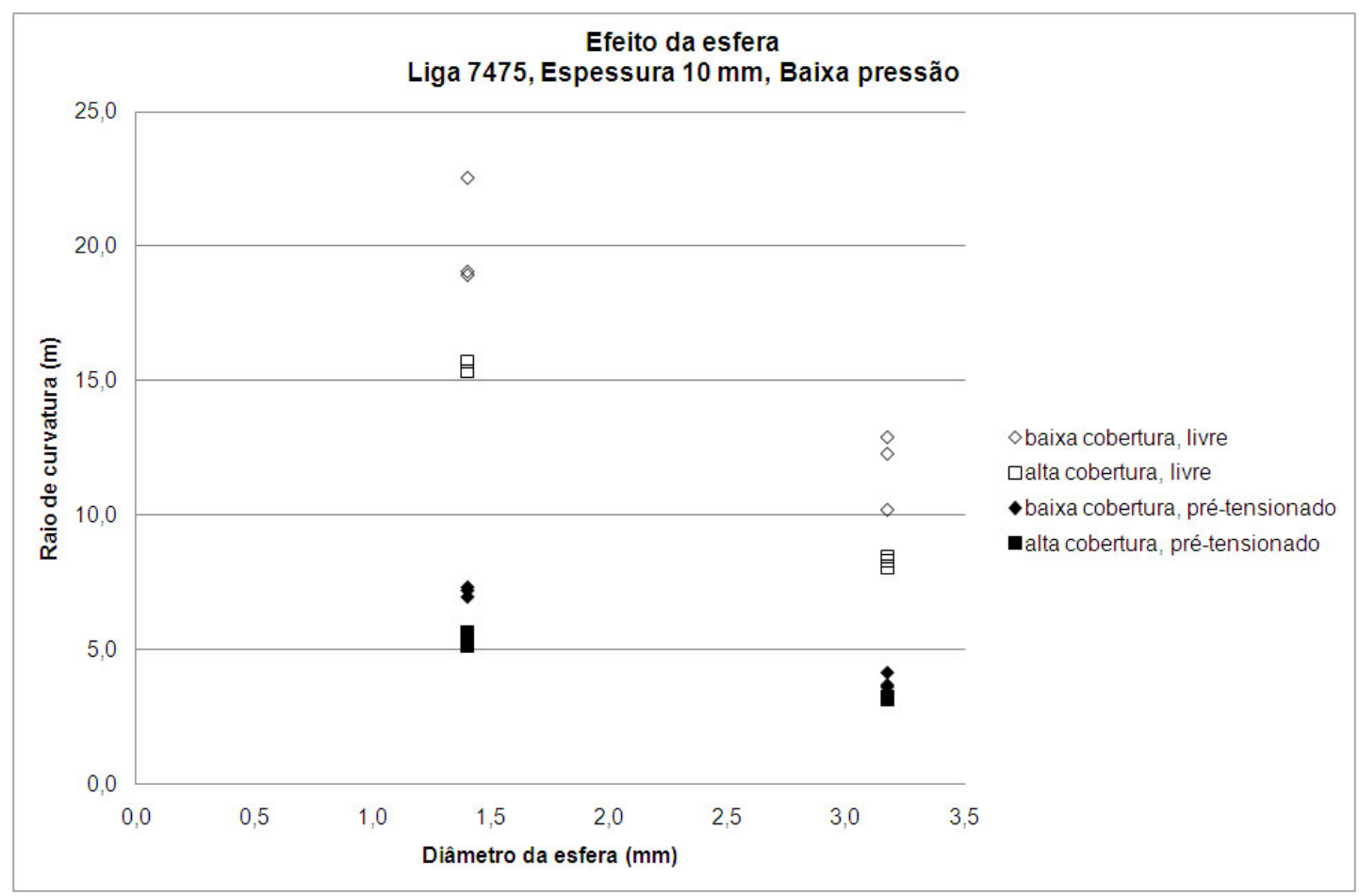

Figura 4.100: Efeito do diâmetro da esfera sobre o raio de curvatura. Chapas da liga 7475, espessura $10 \mathrm{~mm}$, baixa pressão do jato.

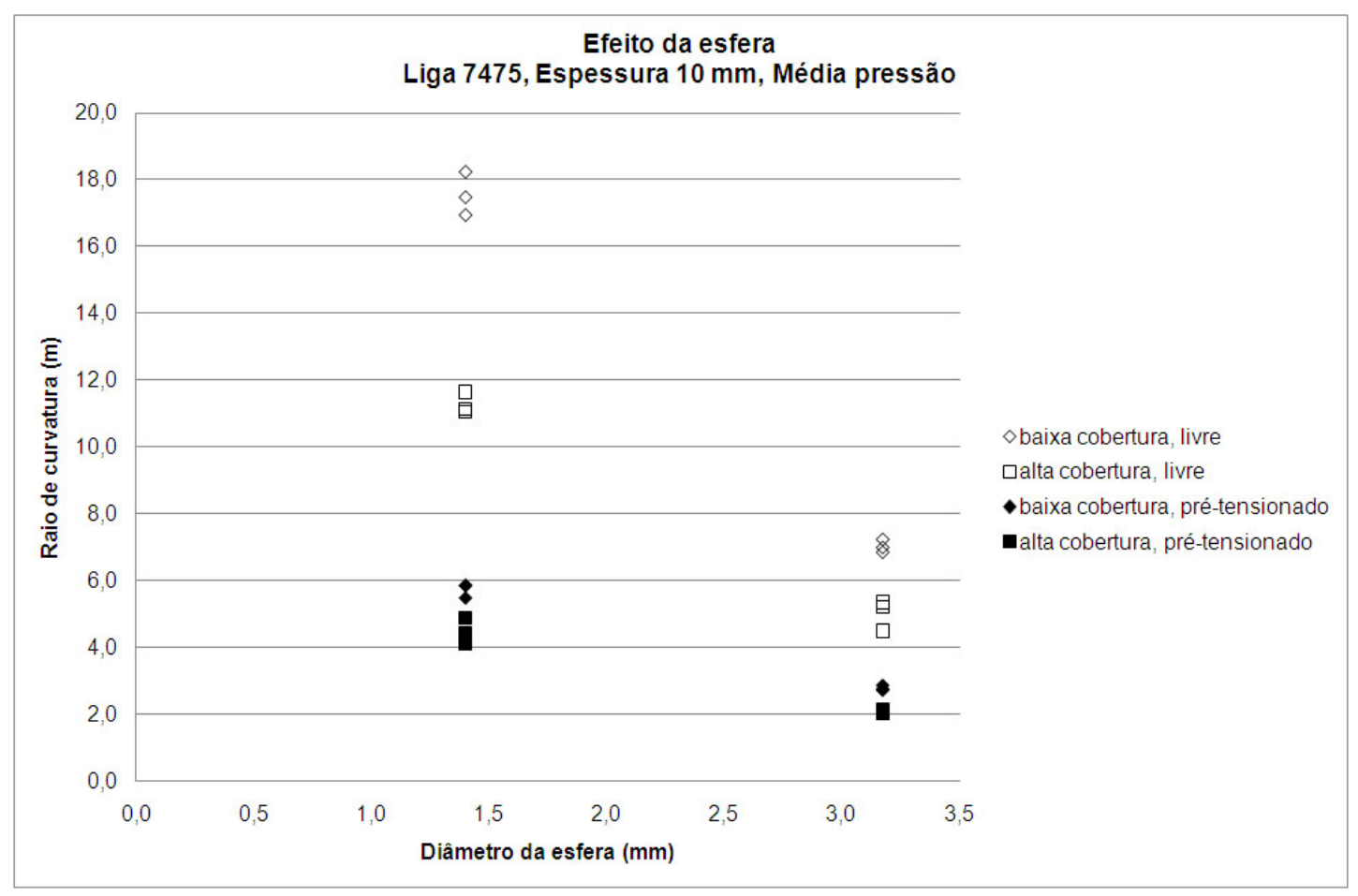

Figura 4.101: Efeito do diâmetro da esfera sobre o raio de curvatura. Chapas da liga 7475, espessura $10 \mathrm{~mm}$, média pressão do jato. 


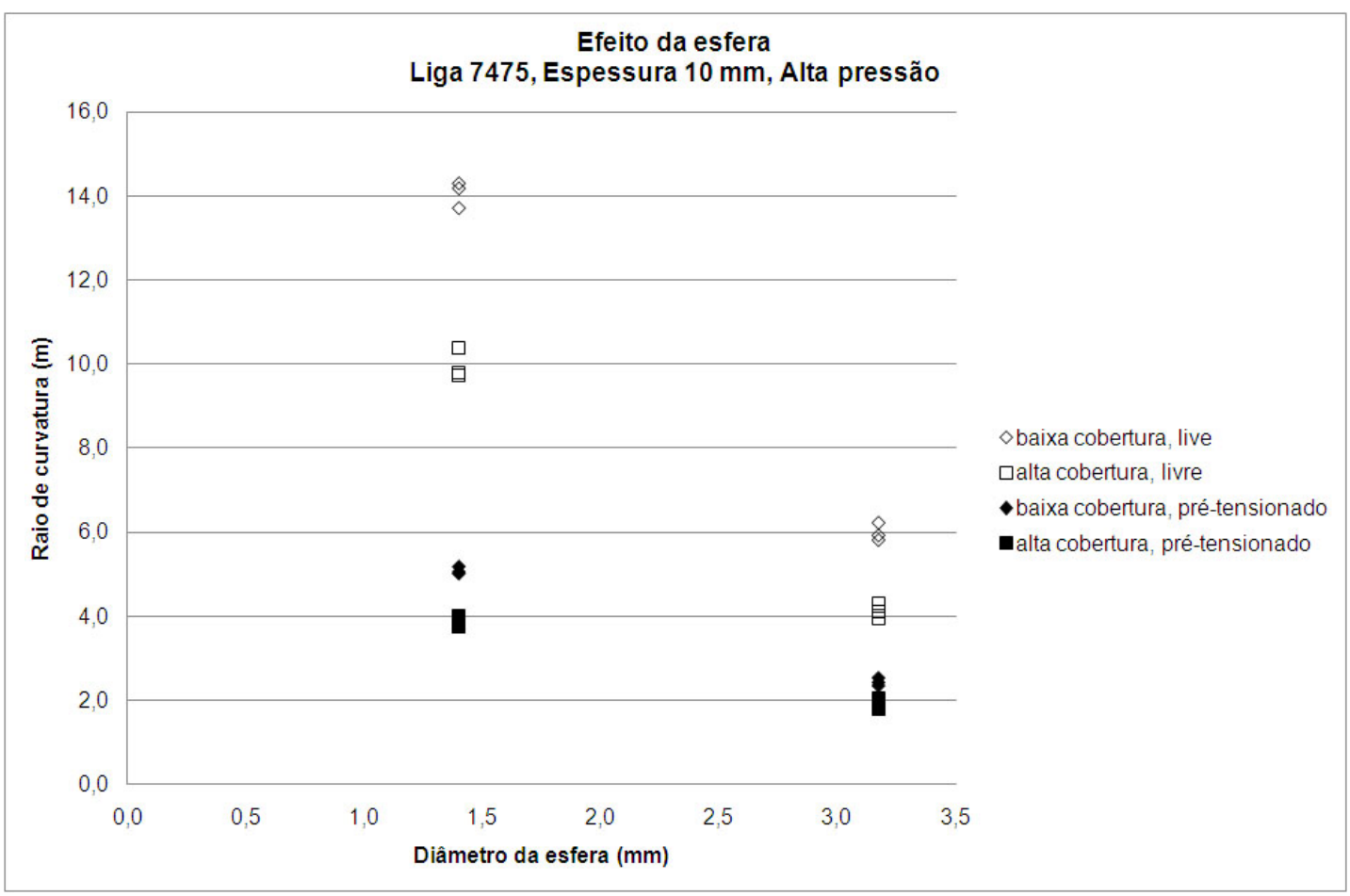

Figura 4.102: Efeito do diâmetro da esfera sobre o raio de curvatura. Chapas da liga 7475 , espessura $10 \mathrm{~mm}$, alta pressão do jato.

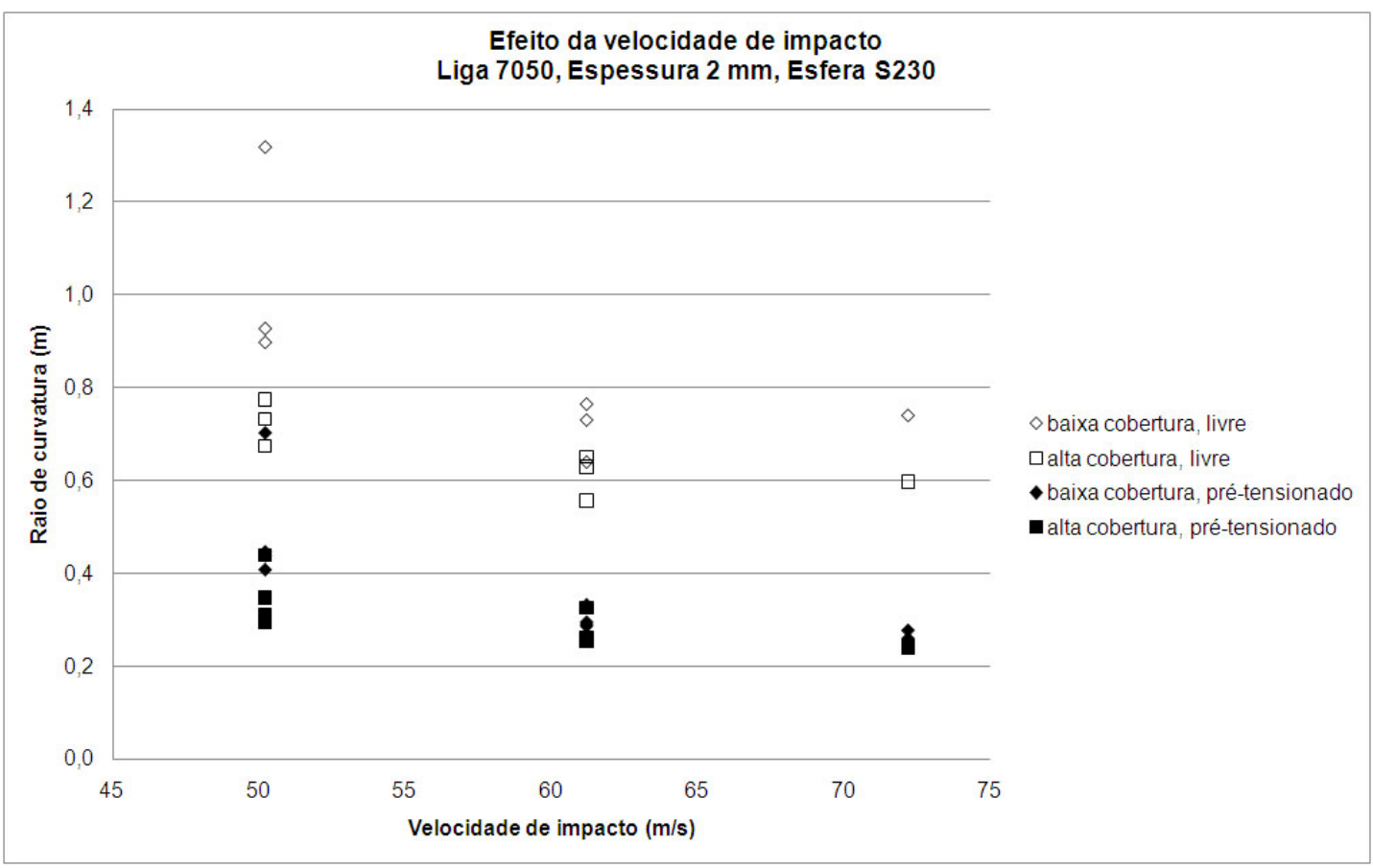

Figura 4.103: Efeito da velocidade de impacto sobre o raio de curvatura. Chapas da liga 7050, espessura 2 mm, jateadas com esfera S230. 


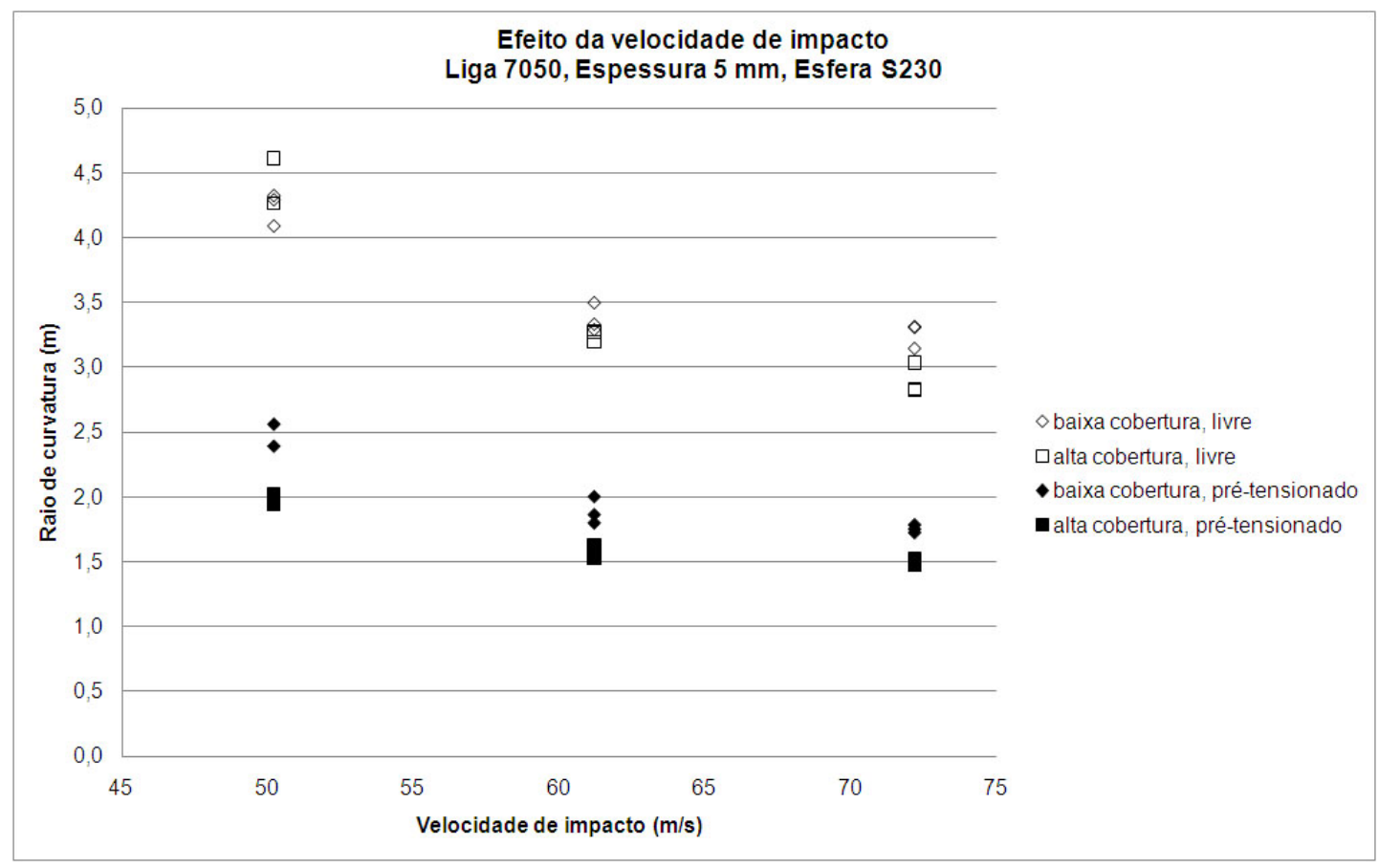

Figura 4.104: Efeito da velocidade de impacto sobre o raio de curvatura. Chapas da liga 7050, espessura $5 \mathrm{~mm}$, jateadas com esfera S230.

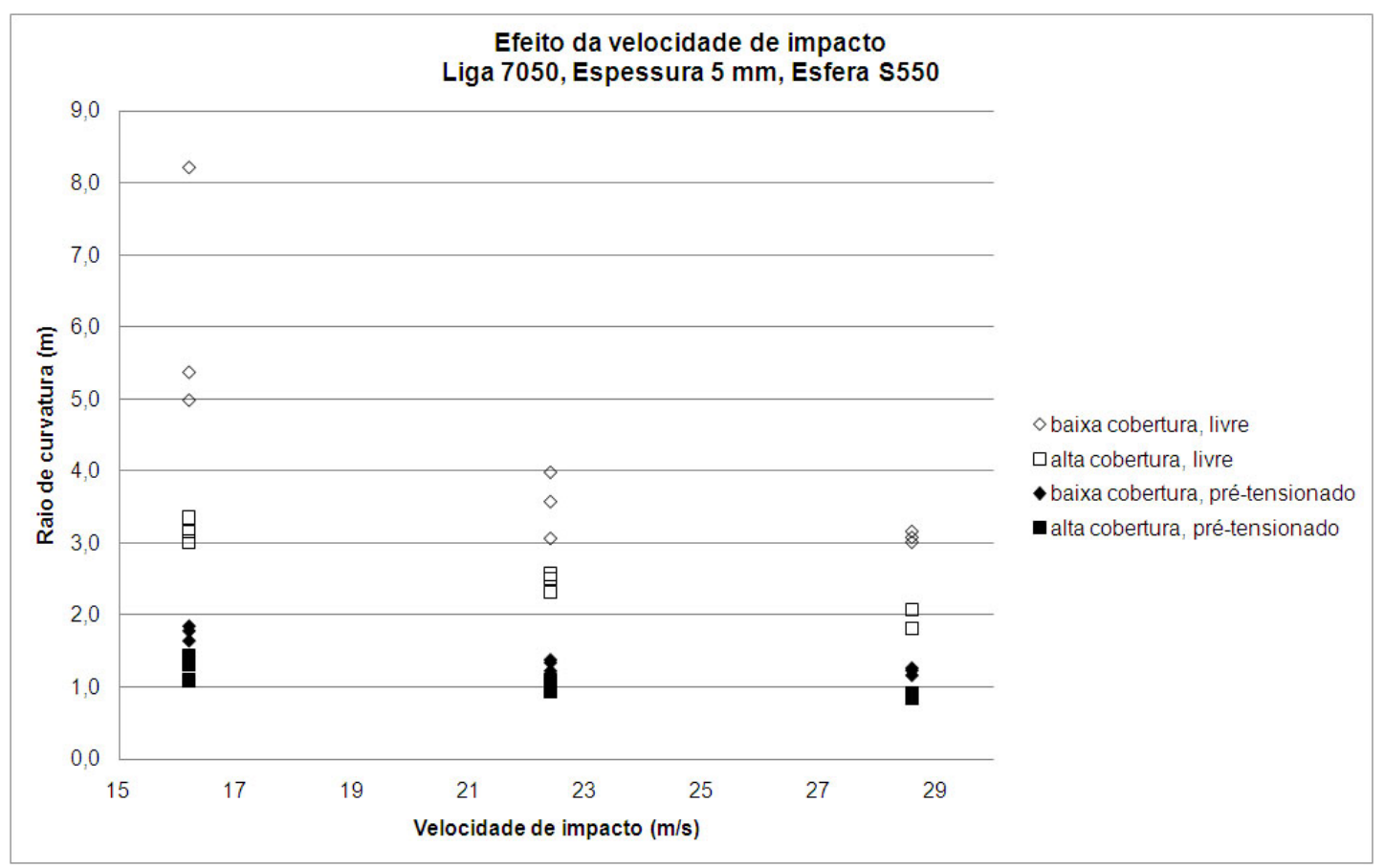

Figura 4.105: Efeito da velocidade de impacto sobre o raio de curvatura. Chapas da liga 7050, espessura $5 \mathrm{~mm}$, jateadas com esfera S550. 


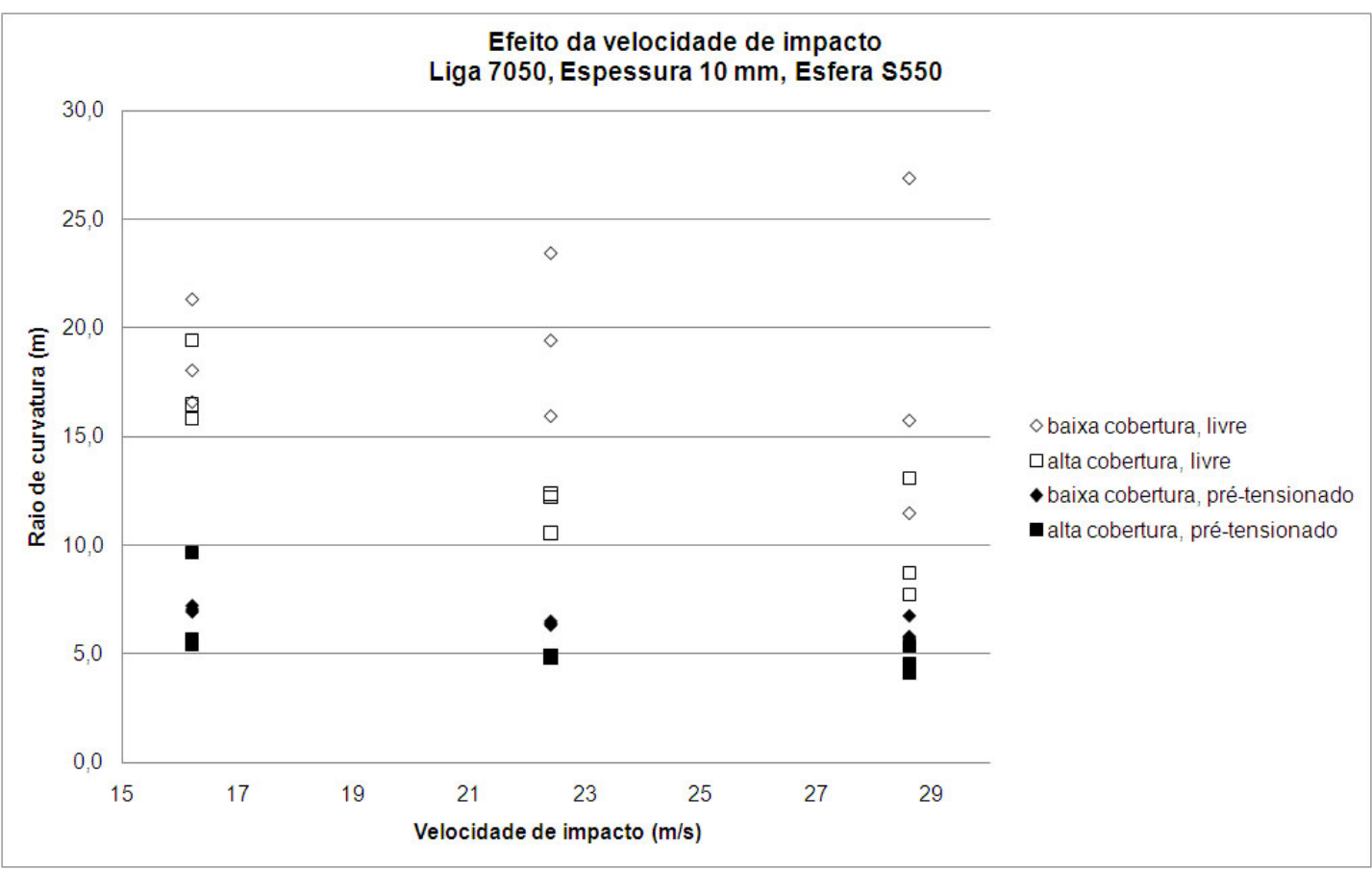

Figura 4.106: Efeito da velocidade de impacto sobre o raio de curvatura. Chapas da liga 7050, espessura $10 \mathrm{~mm}$, jateadas com esfera S550.

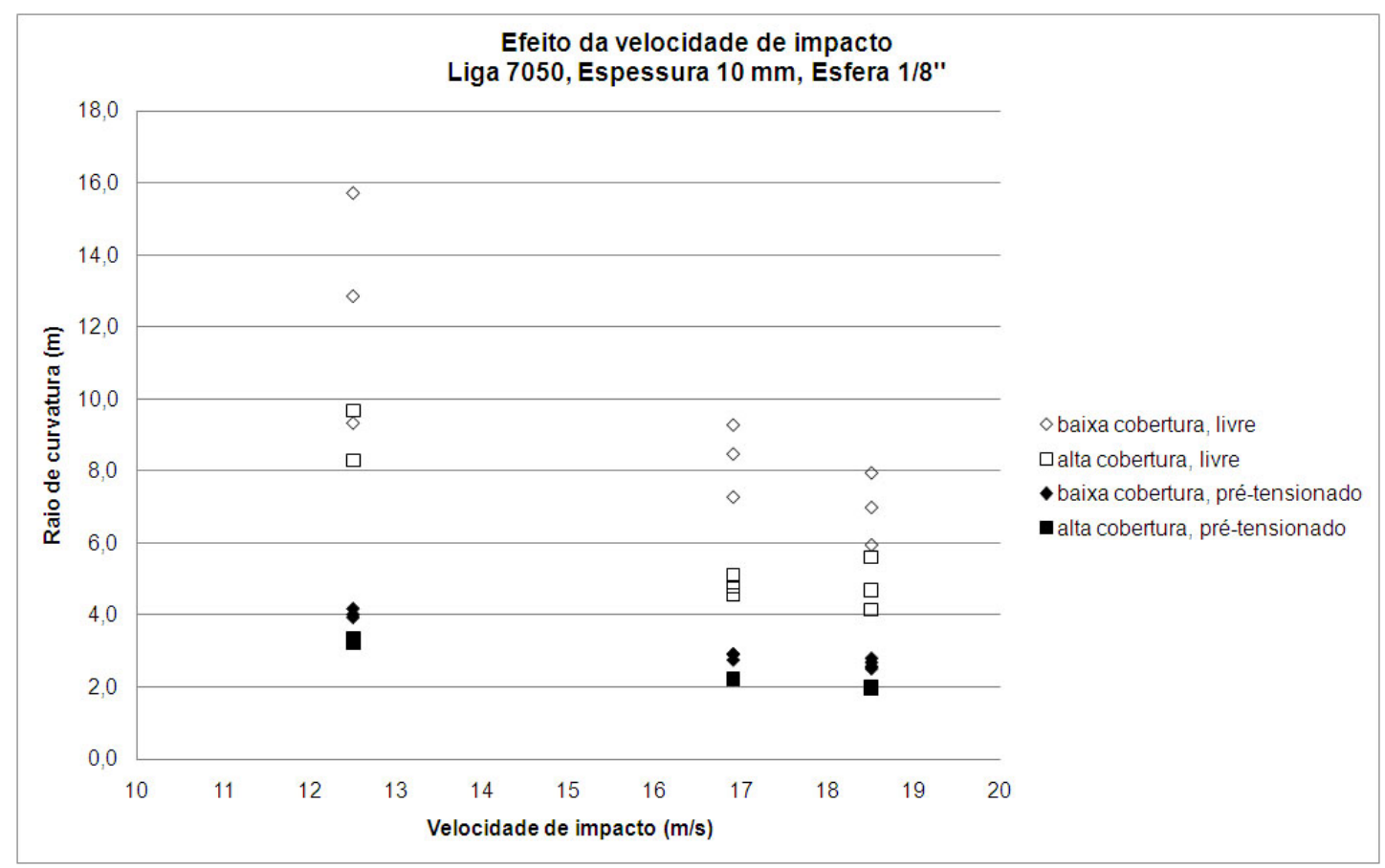

Figura 4.107: Efeito da velocidade de impacto sobre o raio de curvatura. Chapas da liga 7050, espessura $10 \mathrm{~mm}$, jateadas com esfera 1/8". 


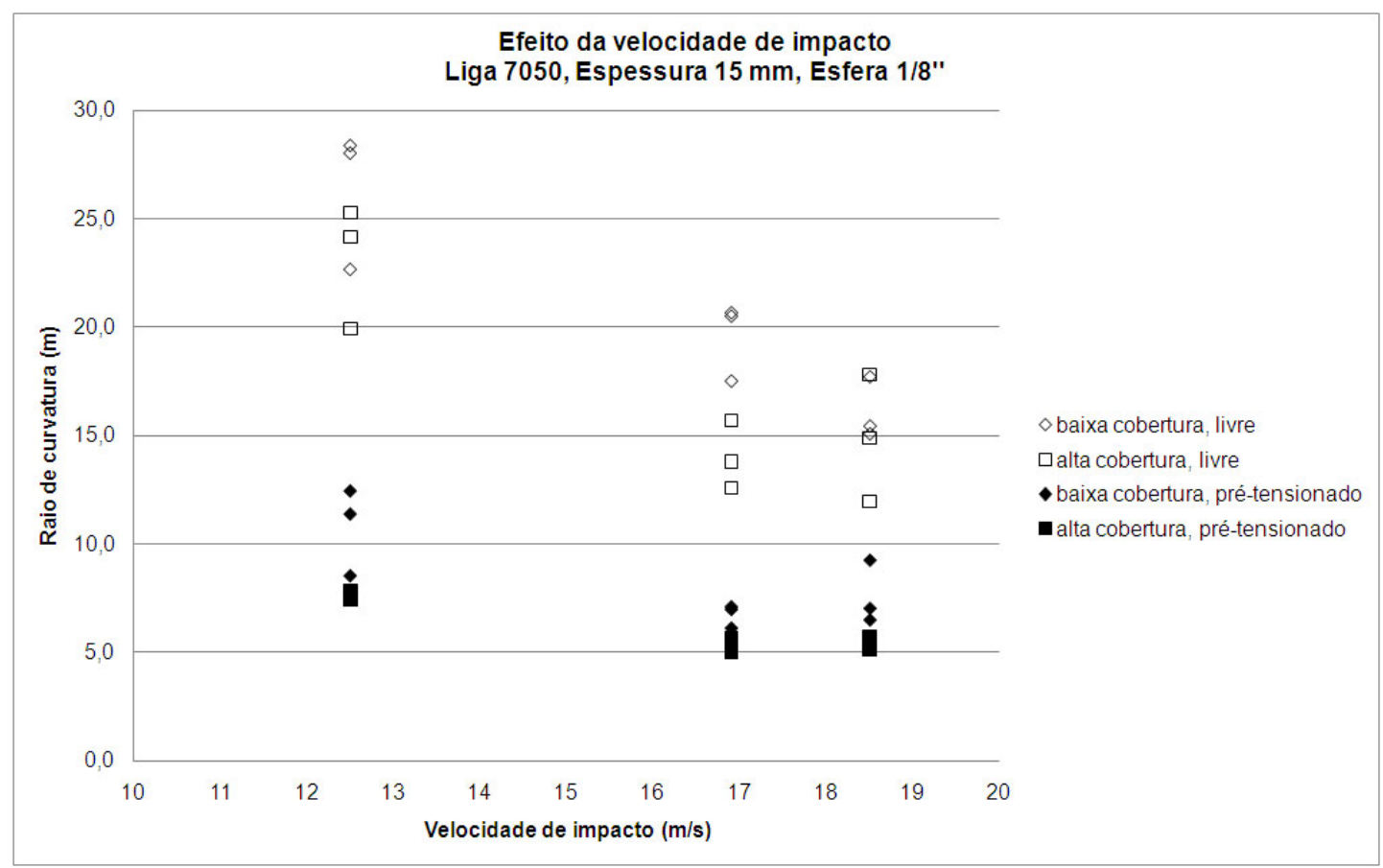

Figura 4.108: Efeito da velocidade de impacto sobre o raio de curvatura. Chapas da liga 7050, espessura $15 \mathrm{~mm}$, jateadas com esfera 1/8".

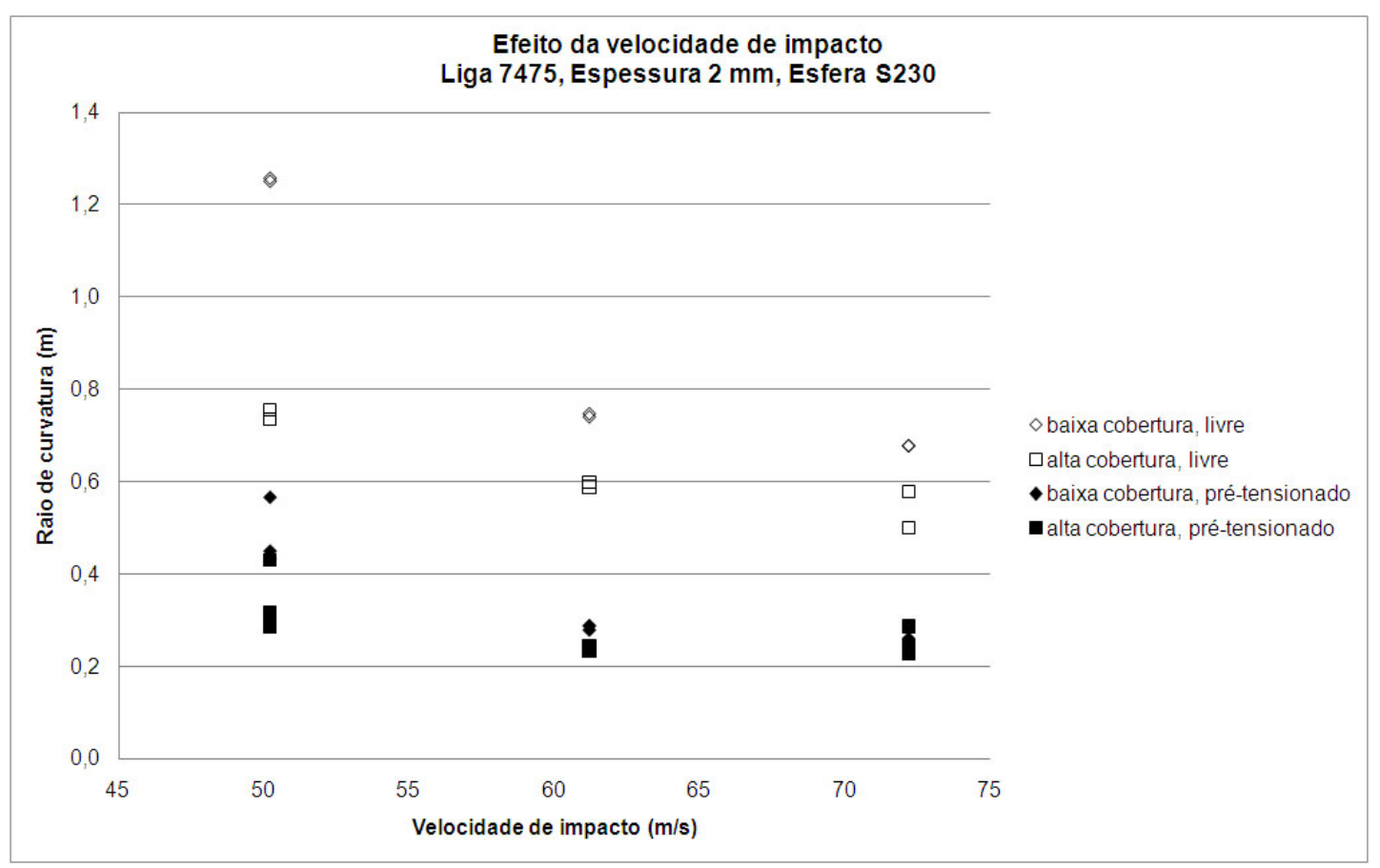

Figura 4.109: Efeito da velocidade de impacto sobre o raio de curvatura. Chapas da liga 7475, espessura 2 mm, jateadas com esfera S230. 


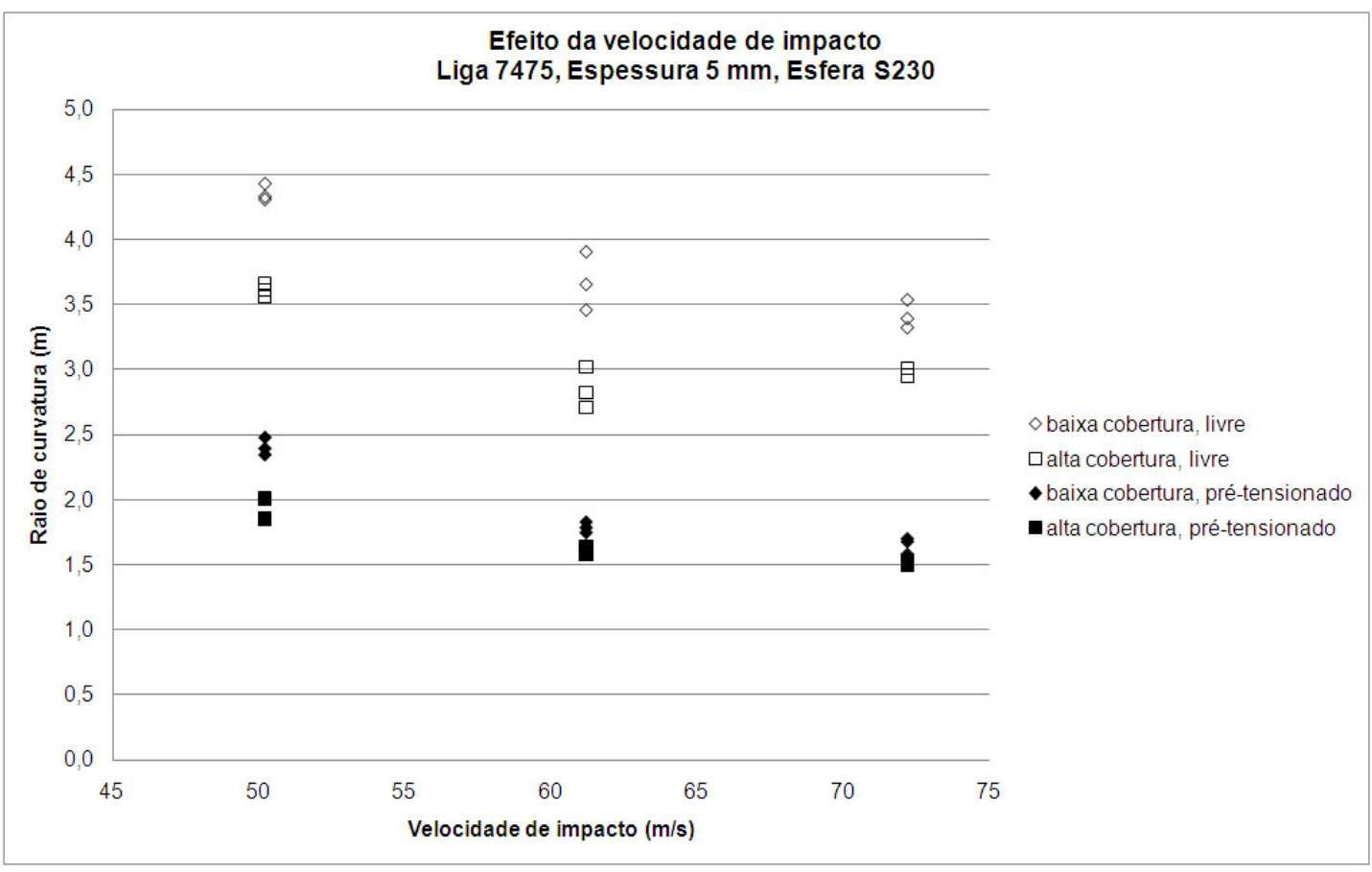

Figura 4.110: Efeito da velocidade de impacto sobre o raio de curvatura. Chapas da liga 7475, espessura $5 \mathrm{~mm}$, jateadas com esfera S230.

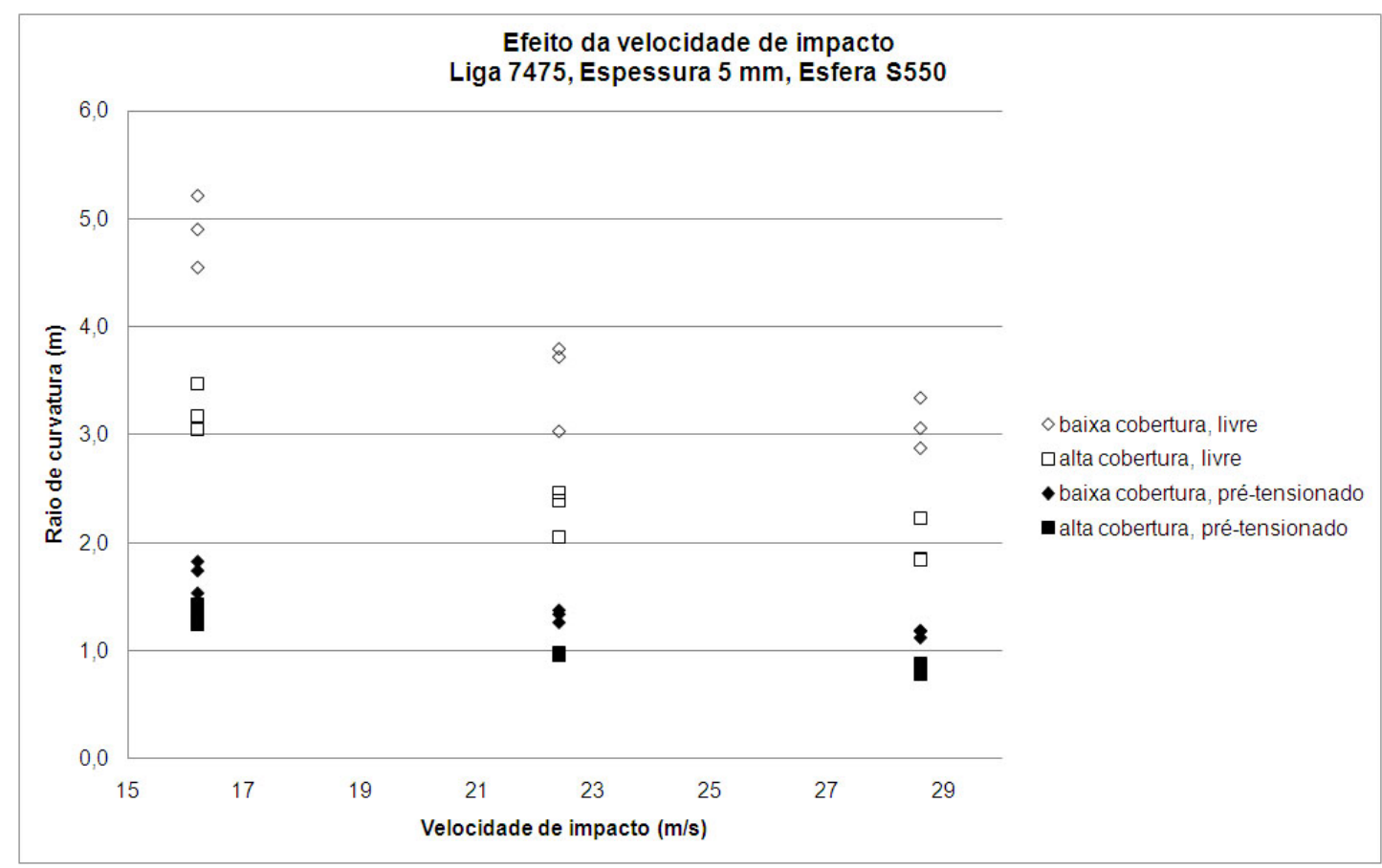

Figura 4.111: Efeito da velocidade de impacto sobre o raio de curvatura. Chapas da liga 7475, espessura $5 \mathrm{~mm}$, jateadas com esfera S550. 


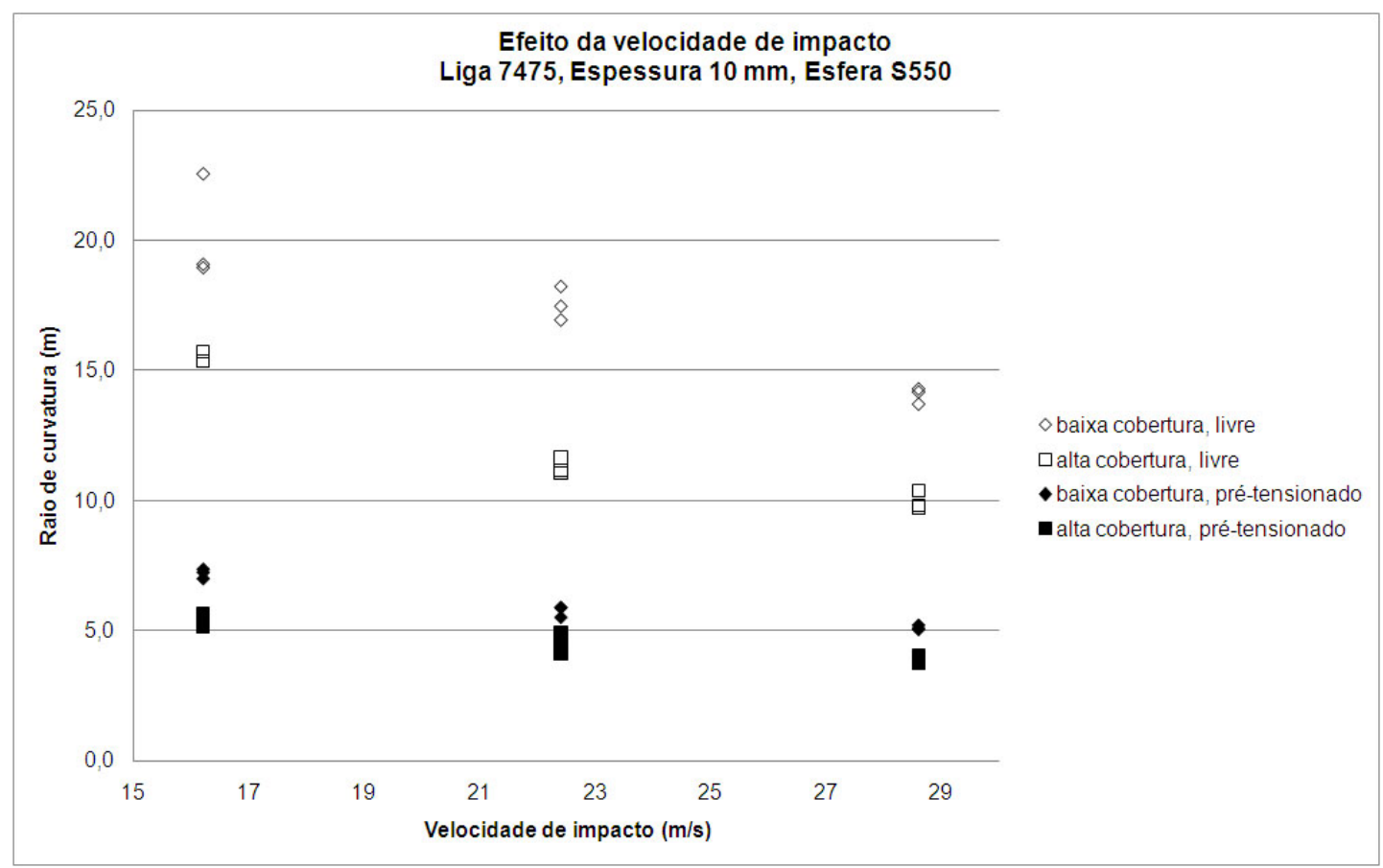

Figura 4.112: Efeito da velocidade de impacto sobre o raio de curvatura. Chapas da liga 7475, espessura $10 \mathrm{~mm}$, jateadas com esfera S550.

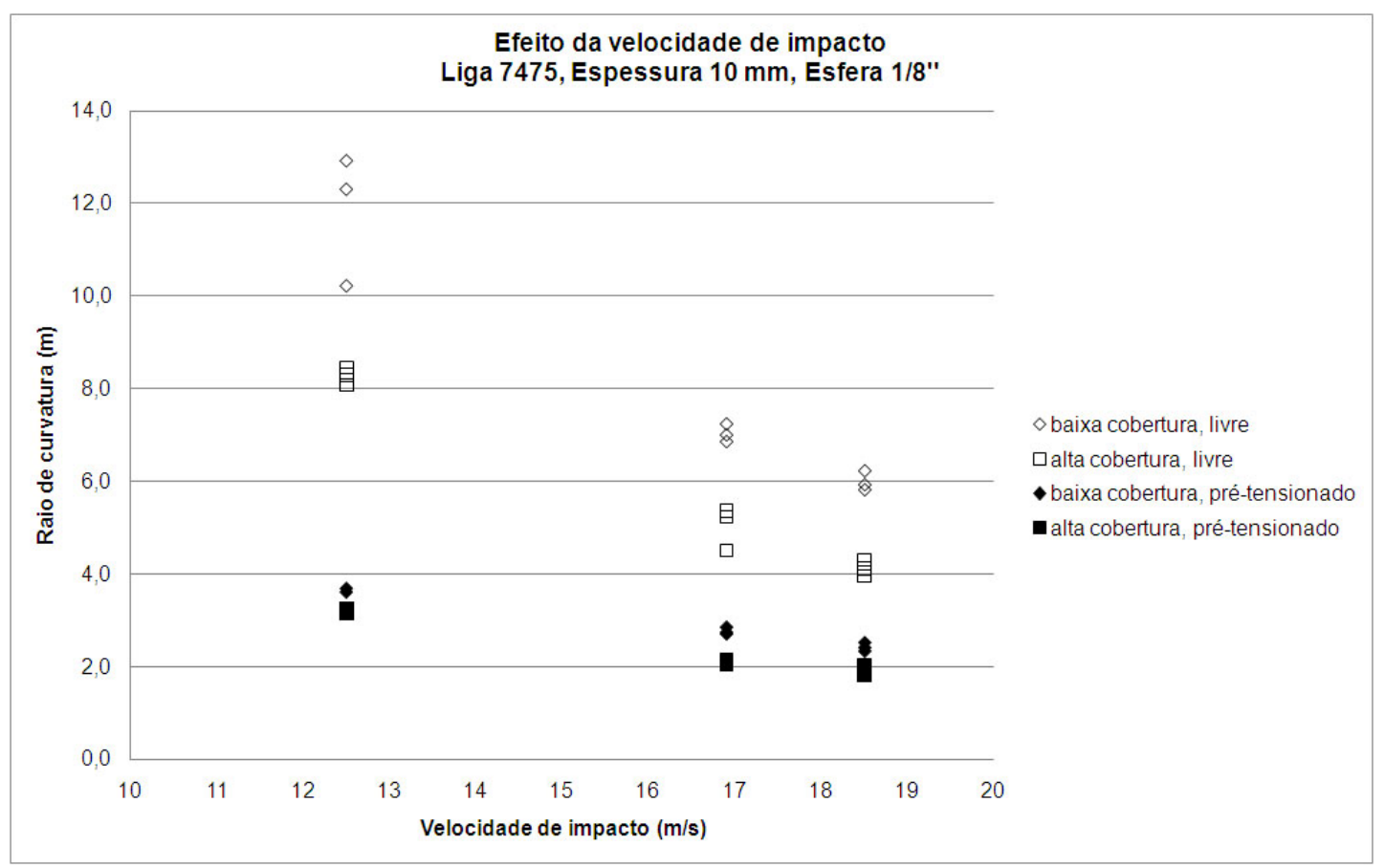

Figura 4.113: Efeito da velocidade de impacto sobre o raio de curvatura. Chapas da liga 7475, espessura $10 \mathrm{~mm}$, jateadas com esfera $1 / 8$ ". 


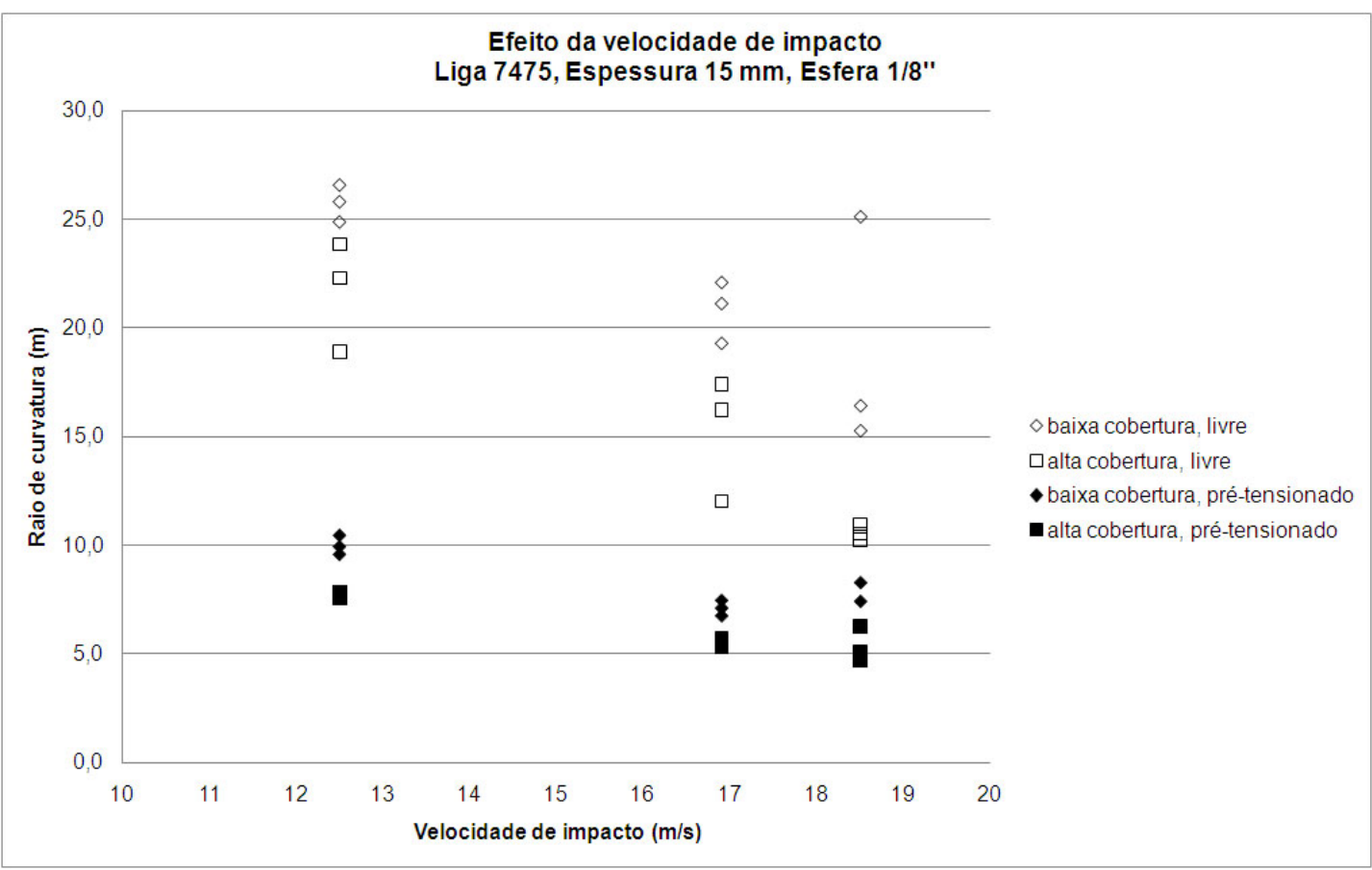

Figura 4.114: Efeito da velocidade de impacto sobre o raio de curvatura. Chapas da liga 7475 , espessura $15 \mathrm{~mm}$, jateadas com esfera $1 / 8$ ".

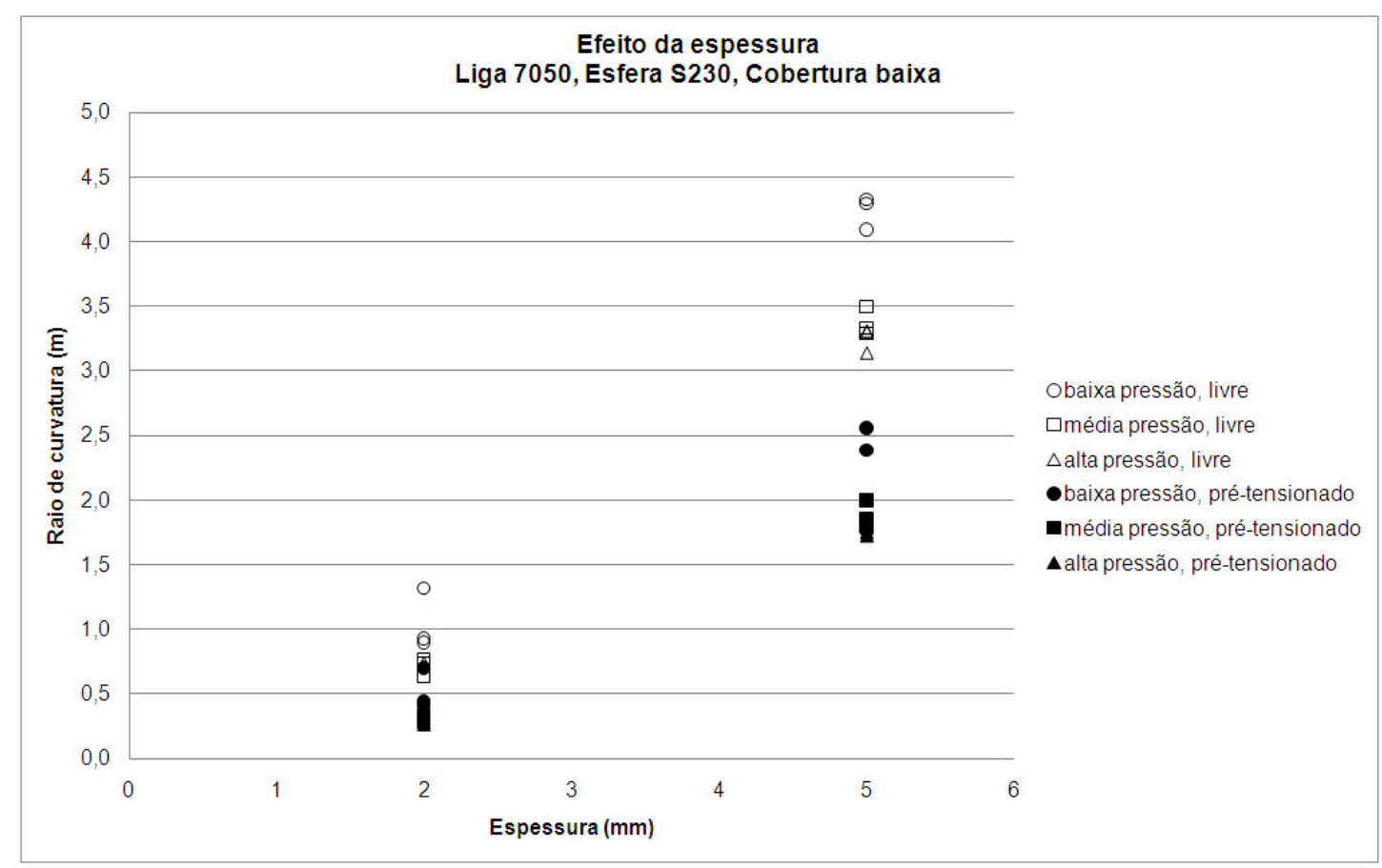

Figura 4.115: Efeito da espessura da chapa sobre o raio de curvatura. Chapas da liga 7050, jateadas com esfera S230, baixa cobertura. 


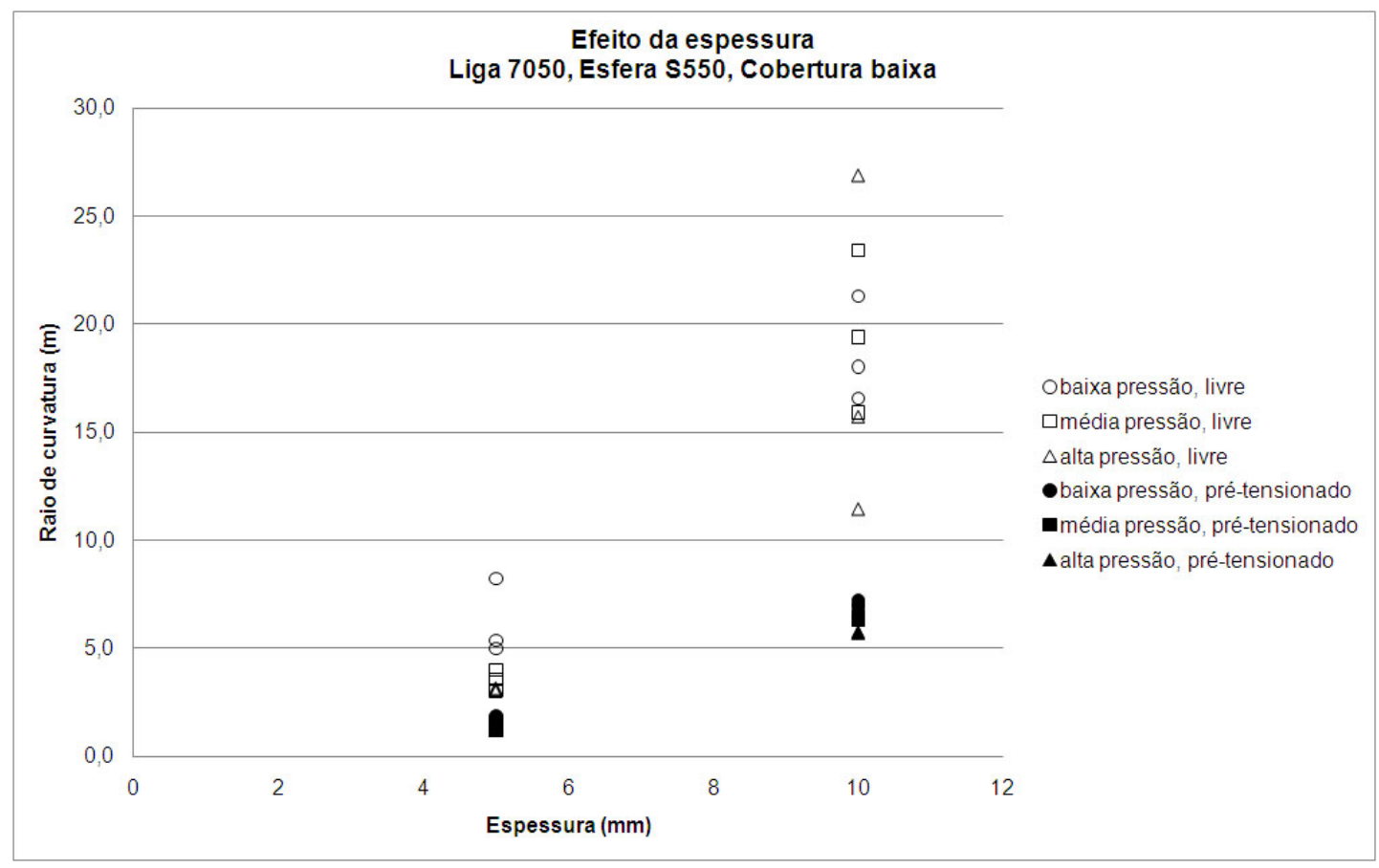

Figura 4.116: Efeito da espessura da chapa sobre o raio de curvatura. Chapas da liga 7050, jateadas com esfera S550, baixa cobertura.

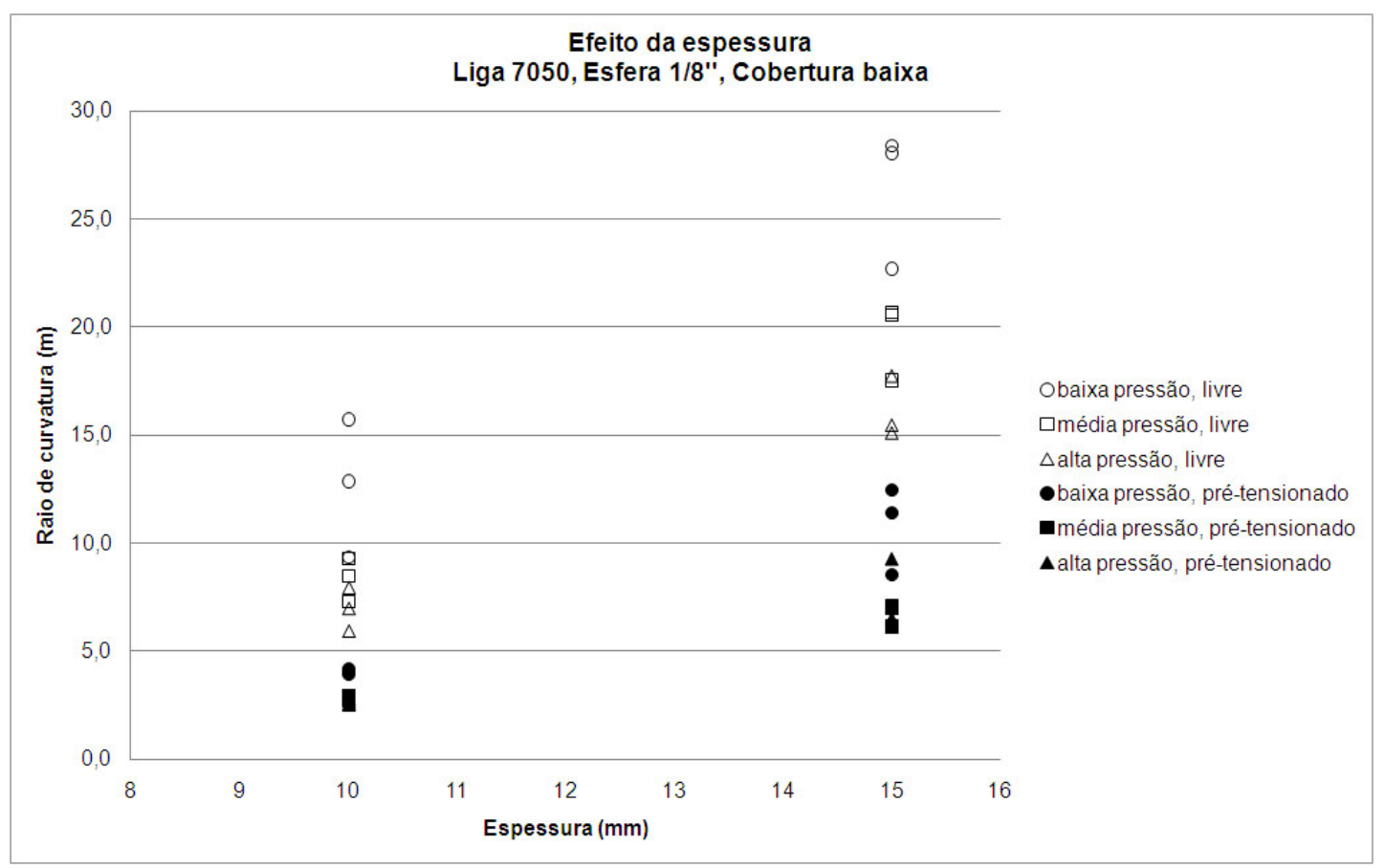

Figura 4.117: Efeito da espessura da chapa sobre o raio de curvatura. Chapas da liga 7050 , jateadas com esfera $1 / 8$ ", baixa cobertura. 


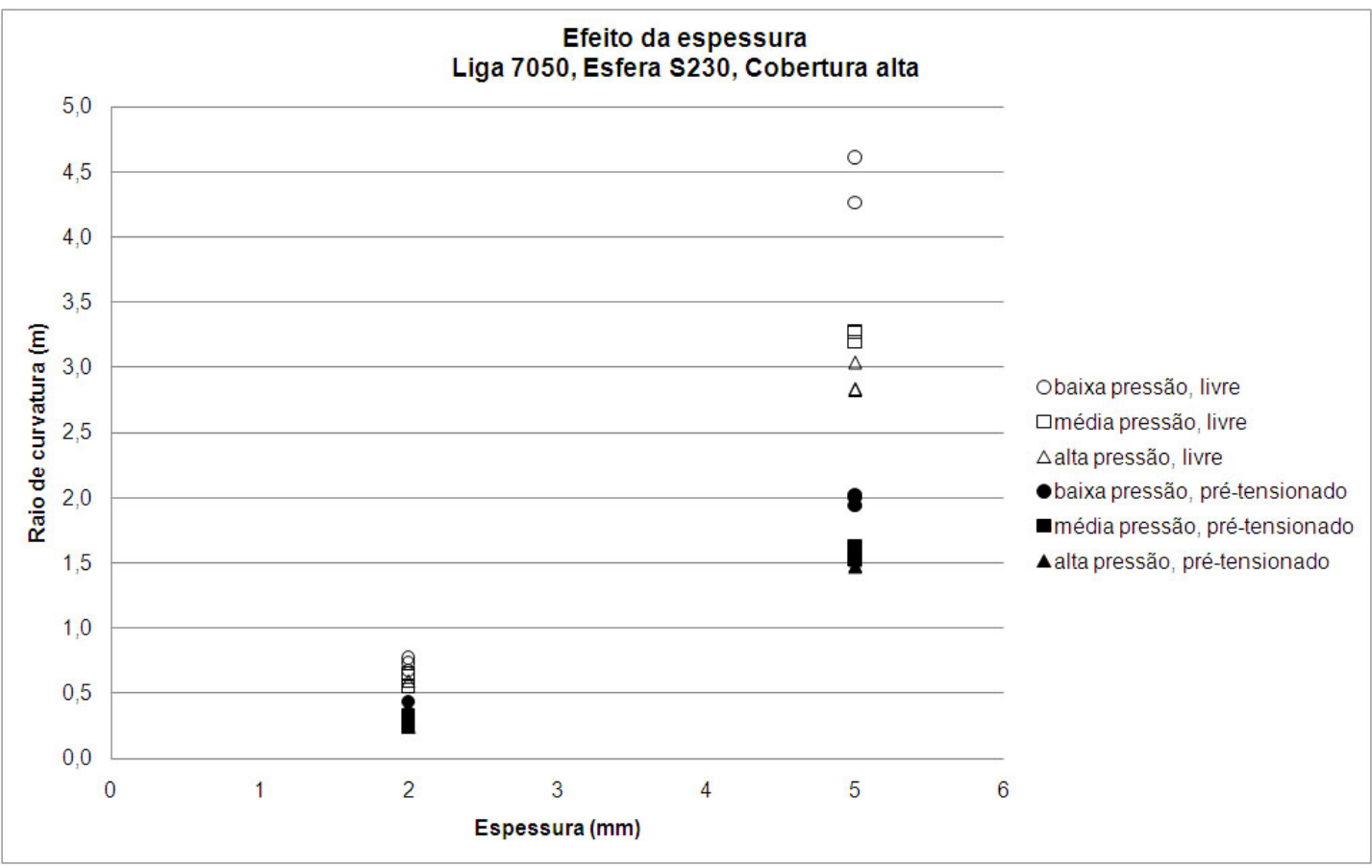

Figura 4.118: Efeito da espessura da chapa sobre o raio de curvatura. Chapas da liga 7050, jateadas com esfera S230, alta cobertura.

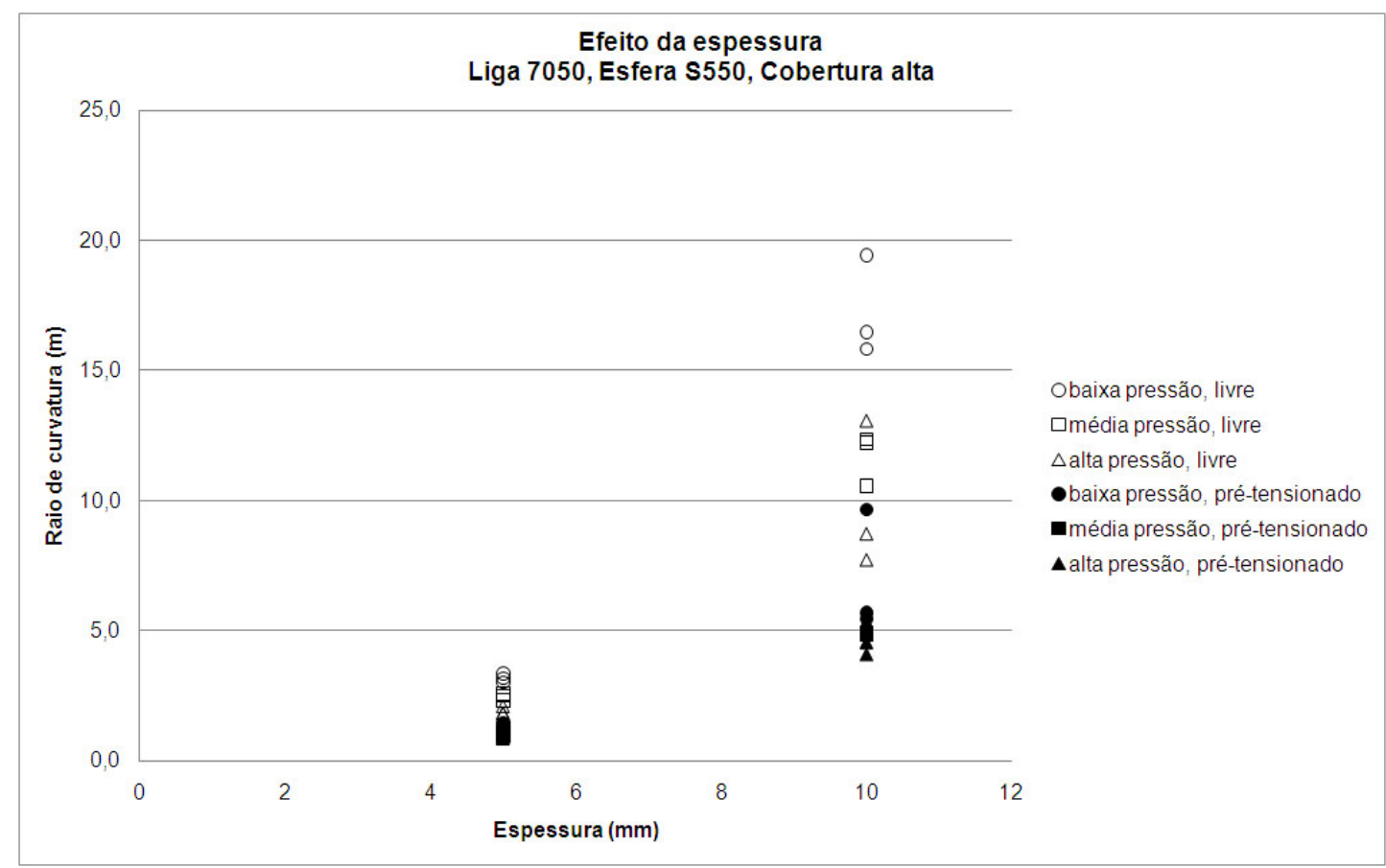

Figura 4.119: Efeito da espessura da chapa sobre o raio de curvatura. Chapas da liga 7050, jateadas com esfera S550, alta cobertura. 


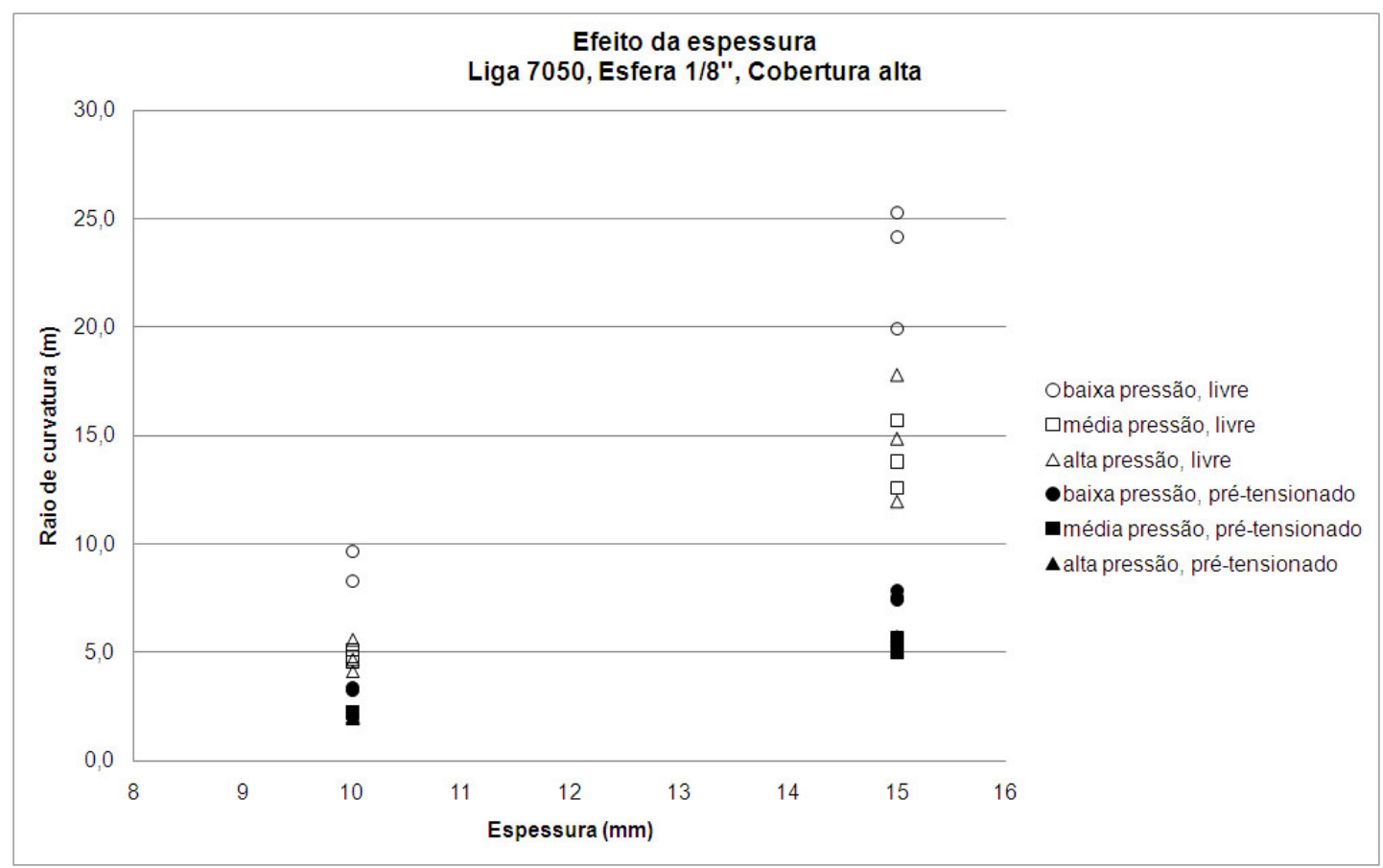

Figura 4.120: Efeito da espessura da chapa sobre o raio de curvatura. Chapas da liga 7050 , jateadas com esfera 1/8", alta cobertura.

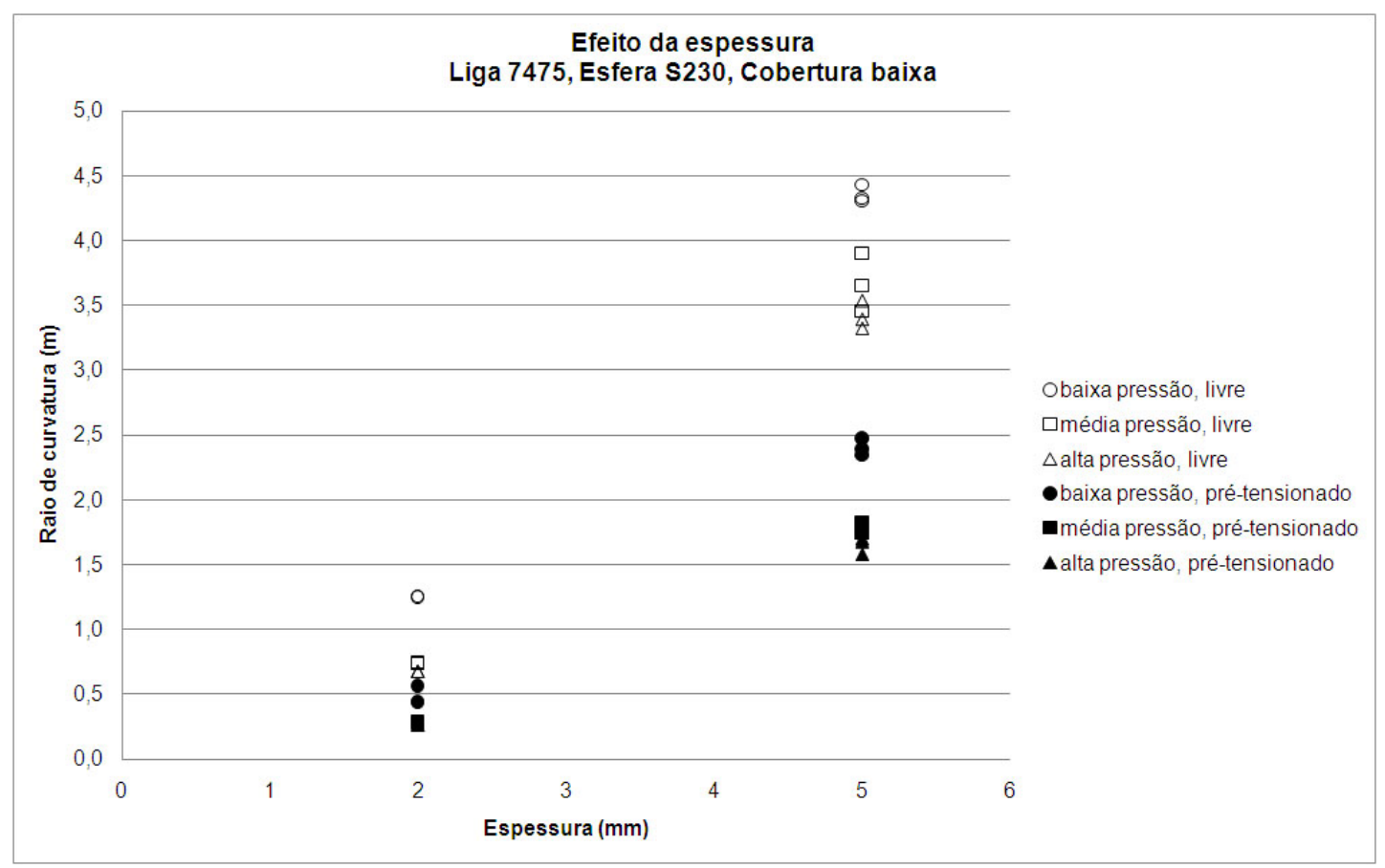

Figura 4.121: Efeito da espessura da chapa sobre o raio de curvatura. Chapas da liga 7475, jateadas com esfera $\$ 230$, baixa cobertura. 
Efeito da espessura

Liga 7475, Esfera S550, Cobertura baixa

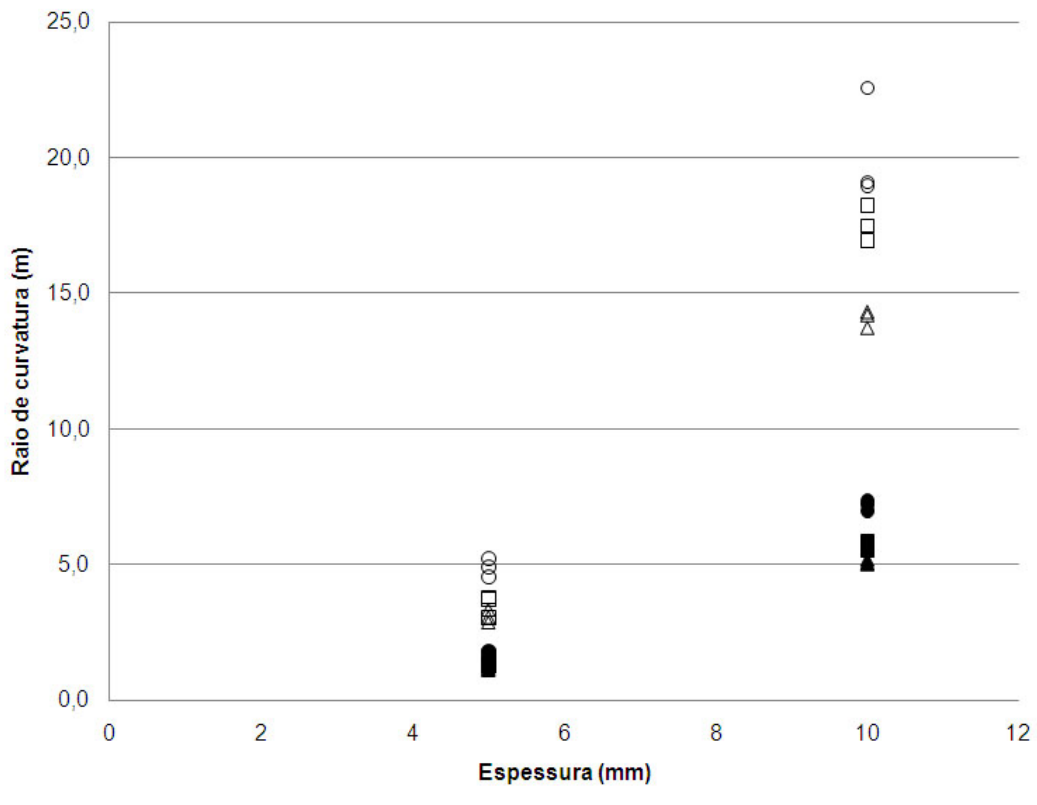

Obaixa pressão, livre $\square$ média pressão, livre $\triangle$ alta pressão, livre

- baixa pressão, pré-tensionado -média pressão, pré-tensionado A alta pressão, pré-tensionado

Figura 4.122: Efeito da espessura da chapa sobre o raio de curvatura. Chapas da liga 7475, jateadas com esfera S550, baixa cobertura.

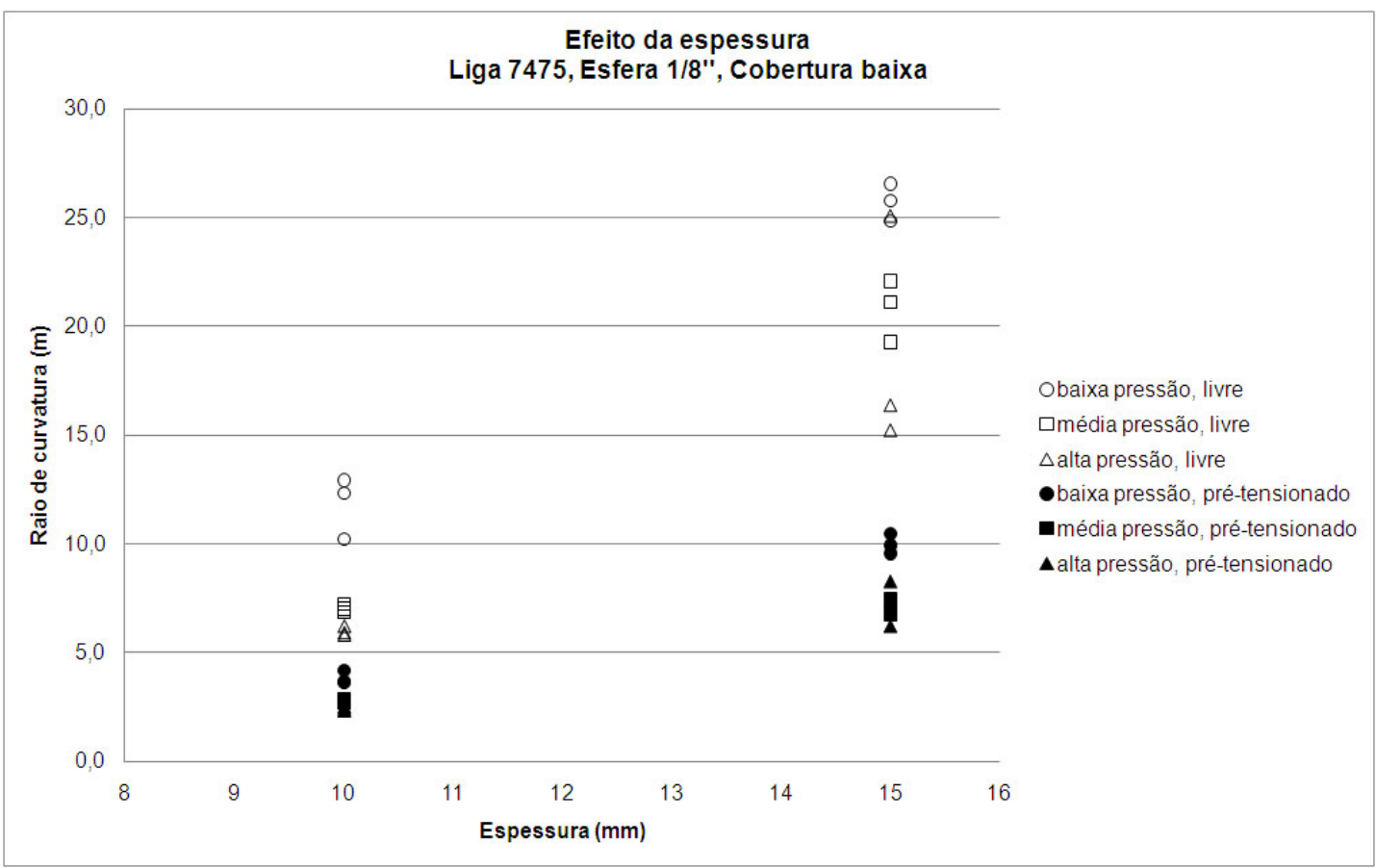

Figura 4.123: Efeito da espessura da chapa sobre o raio de curvatura. Chapas da liga 7475 , jateadas com esfera 1/8", baixa cobertura. 


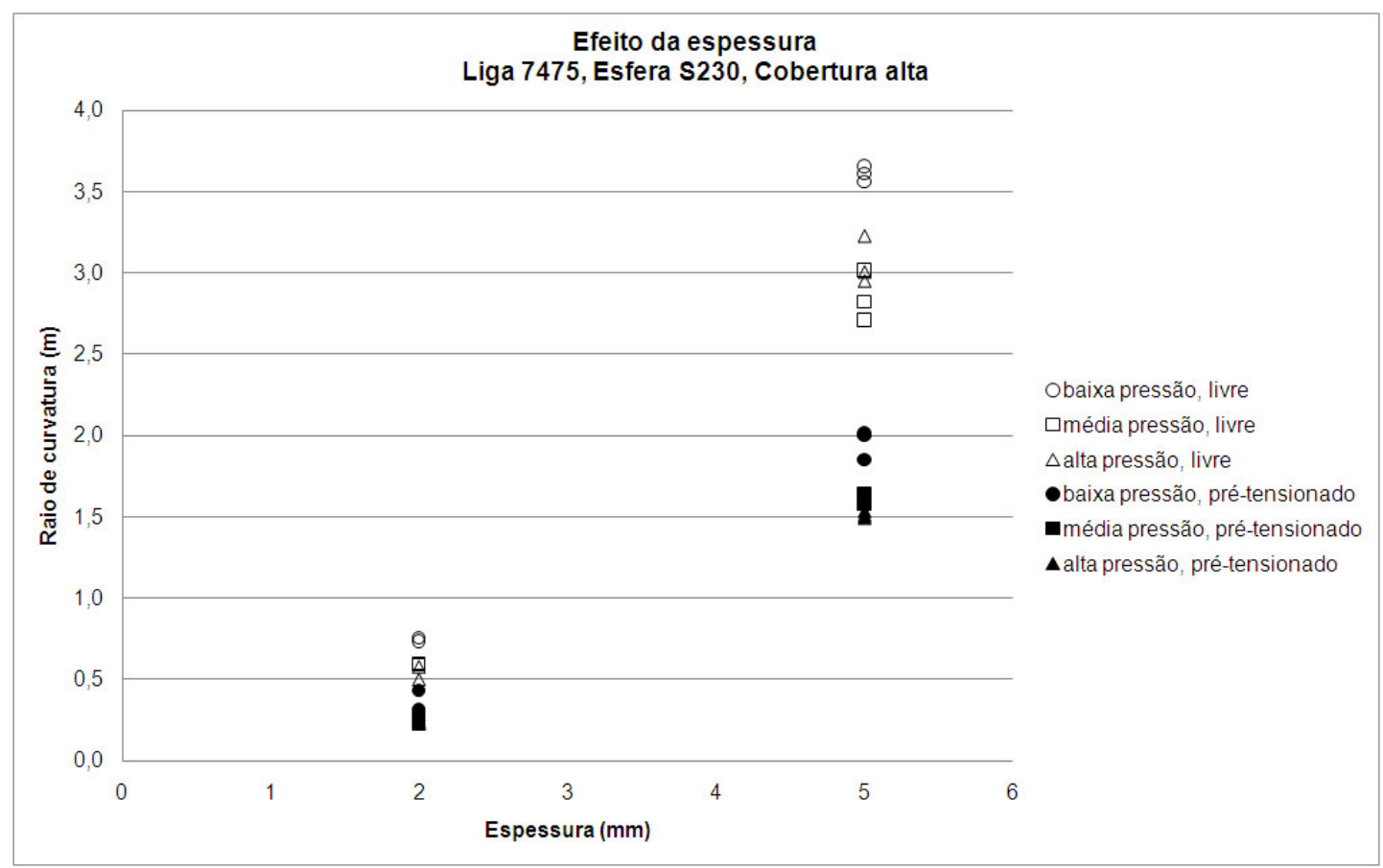

Figura 4.124: Efeito da espessura da chapa sobre o raio de curvatura. Chapas da liga 7475, jateadas com esfera S230, alta cobertura.

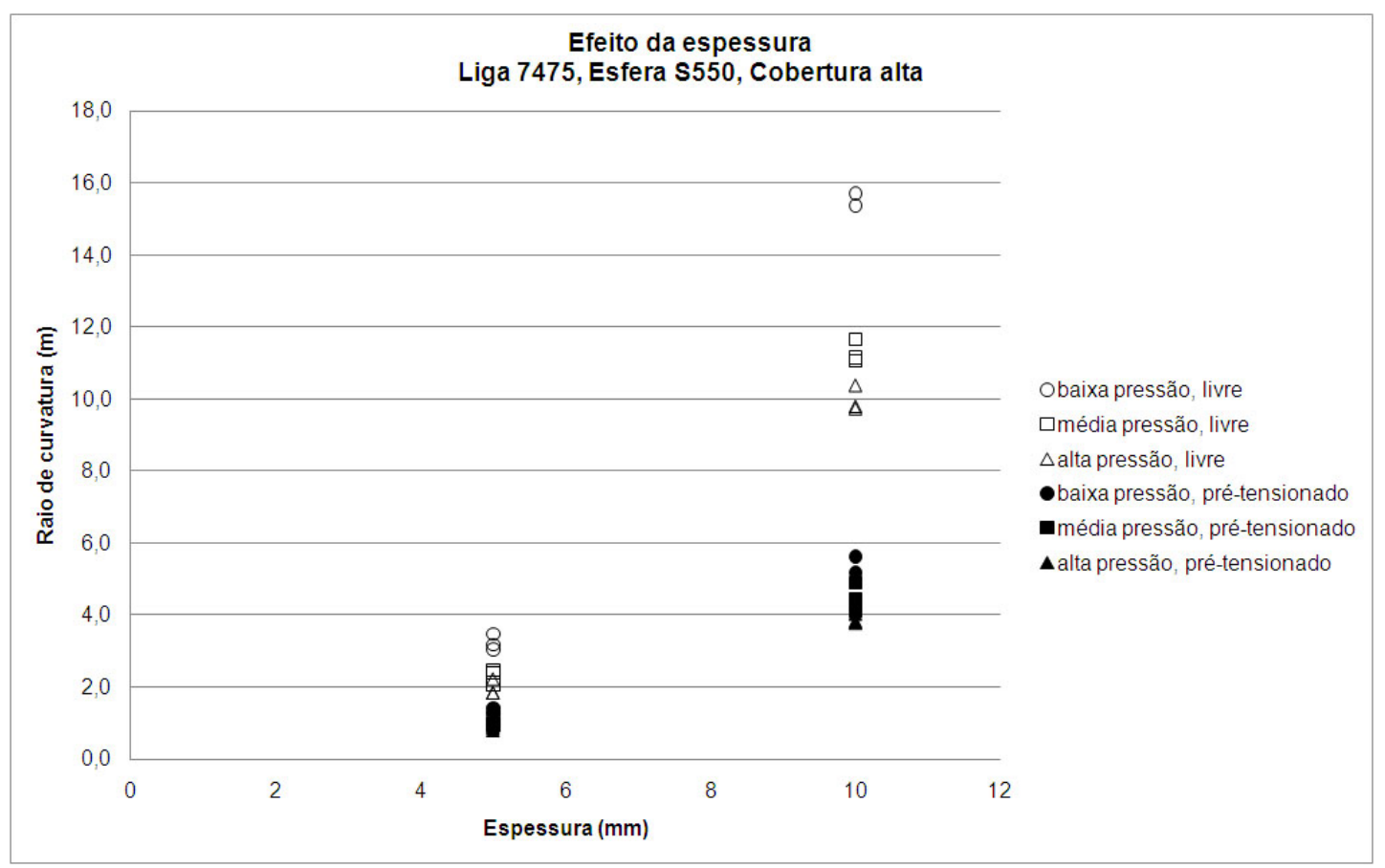

Figura 4.125: Efeito da espessura da chapa sobre o raio de curvatura. Chapas da liga 7475, jateadas com esfera S550, alta cobertura. 


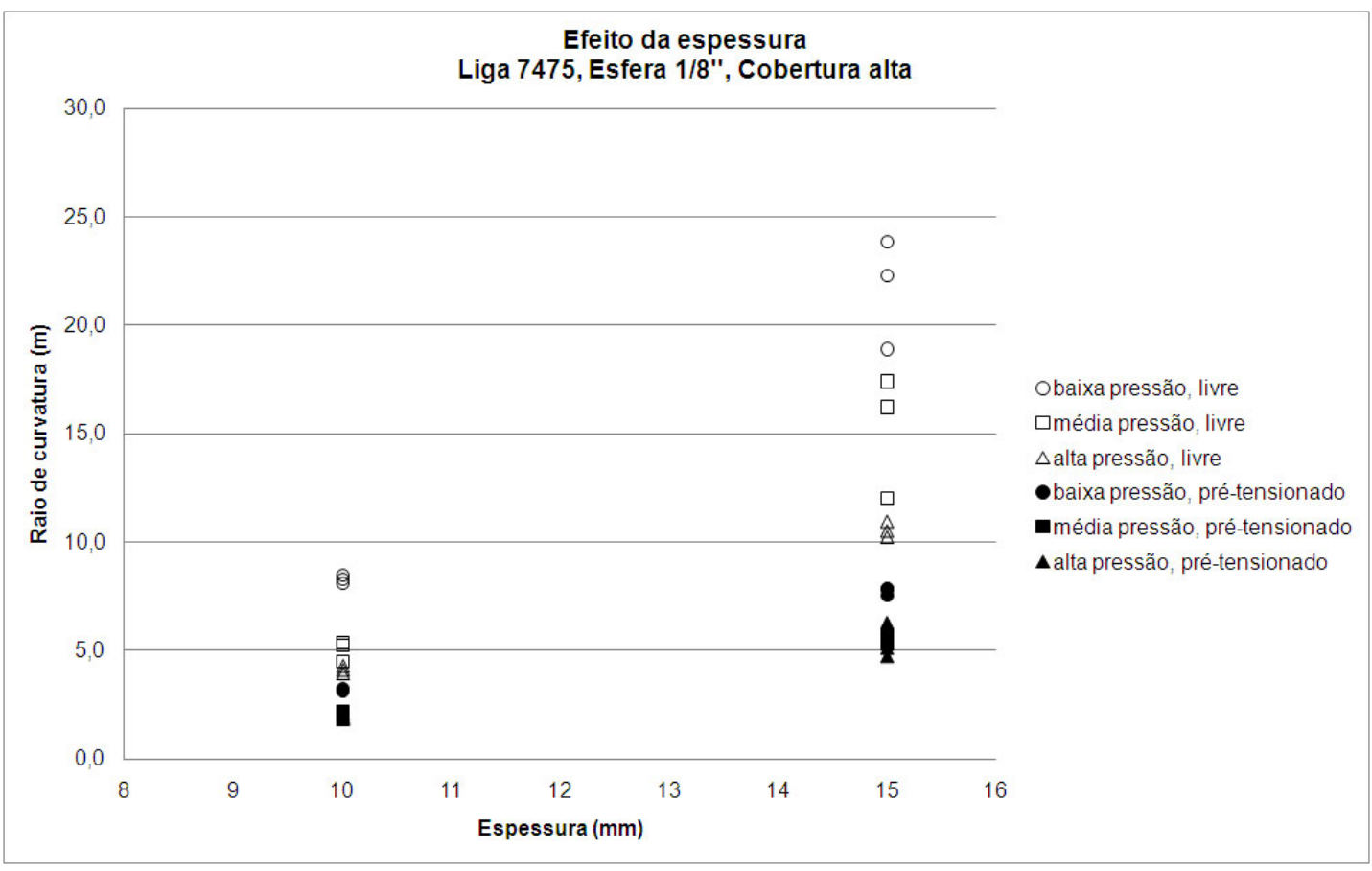

Figura 4.126: Efeito da espessura da chapa sobre o raio de curvatura. Chapas da liga 7475, jateadas com esfera 1/8", alta cobertura.

\subsubsection{Discussão}

Na Figura 4.76 pode-se analisar o efeito da cobertura em chapas da liga 7475, com espessura $5 \mathrm{~mm}$, jateadas com esferas S550. No mesmo gráfico, podemse comparar as 3 pressões (baixa, média e alta - 10, 20 e 30 psi), com e sem pré-tensão. Na Figura 4.78, a espessura das chapas é $10 \mathrm{~mm}$.

Há grande dificuldade em avaliar, no entanto, se há diferenças no efeito de um parâmetro qualquer em relação a chapas de espessuras diferentes, porque o efeito da espessura sobressai a todos os demais, como se pode ver na Figura 4.125, que mostra os valores das chapas anteriores, fixando-se desta vez a cobertura em $200 \%$ e observando-se o efeito da espessura.

Para contornar esse problema, uma normalização das medidas seria de grande auxílio.

Uma forma utilizada na Resistência dos Materiais é dividir os valores de raio de curvatura pelo módulo resistente, $W$, que é dado por:

$$
W=\frac{I}{c}=\frac{\frac{b H^{3}}{\frac{12}{2}}}{\frac{H}{6}} H^{2}
$$

onde $I$ é o momento de inércia, $c$ é a metade da espessura, $H$, e $b$ é a largura. 
Como, em todos os corpos de prova, $b / 6$ é constante, basta dividir os raios de curvatura por $H^{2}$. Assim, os gráficos citados anteriormente poderiam ser sintetizados em um só, pois os valores de $r / H^{2}$ são equivalentes, como mostram as Figuras 4.127 a 4.138 , relacionadas na Tabela 4.5.

Tabela 4.5: Números das figuras com resultados de efeitos dos parâmetros sobre o raio de curvatura normalizado $\left(r / H^{2}\right)$.

\begin{tabular}{c|c|c|c|c|c}
\hline Figura & Parâmetro & Liga & $\mathrm{D}_{\text {medio }}(\mathrm{mm})$ & Pressão & $\mathrm{C}$ \\
\hline 4.127 & Espessura & 7050 & 0,58 & var & baixa \\
\hline 4.128 & Espessura & 7475 & 0,58 & var & baixa \\
\hline 4.129 & Espessura & 7050 & 1,40 & var & baixa \\
\hline 4.130 & Espessura & 7475 & 1,40 & var & baixa \\
\hline 4.131 & Espessura & 7050 & 3,40 & var & baixa \\
\hline 4.132 & Espessura & 7475 & 3,40 & var & baixa \\
\hline 4.133 & Espessura & 7050 & 0,58 & var & alta \\
\hline 4.134 & Espessura & 7475 & 0,58 & var & alta \\
\hline 4.135 & Espessura & 7050 & 1,40 & var & alta \\
\hline 4.136 & Espessura & 7475 & 1,40 & var & alta \\
\hline 4.137 & Espessura & 7050 & 3,18 & var & alta \\
\hline 4.138 & Espessura & 7475 & 3,18 & var & alta \\
\hline \hline 4.139 & Liga & var & 0,58 & var & baixa \\
\hline 4.140 & Liga & var & 1,40 & var & baixa \\
\hline 4.141 & Liga & var & 3,18 & var & baixa \\
\hline 4.142 & Liga & var & 0,58 & var & alta \\
\hline 4.143 & Liga & var & 1,40 & var & alta \\
\hline 4.144 & Liga & var & 3,18 & var & alta \\
\hline \hline 4.145 & Cobertura & ambas & 0,58 & var & var \\
\hline 4.146 & Cobertura & ambas & 1,40 & var & var \\
\hline 4.147 & Cobertura & ambas & 3,18 & var & var \\
\hline 4.148 & Esfera & ambas & var & var & baixa \\
\hline 4.149 & Esfera & ambas & var & var & alta \\
\hline 4.150 & Esfera & ambas & var & baixa & var \\
\hline 4.151 & Esfera & ambas & var & média & var \\
\hline 4.152 & Esfera & ambas & var & alta & var \\
\hline 4.153 & Velocidade & ambas & var & var & baixa \\
\hline 4.154 & Velocidade & ambas & var & var & alta \\
\hline & & & & &
\end{tabular}




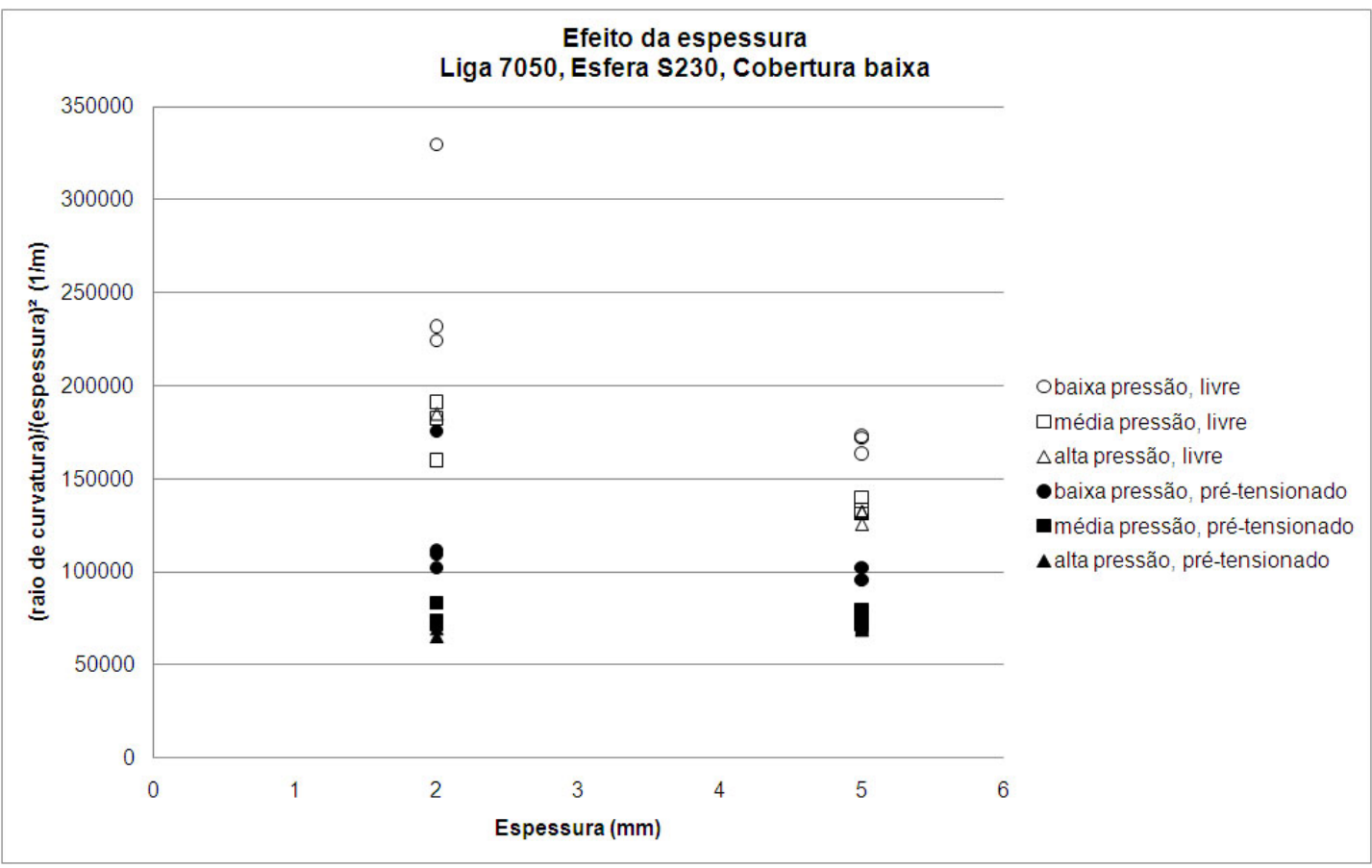

Figura 4.127: Efeito da espessura da chapa sobre $r / H^{2}$. Chapas da liga 7050 , jateadas com esfera S230, baixa cobertura.

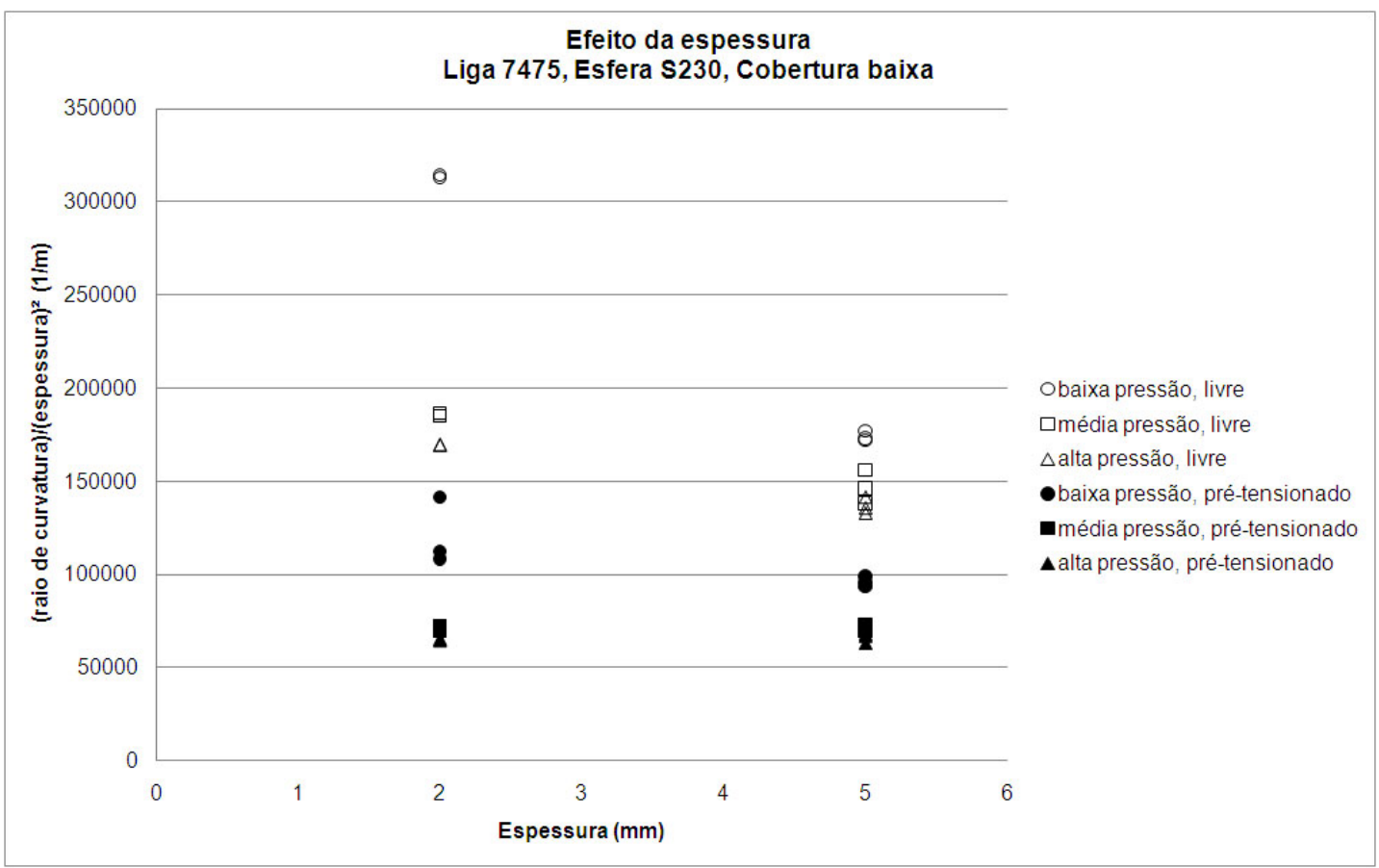

Figura 4.128: Efeito da espessura da chapa sobre $r / H^{2}$. Chapas da liga 7475 , jateadas com esfera S230, baixa cobertura. 


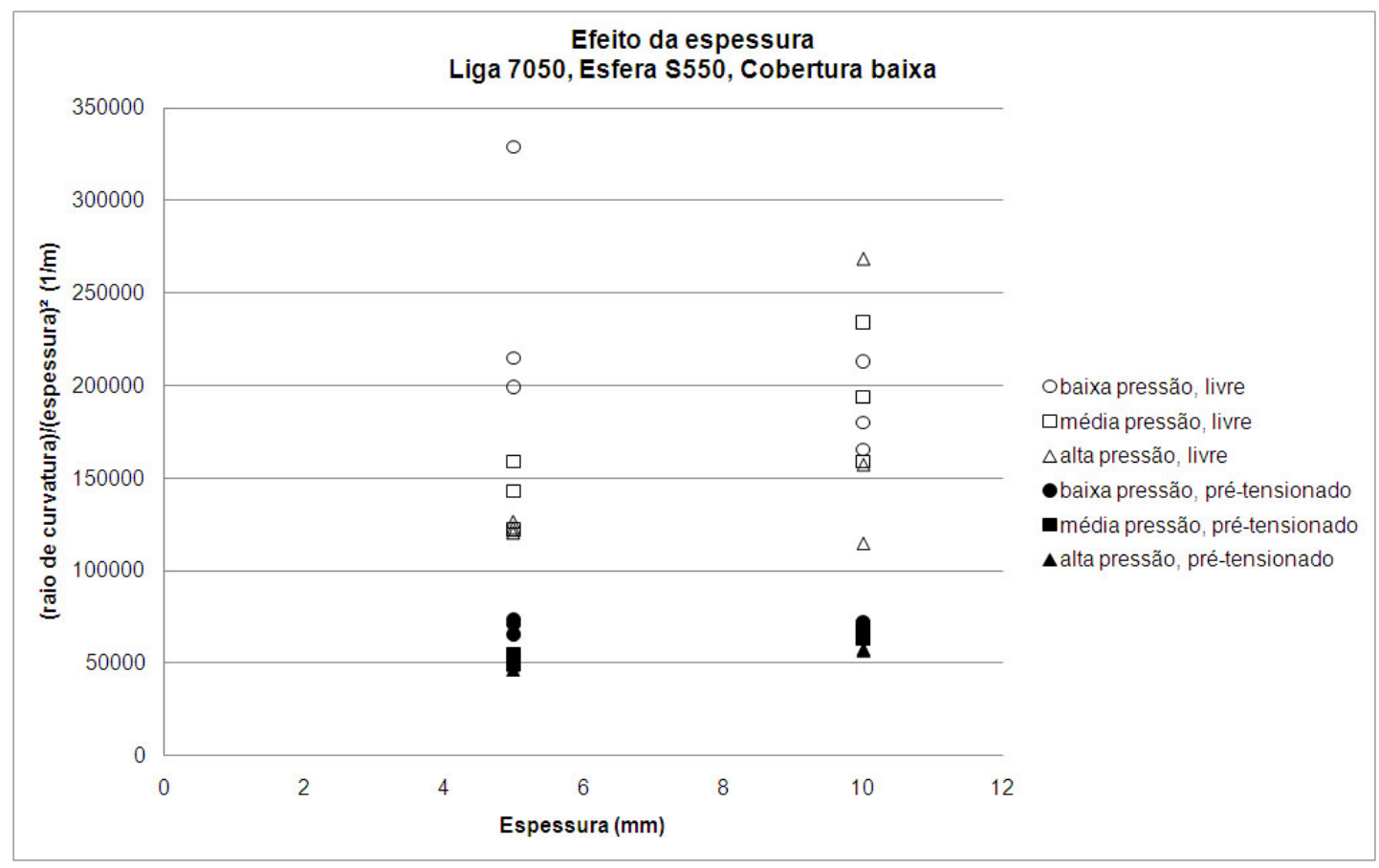

Figura 4.129: Efeito da espessura da chapa sobre $r / H^{2}$. Chapas da liga 7050, jateadas com esfera S550, baixa cobertura.

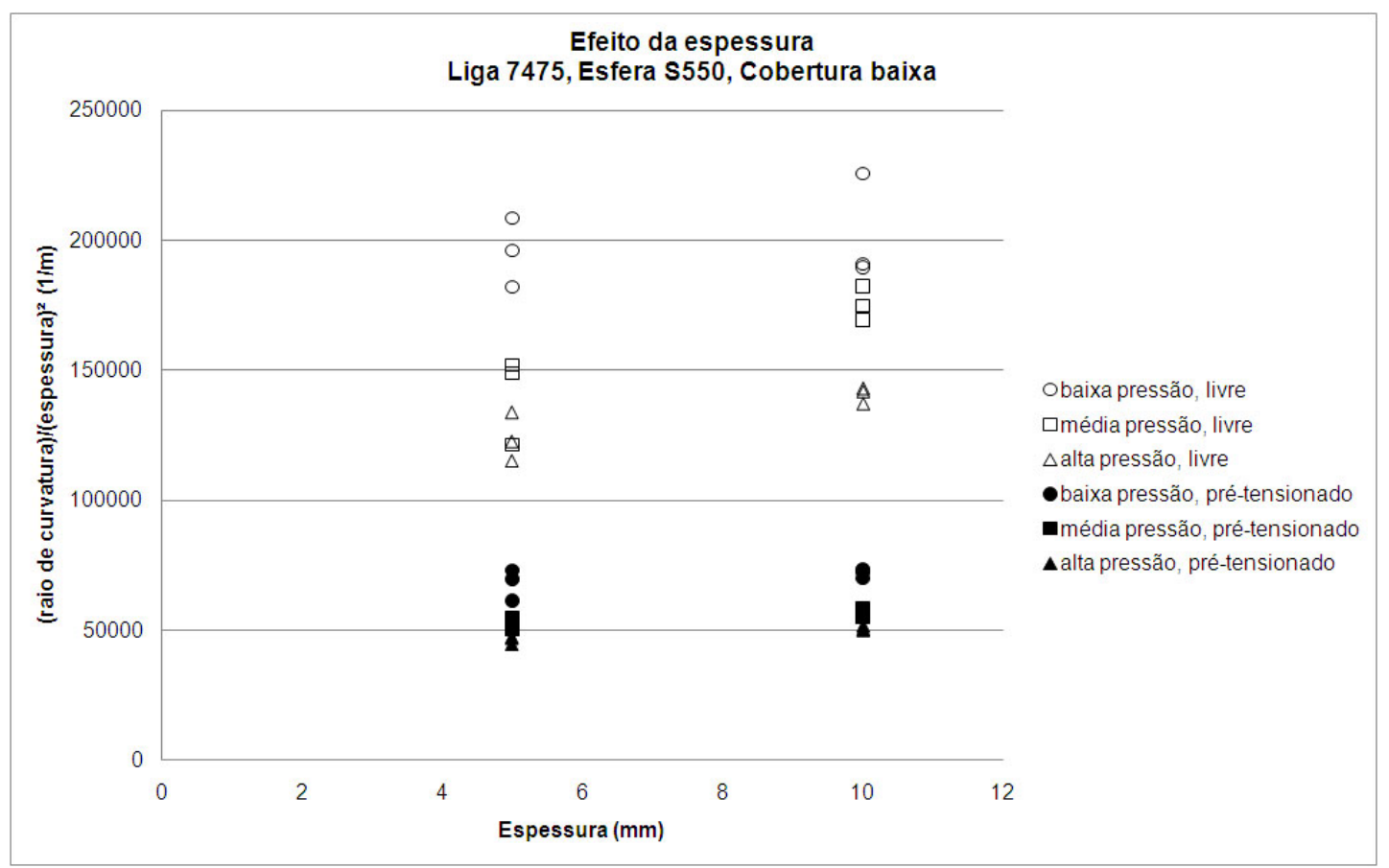

Figura 4.130: Efeito da espessura da chapa sobre $r / H^{2}$. Chapas da liga 7475 , jateadas com esfera $\$ 550$, baixa cobertura. 


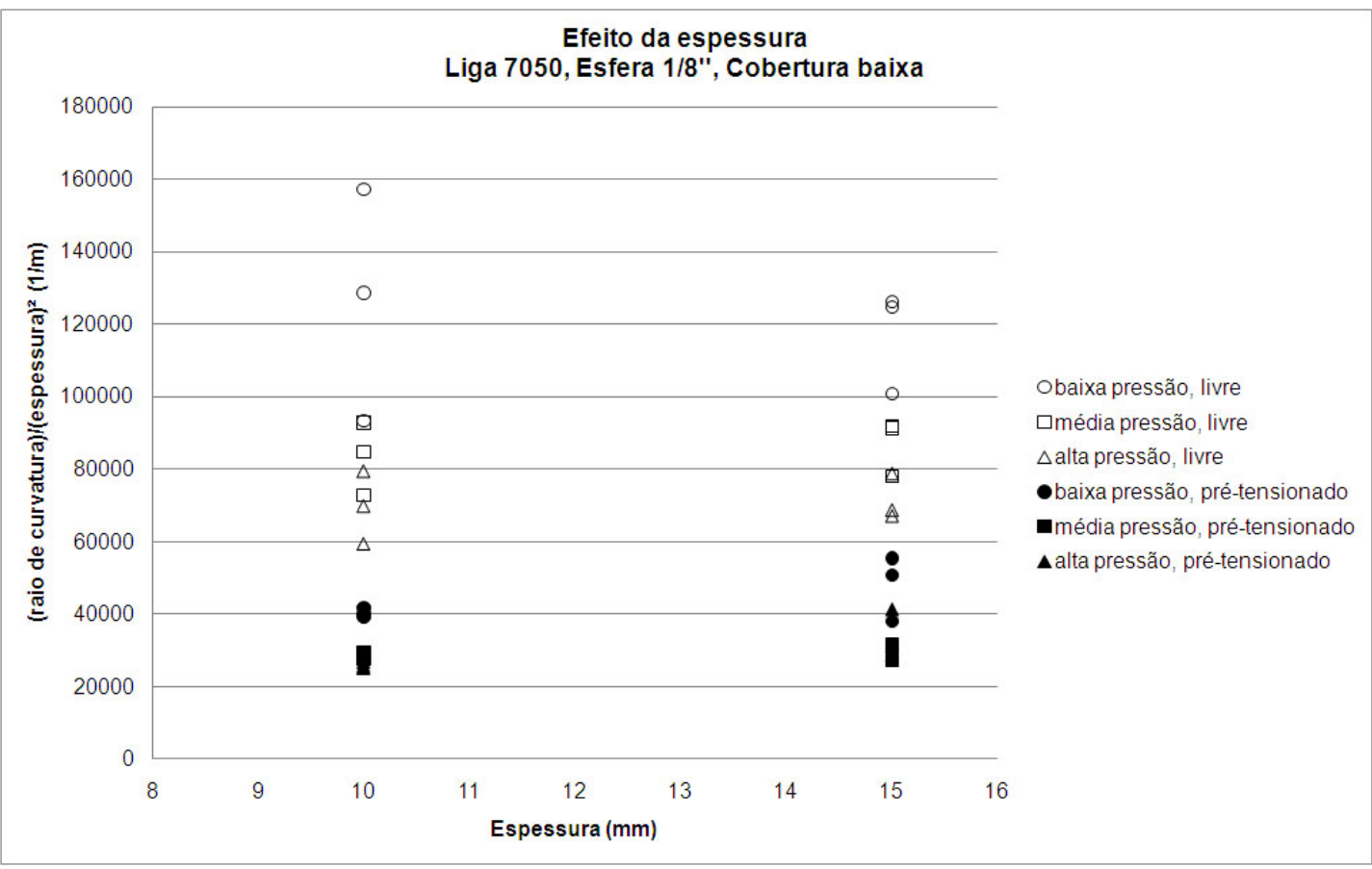

Figura 4.131: Efeito da espessura da chapa sobre $r / H^{2}$. Chapas da liga 7050, jateadas com esfera 1/8", baixa cobertura.

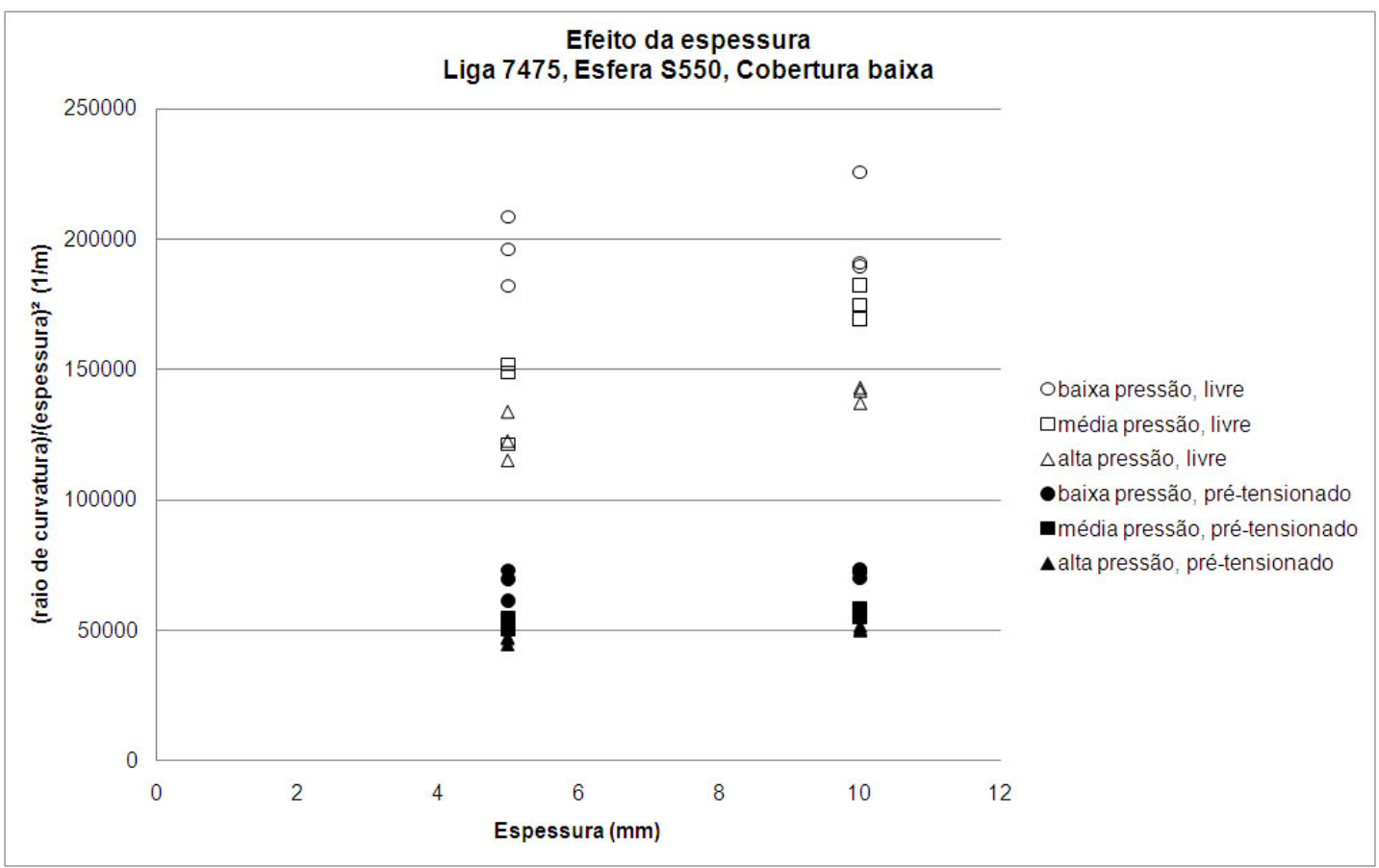

Figura 4.132: Efeito da espessura da chapa sobre $r / H^{2}$. Chapas da liga 7475 , jateadas com esfera $1 / 8$ ", baixa cobertura. 


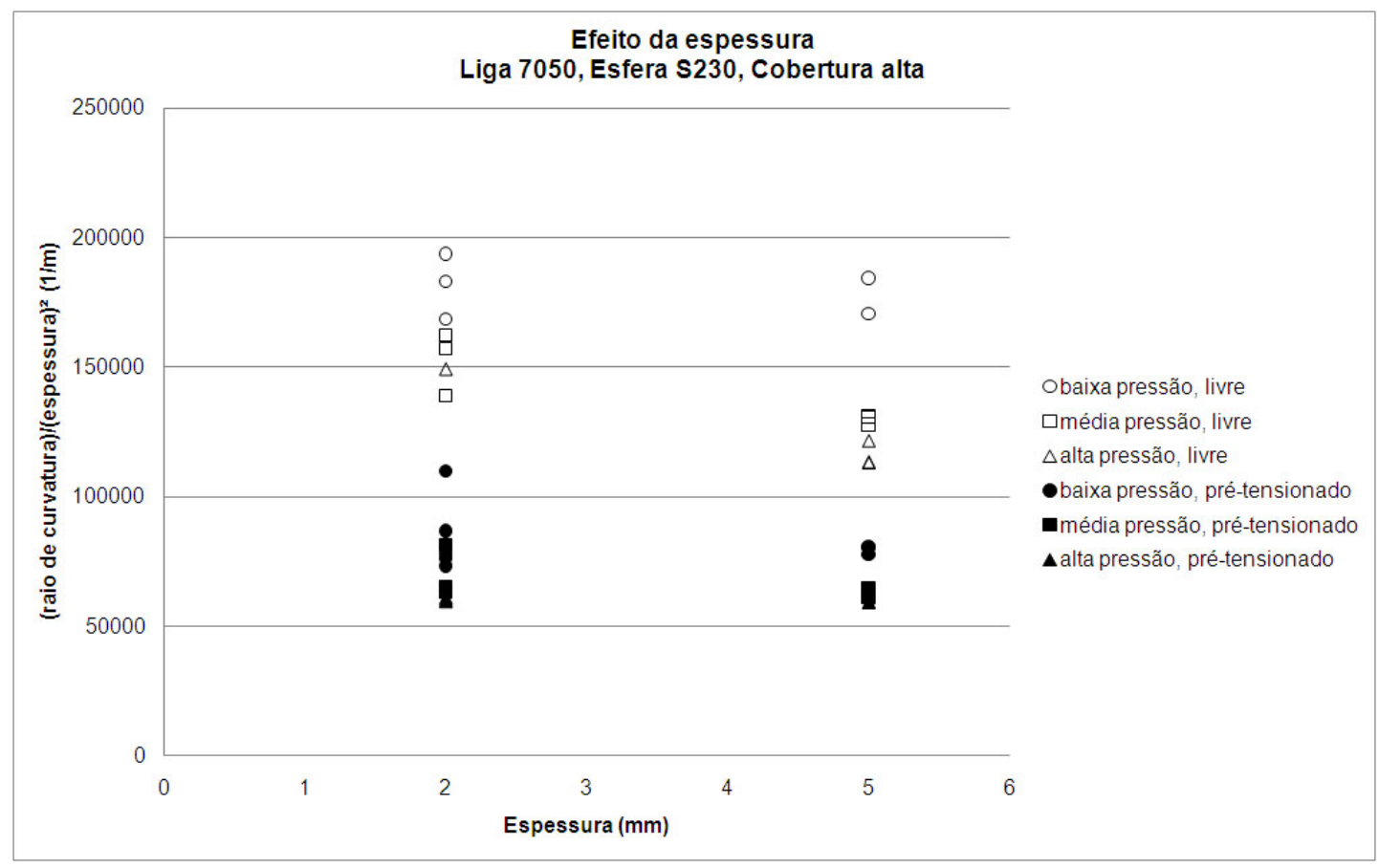

Figura 4.133: Efeito da espessura da chapa sobre $r / H^{2}$. Chapas da liga 7050 , jateadas com esfera S230, alta cobertura.

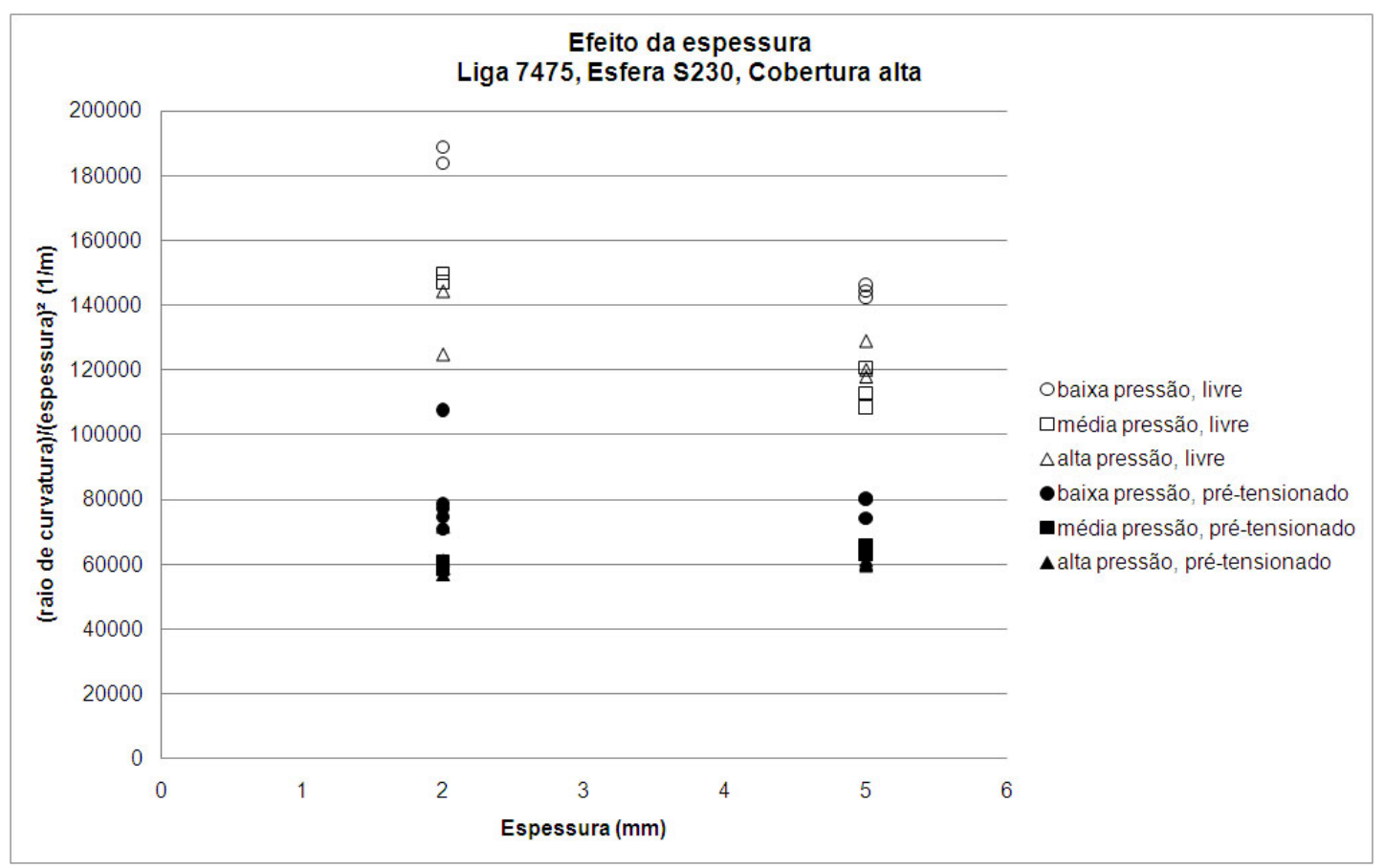

Figura 4.134: Efeito da espessura da chapa sobre $r / H^{2}$. Chapas da liga 7475 , jateadas com esfera S230, alta cobertura. 
Efeito da espessura

Liga 7050, Esfera S550, Cobertura alta

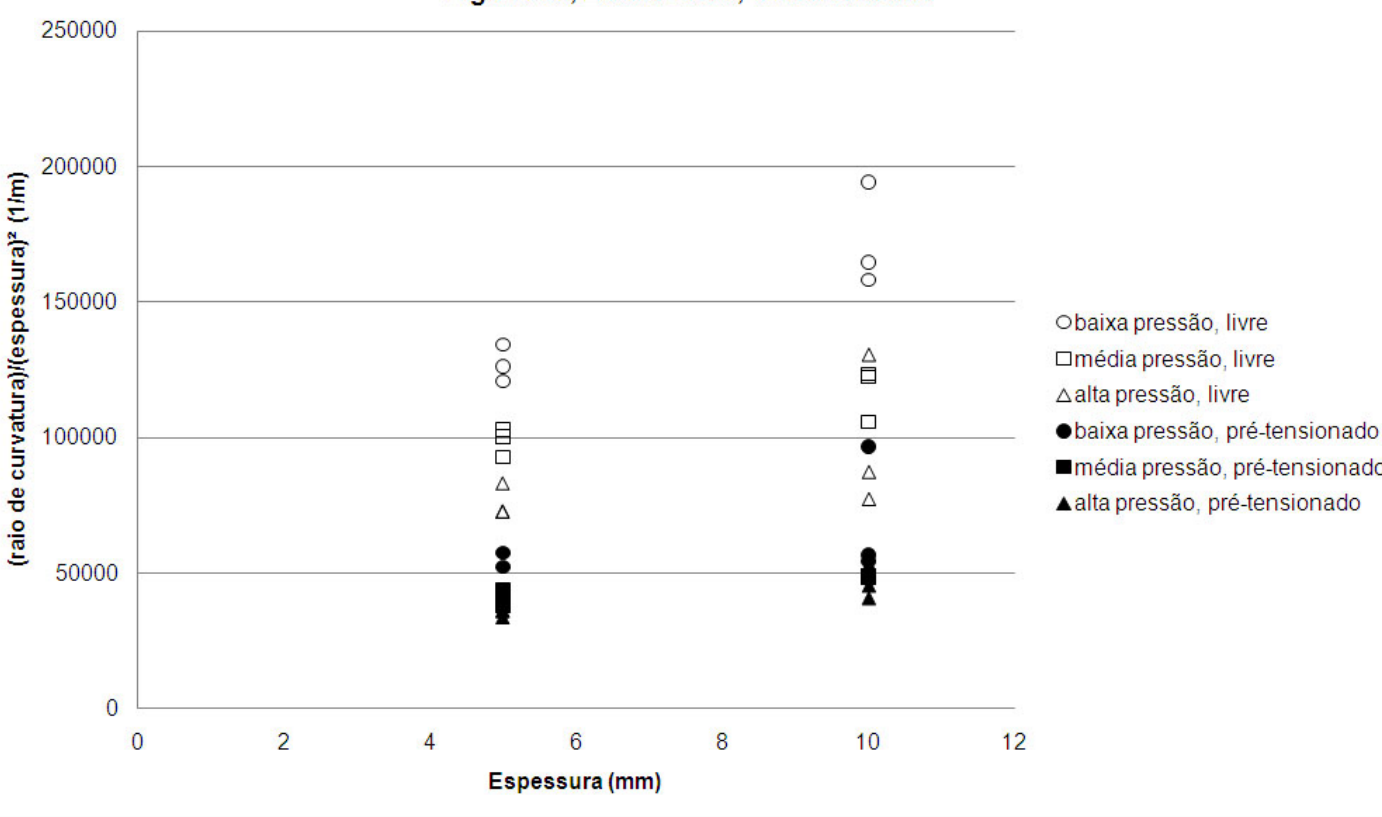

Figura 4.135: Efeito da espessura da chapa sobre $r / H^{2}$. Chapas da liga 7050 , jateadas com esfera S550, alta cobertura.

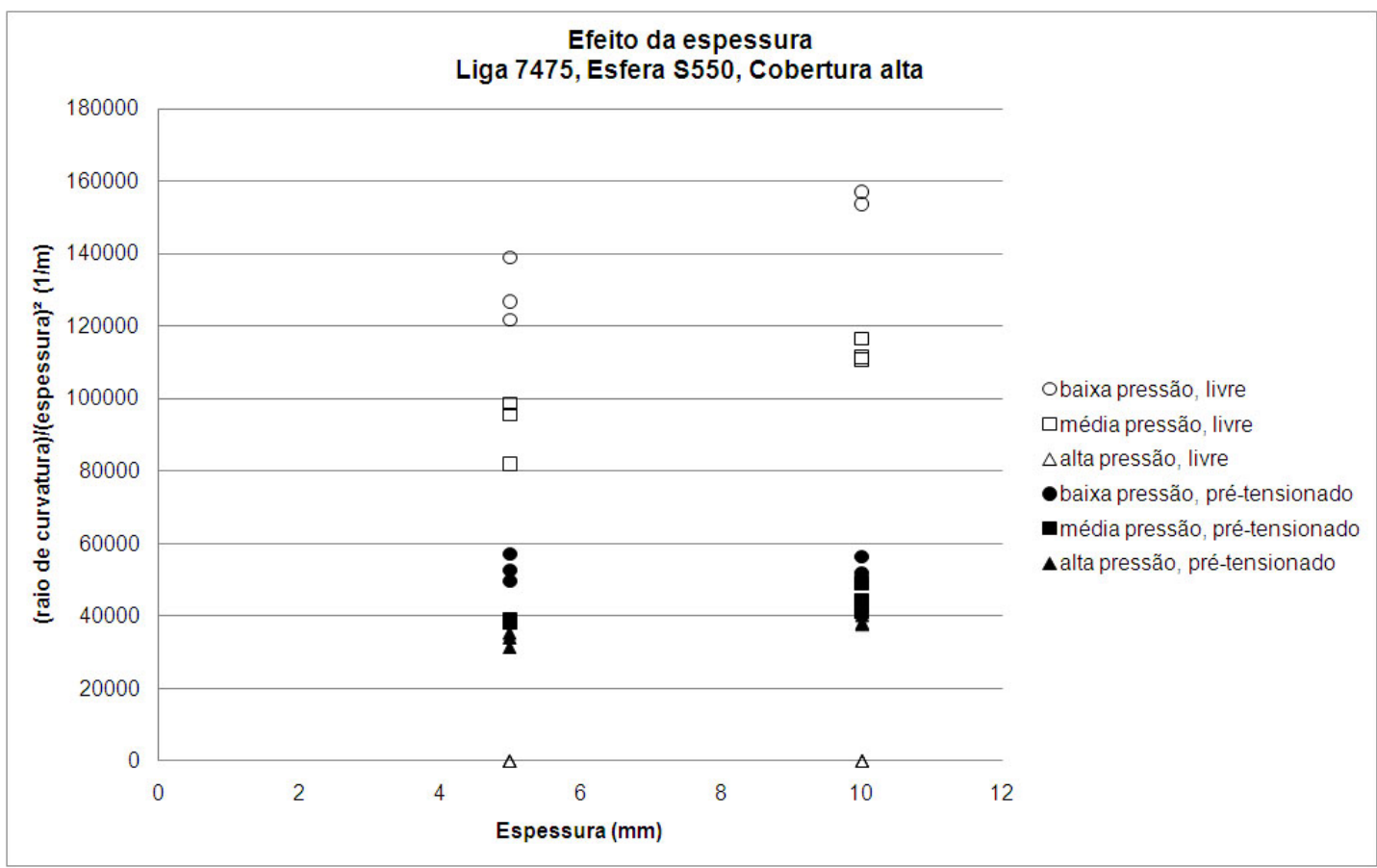

Figura 4.136: Efeito da espessura da chapa sobre $r / H^{2}$. Chapas da liga 7475 , jateadas com esfera $\$ 550$, alta cobertura. 


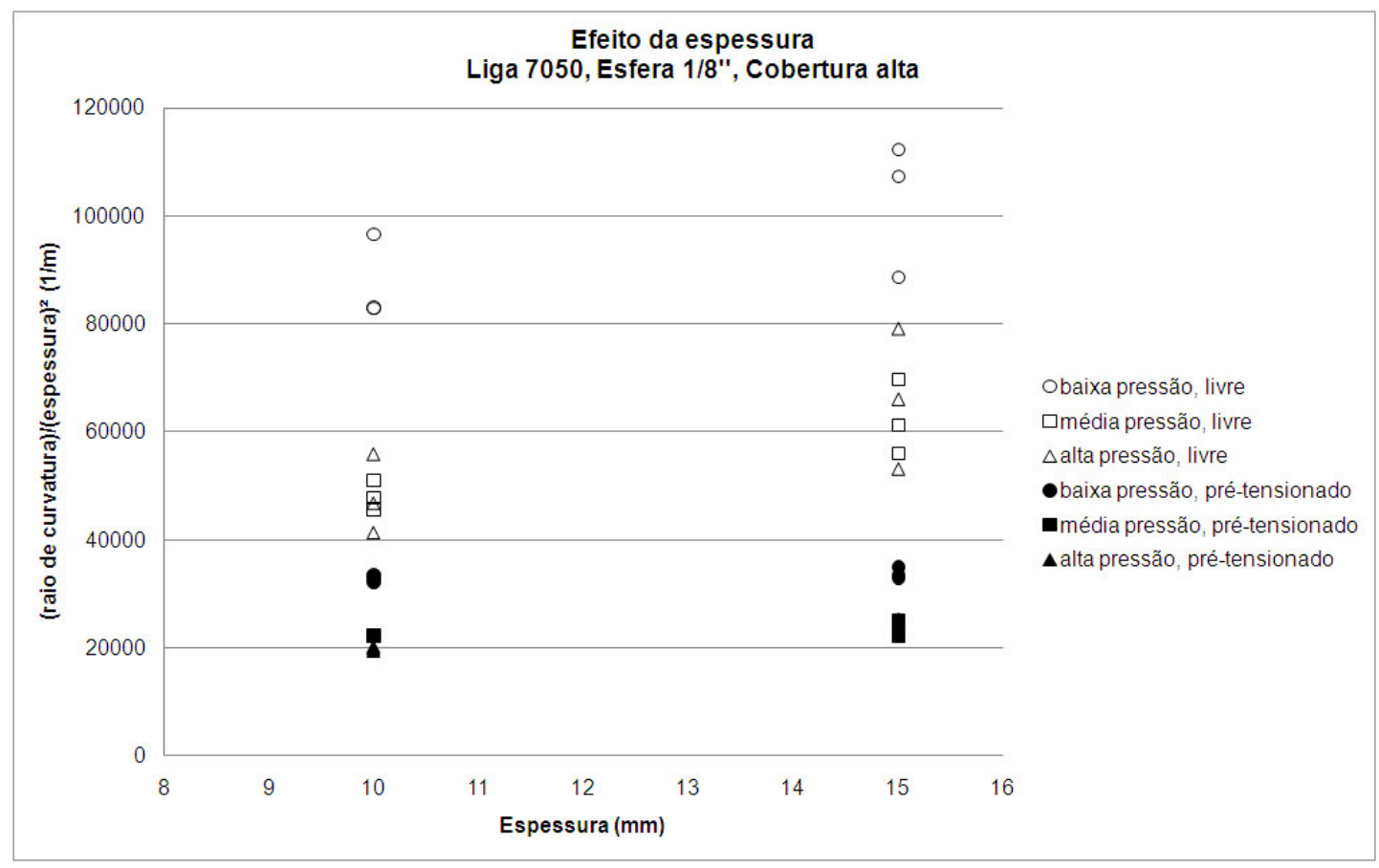

Figura 4.137: Efeito da espessura da chapa sobre $r / H^{2}$. Chapas da liga 7050, jateadas com esfera 1/8", alta cobertura.

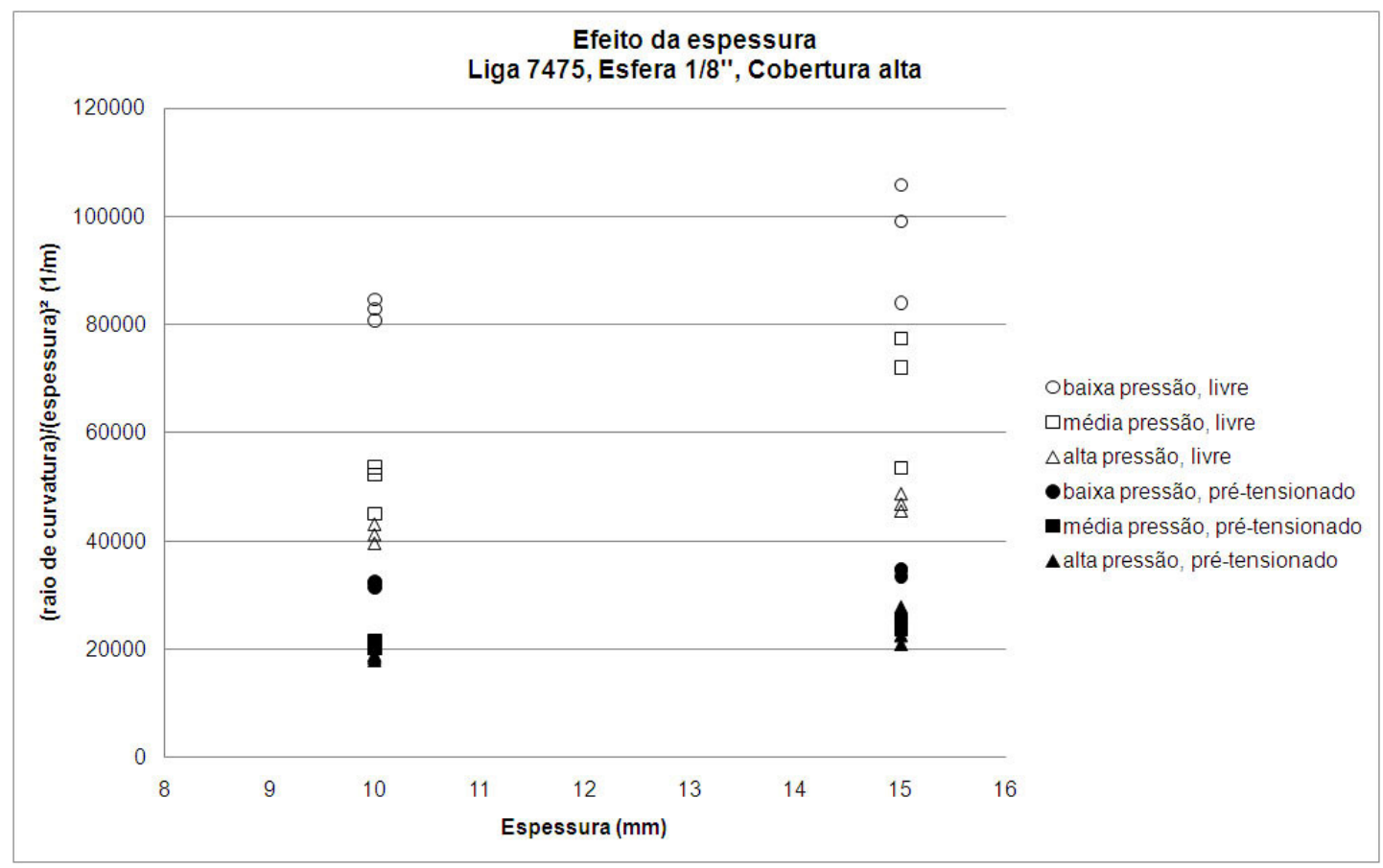

Figura 4.138: Efeito da espessura da chapa sobre $r / H^{2}$. Chapas da liga 7475 , jateadas com esfera 1/8", alta cobertura.

Vale ressaltar que o método da normalização pelo módulo resistente não elimina os problemas de comparação dos efeitos dos parâmetros de jateamento sobre chapas de espessuras diferentes. Há ainda muita dispersão nos valores de $\mathrm{r} / \mathrm{H}^{2}$ e em alguns casos, como, por exemplo, da Figura 4.136, 'média pressão, livre', o raio de curvatura de chapas mais grossas varia $40 \%$. 
Mesmo assim, a normalização facilita bastante a análise de valores tão diferentes.

As Figuras 4.139 a 4.144 (Tabela 4.5) mostram os efeitos da mudança de liga sobre a curvatura obtida, observando-se, a partir de agora, os valores de $\mathrm{r} / \mathrm{H}^{2}$.

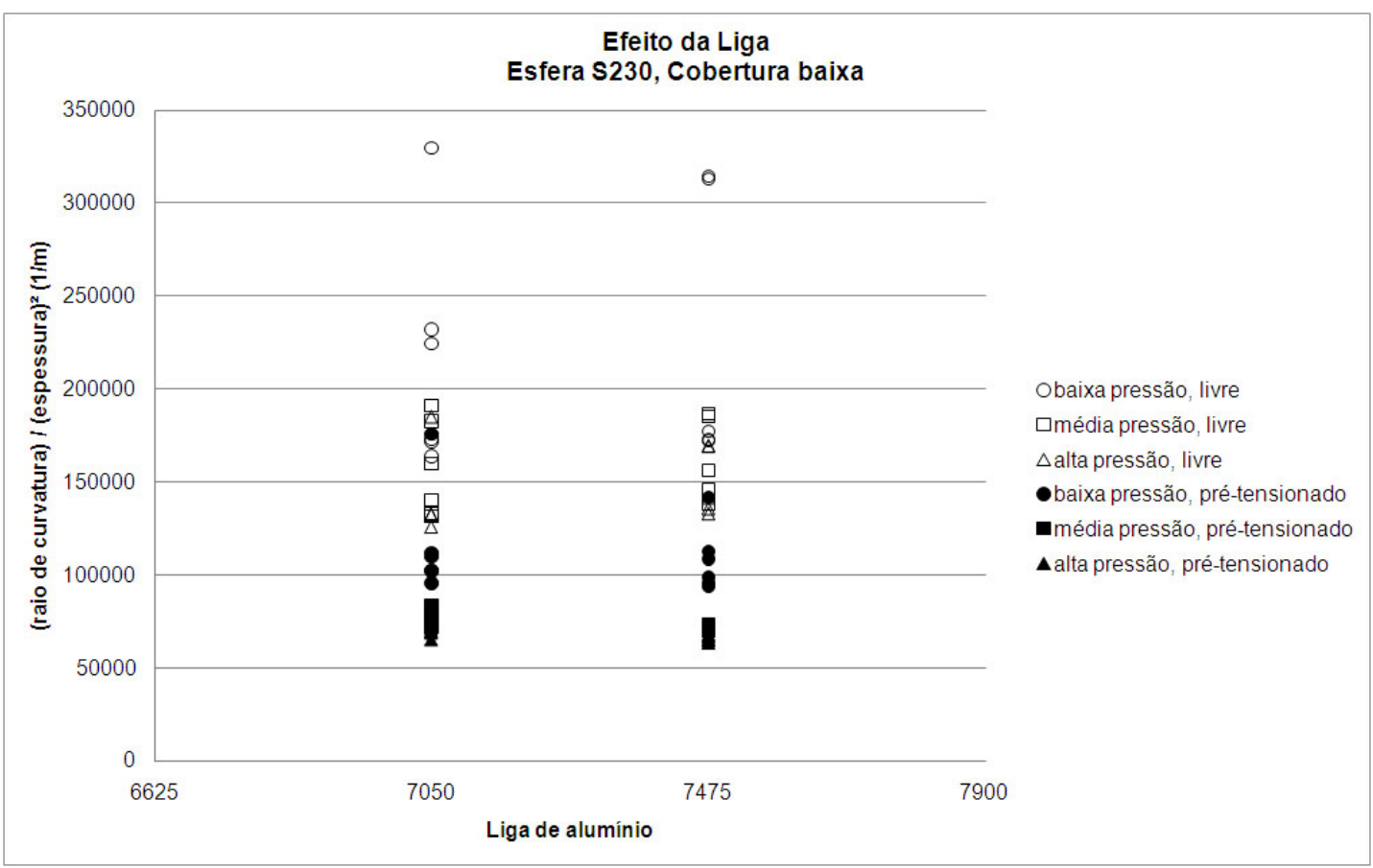

Figura 4.139: Efeito da liga sobre $r / H^{2}$. Chapas jateadas com esfera S230, baixa cobertura.

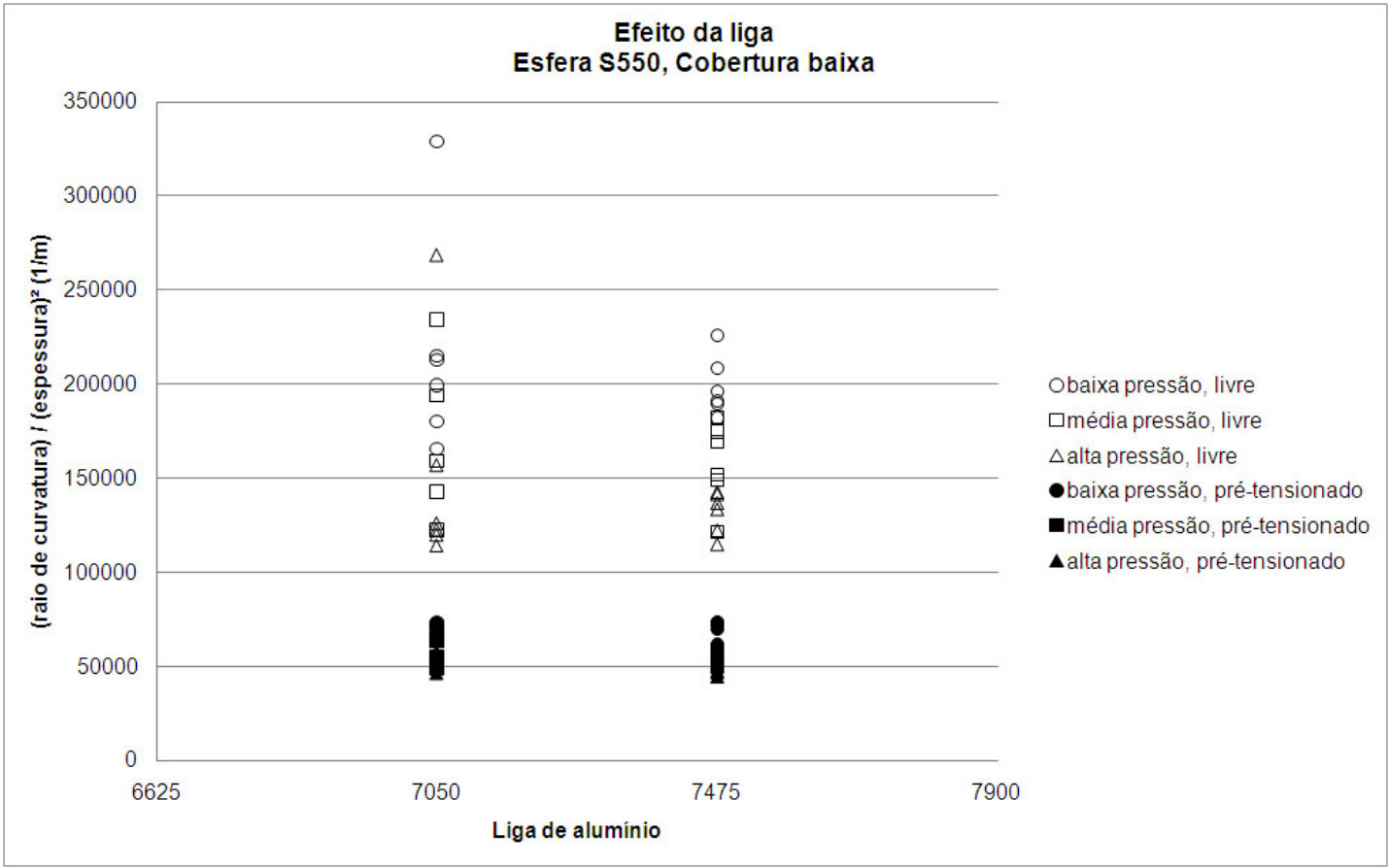

Figura 4.140: Efeito da liga sobre $r / H^{2}$. Chapas jateadas com esfera S550, baixa cobertura. 


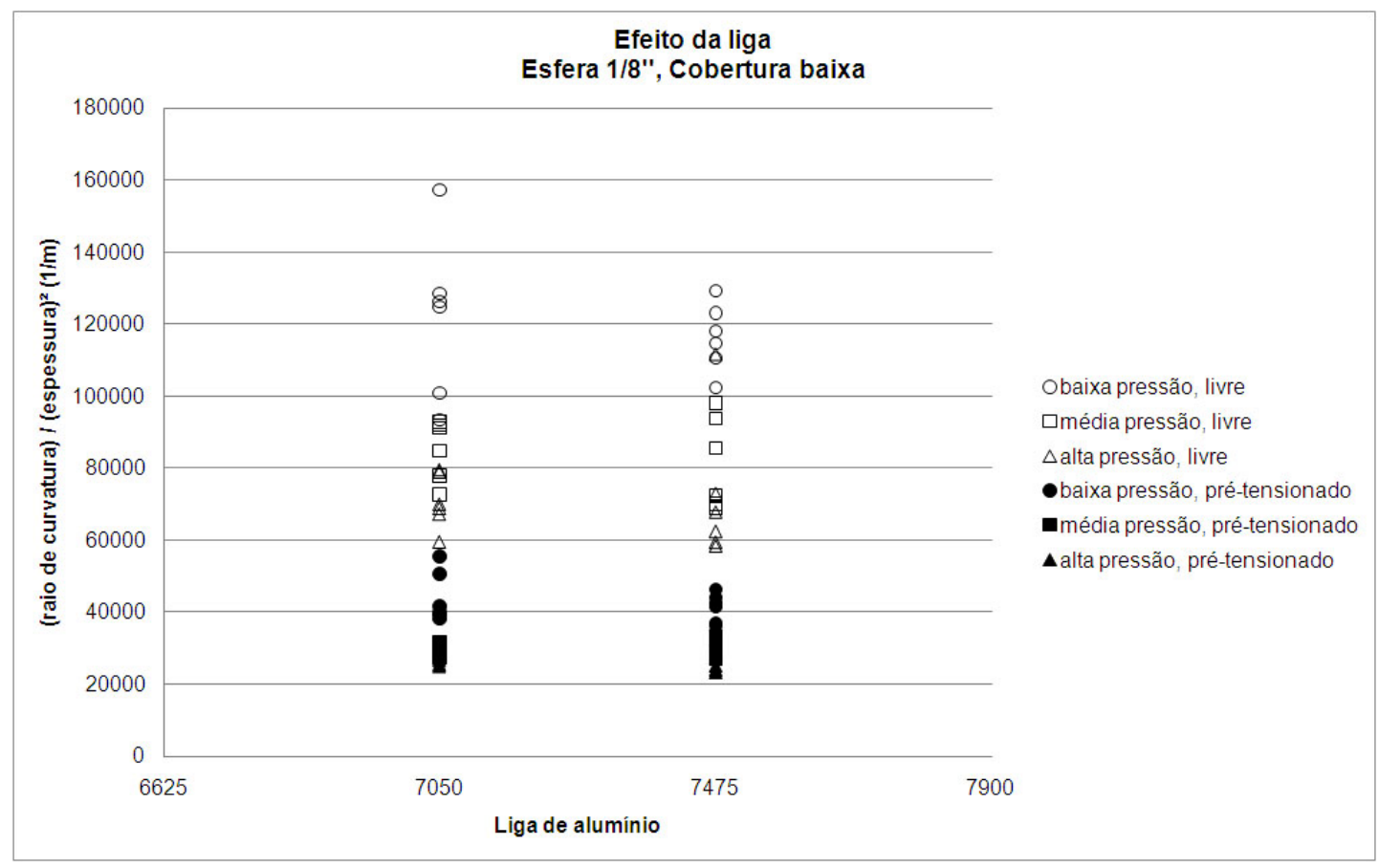

Figura 4.141: Efeito da liga sobre $r / H^{2}$. Chapas jateadas com esfera 1/8", baixa cobertura.

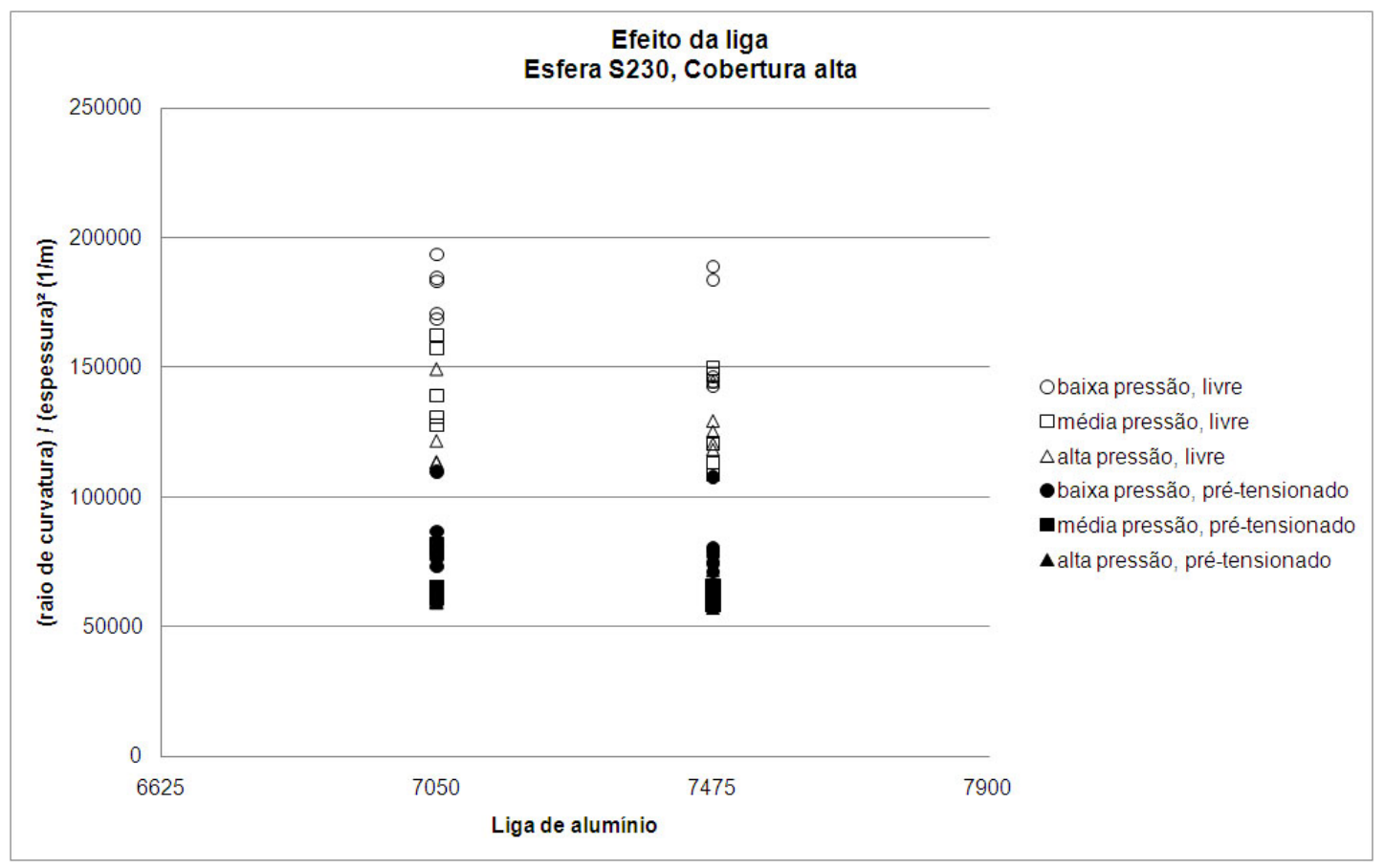

Figura 4.142: Efeito da liga sobre $r / H^{2}$. Chapas jateadas com esfera S230, alta cobertura. 


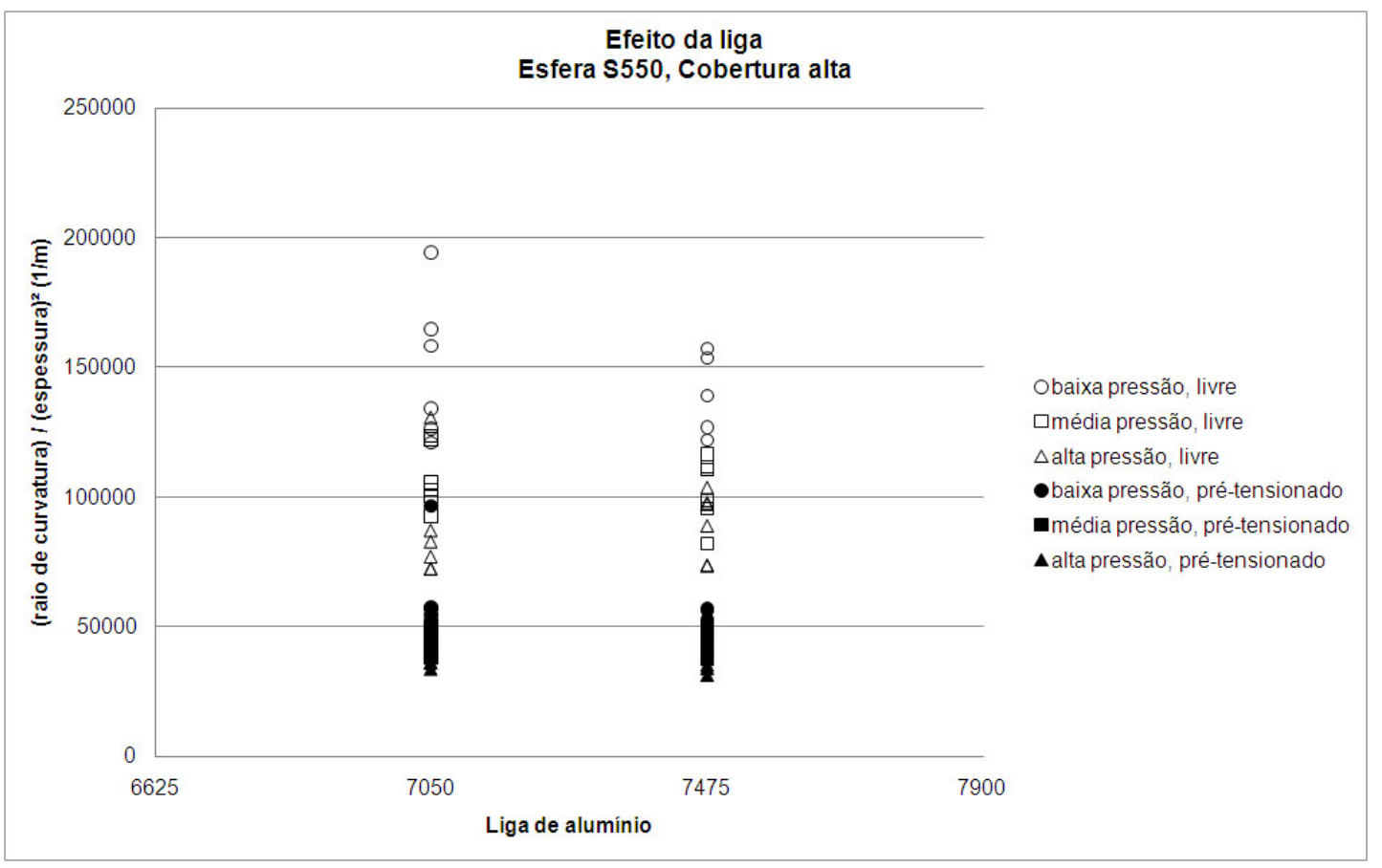

Figura 4.143: Efeito da liga sobre $r / H^{2}$. Chapas jateadas com esfera S550, alta cobertura.

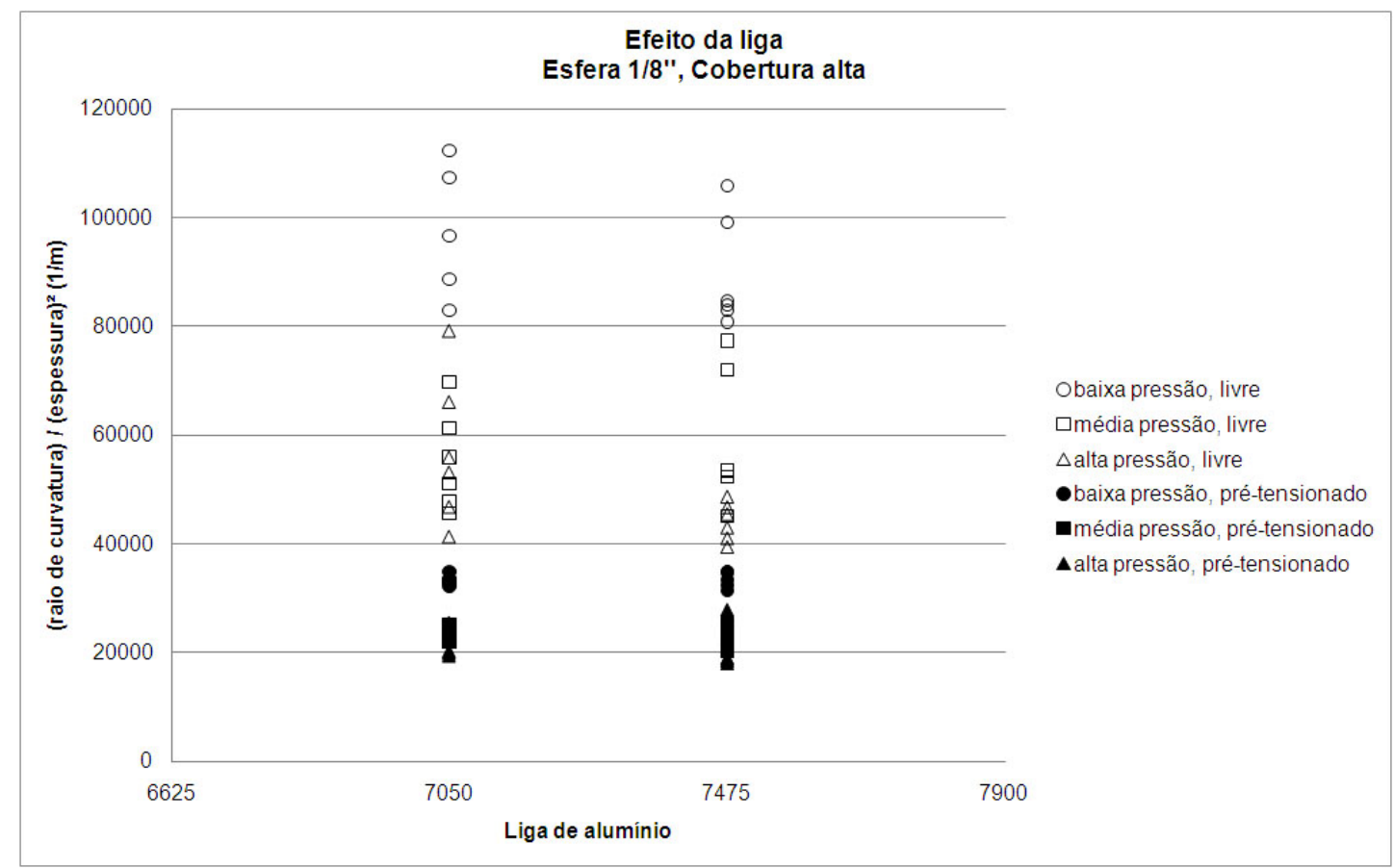

Figura 4.144: Efeito da liga sobre $r / H^{2}$. Chapas jateadas com esfera 1/8", alta cobertura.

Nota-se que a liga não exerce influência notável na deformação das chapas. Portanto, a partir de agora serão analisadas juntas as duas ligas, para observação dos demais parâmetros. 


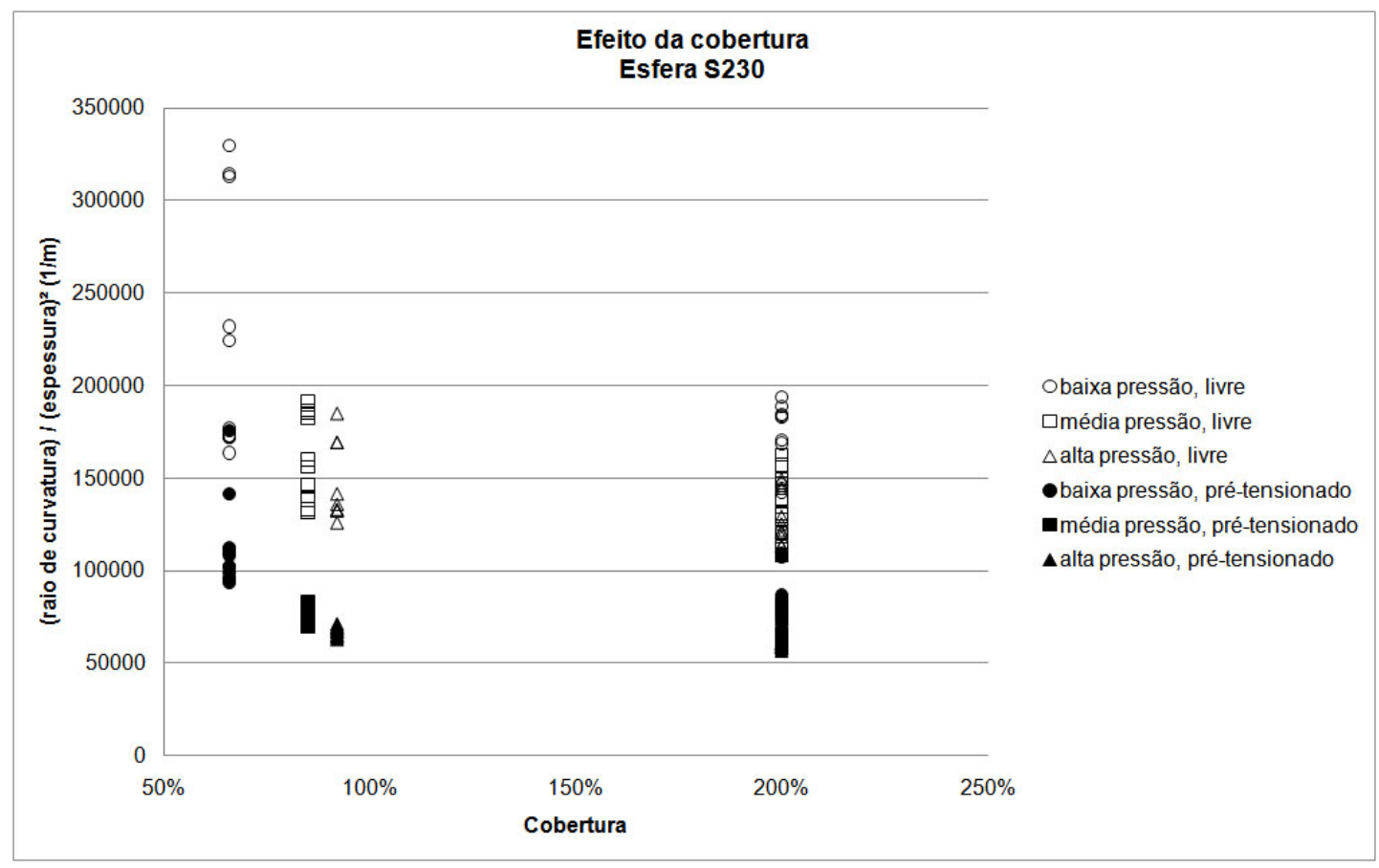

Figura 4.145: Efeito da cobertura sobre $r / H^{2}$. Chapas das ligas $7050 \mathrm{e}$ 7475 jateadas com esfera S230.

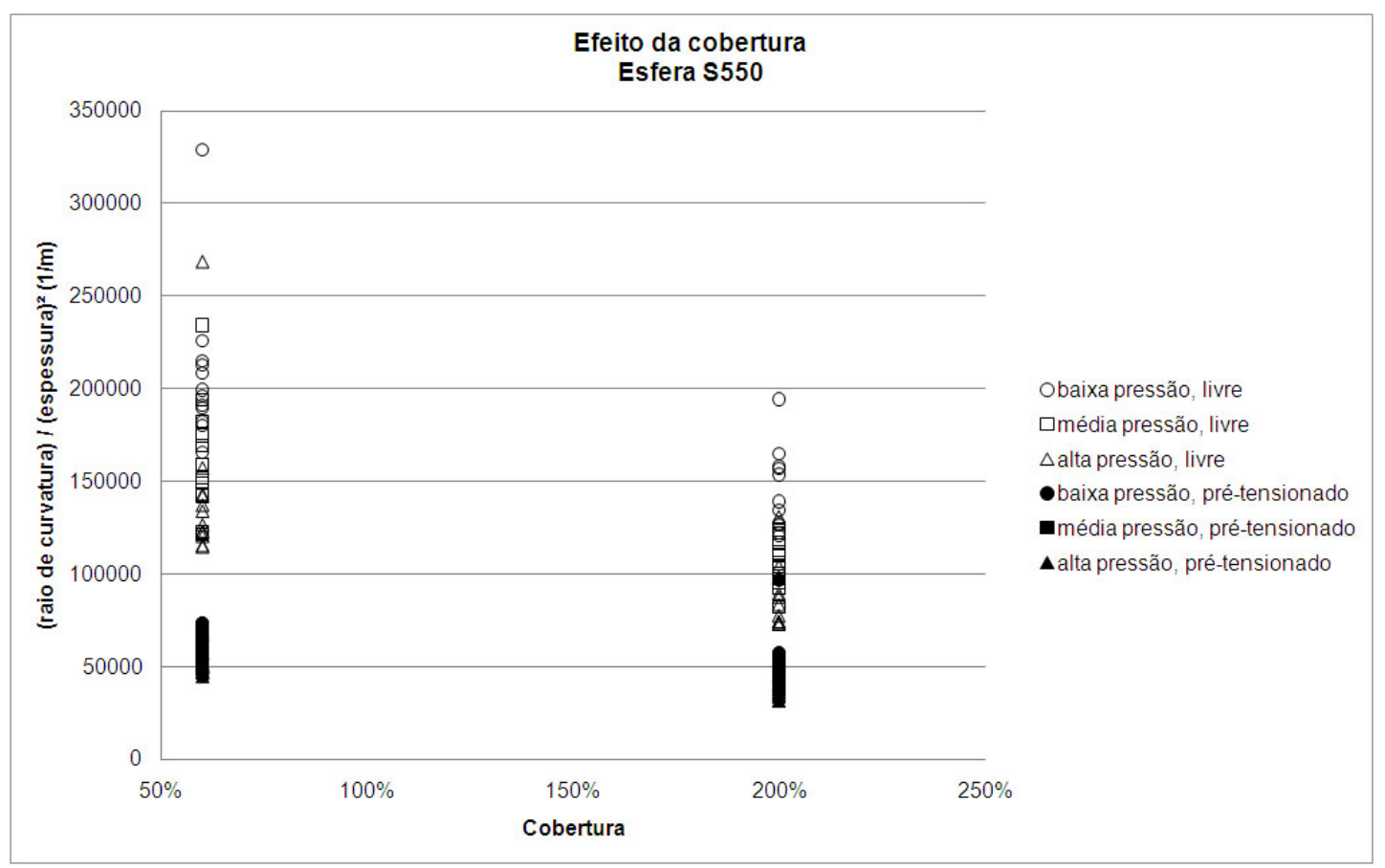

Figura 4.146: Efeito da cobertura sobre $r / H^{2}$. Chapas das ligas $7050 \mathrm{e}$ 7475 jateadas com esfera S550. 


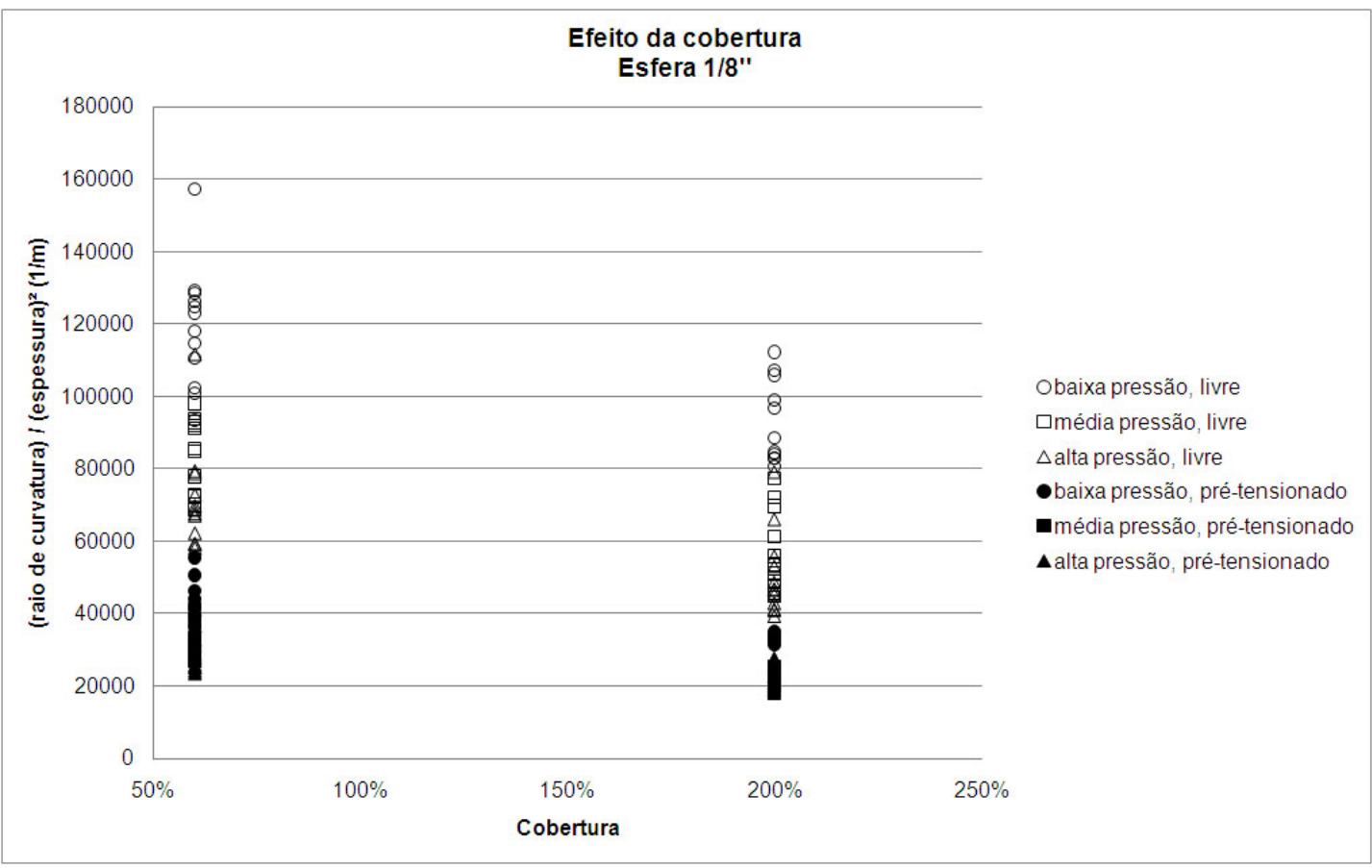

Figura 4.147: Efeito da cobertura sobre $r / H^{2}$. Chapas das ligas $7050 \mathrm{e}$ 7475 jateadas com esfera $1 / 8 "$.

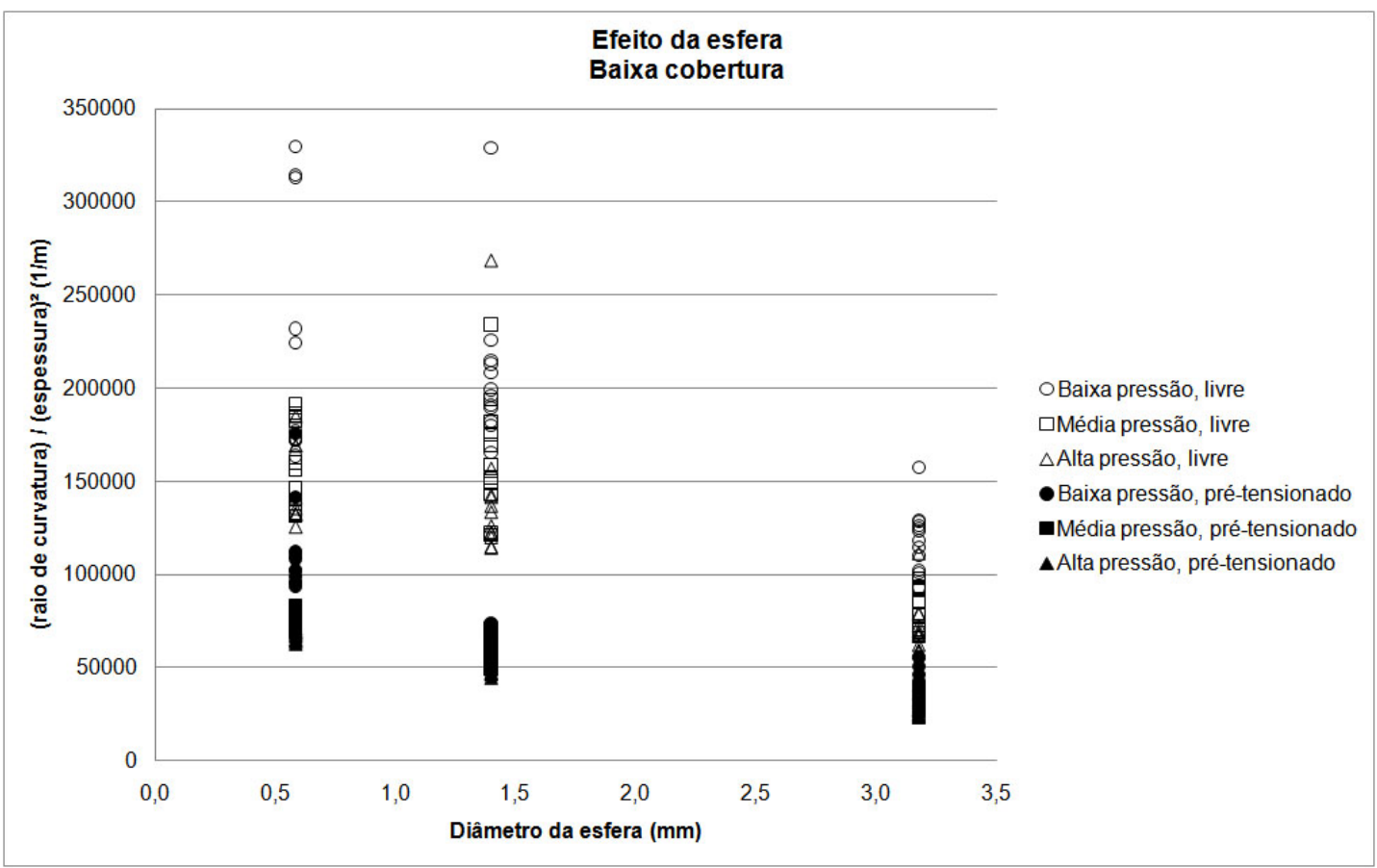

Figura 4.148: Efeito do diâmetro da esfera sobre $r / H^{2}$. Chapas das ligas 7050 e 7475 jateadas com baixa cobertura. 


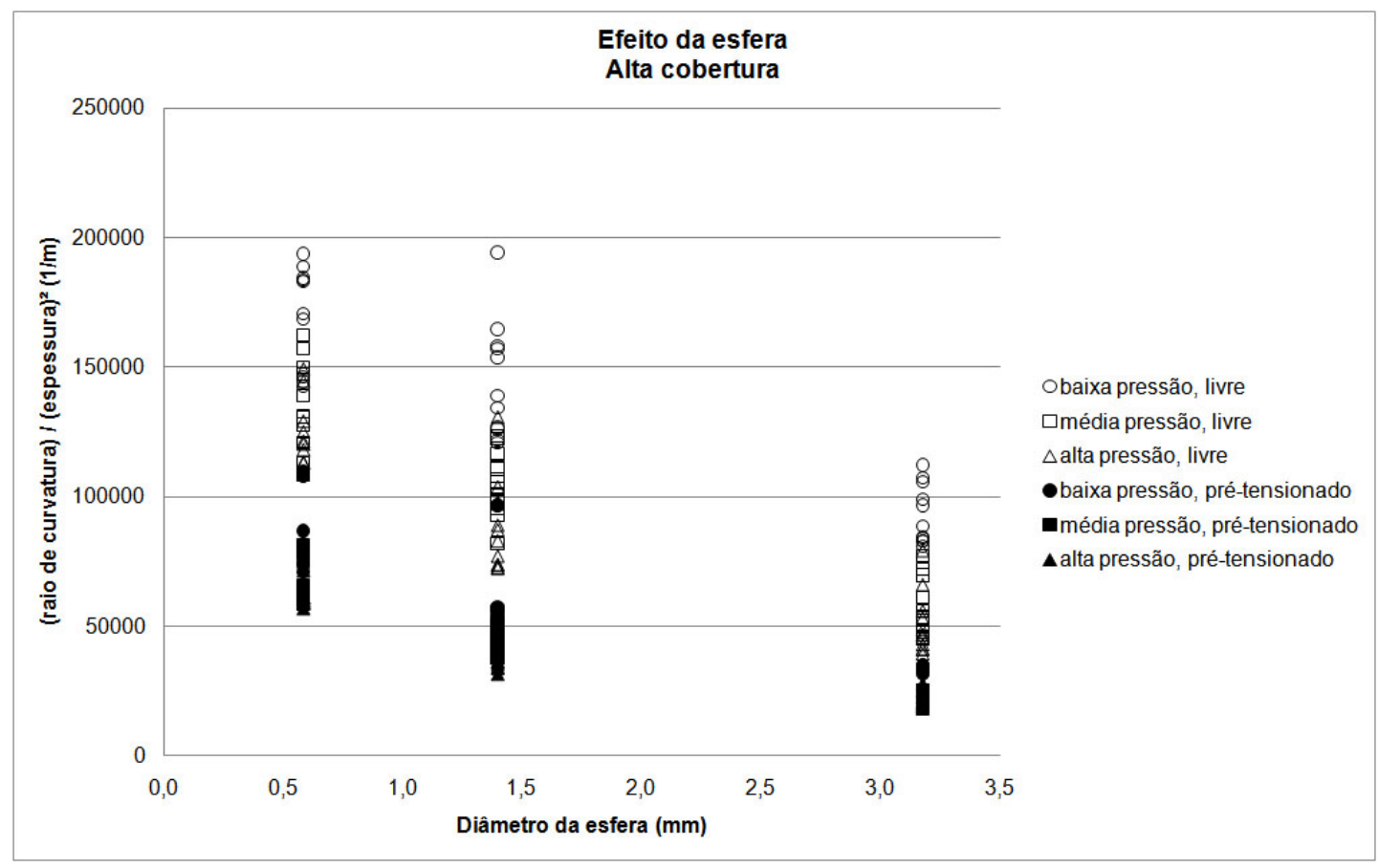

Figura 4.149: Efeito do diâmetro da esfera sobre $r / H^{2}$. Chapas das ligas 7050 e 7475 jateadas com alta cobertura.

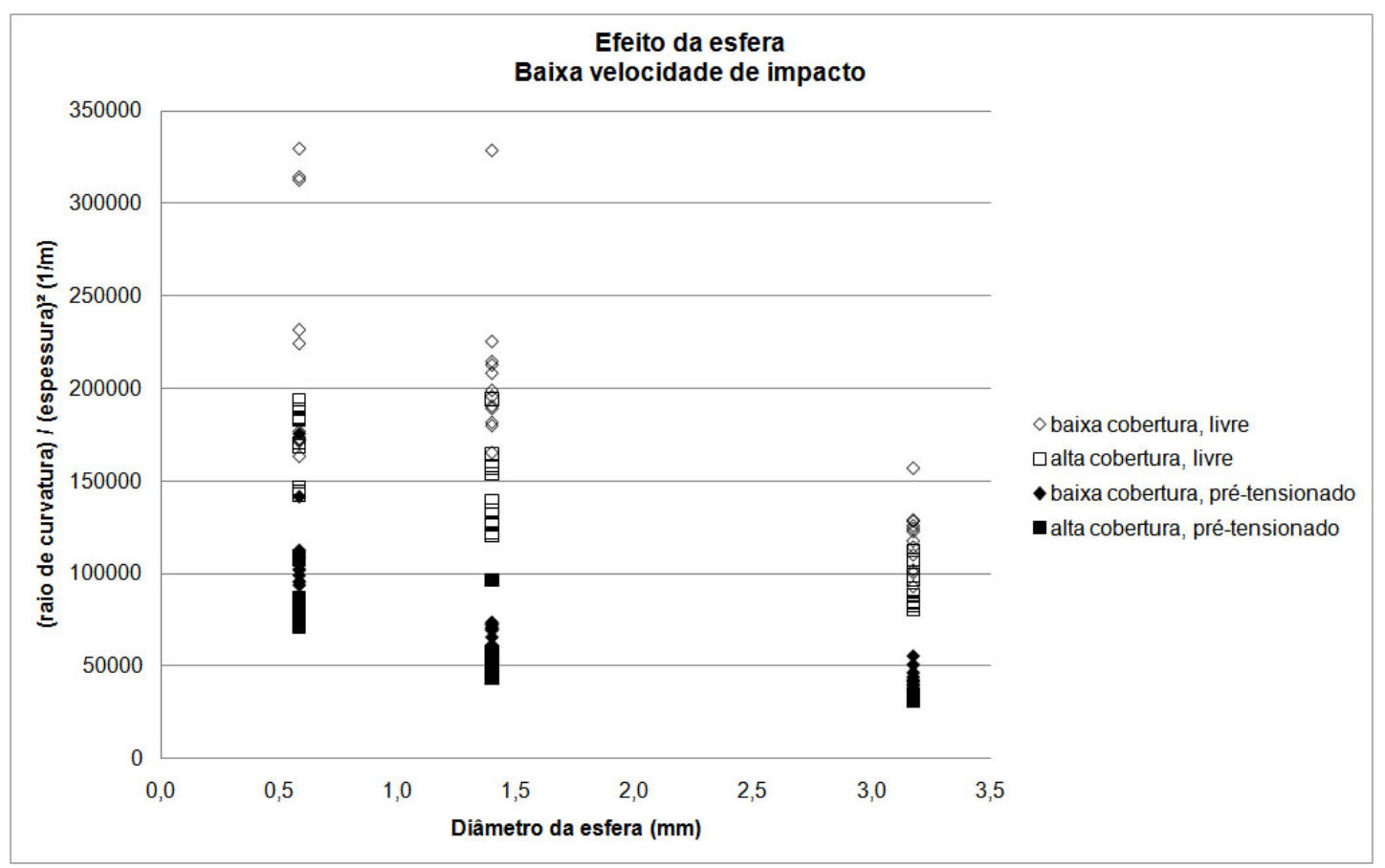

Figura 4.150: Efeito do diâmetro da esfera sobre $r / H^{2}$. Chapas das ligas 7050 e 7475 jateadas com baixa pressão. 


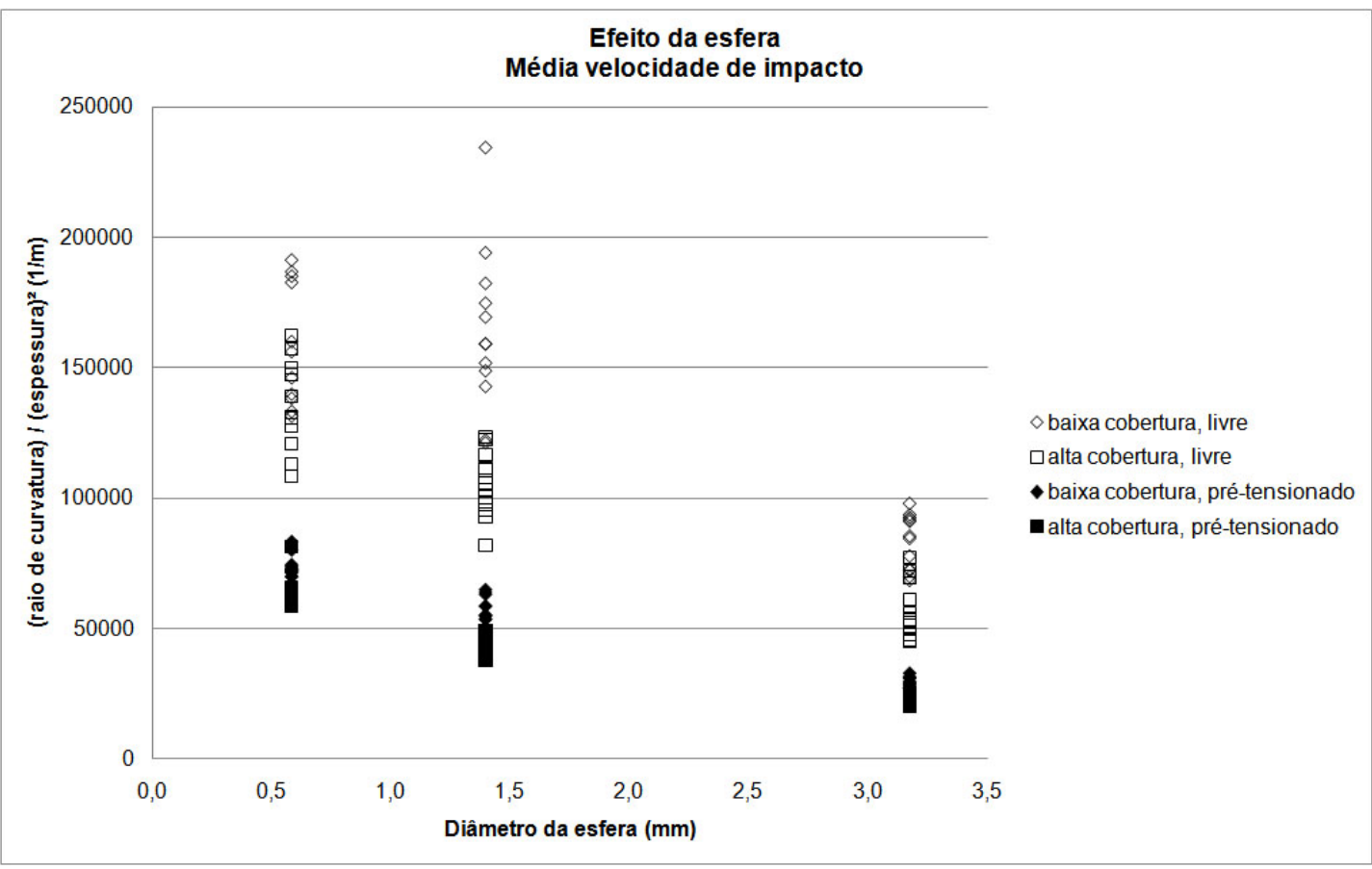

Figura 4.151: Efeito do diâmetro da esfera sobre $r / H^{2}$. Chapas das ligas 7050 e 7475 jateadas com média pressão.

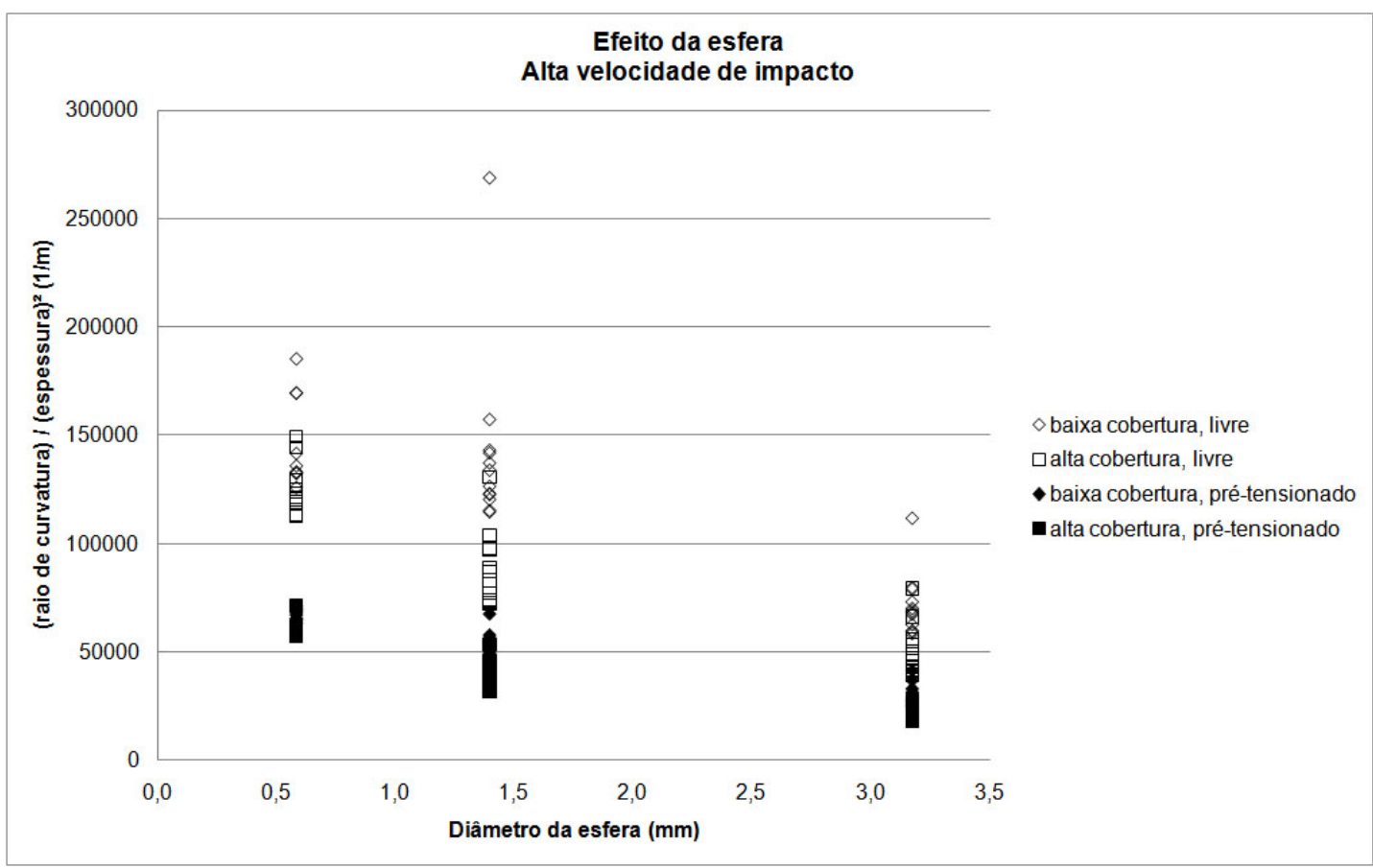

Figura 4.152: Efeito do diâmetro da esfera sobre $r / H^{2}$. Chapas das ligas 7050 e 7475 jateadas com alta pressão. 


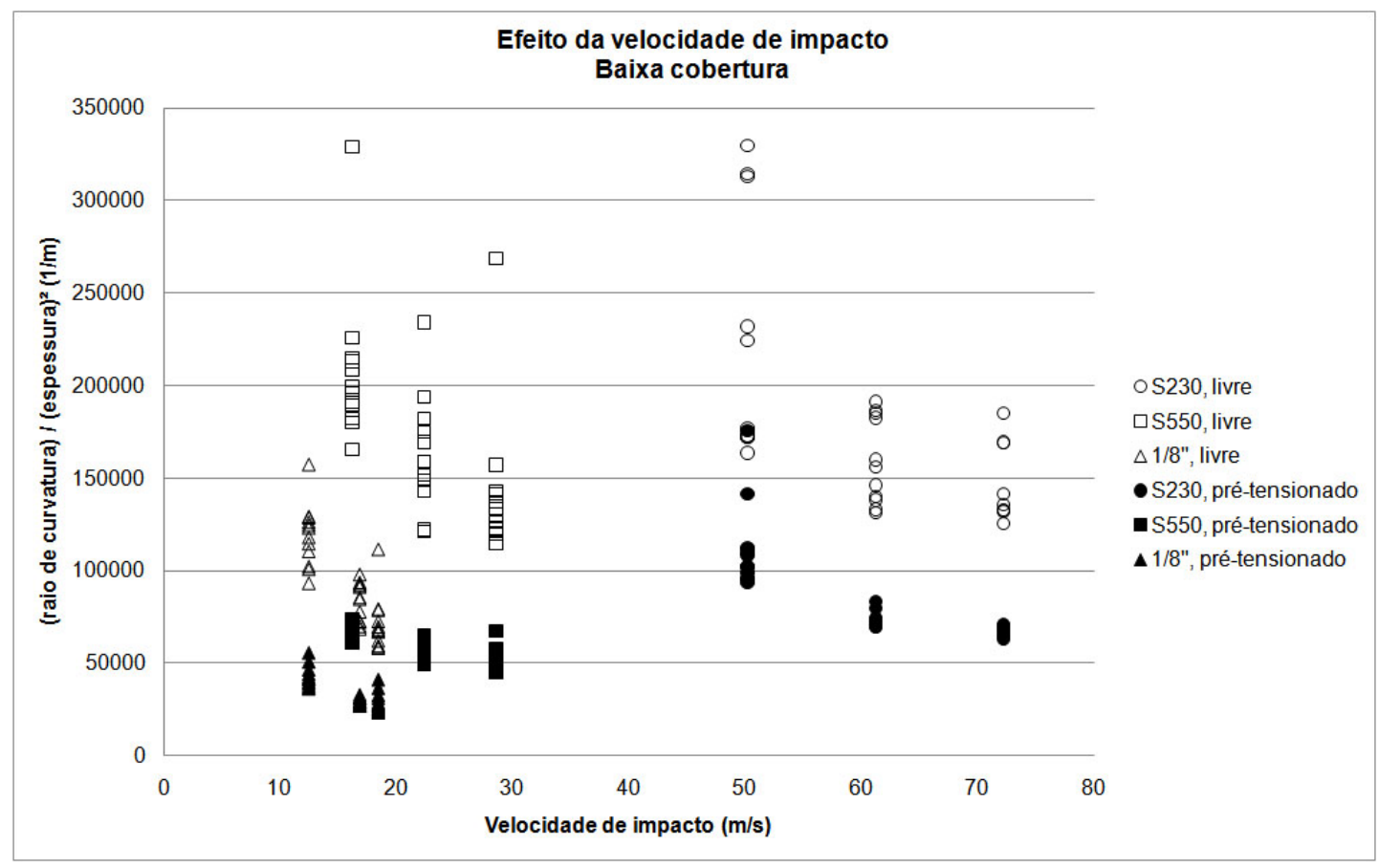

Figura 4.153: Efeito da velocidade de impacto sobre $r / H^{2}$. Chapas das ligas 7050 e 7475 jateadas com baixa cobertura.

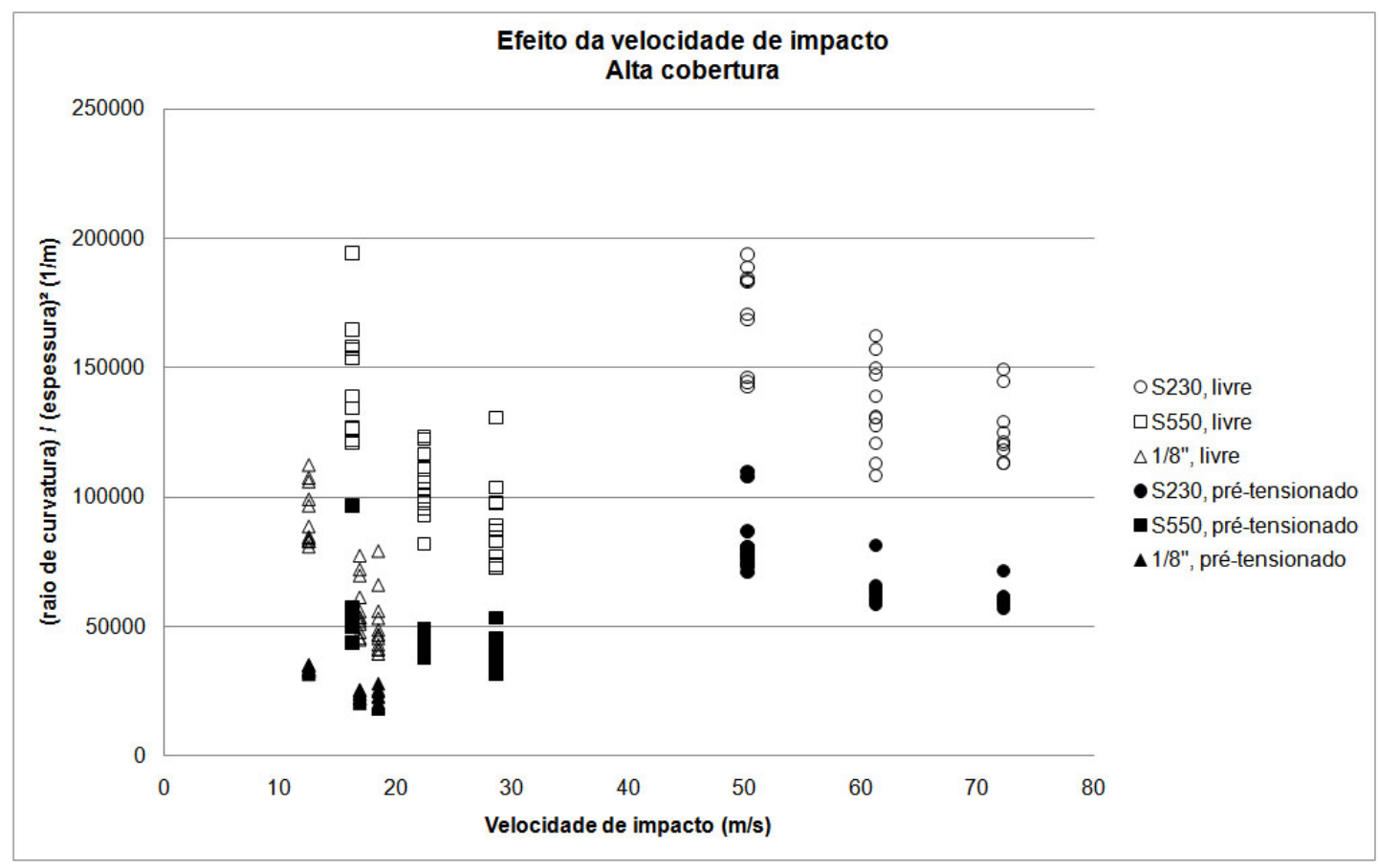

Figura 4.154: Efeito da velocidade de impacto sobre $r / H^{2}$. Chapas das ligas 7050 e 7475 jateadas com alta cobertura.

A partir da observação dos gráficos, pode-se afirmar que, entre os principais parâmetros observados (cobertura, diâmetro da esfera, velocidade de impacto e pré-tensão), a pré-tensão é o maior influente na curvatura final obtida após o jateamento das esferas sobre as chapas. Em segundo lugar, o mais influente é o tamanho da esfera. A velocidade de impacto e a cobertura 
são as menos influentes na deformação da chapa.

A utilização da normalização do raio de curvatura, dividindo-o pelo módulo resistente, $W$, ou simplesmente por $\mathrm{H}^{2}$, reduziu significantemente o número de gráficos a serem analisados para observação dos parâmetros mas, ainda assim, é muito grande para a previsão da curvatura final em um processo de muitas variáveis. Deste modo, investigou-se qual a relação entre a energia cinética das esferas e a curvatura da chapa.

A Figura 4.155 mostra todos os dados experimentais coletados, relacionando a energia cinética $\left(E_{C}\right)$ e o raio de curvatura $(r)$ dos corpos de prova jateados em todas as condições possíveis, separados em:

- cobertura baixa, sem pré-tensão (BX Livre);

- cobertura alta, sem pré-tensão (AL Livre);

- cobertura baixa, com pré-tensão (BX Pré-tensionado);

- cobertura alta, com pré-tensão (AL Pré-tensionado).

A Figura 4.156 mostra o efeito da energia cinética sobre o raio de curvatura normalizado por $\mathrm{H}^{2}$, nas mesmas condições do gráfico anterior.

Obs: Foram excluídos três pontos (CPs 188, 253 e 391) com raios de curvatura muito diferentes dos demais com mesma condição de jateamento, para evitar distorções nas análises dos demais dados.

É notável a qualidade do ajuste dos pontos de raio de curvatura normalizados $\left(r / H^{2}\right)$ em função da energia cinética $\left(E_{C}\right)$, enquanto a medição da energia cinética parece não dizer nada a respeito do raio de curvatura, independentemente da espessura da chapa.

Agora, busca-se o método que seja mais eficaz para a previsão do raio de curvatura, utilizando-se apenas um parâmetro de medição que englobe todas as variáveis atuantes no processo de JCG.

Pode-se chamar de densidade de energia cinética $(K)$ a quantidade de energia cinética $\left(E_{C}\right)$ que 1 esfera transfere para o volume abaixo da indentação $\left(\mathrm{V}_{\text {ind }}\right)$ produzida por ela, após o impacto. $K$ pode ser calculada pela Equação 4.3:

$$
K=\frac{E_{C}}{V_{\text {ind }}}=\frac{\frac{1}{2} m \cdot v_{i m p}^{2}}{\left(\pi \frac{d_{i n d}^{2}}{4}\right) \cdot H}
$$




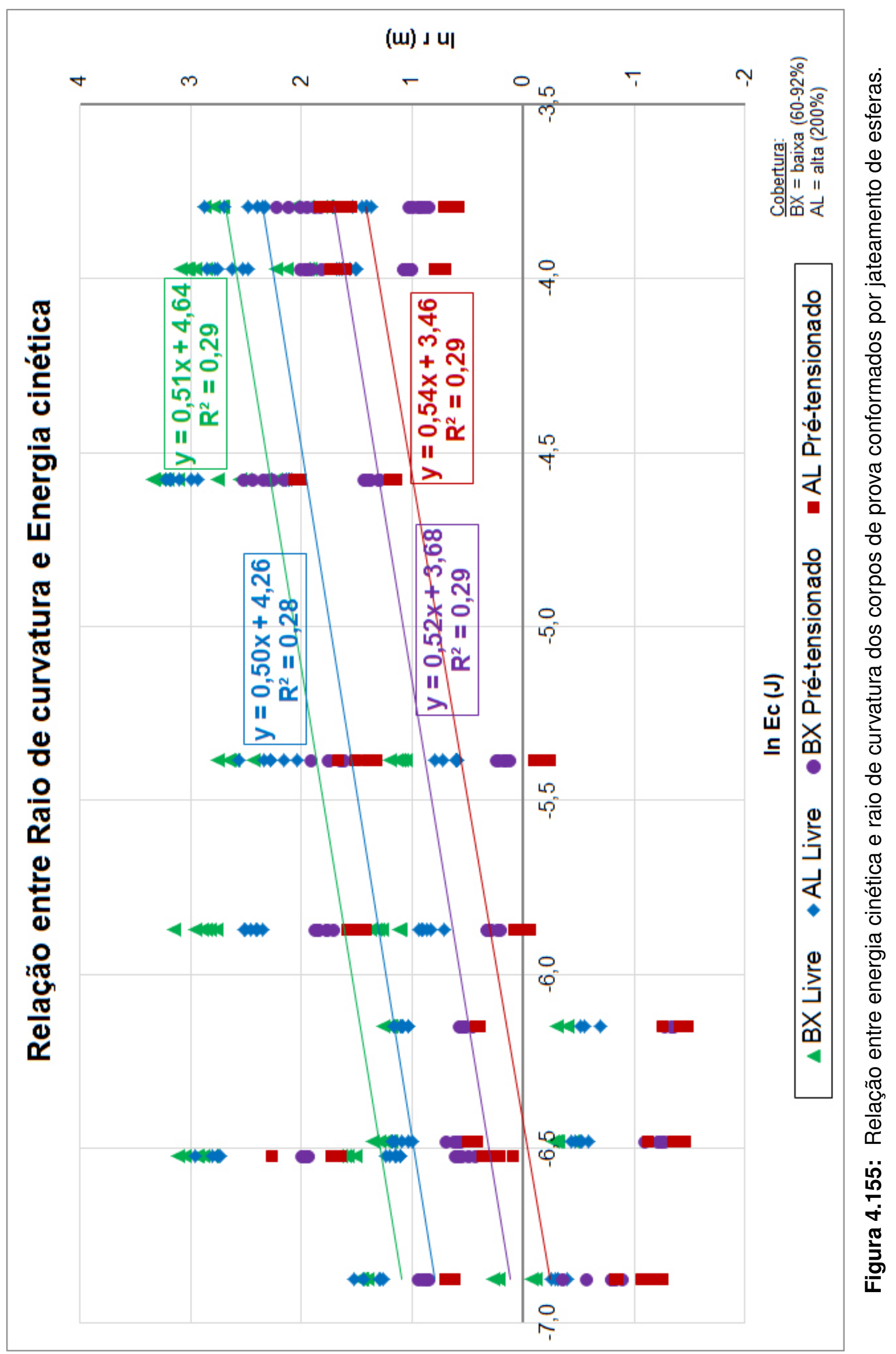




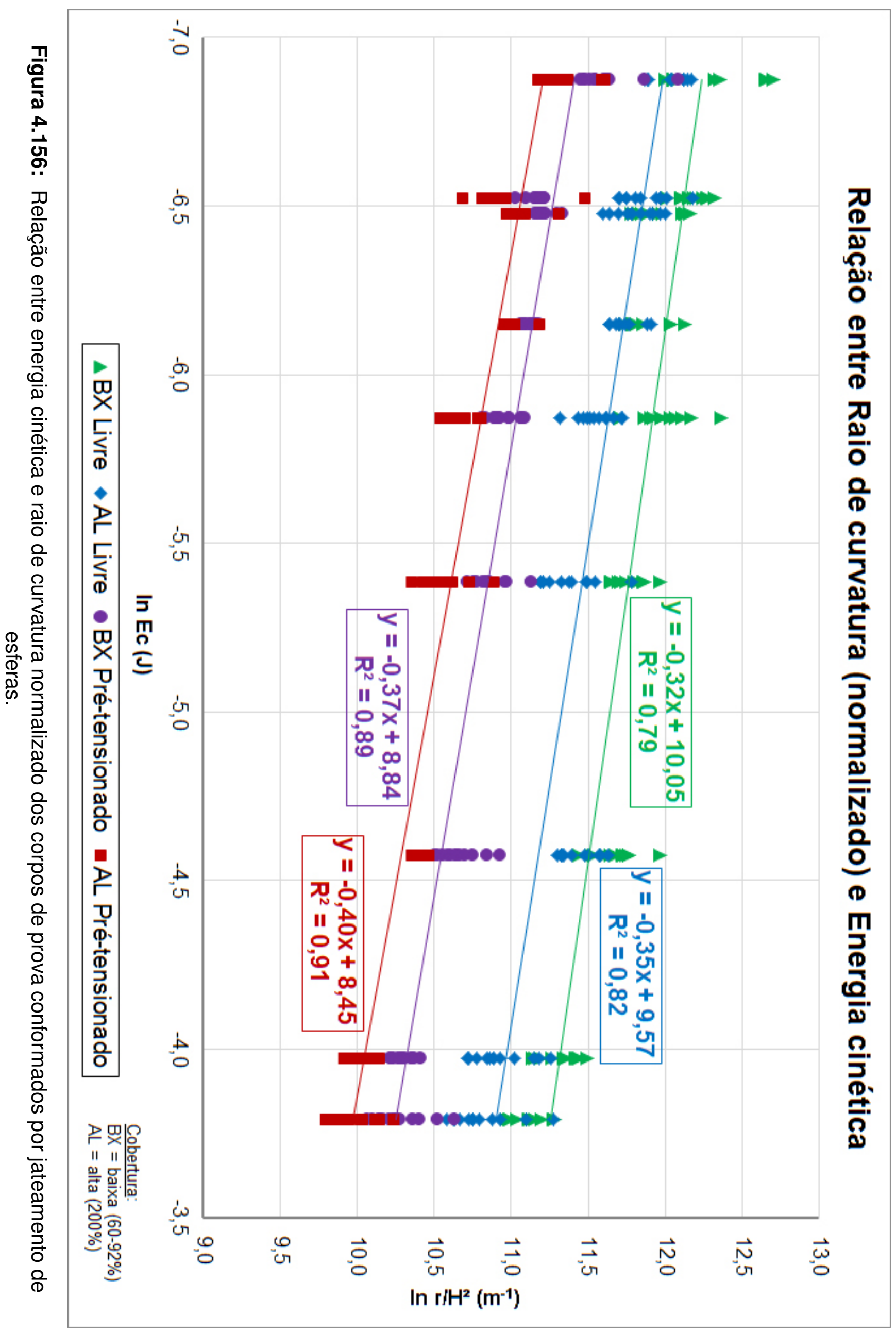


onde $m$ é a massa de 1 esfera, $v_{i m p}$ é a velocidade de impacto, $d_{i n d}$ é o diâmetro da indentação e $H$ é a espessura total da chapa.

No relatório do projeto IPT/Unicamp/Embraer ${ }^{[34]}$, baseado na norma EN40-100 da Embraer ${ }^{[74]}$ adotou-se como diâmetro de indentação $\left(d_{\text {ind }}\right)$ o valor médio de todas as medidas para uma mesma condição, totalizando assim 20 medições de diâmetro para cada cálculo de média (duas ligas, duas amostras, cinco impressões por amostra).

A Figura 4.157 mostra todos os dados experimentais coletados, relacionando a densidade de energia cinética $(K)$ e o raio de curvatura $(r)$. Sem dúvidas, a utilização da densidade de energia cinética $K$ como método de previsão do raio de curvatura é a melhor opção entre as que foram estudadas.

A Tabela 4.6 apresenta os resultados da relação entre $K$ e $r$ na forma $r=A \cdot K^{n}$ e os valores de $R^{2}$ dos ajustes:

Tabela 4.6: Equações de ajuste da relação entre densidade de energia cinética e raio de curvatura dos corpos de prova conformados por jateamento com granalhas.

\begin{tabular}{c|c|c|c|c}
\hline & Cobertura & Pré-tensão & Equação & $R^{2}$ do ajuste \\
\hline 1. & Baixa & Não & $r=2,60 \cdot 10^{12} \cdot K^{-1,78}$ & 0,956 \\
2. & Alta & Não & $r=2,27 \cdot 10^{12} \cdot K^{-1,79}$ & 0,955 \\
3. & Baixa & Sim & $r=3,26 \cdot 10^{11} \cdot K^{-1,70}$ & 0,950 \\
4. & Alta & Sim & $r=1,67 \cdot 10^{11} \cdot K^{-1,67}$ & 0,952 \\
\hline
\end{tabular}

As equações acima são de grande importância, pois permitem uma previsão razoável da curvatura final de chapas de alumínio das ligas 7050 e 7475 em todas as condições de jateamento estudadas.

Nota-se consistência entre as condições de jateamento com pré-tensão e livres. O expoente de $K$ é maior para os pontos referentes às amostras jateadas sem pré-tensão, o que significa que o aumento da intensidade do jateamento é menos pronunciado quando a chapa já está submetida a uma pré-tensão. Além disso, o fator pré-exponencial das amostras livres também é maior, pois a deformação obtida após o jateamento sob tensão é maior.

Considerando-se que a variação dos valores é grande, dado ao caráter experimental e ao às vezes fraco controle dos parâmetros de processo, podese dizer que são iguais os expoentes das equações 1 e 2 e das equações 3 e 4 , caracterizando uma constante dependente do processo. 


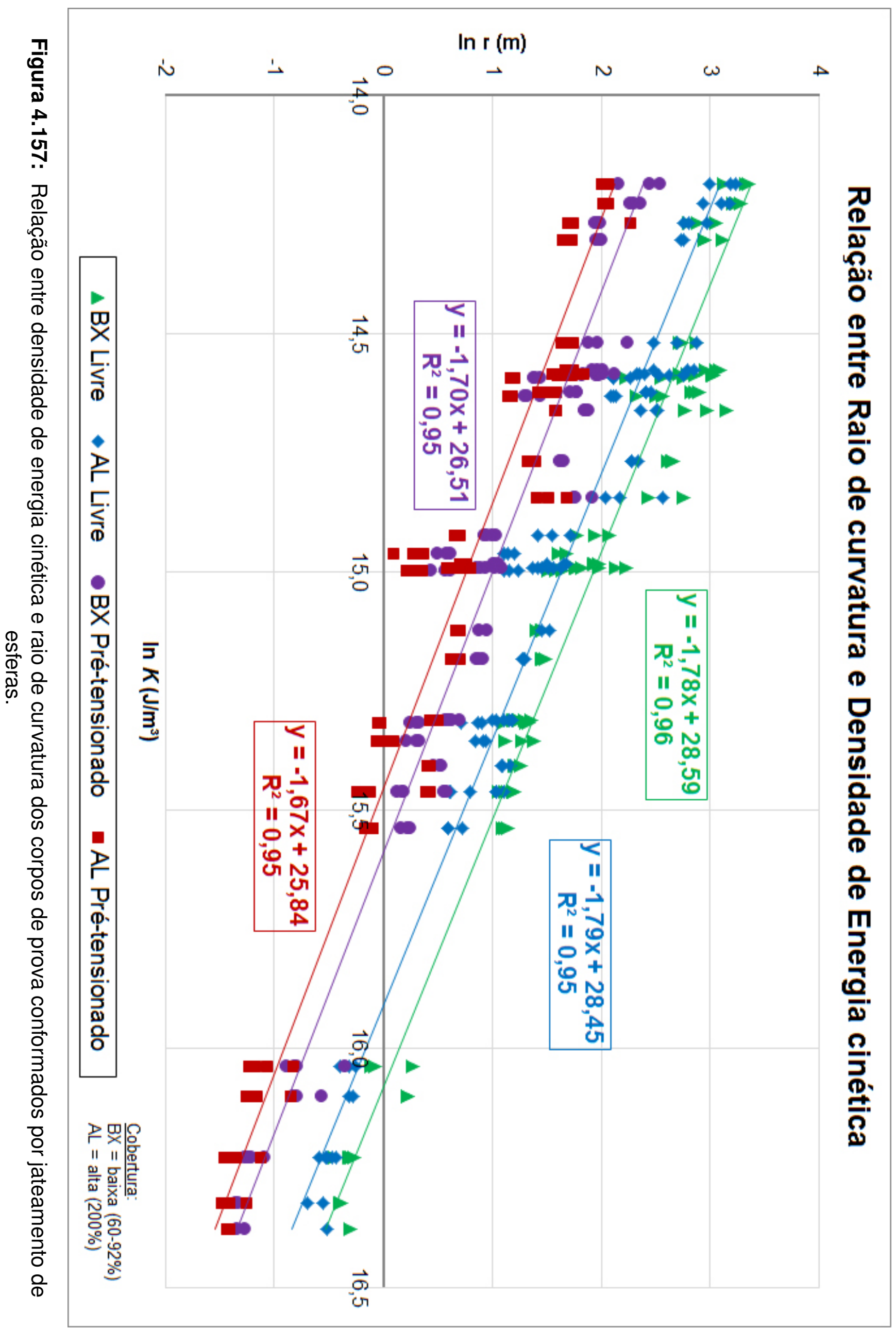




\subsection{Perfil de tensões residuais}

A Figura 4.158 mostra o perfil de tensões residuais a partir da superfície jateada de uma chapa da liga 7050, com 2 mm de espessura, jateada com esfera S230, baixa velocidade $(50,2 \mathrm{~m} / \mathrm{s})$, sem pré-tensão.

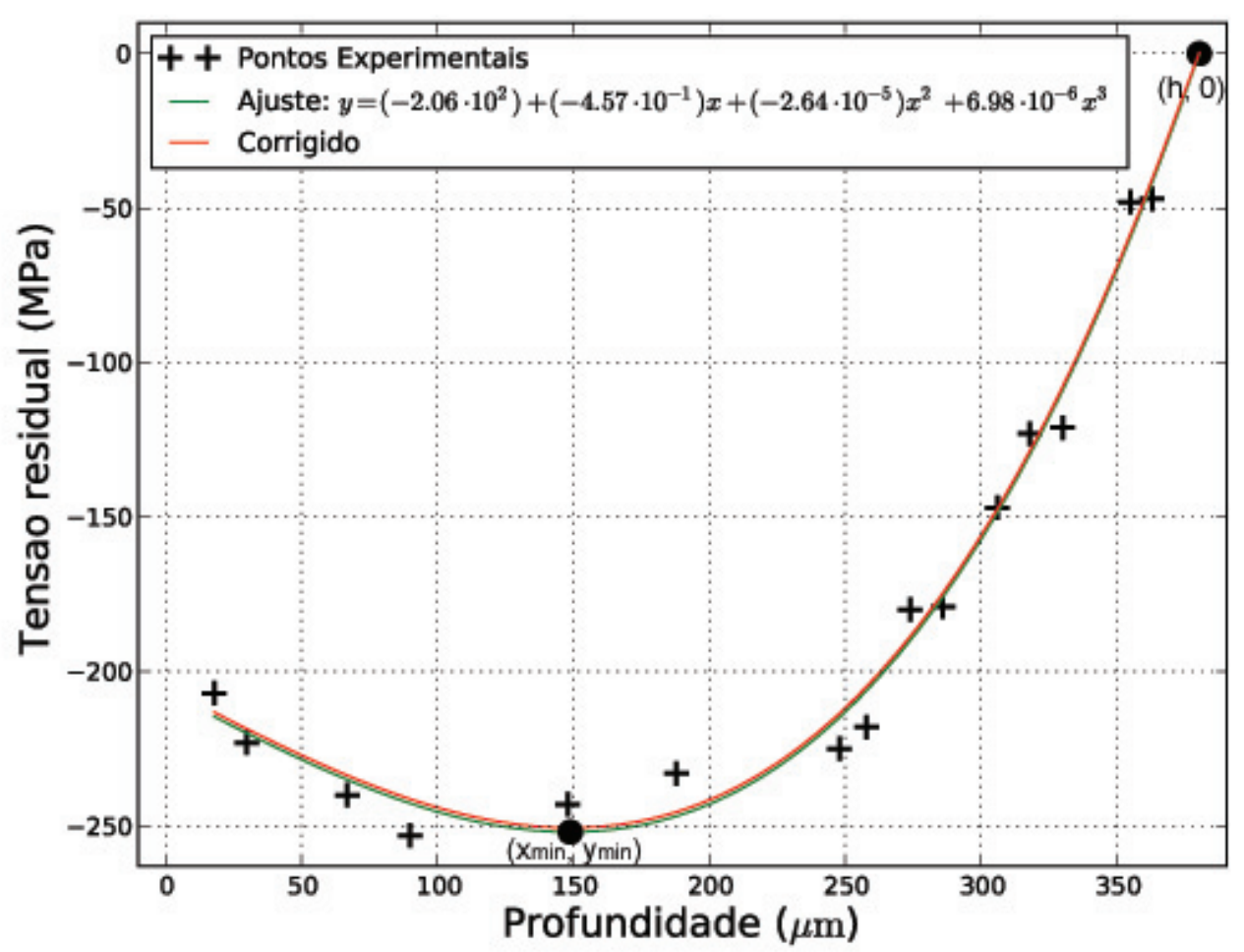

Figura 4.158: Perfil de tensões residuais após JCG em chapa da liga 7050, $2 \mathrm{~mm}$ de espessura, esfera S230, velocidade baixa, sem pré-tensão.

A equação da função de ajuste dos pontos experimentais (linha verde) é um polinômio de grau 3 e está indicada na figura. Pode-se ver que a correção matemática (equação 1.12) para o relaxamento de tensões devido à remoção de camadas sugerida por Moore e Evans ${ }^{[56]}$ (linha vermelha) foi desprezível nos pontos experimentais obtidos e será, doravante, desconsiderada. Os pontos indicados por • são o ponto de máxima tensão residual de compressão (calculada pela equação de ajuste) e o ponto onde a tensão residual é nula.

Os valores calculados para os pontos de mínimo $\left(x_{\min }, y_{\min }\right)$ e de zero $(h, 0)$ são mostrados na Tabela 4.7. 
Tabela 4.7: Pontos $\left(\mathrm{x}_{\min }, \mathrm{y}_{\min }\right)$ de máxima compressão e espessura das camadas deformadas (h).

\begin{tabular}{|c|c|c|c|c|c|c|c|}
\hline$C P n^{\circ}$ & $\begin{array}{l}\text { Espessura } \\
\qquad(\mathrm{mm})\end{array}$ & Esfera & Velocidade & Pré-tensão & $\begin{array}{l}\mathbf{x}_{\min } \\
(\mu m)\end{array}$ & $\begin{array}{c}\mathrm{y}_{\min } \\
(\mathrm{MPa})\end{array}$ & $\begin{array}{c}\mathrm{h} \\
(\mu m)\end{array}$ \\
\hline 009 & 2 & $\mathrm{~S} 230$ & baixa & não & 149 & -252 & 380 \\
\hline 008 & 2 & S230 & média & não & 119 & -254 & 526 \\
\hline 100 & 2 & $\mathrm{~S} 230$ & alta & não & 132 & -250 & 488 \\
\hline 092 & 5 & $\mathrm{~S} 230$ & baixa & não & 80 & -238 & 333 \\
\hline 090 & 5 & S230 & média & não & 75 & -230 & 339 \\
\hline 038 & 5 & $\mathrm{~S} 230$ & alta & não & 101 & -234 & 362 \\
\hline 187 & 5 & S550 & baixa & não & 116 & -156 & 480 \\
\hline 179 & 5 & S550 & média & não & 200 & -164 & 515 \\
\hline 193 & 5 & S550 & alta & não & 216 & -158 & 539 \\
\hline 314 & 10 & S550 & baixa & não & 159 & -288 & 537 \\
\hline 286 & 10 & S550 & média & não & 219 & -299 & 567 \\
\hline 255 & 10 & S550 & alta & não & 215 & -315 & 723 \\
\hline 376 & 10 & 1/8" & baixa & não & 285 & -278 & 709 \\
\hline 371 & 10 & $1 / 8 "$ & média & não & 458 & -266 & 1143 \\
\hline 365 & 10 & $1 / 8 "$ & alta & não & 729 & -295 & 1360 \\
\hline 432 & 15 & $1 / 8^{\prime \prime}$ & baixa & não & 418 & -205 & 770 \\
\hline 423 & 15 & $1 / 8^{\prime \prime}$ & média & não & 588 & -261 & 1057 \\
\hline 418 & 15 & $1 / 8^{\prime \prime}$ & alta & não & 430 & -336 & 1323 \\
\hline 062 & 2 & S230 & baixa & sim & 98 & -241 & 391 \\
\hline 024 & 2 & S230 & média & $\operatorname{sim}$ & 124 & -243 & 427 \\
\hline 015 & 2 & S230 & alta & $\operatorname{sim}$ & 126 & -253 & 428 \\
\hline 144 & 5 & S230 & baixa & $\operatorname{sim}$ & 34 & -234 & 386 \\
\hline 137 & 5 & S230 & média & $\operatorname{sim}$ & 135 & -232 & 559 \\
\hline 133 & 5 & $\mathrm{~S} 230$ & alta & $\operatorname{sim}$ & 125 & -258 & 430 \\
\hline 185 & 5 & S550 & baixa & $\operatorname{sim}$ & 101 & -183 & 506 \\
\hline 182 & 5 & S550 & média & $\operatorname{sim}$ & 290 & -346 & 715 \\
\hline 171 & 5 & S550 & alta & $\operatorname{sim}$ & 333 & -375 & 874 \\
\hline 292 & 10 & S550 & baixa & $\operatorname{sim}$ & 173 & -329 & 645 \\
\hline 263 & 10 & S550 & média & $\operatorname{sim}$ & 237 & -383 & 874 \\
\hline 252 & 10 & S550 & alta & $\operatorname{sim}$ & 283 & -382 & 956 \\
\hline 378 & 10 & 1/8" & baixa & $\operatorname{sim}$ & 371 & -357 & 840 \\
\hline 370 & 10 & 1/8" & média & $\operatorname{sim}$ & 514 & -370 & 1267 \\
\hline 364 & 10 & $1 / 8^{\prime \prime}$ & alta & sim & 448 & -368 & 1639 \\
\hline 431 & 15 & 1/8" & baixa & $\operatorname{sim}$ & 347 & -376 & 1119 \\
\hline 420 & 15 & 1/8" & média & $\operatorname{sim}$ & 447 & -421 & 1406 \\
\hline 413 & 15 & $1 / 8 "$ & alta & $\operatorname{sim}$ & 578 & -396 & 1433 \\
\hline
\end{tabular}

O Apêndice $D$ mostra os ajustes dos valores experimentais, obtidos pela equipe do IPEN ${ }^{[66]}$, e os pontos $\left(\mathrm{x}_{\min }, \mathrm{y}_{\min }\right)$ de máxima compressão e espes- 
sura das camadas deformadas (h) das chapas jateadas com esferas S230, S550 e 1/8", nas três velocidades, com e sem pré-tensão.

\subsubsection{Discussão}

Em diversos casos, como no da amostra de espessura $10 \mathrm{~mm}$, jateada com granalha 1/8", velocidade média, com pré-tensão (Figura 4.159), há uma inflexão no comportamento dos valores de tensões residuais, em geral em profundidades entre 50 e $150 \mu \mathrm{m}$, ou seja, logo nos primeiros pontos abaixo da superfície. Ainda é desconhecida a causa deste comportamento e não há relatos na literatura de casos semelhantes, porém algumas hipóteses são levantadas:

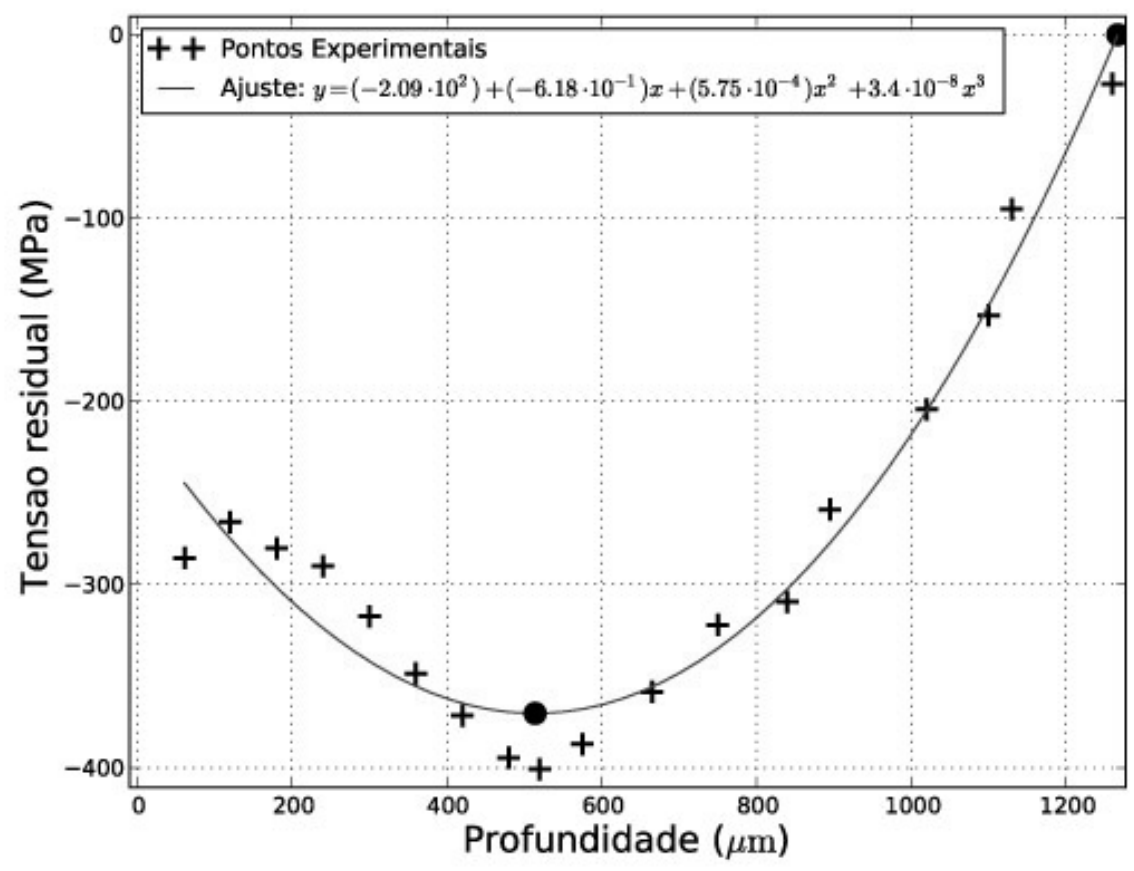

Figura 4.159: Perfil de tensões residuais, com valores de máxima tensão de compressão e espessura da camada deformada, mostrando inflexão a 150 $\mu \mathrm{m}$ da superfície. Chapa da liga 7050, espessura $10 \mathrm{~mm}$, esfera 1/8", velocidade média, com pré-tensão.

- Há uma região de tensões residuais causadas pela deformação plástica e outra região de tensões causadas pela deformação elástica, que não se sobrepõem totalmente nesses casos;

- Houve alteração na microestrutura causada pelo ataque químico com $\mathrm{HCl}$ ou por aquecimento da superfície; 
- O relaxamento das tensões causado pela remoção de camadas é mais significativo na região mais próxima à superfície.

Oliveira ${ }^{[6]]}$, do IPEN, em seu trabalho de mestrado, fez análises mais profundas sobre os dados obtidos.

\subsubsection{Correlação com os parâmetros de processo}

A partir de observações de corpos de prova com condições de jateamento semelhantes senão por 1 dos parâmetros, é possível avaliar qualitativamente o efeito de cada parâmetro na profundidade do ponto $\left(\mathbf{x}_{\min }, \mathrm{y}_{\min }\right)$ de máxima compressão e na espessura (h) da camada deformada. O resultado que foi considerado foi a tendência predominante de aumento ou diminuição do valor, em módulo. Nos casos em que não é possível definir qual tendência acontece no maior número de amostras, o parâmetro foi considerado "não influente". A Tabela 4.8 mostra o resultado das avaliações.

Tabela 4.8: Efeito qualitativo dos parâmetros de jateamento nos pontos de máxima tensão residual de compressão e na espessura da camada deformada.

\begin{tabular}{c|c|c|c}
\hline Parâmetro & $\mathrm{x}_{\min }(\mu m)$ & $\left|\mathrm{y}_{\text {min }}\right|(\mathrm{MPa})$ & $\mathrm{h}(\mu m)$ \\
\hline Espessura & diminui & aumenta & aumenta \\
Esfera & aumenta & diminui & aumenta \\
Velocidade & aumenta & aumenta & aumenta \\
Pré-tensão & não influente & aumenta & aumenta \\
\hline
\end{tabular}

De modo geral, a tendência, quando a intensidade do jateamento aumenta, é aumentar as tensões residuais de compressão, aumentar a espessura da camada deformada (h) e distanciar da superfície o ponto de máxima compressão $\left(\mathbf{x}_{\min }, \mathrm{y}_{\min }\right)$. Deve-se notar, por outro lado, que os valores de tensões residuais medidos são muitas vezes bastante próximos ao limite de escoamento do material (469 MPa).

Conforme o item 7 da seção 2.1 (pág. 78), deseja-se correlacionar o encurvamento com o perfil de tensões residuais. Para isso, cruzando dados das Tabelas 3.6 (pág. 97) e 4.7 (pág. 194), pode-se analisar a relação existente entre a espessura da camada deformada (h) e a deformação das chapas. 
Seria interessante, nesse momento, buscar uma relação direta entre a energia cinética, $\mathrm{E}_{C}$, ou a densidade de energia cinética, $K$, e os valores medidos de $\mathbf{x}_{\min }, \mathbf{y}_{\min }$ e h. Assim, seria possível unir-se a previsão de deformação através de um único parâmetro de processo (Figura 4.157) e a previsão da espessura da camada superficial que é afetada pelo processo.

As Figuras 4.160 a 4.165 mostram o efeito da $E_{C}$ e $K$ nesses valores mencionados:

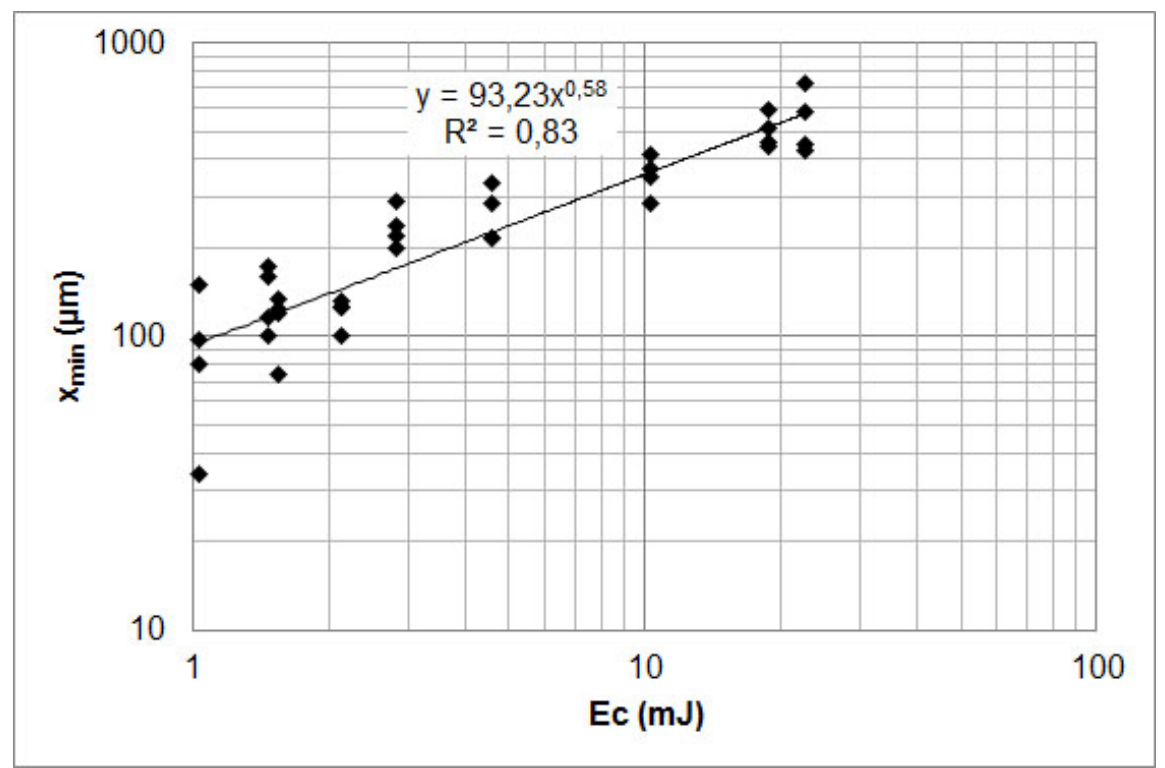

Figura 4.160: Relação entre profundidade de máxima compressão $\left(\mathrm{x}_{\min }\right)$ e energia cinética $\left(\mathrm{E}_{C}\right)$.

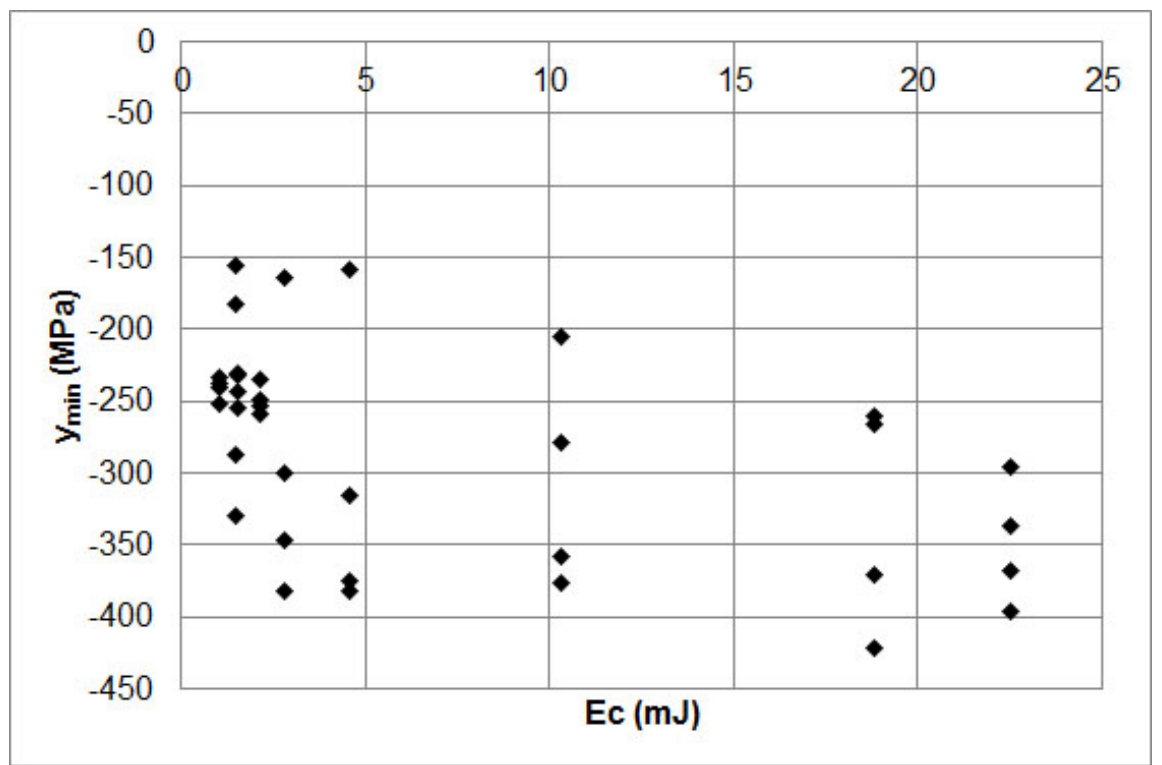

Figura 4.161: Relação entre máxima tensão residual de compressão $\left(\mathrm{y}_{\min }\right)$ e energia cinética $\left(\mathrm{E}_{C}\right)$. 


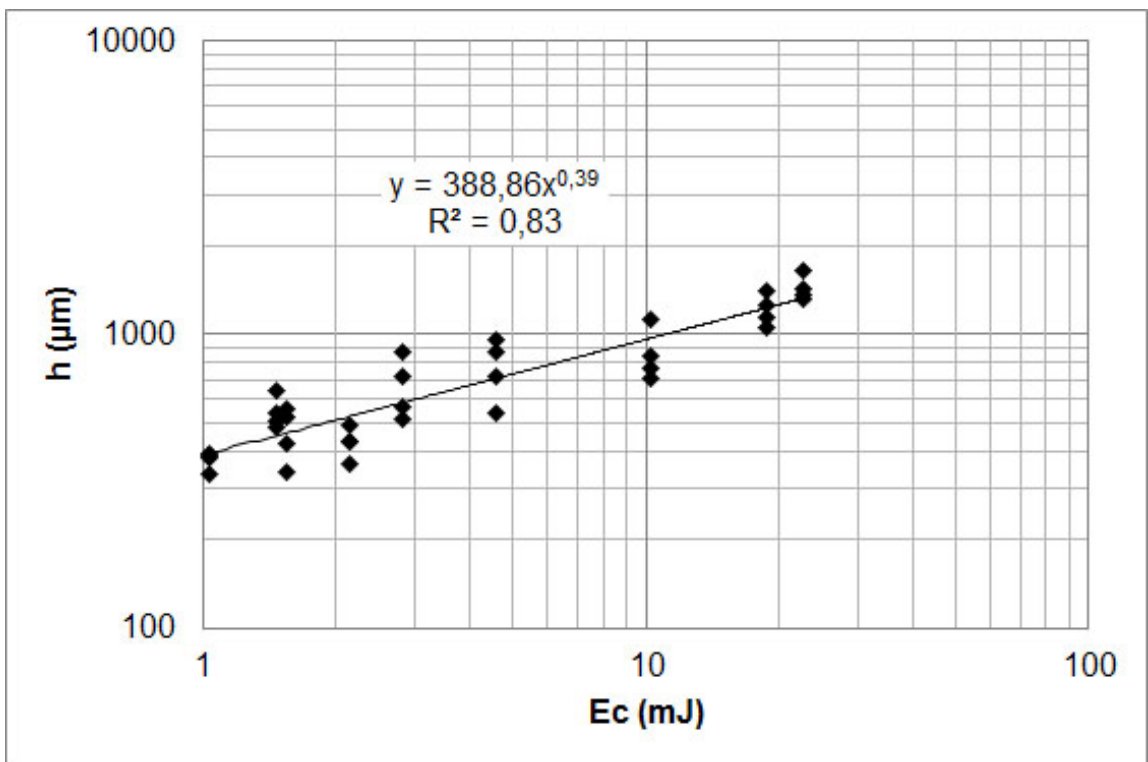

Figura 4.162: Relação entre espessura da camada deformada (h) e energia cinética $\left(\mathrm{E}_{C}\right)$.

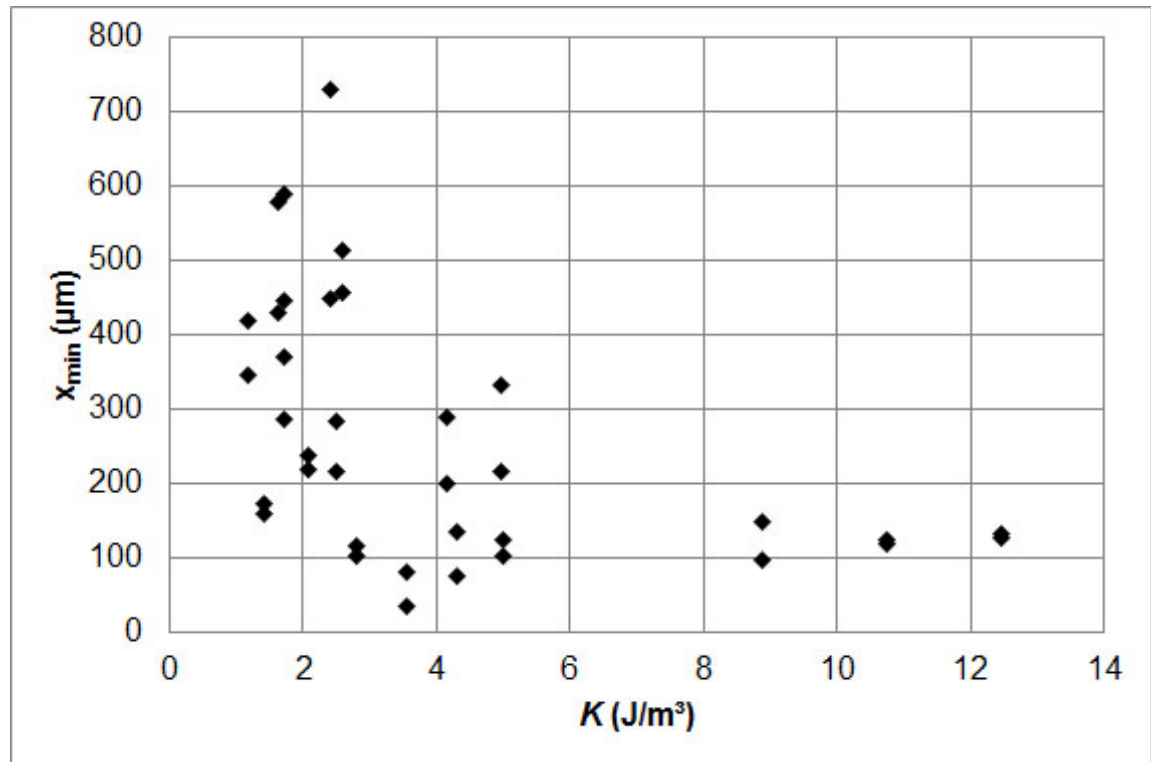

Figura 4.163: Relação entre profundidade de máxima compressão $\left(x_{\min }\right)$ e densidade de energia cinética $(K)$. 


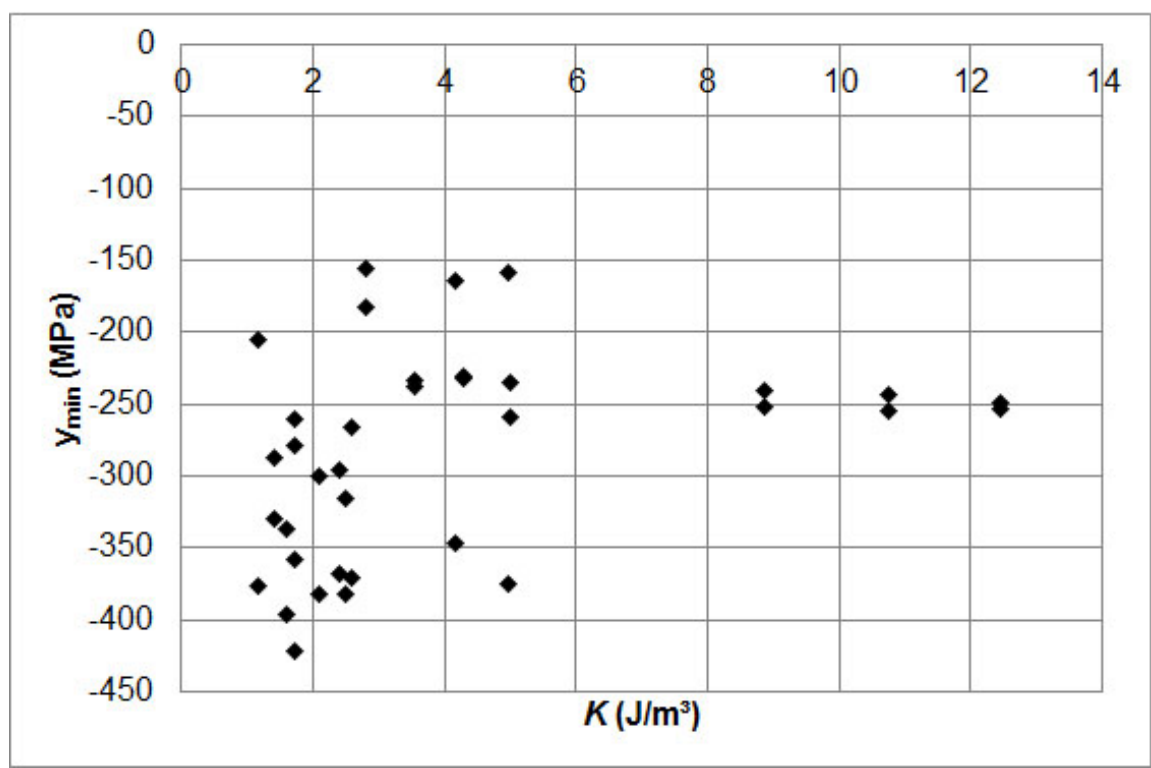

Figura 4.164: Relação entre máxima tensão residual de compressão $\left(\mathrm{y}_{\min }\right)$ e densidade de energia cinética $(K)$.

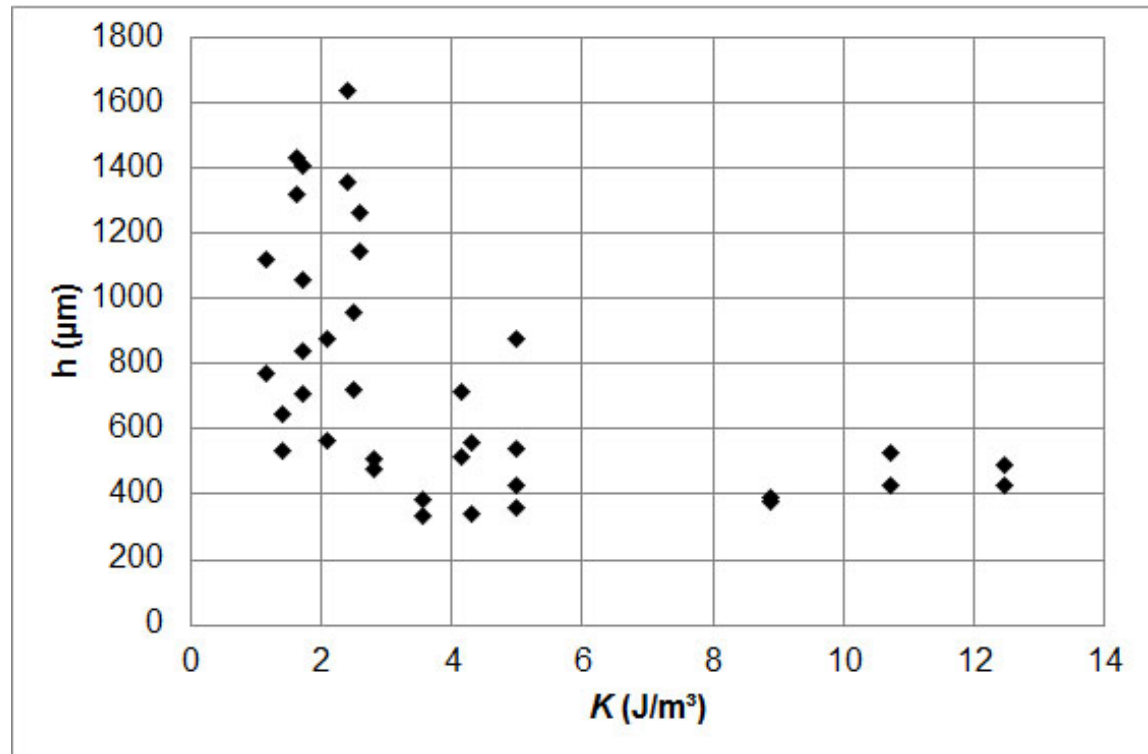

Figura 4.165: Relação entre espessura da camada deformada (h) e densidade de energia cinética $(K)$.

Aparentemente, é possível estabelecer relações apenas entre a energia cinética e os valores de $\mathrm{x}_{\text {min }}$ e $\mathrm{h}$ que seguem uma lei de potência. Os demais gráficos mostram apenas tendências, porém não é possível ajustar equações razoáveis para previsão.

De acordo com a equação 1.7 mostrada na página 53, pode-se relacionar o volume da camada deformada com a energia cinética das esferas:

$$
V^{\prime}=K_{3} \cdot E_{C}
$$


Porém, os dados mostrados na Figura 4.160 indicam que esta equação seria melhor escrita na forma:

$$
V^{\prime}=K_{3} \cdot E_{C}^{n}
$$

$0<n \leqslant 1$

As Figuras 4.166 a 4.171 mostram, respectivamente, o efeito em $\mathrm{x}_{\min }, \mathrm{y}_{\text {min }}$ e h do raio de curvatura como medido $(r)$ e normalizado $\left(r / H^{2}\right)$ (seção 4.5).

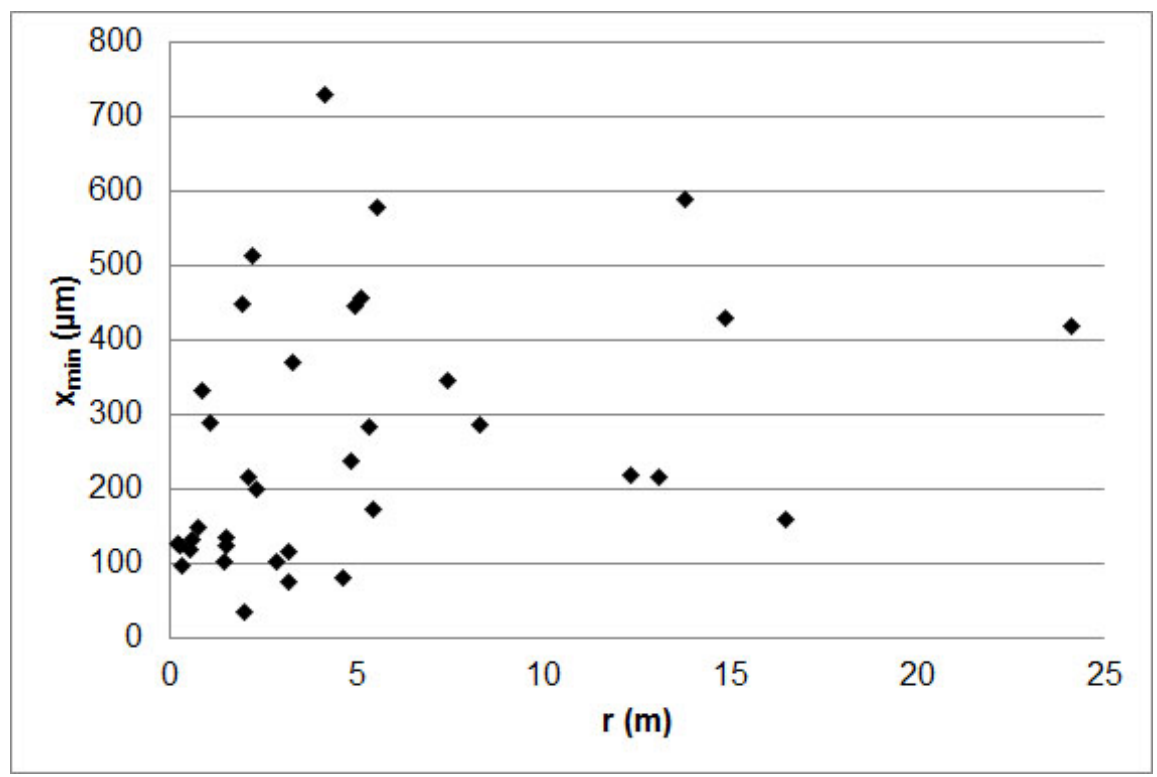

Figura 4.166: Relação entre profundidade de máxima compressão $\left(x_{\min }\right)$ e raio de curvatura $(r)$.

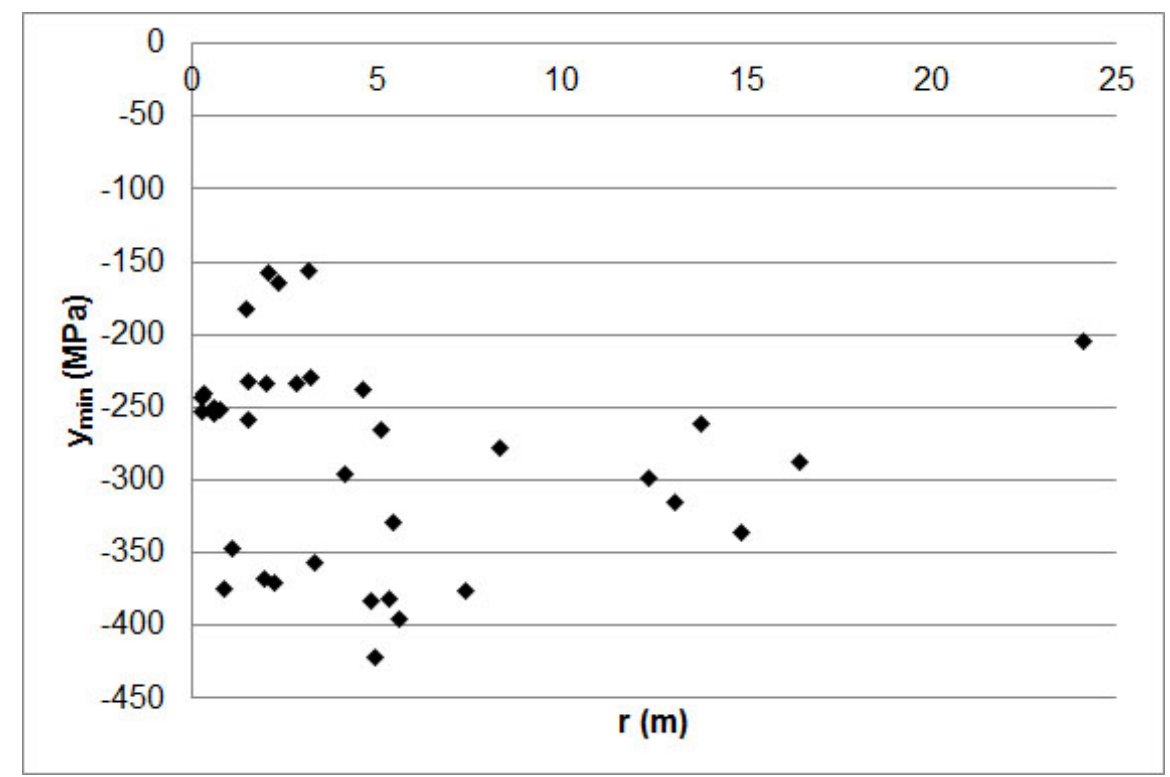

Figura 4.167: Relação entre máxima tensão residual de compressão $\left(\mathrm{y}_{\min }\right)$ e raio de curvatura $(r)$. 


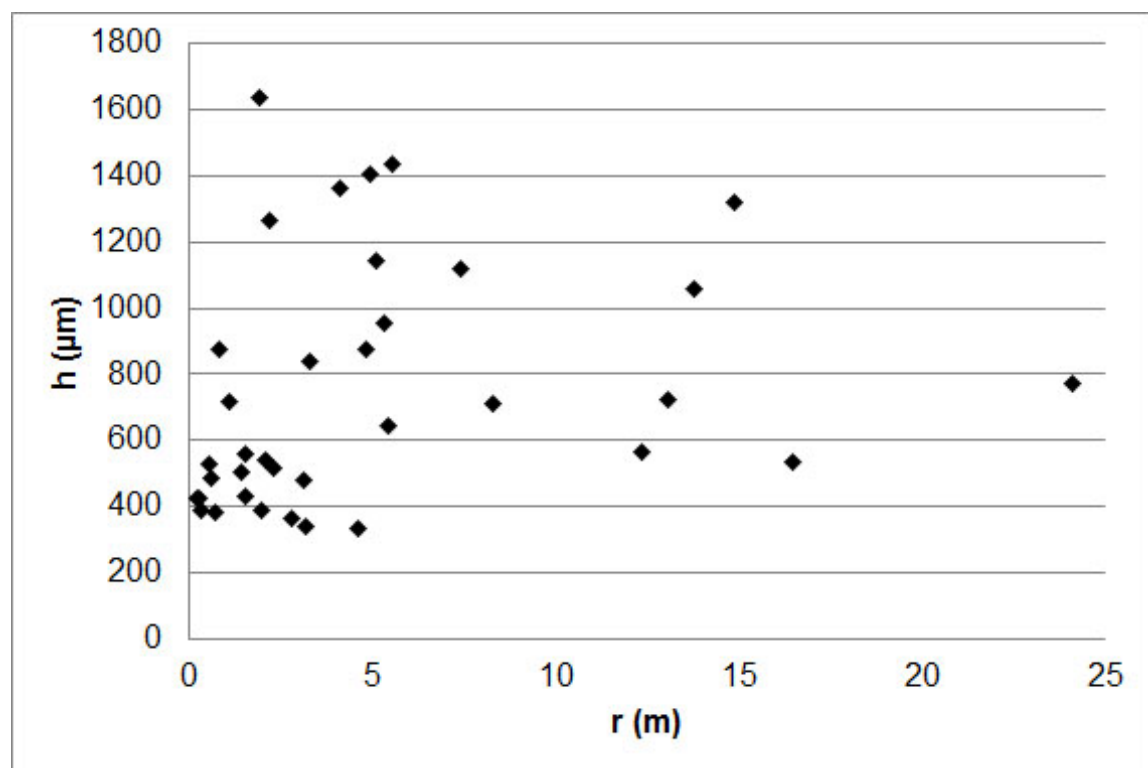

Figura 4.168: Relação entre espessura da camada deformada (h) e raio de curvatura $(r)$.

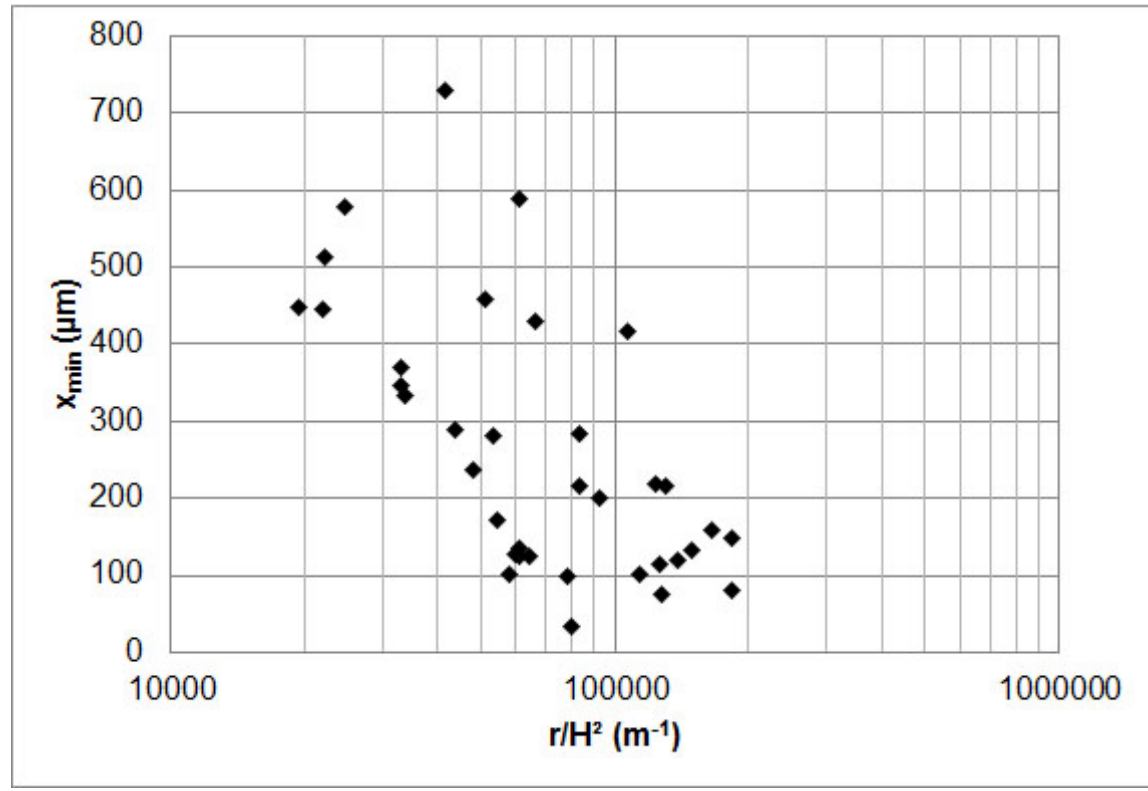

Figura 4.169: Relação entre profundidade de máxima compressão $\left(x_{\min }\right)$ e raio de curvatura normalizado $\left(r / H^{2}\right)$. 


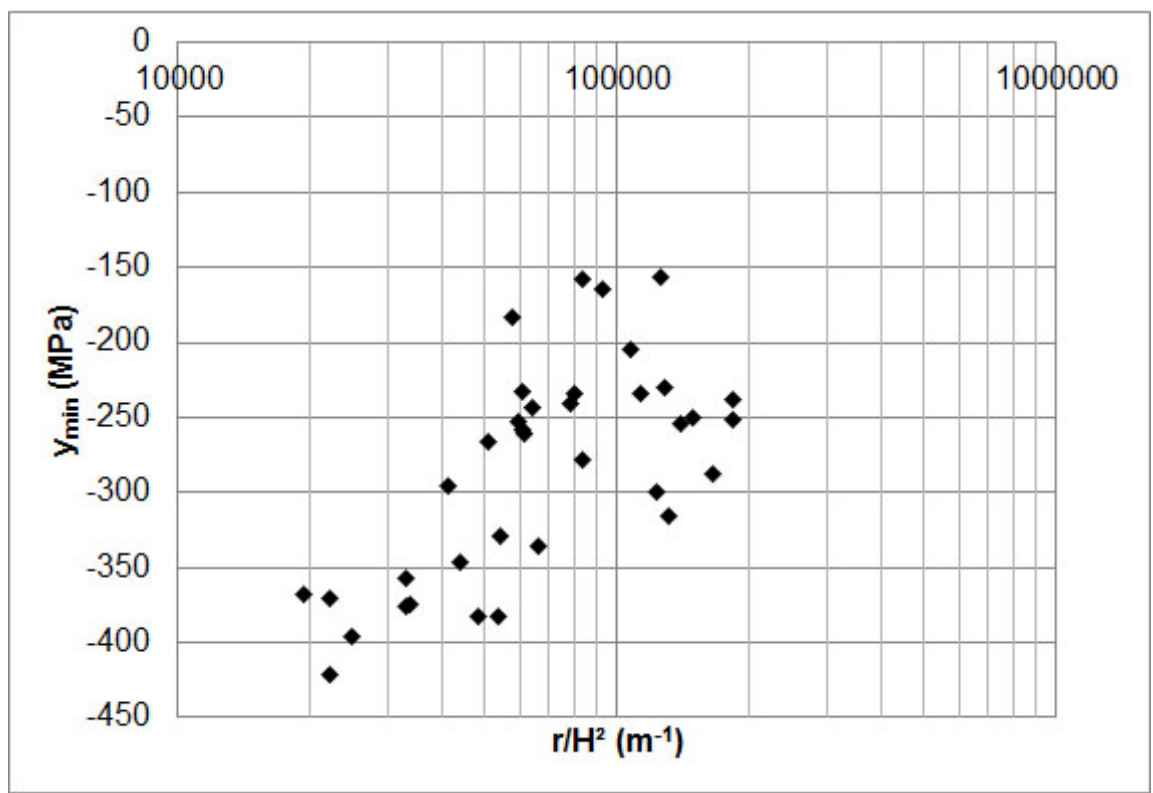

Figura 4.170: Relação entre máxima tensão residual de compressão $\left(\mathrm{y}_{\min }\right)$ e raio de curvatura normalizado $\left(r / H^{2}\right)$.

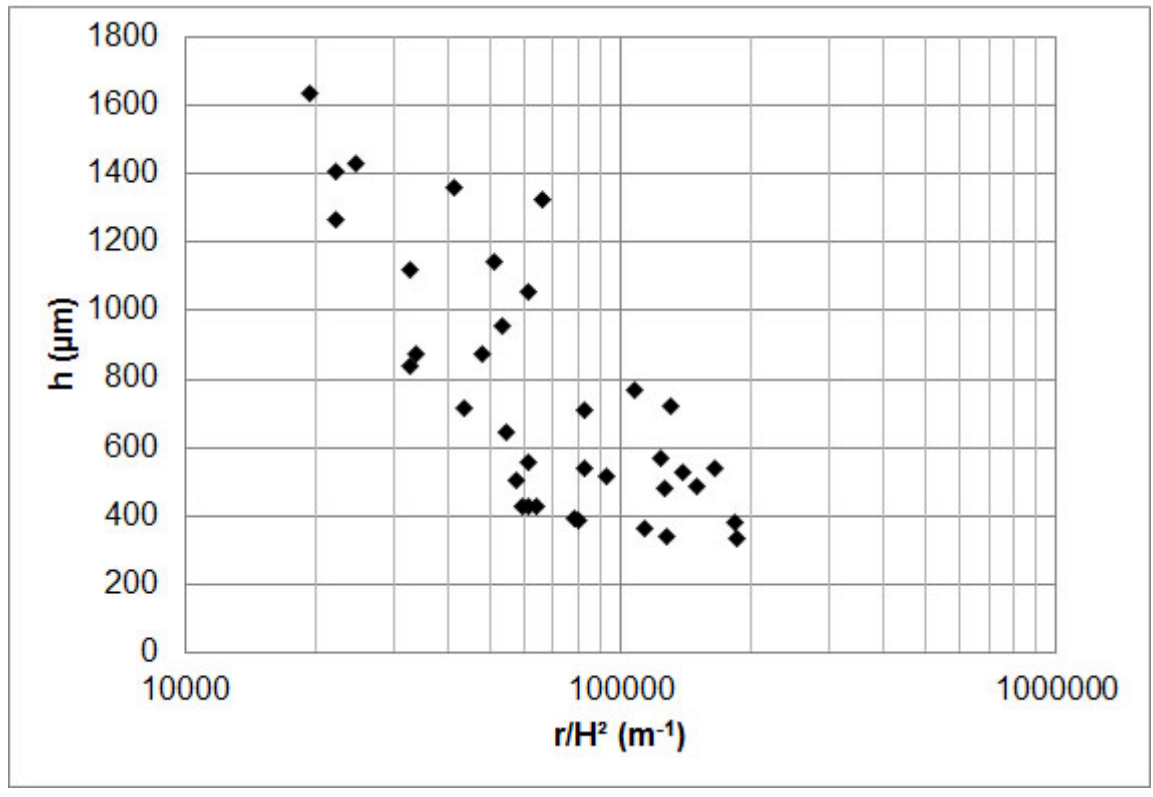

Figura 4.171: Relação entre espessura da camada deformada (h) e raio de curvatura normalizado $\left(r / H^{2}\right)$.

Nota-se que $r / H^{2}$ têm uma boa correlação com os três valores medidos: maiores deformações das chapas são relacionadas a maior espessura da camada deformada, maior tensão residual (compressão) e maior distância do ponto de máxima tensão à superfície. Isso vem ao encontro da suposição de que o momento fletor gerado pela camada deformada é o principal agente no encurvamento da chapa. Entretanto, as relações que puderam ser observadas não são suficientes, per se, para uma boa previsão de deformação durante o projeto de experimentos de conformação por jateamento com granalhas. 


\subsection{Redes Neurais Artificiais}

Após o treinamento e o teste da RNA, o software NeuroSolutions for Exce ${ }^{\circledR}$ apresenta um relatório que contém um gráfico mostrando a aderência da RNA aos dados experimentais das linhas designadas como teste, e uma tabela com os valores dos erros. Ambos são mostrados na Figura 4.172 e na Tabela 4.9:

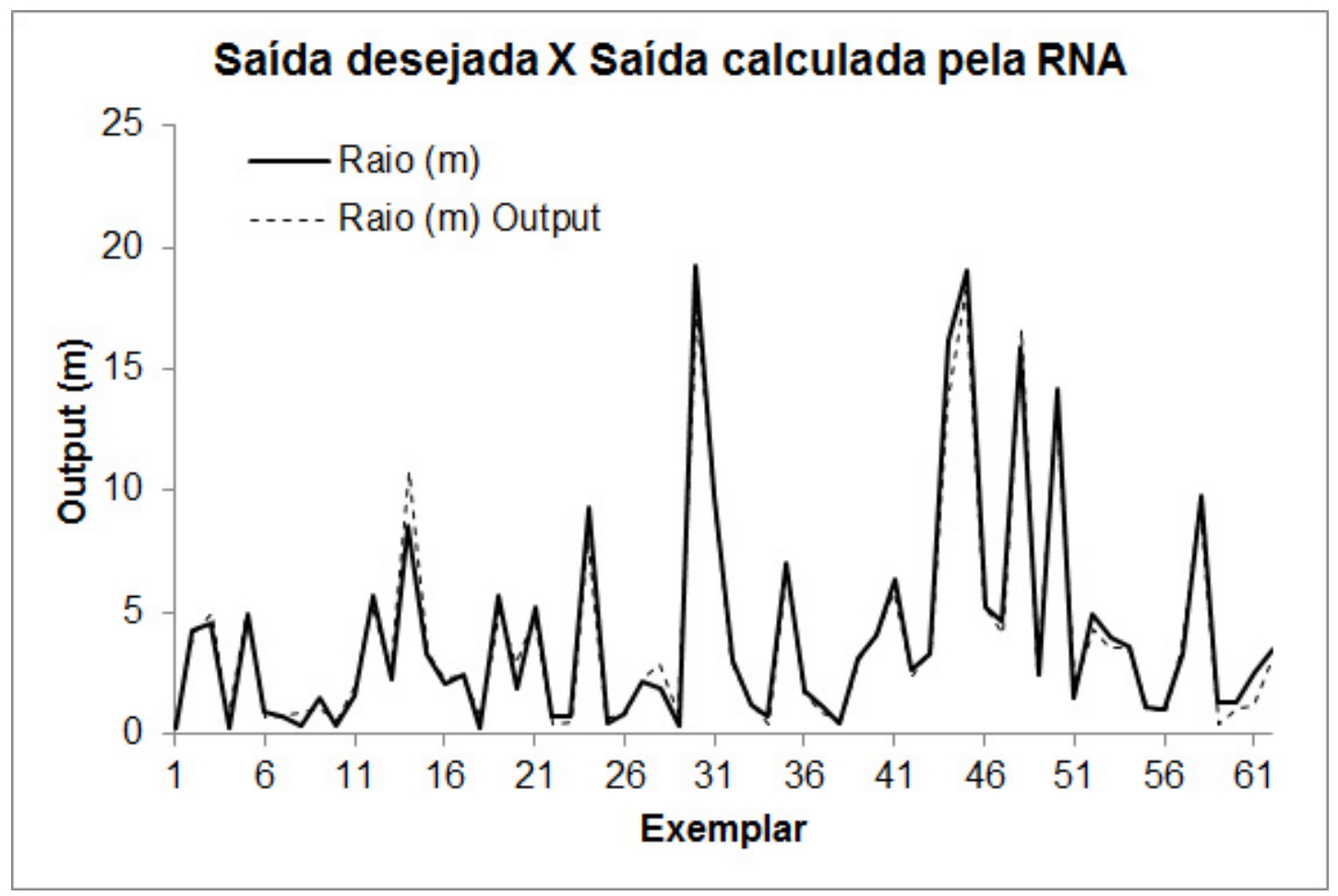

Figura 4.172: Aderência da rede neural artificial aos 62 testes (exemplares).

Tabela 4.9: Relatório de valores estatísticos após treinamento da RNA.

\begin{tabular}{c|c}
\hline Performance & Raio de curvatura $(\mathrm{m})$ \\
\hline Erro quadrático médio (MSE) & 0,457 \\
Erro quadrático médio normalizado (NMSE) & 0,022 \\
Erro absoluto médio (MAE) & 0,438 \\
Mínimo erro absoluto (Min Abs Error) & 0,003 \\
Máximo erro absoluto (Max Abs Error) & 2,680 \\
Coeficiente de correlação linear (r) & 0,990 \\
\hline
\end{tabular}

Para melhor observar a qualidade da previsão da RNA gerada, pode-se observar em um gráfico a relação entre o raio de curvatura real e o raio de curvatura calculado para todos os 402 dados utilizados no treinamento, validação cruzada e teste (Figura 4.173). 


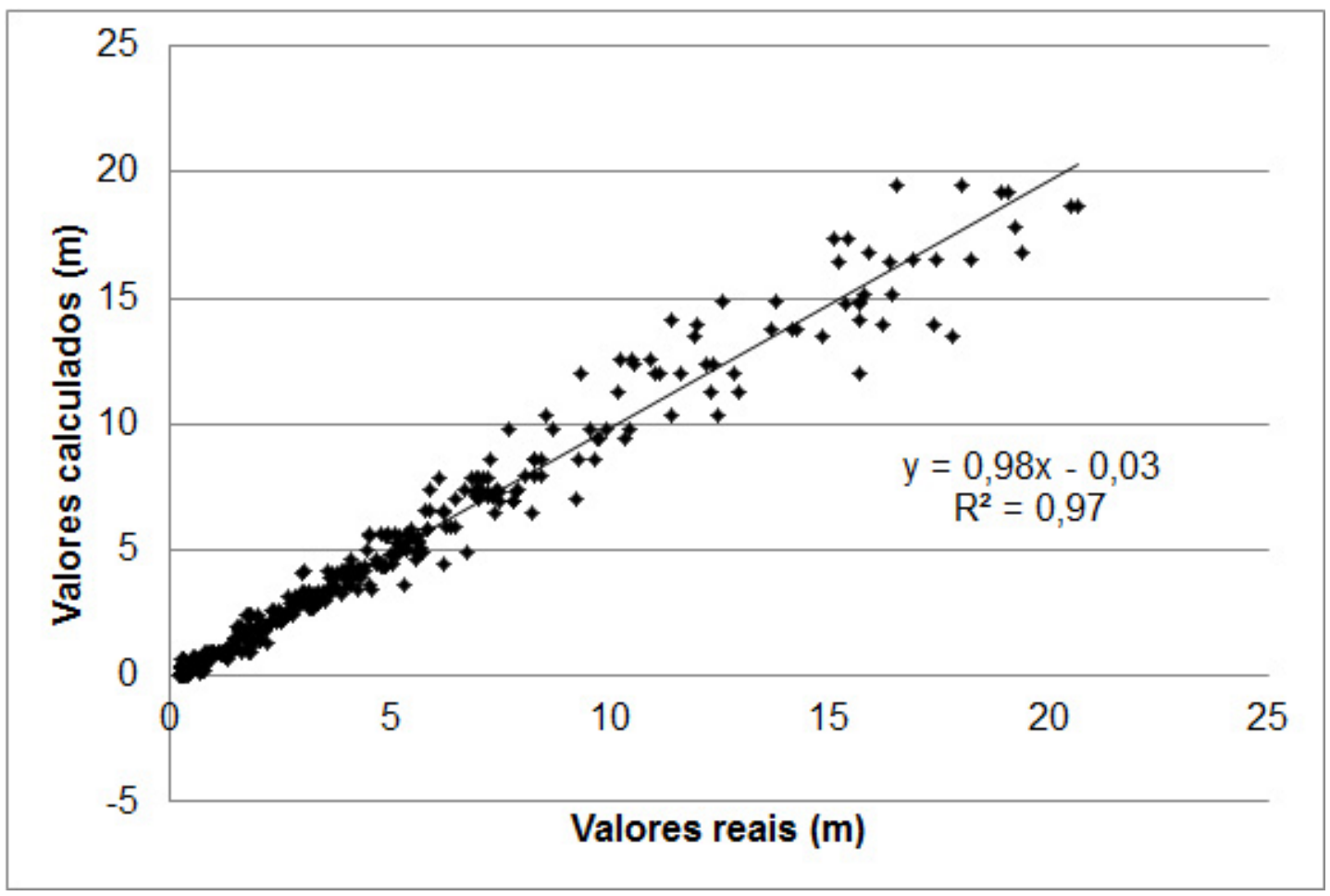

Figura 4.173: Correlação entre a previsão de curvatura e os dados reais.

O coeficiente angular do ajuste linear é 0,98 , o que significa que os valores calculados estão muito próximos dos valores reais.

A Tabela 4.10 mostra os resultados de previsão de raio de curvatura para as chapas fictícias de 4, 7 e $12 \mathrm{~mm}$ de espessura, das ligas 7050 e 7475, com esferas pequenas, médias e grandes, respectivamente. Os parâmetros de jateamento foram os mesmos utilizados para as granalhas S230, S550 e $1 / 8$ ". 
Tabela 4.10: Resultados de previsão de raio de curvatura para as chapas fictícias de 4,7 e $12 \mathrm{~mm}$ de espessura.

\begin{tabular}{|c|c|c|c|c|c|c|}
\hline Liga & $\begin{array}{l}\text { Espessura } \\
\qquad(\mathrm{mm})\end{array}$ & $\begin{array}{l}\text { Diâmetro da } \\
\text { esfera }(\mathrm{mm})\end{array}$ & $\begin{array}{c}\text { Velocidade } \\
(\mathrm{m} / \mathrm{s})\end{array}$ & Pré-tensão & Cobertura & $\begin{array}{c}\text { Raio de } \\
\text { curvatura (m) }\end{array}$ \\
\hline 7050 & 4 & 0,584 & 50,2 & não & $66 \%$ & 2,988 \\
\hline 7475 & 4 & 0,584 & 61,2 & não & $85 \%$ & 2,362 \\
\hline 7050 & 4 & 0,584 & 72,2 & não & $92 \%$ & 2,191 \\
\hline 7475 & 4 & 0,584 & 50,2 & não & $200 \%$ & 2,383 \\
\hline 7050 & 4 & 0,584 & 61,2 & não & $200 \%$ & 2,294 \\
\hline 7475 & 4 & 0,584 & 72,2 & não & $200 \%$ & 2,259 \\
\hline 7050 & 4 & 0,584 & 50,2 & $\operatorname{sim}$ & $66 \%$ & 1,740 \\
\hline 7475 & 4 & 0,584 & 61,2 & $\operatorname{sim}$ & $85 \%$ & 1,852 \\
\hline 7050 & 4 & 0,584 & 72,2 & $\operatorname{sim}$ & $92 \%$ & 1,368 \\
\hline 7475 & 4 & 0,584 & 50,2 & $\operatorname{sim}$ & $200 \%$ & 1,337 \\
\hline 7050 & 4 & 0,584 & 61,2 & $\operatorname{sim}$ & $200 \%$ & 1,472 \\
\hline 7475 & 4 & 0,584 & 72,2 & $\operatorname{sim}$ & $200 \%$ & 0,957 \\
\hline 7475 & 7 & 1,397 & 16,2 & não & $60 \%$ & 10,785 \\
\hline 7475 & 7 & 1,397 & 22,4 & não & $60 \%$ & 8,680 \\
\hline 7475 & 7 & 1,397 & 28,6 & não & $60 \%$ & 6,841 \\
\hline 7475 & 7 & 1,397 & 16,2 & não & $200 \%$ & 7,528 \\
\hline 7475 & 7 & 1,397 & 22,4 & não & $200 \%$ & 5,721 \\
\hline 7475 & 7 & 1,397 & 28,6 & não & $200 \%$ & 4,220 \\
\hline 7475 & 7 & 1,397 & 16,2 & $\operatorname{sim}$ & $60 \%$ & 3,229 \\
\hline 7475 & 7 & 1,397 & 22,4 & $\operatorname{sim}$ & $60 \%$ & 2,739 \\
\hline 7475 & 7 & 1,397 & 28,6 & $\operatorname{sim}$ & $60 \%$ & 2,356 \\
\hline 7475 & 7 & 1,397 & 16,2 & $\operatorname{sim}$ & $200 \%$ & 2,507 \\
\hline 7475 & 7 & 1,397 & 22,4 & $\operatorname{sim}$ & $200 \%$ & 2,195 \\
\hline 7475 & 7 & 1,397 & 28,6 & $\operatorname{sim}$ & $200 \%$ & 1,909 \\
\hline 7050 & 12 & 3,175 & 12,5 & não & $60 \%$ & 16,222 \\
\hline 7050 & 12 & 3,175 & 16,9 & não & $60 \%$ & 12,627 \\
\hline 7050 & 12 & 3,175 & 18,5 & não & $60 \%$ & 11,288 \\
\hline 7050 & 12 & 3,175 & 12,5 & não & $200 \%$ & 12,386 \\
\hline 7050 & 12 & 3,175 & 16,9 & não & $200 \%$ & 9,020 \\
\hline 7050 & 12 & 3,175 & 18,5 & não & $200 \%$ & 7,790 \\
\hline 7050 & 12 & 3,175 & 12,5 & $\operatorname{sim}$ & $60 \%$ & 6,115 \\
\hline 7050 & 12 & 3,175 & 16,9 & $\operatorname{sim}$ & $60 \%$ & 4,436 \\
\hline 7050 & 12 & 3,175 & 18,5 & $\operatorname{sim}$ & $60 \%$ & 3,836 \\
\hline 7050 & 12 & 3,175 & 12,5 & $\operatorname{sim}$ & $200 \%$ & 4,257 \\
\hline 7050 & 12 & 3,175 & 16,9 & $\operatorname{sim}$ & $200 \%$ & 3,078 \\
\hline 7050 & 12 & 3,175 & 18,5 & $\operatorname{sim}$ & $200 \%$ & 2,652 \\
\hline
\end{tabular}

A fim de avaliar a qualidade dessas previsões, podem-se comparar os gráficos de efeito da velocidade de impacto e da cobertura (Figuras 4.174 a 
4.178) com os gráficos dos valores reais, para observar se os dados previstos seguem a mesma tendência.

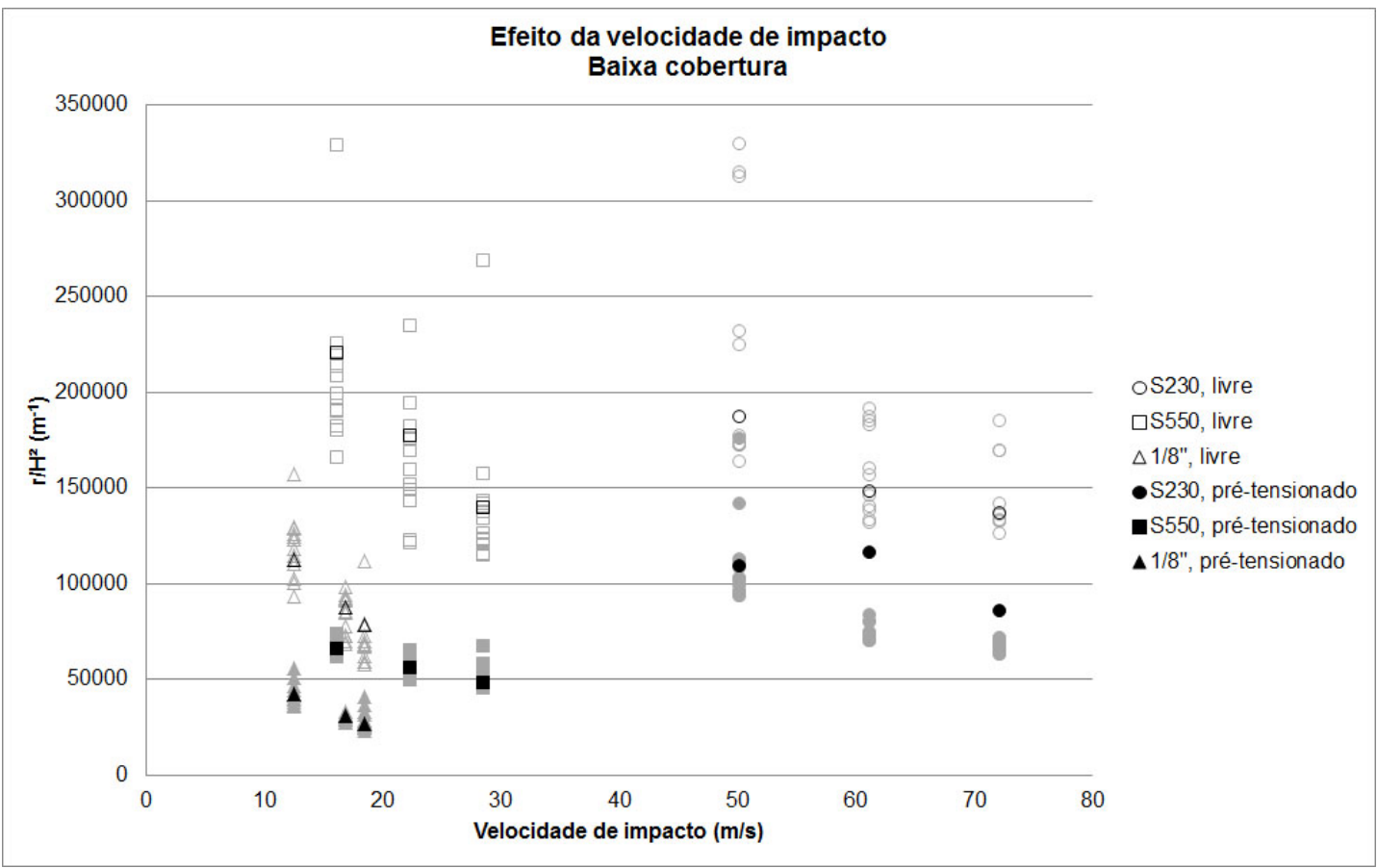

Figura 4.174: Efeito da velocidade de impacto sobre $r / \mathrm{H}^{2}$. Chapas com cobertura baixa (60 a 92\%). Em preto: dados fictícios calculados.

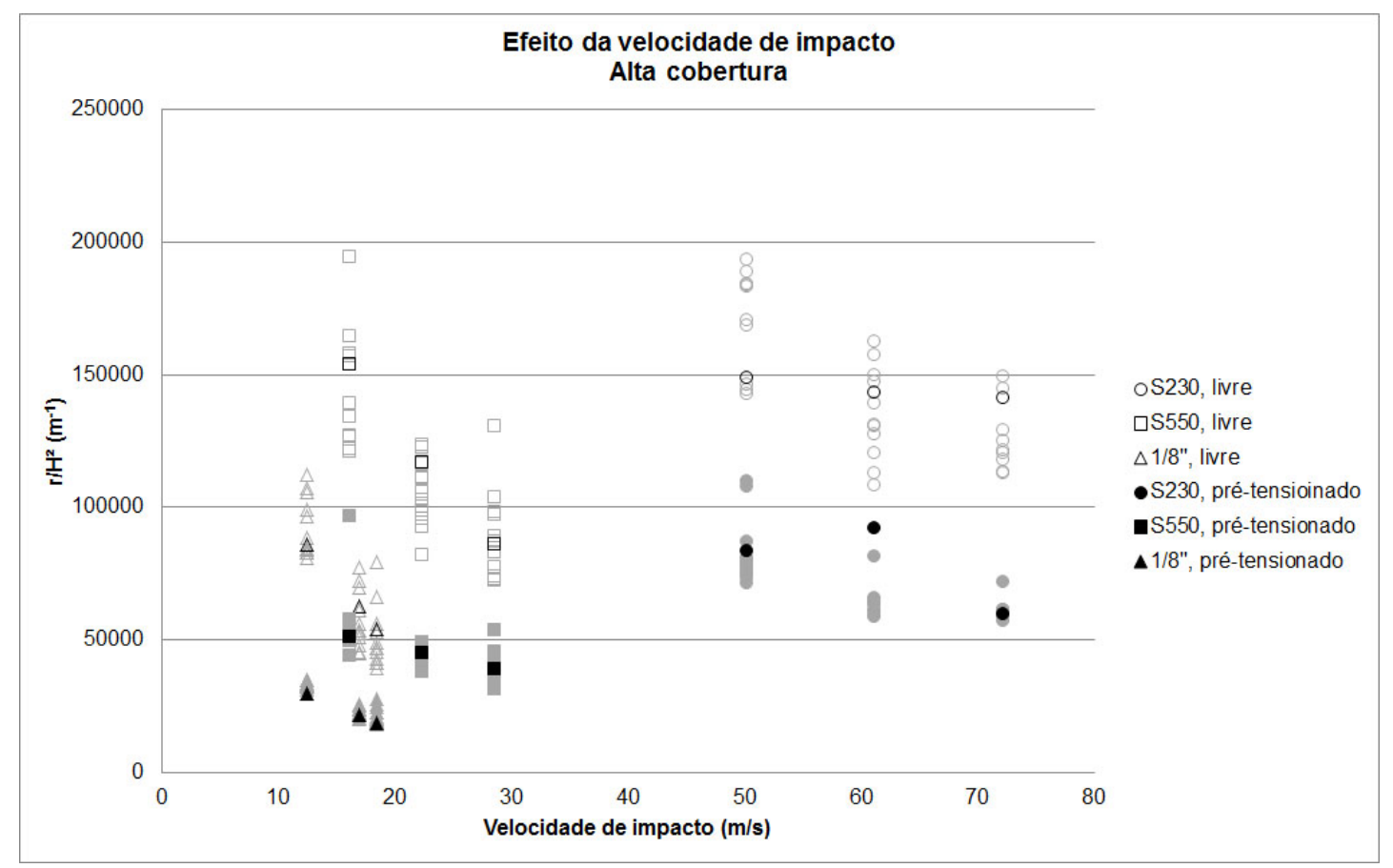

Figura 4.175: Efeito da velocidade de impacto sobre $r / \mathrm{H}^{2}$. Chapas com cobertura alta (200\%). Em preto: dados fictícios calculados.

Há uma aparente anormalidade no comportamento das chapas fictícias de $4 \mathrm{~mm}$ pré-tensionadas (série 'S230, pré-tensionado'), facilmente observável 
nas duas figuras anteriores. O raio de curvatura calculada para a velocidade de impacto média é maior (menor deformação) que as chapas simuladas com velocidades baixa e alta. Isto se justifica, porque, para as chapas de $4 \mathrm{~mm}$, foram simuladas as duas ligas ao mesmo tempo, alternadamente, como pode ser visto na Tabela 4.10. Fica claro, a partir de então, que a diferença de comportamento das duas ligas não é tão desprezível como suposto anteriormente, apesar de se mesclar às incertezas de medições das 3 repetições de ensaio para cada condição de jateamento (Figura 4.139, pág. 180). A liga 7050, por ter maior resistência mecânica, deforma menos que a liga 7475 , que desenvolve raios de curvatura menores.

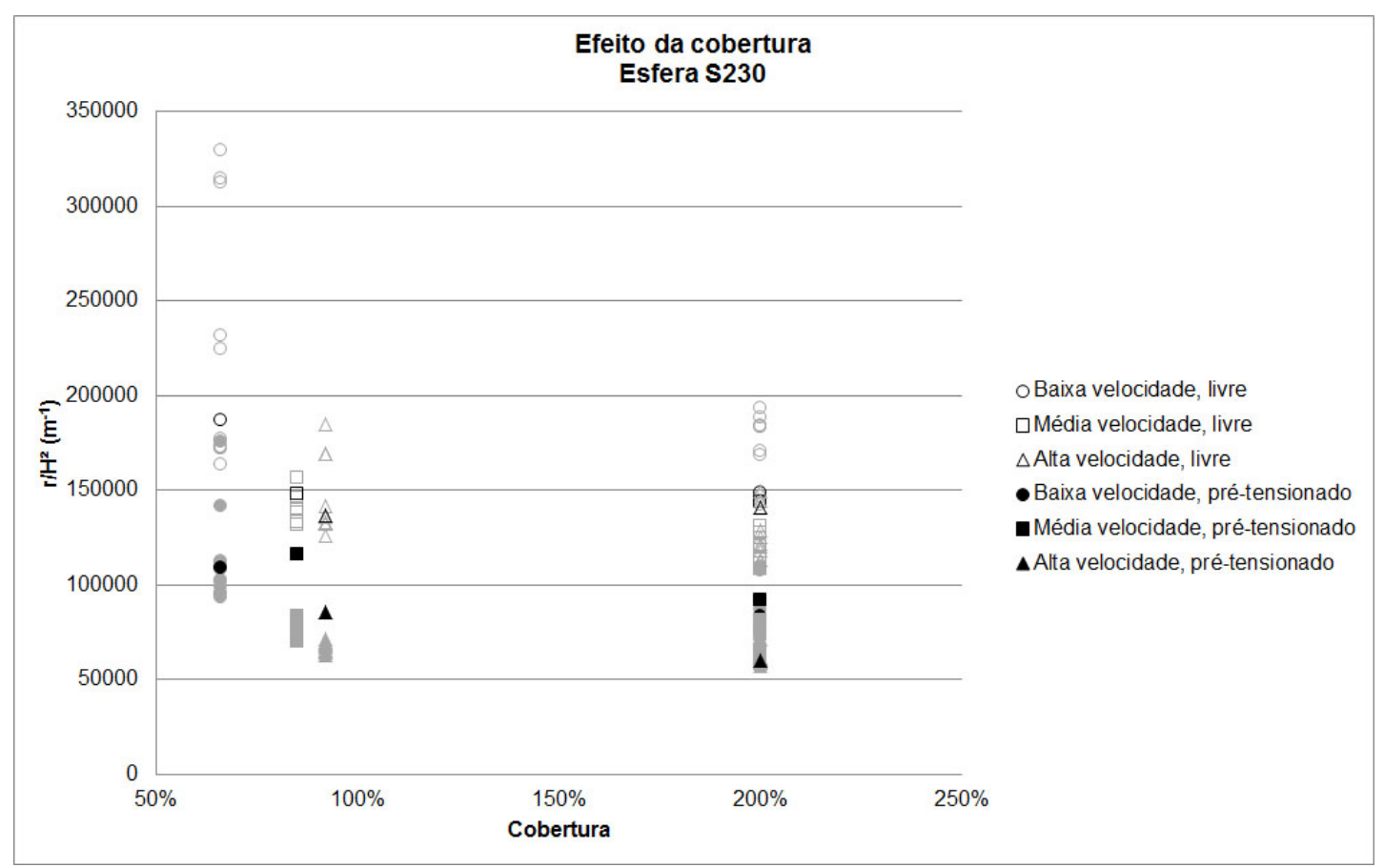

Figura 4.176: Efeito da cobertura sobre $r / \mathrm{H}^{2}$. Chapas jateadas com granalha S230. Em preto: dados fictícios calculados. 


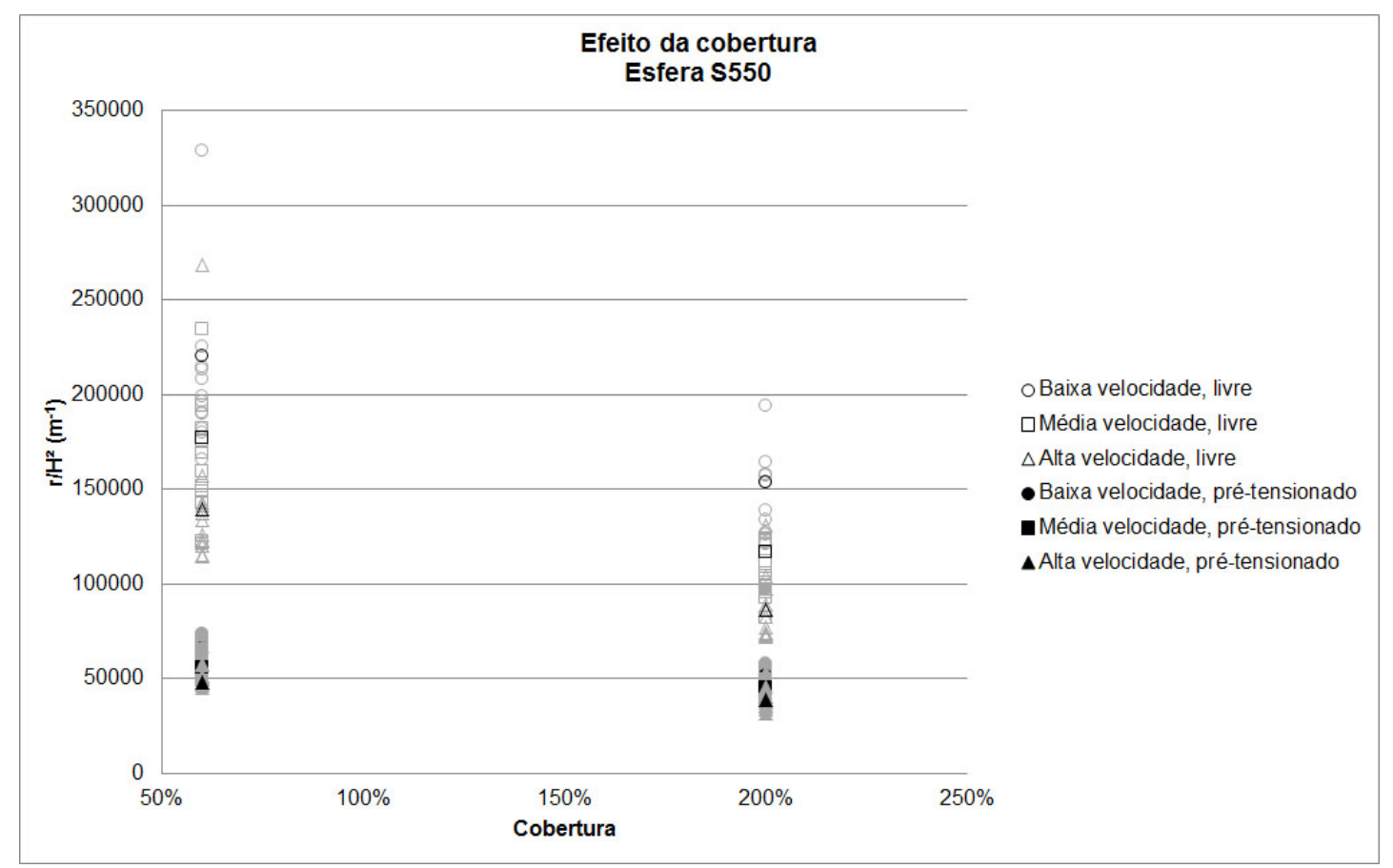

Figura 4.177: Efeito da cobertura sobre $\mathrm{r} / \mathrm{H}^{2}$. Chapas jateadas com granalha S550. Em preto: dados fictícios calculados.

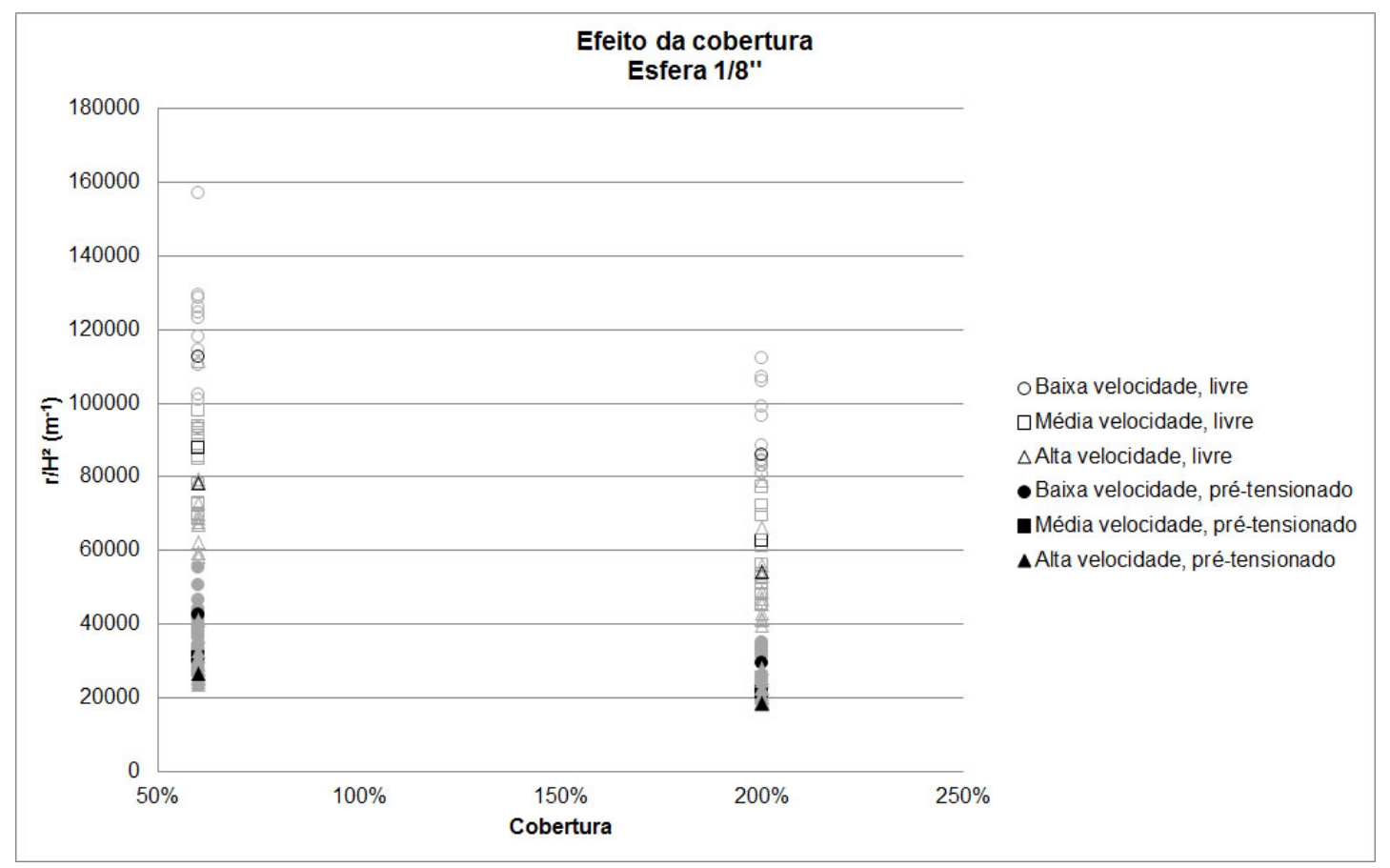

Figura 4.178: Efeito da cobertura sobre $\mathrm{r} / \mathrm{H}^{2}$. Chapas jateadas com granalha 1/8". Em preto: dados fictícios calculados.

O comportamento das chapas de $7 \mathrm{~mm}$ é igual ao comportamento das chapas de 5 e $10 \mathrm{~mm}$, pois os pontos em destaque estão exatamente no meio das faixas de valores medidos para os pontos verdadeiros. Isto mostra que 0 uso de redes neurais artificiais seria de grande utilidade na previsão de deformação de chapas de diferentes espessuras e poderia ser utilizado para con- 
trole do processo, por automação do equipamento. No caso do processo de conformação por jateamento com granalhas, uma solução tecnologicamente viável seria o acoplamento de um sistema de mediçãode curvaturas a um computador que ajusta um ou mais parâmetros (p.e. pressão do jato), de acordo com o resultado desejado. Desta forma, grandes peças, como asas de avião, poderiam ser fabricadas com maior precisão e com necessidades de correções e ajustes cada vez menores, uma vez que a rede neural aprende com cada experiência de jateamento e melhora a sua previsão. 


\section{Conclusões}


Após análise dos resultados obtidos, pode-se observar que:

- O processo de conformação por jateamento com granalhas no alumínio possibilitou a obtenção de diversos níveis de deformação (curvaturas), tornando viável a conformação de formas complexas.

- A visualização e caracterização da camada deformada plasticamente não pode ser feita satisfatoriamente através de microscopia óptica.

- Não foi possível caracterizar as amostras com medidas de dureza, mesmo comparando-se amostras recozidas e encruadas.

- Tratamentos térmicos de recristalização não são eficazes para revelar a camada deformada devido ao encruamento pré-existente nas chapas devido à laminação.

- Apesar de resultados anteriores serem satisfatórios, a técnica de EBSD não é prática o suficiente para ser realizada em grandes quantidades de amostras e os resultados obtidos não possibilitam a caracterização da camada deformada.

- As ligas 7050-T7451 e 7475-T7351 mostraram o mesmo comportamento em parâmetros de processo semelhantes.

- As chapas que sofrem o maior encurvamento são as mais finas.

- Os efeitos do tamanho da esfera e da velocidade de impacto são os mais significativos.

- O efeito da porcentagem de cobertura é o mais indicado para pequenas correções durante o jateamento de formas complexas.

- A pré-tensão do componente é muito influente na deformação final e no perfil de tensões residuais.

- A liga 7050 tem resistência mecânica pouco maior que a liga 7475. Embora não seja relevante para a maioria das análises, a rede neural se mostrou sensível a esta diferença, prevendo raios de curvatura menores para a liga mais resistente.

- Há correlação entre a espessura da camada deformada e a profundidade de máxima compressão, medidas através dos perfis de tensões residuais, e a energia cinética das granalhas. 
- Foi possível obter equações semi-empíricas de relação entre processo e encurvamento através do valor de densidade de energia cinética $(K)$. $O$ raio de curvatura, $r$, é proporcional a $K$, valor que engloba os parâmetros diâmetro de granalha, velocidade de impacto e espessura da chapa, segundo uma lei de potência.

- A previsão do valor de raio de curvatura através de redes neurais artificiais mostrou-se o método mais eficaz para controle rápido do processo. Sugere-se a investigação dessa ferramenta em trabalhos futuros, em diferentes grupos de dados, ou com novas arquiteturas, ou observando-se outros valores de saída, como os dados de tensão residual.

Em resumo, conclui-se que há pouca possibilidade de se caracterizar a camada deformada plasticamente pelo processo de conformação por jateamento com granalhas através de técnicas envolvendo microscopia, porém o melhor método para medição da sua espessura é por obtenção de perfis de tensões residuais. Foi possível obter um eficiente método de previsão de raio de curvatura através de valores empíricos de corpo de prova e processo. $\mathrm{O}$ método mais prático e preciso de previsão de curvatura e controle do processo parece ser o uso de redes neurais artificiais. 
214 


\section{Referências}

1 GONÇALVES, M. Desenvolvimentos recentes no segmento de ligas de alumínio aeronáuticas. In: ABAL. IV Congresso Internacional do Alumínio. São Paulo, 2010.

2 FONTANARI, V. et al. Comparison of the hole-drilling and x-ray diffraction methods for measuring the residual stresses in shot-peened aluminum alloys. Journal of Strain Analysis, v. 40, n. 2, p. 199-209, set. 2005.

3 YOSHIZATO, A. Shot Peening - Training: Concepts and technology. São José dos Campos, SP, jun. 2004.

4 O'HARA, P. Peen forming - a developing technique. In: Shot Peening. Alemanha: DGM, 2002. p. 217-226.

5 DUCKER WORLDWIDE. Executive Summary. EUA, dec. 2009.

6 VIANA, T. G. et al. Caracterização do fechamento de trinca de fadiga numa liga Al 7475 pré-deformada e com shot peening. Revista Matéria, v. 10, n. 3, p. 454-462, 2005. ISSN 1517-7076. Disponível em: $<$ http://www.materia.coppe.ufrj.br/sarra/artigos/artigo10683>.

7 ABAL - ASSOCIAÇÃO BRASILEIRA DO ALUMÍNIO. Aplicações. Disponível em: <http://abal .org. br>. Acesso em: ago. 2009.

8 DAVIS, J. (Ed.). ASM Specialty Handbook: Aluminum and aluminum alloys. OH, EUA, jan. 1993.784 p.

9 CONSERVA, M.; DONZELLI, G.; TRIPPODO, R. Classification of aluminum alloys and their tempers. In: Aluminum and its applications.

IT: Edimet, 1992. p. 76-77.

10 TOTTEN, G. E.; MACKENZIE, D. S. (Ed.). Handbook of Aluminum: Physical metallurgy and processes. Nova lorque, EUA, 2003. v. 1.

11 ROBSON, J. D. A new model for prediction of dispersoid precipitation in aluminium alloys containing zirconium and scandium. Acta Materialia, v. 52, p. 1409-1421, nov. 2003.

12 Starke Jr., E. A.; STALEY, J. T. Application of modern aluminum alloys to aircraft. Progress in Aerospace Sciences, v. 32, p. 131-172, fev. 1996.

$13 \mathrm{HU}, \mathrm{H}$. E. et al. Microstructure characterization of 7050 aluminum alloy during dynamic recrystallization and dynamic recovery. Materials Characterization, v. 59, p. 1185-1189, 2008.

14 AMERICAN SOCIETY FOR METALS. ASM Metals Handbook: Volume 2, properties and selection: Nonferrous alloys and special-purpose materials. OH, EUA, 1992. 
15 LIU, J. hua et al. Effect of the microstructure of al 7050-t7451 on anodic oxide formation in sulfuric acid. International Journal of Minerals, Metallurgy and Materials, v. 16, n. 4, p. 432-439, 2009.

16 AMERICAN NATIONAL STANDARDS INSTITUTE. ANSI H35.1/H35.1M: Standard alloy and temper designation systems for aluminum. [S.I.], 2009.

17 METAL SUPPLIERS ONLINE. 7050 Aluminum Material Property Data Sheet. Disponível em: <http://www. suppliersonline.com/propertypages/ 7050. asp >. Acesso em: jun. 2008.

18 METAL SUPPLIERS ONLINE. 7475 Aluminum Material Property Data Sheet. Disponível em: <http://www. suppliersonline.com/propertypages/ 7475. asp >. Acesso em: jun. 2008.

19 MatWeb - MATERIAL PROPERTY DATA. The Online Materials Information Resource: Aluminum 7050-T7451 (7050-T73651). Disponível em: <http://www. matweb.com/search/DataSheet.aspx?MatGUID= 142262cf7fbc4c83917ca5c3d17df1ed >. Acesso em: ago. 2009.

20 MatWeb - MATERIAL PROPERTY DATA. The Online Materials Information Resource: Aluminum 7475-T7351. Disponível em: <http://www. matweb.com/search/DataSheet.aspx?MatGUID= 92620a0b7b9a44f cb34799eda01d2b18>. Acesso em: ago. 2009.

21 AL-HASSANI, S. T. S. Mechanical aspects of residual stress development in shot peening. In: ICSP, 1. International Conference on Shot Peening. França, 1981. p. 583-602.

22 MARKOVINA, R.; BLAGOJEVIC, B.; BAN, D. Peen-forming - the possibility of technology transfer from aircraft industry to the production of high-speed ships. BrodoGradnja, Croácia, v. 59, p. 35-43, 2008.

23 BROWN, S. Feasibility of Replacing Structural Steel with Aluminum Alloys in the Shipbuilding Industry. Disponível em: $<$ http://tc. engr.wisc. edu/uer/uer99/author1/content.html >. Acesso em: abr. 2011.

24 MARKOVINA, R. The main principles of using integral panels (skins) in modern shipbuilding industry. In: Proceedings of the Sixth International Conference on Advanced Manufacturing Systems and Technology. Austria: [s.n.], 2002.

25 GONZALES, M. A. C. et al. Modelagem computacional da influência da espessura da peça e a velocidade de impacto do jato no processo de jateamento com granalha. In: PUCP. $8^{\circ}$ Congresso Iberoamericano de Engenharia Mecânica. Cusco, Peru, 2007.

26 BAUGHMAN, D. L. An overview of peen forming technology. In: ICSP, 2. International Conference on Shot Peening. Chicago, U.S.A., 1984. p. 28-32.

27 ALMEN, J. O. Shot blasting test. [S.I.], jun. 1944. Disponível em: $<$ http://www.freepatent sonline.com/2350440.html>.

28 SAE INTERNATIONAL. SAE J 444: Cast shot and grit size specifications. [S.I.], 1993. 
29 FUCHS, H. O. Defects and virtues of the almen intensity scale. In: ICSP, 2. International Conference on Shot Peening. USA, 1984. p. 74-78.

30 KIRK, D. Interactive shot peening control. In: ICSP, 5. International Conference on Shot Peening. U.K., 1993. p. 10-15.

31 ZENG, Y. Finite element simulation of shot peen forming. In: Shot Peening. Alemanha: DGM, 2002. p. 555-561.

32 SILVA, E. C. da; BUTTON, S. T.; PAVANELLO, R. Estado atual da conformação pelo processo "peen forming". Revista UNIVILLE, Joinville, SC, v. 11, n. 2, 2006.

33 IIDA, K. Dent and affected layer produced by shot peening. In: ICSP, 2. International Conference on Shot Peening. USA, 1984. p. 283-292.

34 CINTEQ/IPT, CTPP/IPT, UNICAMP, EMBRAER. RELATÓRIO TÉCNICO No 102200-205: Análise experimental e modelagem numérica do processo de conformação de placas de ligas de alumínio por jateamento de esferas. São Paulo, set. 2008.

35 WOHLFAHRT, $\mathrm{H}$. The influence of peening conditions on the resulting distribution of residual stress. In: ICSP, 2. International Conference on Shot Peening. Chicago, USA, 1984. p. 316-331.

36 MENIG, R. Depth profiles of macro residual stresses in thin shot peened steel plates determined by X-ray and neutron diffraction. Scripta Materialia, v. 45, p. 977-983, outubro 2001. ISSN 13596462. Disponível em: <http://linkinghub.elsevier.com/retrieve/pii/S1359646201010636>.

37 GRASTY, L. V.; ANDREW, C. Shot peen forming sheet metal: finite element prediction of deformed shape. Proc Instn Mech Engrs, v. 210, p. 361-366, 1996.

38 HAN, K.; OWEN, D. R. J.; PERIC, D. Combined finite/discrete element and explicit/implicit simulations of peen forming process.

Engineering Computations, v. 19, n. 1, p. 92-118, 2002. Disponível em: <http://www.emeraldinsight.com/0264-4401.htm>.

39 KITTEL, S. et al. Tight tolerance peen forming with on-line shape control. In: ICSP. International Conference on Shot Peening. Poland, 1999. p. 301-307.

40 WANG, T.; PLATTS, J.; LEVERS, A. Finite element impact modeling for shot peen forming. In: ICSP, 8. International Conference on Shot Peening. Alemanha, 2002. p. 541-546.

41 AL-OBAID, Y. F. Shot peening mechanics: experimental and theoretical analysis. Mechanics of Materials, v. 19, n. 2-3, p. 251-260, 1995. ISSN 0167-6636. Disponível em: <http://www.sciencedirect.com/science/ article/B6TX6-3YB571C-N/2/965035ae028bf7aacff08c497cfc6070>.

42 CAMA, H. et al. Effect of Strain on Recovery. Disponível em: $<$ http://aluminium.matter.org.uk/content/html/ENG/default.asp? catid=67\\&pageid=1247713831 $>$. 
43 OXFORD INSTRUMENTS. Electron Backscatter Diffraction. Disponível em: <http://www. ebsd.com/ebsdexplained.htm>. Acesso em: fev. 2009.

44 CASTRO, N. A. Controle da textura e da microtextura durante o processo de fabricação de aços elétricos semiprocessados. Tese (Doutorado) - Escola Politécnica da USP, São Paulo, 2008.

45 WRIGHT, S. I.; NOWELL, M. M. EBSD image quality mapping. Microscopy and Analysis, v. 12, p. 72-84, 2006.

46 NOWELL, M. M.; WITT, R. A.; TRUE, B. EBSD sample preparation: Techniques, tips and tricks. Microsc. Microanal, v. 11(Supp 2), p. 504-505, 2005.

47 WUHRER, R. et al. EBSD and XRM of phases in vacuum cast composite alloys. Microsc. Microanal, v. 11(Supp 2), p. 1678-1679, 2005.

48 POETSCHER, F. Efeito do número de passes e do tratamento térmico pós-soldagem de liga de alumínio AA 6063 soldada por atrito linear com mistura (FSW). Tese (Doutorado) - Escola Politécnica da Universidade de São Paulo, 2009.

$49 \mathrm{GAO}, \mathrm{N}$. et al. A comparison of grain size determination by light microscopy and EBSD analysis. Journal of Materials Science, v. 40, n. 18, p. 4971-4974, set. 2005.

50 FONDA, R.; BINGERT, J. Texture variations in an aluminum friction stir weld. Scripta Materialia, v. 57, n. 11, p. 1052-1055, 2007. ISSN 1359-6462.

Disponível em: <http://www.sciencedirect.com/science/article/ B6TY2-4PKP4K2-1/2/57079dc03763437b70b1363be7b8021b >.

51 IMS. SlipLines: The international metallographic society newsletter. jun. 2007. 8 p. Disponível em: <http://www. internationalmetallographicsociety. org/sliplines/june07. pdf $>$.

52 MARTINS, J. de P.; PADILHA, A. F. Caracterização da liga comercial de alumínio 3003 produzida por fundição contínua de chapas ("twin roll caster") - textura cristalográfica. R. Esc. Minas, v. 60(3), p. 565-569, jul. set. 2007. Disponível em: <http://www. scielo.br/pdf/rem/v60n3/v60n3a19.pdf >.

53 FONSECA, G. S. da. Preparo para EBSD. [mensagem pessoal] Mensagem recebida por: <anapaola@ipt.br> em 7 de abril de 2009.

54 CULLITY, B. D. Stress measurement. In: . Elements of X-ray diffraction. University of Notre Dame: ADDISON-WESLEY PUBLISHING COMPANY, 2001. cap. 17, p. 431-453.

55 PREVEY, P. S. ASM Metals Handbook: Volume 10, materials characterization. OH, EUA.

56 MOORE, M. G.; EVANS, W. P. Mathematical correction for stress in removed layers in $\mathrm{x}$-ray diffraction residual stress analysis. SAE Transactions, v. 66, p. $340-345,1958$.

57 HILLEY, M. E. (Ed.). SAE J 784-A: Residual stress measurement by X-ray diffraction. [S.I.], 1971. 
58 WICK, A. et al. Effect of shot peening parameters on the surface characteristics of differently heat treated aisi 4140 . In: ICSP, 7. International Conference on Shot Peening. Warsaw, Polônia, 1999. p. 42-53.

59 STERGIOU, C.; SIGANOS, D. Neural Networks. London, UK, 1996. Disponível em: <http://www.doc.ic.ac.uk/ nd/surprise_96/journal/ vol4/cs11/report.html $>$.

60 MACKAY, D. J. C. Information Theory, Inference, and Learning Algorithms. Cambridge, UK: Cambridge University Press, 2003.

61 MEDEIROS, J. S. de. Bancos de Dados Geográficos e Redes Neurais Artificiais: Tecnologias de Apoio à Gestão de Território. Tese (Doutorado) - FFLCH-USP, São Paulo, ago. 1999. Disponível em: $<$ http://www.dpi.inpe.br/teses/simeao $>$.

62 CAMPANA, R. C.; PLAUT, R. L. Aplicabilidade de redes neurais adaptativas (RNA) na extrusão de ligas de alumínio. In: III CONGRESSO INTERNACIONAL DO ALUMíNIO. São Paulo, 2007. p. 460-468.

63 CAMPANA, R. C.; PLAUT, R. L. Use of adaptive neural networks (ANN) in the aluminum extrusion process control. In: NINTH INTERNATIONAL ALUMINUM EXTRUSION SEMINAR ET'08. Orlando, Florida USA, 2008.

64 ALMEIDA, R. Z. H.; MARTINS, F. P. R.; FLEURY, A. T. Planejamento de trajetória de jateamento para obtenção de cobertura uniforme em processos de peen forming. In: ABCM. V Congresso Nacional de Engenharia Mecânica. Salvador, 2008.

65 KIRK, D. Size and variability of cast steel shot particles. The Shot Peener, v. 23, p. 24-32, 2009.

66 OLIVEIRA, R. R. Avaliação da tensão residual em Aluminio 7050 conformado pelo processo peen forming. Dissertação (Mestrado) - Instituto de Pesquisas Energéticas e Nucleares - IPEN, São Paulo, mar. 2011.

67 NEURODIMENSION INC. NeuroSolutions Frequently Asked Questions (FAQ). Disponível em: <http://www. neurosolutions . com/products/ns/ faq.html>. Acesso em: mai. 2011.

68 SCHUBBE, J. J. Fatigue crack propagation in 7050-t7451 plate alloy. Engineering Fracture Mechanics, v. 76, p. 1037-1048, mai. 2009.

69 RUCKERT, C. O. F. T. et al. On the relation between micro- and macroscopic fatigue crack growth rates in aluminum alloy AMS 7475-t7351. International Journal of Fracture, v. 142, n. 3-4, dez. 2006.

70 EFFECT of combined shot-peening and PEO treatment on fatigue life of 2024 Al alloy. Thin Solid Films, v. 515, p. 1187-1191, 2006.

71 LEE, W. B. et al. Strengthening dual phase steel welds by shot peening. ISIJ International, v. 49, n. 12, p. 1972-1974, 2009.

72 PADILHA, A. F. Encruamento, Recristalização e Crescimento de Grão. São Paulo: ABM, 2005. 
73 CLAUSEN, R.; STANGENBERG, J. Device for the determination of impact velocities in shot peening. In: ICSP, 8. International Conference on Shot Peening. Alemanha, 2002. p. 89-95.

74 EMBRAER. NE40-100: Shot peening - Rev. Q. [S.I.], 2006. 18 p.

75 KLUG, H. P.; ALEXANDER, L. Stress measurement in metals. In: $X$-ray diffraction procedures. [S.I.]: John Wiley \& Sons Inc., 1954. cap. 11, p. 755-790. 


\section{Apêndice A - Método de determinação de tensões residuais por difração de raios- $X$}

A teoria clássica da elasticidade admite os materiais como perfeitamente elásticos, homogêneos e isotrópicos. Ainda é admitido que as constantes elásticas sejam as mesmas em compressão e sistemas combinados de tensões, como em tração, e que elas aderem fielmente à lei de Hooke ${ }^{[75]}$ :

$$
\sigma=E \cdot \epsilon
$$

onde E é o módulo de Young ou módulo de elasticidade e

$$
\epsilon_{\phi \psi}=\frac{\Delta d}{d_{0}}=\frac{d_{\phi \psi}-d_{0}}{d_{0}}
$$

onde $d_{\phi \psi}$ é o espaçamento entre os planos medido em qualquer direção definida pelos ângulos $\phi$ e $\psi$ e $d_{0}$ é o espaçamento no estado livre de tensões, que pode ser previamente medido, calculado ou consultado em um banco de dados.

Normalmente, deseja-se medir a tensão $\sigma_{\phi}$ em uma direção específica, como por exemplo a direção $O B$ da Figura $A .1$, onde $O B$ faz um ângulo $\phi$ com a direção principal 1 e um ângulo $\beta$ com o eixo x.

De acordo com a norma SAE J 784a (1971), supõe-se um estado plano de tensões, ou seja, que a tensão fora do plano da superfície, $\sigma_{z}=\sigma_{3}$, é zero e que o estado de tensões no volume amostral analizado é homogêneo ${ }^{[57]}$. No entanto, existe uma componente de deformação, $\epsilon_{z}=\epsilon_{3}$, perpendicular à superfície, como resultante da contração dada pelo coeficiente de Poisson $\nu$ : 


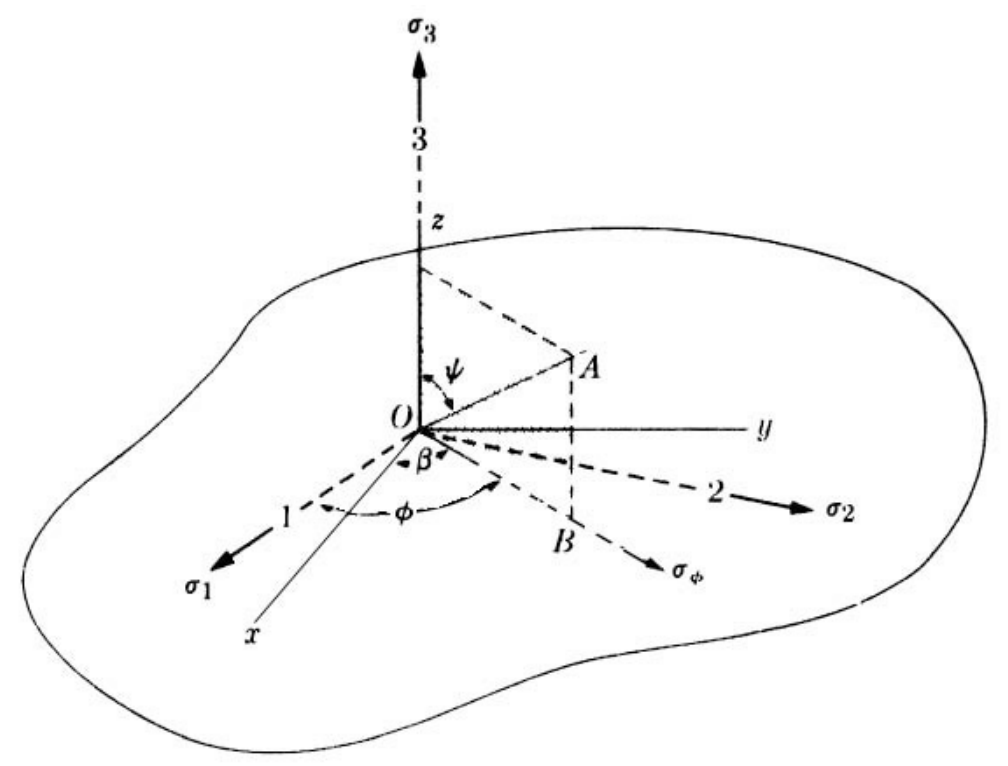

Figura A.1: Relações angulares entre a tensão a ser medida $\left(\sigma_{\phi}\right)$, tensões principais $\left(\sigma_{1}, \sigma_{2}\right.$ e $\left.\sigma_{3}\right)$, e eixos arbitrários $(x, y \text { e } z)^{[54]}$.

$$
\begin{aligned}
\epsilon_{x} & =\frac{1}{E}\left[\sigma_{x}-\nu\left(\sigma_{y}+\sigma_{z}\right)\right] \\
\epsilon_{y} & =\frac{1}{E}\left[\sigma_{y}-\nu\left(\sigma_{x}+\sigma_{y}\right)\right] \\
\epsilon_{z} & =\frac{1}{E}\left[\sigma_{z}-\nu\left(\sigma_{x}+\sigma_{y}\right)\right] \Rightarrow \epsilon_{3}=-\frac{\nu}{E}\left(\sigma_{1}+\sigma_{2}\right)^{[54]}
\end{aligned}
$$

A deformação, $\epsilon_{\phi \psi}$, na direção definida pelos ângulos $\phi$ e $\psi$ é:

$$
\epsilon_{\phi \psi}=\left[\frac{1+\nu}{E}\left(\sigma_{1} \cos ^{2} \phi+\sigma_{2} \sin ^{2} \phi\right) \sin ^{2} \psi\right]-\left[\frac{\nu}{E}\left(\sigma_{1}+\sigma_{2}\right)\right]
$$

Substituindo-se a equação A.2 na equação A.4, obtém-se o espaçamento interplanar para qualquer orientação:

$$
d_{\phi \psi}=\left[\left(\frac{1+\nu}{E}\right)_{(h k l)} \sigma_{\phi} d_{0}\right] \sin ^{2} \psi-\left[\left(\frac{\nu}{E}\right)_{(h k l)} d_{0}\left(\sigma_{1}+\sigma_{2}\right)+d_{0}\right]
$$

O subscrito (hkl) significa que as constantes elásticas $E$ e $\nu$ não são os valores do bulk, mas de uma direção cristalográfica especificada pelos índices de $\operatorname{Miller}(h k l)^{[55]}$.

$\mathrm{Na}$ prática, usa-se o método chamado $\sin ^{2} \psi$ para determinar a tensão a partir do valor experimental de deformação. De acordo com o método $\sin ^{2} \psi$, o espaçamento cristalino $d_{\phi \psi}$ é uma função linear de $\sin ^{2} \psi$ e a tensão pode ser 
determinada medindo-se o espaçamento cristalino para múltiplas inclinações $\psi\left(0^{\circ} \leq|\psi| \leq 45^{\circ}\right)$ e ajustando-se uma reta. A tensão é, então, calculada pela inclinação da reta, usando a equação A.6:

$$
\sigma_{\phi}=\left(\frac{E}{1+\nu}\right)_{(h k l)} \frac{1}{d_{0}}\left(\frac{\partial d_{\phi \psi}}{\partial \sin ^{2} \psi}\right)
$$

Utilizando a lei de Bragg:

$$
n \lambda=2 d \sin \theta \Leftrightarrow d=\frac{n \lambda}{2 \sin \theta} \Leftrightarrow 2 \theta=2 \sin ^{-1}\left(\frac{n \lambda}{2 d}\right)
$$

onde $\lambda$ é o comprimento de onda do raio-X incidente, $n$ é um inteiro e $\theta$ é o ângulo de incidência do feixe, pode-se rearranjar as equações A.5 e A.6 para facilitar a análise repetitiva, plotando-se os valores de $2 \theta$ em função de $\sin ^{2} \psi$. 
224 


\section{Apêndice B - Parâmetros de jateamento dos corpos de prova}

Tabela B.1: Parâmetros de jateamento dos corpos de prova ensaiados.

\begin{tabular}{c|c|c|c|c|c|c}
\hline $\mathrm{CP} \mathrm{n}^{\circ}$ & Liga & $\mathrm{H}(\mathrm{mm})$ & $\mathrm{D}(\mathrm{mm})$ & $\mathrm{P}(\mathrm{psi})$ & $\mathrm{P}$-tens & Cobertura \\
\hline 6 & 7050 & 2 & 0,584 & 20 & não & $66 \%$ \\
\hline 7 & 7050 & 2 & 0,584 & 40 & não & $85 \%$ \\
\hline 8 & 7050 & 2 & 0,584 & 40 & não & $200 \%$ \\
\hline 9 & 7050 & 2 & 0,584 & 20 & não & $200 \%$ \\
\hline 10 & 7050 & 2 & 0,584 & 20 & não & $66 \%$ \\
\hline 11 & 7050 & 2 & 0,584 & 40 & não & $85 \%$ \\
\hline 12 & 7050 & 2 & 0,584 & 40 & não & $200 \%$ \\
\hline 13 & 7050 & 2 & 0,584 & 20 & não & $200 \%$ \\
\hline 14 & 7050 & 2 & 0,584 & 20 & sim & $66 \%$ \\
\hline 15 & 7050 & 2 & 0,584 & 60 & sim & $200 \%$ \\
\hline 17 & 7050 & 2 & 0,584 & 40 & sim & $85 \%$ \\
\hline 18 & 7050 & 2 & 0,584 & 40 & sim & $200 \%$ \\
\hline 20 & 7050 & 2 & 0,584 & 60 & sim & $200 \%$ \\
\hline 22 & 7050 & 2 & 0,584 & 20 & sim & $200 \%$ \\
\hline 23 & 7050 & 2 & 0,584 & 40 & sim & $85 \%$ \\
\hline 24 & 7050 & 2 & 0,584 & 40 & sim & $200 \%$ \\
\hline 27 & 7050 & 5 & 0,584 & 20 & não & $66 \%$ \\
\hline 28 & 7050 & 5 & 0,584 & 20 & não & $66 \%$ \\
\hline 29 & 7050 & 5 & 0,584 & 20 & não & $66 \%$ \\
\hline 30 & 7050 & 5 & 0,584 & 40 & não & $85 \%$ \\
\hline 31 & 7050 & 5 & 0,584 & 40 & não & $85 \%$ \\
\hline 32 & 7050 & 5 & 0,584 & 40 & não & $85 \%$ \\
\hline 34 & 7050 & 5 & 0,584 & 60 & não & $92 \%$ \\
\hline & & & & Continua na próxima página \\
\hline
\end{tabular}


Tabela B.1 - Continuação da página anterior.

\begin{tabular}{|c|c|c|c|c|c|c|}
\hline $\mathrm{CP} \mathrm{n} \mathrm{n}^{\circ}$ & Liga & $\mathrm{H}(\mathrm{mm})$ & $\mathrm{D}(\mathrm{mm})$ & $P(p s i)$ & P-tens & Cobertura \\
\hline 35 & 7050 & 5 & 0,584 & 60 & não & $92 \%$ \\
\hline 36 & 7050 & 5 & 0,584 & 60 & não & $200 \%$ \\
\hline 37 & 7050 & 5 & 0,584 & 60 & não & $200 \%$ \\
\hline 38 & 7050 & 5 & 0,584 & 60 & não & $200 \%$ \\
\hline 40 & 7475 & 5 & 0,584 & 20 & não & $66 \%$ \\
\hline 41 & 7475 & 5 & 0,584 & 20 & não & $66 \%$ \\
\hline 42 & 7475 & 5 & 0,584 & 20 & não & $66 \%$ \\
\hline 43 & 7475 & 5 & 0,584 & 40 & não & $85 \%$ \\
\hline 44 & 7475 & 5 & 0,584 & 40 & não & $85 \%$ \\
\hline 45 & 7475 & 5 & 0,584 & 40 & não & $85 \%$ \\
\hline 46 & 7475 & 5 & 0,584 & 60 & não & $92 \%$ \\
\hline 47 & 7475 & 5 & 0,584 & 60 & não & $92 \%$ \\
\hline 48 & 7475 & 5 & 0,584 & 60 & não & $92 \%$ \\
\hline 49 & 7475 & 5 & 0,584 & 60 & não & $200 \%$ \\
\hline 50 & 7475 & 5 & 0,584 & 60 & não & $200 \%$ \\
\hline 51 & 7475 & 5 & 0,584 & 60 & não & $200 \%$ \\
\hline 52 & 7050 & 2 & 0,584 & 60 & $\operatorname{sim}$ & $92 \%$ \\
\hline 53 & 7050 & 2 & 0,584 & 60 & $\operatorname{sim}$ & $200 \%$ \\
\hline 54 & 7050 & 2 & 0,584 & 40 & $\operatorname{sim}$ & $85 \%$ \\
\hline 55 & 7050 & 2 & 0,584 & 40 & $\operatorname{sim}$ & $200 \%$ \\
\hline 56 & 7050 & 2 & 0,584 & 20 & $\operatorname{sim}$ & $66 \%$ \\
\hline 57 & 7050 & 2 & 0,584 & 20 & $\operatorname{sim}$ & $200 \%$ \\
\hline 58 & 7050 & 2 & 0,584 & 20 & $\operatorname{sim}$ & $66 \%$ \\
\hline 59 & 7050 & 2 & 0,584 & 20 & $\operatorname{sim}$ & $200 \%$ \\
\hline 60 & 7050 & 2 & 0,584 & 20 & $\operatorname{sim}$ & $66 \%$ \\
\hline 61 & 7050 & 2 & 0,584 & 20 & $\operatorname{sim}$ & $200 \%$ \\
\hline 62 & 7050 & 2 & 0,584 & 20 & $\operatorname{sim}$ & $200 \%$ \\
\hline 63 & 7050 & 2 & 0,584 & 60 & $\operatorname{sim}$ & $92 \%$ \\
\hline 64 & 7050 & 2 & 0,584 & 40 & $\operatorname{sim}$ & $85 \%$ \\
\hline 65 & 7050 & 2 & 0,584 & 40 & $\operatorname{sim}$ & $200 \%$ \\
\hline 66 & 7050 & 2 & 0,584 & 20 & não & $200 \%$ \\
\hline 67 & 7475 & 2 & 0,584 & 60 & $\operatorname{sim}$ & $92 \%$ \\
\hline 68 & 7475 & 2 & 0,584 & 60 & $\operatorname{sim}$ & $200 \%$ \\
\hline 70 & 7475 & 2 & 0,584 & 40 & $\operatorname{sim}$ & $85 \%$ \\
\hline 71 & 7475 & 2 & 0,584 & 40 & $\operatorname{sim}$ & $200 \%$ \\
\hline 72 & 7475 & 2 & 0,584 & 20 & $\operatorname{sim}$ & $66 \%$ \\
\hline 73 & 7475 & 2 & 0,584 & 20 & $\operatorname{sim}$ & $200 \%$ \\
\hline 74 & 7475 & 2 & 0,584 & 20 & $\operatorname{sim}$ & $66 \%$ \\
\hline
\end{tabular}


Tabela B.1 - Continuação da página anterior.

\begin{tabular}{|c|c|c|c|c|c|c|}
\hline $\mathrm{CP} \mathrm{n}^{\circ}$ & Liga & $\mathrm{H}(\mathrm{mm})$ & $\mathrm{D}(\mathrm{mm})$ & $\mathrm{P}$ (psi) & P-tens & Cobertura \\
\hline 75 & 7475 & 2 & 0,584 & 20 & $\operatorname{sim}$ & $200 \%$ \\
\hline 76 & 7475 & 2 & 0,584 & 20 & $\operatorname{sim}$ & $66 \%$ \\
\hline 77 & 7475 & 2 & 0,584 & 20 & $\operatorname{sim}$ & $200 \%$ \\
\hline 78 & 7475 & 2 & 0,584 & 40 & $\operatorname{sim}$ & $200 \%$ \\
\hline 79 & 7475 & 2 & 0,584 & 40 & $\operatorname{sim}$ & $85 \%$ \\
\hline 80 & 7475 & 2 & 0,584 & 40 & $\operatorname{sim}$ & $200 \%$ \\
\hline 81 & 7475 & 2 & 0,584 & 40 & $\operatorname{sim}$ & $85 \%$ \\
\hline 82 & 7475 & 2 & 0,584 & 60 & $\operatorname{sim}$ & $200 \%$ \\
\hline 83 & 7475 & 2 & 0,584 & 60 & $\operatorname{sim}$ & $92 \%$ \\
\hline 84 & 7475 & 2 & 0,584 & 60 & $\operatorname{sim}$ & $200 \%$ \\
\hline 87 & 7050 & 5 & 0,584 & 60 & não & $92 \%$ \\
\hline 88 & 7050 & 5 & 0,584 & 40 & não & $200 \%$ \\
\hline 89 & 7050 & 5 & 0,584 & 40 & não & $200 \%$ \\
\hline 90 & 7050 & 5 & 0,584 & 40 & não & $200 \%$ \\
\hline 91 & 7050 & 5 & 0,584 & 20 & não & $200 \%$ \\
\hline 92 & 7050 & 5 & 0,584 & 20 & não & $200 \%$ \\
\hline 94 & 7050 & 5 & 0,584 & 60 & $\operatorname{sim}$ & $92 \%$ \\
\hline 95 & 7050 & 5 & 0,584 & 60 & $\operatorname{sim}$ & $92 \%$ \\
\hline 96 & 7050 & 5 & 0,584 & 60 & $\operatorname{sim}$ & $92 \%$ \\
\hline 97 & 7050 & 2 & 0,584 & 20 & não & $66 \%$ \\
\hline 98 & 7050 & 2 & 0,584 & 40 & não & $200 \%$ \\
\hline 99 & 7050 & 2 & 0,584 & 40 & não & $85 \%$ \\
\hline 100 & 7050 & 2 & 0,584 & 60 & não & $200 \%$ \\
\hline 101 & 7050 & 2 & 0,584 & 60 & não & $92 \%$ \\
\hline 106 & 7475 & 2 & 0,584 & 20 & $\operatorname{sim}$ & $200 \%$ \\
\hline 107 & 7475 & 2 & 0,584 & 20 & $\operatorname{sim}$ & $200 \%$ \\
\hline 108 & 7475 & 2 & 0,584 & 60 & $\operatorname{sim}$ & $200 \%$ \\
\hline 109 & 7475 & 2 & 0,584 & 60 & $\operatorname{sim}$ & $200 \%$ \\
\hline 110 & 7475 & 2 & 0,584 & 20 & não & $66 \%$ \\
\hline 111 & 7475 & 2 & 0,584 & 20 & não & $66 \%$ \\
\hline 112 & 7475 & 2 & 0,584 & 20 & não & $200 \%$ \\
\hline 113 & 7475 & 2 & 0,584 & 20 & não & $200 \%$ \\
\hline 114 & 7475 & 2 & 0,584 & 40 & não & $200 \%$ \\
\hline 115 & 7475 & 2 & 0,584 & 40 & não & $200 \%$ \\
\hline 116 & 7475 & 2 & 0,584 & 40 & não & $85 \%$ \\
\hline 117 & 7475 & 2 & 0,584 & 40 & não & $85 \%$ \\
\hline 118 & 7475 & 2 & 0,584 & 60 & não & $200 \%$ \\
\hline 119 & 7475 & 2 & 0,584 & 60 & não & $200 \%$ \\
\hline
\end{tabular}


Tabela B.1 - Continuação da página anterior.

\begin{tabular}{c|c|c|c|c|c|c}
\hline $\mathrm{CP}^{\circ}$ & Liga & $\mathrm{H}(\mathrm{mm})$ & $\mathrm{D}(\mathrm{mm})$ & $\mathrm{P}(\mathrm{psi})$ & P-tens & Cobertura \\
\hline \hline 120 & 7475 & 2 & 0,584 & 60 & não & $92 \%$ \\
\hline 121 & 7475 & 2 & 0,584 & 60 & não & $92 \%$ \\
\hline 125 & 7475 & 5 & 0,584 & 40 & não & $200 \%$ \\
\hline 126 & 7475 & 5 & 0,584 & 40 & não & $200 \%$ \\
\hline 127 & 7475 & 5 & 0,584 & 40 & não & $200 \%$ \\
\hline 128 & 7475 & 5 & 0,584 & 20 & não & $200 \%$ \\
\hline 129 & 7475 & 5 & 0,584 & 20 & não & $200 \%$ \\
\hline 130 & 7475 & 5 & 0,584 & 20 & não & $200 \%$ \\
\hline 131 & 7050 & 5 & 0,584 & 60 & sim & $200 \%$ \\
\hline 132 & 7050 & 5 & 0,584 & 60 & sim & $200 \%$ \\
\hline 133 & 7050 & 5 & 0,584 & 60 & sim & $200 \%$ \\
\hline 134 & 7050 & 5 & 0,584 & 40 & sim & $85 \%$ \\
\hline 135 & 7050 & 5 & 0,584 & 40 & sim & $200 \%$ \\
\hline 136 & 7050 & 5 & 0,584 & 40 & sim & $200 \%$ \\
\hline 137 & 7050 & 5 & 0,584 & 40 & sim & $200 \%$ \\
\hline 138 & 7050 & 5 & 0,584 & 40 & sim & $85 \%$ \\
\hline 139 & 7050 & 5 & 0,584 & 40 & sim & $85 \%$ \\
\hline 140 & 7050 & 5 & 0,584 & 20 & sim & $66 \%$ \\
\hline 142 & 7050 & 5 & 0,584 & 20 & sim & $66 \%$ \\
\hline 143 & 7050 & 5 & 0,584 & 20 & sim & $200 \%$ \\
\hline 144 & 7050 & 5 & 0,584 & 20 & sim & $200 \%$ \\
\hline 145 & 7050 & 5 & 0,584 & 20 & sim & $200 \%$ \\
\hline 146 & 7475 & 5 & 0,584 & 60 & sim & $92 \%$ \\
\hline 147 & 7475 & 5 & 0,584 & 60 & sim & $92 \%$ \\
\hline 148 & 7475 & 5 & 0,584 & 60 & sim & $92 \%$ \\
\hline 149 & 7475 & 5 & 0,584 & 60 & sim & $200 \%$ \\
\hline 150 & 7475 & 5 & 0,584 & 60 & sim & $200 \%$ \\
\hline 151 & 7475 & 5 & 0,584 & 60 & sim & $200 \%$ \\
\hline 152 & 7475 & 5 & 0,584 & 40 & sim & $85 \%$ \\
\hline 153 & 7475 & 5 & 0,584 & 40 & sim & $200 \%$ \\
\hline 154 & 7475 & 5 & 0,584 & 40 & sim & $200 \%$ \\
\hline 155 & 7475 & 5 & 0,584 & 40 & sim & $200 \%$ \\
\hline 156 & 7475 & 5 & 0,584 & 40 & sim & $85 \%$ \\
\hline 157 & 7475 & 5 & 0,584 & 40 & sim & $85 \%$ \\
\hline 158 & 7475 & 5 & 0,584 & 20 & sim & $66 \%$ \\
\hline 159 & 7475 & 5 & 0,584 & 20 & sim & $66 \%$ \\
\hline 160 & 7475 & 5 & 0,584 & 20 & sim & $66 \%$ \\
\hline 161 & 7475 & 5 & 0,584 & 20 & sim & $200 \%$ \\
\hline & & & & Continua na próxima página \\
\hline & & & & & & \\
\hline
\end{tabular}


Tabela B.1 - Continuação da página anterior.

\begin{tabular}{|c|c|c|c|c|c|c|}
\hline$C P n^{\circ}$ & Liga & $\mathrm{H}(\mathrm{mm})$ & $\mathrm{D}(\mathrm{mm})$ & $\mathrm{P}$ (psi) & P-tens & Cobertura \\
\hline 162 & 7475 & 5 & 0,584 & 20 & $\operatorname{sim}$ & $200 \%$ \\
\hline 163 & 7475 & 5 & 0,584 & 20 & $\operatorname{sim}$ & $200 \%$ \\
\hline 164 & 7050 & 5 & 1,397 & 30 & $\operatorname{sim}$ & $60 \%$ \\
\hline 165 & 7050 & 5 & 1,397 & 30 & $\operatorname{sim}$ & $200 \%$ \\
\hline 166 & 7050 & 5 & 1,397 & 20 & $\operatorname{sim}$ & $60 \%$ \\
\hline 167 & 7050 & 5 & 1,397 & 20 & $\operatorname{sim}$ & $200 \%$ \\
\hline 168 & 7050 & 5 & 1,397 & 10 & $\operatorname{sim}$ & $60 \%$ \\
\hline 169 & 7050 & 5 & 1,397 & 10 & $\operatorname{sim}$ & $200 \%$ \\
\hline 170 & 7050 & 5 & 1,397 & 30 & $\operatorname{sim}$ & $60 \%$ \\
\hline 171 & 7050 & 5 & 1,397 & 30 & $\operatorname{sim}$ & $200 \%$ \\
\hline 172 & 7050 & 5 & 1,397 & 20 & $\operatorname{sim}$ & $60 \%$ \\
\hline 173 & 7050 & 5 & 1,397 & 20 & $\operatorname{sim}$ & $200 \%$ \\
\hline 174 & 7050 & 5 & 1,397 & 10 & $\operatorname{sim}$ & $60 \%$ \\
\hline 175 & 7050 & 5 & 1,397 & 10 & $\operatorname{sim}$ & $200 \%$ \\
\hline 176 & 7050 & 5 & 1,397 & 30 & não & $60 \%$ \\
\hline 177 & 7050 & 5 & 1,397 & 30 & não & $200 \%$ \\
\hline 178 & 7050 & 5 & 1,397 & 20 & não & $60 \%$ \\
\hline 179 & 7050 & 5 & 1,397 & 20 & não & $200 \%$ \\
\hline 180 & 7050 & 5 & 1,397 & 30 & $\operatorname{sim}$ & $200 \%$ \\
\hline 181 & 7050 & 5 & 1,397 & 30 & $\operatorname{sim}$ & $60 \%$ \\
\hline 182 & 7050 & 5 & 1,397 & 20 & $\operatorname{sim}$ & $200 \%$ \\
\hline 183 & 7050 & 5 & 1,397 & 20 & $\operatorname{sim}$ & $60 \%$ \\
\hline 184 & 7050 & 5 & 1,397 & 10 & $\operatorname{sim}$ & $60 \%$ \\
\hline 185 & 7050 & 5 & 1,397 & 10 & $\operatorname{sim}$ & $200 \%$ \\
\hline 186 & 7050 & 5 & 1,397 & 10 & não & $60 \%$ \\
\hline 187 & 7050 & 5 & 1,397 & 10 & não & $200 \%$ \\
\hline 188 & 7050 & 5 & 1,397 & 10 & não & $60 \%$ \\
\hline 189 & 7050 & 5 & 1,397 & 10 & não & $200 \%$ \\
\hline 190 & 7050 & 5 & 1,397 & 20 & não & $60 \%$ \\
\hline 191 & 7050 & 5 & 1,397 & 20 & não & $200 \%$ \\
\hline 192 & 7050 & 5 & 1,397 & 30 & não & $60 \%$ \\
\hline 193 & 7050 & 5 & 1,397 & 30 & não & $200 \%$ \\
\hline 194 & 7050 & 5 & 1,397 & 10 & não & $60 \%$ \\
\hline 195 & 7050 & 5 & 1,397 & 10 & não & $200 \%$ \\
\hline 196 & 7050 & 5 & 1,397 & 20 & não & $60 \%$ \\
\hline 197 & 7050 & 5 & 1,397 & 20 & não & $200 \%$ \\
\hline 198 & 7050 & 5 & 1,397 & 30 & não & $60 \%$ \\
\hline 199 & 7050 & 5 & 1,397 & 30 & não & $200 \%$ \\
\hline
\end{tabular}


Tabela B.1 - Continuação da página anterior.

\begin{tabular}{|c|c|c|c|c|c|c|}
\hline $\mathrm{CP} \mathrm{n}^{\circ}$ & Liga & $\mathrm{H}(\mathrm{mm})$ & $\mathrm{D}(\mathrm{mm})$ & $P(p s i)$ & P-tens & Cobertura \\
\hline 200 & 7475 & 5 & 1,397 & 10 & não & $60 \%$ \\
\hline 201 & 7475 & 5 & 1,397 & 10 & não & $200 \%$ \\
\hline 202 & 7475 & 5 & 1,397 & 20 & não & $60 \%$ \\
\hline 203 & 7475 & 5 & 1,397 & 20 & não & $200 \%$ \\
\hline 204 & 7475 & 5 & 1,397 & 30 & não & $60 \%$ \\
\hline 205 & 7475 & 5 & 1,397 & 30 & sim & $60 \%$ \\
\hline 206 & 7475 & 5 & 1,397 & 30 & sim & $200 \%$ \\
\hline 207 & 7475 & 5 & 1,397 & 20 & sim & $60 \%$ \\
\hline 208 & 7475 & 5 & 1,397 & 20 & sim & $200 \%$ \\
\hline 209 & 7475 & 5 & 1,397 & 10 & sim & $60 \%$ \\
\hline 210 & 7475 & 5 & 1,397 & 10 & sim & $200 \%$ \\
\hline 211 & 7475 & 5 & 1,397 & 30 & sim & $60 \%$ \\
\hline 212 & 7475 & 5 & 1,397 & 30 & sim & $200 \%$ \\
\hline 213 & 7475 & 5 & 1,397 & 20 & sim & $60 \%$ \\
\hline 214 & 7475 & 5 & 1,397 & 20 & sim & $200 \%$ \\
\hline 215 & 7475 & 5 & 1,397 & 10 & sim & $60 \%$ \\
\hline 216 & 7475 & 5 & 1,397 & 10 & sim & $200 \%$ \\
\hline 217 & 7475 & 5 & 1,397 & 30 & não & $60 \%$ \\
\hline 218 & 7475 & 5 & 1,397 & 30 & não & $200 \%$ \\
\hline 219 & 7475 & 5 & 1,397 & 20 & não & $60 \%$ \\
\hline 220 & 7475 & 5 & 1,397 & 20 & não & $200 \%$ \\
\hline 221 & 7475 & 5 & 1,397 & 30 & sim & $200 \%$ \\
\hline 222 & 7475 & 5 & 1,397 & 30 & sim & $60 \%$ \\
\hline 223 & 7475 & 5 & 1,397 & 20 & sim & $200 \%$ \\
\hline 224 & 7475 & 5 & 1,397 & 20 & sim & $60 \%$ \\
\hline 225 & 7475 & 5 & 1,397 & 10 & sim & $60 \%$ \\
\hline 226 & 7475 & 5 & 1,397 & 10 & $\operatorname{sim}$ & $200 \%$ \\
\hline 227 & 7475 & 5 & 1,397 & 10 & não & $60 \%$ \\
\hline 228 & 7475 & 5 & 1,397 & 10 & não & $200 \%$ \\
\hline 229 & 7475 & 5 & 1,397 & 30 & não & $200 \%$ \\
\hline 230 & 7475 & 5 & 1,397 & 10 & não & $60 \%$ \\
\hline 231 & 7475 & 5 & 1,397 & 10 & não & $200 \%$ \\
\hline 232 & 7475 & 5 & 1,397 & 20 & não & $60 \%$ \\
\hline 233 & 7475 & 5 & 1,397 & 20 & não & $200 \%$ \\
\hline 234 & 7475 & 5 & 1,397 & 30 & não & $60 \%$ \\
\hline 235 & 7475 & 5 & 1,397 & 30 & não & $200 \%$ \\
\hline 236 & 7475 & 10 & 1,397 & 30 & não & $60 \%$ \\
\hline 237 & 7475 & 10 & 1,397 & 30 & $\operatorname{sim}$ & $60 \%$ \\
\hline
\end{tabular}


Tabela B.1 - Continuação da página anterior.

\begin{tabular}{|c|c|c|c|c|c|c|}
\hline $\mathrm{CP} \mathrm{n}^{\circ}$ & Liga & $\mathrm{H}(\mathrm{mm})$ & $\mathrm{D}(\mathrm{mm})$ & $P(p s i)$ & P-tens & Cobertura \\
\hline 238 & 7475 & 10 & 1,397 & 30 & não & $200 \%$ \\
\hline 239 & 7475 & 10 & 1,397 & 30 & sim & $200 \%$ \\
\hline 240 & 7475 & 10 & 1,397 & 30 & não & $60 \%$ \\
\hline 241 & 7475 & 10 & 1,397 & 30 & sim & $60 \%$ \\
\hline 242 & 7475 & 10 & 1,397 & 30 & não & $200 \%$ \\
\hline 243 & 7475 & 10 & 1,397 & 30 & sim & $200 \%$ \\
\hline 244 & 7475 & 10 & 1,397 & 30 & não & $60 \%$ \\
\hline 245 & 7475 & 10 & 1,397 & 30 & sim & $60 \%$ \\
\hline 246 & 7475 & 10 & 1,397 & 30 & não & $200 \%$ \\
\hline 247 & 7475 & 10 & 1,397 & 30 & $\operatorname{sim}$ & $200 \%$ \\
\hline 248 & 7475 & 10 & 1,397 & 20 & sim & $60 \%$ \\
\hline 249 & 7050 & 10 & 1,397 & 30 & não & $60 \%$ \\
\hline 250 & 7050 & 10 & 1,397 & 30 & $\operatorname{sim}$ & $60 \%$ \\
\hline 251 & 7050 & 10 & 1,397 & 30 & não & $200 \%$ \\
\hline 252 & 7050 & 10 & 1,397 & 30 & $\operatorname{sim}$ & $200 \%$ \\
\hline 253 & 7050 & 10 & 1,397 & 30 & não & $60 \%$ \\
\hline 254 & 7050 & 10 & 1,397 & 30 & $\operatorname{sim}$ & $60 \%$ \\
\hline 255 & 7050 & 10 & 1,397 & 30 & não & $200 \%$ \\
\hline 256 & 7050 & 10 & 1,397 & 30 & $\operatorname{sim}$ & $200 \%$ \\
\hline 257 & 7050 & 10 & 1,397 & 30 & não & $60 \%$ \\
\hline 258 & 7050 & 10 & 1,397 & 30 & sim & $60 \%$ \\
\hline 259 & 7050 & 10 & 1,397 & 30 & não & $200 \%$ \\
\hline 260 & 7050 & 10 & 1,397 & 30 & sim & $200 \%$ \\
\hline 261 & 7050 & 10 & 1,397 & 20 & sim & $60 \%$ \\
\hline 262 & 7050 & 10 & 1,397 & 20 & não & $60 \%$ \\
\hline 263 & 7050 & 10 & 1,397 & 20 & $\operatorname{sim}$ & $200 \%$ \\
\hline 264 & 7475 & 10 & 1,397 & 20 & não & $60 \%$ \\
\hline 265 & 7050 & 10 & 1,397 & 20 & não & $200 \%$ \\
\hline 266 & 7475 & 10 & 1,397 & 20 & sim & $200 \%$ \\
\hline 267 & 7475 & 10 & 1,397 & 20 & não & $200 \%$ \\
\hline 268 & 7475 & 10 & 1,397 & 20 & sim & $60 \%$ \\
\hline 269 & 7475 & 10 & 1,397 & 20 & não & $60 \%$ \\
\hline 270 & 7475 & 10 & 1,397 & 20 & $\operatorname{sim}$ & $200 \%$ \\
\hline 271 & 7475 & 10 & 1,397 & 20 & não & $200 \%$ \\
\hline 272 & 7475 & 10 & 1,397 & 20 & sim & $60 \%$ \\
\hline 273 & 7475 & 10 & 1,397 & 20 & não & $60 \%$ \\
\hline 274 & 7475 & 10 & 1,397 & 20 & sim & $200 \%$ \\
\hline 275 & 7475 & 10 & 1,397 & 20 & não & $200 \%$ \\
\hline
\end{tabular}


Tabela B.1 - Continuação da página anterior.

\begin{tabular}{|c|c|c|c|c|c|c|}
\hline $\mathrm{CP} \mathrm{n}^{\circ}$ & Liga & $\mathrm{H}(\mathrm{mm})$ & $\mathrm{D}(\mathrm{mm})$ & $P(p s i)$ & P-tens & Cobertura \\
\hline 276 & 7475 & 10 & 1,397 & 10 & $\operatorname{sim}$ & $60 \%$ \\
\hline 277 & 7475 & 10 & 1,397 & 10 & sim & $60 \%$ \\
\hline 278 & 7475 & 10 & 1,397 & 10 & $\operatorname{sim}$ & $60 \%$ \\
\hline 279 & 7050 & 10 & 1,397 & 20 & $\operatorname{sim}$ & $60 \%$ \\
\hline 280 & 7050 & 10 & 1,397 & 20 & não & $60 \%$ \\
\hline 281 & 7050 & 10 & 1,397 & 20 & $\operatorname{sim}$ & $200 \%$ \\
\hline 282 & 7050 & 10 & 1,397 & 20 & não & $200 \%$ \\
\hline 283 & 7050 & 10 & 1,397 & 20 & sim & $60 \%$ \\
\hline 284 & 7050 & 10 & 1,397 & 20 & não & $60 \%$ \\
\hline 285 & 7050 & 10 & 1,397 & 20 & $\operatorname{sim}$ & $200 \%$ \\
\hline 286 & 7050 & 10 & 1,397 & 20 & não & $200 \%$ \\
\hline 287 & 7050 & 10 & 1,397 & 10 & $\operatorname{sim}$ & $60 \%$ \\
\hline 288 & 7050 & 10 & 1,397 & 10 & $\operatorname{sim}$ & $60 \%$ \\
\hline 289 & 7050 & 10 & 1,397 & 10 & $\operatorname{sim}$ & $60 \%$ \\
\hline 290 & 7050 & 10 & 1,397 & 10 & $\operatorname{sim}$ & $200 \%$ \\
\hline 291 & 7050 & 10 & 1,397 & 10 & $\operatorname{sim}$ & $200 \%$ \\
\hline 292 & 7050 & 10 & 1,397 & 10 & $\operatorname{sim}$ & $200 \%$ \\
\hline 293 & 7050 & 10 & 1,397 & 10 & não & $60 \%$ \\
\hline 294 & 7475 & 10 & 1,397 & 10 & $\operatorname{sim}$ & $200 \%$ \\
\hline 295 & 7475 & 10 & 1,397 & 10 & $\operatorname{sim}$ & $200 \%$ \\
\hline 296 & 7475 & 10 & 1,397 & 10 & $\operatorname{sim}$ & $200 \%$ \\
\hline 297 & 7475 & 10 & 1,397 & 10 & não & $60 \%$ \\
\hline 298 & 7475 & 10 & 1,397 & 10 & não & $200 \%$ \\
\hline 299 & 7475 & 10 & 1,397 & 10 & não & $60 \%$ \\
\hline 301 & 7475 & 10 & 1,397 & 10 & não & $60 \%$ \\
\hline 302 & 7475 & 10 & 1,397 & 10 & não & $200 \%$ \\
\hline 303 & 7475 & 10 & 3,175 & 25 & $\operatorname{sim}$ & $60 \%$ \\
\hline 304 & 7475 & 10 & 3,175 & 25 & não & $60 \%$ \\
\hline 305 & 7475 & 10 & 3,175 & 20 & $\operatorname{sim}$ & $60 \%$ \\
\hline 306 & 7475 & 10 & 3,175 & 20 & não & $60 \%$ \\
\hline 307 & 7475 & 10 & 3,175 & 25 & $\operatorname{sim}$ & $60 \%$ \\
\hline 308 & 7475 & 10 & 3,175 & 25 & não & $60 \%$ \\
\hline 309 & 7050 & 10 & 3,175 & 25 & $\operatorname{sim}$ & $60 \%$ \\
\hline 310 & 7050 & 10 & 3,175 & 25 & não & $60 \%$ \\
\hline 311 & 7050 & 10 & 3,175 & 20 & sim & $60 \%$ \\
\hline 312 & 7050 & 10 & 1,397 & 10 & não & $200 \%$ \\
\hline 313 & 7050 & 10 & 1,397 & 10 & não & $60 \%$ \\
\hline 314 & 7050 & 10 & 1,397 & 10 & não & $200 \%$ \\
\hline
\end{tabular}


Tabela B.1 - Continuação da página anterior.

\begin{tabular}{c|c|c|c|c|c|c}
\hline $\mathrm{CP} \mathrm{n}^{\circ}$ & Liga & $\mathrm{H}(\mathrm{mm})$ & $\mathrm{D}(\mathrm{mm})$ & $\mathrm{P}(\mathrm{psi})$ & $\mathrm{P}$-tens & Cobertura \\
\hline \hline 315 & 7050 & 10 & 1,397 & 10 & não & $60 \%$ \\
\hline 316 & 7050 & 10 & 1,397 & 10 & não & $200 \%$ \\
\hline 317 & 7050 & 10 & 3,175 & 20 & não & $60 \%$ \\
\hline 318 & 7050 & 10 & 3,175 & 25 & sim & $60 \%$ \\
\hline 319 & 7050 & 10 & 3,175 & 25 & não & $60 \%$ \\
\hline 320 & 7050 & 10 & 3,175 & 20 & sim & $60 \%$ \\
\hline 321 & 7050 & 10 & 3,175 & 20 & não & $60 \%$ \\
\hline 322 & 7050 & 10 & 3,175 & 25 & não & $60 \%$ \\
\hline 323 & 7050 & 10 & 3,175 & 20 & sim & $60 \%$ \\
\hline 324 & 7050 & 10 & 3,175 & 25 & sim & $60 \%$ \\
\hline 325 & 7050 & 10 & 3,175 & 20 & não & $60 \%$ \\
\hline 326 & 7050 & 10 & 3,175 & 10 & sim & $60 \%$ \\
\hline 327 & 7050 & 10 & 3,175 & 10 & não & $60 \%$ \\
\hline 328 & 7050 & 10 & 3,175 & 10 & sim & $60 \%$ \\
\hline 329 & 7050 & 10 & 3,175 & 10 & não & $60 \%$ \\
\hline 330 & 7050 & 10 & 3,175 & 10 & sim & $60 \%$ \\
\hline 331 & 7050 & 10 & 3,175 & 10 & não & $60 \%$ \\
\hline 332 & 7050 & 10 & 3,175 & 25 & sim & $200 \%$ \\
\hline 333 & 7050 & 10 & 3,175 & 25 & não & $200 \%$ \\
\hline 334 & 7050 & 10 & 3,175 & 25 & sim & $200 \%$ \\
\hline 335 & 7050 & 10 & 3,175 & 25 & não & $200 \%$ \\
\hline 336 & 7475 & 10 & 3,175 & 20 & sim & $60 \%$ \\
\hline 337 & 7475 & 10 & 3,175 & 20 & não & $60 \%$ \\
\hline 338 & 7475 & 10 & 3,175 & 25 & sim & $60 \%$ \\
\hline 339 & 7475 & 10 & 3,175 & 25 & não & $60 \%$ \\
\hline 340 & 7475 & 10 & 3,175 & 20 & sim & $60 \%$ \\
\hline 341 & 7475 & 10 & 3,175 & 20 & não & $60 \%$ \\
\hline 342 & 7475 & 10 & 3,175 & 10 & sim & $60 \%$ \\
\hline 343 & 7475 & 10 & 3,175 & 10 & não & $60 \%$ \\
\hline 344 & 7475 & 10 & 3,175 & 10 & sim & $60 \%$ \\
\hline 345 & 7475 & 10 & 3,175 & 10 & não & $60 \%$ \\
\hline 346 & 7475 & 10 & 3,175 & 10 & sim & $60 \%$ \\
\hline 347 & 7475 & 10 & 3,175 & 10 & não & $60 \%$ \\
\hline 348 & 7475 & 10 & 3,175 & 25 & sim & $200 \%$ \\
\hline 349 & 7475 & 10 & 3,175 & 25 & não & $200 \%$ \\
\hline 350 & 7475 & 10 & 3,175 & 25 & sim & $200 \%$ \\
\hline 351 & 7475 & 10 & 3,175 & 25 & não & $200 \%$ \\
\hline & 7475 & 10 & 3,175 & 25 & sim & $200 \%$ \\
\hline & & & & Continua na próxima página \\
\hline 352 & & & & &
\end{tabular}


Tabela B.1 - Continuação da página anterior.

\begin{tabular}{|c|c|c|c|c|c|c|}
\hline $\mathrm{CP} \mathrm{n} \mathrm{n}^{\circ}$ & Liga & $\mathrm{H}(\mathrm{mm})$ & $\mathrm{D}(\mathrm{mm})$ & $P(p s i)$ & P-tens & Cobertura \\
\hline 353 & 7475 & 10 & 3,175 & 25 & não & $200 \%$ \\
\hline 354 & 7475 & 10 & 3,175 & 20 & $\operatorname{sim}$ & $200 \%$ \\
\hline 355 & 7475 & 10 & 3,175 & 20 & não & $200 \%$ \\
\hline 356 & 7475 & 10 & 3,175 & 20 & $\operatorname{sim}$ & $200 \%$ \\
\hline 357 & 7475 & 10 & 3,175 & 20 & não & $200 \%$ \\
\hline 358 & 7475 & 10 & 3,175 & 20 & $\operatorname{sim}$ & $200 \%$ \\
\hline 359 & 7475 & 10 & 3,175 & 20 & não & $200 \%$ \\
\hline 360 & 7475 & 10 & 3,175 & 10 & $\operatorname{sim}$ & $200 \%$ \\
\hline 361 & 7475 & 10 & 3,175 & 10 & não & $200 \%$ \\
\hline 362 & 7475 & 10 & 3,175 & 10 & não & $200 \%$ \\
\hline 363 & 7475 & 10 & 3,175 & 10 & não & $200 \%$ \\
\hline 364 & 7050 & 10 & 3,175 & 25 & $\operatorname{sim}$ & $200 \%$ \\
\hline 365 & 7050 & 10 & 3,175 & 25 & não & $200 \%$ \\
\hline 366 & 7050 & 10 & 3,175 & 20 & $\operatorname{sim}$ & $200 \%$ \\
\hline 367 & 7050 & 10 & 3,175 & 20 & não & $200 \%$ \\
\hline 368 & 7050 & 10 & 3,175 & 20 & $\operatorname{sim}$ & $200 \%$ \\
\hline 369 & 7050 & 10 & 3,175 & 20 & não & $200 \%$ \\
\hline 370 & 7050 & 10 & 3,175 & 20 & $\operatorname{sim}$ & $200 \%$ \\
\hline 371 & 7050 & 10 & 3,175 & 20 & não & $200 \%$ \\
\hline 372 & 7050 & 10 & 3,175 & 10 & $\operatorname{sim}$ & $200 \%$ \\
\hline 373 & 7050 & 10 & 3,175 & 10 & não & $200 \%$ \\
\hline 375 & 7050 & 10 & 3,175 & 10 & não & $200 \%$ \\
\hline 376 & 7050 & 10 & 3,175 & 10 & não & $200 \%$ \\
\hline 377 & 7050 & 10 & 3,175 & 10 & $\operatorname{sim}$ & $200 \%$ \\
\hline 378 & 7050 & 10 & 3,175 & 10 & $\operatorname{sim}$ & $200 \%$ \\
\hline 380 & 7050 & 10 & 3,175 & 25 & $\operatorname{sim}$ & $60 \%$ \\
\hline 381 & 7475 & 10 & 3,175 & 10 & $\operatorname{sim}$ & $200 \%$ \\
\hline 382 & 7475 & 10 & 3,175 & 10 & $\operatorname{sim}$ & $200 \%$ \\
\hline 384 & 7475 & 10 & 3,175 & 25 & $\operatorname{sim}$ & $200 \%$ \\
\hline 385 & 7475 & 10 & 3,175 & 25 & $\operatorname{sim}$ & $200 \%$ \\
\hline 386 & 7475 & 15 & 3,175 & 25 & $\operatorname{sim}$ & $60 \%$ \\
\hline 387 & 7475 & 15 & 3,175 & 25 & não & $60 \%$ \\
\hline 388 & 7475 & 15 & 3,175 & 20 & sim & $60 \%$ \\
\hline 389 & 7475 & 15 & 3,175 & 20 & não & $60 \%$ \\
\hline 390 & 7475 & 15 & 3,175 & 25 & $\operatorname{sim}$ & $60 \%$ \\
\hline 391 & 7475 & 15 & 3,175 & 25 & não & $60 \%$ \\
\hline 392 & 7475 & 15 & 3,175 & 20 & $\operatorname{sim}$ & $60 \%$ \\
\hline 393 & 7475 & 15 & 3,175 & 20 & não & $60 \%$ \\
\hline
\end{tabular}


Tabela B.1 - Continuação da página anterior.

\begin{tabular}{c|c|c|c|c|c|c}
\hline $\mathrm{CP} \mathrm{n}^{\circ}$ & Liga & $\mathrm{H}(\mathrm{mm})$ & $\mathrm{D}(\mathrm{mm})$ & $\mathrm{P}(\mathrm{psi})$ & $\mathrm{P}$-tens & Cobertura \\
\hline \hline 394 & 7475 & 15 & 3,175 & 25 & não & $60 \%$ \\
\hline 395 & 7475 & 15 & 3,175 & 25 & sim & $60 \%$ \\
\hline 396 & 7475 & 15 & 3,175 & 20 & sim & $60 \%$ \\
\hline 397 & 7475 & 15 & 3,175 & 20 & não & $60 \%$ \\
\hline 398 & 7475 & 15 & 3,175 & 25 & sim & $200 \%$ \\
\hline 399 & 7475 & 15 & 3,175 & 25 & sim & $200 \%$ \\
\hline 400 & 7050 & 15 & 3,175 & 25 & sim & $60 \%$ \\
\hline 401 & 7050 & 15 & 3,175 & 25 & não & $60 \%$ \\
\hline 402 & 7050 & 15 & 3,175 & 20 & sim & $60 \%$ \\
\hline 403 & 7050 & 15 & 3,175 & 20 & não & $60 \%$ \\
\hline 404 & 7050 & 15 & 3,175 & 25 & sim & $60 \%$ \\
\hline 405 & 7050 & 15 & 3,175 & 25 & não & $60 \%$ \\
\hline 406 & 7050 & 15 & 3,175 & 20 & sim & $60 \%$ \\
\hline 407 & 7050 & 15 & 3,175 & 20 & não & $60 \%$ \\
\hline 408 & 7050 & 15 & 3,175 & 25 & sim & $60 \%$ \\
\hline 409 & 7050 & 15 & 3,175 & 25 & não & $60 \%$ \\
\hline 410 & 7050 & 15 & 3,175 & 20 & sim & $60 \%$ \\
\hline 411 & 7050 & 15 & 3,175 & 20 & não & $60 \%$ \\
\hline 412 & 7050 & 15 & 3,175 & 25 & sim & $200 \%$ \\
\hline 413 & 7050 & 15 & 3,175 & 25 & sim & $200 \%$ \\
\hline 414 & 7050 & 15 & 3,175 & 25 & sim & $200 \%$ \\
\hline 415 & 7050 & 15 & 3,175 & 20 & sim & $200 \%$ \\
\hline 416 & 7050 & 15 & 3,175 & 25 & não & $200 \%$ \\
\hline 417 & 7050 & 15 & 3,175 & 25 & não & $200 \%$ \\
\hline 418 & 7050 & 15 & 3,175 & 25 & não & $200 \%$ \\
\hline 419 & 7050 & 15 & 3,175 & 20 & sim & $200 \%$ \\
\hline 420 & 7050 & 15 & 3,175 & 20 & sim & $200 \%$ \\
\hline 421 & 7050 & 15 & 3,175 & 20 & não & $200 \%$ \\
\hline 422 & 7050 & 15 & 3,175 & 20 & não & $200 \%$ \\
\hline 423 & 7050 & 15 & 3,175 & 20 & não & $200 \%$ \\
\hline 424 & 7050 & 15 & 3,175 & 10 & sim & $60 \%$ \\
\hline 425 & 7050 & 15 & 3,175 & 10 & sim & $60 \%$ \\
\hline 426 & 7050 & 15 & 3,175 & 10 & sim & $60 \%$ \\
\hline 427 & 7050 & 15 & 3,175 & 10 & não & $60 \%$ \\
\hline 428 & 7050 & 15 & 3,175 & 10 & não & $60 \%$ \\
\hline 429 & 7050 & 15 & 3,175 & 10 & não & $60 \%$ \\
\hline 430 & 7050 & 15 & 3,175 & 10 & sim & $200 \%$ \\
\hline 431 & 7050 & 15 & 3,175 & 10 & sim & $200 \%$ \\
\hline & & & & Continua na próxima página \\
\hline & & & & & &
\end{tabular}


Tabela B.1 - Concluído da página anterior.

\begin{tabular}{c|c|c|c|c|c|c}
\hline $\mathrm{CP} \mathrm{n}^{\circ}$ & Liga & $\mathrm{H}(\mathrm{mm})$ & $\mathrm{D}(\mathrm{mm})$ & $\mathrm{P}(\mathrm{psi})$ & P-tens & Cobertura \\
\hline \hline 432 & 7050 & 15 & 3,175 & 10 & não & $200 \%$ \\
\hline 433 & 7050 & 15 & 3,175 & 10 & sim & $200 \%$ \\
\hline 434 & 7050 & 15 & 3,175 & 10 & não & $200 \%$ \\
\hline 435 & 7050 & 15 & 3,175 & 10 & não & $200 \%$ \\
\hline 439 & 7475 & 15 & 3,175 & 25 & sim & $200 \%$ \\
\hline 440 & 7475 & 15 & 3,175 & 25 & não & $200 \%$ \\
\hline 441 & 7475 & 15 & 3,175 & 25 & não & $200 \%$ \\
\hline 442 & 7475 & 15 & 3,175 & 25 & não & $200 \%$ \\
\hline 443 & 7475 & 15 & 3,175 & 20 & sim & $200 \%$ \\
\hline 444 & 7475 & 15 & 3,175 & 20 & sim & $200 \%$ \\
\hline 445 & 7475 & 15 & 3,175 & 20 & sim & $200 \%$ \\
\hline 446 & 7475 & 15 & 3,175 & 20 & não & $200 \%$ \\
\hline 447 & 7475 & 15 & 3,175 & 20 & não & $200 \%$ \\
\hline 448 & 7475 & 15 & 3,175 & 20 & não & $200 \%$ \\
\hline 449 & 7475 & 15 & 3,175 & 10 & sim & $60 \%$ \\
\hline 450 & 7475 & 15 & 3,175 & 10 & sim & $60 \%$ \\
\hline 451 & 7475 & 15 & 3,175 & 10 & sim & $60 \%$ \\
\hline 452 & 7475 & 15 & 3,175 & 10 & não & $60 \%$ \\
\hline 453 & 7475 & 15 & 3,175 & 10 & não & $60 \%$ \\
\hline 454 & 7475 & 15 & 3,175 & 10 & não & $60 \%$ \\
\hline 455 & 7475 & 15 & 3,175 & 10 & sim & $200 \%$ \\
\hline 456 & 7475 & 15 & 3,175 & 10 & sim & $200 \%$ \\
\hline 457 & 7475 & 15 & 3,175 & 10 & sim & $200 \%$ \\
\hline 458 & 7475 & 15 & 3,175 & 10 & não & $200 \%$ \\
\hline 459 & 7475 & 15 & 3,175 & 10 & não & $200 \%$ \\
\hline 460 & 7475 & 15 & 3,175 & 10 & não & $200 \%$ \\
\hline & & & & & &
\end{tabular}




\section{Apêndice C - Medidas do raio de curvatura dos corpos de prova}

Curvatura dos corpos de prova de $2 \mathrm{~mm}$ nas ligas AA 7050 e AA 7475

Conforme indicado na matriz de experimentos, esses corpos de prova foram submetidos a ensaios de JCG utilizando granalhas S230. As medidas de curvatura obtidas, para as diferentes condições experimentais, são apresentadas nas tabelas C.1 e C.2 a seguir. 
Tabela C.1: Curvatura dos corpos de prova de $2 \mathrm{~mm}$ da liga AA 7050.

\begin{tabular}{|c|c|c|c|c|c|}
\hline Liga & Pressão (psi) & Cobertura & Pré-tensão & $\mathrm{CP} \mathrm{n}^{\circ}$ & Raio de Curvatura (mm) \\
\hline \multirow{31}{*}{7050} & \multirow{12}{*}{20} & \multirow{6}{*}{$66 \%$} & \multirow{3}{*}{$\mathrm{N}$} & 006 & 927,76 \\
\hline & & & & 010 & 898,10 \\
\hline & & & & 097 & 1318,90 \\
\hline & & & \multirow{3}{*}{ S } & 014 & 446,66 \\
\hline & & & & 056 & 408,15 \\
\hline & & & & 058 & 437,98 \\
\hline & & \multirow{6}{*}{$200 \%$} & \multirow{3}{*}{$\mathrm{N}$} & 009 & 732,48 \\
\hline & & & & 013 & 774,49 \\
\hline & & & & 066 & 674,74 \\
\hline & & & \multirow{3}{*}{$\mathrm{S}$} & 022 & 304,77 \\
\hline & & & & 059 & 293,09 \\
\hline & & & & 062 & 311,84 \\
\hline & \multirow{12}{*}{40} & \multirow{6}{*}{$85 \%$} & \multirow{3}{*}{$\mathrm{N}$} & 007 & 640,02 \\
\hline & & & & 011 & 730,59 \\
\hline & & & & 099 & 764,85 \\
\hline & & & \multirow{3}{*}{$\mathrm{S}$} & 017 & 286,93 \\
\hline & & & & 054 & 295,51 \\
\hline & & & & 064 & 291,29 \\
\hline & & \multirow{6}{*}{$200 \%$} & \multirow{3}{*}{$\mathrm{N}$} & 008 & 556,26 \\
\hline & & & & 012 & 649,90 \\
\hline & & & & 098 & 628,94 \\
\hline & & & \multirow{3}{*}{ S } & 018 & 260,06 \\
\hline & & & & 024 & 256,48 \\
\hline & & & & 064 & 254,03 \\
\hline & \multirow{7}{*}{60} & \multirow{3}{*}{$92 \%$} & $\mathrm{~N}$ & 101 & 740,49 \\
\hline & & & \multirow{2}{*}{ S } & 052 & 260,05 \\
\hline & & & & 063 & 277,83 \\
\hline & & \multirow{4}{*}{$200 \%$} & $\mathrm{~N}$ & 100 & 596,79 \\
\hline & & & \multirow{3}{*}{$S$} & 015 & 237,97 \\
\hline & & & & 020 & 241,22 \\
\hline & & & & 053 & 244,06 \\
\hline
\end{tabular}


Tabela C.2: Curvatura dos corpos de prova de 2 mm da liga AA 7475.

\begin{tabular}{|c|c|c|c|c|c|}
\hline Liga & Pressão (psi) & Cobertura & Pré-tensão & $\mathrm{CP} \mathrm{n}^{\circ}$ & Raio de Curvatura (mm) \\
\hline \multirow{28}{*}{7475} & \multirow{9}{*}{20} & \multirow{4}{*}{$66 \%$} & \multirow{2}{*}{$\mathrm{N}$} & 110 & 1257,75 \\
\hline & & & & 111 & 1251,26 \\
\hline & & & \multirow{2}{*}{ S } & 072 & 433,96 \\
\hline & & & & 074 & 450,24 \\
\hline & & \multirow{5}{*}{$200 \%$} & & 112 & 734,89 \\
\hline & & & $\mathrm{N}$ & 113 & 754,73 \\
\hline & & & \multirow{3}{*}{ S } & 075 & 284,08 \\
\hline & & & & 106 & 309,15 \\
\hline & & & & 107 & 315,39 \\
\hline & \multirow{10}{*}{40} & \multirow{5}{*}{$85 \%$} & \multirow{2}{*}{$\mathrm{N}$} & 116 & 746,91 \\
\hline & & & & 117 & 740,09 \\
\hline & & & \multirow{3}{*}{ S } & 070 & 289,14 \\
\hline & & & & 079 & 288,85 \\
\hline & & & & 081 & 279,63 \\
\hline & & \multirow{5}{*}{$200 \%$} & \multirow{2}{*}{$\mathrm{N}$} & 114 & 588,43 \\
\hline & & & & 115 & 598,83 \\
\hline & & & \multirow{3}{*}{$\mathrm{S}$} & 071 & 243,01 \\
\hline & & & & 078 & 235,90 \\
\hline & & & & 080 & 233,53 \\
\hline & \multirow{9}{*}{60} & \multirow{4}{*}{$92 \%$} & \multirow{2}{*}{$\mathrm{N}$} & 120 & 677,70 \\
\hline & & & & 121 & 677,06 \\
\hline & & & \multirow{2}{*}{ S } & 067 & 257,68 \\
\hline & & & & 083 & 261,46 \\
\hline & & \multirow{5}{*}{$200 \%$} & \multirow{2}{*}{$\mathrm{N}$} & 118 & 500,05 \\
\hline & & & & 119 & 577,97 \\
\hline & & & \multirow{3}{*}{ S } & 082 & 227,83 \\
\hline & & & & 108 & 235,83 \\
\hline & & & & 109 & 235,33 \\
\hline
\end{tabular}




\section{Curvatura dos corpos de prova de $5 \mathrm{~mm}$ nas ligas AA 7050 e AA 7475}

Conforme indicado na matriz de experimentos, esses corpos de prova foram submetidos a ensaios de JCG utilizando-se granalhas S230 e S550. As medidas de curvatura obtidas para as diferentes condições experimentais, referentes, respectivamente, a esses dois tipos de granalhas, são apresentadas nas Tabelas C.3, C.4, C.5 e C.6 a seguir.

Tabela C.3: Curvaturas dos corpos de prova de $5 \mathrm{~mm}$, granalhas S230, liga AA 7050.

\begin{tabular}{|c|c|c|c|c|c|}
\hline Liga & Pressão (psi) & Cobertura & Pré-tensão & $\mathrm{CP} \mathrm{n}^{\circ}$ & Raio de Curvatura $(\mathrm{mm})$ \\
\hline \multirow{34}{*}{7050} & \multirow{10}{*}{20} & \multirow{5}{*}{$66 \%$} & \multirow{3}{*}{$\mathrm{N}$} & 027 & 4294,59 \\
\hline & & & & 028 & 4327,59 \\
\hline & & & & 029 & 4091,61 \\
\hline & & & \multirow{2}{*}{$\mathrm{S}$} & 140 & 2387,29 \\
\hline & & & & 142 & 2556,54 \\
\hline & & \multirow{5}{*}{$200 \%$} & \multirow{2}{*}{$\mathrm{N}$} & 091 & 4263,60 \\
\hline & & & & 092 & 4610,31 \\
\hline & & & \multirow{3}{*}{$\mathrm{s}$} & 143 & 1943,48 \\
\hline & & & & 144 & 2004,64 \\
\hline & & & & 145 & 2024,40 \\
\hline & \multirow{12}{*}{40} & \multirow{6}{*}{$85 \%$} & \multirow{3}{*}{$\mathrm{N}$} & 030 & 3496,75 \\
\hline & & & & 031 & 3330,68 \\
\hline & & & & 032 & 3287,37 \\
\hline & & & \multirow{3}{*}{$\mathrm{s}$} & 134 & 1859,59 \\
\hline & & & & 138 & 1795,06 \\
\hline & & & & 139 & 1998,03 \\
\hline & & \multirow{6}{*}{$200 \%$} & \multirow{3}{*}{$\mathrm{N}$} & 088 & 3272,00 \\
\hline & & & & 089 & 3269,16 \\
\hline & & & & 090 & 3192,92 \\
\hline & & & \multirow{3}{*}{$\mathrm{s}$} & 135 & 1622,56 \\
\hline & & & & 136 & 1603,41 \\
\hline & & & & 137 & 1526,20 \\
\hline & \multirow{12}{*}{60} & \multirow{6}{*}{$92 \%$} & \multirow{3}{*}{$\mathrm{N}$} & 034 & 3311,95 \\
\hline & & & & 035 & 3142,11 \\
\hline & & & & 087 & 3304,84 \\
\hline & & & \multirow{3}{*}{$S$} & 094 & 1781,40 \\
\hline & & & & 095 & 1748,32 \\
\hline & & & & 096 & 1720,33 \\
\hline & & \multirow{6}{*}{$200 \%$} & \multirow{3}{*}{$\mathrm{N}$} & 036 & 3034,84 \\
\hline & & & & 037 & 2823,41 \\
\hline & & & & 038 & 2831,71 \\
\hline & & & \multirow{3}{*}{ S } & 131 & 1474,60 \\
\hline & & & & 132 & 1480,30 \\
\hline & & & & 133 & 1527,98 \\
\hline
\end{tabular}


Tabela C.4: Curvaturas dos corpos de prova de $5 \mathrm{~mm}$, granalhas S230, liga AA 7475.

\begin{tabular}{|c|c|c|c|c|c|}
\hline Liga & Pressão (psi) & Cobertura & Pré-tensão & $\mathrm{CP} \mathrm{n}^{\circ}$ & Raio de Curvatura $(\mathrm{mm})$ \\
\hline \multirow{36}{*}{7475} & \multirow{12}{*}{20} & \multirow{6}{*}{$66 \%$} & \multirow{3}{*}{$\mathrm{N}$} & 040 & 4305,72 \\
\hline & & & & 041 & 4426,35 \\
\hline & & & & 042 & 4327,17 \\
\hline & & & \multirow{3}{*}{$\mathrm{s}$} & 158 & 2389,93 \\
\hline & & & & 159 & 2474,51 \\
\hline & & & & 160 & 2341,63 \\
\hline & & \multirow{6}{*}{$200 \%$} & \multirow{3}{*}{$\mathrm{N}$} & 128 & 3656,10 \\
\hline & & & & 129 & 3562,84 \\
\hline & & & & 130 & 3609,77 \\
\hline & & & \multirow{3}{*}{$\mathrm{s}$} & 161 & 2000,04 \\
\hline & & & & 162 & 2012,40 \\
\hline & & & & 163 & 1853,21 \\
\hline & \multirow{12}{*}{40} & \multirow{6}{*}{$85 \%$} & \multirow{3}{*}{$\mathrm{N}$} & 043 & 3457,24 \\
\hline & & & & 044 & 3653,98 \\
\hline & & & & 045 & 3904,08 \\
\hline & & & \multirow{3}{*}{$\mathrm{S}$} & 152 & 1782,31 \\
\hline & & & & 156 & 1743,40 \\
\hline & & & & 157 & 1825,44 \\
\hline & & \multirow{6}{*}{$200 \%$} & \multirow{3}{*}{$\mathrm{N}$} & 125 & 2823,90 \\
\hline & & & & 126 & 2710,52 \\
\hline & & & & 127 & 3016,12 \\
\hline & & & \multirow{3}{*}{$\mathrm{S}$} & 153 & 1642,67 \\
\hline & & & & 154 & 1575,23 \\
\hline & & & & 155 & 1600,17 \\
\hline & \multirow{12}{*}{60} & \multirow{6}{*}{$92 \%$} & \multirow{3}{*}{$\mathrm{N}$} & 046 & 3535,76 \\
\hline & & & & 047 & 3322,42 \\
\hline & & & & 048 & 3391,87 \\
\hline & & & \multirow{3}{*}{ S } & 146 & 1696,89 \\
\hline & & & & 147 & 1673,80 \\
\hline & & & & 148 & 1576,44 \\
\hline & & \multirow{6}{*}{$200 \%$} & \multirow{3}{*}{$\mathrm{N}$} & 049 & 3006,83 \\
\hline & & & & 050 & 2951,79 \\
\hline & & & & 051 & 3228,74 \\
\hline & & & \multirow{3}{*}{$S$} & 149 & 1507,47 \\
\hline & & & & 150 & 1492,36 \\
\hline & & & & 151 & 1533,28 \\
\hline
\end{tabular}


Tabela C.5: Curvaturas dos corpos de prova de $5 \mathrm{~mm}$, granalhas S550, liga AA 7050.

\begin{tabular}{|c|c|c|c|c|c|}
\hline Liga & Pressão (psi) & Cobertura & Pré-tensão & $\mathrm{CP} \mathrm{n}^{\circ}$ & Raio de Curvatura $(\mathrm{mm})$ \\
\hline \multirow{36}{*}{7050} & \multirow{12}{*}{10} & \multirow{6}{*}{$60 \%$} & \multirow{3}{*}{$\mathrm{N}$} & 186 & 5369,71 \\
\hline & & & & 188 & 8219,34 \\
\hline & & & & 194 & 4981,71 \\
\hline & & & \multirow{3}{*}{$S$} & 168 & 1773,04 \\
\hline & & & & 174 & 1638,73 \\
\hline & & & & 184 & 1837,51 \\
\hline & & \multirow{6}{*}{$200 \%$} & \multirow{3}{*}{$\mathrm{N}$} & 187 & 3157,78 \\
\hline & & & & 189 & 3018,60 \\
\hline & & & & 195 & 3353,40 \\
\hline & & & \multirow{3}{*}{ S } & 169 & 1308,57 \\
\hline & & & & 175 & 1094,57 \\
\hline & & & & 185 & 1440,01 \\
\hline & \multirow{12}{*}{20} & \multirow{6}{*}{$60 \%$} & \multirow{3}{*}{$\mathrm{N}$} & 178 & 3058,09 \\
\hline & & & & 190 & 3570,58 \\
\hline & & & & 196 & 3978,37 \\
\hline & & & \multirow{3}{*}{$S$} & 166 & 1340,85 \\
\hline & & & & 172 & 1227,01 \\
\hline & & & & 183 & 1379,45 \\
\hline & & \multirow{6}{*}{$200 \%$} & \multirow{3}{*}{$\mathrm{N}$} & 179 & 2316,81 \\
\hline & & & & 191 & 2570,48 \\
\hline & & & & 197 & 2505,70 \\
\hline & & & \multirow{3}{*}{$S$} & 167 & 993,71 \\
\hline & & & & 173 & 944,02 \\
\hline & & & & 182 & 1092,39 \\
\hline & \multirow{12}{*}{30} & \multirow{6}{*}{$60 \%$} & \multirow{3}{*}{$\mathrm{N}$} & 176 & 3072,10 \\
\hline & & & & 192 & 3155,61 \\
\hline & & & & 198 & 3004,16 \\
\hline & & & \multirow{3}{*}{$S$} & 164 & 1235,57 \\
\hline & & & & 170 & 1167,82 \\
\hline & & & & 181 & 1267,34 \\
\hline & & \multirow{6}{*}{$200 \%$} & \multirow{3}{*}{$\mathrm{N}$} & 177 & 1816,12 \\
\hline & & & & 193 & 2074,81 \\
\hline & & & & 199 & 1810,53 \\
\hline & & & \multirow{3}{*}{$S$} & 165 & 905,28 \\
\hline & & & & 171 & 844,30 \\
\hline & & & & 180 & 905,81 \\
\hline
\end{tabular}


Tabela C.6: Curvaturas dos corpos de prova de $5 \mathrm{~mm}$, granalhas S550, liga AA 7475.

\begin{tabular}{|c|c|c|c|c|c|}
\hline Liga & Pressão (psi) & Cobertura & Pré-tensão & $\mathrm{CP} \mathrm{n}^{\circ}$ & Raio de Curvatura $(\mathrm{mm})$ \\
\hline \multirow{36}{*}{7475} & \multirow{12}{*}{10} & \multirow{6}{*}{$60 \%$} & \multirow{3}{*}{$\mathrm{N}$} & 200 & 4548,86 \\
\hline & & & & 227 & 5213,33 \\
\hline & & & & 230 & 4901,46 \\
\hline & & & \multirow{3}{*}{$S$} & 209 & 1741,03 \\
\hline & & & & 215 & 1533,28 \\
\hline & & & & 225 & 1825,78 \\
\hline & & \multirow{6}{*}{$200 \%$} & \multirow{3}{*}{$\mathrm{N}$} & 201 & 3170,14 \\
\hline & & & & 228 & 3475,62 \\
\hline & & & & 231 & 3044,96 \\
\hline & & & \multirow{3}{*}{$\mathrm{S}$} & 210 & 1317,45 \\
\hline & & & & 216 & 1242,62 \\
\hline & & & & 226 & 1427,80 \\
\hline & \multirow{12}{*}{20} & \multirow{6}{*}{$60 \%$} & \multirow{3}{*}{$\mathrm{N}$} & 202 & 3720,28 \\
\hline & & & & 219 & 3032,12 \\
\hline & & & & 232 & 3795,49 \\
\hline & & & \multirow{3}{*}{$\mathrm{S}$} & 207 & 1375,34 \\
\hline & & & & 213 & 1261,63 \\
\hline & & & & 224 & 1338,38 \\
\hline & & \multirow{6}{*}{$200 \%$} & \multirow{3}{*}{$\mathrm{N}$} & 203 & 2462,94 \\
\hline & & & & 220 & 2048,26 \\
\hline & & & & 233 & 2386,48 \\
\hline & & & \multirow{3}{*}{$\mathrm{S}$} & 208 & 975,20 \\
\hline & & & & 214 & 956,57 \\
\hline & & & & 223 & 971,15 \\
\hline & \multirow{12}{*}{30} & \multirow{6}{*}{$60 \%$} & \multirow{3}{*}{$\mathrm{N}$} & 204 & 3342,27 \\
\hline & & & & 217 & 2876,90 \\
\hline & & & & 234 & 3062,15 \\
\hline & & & \multirow{3}{*}{$\mathrm{s}$} & 205 & 1180,84 \\
\hline & & & & 211 & 1120,32 \\
\hline & & & & 222 & 1188,39 \\
\hline & & \multirow{6}{*}{$200 \%$} & \multirow{3}{*}{$\mathrm{N}$} & 218 & 1841,25 \\
\hline & & & & 229 & 2225,51 \\
\hline & & & & 235 & 1847,09 \\
\hline & & & \multirow{3}{*}{ S } & 206 & 850,99 \\
\hline & & & & 212 & 785,20 \\
\hline & & & & 221 & 883,44 \\
\hline
\end{tabular}


Curvatura dos corpos de prova de $10 \mathrm{~mm}$ nas ligas AA 7050 e AA 7475.

Conforme indicado na matriz de experimentos, esses corpos de prova foram submetidos a ensaios de JCG utilizando-se granalhas S550 e 1/8". As medidas de curvatura obtidas para as diferentes condições experimentais, referentes, respectivamente, a esses dois tipos de granalhas e aos dois tipos de ligas, são apresentadas nas Tabelas C.7, C.8, C.9 e C.10 a seguir. 
Tabela C.7: Curvaturas dos corpos de prova de $10 \mathrm{~mm}$, granalhas S550, liga AL7050.

\begin{tabular}{|c|c|c|c|c|c|}
\hline Liga & Pressão (psi) & Cobertura & Pré-tensão & $\mathrm{CP} \mathrm{n}^{\circ}$ & Raio de Curvatura $(\mathrm{mm})$ \\
\hline \multirow{36}{*}{7050} & \multirow{12}{*}{10} & \multirow{6}{*}{$60 \%$} & \multirow{3}{*}{$\mathrm{N}$} & 293 & 18021,66 \\
\hline & & & & 313 & 16563,61 \\
\hline & & & & 315 & 21296,75 \\
\hline & & & \multirow{3}{*}{$\mathrm{s}$} & 287 & 7225,84 \\
\hline & & & & 288 & 7048,94 \\
\hline & & & & 289 & 6932,85 \\
\hline & & \multirow{6}{*}{$200 \%$} & \multirow{3}{*}{$\mathrm{N}$} & 312 & 15806,55 \\
\hline & & & & 314 & 16462,86 \\
\hline & & & & 316 & 19421,45 \\
\hline & & & \multirow{3}{*}{$\mathrm{S}$} & 290 & 9660,79 \\
\hline & & & & 291 & 5676,13 \\
\hline & & & & 292 & 5434,13 \\
\hline & \multirow{12}{*}{20} & \multirow{6}{*}{$60 \%$} & \multirow{3}{*}{$\mathrm{N}$} & 262 & 23424,07 \\
\hline & & & & 280 & 19399,66 \\
\hline & & & & 284 & 15914,24 \\
\hline & & & \multirow{3}{*}{$\mathrm{S}$} & 261 & 6306,63 \\
\hline & & & & 279 & 6377,64 \\
\hline & & & & 283 & 6488,22 \\
\hline & & \multirow{6}{*}{$200 \%$} & \multirow{3}{*}{$N$} & 265 & 12222,90 \\
\hline & & & & 282 & 10562,72 \\
\hline & & & & 286 & 12350,52 \\
\hline & & & \multirow{3}{*}{$\mathrm{S}$} & 263 & 4821,73 \\
\hline & & & & 281 & 4883,70 \\
\hline & & & & 285 & 4909,30 \\
\hline & \multirow{12}{*}{30} & \multirow{6}{*}{$60 \%$} & \multirow{3}{*}{$\mathrm{N}$} & 249 & 11438,36 \\
\hline & & & & 253 & 26875,55 \\
\hline & & & & 257 & 15712,41 \\
\hline & & & \multirow{3}{*}{ S } & 250 & 5774,35 \\
\hline & & & & 254 & 5712,19 \\
\hline & & & & 258 & 6745,18 \\
\hline & & \multirow{6}{*}{$200 \%$} & \multirow{3}{*}{$\mathrm{N}$} & 251 & 8720,49 \\
\hline & & & & 255 & 13070,33 \\
\hline & & & & 259 & 7713,17 \\
\hline & & & \multirow{3}{*}{ S } & 252 & 5342,48 \\
\hline & & & & 256 & 4551,76 \\
\hline & & & & 260 & 4092,28 \\
\hline
\end{tabular}


Tabela C.8: Curvaturas dos corpos de prova de $10 \mathrm{~mm}$, granalhas S550, liga AA 7475.

\begin{tabular}{|c|c|c|c|c|c|}
\hline Liga & Pressão (psi) & Cobertura & Pré-tensão & $\mathrm{CP} \mathrm{n}^{\circ}$ & Raio de Curvatura $(\mathrm{mm})$ \\
\hline \multirow{36}{*}{7475} & \multirow{12}{*}{10} & \multirow{6}{*}{$60 \%$} & \multirow{3}{*}{$\mathrm{N}$} & 297 & 22562,87 \\
\hline & & & & 299 & 18951,44 \\
\hline & & & & 301 & 19081,01 \\
\hline & & & \multirow{3}{*}{$S$} & 276 & 6979,24 \\
\hline & & & & 277 & 7343,49 \\
\hline & & & & 278 & 7221,14 \\
\hline & & \multirow{6}{*}{$200 \%$} & \multirow{3}{*}{$\mathrm{N}$} & 298 & 15368,49 \\
\hline & & & & 300 & 36600,51 \\
\hline & & & & 302 & 15706,27 \\
\hline & & & \multirow{3}{*}{$\mathrm{S}$} & 294 & 5179,62 \\
\hline & & & & 295 & 5172,07 \\
\hline & & & & 296 & 5625,70 \\
\hline & \multirow{12}{*}{20} & \multirow{6}{*}{$60 \%$} & \multirow{3}{*}{$\mathrm{N}$} & 264 & 17468,71 \\
\hline & & & & 269 & 18226,79 \\
\hline & & & & 273 & 16938,36 \\
\hline & & & \multirow{3}{*}{ S } & 248 & 5487,92 \\
\hline & & & & 268 & 5857,11 \\
\hline & & & & 272 & 5865,61 \\
\hline & & \multirow{6}{*}{$200 \%$} & \multirow{3}{*}{$\mathrm{N}$} & 267 & 11148,15 \\
\hline & & & & 271 & 11652,41 \\
\hline & & & & 275 & 11065,16 \\
\hline & & & \multirow{3}{*}{$S$} & 266 & 4125,44 \\
\hline & & & & 270 & 4427,58 \\
\hline & & & & 274 & 4903,06 \\
\hline & \multirow{12}{*}{30} & \multirow{6}{*}{$60 \%$} & \multirow{3}{*}{$N$} & 236 & 14286,98 \\
\hline & & & & 240 & 14169,28 \\
\hline & & & & 244 & 13700,10 \\
\hline & & & \multirow{3}{*}{$S$} & 237 & 5185,36 \\
\hline & & & & 241 & 5018,17 \\
\hline & & & & 245 & 5061,30 \\
\hline & & \multirow{6}{*}{$200 \%$} & \multirow{3}{*}{$\mathrm{N}$} & 238 & 9733,71 \\
\hline & & & & 242 & 9794,84 \\
\hline & & & & 246 & 10376,31 \\
\hline & & & \multirow{3}{*}{$S$} & 239 & 4020,32 \\
\hline & & & & 243 & 3765,61 \\
\hline & & & & 247 & 3815,07 \\
\hline
\end{tabular}


Tabela C.9: Curvaturas dos corpos de prova de $10 \mathrm{~mm}$, granalhas 1/8", liga AA 7050.

\begin{tabular}{|c|c|c|c|c|c|}
\hline Liga & Pressão (psi) & Cobertura & Pré-tensão & $\mathrm{CP} \mathrm{n}^{\circ}$ & Raio de Curvatura (mm) \\
\hline \multirow{37}{*}{7050} & \multirow{12}{*}{10} & \multirow{6}{*}{$60 \%$} & \multirow{3}{*}{$\mathrm{N}$} & 327 & 12857,55 \\
\hline & & & & 329 & 15725,11 \\
\hline & & & & 331 & 9329,11 \\
\hline & & & \multirow{3}{*}{ S } & 326 & 3927,46 \\
\hline & & & & 328 & 4169,61 \\
\hline & & & & 330 & 4008,19 \\
\hline & & \multirow{6}{*}{$200 \%$} & \multirow{3}{*}{$\mathrm{N}$} & 373 & 9662,05 \\
\hline & & & & 375 & 8288,86 \\
\hline & & & & 376 & 8298,32 \\
\hline & & & \multirow{3}{*}{$\mathrm{S}$} & 372 & 3223,31 \\
\hline & & & & 377 & 3352,78 \\
\hline & & & & 378 & 3297,44 \\
\hline & \multirow{12}{*}{20} & \multirow{6}{*}{$60 \%$} & \multirow{3}{*}{$\mathrm{N}$} & 317 & 8470,30 \\
\hline & & & & 321 & 7271,42 \\
\hline & & & & 325 & 9275,74 \\
\hline & & & \multirow{3}{*}{$\mathrm{S}$} & 311 & 2912,37 \\
\hline & & & & 320 & 2754,96 \\
\hline & & & & 323 & 2920,87 \\
\hline & & \multirow{6}{*}{$200 \%$} & \multirow{3}{*}{$\mathrm{N}$} & 367 & 4784,22 \\
\hline & & & & 369 & 4564,01 \\
\hline & & & & 371 & 5102,87 \\
\hline & & & \multirow{3}{*}{$\mathrm{S}$} & 366 & 2234,78 \\
\hline & & & & 368 & 2232,66 \\
\hline & & & & 370 & 2217,50 \\
\hline & \multirow{13}{*}{25} & \multirow{7}{*}{$60 \%$} & \multirow{3}{*}{$\mathrm{N}$} & 310 & 7942,69 \\
\hline & & & & 319 & 6983,86 \\
\hline & & & & 322 & 5939,76 \\
\hline & & & \multirow{4}{*}{$S$} & 309 & 2802,60 \\
\hline & & & & 318 & 2575,73 \\
\hline & & & & 324 & 2688,60 \\
\hline & & & & 380 & 2516,67 \\
\hline & & \multirow{6}{*}{$200 \%$} & \multirow{3}{*}{$\mathrm{N}$} & 333 & 5592,14 \\
\hline & & & & 335 & 4684,05 \\
\hline & & & & 365 & 4137,11 \\
\hline & & & \multirow{3}{*}{$S$} & 332 & 2020,00 \\
\hline & & & & 334 & 1983,46 \\
\hline & & & & 364 & 1935,16 \\
\hline
\end{tabular}


Tabela C.10: Curvaturas dos corpos de prova de $10 \mathrm{~mm}$, granalhas 1/8", liga AA 7475.

\begin{tabular}{|c|c|c|c|c|c|}
\hline Liga & Pressão (psi) & Cobertura & Pré-tensão & $\mathrm{CP} \mathrm{n}^{\circ}$ & Raio de Curvatura $(\mathrm{mm})$ \\
\hline \multirow{38}{*}{7475} & \multirow{12}{*}{10} & \multirow{6}{*}{$60 \%$} & \multirow{3}{*}{$\mathrm{N}$} & 343 & 12310,34 \\
\hline & & & & 345 & 10224,68 \\
\hline & & & & 347 & 12925,33 \\
\hline & & & \multirow{3}{*}{$S$} & 342 & 4158,16 \\
\hline & & & & 344 & 3695,41 \\
\hline & & & & 346 & 3617,62 \\
\hline & & \multirow{6}{*}{$200 \%$} & \multirow{3}{*}{$\mathrm{N}$} & 361 & 8462,43 \\
\hline & & & & 362 & 8078,08 \\
\hline & & & & 363 & 8292,07 \\
\hline & & & \multirow{3}{*}{ S } & 360 & 3245,82 \\
\hline & & & & 381 & 3141,21 \\
\hline & & & & 382 & 3236,84 \\
\hline & \multirow{12}{*}{20} & \multirow{6}{*}{$60 \%$} & \multirow{3}{*}{$N$} & 306 & 6863,02 \\
\hline & & & & 337 & 7006,27 \\
\hline & & & & 341 & 7244,51 \\
\hline & & & \multirow{3}{*}{$\mathrm{s}$} & 305 & 2715,37 \\
\hline & & & & 336 & 2859,68 \\
\hline & & & & 340 & 2747,38 \\
\hline & & \multirow{6}{*}{$200 \%$} & \multirow{3}{*}{$\mathrm{N}$} & 355 & 4501,02 \\
\hline & & & & 357 & 5227,31 \\
\hline & & & & 359 & 5361,92 \\
\hline & & & \multirow{3}{*}{ S } & 354 & 2069,04 \\
\hline & & & & 356 & 2027,42 \\
\hline & & & & 358 & 2151,30 \\
\hline & \multirow{14}{*}{25} & \multirow{6}{*}{$60 \%$} & \multirow{3}{*}{$\mathrm{N}$} & 304 & 6231,59 \\
\hline & & & & 308 & 5821,26 \\
\hline & & & & 339 & 5932,28 \\
\hline & & & \multirow{3}{*}{$S$} & 303 & 2529,36 \\
\hline & & & & 307 & 2419,69 \\
\hline & & & & 338 & 2342,43 \\
\hline & & \multirow{8}{*}{$200 \%$} & \multirow{3}{*}{$\mathrm{N}$} & 349 & 4305,66 \\
\hline & & & & 351 & 4111,65 \\
\hline & & & & 353 & 3947,91 \\
\hline & & & \multirow{5}{*}{ S } & 348 & 1896,28 \\
\hline & & & & 350 & 1793,77 \\
\hline & & & & 352 & 1882,21 \\
\hline & & & & 385 & 2038,81 \\
\hline & & & & 384 & 1846,91 \\
\hline
\end{tabular}


Curvatura dos corpos de prova de $15 \mathrm{~mm}$ nas ligas AA 7050 e AA 7475.

Conforme indicado na matriz de experimentos, esses corpos de prova foram submetidos a ensaios de JCG utilizando-se granalhas 1/8". As medidas de curvatura obtidas para as diferentes condições experimentais são apresentadas nas Tabelas C.11 e C.12 a seguir.

Tabela C.11: Curvaturas dos corpos de prova de $15 \mathrm{~mm}$, granalhas 1/8", liga AA 7050.

\begin{tabular}{|c|c|c|c|c|c|}
\hline Liga & Pressão (psi) & Cobertura & Pré-tensão & $\mathrm{CP} \mathrm{n}^{\circ}$ & Raio de Curvatura (mm) \\
\hline \multirow{36}{*}{7050} & \multirow{12}{*}{10} & \multirow{6}{*}{$60 \%$} & \multirow{3}{*}{$\mathrm{N}$} & 427 & 28394,59 \\
\hline & & & & 428 & 22681,00 \\
\hline & & & & 429 & 28040,61 \\
\hline & & & \multirow{3}{*}{ S } & 424 & 11402,16 \\
\hline & & & & 425 & 12469,97 \\
\hline & & & & 426 & 8548,79 \\
\hline & & \multirow{6}{*}{$200 \%$} & \multirow{3}{*}{$\mathrm{N}$} & 432 & 24136,33 \\
\hline & & & & 434 & 19926,72 \\
\hline & & & & 435 & 25257,14 \\
\hline & & & \multirow{3}{*}{ S } & 430 & 7856,59 \\
\hline & & & & 431 & 7421,19 \\
\hline & & & & 433 & 7518,04 \\
\hline & \multirow{12}{*}{20} & \multirow{6}{*}{$60 \%$} & \multirow{3}{*}{$\mathrm{N}$} & 403 & 20524,14 \\
\hline & & & & 407 & 17530,84 \\
\hline & & & & 411 & 20681,34 \\
\hline & & & \multirow{3}{*}{$\mathrm{S}$} & 402 & 7113,97 \\
\hline & & & & 406 & 6992,26 \\
\hline & & & & 410 & 6127,62 \\
\hline & & \multirow{6}{*}{$200 \%$} & \multirow{3}{*}{$\mathrm{N}$} & 421 & 12578,45 \\
\hline & & & & 422 & 15685,19 \\
\hline & & & & 423 & 13784,66 \\
\hline & & & \multirow{3}{*}{$\mathrm{S}$} & 415 & 5654,65 \\
\hline & & & & 419 & 5469,91 \\
\hline & & & & 420 & 4963,43 \\
\hline & \multirow{12}{*}{25} & \multirow{6}{*}{$60 \%$} & \multirow{3}{*}{$\mathrm{N}$} & 401 & 15097,88 \\
\hline & & & & 405 & 17728,34 \\
\hline & & & & 409 & 15456,68 \\
\hline & & & \multirow{3}{*}{$\mathrm{S}$} & 400 & 9265,85 \\
\hline & & & & 404 & 7041,78 \\
\hline & & & & 408 & 6508,66 \\
\hline & & \multirow{6}{*}{$200 \%$} & \multirow{3}{*}{$\mathrm{N}$} & 416 & 11968,49 \\
\hline & & & & 417 & 17809,34 \\
\hline & & & & 418 & 14871,01 \\
\hline & & & \multirow{3}{*}{ S } & 412 & 5718,24 \\
\hline & & & & 413 & 5574,16 \\
\hline & & & & 414 & 5135,81 \\
\hline
\end{tabular}


Tabela C.12: Curvaturas dos corpos de prova de $15 \mathrm{~mm}$, granalhas 1/8", liga AA 7475.

\begin{tabular}{|c|c|c|c|c|c|}
\hline Liga & Pressão (psi) & Cobertura & Pré-tensão & $\mathrm{CP} \mathrm{n}^{\circ}$ & Raio de Curvatura (mm) \\
\hline \multirow{36}{*}{7475} & \multirow{12}{*}{10} & \multirow{6}{*}{$60 \%$} & \multirow{3}{*}{$\mathrm{N}$} & 452 & 26551,85 \\
\hline & & & & 453 & 24852,44 \\
\hline & & & & 454 & 25780,54 \\
\hline & & & \multirow{3}{*}{ S } & 449 & 9562,51 \\
\hline & & & & 450 & 10443,83 \\
\hline & & & & 451 & 9922,09 \\
\hline & & \multirow{6}{*}{$200 \%$} & \multirow{3}{*}{$\mathrm{N}$} & 458 & 18894,92 \\
\hline & & & & 459 & 23821,80 \\
\hline & & & & 460 & 22293,34 \\
\hline & & & \multirow{3}{*}{ S } & 455 & 7527,61 \\
\hline & & & & 456 & 7842,01 \\
\hline & & & & 457 & 7813,56 \\
\hline & \multirow{12}{*}{20} & \multirow{6}{*}{$60 \%$} & \multirow{3}{*}{$\mathrm{N}$} & 389 & 22062,80 \\
\hline & & & & 393 & 21092,32 \\
\hline & & & & 397 & 19261,62 \\
\hline & & & \multirow{3}{*}{ S } & 388 & 7080,90 \\
\hline & & & & 392 & 6724,81 \\
\hline & & & & 396 & 7436,98 \\
\hline & & \multirow{6}{*}{$200 \%$} & \multirow{3}{*}{$\mathrm{N}$} & 446 & 16208,63 \\
\hline & & & & 447 & 12018,66 \\
\hline & & & & 448 & 17404,36 \\
\hline & & & \multirow{3}{*}{ S } & 443 & 5317,53 \\
\hline & & & & 444 & 5315,84 \\
\hline & & & & 445 & 5714,68 \\
\hline & \multirow{12}{*}{25} & \multirow{6}{*}{$60 \%$} & \multirow{3}{*}{$\mathrm{N}$} & 387 & 15233,39 \\
\hline & & & & 391 & 25088,74 \\
\hline & & & & 394 & 16385,34 \\
\hline & & & \multirow{3}{*}{$\mathrm{S}$} & 386 & 6211,81 \\
\hline & & & & 390 & 8257,05 \\
\hline & & & & 395 & 7392,18 \\
\hline & & \multirow{6}{*}{$200 \%$} & \multirow{3}{*}{$\mathrm{N}$} & 440 & 10531,23 \\
\hline & & & & 441 & 10245,77 \\
\hline & & & & 442 & 10965,14 \\
\hline & & & \multirow{3}{*}{ S } & 398 & 6251,75 \\
\hline & & & & 399 & 5081,06 \\
\hline & & & & 439 & 4708,22 \\
\hline
\end{tabular}




\section{Apêndice D - Perfis de Tensão Residual}

As Figuras D.1 a D.36 mostram os valores experimentais corrigidos, obtidos pela equipe do IPEN ${ }^{[66]}$, e os pontos $\left(\mathrm{x}_{\min }, \mathrm{y}_{\min }\right)$ de máxima compressão e espessura das camadas deformadas ( $h$ ) das chapas jateadas com esferas S230, S550 e 1/8", nas três velocidades, com e sem pré-tensão.

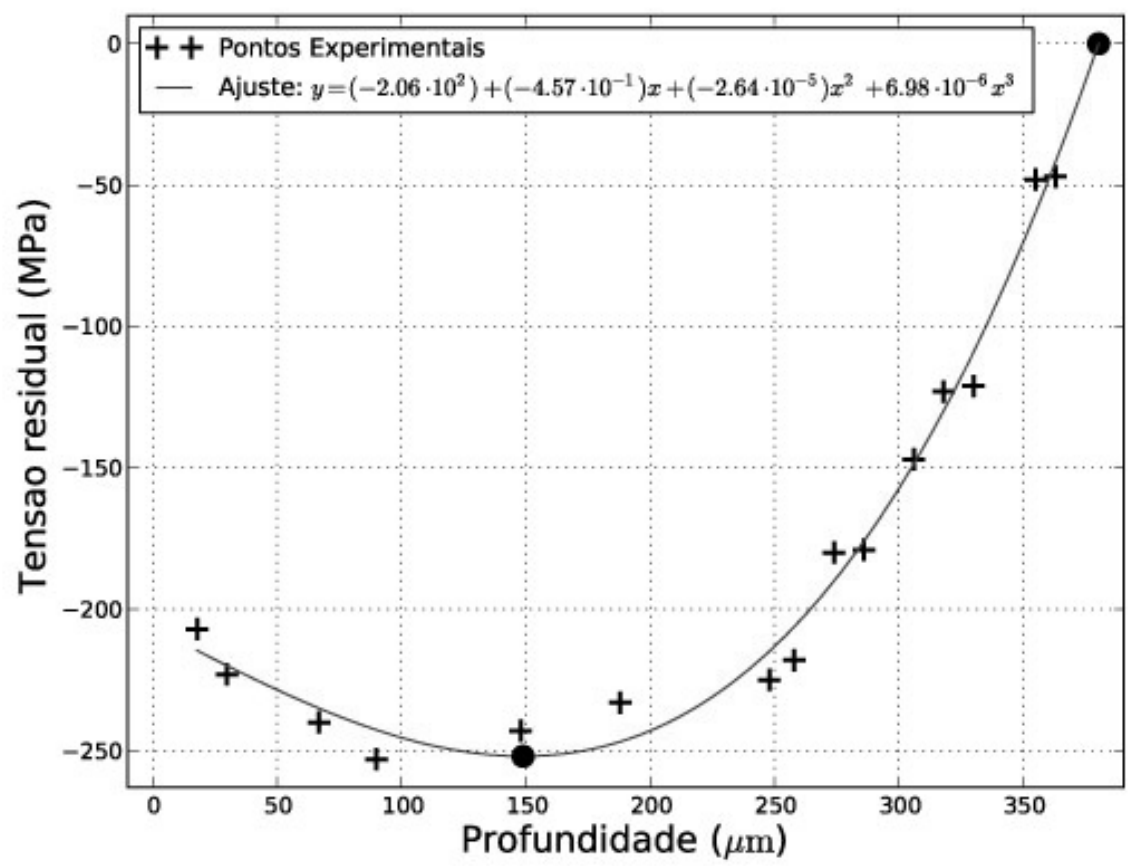

Figura D.1: Perfil de tensões residuais, com valores de máxima tensão de compressão e espessura da camada deformada. Chapa da liga 7050, espessura 2 mm, esfera S230, velocidade baixa, sem pré-tensão. 


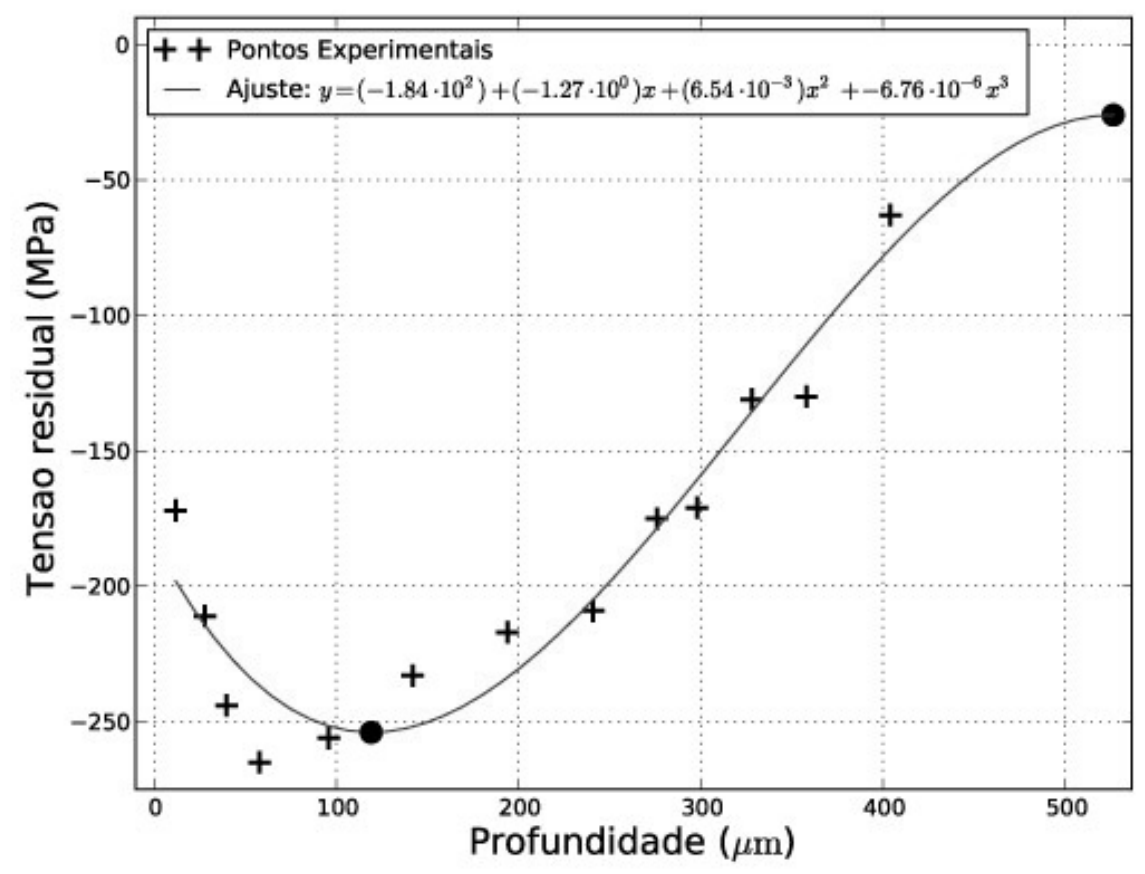

Figura D.2: Perfil de tensões residuais, com valores de máxima tensão de compressão e espessura da camada deformada. Chapa da liga 7050, espessura $2 \mathrm{~mm}$, esfera S230, velocidade média, sem pré-tensão.

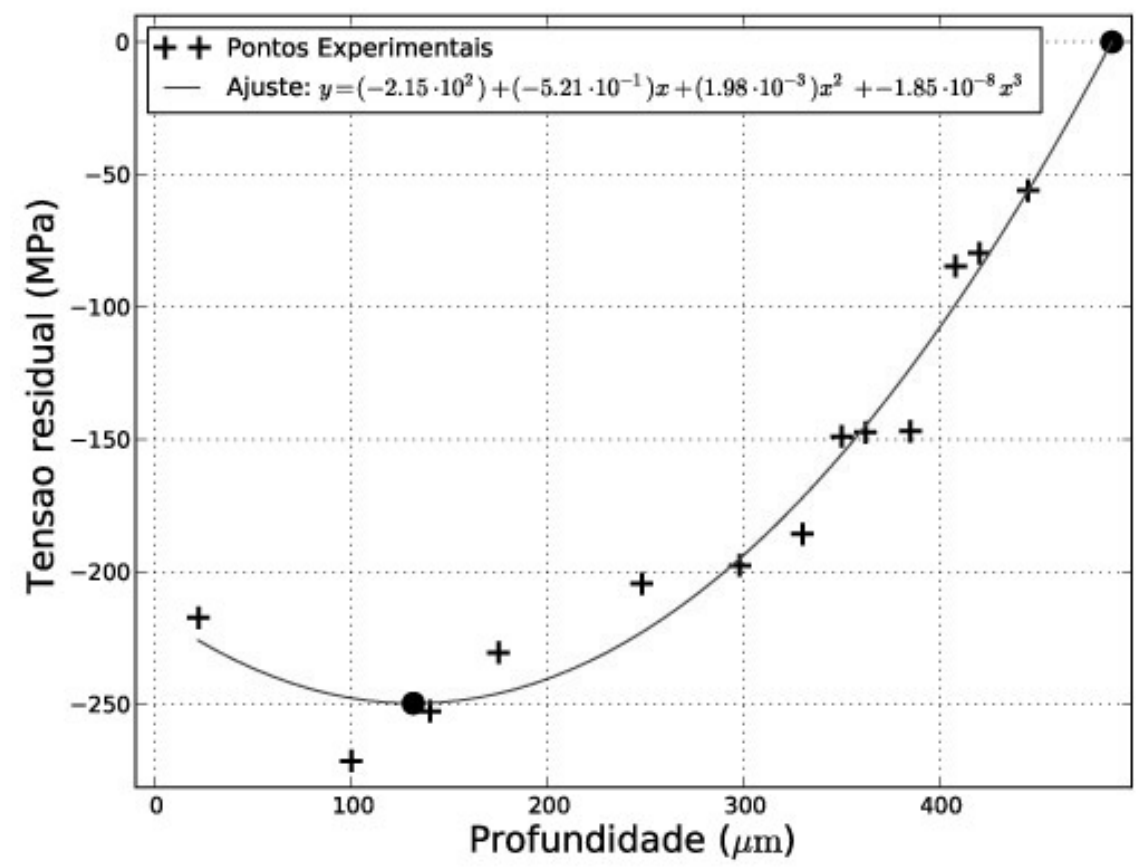

Figura D.3: Perfil de tensões residuais, com valores de máxima tensão de compressão e espessura da camada deformada. Chapa da liga 7050, espessura $2 \mathrm{~mm}$, esfera S230, velocidade alta, sem pré-tensão. 


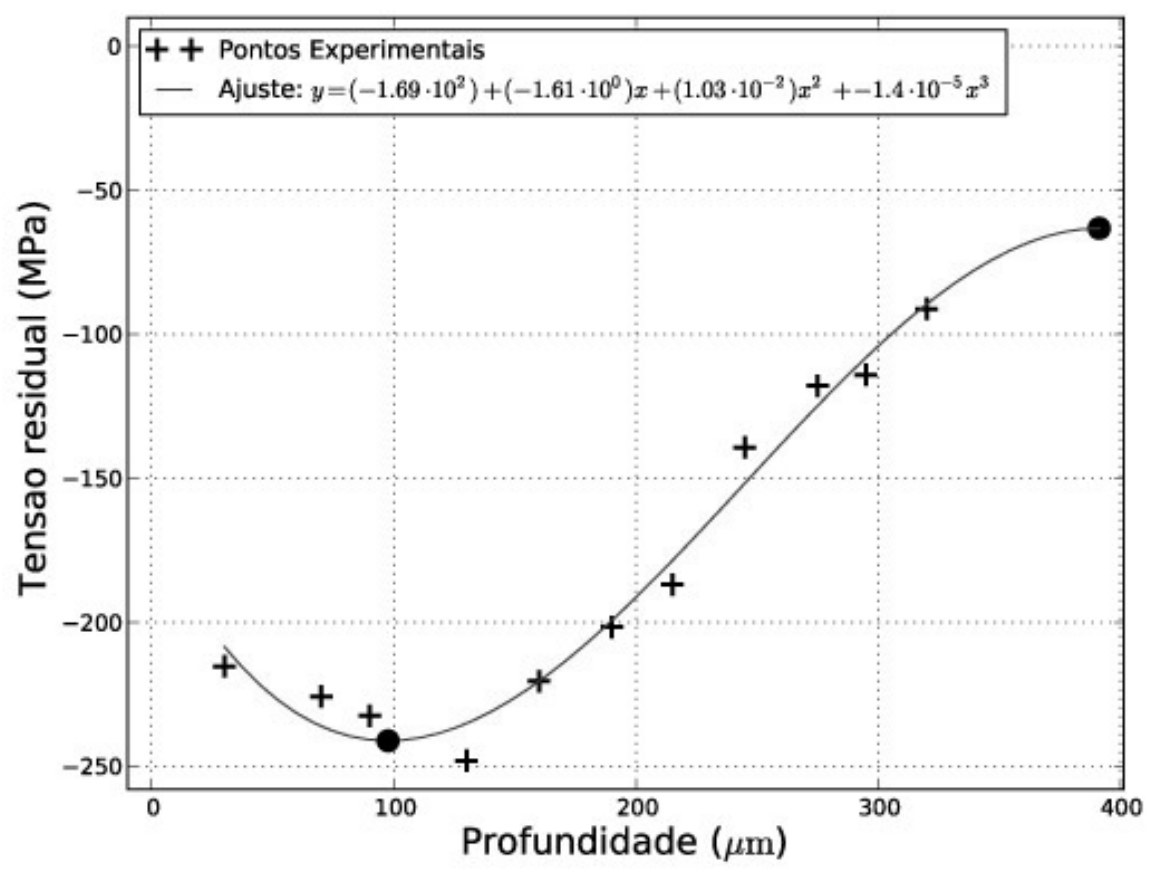

Figura D.4: Perfil de tensões residuais, com valores de máxima tensão de compressão e espessura da camada deformada. Chapa da liga 7050, espessura $2 \mathrm{~mm}$, esfera S230, velocidade baixa, com pré-tensão.

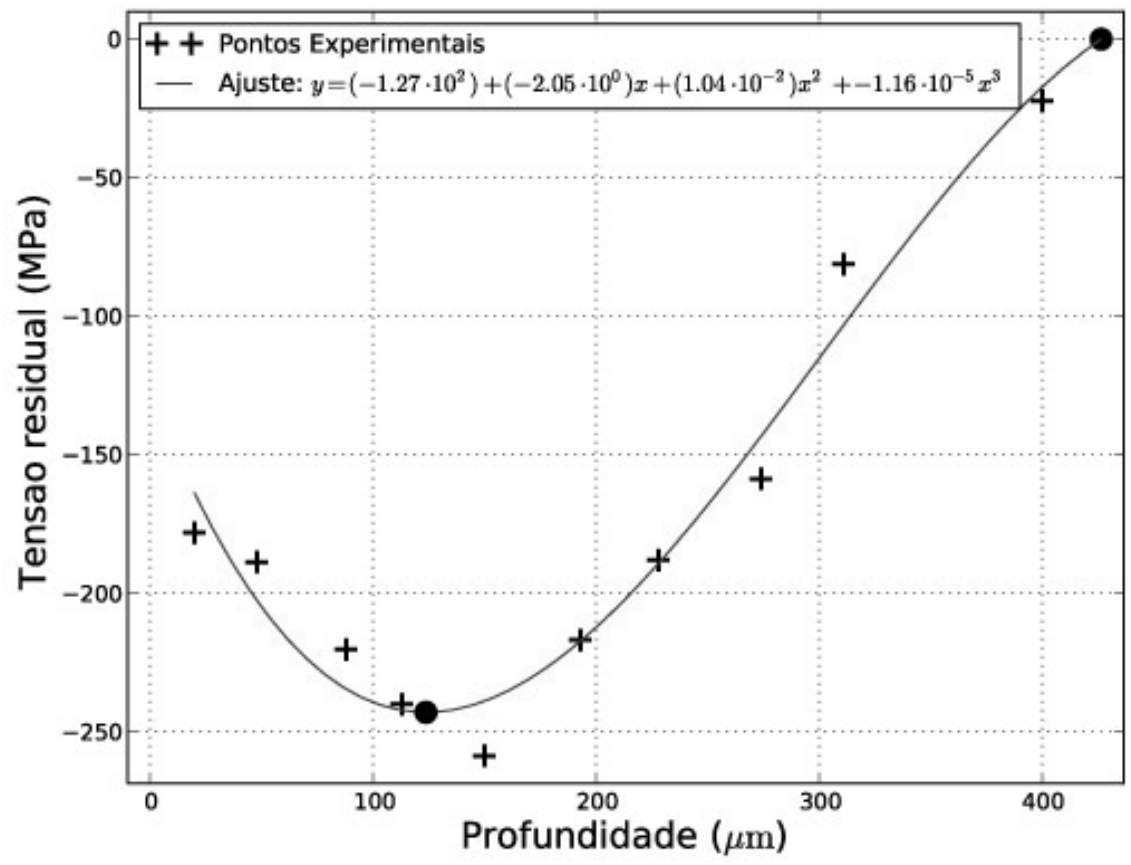

Figura D.5: Perfil de tensões residuais, com valores de máxima tensão de compressão e espessura da camada deformada. Chapa da liga 7050, espessura 2 mm, esfera S230, velocidade média, com pré-tensão. 


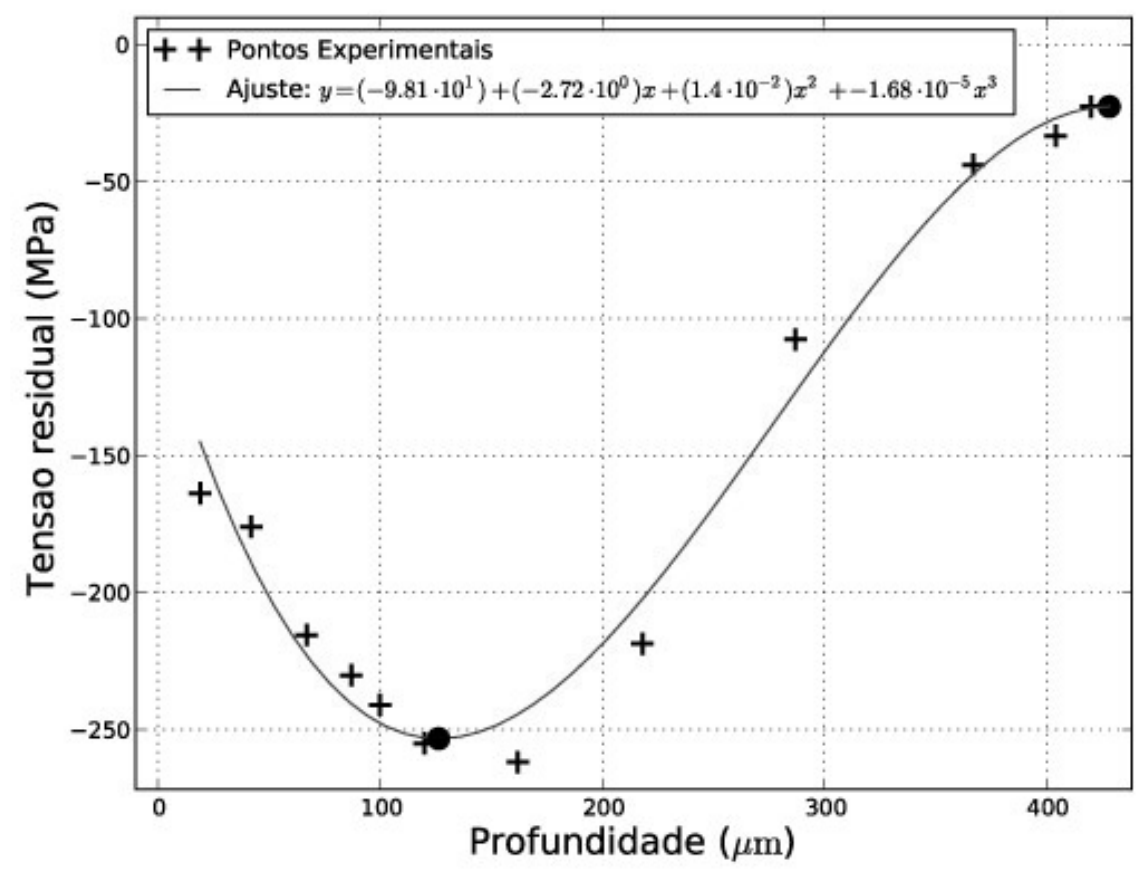

Figura D.6: Perfil de tensões residuais, com valores de máxima tensão de compressão e espessura da camada deformada. Chapa da liga 7050, espessura $2 \mathrm{~mm}$, esfera S230, velocidade alta, com pré-tensão.

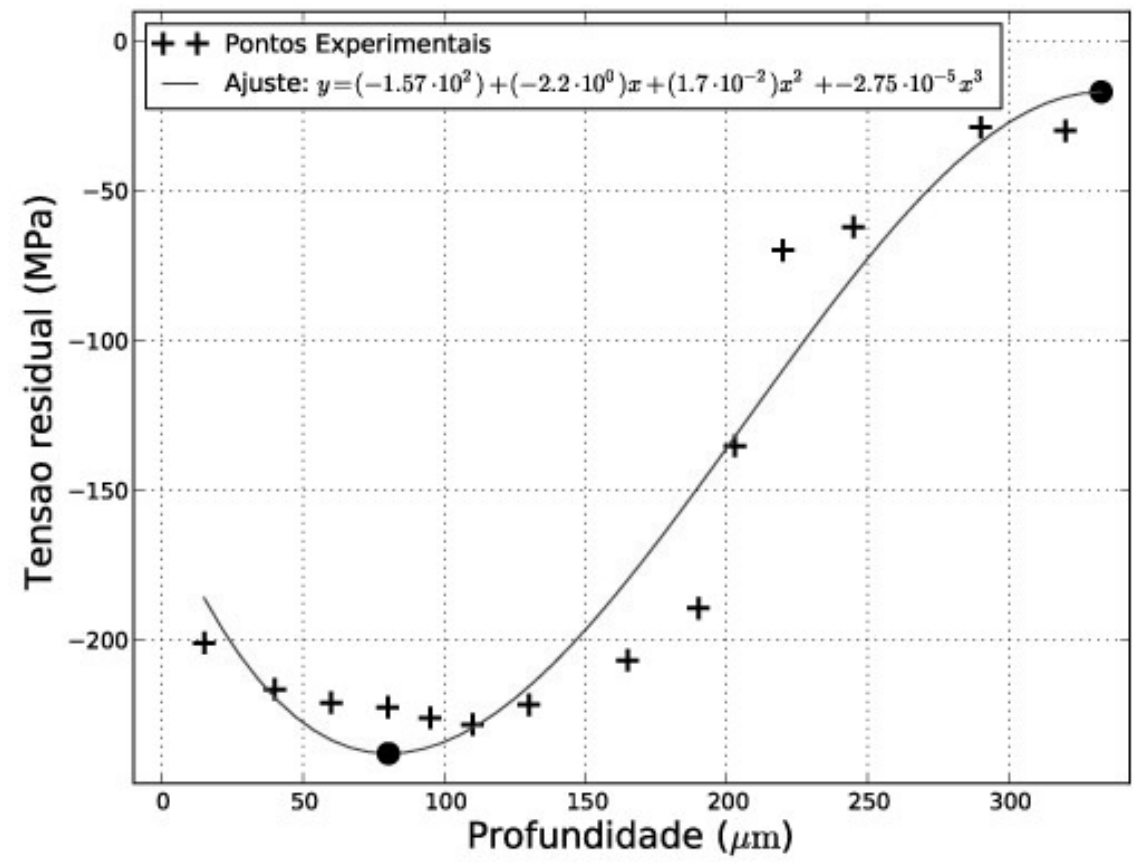

Figura D.7: Perfil de tensões residuais, com valores de máxima tensão de compressão e espessura da camada deformada. Chapa da liga 7050, espessura $5 \mathrm{~mm}$, esfera S230, velocidade baixa, sem pré-tensão. 


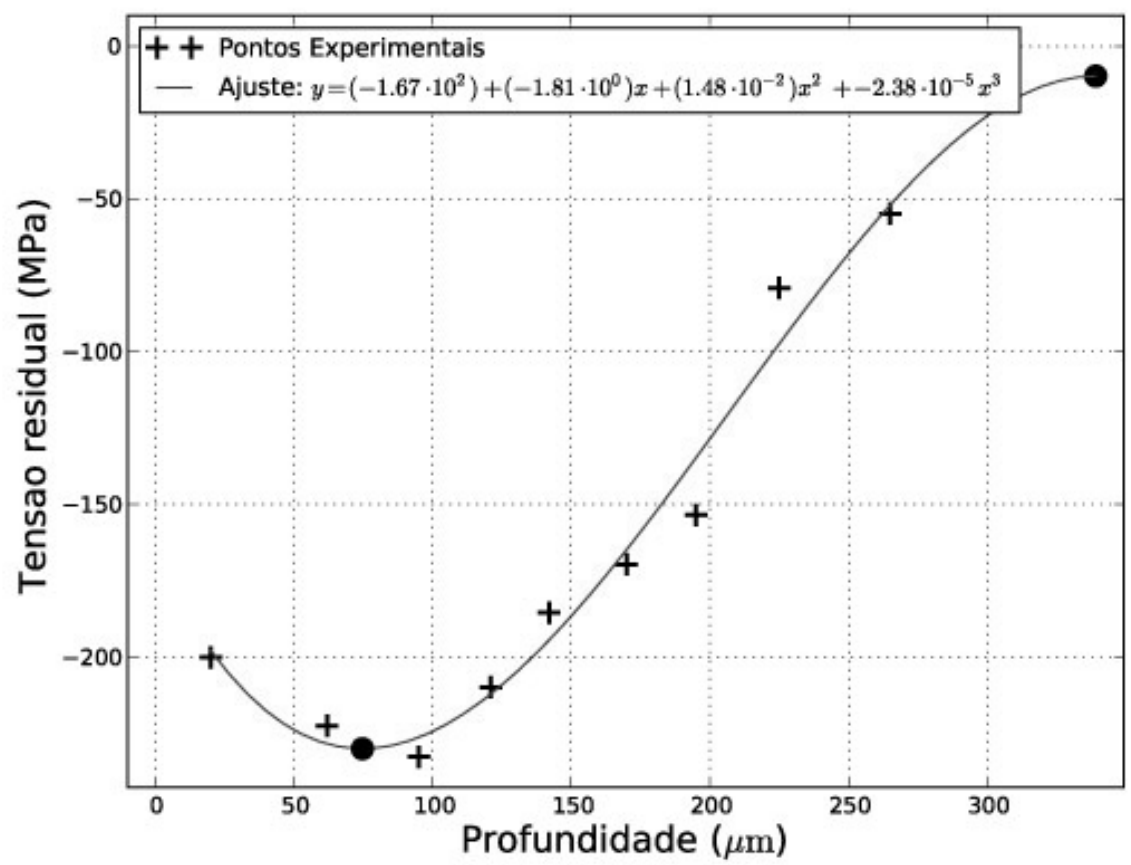

Figura D.8: Perfil de tensões residuais, com valores de máxima tensão de compressão e espessura da camada deformada. Chapa da liga 7050, espessura $5 \mathrm{~mm}$, esfera S230, velocidade média, sem pré-tensão.

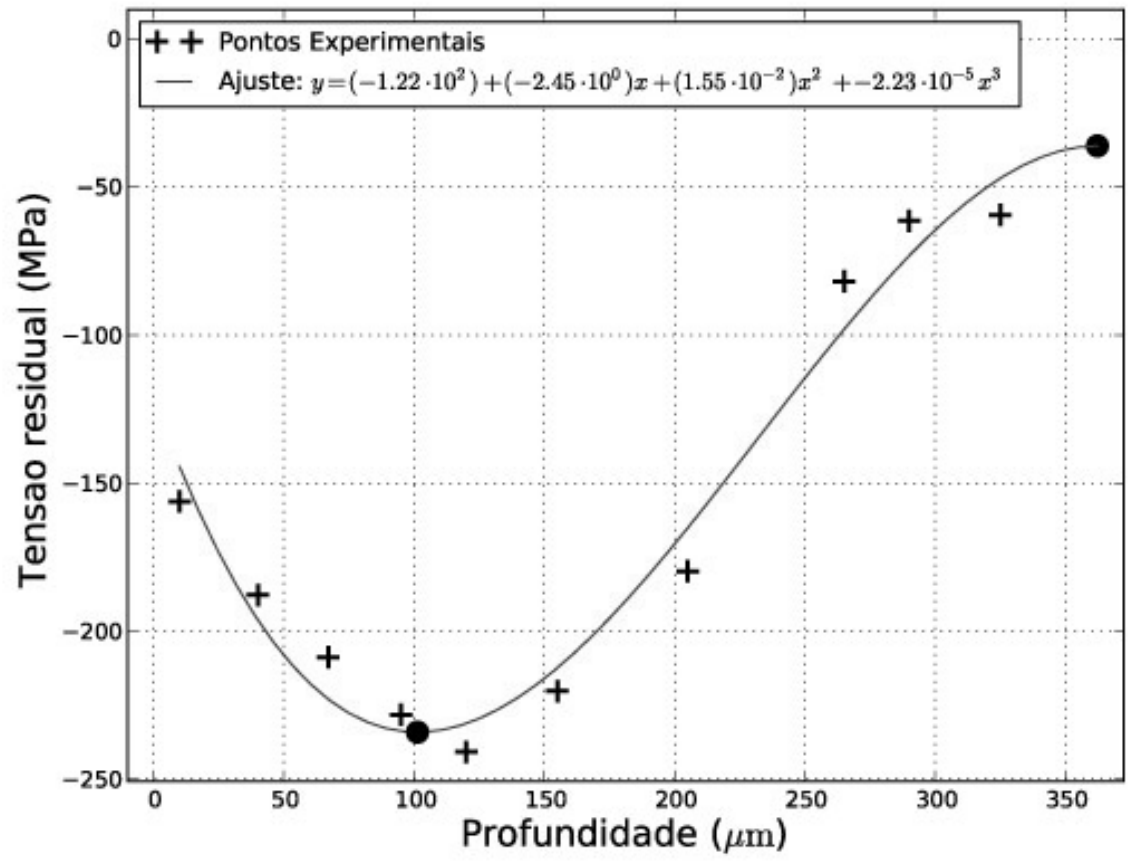

Figura D.9: Perfil de tensões residuais, com valores de máxima tensão de compressão e espessura da camada deformada. Chapa da liga 7050, espessura $5 \mathrm{~mm}$, esfera S230, velocidade alta, sem pré-tensão. 


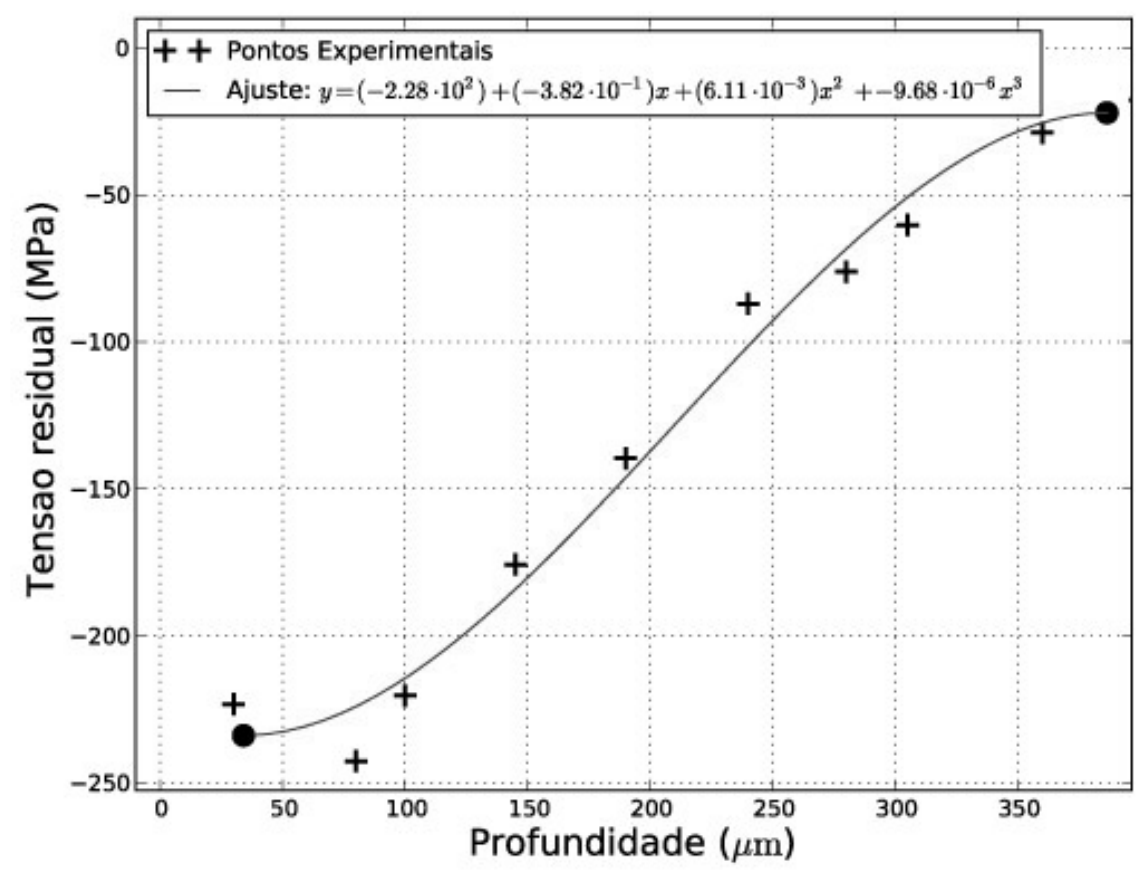

Figura D.10: Perfil de tensões residuais, com valores de máxima tensão de compressão e espessura da camada deformada. Chapa da liga 7050, espessura $5 \mathrm{~mm}$, esfera S230, velocidade baixa, com pré-tensão.

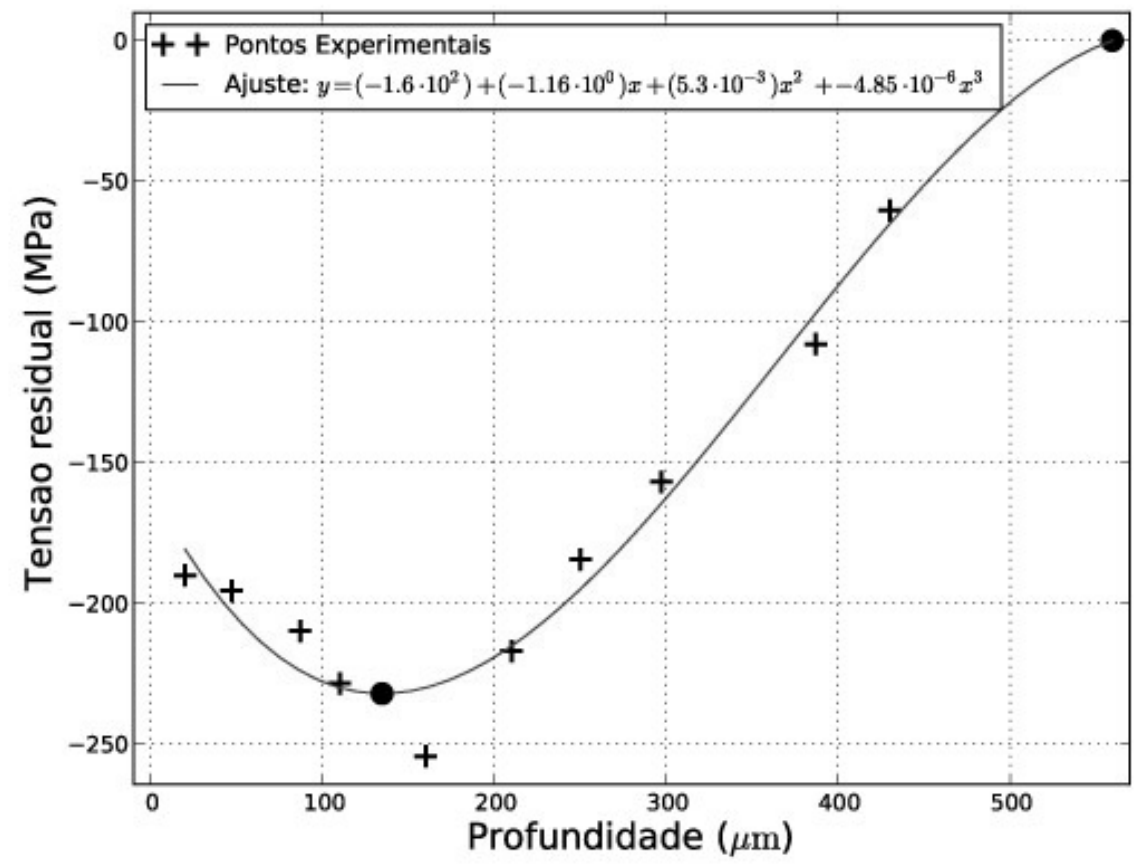

Figura D.11: Perfil de tensões residuais, com valores de máxima tensão de compressão e espessura da camada deformada. Chapa da liga 7050, espessura $5 \mathrm{~mm}$, esfera S230, velocidade média, com pré-tensão. 


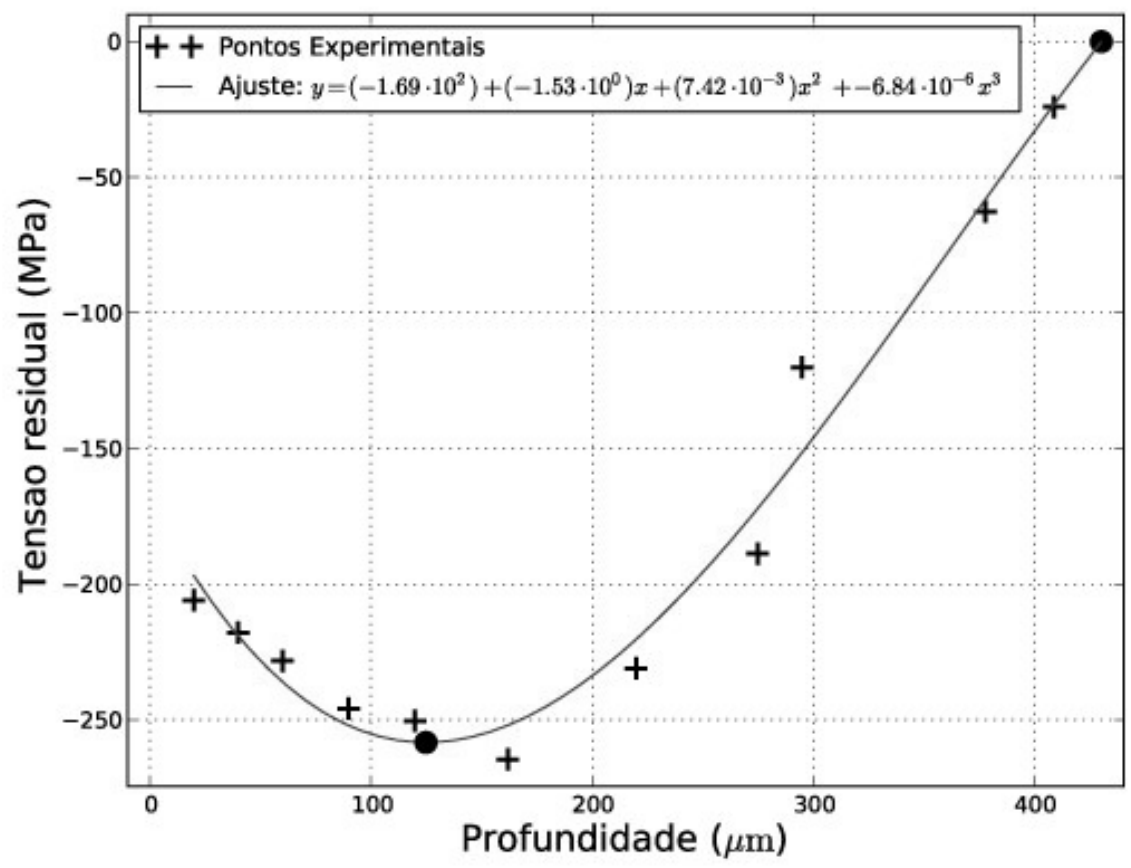

Figura D.12: Perfil de tensões residuais, com valores de máxima tensão de compressão e espessura da camada deformada. Chapa da liga 7050, espessura $5 \mathrm{~mm}$, esfera S230, velocidade alta, com pré-tensão.

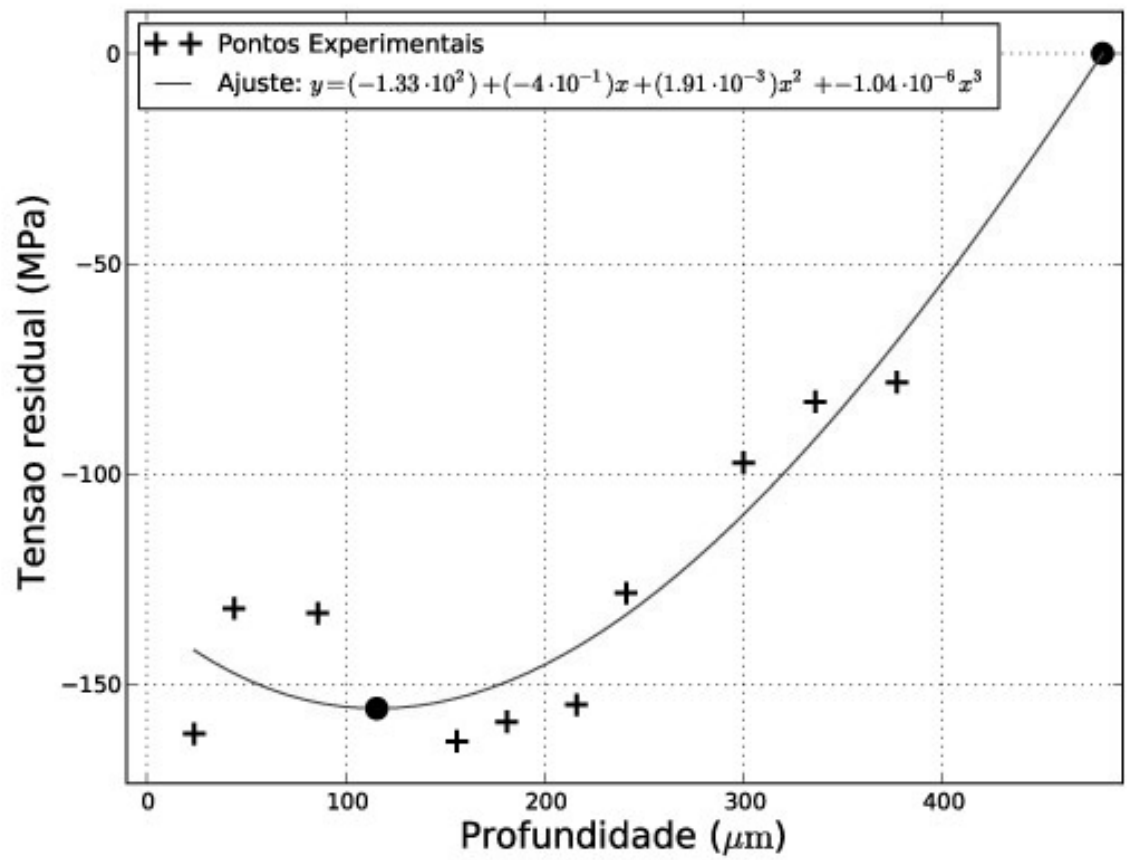

Figura D.13: Perfil de tensões residuais, com valores de máxima tensão de compressão e espessura da camada deformada. Chapa da liga 7050, espessura $5 \mathrm{~mm}$, esfera $\mathbf{5 5 0}$, velocidade baixa, sem pré-tensão. 


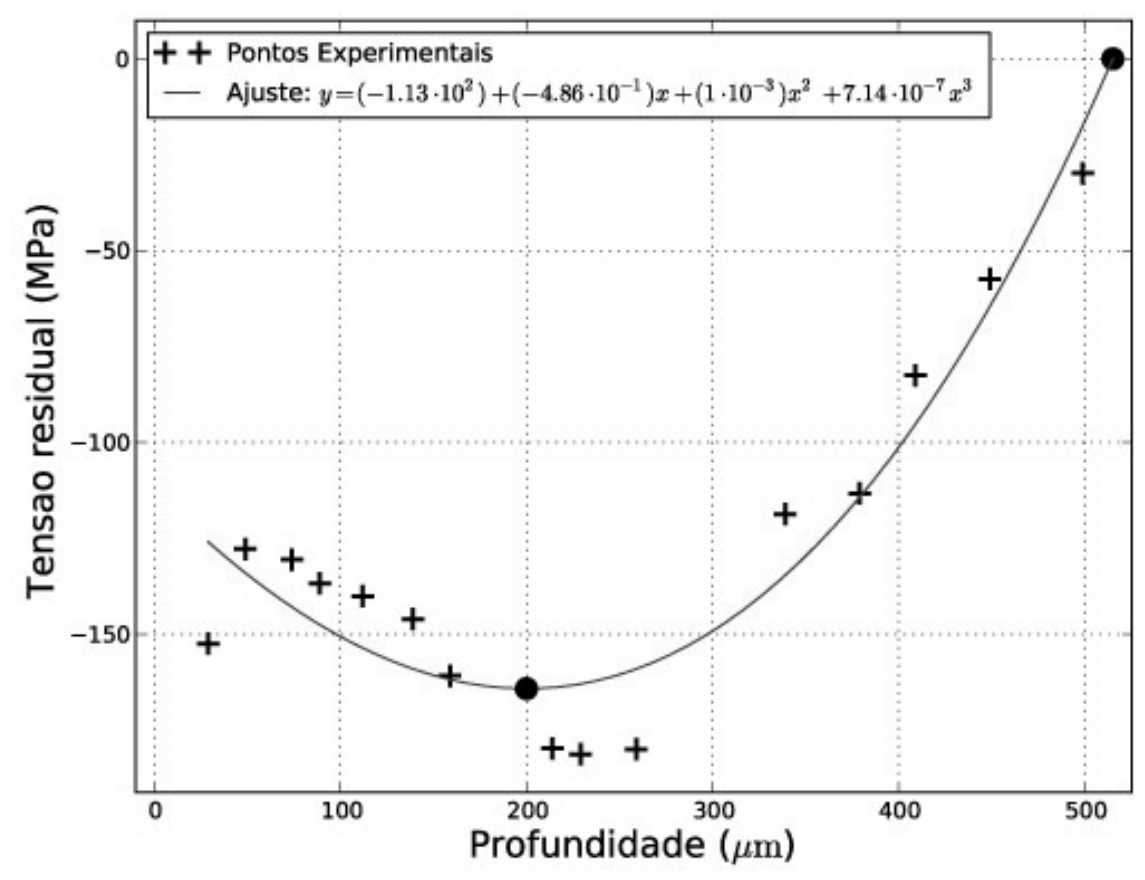

Figura D.14: Perfil de tensões residuais, com valores de máxima tensão de compressão e espessura da camada deformada. Chapa da liga 7050, espessura $5 \mathrm{~mm}$, esfera S550, velocidade média, sem pré-tensão.

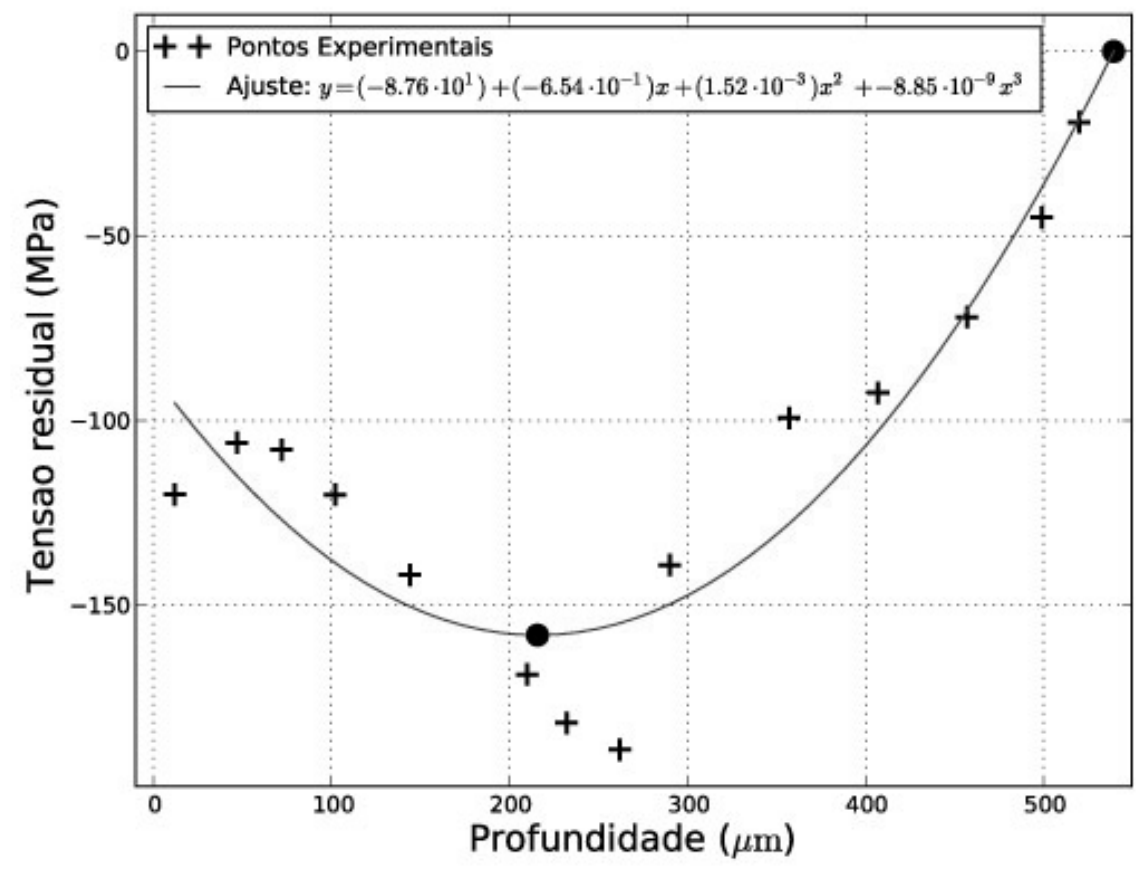

Figura D.15: Perfil de tensões residuais, com valores de máxima tensão de compressão e espessura da camada deformada. Chapa da liga 7050, espessura $5 \mathrm{~mm}$, esfera S550, velocidade alta, sem pré-tensão. 


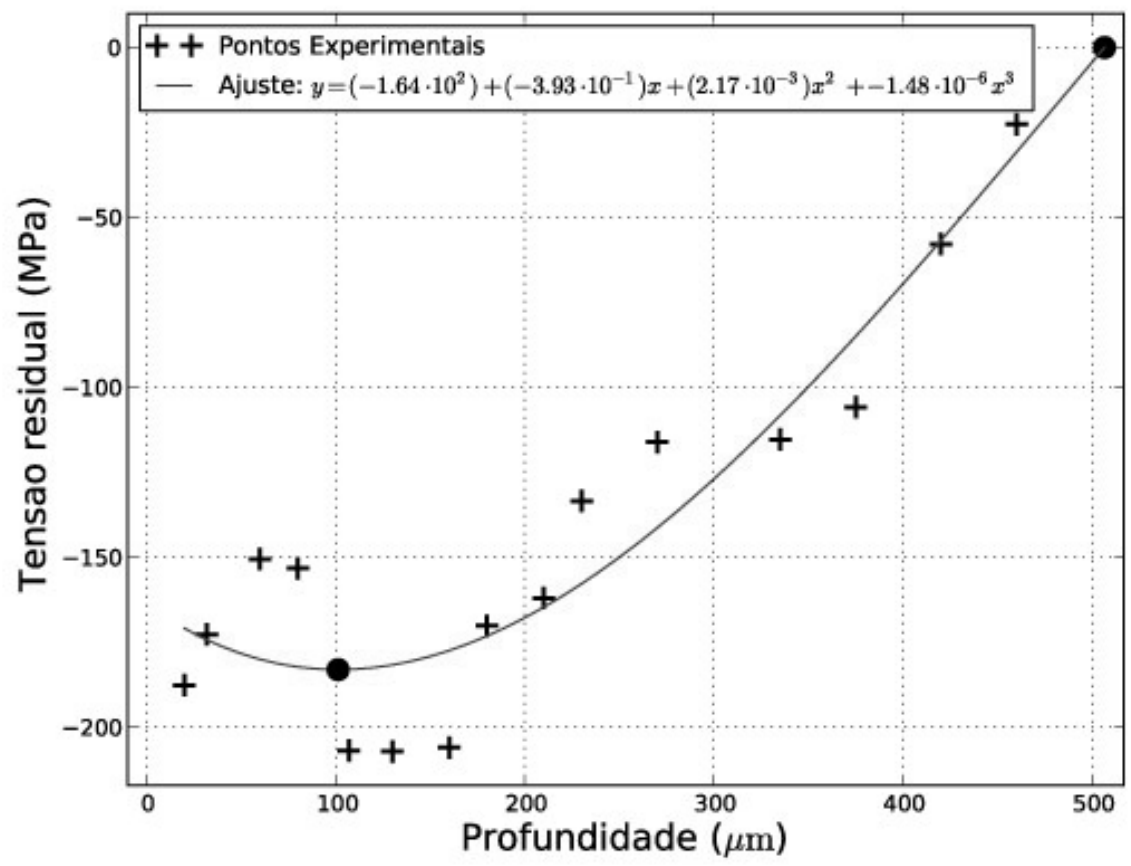

Figura D.16: Perfil de tensões residuais, com valores de máxima tensão de compressão e espessura da camada deformada. Chapa da liga 7050, espessura $5 \mathrm{~mm}$, esfera S550, velocidade baixa, com pré-tensão.

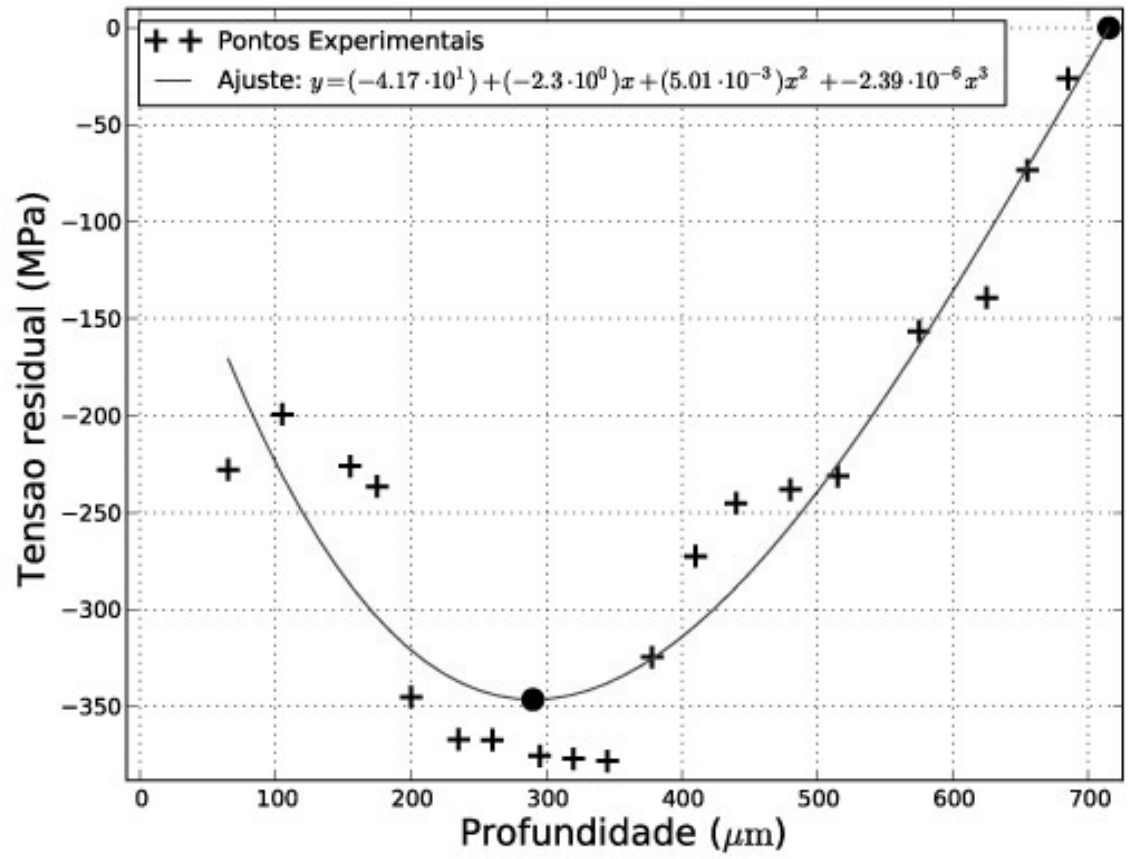

Figura D.17: Perfil de tensões residuais, com valores de máxima tensão de compressão e espessura da camada deformada. Chapa da liga 7050, espessura $5 \mathrm{~mm}$, esfera S550, velocidade média, com pré-tensão. 


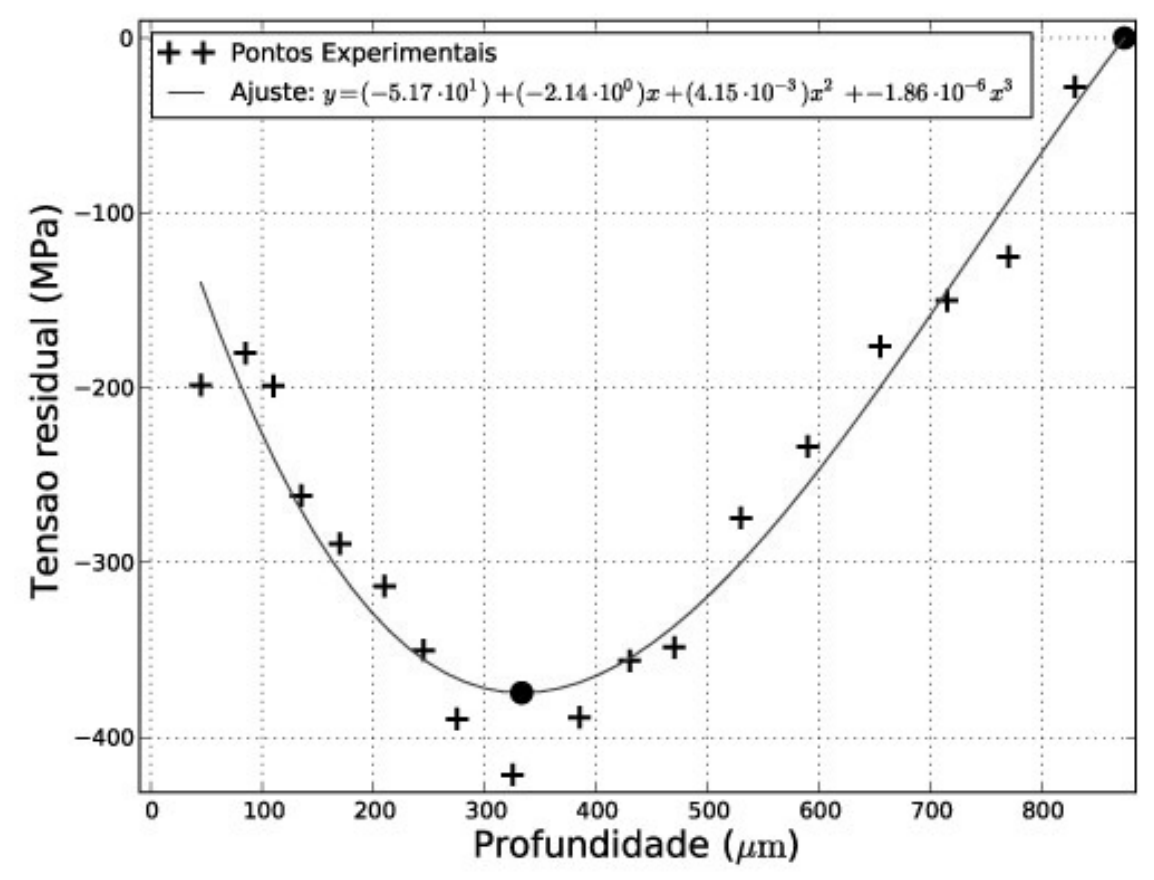

Figura D.18: Perfil de tensões residuais, com valores de máxima tensão de compressão e espessura da camada deformada. Chapa da liga 7050, espessura $5 \mathrm{~mm}$, esfera S550, velocidade alta, com pré-tensão.

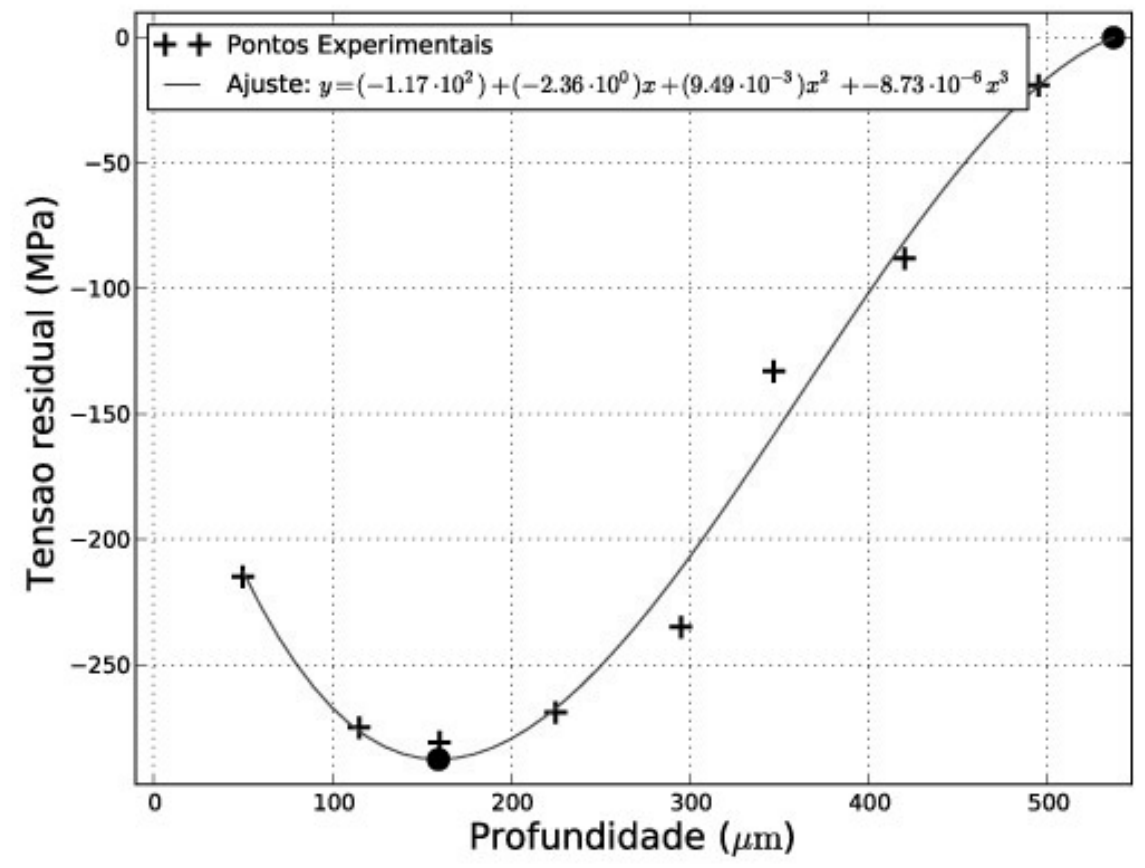

Figura D.19: Perfil de tensões residuais, com valores de máxima tensão de compressão e espessura da camada deformada. Chapa da liga 7050, espessura $10 \mathrm{~mm}$, esfera S550, velocidade baixa, sem pré-tensão. 


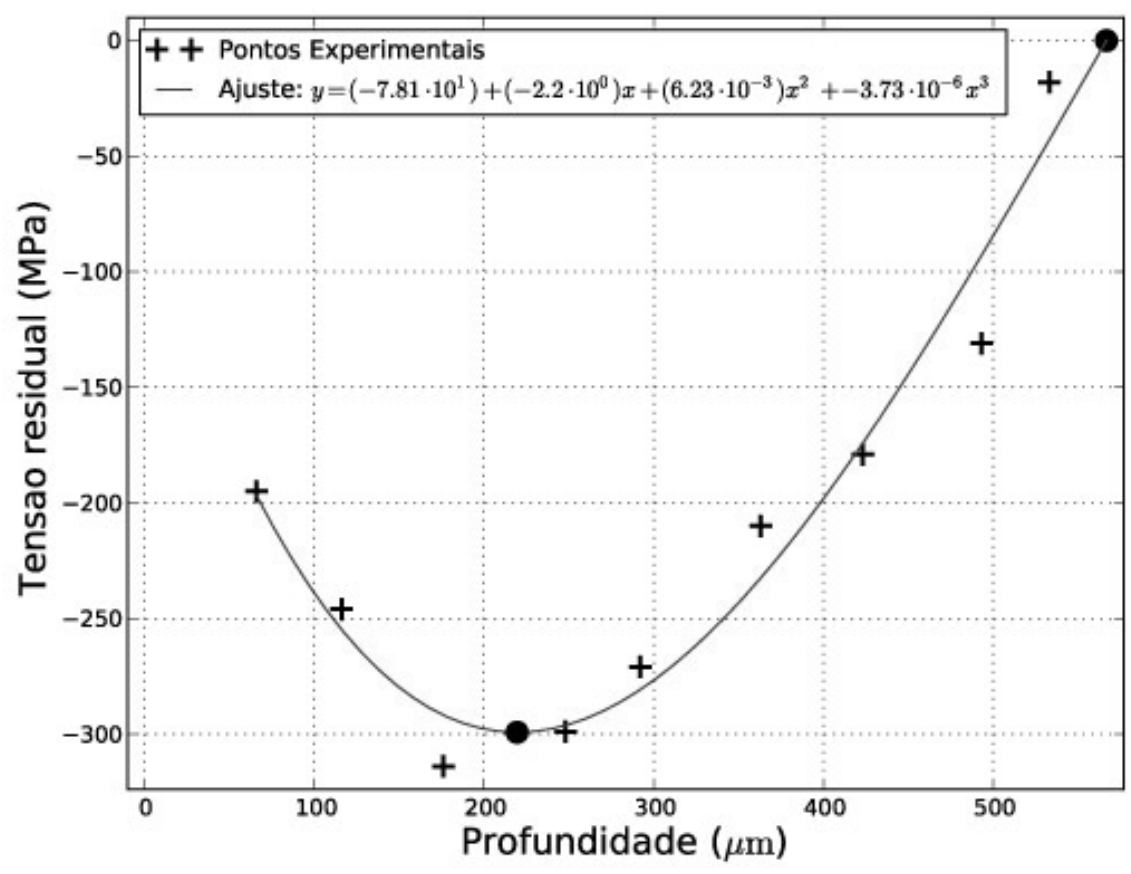

Figura D.20: Perfil de tensões residuais, com valores de máxima tensão de compressão e espessura da camada deformada. Chapa da liga 7050, espessura $10 \mathrm{~mm}$, esfera S550, velocidade média, sem pré-tensão.

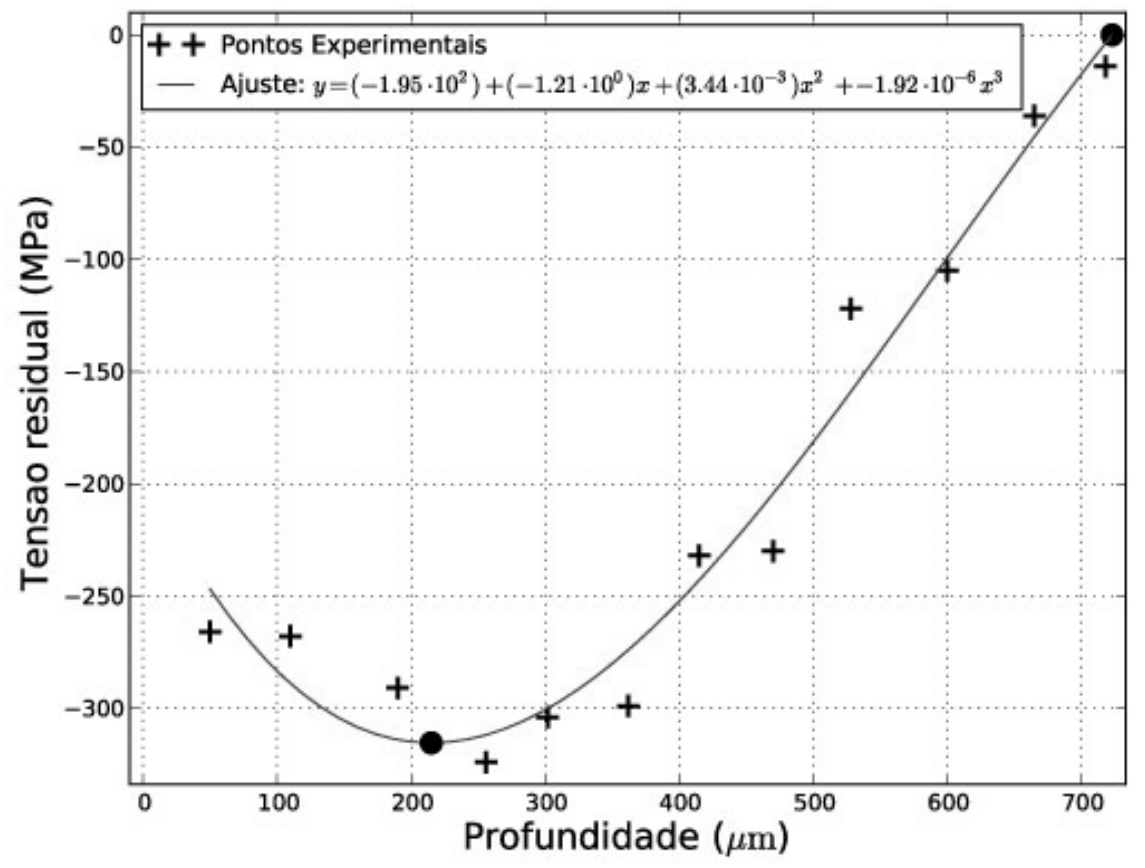

Figura D.21: Perfil de tensões residuais, com valores de máxima tensão de compressão e espessura da camada deformada. Chapa da liga 7050, espessura $10 \mathrm{~mm}$, esfera S550, velocidade alta, sem pré-tensão. 


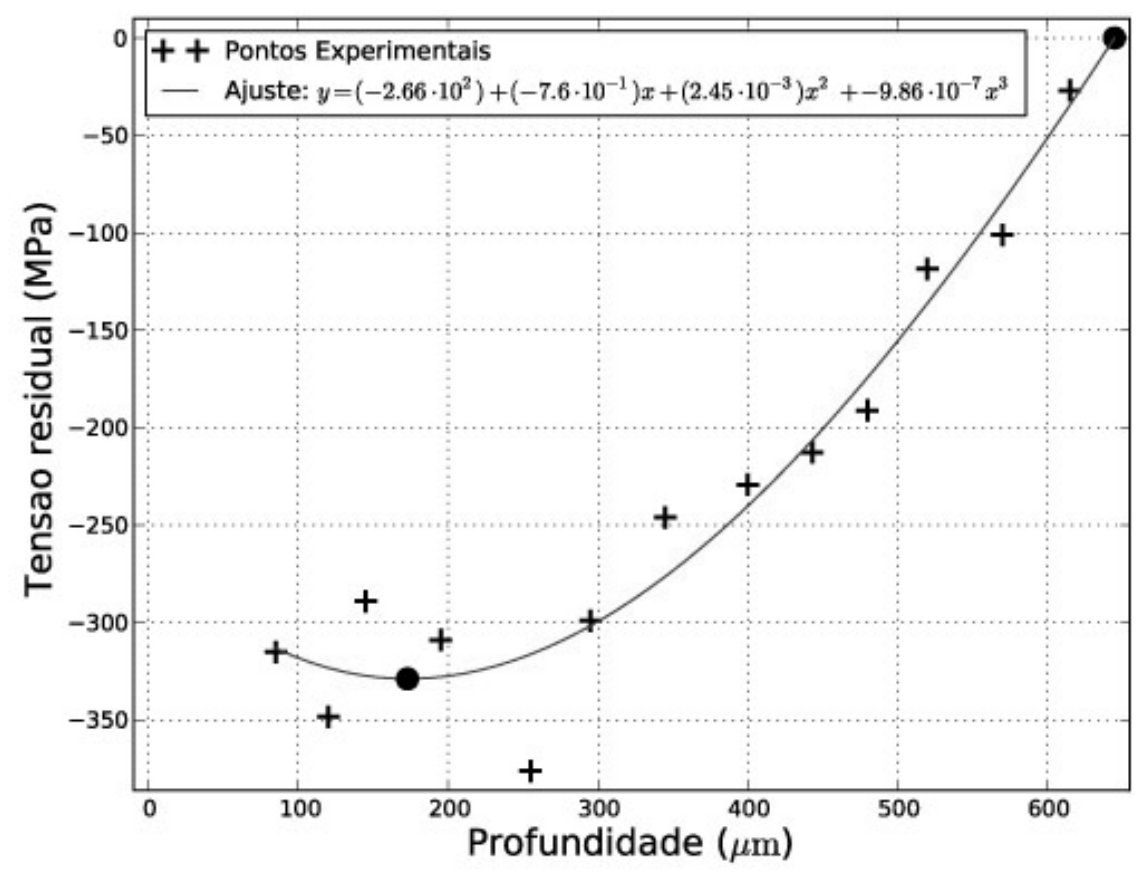

Figura D.22: Perfil de tensões residuais, com valores de máxima tensão de compressão e espessura da camada deformada. Chapa da liga 7050, espessura $10 \mathrm{~mm}$, esfera S550, velocidade baixa, com pré-tensão.

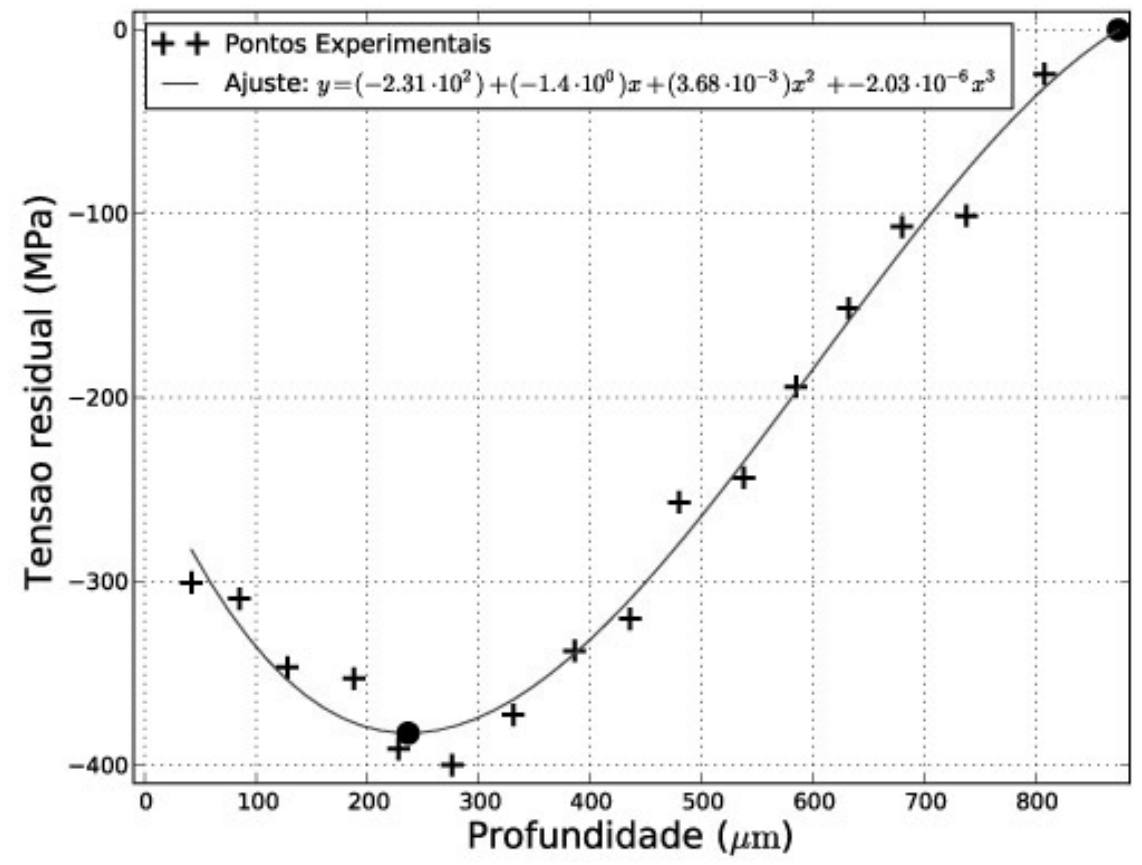

Figura D.23: Perfil de tensões residuais, com valores de máxima tensão de compressão e espessura da camada deformada. Chapa da liga 7050, espessura 10 mm, esfera S550, velocidade média, com pré-tensão. 


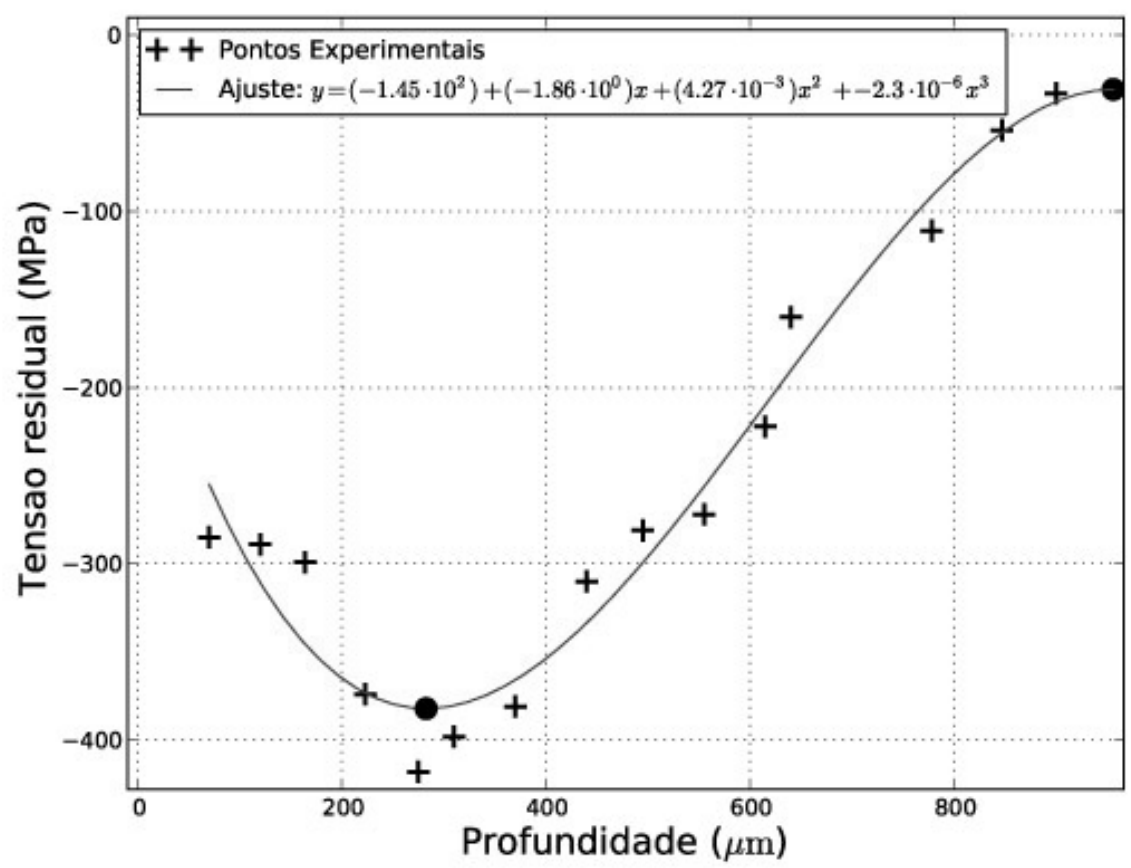

Figura D.24: Perfil de tensões residuais, com valores de máxima tensão de compressão e espessura da camada deformada. Chapa da liga 7050, espessura $10 \mathrm{~mm}$, esfera S550, velocidade alta, com pré-tensão.

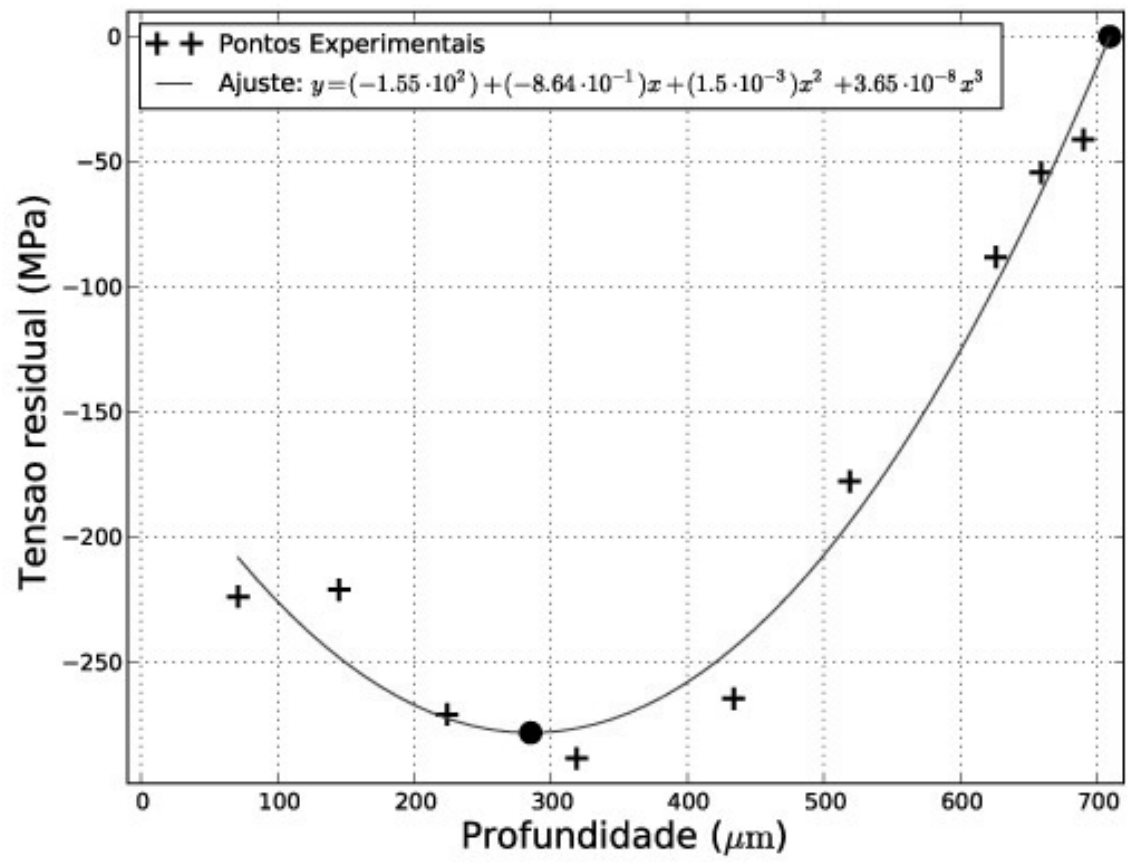

Figura D.25: Perfil de tensões residuais, com valores de máxima tensão de compressão e espessura da camada deformada. Chapa da liga 7050, espessura $10 \mathrm{~mm}$, esfera 1/8", velocidade baixa, sem pré-tensão. 


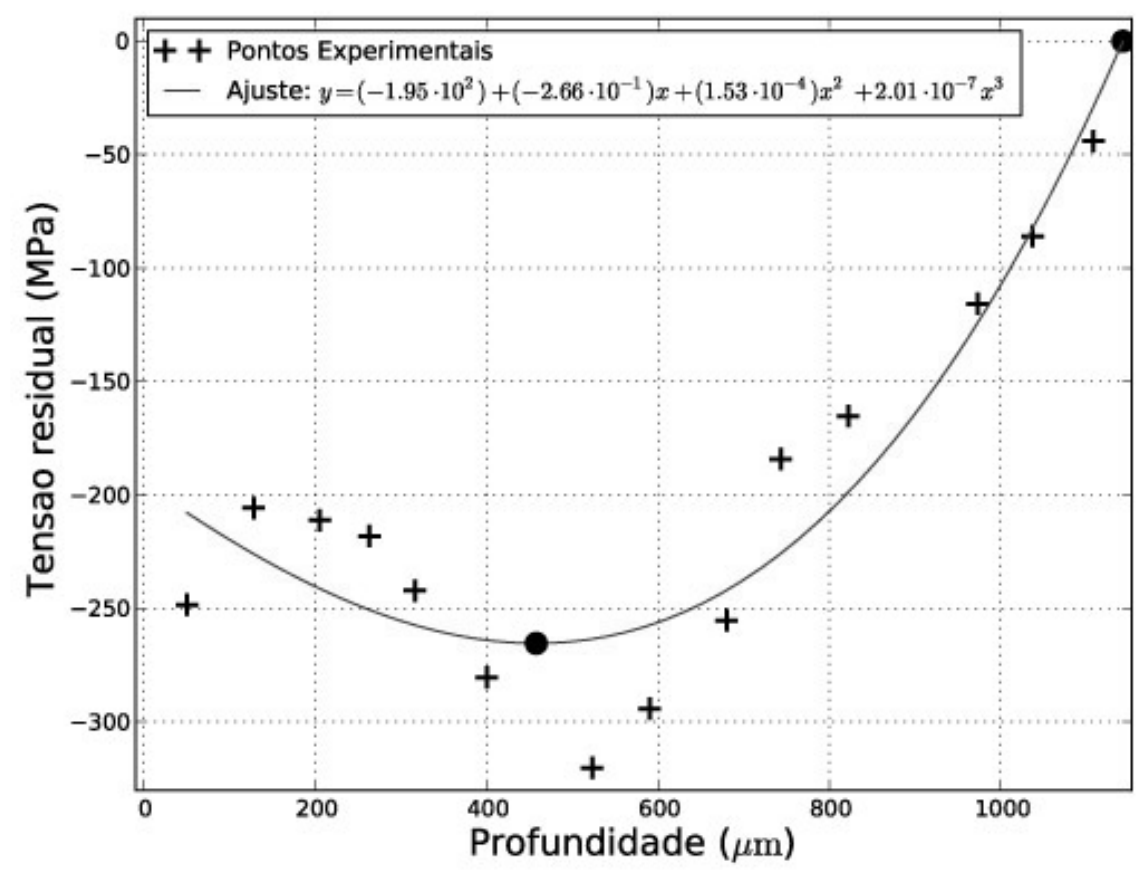

Figura D.26: Perfil de tensões residuais, com valores de máxima tensão de compressão e espessura da camada deformada. Chapa da liga 7050, espessura $10 \mathrm{~mm}$, esfera 1/8", velocidade média, sem pré-tensão.

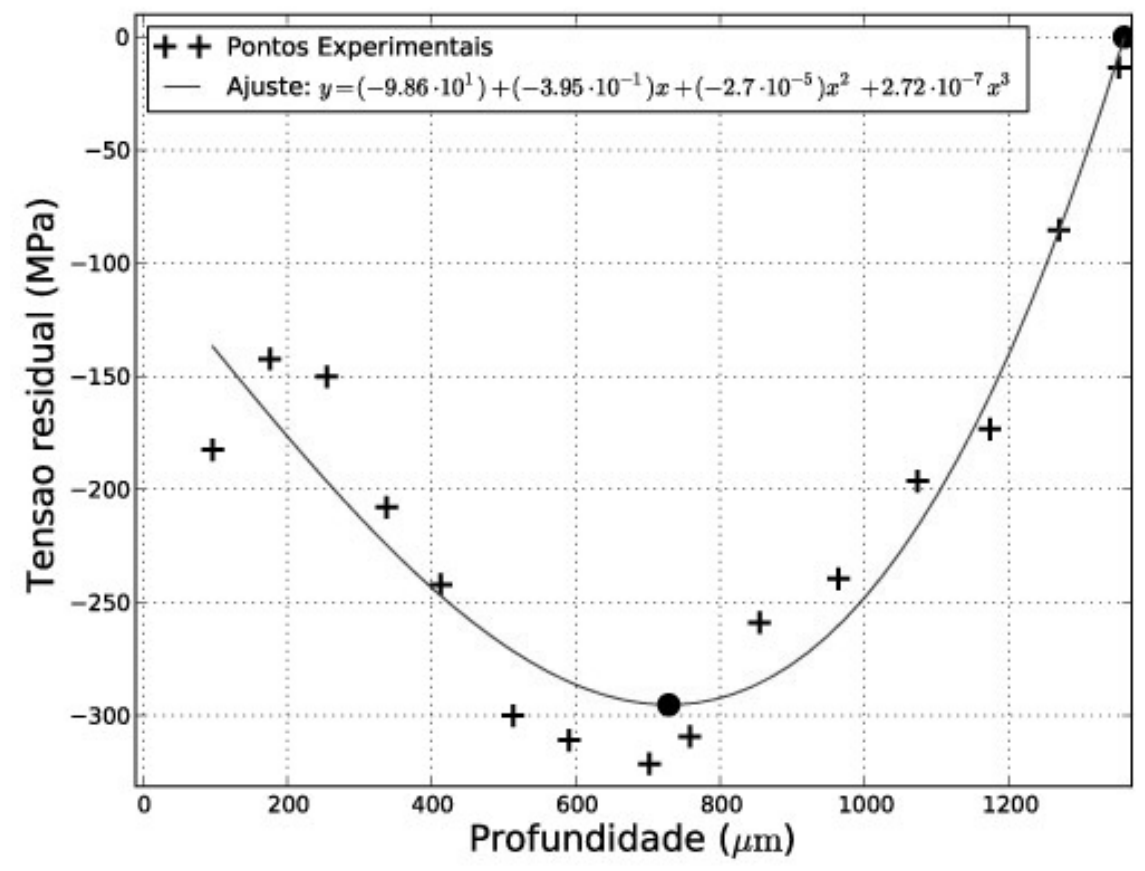

Figura D.27: Perfil de tensões residuais, com valores de máxima tensão de compressão e espessura da camada deformada. Chapa da liga 7050, espessura $10 \mathrm{~mm}$, esfera 1/8", velocidade alta, sem pré-tensão. 


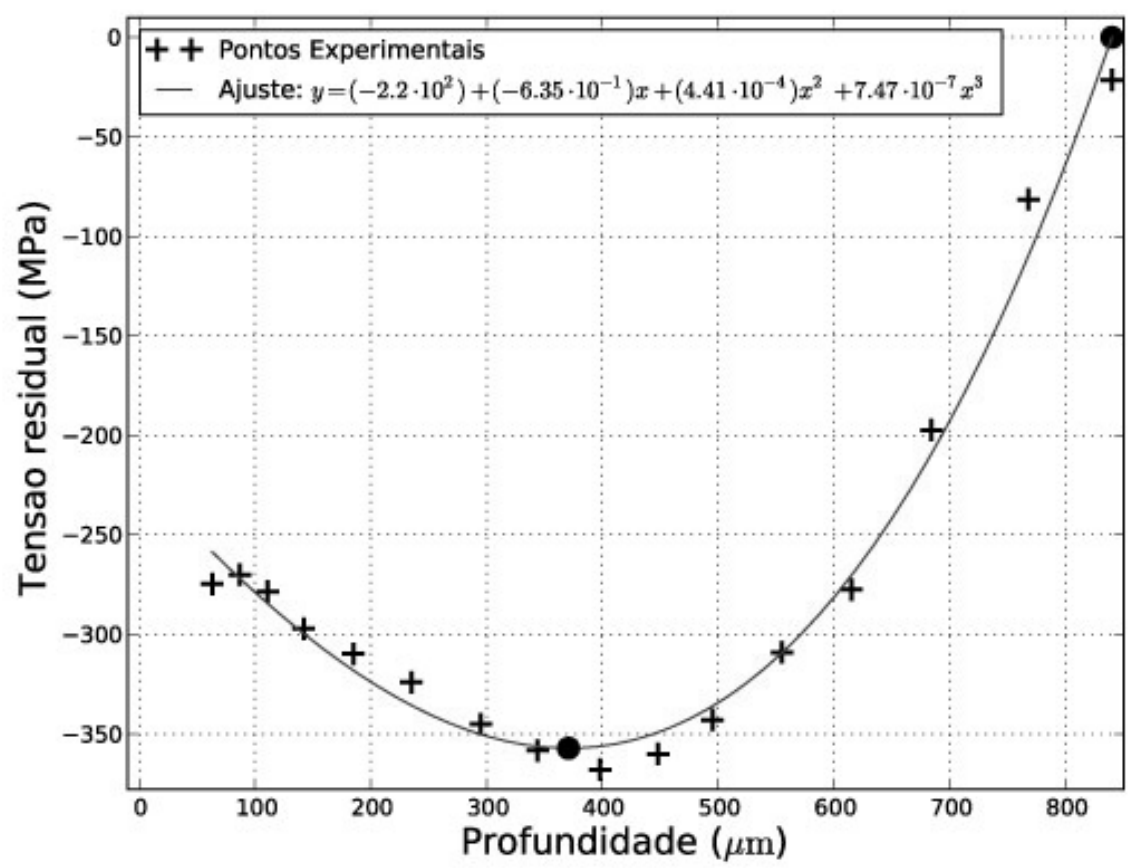

Figura D.28: Perfil de tensões residuais, com valores de máxima tensão de compressão e espessura da camada deformada. Chapa da liga 7050, espessura $10 \mathrm{~mm}$, esfera 1/8", velocidade baixa, com pré-tensão.

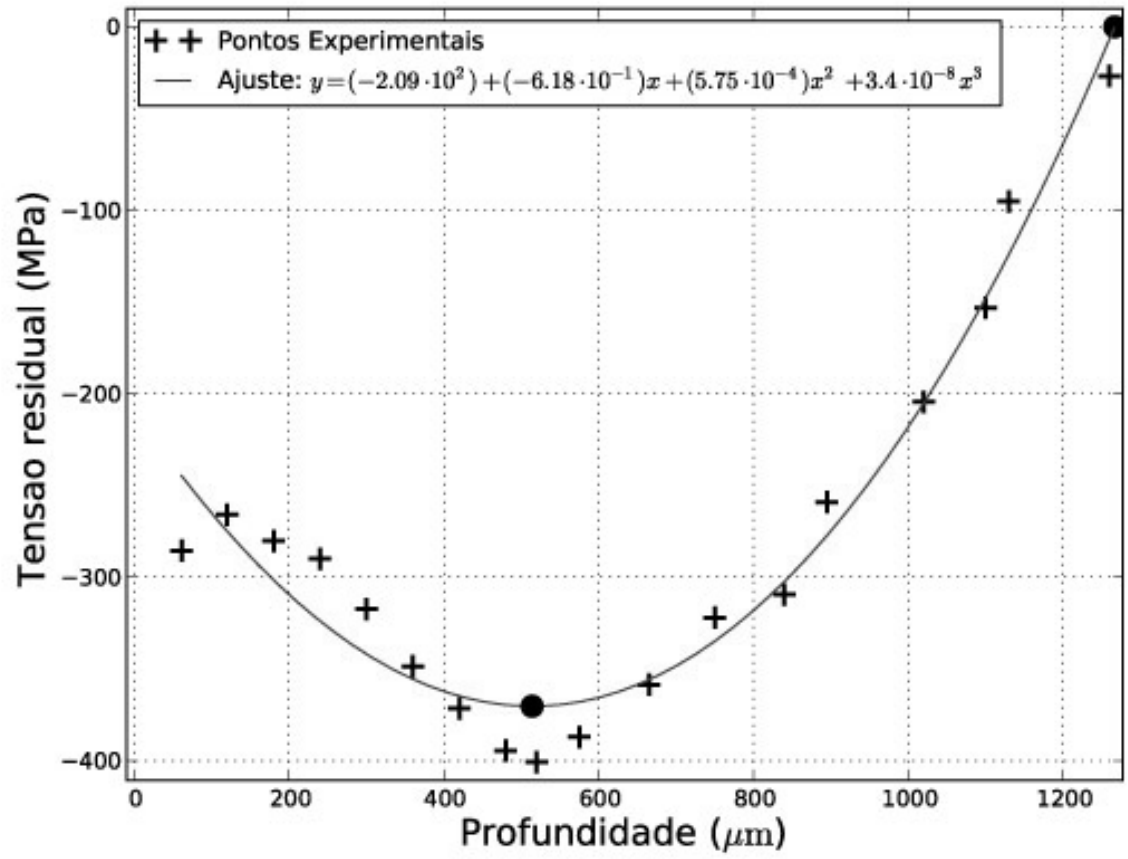

Figura D.29: Perfil de tensões residuais, com valores de máxima tensão de compressão e espessura da camada deformada. Chapa da liga 7050, espessura $10 \mathrm{~mm}$, esfera 1/8", velocidade média, com pré-tensão. 


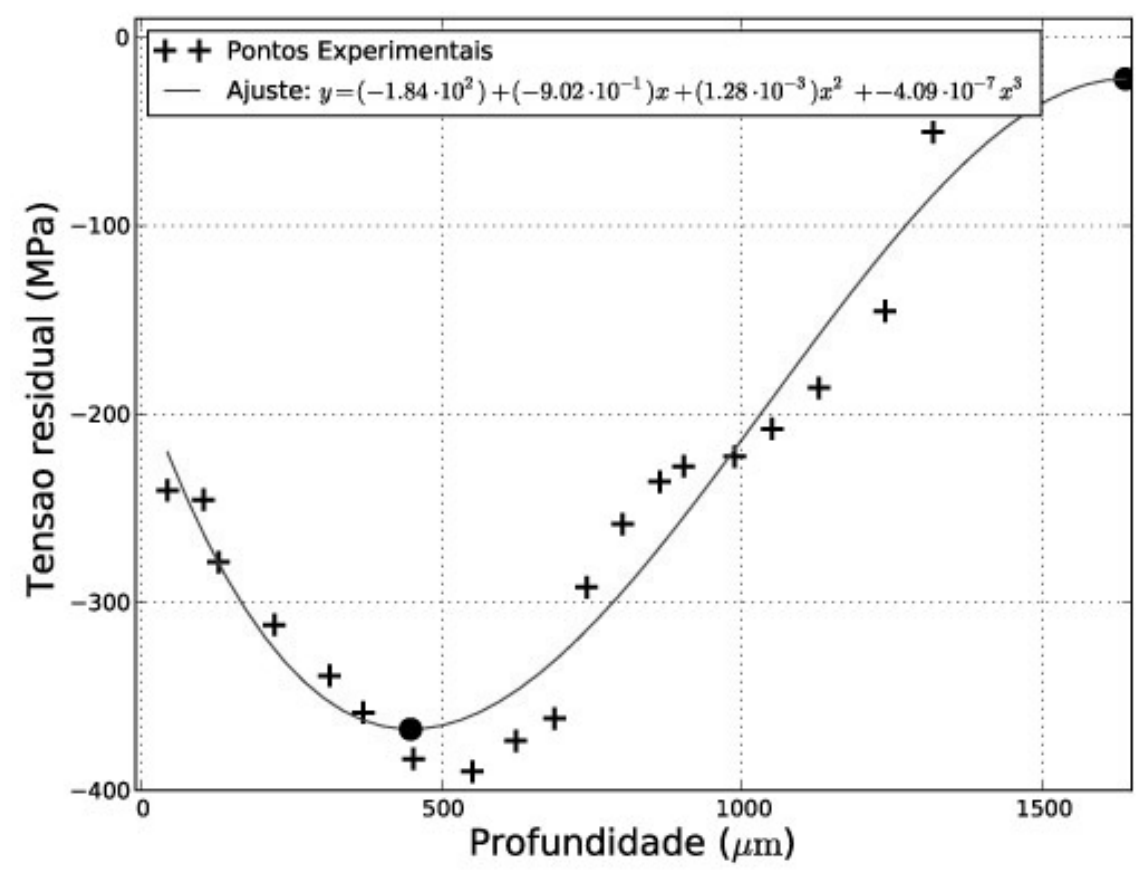

Figura D.30: Perfil de tensões residuais, com valores de máxima tensão de compressão e espessura da camada deformada. Chapa da liga 7050, espessura 10 mm, esfera 1/8", velocidade alta, com pré-tensão.

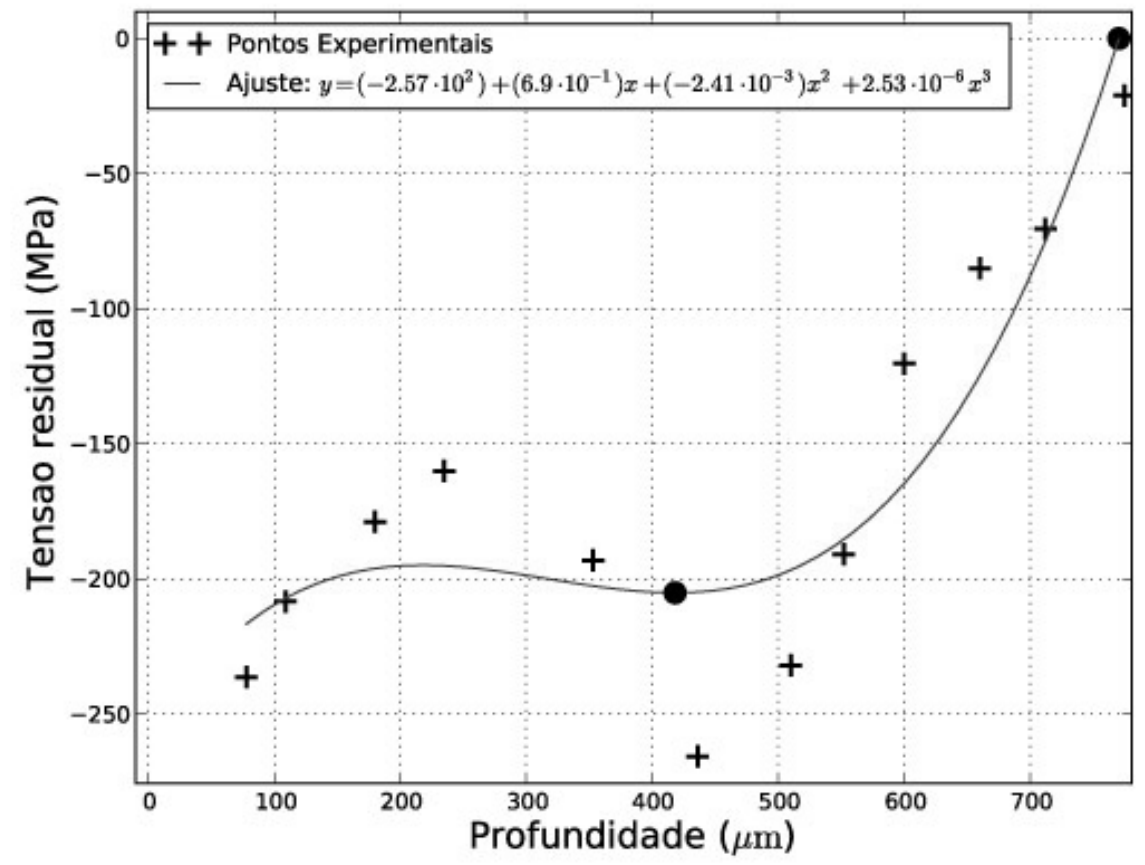

Figura D.31: Perfil de tensões residuais, com valores de máxima tensão de compressão e espessura da camada deformada. Chapa da liga 7050, espessura 15 mm, esfera 1/8", velocidade baixa, sem pré-tensão. 


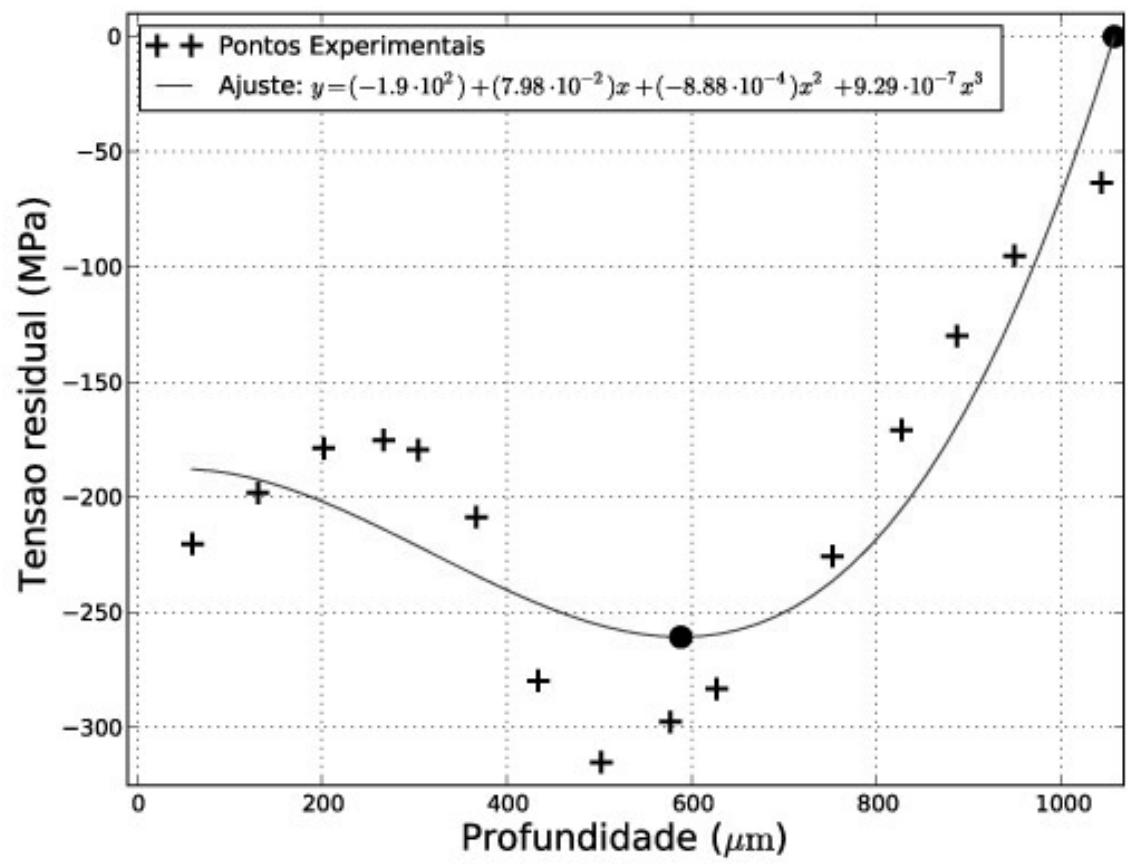

Figura D.32: Perfil de tensões residuais, com valores de máxima tensão de compressão e espessura da camada deformada. Chapa da liga 7050, espessura 15 mm, esfera 1/8", velocidade média, sem pré-tensão.

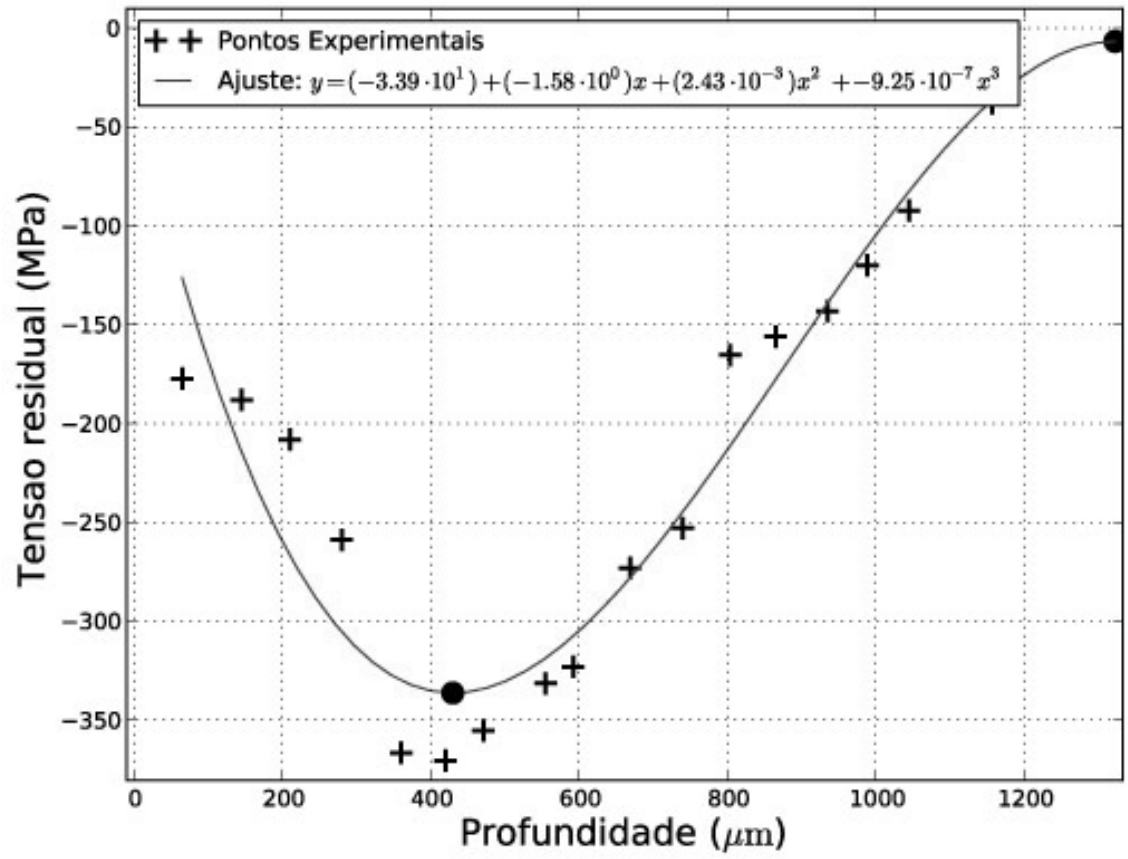

Figura D.33: Perfil de tensões residuais, com valores de máxima tensão de compressão e espessura da camada deformada. Chapa da liga 7050, espessura $15 \mathrm{~mm}$, esfera 1/8", velocidade alta, sem pré-tensão. 


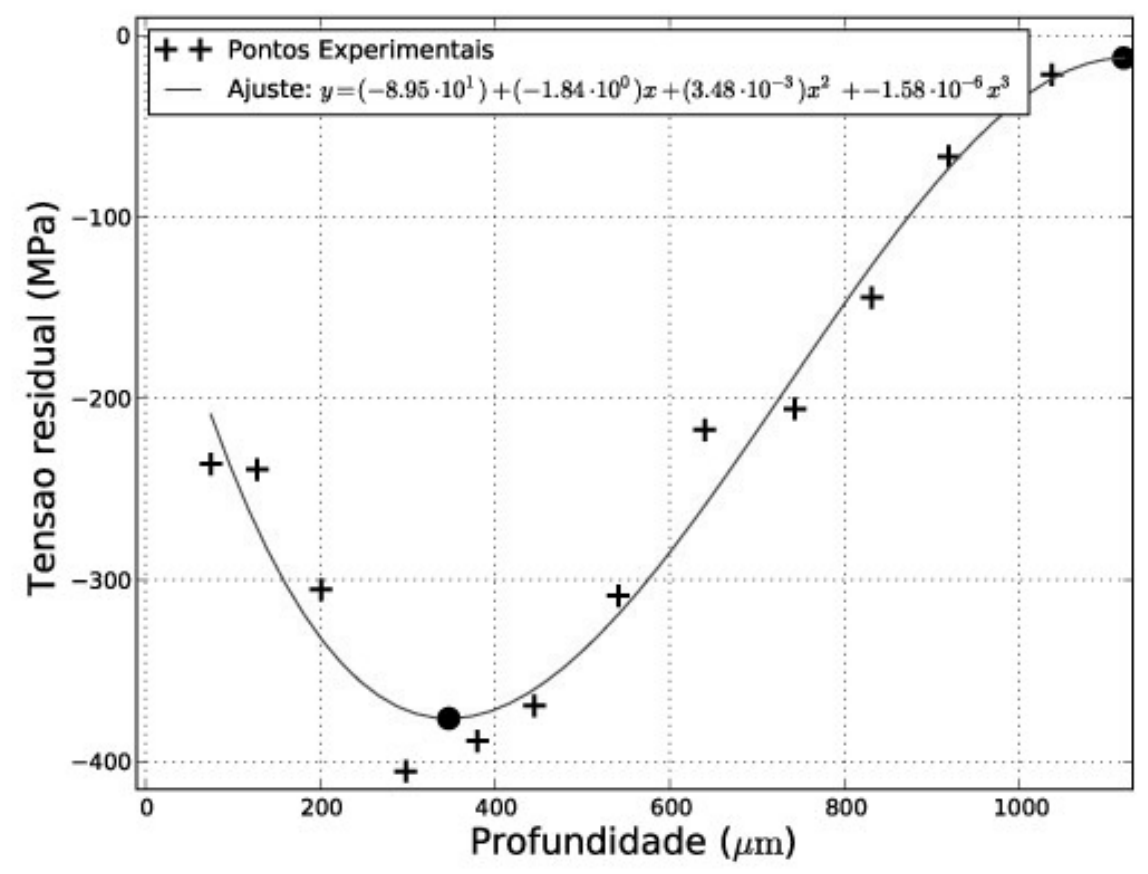

Figura D.34: Perfil de tensões residuais, com valores de máxima tensão de compressão e espessura da camada deformada. Chapa da liga 7050, espessura 15 mm, esfera 1/8", velocidade baixa, com pré-tensão.

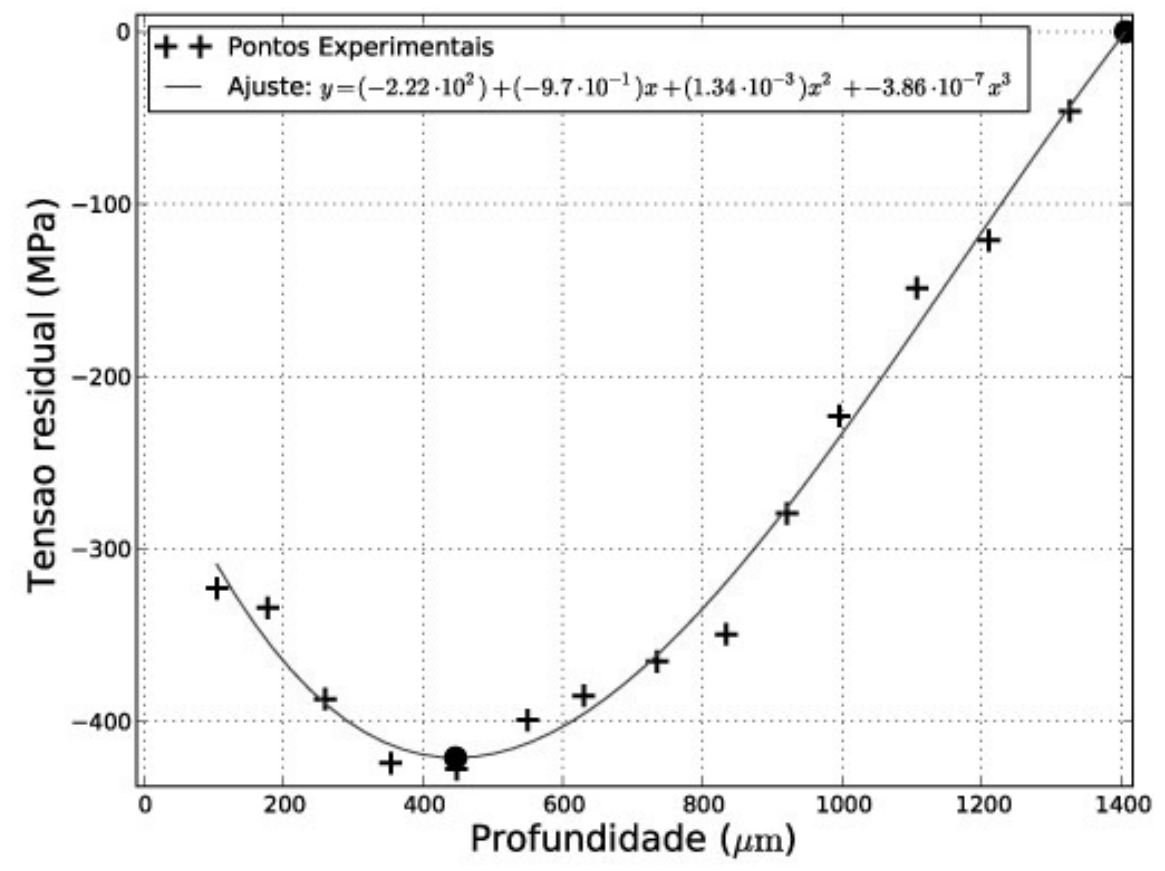

Figura D.35: Perfil de tensões residuais, com valores de máxima tensão de compressão e espessura da camada deformada. Chapa da liga 7050, espessura 15 mm, esfera 1/8", velocidade média, com pré-tensão. 


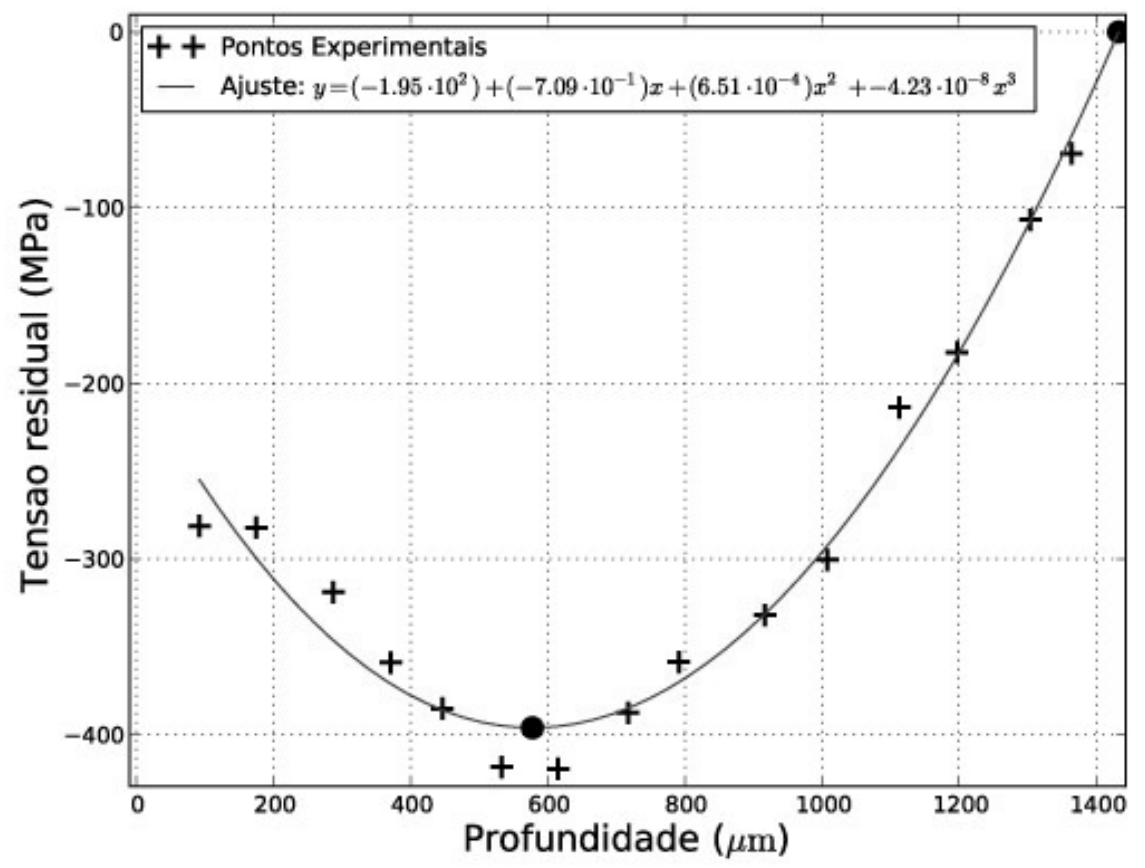

Figura D.36: Perfil de tensões residuais, com valores de máxima tensão de compressão e espessura da camada deformada. Chapa da liga 7050, espessura 15 mm, esfera 1/8", velocidade alta, com pré-tensão. 